
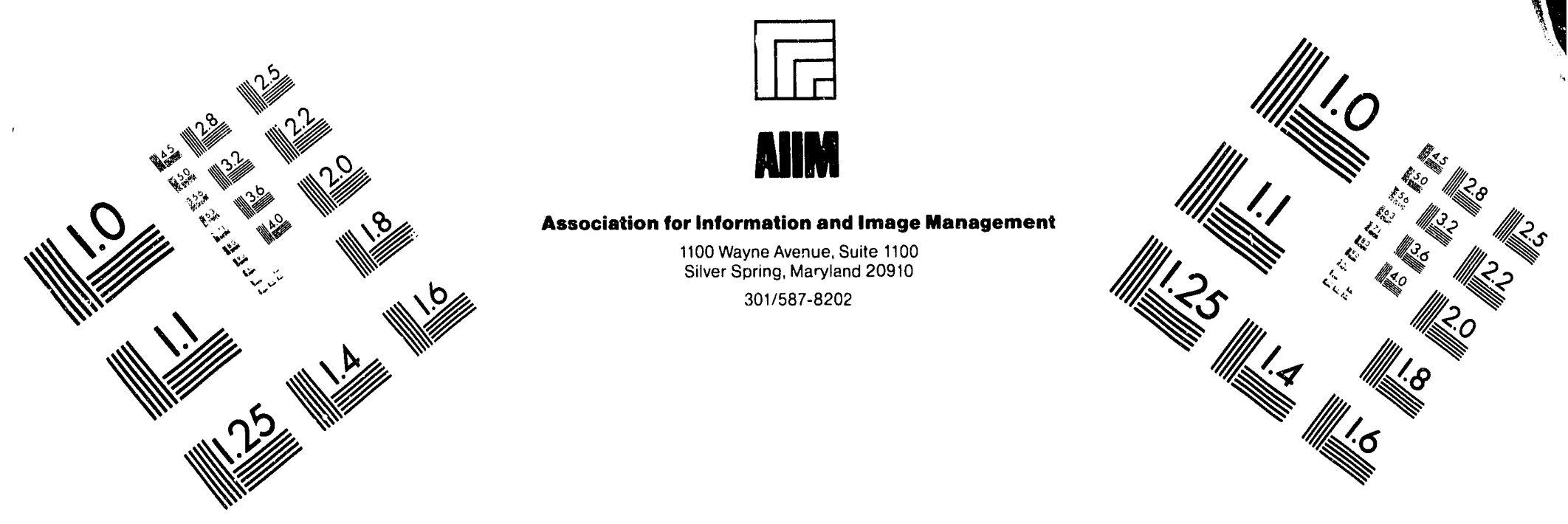

\title{
Centimeter
}

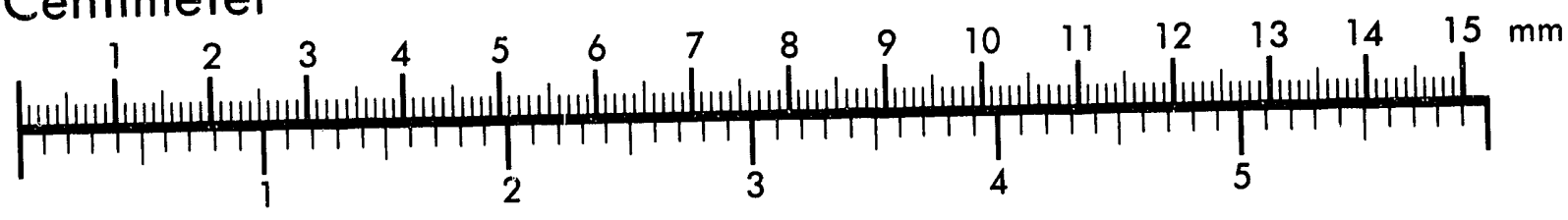
Inches
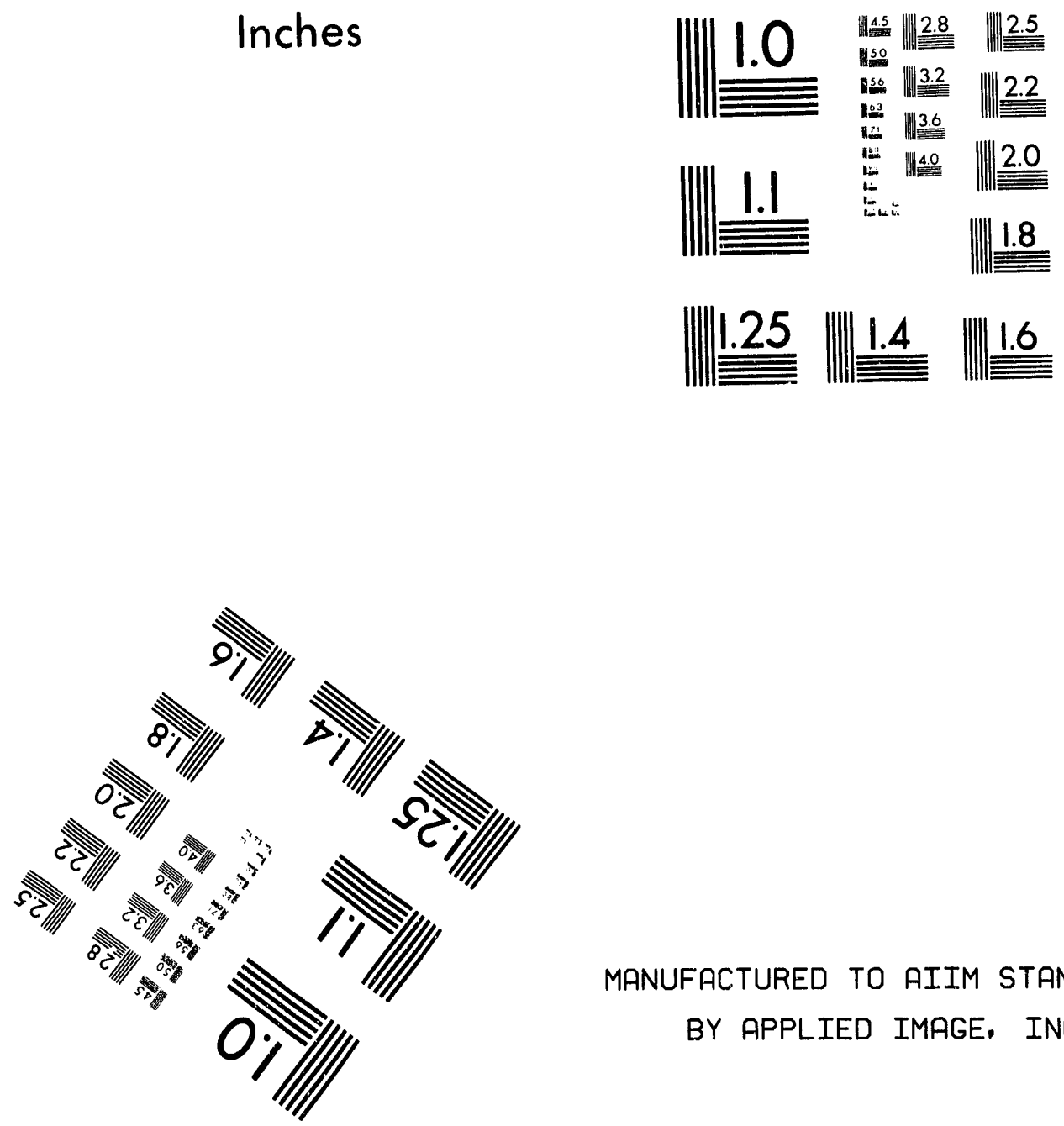

MANUFACTURED TO AIIM STANDARDS

BY APPLIED IMAGE, INC.

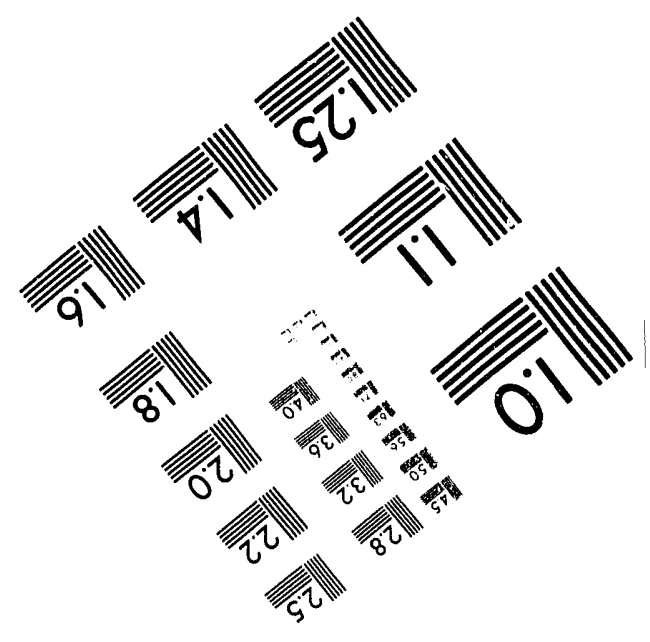



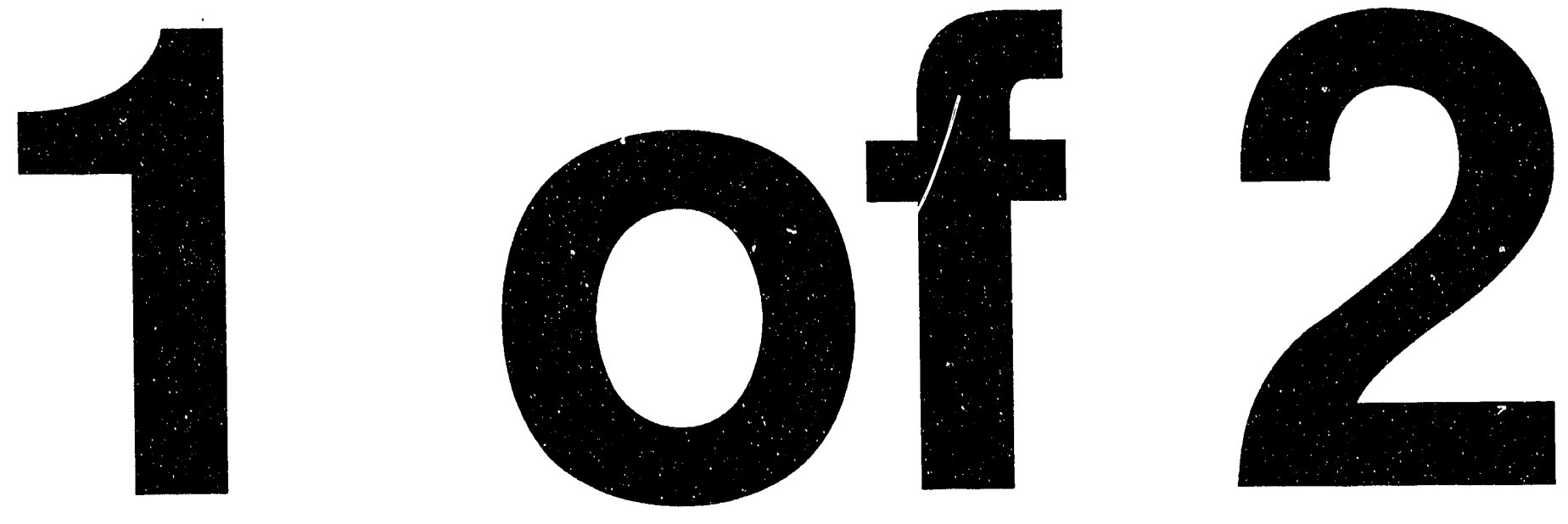
NUREG/CR-4744

Vol. 7, No. 1

ANL-92/42

\section{Long-Term Embrittlement of Cast Duplex Stainless Steels in LWR Systems}

Semiannual Report

October 1991-March 1992

Prepared by O. K. Chopra

Argonne National Laboratory

Prepared for

U.S. Nuclear Regulatory Commission

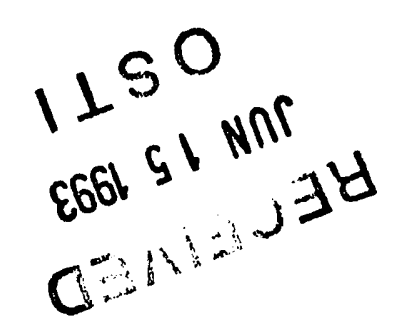




\section{AVAILABILITY NOTICE}

Availability of Reference Materials Cited in NRC Publications

Most documents clted in NRC publications will be avallable from one of the following sources:

1. The NRC Public Document Room, 2120 L Street, NW., Lower Level, Washington, DC 20555

2. The Superintendent of Documents, U.S. Government Printing Office, P.O. Box 37082, Washington, DC 20013-7082

3. The National Technical Information Service. Springfield, VA 22161

Although the llsting that follows represents the majority of docurnents clted in NRC publications, it is not intended to be exhaustive.

Referenced documents available for inspection and copying for a fee from the NRC Public Document Room Include NRC correspondence and internal NRC memoranda; NRC bulletins, clrculars, information notices. Inspection and investigation notices; licensee event reports; verdor reports and correspondence: Commission papers: and applicant and licensee documents and correspondence.

The following documents In the NUREG serles are available for purchase from the GPO Sales Program: formal NRC staff and contractor reports, NRC-sponsored conference proceedings, international agreement reports, grant publications, and NRC booklets and brochures. Also available are regulatory guides, NRC regulations in the Code of Federal Regulations, and Nuclear Regulatory Commission Issuances.

Documents avallable from the National Technical Information Service Include NUREG-series reports and technical reports prepared by other Federal agencies and reports prepared by the Atomic Energy Commission, forerunner agency to the Nuclear Regulatory Commission.

Documents avallable from public and special technical libraries include all open literature items, such as books, Journal articles, and transactions. Federal Register notices, Federal and State legislation, and congressional reports can usually be obtained from these libraries.

Documents such as theses, dissertations, foreign reports and translations, and non-NRC conference proceedings are available for purchase from the organization sponsoring the publication cited.

Single coples of NRC dratt reports are avallable free, to the extent of supply, upon written request to the Office of Administration. Distribution and Mail Services Section, U.S. Nuclear Regulatory Commission, Washington, DC 20555.

Coples of industry codes and standards used in a substantive manner in the NRC regulatory process are maintalned at the NRC Llbrary, 7920 Norfolk Avenue, Bethesda, Maryland, for use by the public. Codes and standards are usually copyrighted and may be purchased from the originating organization or, If they are American National Standards, from the American National Standards Institute, 1430 Broadway. New York. NY 10018.

\section{DISCLAIMER NOTICE}

This report was prepared as an account of work sponsored by an agency of the United States Government. Neither the United States Government nor any agency thereof, or any of their employees, makes any warranty, expressed or implied, or assumes any legal liability of responsibility for any third party's use, or the results of such use, of any information, apparatus, product or process disclosed in this report, or represents that its use by such third party would not infringe privately owned rights. 
NUREG/CR-4744

Vol. 7, No. 1

ANL-92/42

R5

\section{Long-Term Embrittlement of Cast Duplex Stainless Steels in LWR Systems}

Semiannual Report

October 1991-March 1992

Manuscript Completed: February 1993

Date Published: May 1993

Prepared by

O. K. Chopra

Argonne National Laboratory

9700 South Cass Avenue

Argonne, IL 60439

Prepared for

Division of Engineering

Office of Nuclear Regulatory Research

U.S. Nuclear Regulatory Commission

Washington, DC 20555

NRC FIN A2243 


\section{Previous Documents in Series}

Long-Term Embrittlement of Cast Duplex Stainless Steels in LWR Systems: Annual Report, October 1982-September 1983, NUREG/CR-3857, ANL-84-44 (August 1984).

Long-Term Embrittlement of Cast Duplex Stainless Steels in LWR Systems: Annual Report, October 1983-September 1984, NUREG/CR-4204, ANL-85-20 (March 1985).

Long-Term Embrittlement of Cast Duplex Stainless Steels in LWR Systems: Annual Report, October 1984-September 1985, NUREG/CR-4503, ANL-86-3 (January 1986).

Long-Term Embrittlement of Cast Duplex Stainless Steels in LWR Systems: Semiannual Report, October 1985-March 1986, NUREG/CR-4744 Vol. I, No. 1, ANL-86-54 (January 1987).

Long-Term Embrittlement of Cast Duplex Stainless Steels in LWR Systems: Semiannual Report, April-September 1986, NUREG/CR-4744 Vol. I, No. 2, ANL-87-16 (March 1987).

Long-Term Embrittlement of Cast Duplex Stainless Steels in LWR Systems: Semiannual Report, October 1986-March 1987, NUREG/CR-4744, Vol. 2, No. 1, ANL-87-45 (July 1987).

Long-Term Embrittlement of Cast Duplex Stainless Steels in LWR Systems: Semiannual Report, April-September 1987, NUREG/CR-4744, Vol. 2, No. 2, ANL-89/6 (August 1989).

Long-Term Embrittlement of Cast Duplex Stainless Steels in LWR Systems: Semiannual Report, October 1987-March 1988, NUREG/CR-4744, Vol. 3, No. 1, ANL-89/22 (February 1990).

Long-Term Embrittlement of Cast Duplex Stainless Steels in LWR Systems: Semiannual Report, Aprll-September 1988, NUREG/CR-4744, Vol. 3, No. 2, ANL-90/5 (August 1990).

Long-Term Embrittlement of Cast Duplex Stainless Steels in LWR Systems: Semiannual Report, October 1988-March 1989, NUREG/CR-4744, Vol. 4, No. 1, ANL-90/44 (May 1991).

Long-Term Embrittlement of Cast Duplex Stainless Steels in LWR Systems: Semiannual Report, April-September 1989, NUREG/CR-4744, Vol. 4, No. 2, ANL-90/49 (June 1991).

Long-Term Embrittlement of Cast Duplex Stainless Steels in LWR Systems: Semiannual Report, October 1989-March 1990. NUREG/CR-4744, Vol. 5, No. 1, ANL-91/7 (July 1991).

Long-Term Embrittlement of Cast Duplex Stainless Steels in LWR Systems: Semiannual Report, Aprll-September 1990, NUREG/CR-4744, Vol. 5, No. 2, ANL-91/10 (July 1991).

Long-Term Embrittlement of Cast Duplex Stainless Steels in LWR Systems: Semiannual Report, October 1990-March 1991, NUREG/CR-4744, Vol. 6, No. 1, ANL-91/22 (August 1992).

Long-Term Embrittlement of Cast Duplex Stainless Steels in LWR Systems: Semiannual Report, Aprll-September 1991, NUREG/CR-4744, Vol. 6, No. 2, ANL-92/32 (November 1992). 


\title{
Long-Term Embrittlement of Cast Duplex Stainless Steels in LWR Systems
}

by

O. K. Chopra

\begin{abstract}
This progress report summarizes work performed by Argonne National Laboratory on long-term thermal embrittlement of cast duplex stainless steels in LWR systems during the six months from October 1991 to March 1992. Charpy-impact, tensile, and fracture toughness $\mathrm{J}-\mathrm{R}$ curve data are presented for several heats of cast stainless steel that were aged $10,000-58,000 \mathrm{~h}$ at 290,320 , and $350^{\circ} \mathrm{C}$. The results indicate that thermal aging decreases the fracture toughness of cast stainless steels. In general, CF-3 steels are the least sensitive to thermal aging and $C F-8 M$ steels are the most sensitive. The values of fracture toughness $\mathrm{J}_{I C}$ and tearing modulus for $\mathrm{CF}-8 \mathrm{M}$ steels can be as low as $\approx 90 \mathrm{~kJ} / \mathrm{m}^{2}$ and $\approx 60$, respectively. The fracture toughness data are consistent with the Charpy-impact results, 1.e., unaged and aged steels that show low impact energy also exhibit lower fracture toughness. All steels reach a minimum saturation fracture toughness after thermal aging; the time to reach saturation depends on the aging temperature. The results also indicate that low-strength cast stainless steels are generally insensitive to thermal aging.
\end{abstract}




\section{Contents}

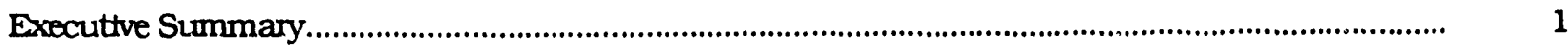

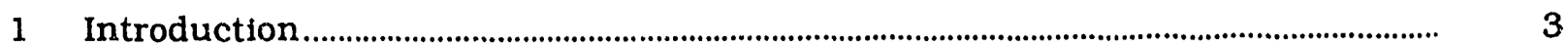

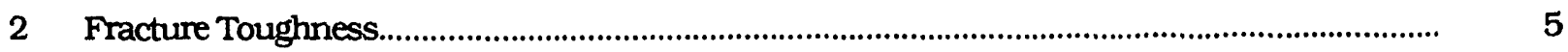

2.1 Unaged Cast Stainless Steels............................................................................ $\quad 5$

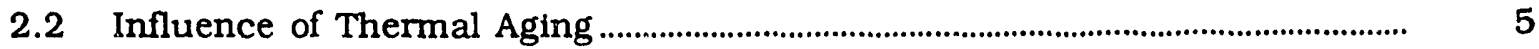

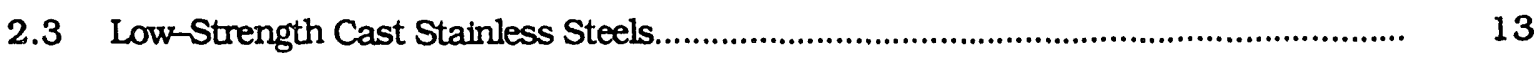

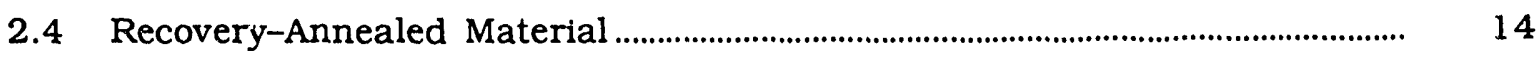

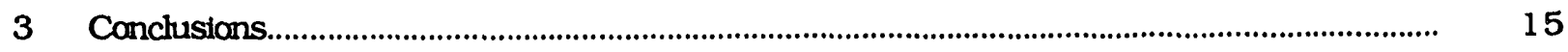

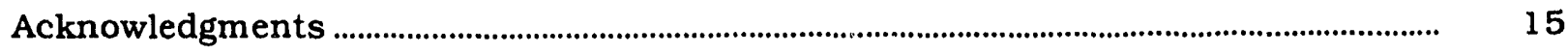

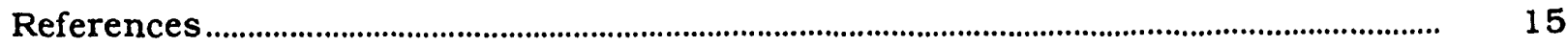

Appendix: J-R Curve Characterization ....................................................................................... A-1

\section{List of Figures}

1. Fracture toughness J-R curves for centrifugally and static-cast stainless steels at room temperature and at $290^{\circ} \mathrm{C}$

2. Fracture toughness J-R curves for wrought stainless steels at temperatures $\geq 290^{\circ} \mathrm{C}$ and lower-bound $\mathrm{J}-\mathrm{R}$ curve for static-cast stainless steel

3. Effect of aging time and temperature on the fracture toughness $J-R$ curves at room temperature and at $290^{\circ} \mathrm{C}$ for static-cast Heat 68

4. Effect of aging time and temperature on the fracture toughness $J-R$ curves at room temperature and at $290^{\circ} \mathrm{C}$ for static-cast Heat 69.

5. Effect of aging time and temperature on the fracture toughness J-R curves at room temperature and at $290^{\circ} \mathrm{C}$ for static-cast Heat 75.

6. Effect of aging time and temperature on the fracture toughness $\mathrm{J}-\mathrm{R}$ curves at room temperature and at $290^{\circ} \mathrm{C}$ for static-cast Heat 74 
7. Effect of aging time and temperature on the fracture toughness $\mathrm{J}-\mathrm{R}$ curves at room temperature and at $290^{\circ} \mathrm{C}$ for static-cast Heat $\mathrm{Cl}$

8. Effect of aging time and temperature on the fracture toughness $\mathrm{J}-\mathrm{R}$ curves at room temperature and at $290^{\circ} \mathrm{C}$ for centrifugally cast Heat $\mathrm{P} 1$

9. Effect of aging time and temperature on the fracture toughness $J-R$ curves at room temperature and at $290^{\circ} \mathrm{C}$ for centrifugally cast Heat P2

10. Reembrittlement of static-cast Heats 68 and 75 .

A-1. Configuration of compact-tension test specimen.

A-6

A-2. Deformation and modified J-R curves at room temp. for Heat P2 aged $58,000 \mathrm{~h}$ at $290^{\circ} \mathrm{C}$

A-14

A-3. Deformation $J_{I C}$ at room temp. for Heat P2 aged $58.000 \mathrm{~h}$ at $290^{\circ} \mathrm{C}$

A-15

A-4. Modified $\mathrm{J}_{\mathrm{IC}}$ at room temp. for Heat $\mathrm{P} 2$ aged $58,000 \mathrm{~h}$ at $290^{\circ} \mathrm{C}$

A-15

A-5. Deformation and modified J-R curves at room temp. for Heat P2 aged $55,000 \mathrm{~h}$ at $320^{\circ} \mathrm{C}$

A-18

A-6. Deformation $\mathrm{J}_{\mathrm{IC}}$ at room temp. for Heat $\mathrm{P} 2$ aged $55,000 \mathrm{~h}$ at $320^{\circ} \mathrm{C}$

A-19

A-7. Modified $\mathrm{J}_{\mathrm{IC}}$ at room temp. for Heat $\mathrm{P} 2$ aged $55,000 \mathrm{~h}$ at $320^{\circ} \mathrm{C}$.

A-19

A-8. Deformation and modified J-R curves at $290^{\circ} \mathrm{C}$ for Heat P2 aged $58,000 \mathrm{~h}$ at $290^{\circ} \mathrm{C}$

A-22

A-9. Deformation $\mathrm{J}_{\mathrm{IC}}$ at $290^{\circ} \mathrm{C}$ for Heat $\mathrm{P} 2$ aged $58,000 \mathrm{~h}$ at $290^{\circ} \mathrm{C}$.

A-23

A-10. Modified $\mathrm{J}_{\mathrm{IC}}$ at $290^{\circ} \mathrm{C}$ for Heat $\mathrm{P} 2$ aged $58,000 \mathrm{~h}$ at $290^{\circ} \mathrm{C}$

A-23

A-11. Deformation and modified J-R curves at $290^{\circ} \mathrm{C}$ for Heat P2 aged $55,000 \mathrm{~h}$ at $320^{\circ} \mathrm{C}$

A-12. Deformation $\mathrm{J}_{\mathrm{IC}}$ at $290^{\circ} \mathrm{C}$ for Heat $\mathrm{P} 2$ aged $55,000 \mathrm{~h}$ at $320^{\circ} \mathrm{C}$.

A-13. Modified $\mathrm{J}_{\mathrm{IC}}$ at $290^{\circ} \mathrm{C}$ for Heat $\mathrm{P} 2$ aged $55,000 \mathrm{~h}$ at $320^{\circ} \mathrm{C}$

A-14. Deformation and modified J-R curves at room temp. for Heat 69 aged $50,000 \mathrm{~h}$ at $320^{\circ} \mathrm{C}$

A-15. Deformation $\mathrm{J}_{\mathrm{IC}}$ at room temp. for Heat 69 aged $50,000 \mathrm{~h}$ at $320^{\circ} \mathrm{C}$

A-16. Modified $\mathrm{J}_{\mathrm{IC}}$ at room temp. for Heat 69 aged $50,000 \mathrm{~h}$ at $320^{\circ} \mathrm{C}$. 
A-17. Deformation and modified $J-R$ curves at room temp. for Heat 69 aged $50,000 \mathrm{~h}$ at $320^{\circ} \mathrm{C}$

A-18. Deformation $\mathrm{J}_{\mathrm{IC}}$ at room temp. for Heat 69 aged $50,000 \mathrm{~h}$ at $320^{\circ} \mathrm{C}$.

A-19. Modified $\mathrm{J}_{\mathrm{IC}}$ at room temp. for Heat 69 aged $50,000 \mathrm{~h}$ at $320^{\circ} \mathrm{C}$

A-20. Deformation and modified $J-R$ curves at $290^{\circ} \mathrm{C}$ for Heat 69 aged $50,000 \mathrm{~h}$ at $320^{\circ} \mathrm{C}$

A-2 1. Deformation $\mathrm{J}_{\mathrm{IC}}$ at $290^{\circ} \mathrm{C}$ for Heat 69 aged $50,000 \mathrm{~h}$ at $320^{\circ} \mathrm{C}$

A-22. Modified $\mathrm{J}_{\mathrm{IC}}$ at $290^{\circ} \mathrm{C}$ for Heat 69 aged $50,000 \mathrm{~h}$ at $320^{\circ} \mathrm{C}$

A-23. Deformation and modified J-R curves at room temp. for Heat P1 aged $58,000 \mathrm{~h}$ at $290^{\circ} \mathrm{C}$

A-24. Deformation $\mathrm{J}_{\mathrm{IC}}$ at room temp. for Heat $\mathrm{P} 1$ aged $58,000 \mathrm{~h}$ at $290^{\circ} \mathrm{C}$.

A-43

A-25. Modified $\mathrm{J}_{\mathrm{IC}}$ at room temp. for Heat $\mathrm{Pl}$ aged $58,000 \mathrm{~h}$ at $290^{\circ} \mathrm{C}$

$A-43$

A-26. Deformation and modified $J-R$ curves at room temp. for Heat $P 1$ aged $55,000 \mathrm{~h}$ at $320^{\circ} \mathrm{C}$

A-27. Deformation $\mathrm{J}_{\mathrm{IC}}$ at room temp. for Heat $\mathrm{P} 1$ aged $55,000 \mathrm{~h}$ at $320^{\circ} \mathrm{C}$.

A-28. Modified $\mathrm{J}_{\mathrm{IC}}$ at room temp. for Heat $\mathrm{Pl}$ aged $55,000 \mathrm{~h}$ at $320^{\circ} \mathrm{C}$

$A-47$

A-29. Deformation and modified $\mathrm{J}-\mathrm{R}$ curves at $290^{\circ} \mathrm{C}$ for Heat $\mathrm{P} 1$ aged $58,000 \mathrm{~h}$ at $290^{\circ} \mathrm{C}$

A-30. Deformation $\mathrm{J}_{\mathrm{IC}}$ at $290^{\circ} \mathrm{C}$ for Heat $\mathrm{Pl}$ aged $58,000 \mathrm{~h}$ at $290^{\circ} \mathrm{C}$

A-31. Modified $\mathrm{J}_{\mathrm{IC}}$ at $290^{\circ} \mathrm{C}$ for Heat $\mathrm{Pl}$ aged $58,000 \mathrm{~h}$ at $290^{\circ} \mathrm{C}$

A-32. Deformation and modified $\mathrm{J}-\mathrm{R}$ curves at $290^{\circ} \mathrm{C}$ for Heat $\mathrm{Pl}$ aged $55,000 \mathrm{~h}$ at $320^{\circ} \mathrm{C}$

A-33. Deformation $\mathrm{J}_{\mathrm{IC}}$ at $290^{\circ} \mathrm{C}$ for Heat $\mathrm{Pl}$ aged $55,000 \mathrm{~h}$ at $320^{\circ} \mathrm{C}$

A-55

A-34. Modified $\mathrm{J}_{\mathrm{IC}}$ at $290^{\circ} \mathrm{C}$ for Heat $\mathrm{Pl}$ aged $55,000 \mathrm{~h}$ at $320^{\circ} \mathrm{C}$.

A-35. Deformation and modified $J-R$ curves at room temp. for Heat $\mathrm{C} 1$ aged $30,000 \mathrm{~h}$ at $320^{\circ} \mathrm{C}$

A-36. Deformation $\mathrm{J}_{\mathrm{IC}}$ at room temp. for Heat $\mathrm{Cl}$ aged $30,000 \mathrm{~h}$ at $320^{\circ} \mathrm{C}$ 
A-38. Deformation and modified J-R curves at room temp. for Heat $\mathrm{C} 1$ aged $10,000 \mathrm{~h}$ at $350^{\circ} \mathrm{C}$.

A-39. Deformation $\mathrm{J}_{\mathrm{IC}}$ at room temp. for Heat $\mathrm{Cl}$ aged $10,000 \mathrm{~h}$ at $350^{\circ} \mathrm{C} \ldots \ldots \ldots \ldots \ldots . . . . . . . . .63$

A-40. Modified $\mathrm{J}_{\mathrm{IC}}$ at room temp. for Heat $\mathrm{Cl}$ aged $10,000 \mathrm{~h}$ at $350^{\circ} \mathrm{C}$

A-41. Deformation and modified J-R curves at room temp. for Heat $\mathrm{Cl}$ aged $30,000 \mathrm{~h}$ at $350^{\circ} \mathrm{C}$.

A-42. Deformation $\mathrm{J}_{\mathrm{IC}}$ at room temp. for Heat $\mathrm{C} 1$ aged $30,000 \mathrm{~h}$ at $350^{\circ} \mathrm{C}$.

A-43. Modified $\mathrm{J}_{\mathrm{IC}}$ at room temp. for Heat $\mathrm{Cl}$ aged $30,000 \mathrm{~h}$ at $350^{\circ} \mathrm{C}$

A-44. Deformation and modified $\mathrm{J}-\mathrm{R}$ curves at $290^{\circ} \mathrm{C}$ for Heat $\mathrm{C} 1$ aged $30,000 \mathrm{~h}$ at $320^{\circ} \mathrm{C}$

A-45. Deformation $\mathrm{J}_{\mathrm{IC}}$ at $290^{\circ} \mathrm{C}$ for Heat $\mathrm{Cl}$ aged $30,000 \mathrm{~h}$ at $320^{\circ} \mathrm{C}$

A-71

A-46. Modifled $\mathrm{J}_{\mathrm{IC}}$ at $290^{\circ} \mathrm{C}$ for Heat $\mathrm{C} 1$ aged $30,000 \mathrm{~h}$ at $320^{\circ} \mathrm{C}$

A-71

A-47. Deformation and modified J-R curves at $290^{\circ} \mathrm{C}$ for Heat $\mathrm{Cl}$ aged $10,000 \mathrm{~h}$ at $350^{\circ} \mathrm{C}$

A-48. Deformation $\mathrm{J}_{\mathrm{IC}}$ at $290^{\circ} \mathrm{C}$ for Heat $\mathrm{Cl}$ aged $10,000 \mathrm{~h}$ at $350^{\circ} \mathrm{C}$

A-49. Modified $\mathrm{J}_{\mathrm{IC}}$ at $290^{\circ} \mathrm{C}$ for Heat $\mathrm{Cl}$ aged $10,000 \mathrm{~h}$ at $350^{\circ} \mathrm{C}$.

A-75

A-50. Deformation and modified $\mathrm{J}-\mathrm{R}$ curves at $290^{\circ} \mathrm{C}$ for Heat $\mathrm{Cl}$ aged $30,000 \mathrm{~h}$ at $350^{\circ} \mathrm{C}$

A-51. Deformation $\mathrm{J}_{\mathrm{IC}}$ at $290^{\circ} \mathrm{C}$ for Heat $\mathrm{Cl}$ aged $30,000 \mathrm{~h}$ at $350^{\circ} \mathrm{C}$

A-52. Modified $\mathrm{J}_{\mathrm{IC}}$ at $290^{\circ} \mathrm{C}$ for Heat $\mathrm{Cl}$ aged $30,000 \mathrm{~h}$ at $350^{\circ} \mathrm{C}$.

A-53. Deformation and modified J-R curves at room temp. for Heat 68 aged $52,600 \mathrm{~h}$ at $320^{\circ} \mathrm{C}$

A-54. Deformation $\mathrm{J}_{\mathrm{IC}}$ at room temp. for Heat 68 aged $52,600 \mathrm{~h}$ at $320^{\circ} \mathrm{C}$

A-55. Modified $\mathrm{J}_{\mathrm{IC}}$ at room temp. for Heat 68 aged $52,600 \mathrm{~h}$ at $320^{\circ} \mathrm{C}$.

A-56. Deformation and modified $J-R$ curves at room temp. for Heat 68 aged $52,600 \mathrm{~h}$ at $320^{\circ} \mathrm{C}$

A-57. Deformation $\mathrm{J}_{\mathrm{IC}}$ at room temp. for Heat 68 aged $52,600 \mathrm{~h}$ at $320^{\circ} \mathrm{C}$

A-58. Modified $\mathrm{J}_{\mathrm{IC}}$ at room temp. for Heat 68 aged $52,600 \mathrm{~h}$ at $320^{\circ} \mathrm{C}$ 
A-59. Deformation and modified J-R curves at room temp. for Heat 68 aged $10,000 \mathrm{~h}$ at $400^{\circ} \mathrm{C}$, then recovery-annealed and aged again for $10,000 \mathrm{~h}$ at $400^{\circ} \mathrm{C}$

A-60. Deformation $\mathrm{J}_{\mathrm{IC}}$ at room temp. for Heat 68 aged $10,000 \mathrm{~h}$ at $400^{\circ} \mathrm{C}$, then recovery-annealed and aged again for $10,000 \mathrm{~h}$ at $400^{\circ} \mathrm{C}$

A-61. Modified $\mathrm{J}_{\mathrm{IC}}$ at room temp. for Heat 68 aged $10,000 \mathrm{~h}$ at $400^{\circ} \mathrm{C}$, then recovery-annealed and aged again for $10,000 \mathrm{~h}$ at $400^{\circ} \mathrm{C}$

A-62. Deformation and modified J-R curves at $290^{\circ} \mathrm{C}$ for Heat 68 aged $52,600 \mathrm{~h}$ at $320^{\circ} \mathrm{C}$

A-63. Deformation $\mathrm{JIC}_{\mathrm{IC}}$ at $290^{\circ} \mathrm{C}$ for Heat 68 aged $52,600 \mathrm{~h}$ at $320^{\circ} \mathrm{C}$

A-64. Modified $\mathrm{J}_{\mathrm{IC}}$ at $290^{\circ} \mathrm{C}$ for Heat 68 aged $52,600 \mathrm{~h}$ at $320^{\circ} \mathrm{C}$

A-65. Deformation and modified $J-R$ curves at room temp. for unaged Heat 74

A-98

A-66. Deformation $J_{I C}$ at room temp. for unaged Heat 74

A-99

A-67. Modified $\mathrm{J}_{\mathrm{IC}}$ at room temp. for unaged Heat $\mathbf{7 4}$

A-99

A-68. Deformation and modified $J-R$ curves at room temp. for Heat 74 aged $50,000 \mathrm{~h}$ at $320^{\circ} \mathrm{C}$

A-102

A-69. Deformation $\mathrm{JIC}_{\mathrm{IC}}$ at room temp. for Heat 74 aged $50,000 \mathrm{~h}$ at $320^{\circ} \mathrm{C}$

A-103

A-70. Modified $\mathrm{J}_{\mathrm{IC}}$ at room temp. for Heat 74 aged $50,000 \mathrm{~h}$ at $320^{\circ} \mathrm{C}$

A-103

A-71. Deformation and modified J-R curves at room temp. for Heat 74 aged $50,000 \mathrm{~h}$ at $320^{\circ} \mathrm{C}$

A-106

A-72. Deformation $J_{I C}$ at room temp. for Heat 74 aged $50,000 \mathrm{~h}$ at $320^{\circ} \mathrm{C}$

A-107

A-73. Modified $\mathrm{J}_{\mathrm{IC}}$ at room temp. for Heat 74 aged $50,000 \mathrm{~h}$ at $320^{\circ} \mathrm{C}$

A-107

A-74. Deformation and modified $J-R$ curves at $290^{\circ} \mathrm{C}$ for unaged Heat 74

A-110

A-75. Deformation $\mathrm{J}_{\mathrm{IC}}$ at $290^{\circ} \mathrm{C}$ for unaged Heat 74

A-111

A-76. Modified $\mathrm{J}_{\mathrm{IC}}$ at $290^{\circ} \mathrm{C}$ for unaged Heat 74

A-111

A-77. Deformation and modified $J-R$ curves at $290^{\circ} \mathrm{C}$ for Heat 74 aged $52,600 \mathrm{~h}$ at $320^{\circ} \mathrm{C}$

A-78. Deformation $\mathrm{J}_{\mathrm{IC}}$ at $290^{\circ} \mathrm{C}$ for Heat 74 aged $52,600 \mathrm{~h}$ at $320^{\circ} \mathrm{C}$ 
A-80. Deformation and modified $J-R$ curves at room temp. for Heat 75 aged $50,000 \mathrm{~h}$ at $320^{\circ} \mathrm{C}$

A-81. Deformation $\mathrm{J}_{\mathrm{IC}}$ at room temp. for Heat 75 aged $50,000 \mathrm{~h}$ at $320^{\circ} \mathrm{C}$

A-119

A-82. Modified $\mathrm{J}_{\mathrm{IC}}$ at room temp. for Heat 75 aged $50,000 \mathrm{~h}$ at $320^{\circ} \mathrm{C}$

A-119

A-83. Deformation and modified $J-R$ curves at room temp. for Heat 75 aged $50,000 \mathrm{~h}$ at $320^{\circ} \mathrm{C}$

A-84. Deformation $\mathrm{J}_{I C}$ at room temp. for Heat 75 aged $50,000 \mathrm{~h}$ at $320^{\circ} \mathrm{C}$

A-123

A-85. Modified $\mathrm{J}_{\mathrm{IC}}$ at room temp. for Heat 75 aged $50,000 \mathrm{~h}$ at $320^{\circ} \mathrm{C}$

A-123

A-86. Deformation and modified $J-R$ curves at room temp. for Heat 75 aged $10,000 \mathrm{~h}$ at $400^{\circ} \mathrm{C}$, then recovery-annealed and aged again for $10,000 \mathrm{~h}$ at $400^{\circ} \mathrm{C}$

A-87. Deformation $J_{I C}$ at room temp. for Heat 75 aged $10,000 \mathrm{~h}$ at $400^{\circ} \mathrm{C}$, then recovery-annealed and aged again for $10,000 \mathrm{~h}$ at $400^{\circ} \mathrm{C}$

A-88. Modified $\mathrm{J}_{\mathrm{IC}}$ at room temp. for Heat 75 aged $10,000 \mathrm{~h}$ at $400^{\circ} \mathrm{C}$, then recovery-annealed and aged again for $10,000 \mathrm{~h}$ at $400^{\circ} \mathrm{C}$

A-89. Deformation and modified $J-R$ curves at room temp. for Heat 75 aged $50,000 \mathrm{~h}$ at $320^{\circ} \mathrm{C}$

A-90. Deformation $\mathrm{J}_{\mathrm{IC}}$ at room temp. for Heat 75 aged $50,000 \mathrm{~h}$ at $320^{\circ} \mathrm{C}$

A-131

A-91. Modified $\mathrm{J}_{\mathrm{IC}}$ at room temp. for Heat 75 aged $50,000 \mathrm{~h}$ at $320^{\circ} \mathrm{C}$

A-131

\section{List of Tables}

1. Product form, chemical composition, hardness, and ferrite morphology of various heats of cast stainless steel.

A-1. Results from fracture toughness tests conducted at ANL and MEA on nine heats of cast stainless steel

A-2. Test data for specimen P2T-19.

A-12

A-3. Deformation $J_{I C}$ and $J-R$ curve results for specimen P2T-19.

A-13

A-4. Modified $J_{I C}$ and $J-R$ curve results for specimen P2T-19

$A-14$

A-5. Test data for specimen P2B-16 
A

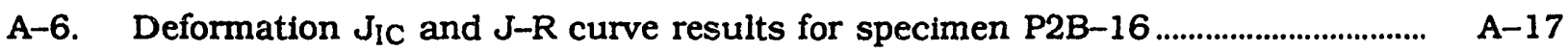

A-7. Modified $J_{I C}$ and $J-R$ curve results for specimen P2B-16 .................................... A-18

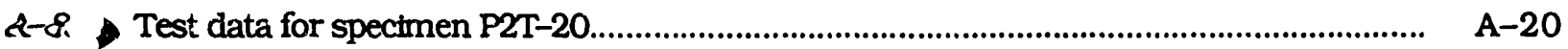

A-9. Deformation $J_{I C}$ and $J-R$ curve results for specimen P2T-20.............................. A-2 1

A-10. Modified $J_{I C}$ and J-R curve results for specimen P2T-20..................................... A-22

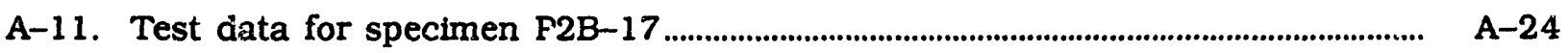

A-12. Deformation $\mathrm{J}_{\mathrm{IC}}$ and $\mathrm{J}-\mathrm{R}$ curve results for specimen $\mathrm{P} 2 \mathrm{~B}-17$...................................25

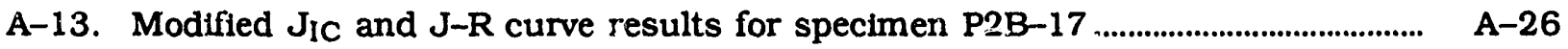

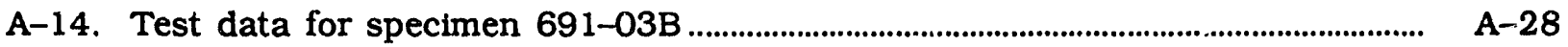

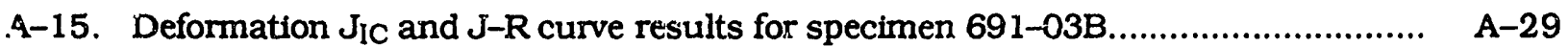

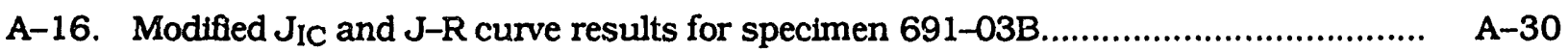

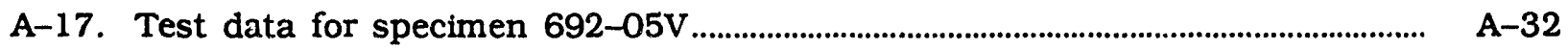

A-18. Deformation $J_{I C}$ and $J-R$ curve results for specimen $692-05 \mathrm{~V}$.............................. A-33

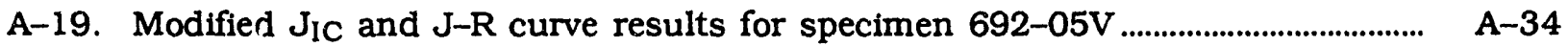

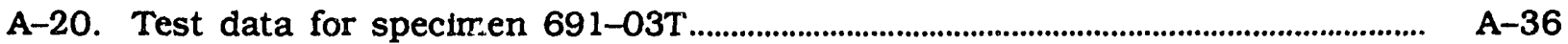

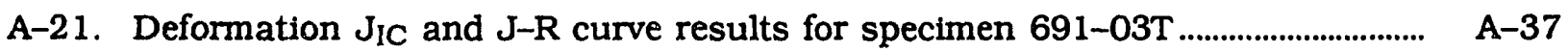

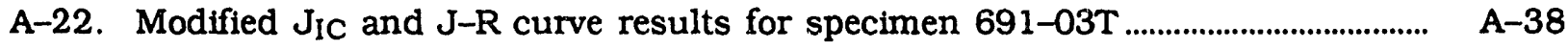

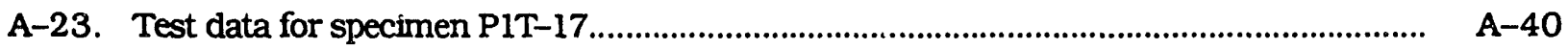

A-24. Deformation $J_{I C}$ and $J-R$ curve results for specimen P1B-17 ................................ A-41

A-25. Modified $J_{I C}$ and $J-R$ curve results for specimen P1B-17 .................................... A-42

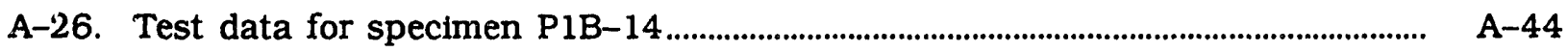

A-27. Deformation $J_{I C}$ and $J-R$ curve results for specimen PIB-14 .............................. A-45

A-28. Modified $\mathrm{J}_{\mathrm{IC}}$ and $\mathrm{J}-\mathrm{R}$ curve results for specimen P1B-14 ...................................... A-46

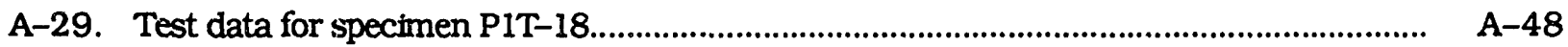

A-30. Deformation $J_{I C}$ and $J-R$ curve results for specimen P1T-18 ............................. A-49 
A-31. Modified $\mathrm{J}_{\mathrm{IC}}$ and $\mathrm{J}-\mathrm{R}$ curve results for specimen PIT-18 ..................................... A-50

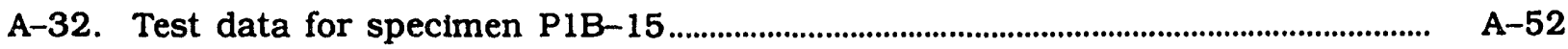

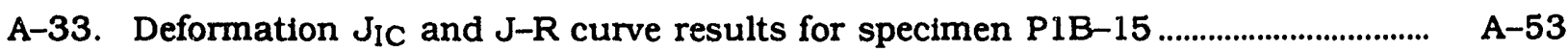

A-34. Modified $J_{I C}$ and $J-R$ curve results for specimen P1B-15 .................................... A-54

A-35. Test data for specimen C1B-18 ................................................................................ A-56

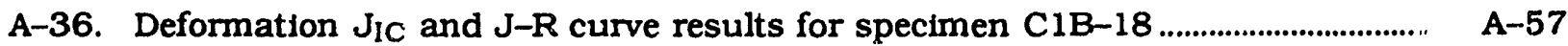

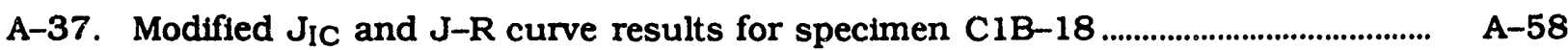

A-38. Test data for specimen C1B-08

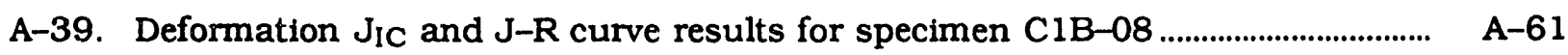

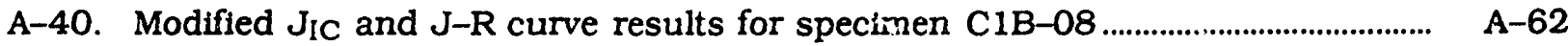

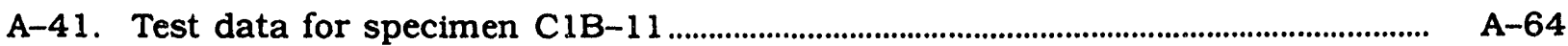

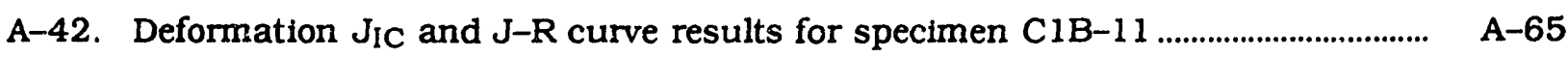

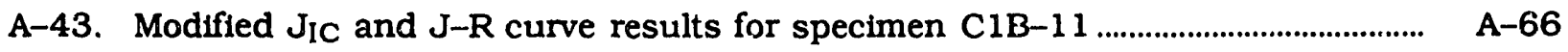

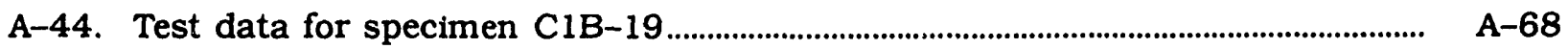

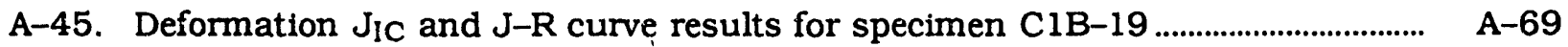

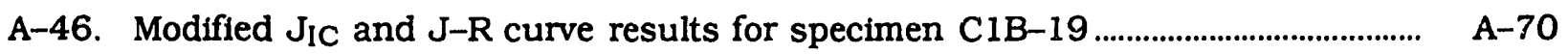

A-47. Test data for specimen C1B-09 ................................................................................. A-72

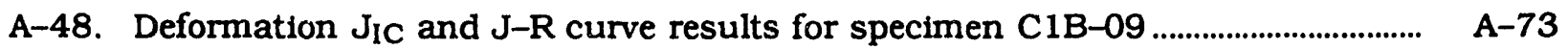

A-49. Modified $\mathrm{J}_{\mathrm{I}}$ and $\mathrm{J}-\mathrm{R}$ curve results for specimen $\mathrm{C} 1 \mathrm{~B}-09$...................................... A-74

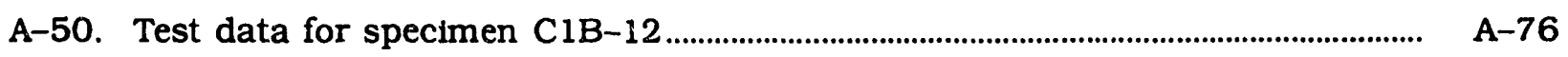

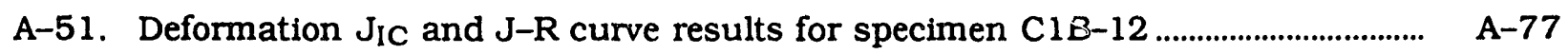

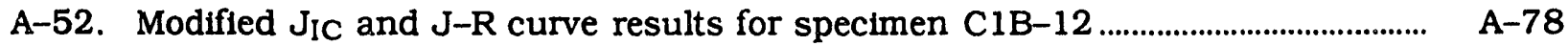

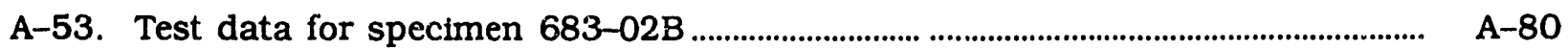

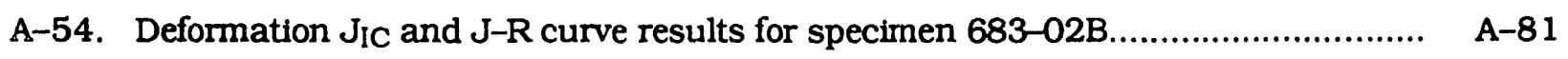

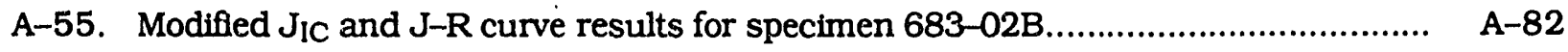


A-56. Test data for specimen $682-05 \mathrm{~V}$

A-57. Deformation $\mathrm{J}_{\mathrm{IC}}$ and $\mathrm{J}-\mathrm{R}$ curve results for specimen $682-05 \mathrm{~V}$...

A-58. Modified $J_{I C}$ and $J-R$ curve results for specimen $682-05 \mathrm{~V}$.

A-86

A-59. Test data for specimen $682-08 B$

A-88

A-60. Deformation $J_{I C}$ and $J-R$ curve results for specimen $682-08 B$.

A-89

A-61. Modiffed $J_{I C}$ and $J-R$ curve results for specimen $682-08 B$.

A-62. Test data for specimen $683-02 T$.

A-92

A-63. Deformation $J_{I C}$ and $J-R$ curve results for specimen 683-02T

A-93

A-64. Modified $J_{I C}$ and J-R curve results for specimen $683-02 T$.

A-94

A-65. Test data for specimen $745-03 \mathrm{~V}$

A-96

A-66. Deformation $J_{I C}$ and $J-R$ curve results for specimen $745-03 V$

A-67. Modified $J_{I C}$ and $J-R$ curve results for specimen $745-03 \mathrm{~V}$

A-68. Test data for specimen $743-03 B$

A-100

A-69. Deformation $J_{I C}$ and $J-R$ curve results for specimen $743-03 B$.

A-101

A-70. Modified $J_{1 C}$ and $J-R$ curve results for specimen 743-03B.

A-102

A-71. Test data for specimen $744-02 \mathrm{~V}$

A-10?

A-72. Deformation $J_{I C}$ and $J-R$ curve results for specimen 744-02V

A-105

A-73. Modified $\mathrm{J}_{\mathrm{IC}}$ and $\mathrm{J}-\mathrm{R}$ curve results for specimen $744-02 \mathrm{~V}$.

A-106

A-74. Test data for specimen $743-07 \mathrm{~T}$

A-108

A-75. Deformation $J_{I C}$ and $J-R$ curve results for specimen 743-07T

A-109

A-76. Modified $J_{I C}$ and $J-R$ curve results for specimen $743-07 T$.

A-1 10

A-77. Test data for specimen 743-03T.

A-1 12

A-78. Deformation $J_{I C}$ and $J-R$ curve results for specimen 743-03T

A-113

A-79. Modified $J_{I C}$ and $J-R$ curve results for specimen $743-03 T$

A-1 14

A-80. Test data for specimen $753-02 B$

A-116 
A-81. Deformation $\mathrm{J}_{I C}$ and $\mathrm{J}-\mathrm{R}$ curve results for specimen 753-02B.

A-82. Modified $\mathrm{J}_{I C}$ and $\mathrm{J}-\mathrm{R}$ curve results for specimen $753-02 B$. A-118

A-83. Test data for specimen $752-05 \mathrm{~V}$. A-120

A-84. Deformation $J_{I C}$ and $J-R$ curve results for specimen $752-05 V$

A-85. Modified $J_{I C}$ and $J-R$ curve results for specimen $752-05 V$ A-122

A-86. Test data for specimen $753-06 \mathrm{~B}$ A-123

A-87. Deformation $J_{I C}$ and $J-R$ curve results for specimen $753-06 B$ A-124

A-88. Deformation $J_{I C}$ and $J-R$ curve results for specimen 753-06B A-125

A-89. Test data for specimen 753-02T. A-126

A-90. Deformation $J_{I C}$ and J-R curve results for specimen 753-02T A-127

A-91. Modified $J_{I C}$ and $J-R$ curve results for specimen $753-02 T$ A-128 


\section{Executive Summary}

Cast stainless steels used in pump casings, valve bodies, piping, and other components in coolant systems of light water nuclear reactors (LWRs) suffer a loss in toughness after many years of service at temperatures in the range of $280-320^{\circ} \mathrm{C}\left(\approx 536-608^{\circ} \mathrm{F}\right)$. A program is being conducted at Argonne National Laboratory to investigate the low-temperature thermal embrittlement of cast duplex stainless steels under LWR operating conditions and to evaluate possible remedies for the thermal embrittlement problem in existing and future plants. The scope of the investigation includes the following goals: (1) characterize and correlate the microstructure of in-service reactor components and laboratory-aged material with loss of fracture toughness to establish the mechanism of aging and validate the simulation of in-reactor degradation by accelerated aging, (2) establish the effects of key compositional and metallurgical variables on the kinetics and extent of thermal embrittlement, and (3) develop the methodology and correlations necessary for predicting the toughness loss suffered by cast stainless steel components during the normal and extended life of LWRs.

Microstructural and mechanical-property data have been obtained on 25 experimental heats (static-cast keel blocks and slabs) and 6 commercial heats (centrifugally cast pipes, a static-cast pump impeller, and a static-cast pump casing ring), as well as on reactor-aged material of CF-3, CF-8, and CF-8M grades of cast stainless steel. The ferrite content of the cast materials ranges from 3 to $30 \%$. Ferrite morphology for the castings containing $>5 \%$ ferrite is either lacy or acicular.

Charpy-impact, tensile, and $J-R$ curve tests have been conducted on several experimental and commercial heats of cast stainless steel that were aged up to $58,000 \mathrm{~h}$ at temperatures of $290-400^{\circ} \mathrm{C}\left(554-752^{\circ} \mathrm{F}\right)$. Results indicate that thermal aging at these temperatures increases the tensile strength and decreases the impact energy and fracture toughness of the steels. The Charpy transition curve shifts to higher temperatures. Different heats exhibit different degrees of thermal embrittlement: in general, the low-carbon CF-3 steels are the most resistant, and the molybdenum-bearing, high-carbon CF-8M steels are the least resistant to thermal embrittlement. Embrittlement of cast stainless steels results in brittle fracture associated with either cleavage of the ferrite or separation of the ferrite/austenite phase boundary. A predominantly brittle fallure occurs when either the ferrite phase is continuous, e.g., in cast material with a high ferrite content, or the ferrite/austenite phase boundary provides an easy path for crack propagation, e.g., in highcarbon grades of cast steels with phase-boundary carbides. Consequently, the amount, size, and distribution of the ferrite phase in the duplex structure and the presence of phaseboundary carbides are important parameters in controlling the degree or extent of thermal embrittlement.

Thermal aging of cast stainless steels at temperatures $<500^{\circ} \mathrm{C}\left(<932^{\circ} \mathrm{F}\right)$ leads to precipitation of additional phases in the ferrite matrix, e.g., formation of a chromium-rich $\alpha^{\prime}$ phase by spinodal decomposition; nucleation and growth of $\alpha^{\prime}$; precipitation of a nickel-and silicon-rich $\mathrm{G}$ phase, $\mathrm{M}_{23} \mathrm{C}_{6}$ carbide, and $\gamma_{2}$ (austenite); and additional precipitation and/or growth of existing carbides at the ferrite/austenite phase boundaries. The additional phases provide the strengthening mechanisms that increase strain hardening and the local tensile stress. Consequently, the critical stress level for brittle fracture is achieved at higher tem- 
peratures. The effects of material variables on the thermal embrittlement of cast stainless steels have been evaluated.

Fracture toughness $J-R$ cuive data are presented for several experimental and commercial heats of cast stainless steel that were aged 10,000-58,000 h at 290,320, and $350^{\circ} \mathrm{C}\left(554,608\right.$, and $\left.662^{\circ} \mathrm{F}\right)$. Thermal aging decreases the fracture toughness of cast stainless steels. The values of fracture toughness $J_{l C}$ and average tearing modulus for heats that are sensitive to thermal aging (e.g., CF-8M steels) are as low as $\approx 90 \mathrm{~kJ} / \mathrm{m}^{2}$ and $\approx 60$, respectively. The results also indicate that the fracture toughness of cast stainless steels can be lower than that of the wrought stainless steels. The low-strength cast stainless steels are generally insensitive to thermal aging. 
Cast duplex stainless steels used in light water reactor (LWR) systems for primary pressure-boundary components such as valve bodies, pump casings, and primary coolant piping are susceptible to thermal embrittlement at reactor operating temperatures, 1.e., 280$320^{\circ} \mathrm{C}\left(536-608^{\circ} \mathrm{F}\right)$. Aging of cast stainless steels at these temperatures causes an increase in hardness and tensile strength and a decrease in ductility, impact strength, ard fracture toughness of the material. Most studies on thermal embrittlement of cast stainless steels involve simulation of end-of-life reactor conditions by accelerated aging at higher temperatures, viz., $400^{\circ} \mathrm{C}\left(752^{\circ} \mathrm{F}\right)$, because the time period for operation of power plants $(\approx 40 \mathrm{y})$ is far longer than can generally be considered for laboratory studies. Thus, estimates of the loss of fracture toughness suffered by cast stainless steel components are based on an Arrhenius extrapolation of high-temperature data to reactor operating conditions.

A program is being conducted at Argonne National Laboratory to investigate the significance of low-temperature embrittlement of cast duplex stainless steels under LWR operating conditions and to evaluate possible remedies for thermal embrittlement problems in existing and future plants. The scope of the program includes the following goals: (1) characterize and correlate the microstructure of in-service reactor components and laboratoryaged material with loss of fracture toughness to establish the mechanism of aging and validate the simulation of in-reactor degradation by accelerated aging, (2) establish the effects of key compositional and metallurgical variables on the kinetics and extent of thermal embrittlement, and (3) develop the methodology and correlations for predicting the toughness loss suffered by cast stainless steel components during normal and extended life of LWRs.

Microstructural and mechanical-property data have been obtained on 25 experimental heats (19 in the form of static-cast keel blocks and 6 in the form of 76-mm slabs) and 6 commercial heats (centrifugally cast pipes and a static-cast pump impeller and pump casing ring), as well as on reactor-aged material of grades CF-3, CF-8, and CF-8M cast stainless steel. Specimen blanks for Charpy-impact, tensile, and fracture toughness J-R curve tests were aged at $290,320,350$, and $400^{\circ} \mathrm{C}\left(554,608,662\right.$, and $\left.752^{\circ} \mathrm{F}\right)$ for times up to $58,000 \mathrm{~h}$. The reactor-aged material is from the recirculating-pump cover plate assembly of the KRB reactor, which was in service in Gundremmingen, Germany, for $\approx 8 \mathrm{yr}$ at $284^{\circ} \mathrm{C}$ $\left(543^{\circ} \mathrm{F}\right)$. Data on chemical composition, ferrite content, hardness, ferrite morphology, and grain structure of the experimental and commercial heats have been reported earlier. 1 The chemical composition, hardness, and ferrite content and distribution of the cast materials are given in Table 1. Results of microstructural characterization and mechanical-property data from Charpy-impact, tensile, and J-R curve tests on 16 heats of cast stainless steel aged up to $30,000 \mathrm{~h}$ at temperatures between 290 and $450^{\circ} \mathrm{C}$ have also been presented earlier. $1-12$

Mechanical-property results from the present study and data from other investigations have been analyzed to develop the procedure and correlations for estimating thermal embrittlement of cast stainless steel components from known material parameters. ${ }^{13-15}$ This report presents fracture toughness data on several heats of cast stainless steel aged for $10,000-58,000 \mathrm{~h}$ at 290,320 , and $350^{\circ} \mathrm{C}\left(554,608\right.$, and $\left.662^{\circ} \mathrm{F}\right)$. 
Table 1. Product form, chemical composition, hardness, and ferrite morphology of various heats of cast stainless steel

\begin{tabular}{|c|c|c|c|c|c|c|c|c|c|c|c|c|c|c|}
\hline \multirow[b]{2}{*}{ Heat } & \multirow[b]{2}{*}{ Grade } & \multicolumn{9}{|c|}{ Chemica! Composition (wt.\%) } & \multicolumn{2}{|c|}{$\begin{array}{c}\text { Ferrite }{ }^{a} \\
(\%)\end{array}$} & \multirow{2}{*}{$\begin{array}{c}\text { Hard- } \\
\text { ness } \\
\mathrm{R}_{\mathrm{B}}\end{array}$} & \multirow{2}{*}{$\begin{array}{c}\text { Ferrite } \\
\text { Spacing } \\
(\mu \mathrm{m})\end{array}$} \\
\hline & & $\mathrm{Mn}$ & S1 & $\mathbf{P}$ & $\mathbf{s}$ & Mo & $\mathrm{Cr}$ & N1 & $\mathbf{N}$ & C & Calc. & Meas. & & \\
\hline \multicolumn{15}{|c|}{ Keel Blocksb } \\
\hline $\begin{array}{l}50 \\
49 \\
48 \\
47 \\
52 \\
51\end{array}$ & $\begin{array}{l}\mathrm{CF}-3 \\
\mathrm{CF}-3 \\
\mathrm{CF}-3 \\
\mathrm{CF}-3 \\
\mathrm{CF}-3 \\
\mathrm{CF}-3\end{array}$ & $\begin{array}{l}0.60 \\
0.60 \\
0.60 \\
0.60 \\
0.57 \\
0.63\end{array}$ & $\begin{array}{l}1.10 \\
0.95 \\
1.08 \\
1.06 \\
0.92 \\
0.86\end{array}$ & $\begin{array}{l}0.016 \\
0.010 \\
0.009 \\
0.007 \\
0.012 \\
0.014\end{array}$ & $\begin{array}{l}0.007 \\
0.007 \\
0.006 \\
0.006 \\
0.005 \\
0.005\end{array}$ & $\begin{array}{l}0.33 \\
0.32 \\
0.30 \\
0.59 \\
0.35 \\
0.32\end{array}$ & $\begin{array}{l}17.89 \\
19.41 \\
19.55 \\
19.81 \\
19.49 \\
20.13\end{array}$ & $\begin{array}{r}9.14 \\
10.69 \\
10.46 \\
10.63 \\
9.40 \\
9.06\end{array}$ & $\begin{array}{l}0.079 \\
0.065 \\
0.072 \\
0.028 \\
0.052 \\
0.058\end{array}$ & $\begin{array}{l}0.034 \\
0.010 \\
0.011 \\
0.018 \\
0.009 \\
0.010\end{array}$ & $\begin{array}{r}3.0 \\
4.4 \\
5.1 \\
8.4 \\
10.3 \\
14.3\end{array}$ & $\begin{array}{r}4.4 \\
7.2 \\
8.7 \\
16.3 \\
13.5 \\
18.0\end{array}$ & $\begin{array}{l}80.1 \\
76.6 \\
78.1 \\
79.7 \\
81.6 \\
83.8\end{array}$ & $\begin{array}{r}194 \\
185 \\
127 \\
68 \\
69 \\
52\end{array}$ \\
\hline $\begin{array}{l}58 \\
54 \\
57 \\
53 \\
56 \\
59 \\
61 \\
60\end{array}$ & $\begin{array}{l}C F-8 \\
C F-8 \\
C F-8 \\
C F-8 \\
C F-8 \\
C F-8 \\
C F-8 \\
C F-8\end{array}$ & $\begin{array}{l}0.62 \\
0.55 \\
0.62 \\
0.64 \\
0.57 \\
0.60 \\
0.65 \\
0.67\end{array}$ & $\begin{array}{l}1.12 \\
1.03 \\
1.08 \\
1.16 \\
1.05 \\
1.08 \\
1.01 \\
0.95\end{array}$ & $\begin{array}{l}0.010 \\
0.011 \\
0.009 \\
0.012 \\
0.007 \\
0.008 \\
0.007 \\
0.008\end{array}$ & $\begin{array}{l}0.005 \\
0.005 \\
0.004 \\
0.009 \\
0.007 \\
0.007 \\
0.007 \\
0.006\end{array}$ & $\begin{array}{l}0.33 \\
0.35 \\
0.34 \\
0.39 \\
0.34 \\
0.32 \\
0.32 \\
0.31\end{array}$ & $\begin{array}{l}19.53 \\
19.31 \\
18.68 \\
19.53 \\
19.65 \\
20.33 \\
20.65 \\
21.05\end{array}$ & $\begin{array}{r}10.89 \\
9.17 \\
9.27 \\
9.23 \\
9.28 \\
9.34 \\
8.86 \\
8.34\end{array}$ & $\begin{array}{l}0.040 \\
0.084 \\
0.047 \\
0.049 \\
0.030 \\
0.045 \\
0.080 \\
0.058\end{array}$ & $\begin{array}{l}0.056 \\
0.063 \\
0.056 \\
0.065 \\
0.066 \\
0.062 \\
0.054 \\
0.064\end{array}$ & $\begin{array}{r}3.2 \\
4.1 \\
4.4 \\
6.3 \\
7.3 \\
8.8 \\
10.0 \\
15.4\end{array}$ & $\begin{array}{r}2.9 \\
1.8 \\
4.0 \\
8.7 \\
10.1 \\
3.5 \\
13.1 \\
21.1\end{array}$ & $\begin{array}{l}77.1 \\
83.3 \\
80.2 \\
83.1 \\
82.5 \\
83.2 \\
85.3 \\
86.7\end{array}$ & $\begin{array}{r}303 \\
317 \\
138 \\
92 \\
84 \\
75 \\
82 \\
63\end{array}$ \\
\hline $\begin{array}{l}62 \\
63 \\
66 \\
65 \\
64\end{array}$ & $\begin{array}{l}C F-8 M \\
C F-8 M \\
C F-8 M \\
C F-8 M \\
C F-8 M\end{array}$ & $\begin{array}{l}0.72 \\
0.61 \\
0.60 \\
0.50 \\
0.60\end{array}$ & $\begin{array}{l}0.56 \\
0.58 \\
0.49 \\
0.48 \\
0.63\end{array}$ & $\begin{array}{l}0.007 \\
0.007 \\
0.012 \\
0.012 \\
0.006\end{array}$ & $\begin{array}{l}0.005 \\
0.006 \\
0.007 \\
0.007 \\
0.005\end{array}$ & $\begin{array}{l}2.57 \\
2.57 \\
2.39 \\
2.57 \\
2.46\end{array}$ & $\begin{array}{l}18.29 \\
19.37 \\
19.45 \\
20.78 \\
20.76\end{array}$ & $\begin{array}{r}12.39 \\
11.85 \\
9.28 \\
9.63 \\
9.40\end{array}$ & $\begin{array}{l}0.030 \\
0.031 \\
0.029 \\
0.064 \\
0.038\end{array}$ & $\begin{array}{l}0.063 \\
0.055 \\
0.047 \\
0.049 \\
0.038\end{array}$ & $\begin{array}{r}2.8 \\
6.4 \\
19.6 \\
20.9 \\
29.0\end{array}$ & $\begin{array}{r}4.5 \\
10.4 \\
19.8 \\
23.4 \\
28.4\end{array}$ & $\begin{array}{l}78.1 \\
81.6 \\
85.3 \\
89.0 \\
89.7\end{array}$ & $\begin{array}{r}140 \\
81 \\
41 \\
43 \\
41\end{array}$ \\
\hline \multicolumn{15}{|c|}{$76-\mathrm{mm}$ Slabs ${ }^{\mathrm{c}}$} \\
\hline 69 & $\mathrm{CF}-3$ & 0.63 & 1.13 & 0.015 & 0.005 & 0.34 & 20.18 & 8.59 & 0.028 & 0.023 & 21.0 & 23.6 & 83.7 & 35 \\
\hline $\begin{array}{l}73 \\
68\end{array}$ & $\begin{array}{l}C F-8 \\
C F-8\end{array}$ & $\begin{array}{l}0.72 \\
0.64\end{array}$ & $\begin{array}{l}1.09 \\
1.07\end{array}$ & $\begin{array}{l}0.028 \\
0.021\end{array}$ & $\begin{array}{l}0.016 \\
0.014\end{array}$ & $\begin{array}{l}0.25 \\
0.31\end{array}$ & $\begin{array}{l}19.43 \\
20.64\end{array}$ & $\begin{array}{l}8.54 \\
8.08\end{array}$ & $\begin{array}{l}0.053 \\
0.062\end{array}$ & $\begin{array}{l}0.070 \\
0.063\end{array}$ & $\begin{array}{r}7.0 \\
14.9\end{array}$ & $\begin{array}{r}7.7 \\
23.4\end{array}$ & $\begin{array}{l}78.8 \\
84.6\end{array}$ & $\begin{array}{r}253 \\
87\end{array}$ \\
\hline $\begin{array}{l}70 \\
74 \\
75\end{array}$ & $\begin{array}{l}C F-8 M \\
C F-8 M \\
C F-8 M\end{array}$ & $\begin{array}{l}0.55 \\
0.54 \\
0.53\end{array}$ & $\begin{array}{l}0.72 \\
0.73 \\
0.67\end{array}$ & $\begin{array}{l}0.021 \\
0.022 \\
0.022\end{array}$ & $\begin{array}{l}0.016 \\
0.016 \\
0.012\end{array}$ & $\begin{array}{l}2.30 \\
2.51 \\
2.58\end{array}$ & $\begin{array}{l}19.17 \\
19.11 \\
20.86\end{array}$ & $\begin{array}{l}9.01 \\
9.03 \\
9.12\end{array}$ & $\begin{array}{l}0.049 \\
0.048 \\
0.052\end{array}$ & $\begin{array}{l}0.066 \\
0.064 \\
0.065\end{array}$ & $\begin{array}{l}14.2 \\
15.5 \\
24.8\end{array}$ & $\begin{array}{l}18.9 \\
18.4 \\
27.8\end{array}$ & $\begin{array}{l}86.5 \\
85.8 \\
89.5\end{array}$ & $\begin{array}{l}96 \\
90 \\
69\end{array}$ \\
\hline \multicolumn{15}{|c|}{ Reactor Components d } \\
\hline $\begin{array}{l}\text { P3 } \\
\text { P2 } \\
1\end{array}$ & $\begin{array}{l}C F-3 \\
C F-3 \\
C F-3\end{array}$ & $\begin{array}{l}1.06 \\
0.74 \\
0.47\end{array}$ & $\begin{array}{l}0.88 \\
0.94 \\
0.83\end{array}$ & $\begin{array}{l}0.017 \\
0.019 \\
0.030\end{array}$ & $\begin{array}{l}0.014 \\
0.006 \\
0.011\end{array}$ & $\begin{array}{l}0.01 \\
0.16 \\
0.45\end{array}$ & $\begin{array}{l}18.89 \\
20.20 \\
20.20\end{array}$ & $\begin{array}{l}8.45 \\
9.38 \\
8.70\end{array}$ & $\begin{array}{l}0.168 \\
0.040 \\
0.032\end{array}$ & $\begin{array}{l}0.021 \\
0.019 \\
0.019\end{array}$ & $\begin{array}{r}2.8 \\
12.5 \\
20.4\end{array}$ & $\begin{array}{r}1.9 \\
15.6 \\
17.1\end{array}$ & $\begin{array}{l}82.2 \\
83.8 \\
81.0\end{array}$ & $\begin{array}{l}- \\
69 \\
65\end{array}$ \\
\hline $\begin{array}{l}\mathrm{Cl} \\
\mathrm{Pl}\end{array}$ & $\begin{array}{l}C F-8 \\
C F-8\end{array}$ & $\begin{array}{l}1.22 \\
0.59\end{array}$ & $\begin{array}{l}1.18 \\
1.12\end{array}$ & $\begin{array}{l}0.033 \\
0.026\end{array}$ & $\begin{array}{l}0.008 \\
0.013\end{array}$ & $\begin{array}{l}0.65 \\
0.04\end{array}$ & $\begin{array}{l}19.00 \\
20.49\end{array}$ & $\begin{array}{l}9.37 \\
8.10\end{array}$ & $\begin{array}{l}0.040 \\
0.056\end{array}$ & $\begin{array}{l}0.039 \\
0.036\end{array}$ & $\begin{array}{r}7.8 \\
17.7\end{array}$ & $\begin{array}{r}2.2 \\
24.1\end{array}$ & $\begin{array}{l}79.5 \\
84.9\end{array}$ & $\overline{90}$ \\
\hline $\begin{array}{l}\text { P4 } \\
205 \\
758\end{array}$ & $\begin{array}{l}C F-8 M \\
C F-8 M \\
C F-8 M\end{array}$ & $\begin{array}{l}1.07 \\
0.93 \\
0.91\end{array}$ & $\begin{array}{l}1.02 \\
0.63 \\
0.62\end{array}$ & $\begin{array}{l}0.019 \\
0.019 \\
0.018\end{array}$ & $\begin{array}{c}0.015 \\
- \\
-\end{array}$ & $\begin{array}{l}2.05 \\
3.37 \\
3.36\end{array}$ & $\begin{array}{l}19.64 \\
17.88 \\
17.91\end{array}$ & $\begin{array}{r}10.00 \\
8.80 \\
8.70\end{array}$ & $\begin{array}{c}0.151 \\
- \\
-\end{array}$ & $\begin{array}{l}0.040 \\
0.040 \\
0.030\end{array}$ & $\begin{array}{r}5.9 \\
21.0 \\
24.2\end{array}$ & $\begin{array}{l}10.0 \\
15.9 \\
19.2\end{array}$ & $\begin{array}{c}83.1 \\
- \\
-\end{array}$ & $\begin{array}{r}182 \\
79 \\
62\end{array}$ \\
\hline \multicolumn{15}{|c|}{ Reactor-Agede } \\
\hline KRB & $\mathrm{CF}-8$ & 0.31 & 1.17 & - & - & 0.17 & 21.99 & 8.03 & 0.038 & 0.062 & 27.7 & 34.0 & - & - \\
\hline 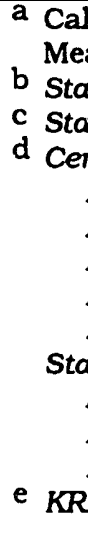 & $\begin{array}{l}\text { atic Cast K } \\
\text { utic Cast S } \\
\text { ntrifugally } \\
\text { P3 Found } \\
\text { P2 Found } \\
\text { P1 Found } \\
\text { P4 Found } \\
205 \text { Size } \\
\text { atic Cast: } \\
\text { Elbow } 758 \\
\text { Pump Imp } \\
\text { Pump Cas }\end{array}$ & $\begin{array}{l}\text { labs: } \\
\text { Cas } \\
\text { dry S } \\
\text { dry F } \\
\text { dry Es } \\
\text { dry S } \\
305 \text { r }\end{array}$ & $\begin{array}{l}\text { Peles: Fo } \\
\text { Pipes: } \\
\text { NDUSK } \\
\text { M, Fran } \\
\text { CO; Siz } \\
\text { NDUSK } \\
\text { m O.D. }\end{array}$ & $\begin{array}{l}\text { oundry } \\
\text { y ESCO; } \\
\text { KY; Size } \\
\text { nce; Size } \\
\text { e } 890 \mathrm{~m} \\
\text { KY; Size } \\
., 25 \mathrm{~mm}\end{array}$ & $\begin{array}{l}\text { ESCO: } \\
\text {; Size } 6 \\
580 \mathrm{mn} \\
\text { e } 930 \mathrm{~m} \\
\text { am O.D. } \\
580 \mathrm{mn} \\
\mathrm{n} \text { wall. }\end{array}$ & $\begin{array}{l}\text {. } \\
\text { mo. }\end{array}$ & $\begin{array}{l}\text { luivale } \\
\text { Type F } \\
0 \times 12 \\
\times 76 \\
76 \mathrm{~mm} \\
73 \mathrm{~m} \\
\text { wall. } \\
32 \mathrm{mn}\end{array}$ & $\begin{array}{l}\text { mall. } \\
\mathrm{m} \text { wall. } \\
\text { wall. }\end{array}$ & $\mathrm{mm}$. & & & & & \\
\hline
\end{tabular}




\section{Fracture Toughness}

The J-R curve tests were conducted at room temperature and at $290^{\circ} \mathrm{C}\left(554^{\circ} \mathrm{F}\right)$ according to ASTM Specifications E 813-85 and E 1152-87. Compact-tension (CT) specimens, $25.4 \mathrm{~mm}$ thick (1.e., $1 \mathrm{~T}$ size), were used for the tests. The fracture toughness results for 10 laboratory-aged heats of cast stainiess steel and service-aged material from the KRB reactor pump cover plate are listed in Table A-1 of the Appendix. The J-R curve test data, as well as an analysis and qualification of the data for tests conducted on longterm aged specimens, are also given in the Appendix; detalls of the tests on specimens aged up to $30,000 \mathrm{~h}$ have been presented earlier. 5,12

\subsection{Unaged Cast Stainless Steels}

The fracture toughness $J-R$ curves of unaged cast stainless steels vary significantly for the various heats. Figure $\mathrm{l}$. shows fracture toughness J-R curves for centrifugally and staticcast steels at room temperature and $290^{\circ} \mathrm{C}\left(554^{\circ} \mathrm{F}\right)$. The centrifugally cast steels exhibit higher fracture toughness than static-cast steels. The static-cast pump casing ring (Heat C1 with $\delta_{c}=8 \%$ ) shows the lowest fracture toughness and the centrifugally cast pipe (Heat P2 with $\delta_{c}=12 \%$ ) shows the highest. The room-temperature J-R curves for unaged Heat $\mathrm{C} 1$ are marginally higher than those at $290^{\circ} \mathrm{C}$. At temperatures up to $320^{\circ} \mathrm{C}\left(608^{\circ} \mathrm{F}\right)$, a minimum $\mathrm{J}-\mathrm{R}$ curve for unaged static-cast stainless steels can be expressed as

$$
J_{d}=400[\Delta a]^{0.40}
$$

and for centrifugally cast stainless steels as

$$
J_{d}=650[\Delta a]^{0.43} \text {, }
$$

where crack extension $\Delta \mathrm{a}$ is in $\mathrm{mm}$ and deformation $\mathrm{J}$ integral $\mathrm{J}_{\mathrm{d}}$ is in $\mathrm{kJ} / \mathrm{m}^{2}$.

Fracture toughness data for unaged cast stainless steels also indicate that $J-R$ curves for structurally "weak" heats may be lower than those for wrought stainless steel. J-R curves for wrought stainless steels $16-21$ at temperatures $\geq 290^{\circ} \mathrm{C}$ are shown with the minimum J-R curve for unaged cast stainless steels, in Fig. 2. The fracture toughness J-R curve of wrought stainless steels is higher than the minimum $J-R$ curve for static-cast stainless steels.

\subsection{Influence of Thermal Aging}

The effects of aging time and temperature on the fracture toughness $J-R$ curves of the various heats of cast stainless steel are shown in Figs. 3-9. Thermal aging of cast stainless steels decreases their fracture toughness at both room temperature and $290^{\circ} \mathrm{C}$. The values of $\mathrm{J}_{\mathrm{IC}}$ and average tearing modulus for heats that are sensitive to thermal aging are as low as $\approx 90 \mathrm{~kJ} / \mathrm{m}^{2}$ and $\approx 60$, respectively. The $\mathrm{J}-\mathrm{R}$ curve data are consistent with the Charpy-impact results, 1.e., unaged and aged materials that show low impact energy also exhibit lower fracture toughness. All materials reach a minimum saturation fracture toughness after thermal aging. The time to reach saturation depends on the aging temperature, e.g., 

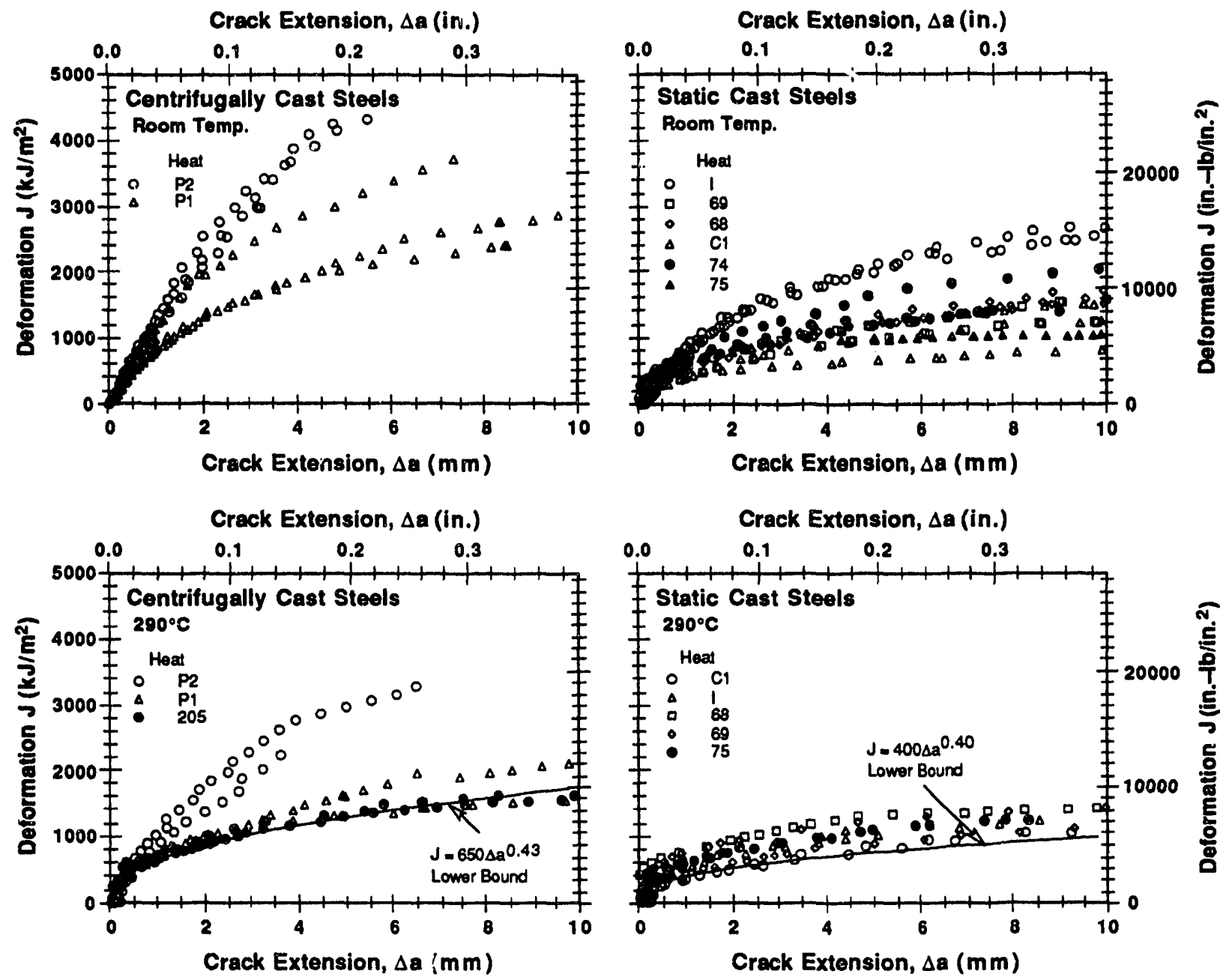

Figure 1. Fracture toughness ${ }^{I}-R$ curves for centrifugally and static-cast stainless steels at room temperature and at $290^{\circ} \mathrm{C}$

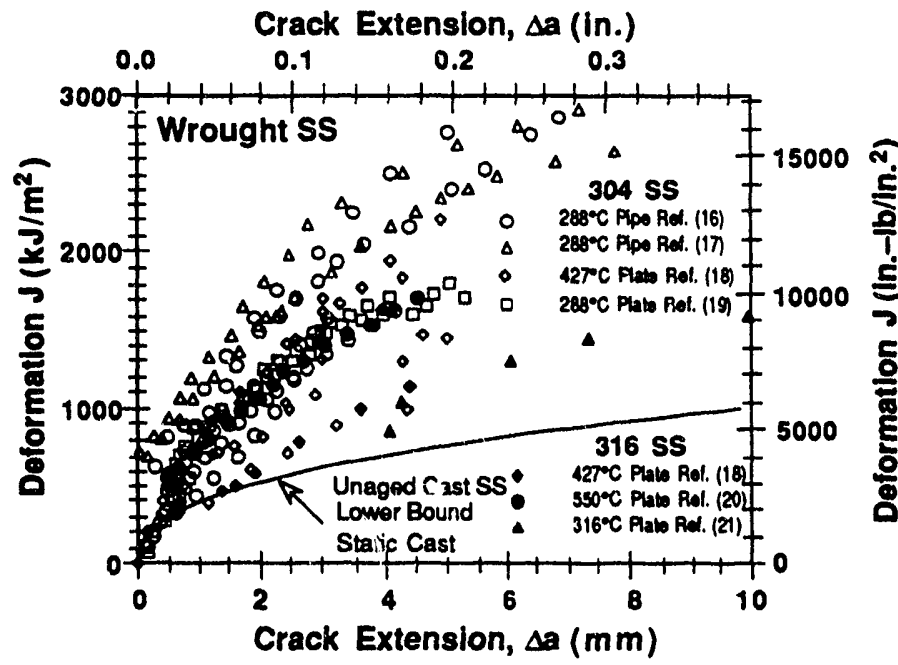

Flgure 2.

Fracture toughness $J-R$ curves for wrought stainless steels at temperatures $\geq 290^{\circ} \mathrm{C}$ and lowerbound $J-R$ curve for static-cast stainless steel 

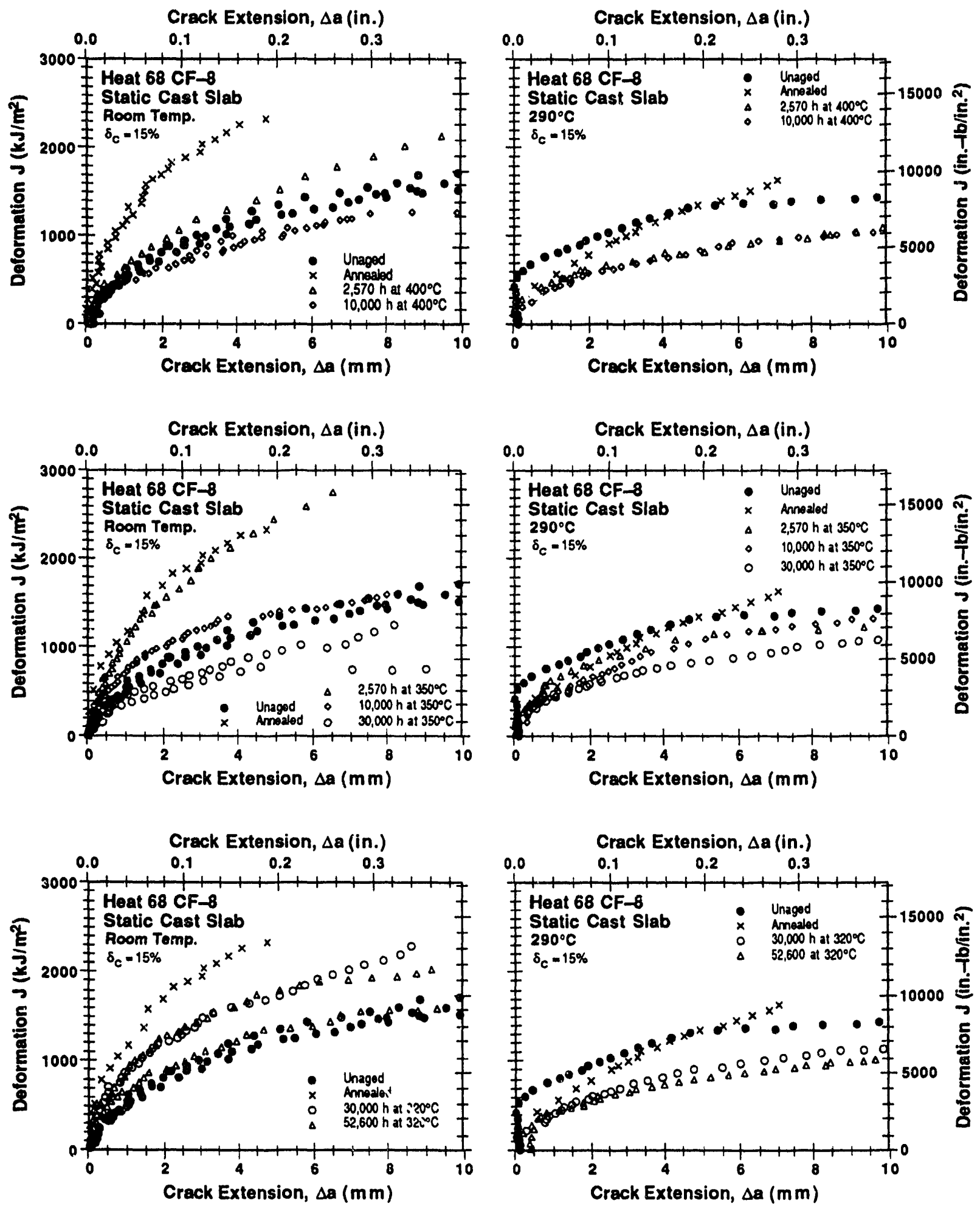

Figure 3. Effect of aging time and temperature on the fracture toughness $J-R$ curves at room temperature and at $290^{\circ} \mathrm{C}$ for static-cast Heat 68 

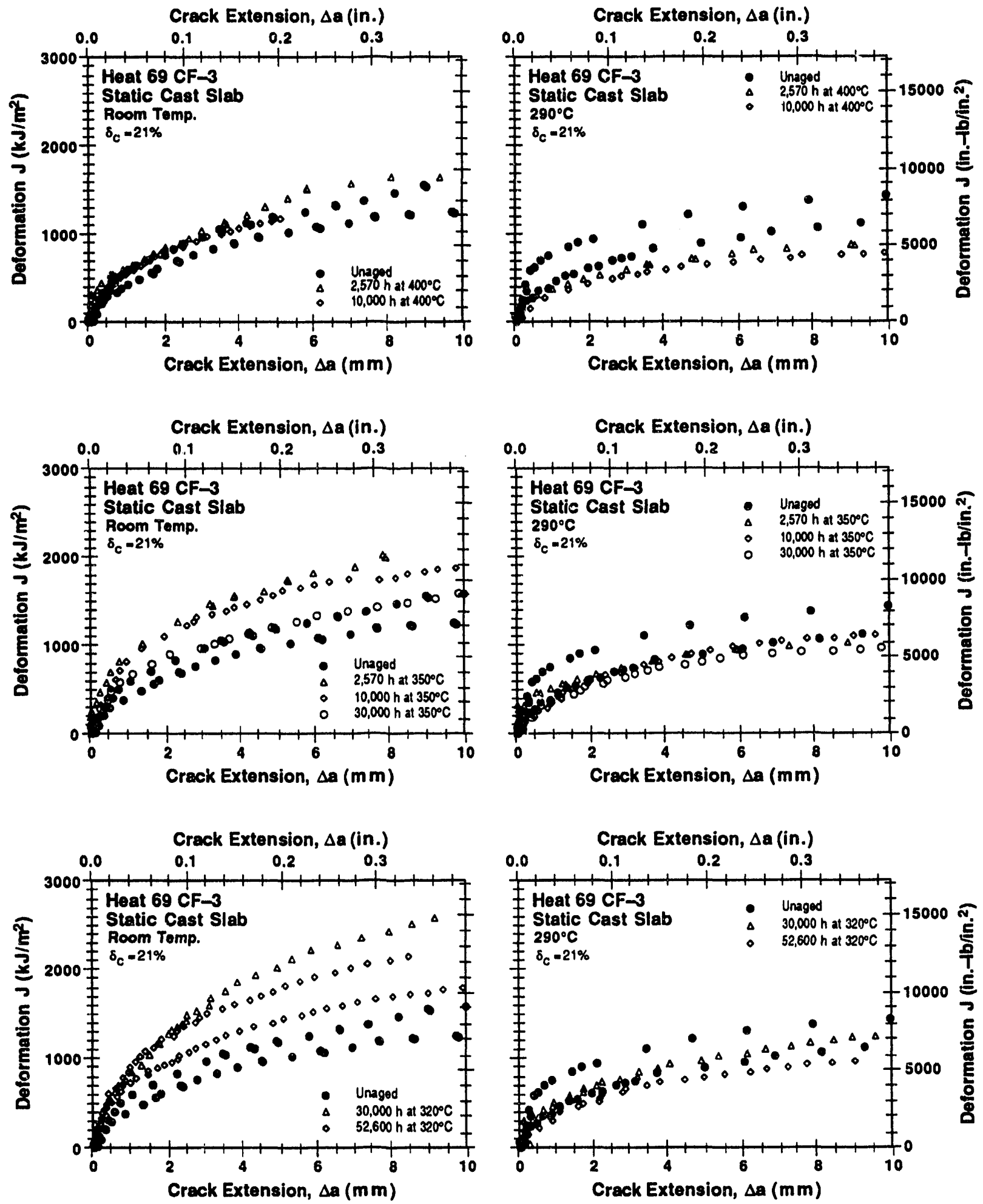

Figure 4. Effect of aging time and temperature on the fracture toughness $J-R$ curves at room temperature and at $290^{\circ} \mathrm{C}$ for static-cast Heat 69 

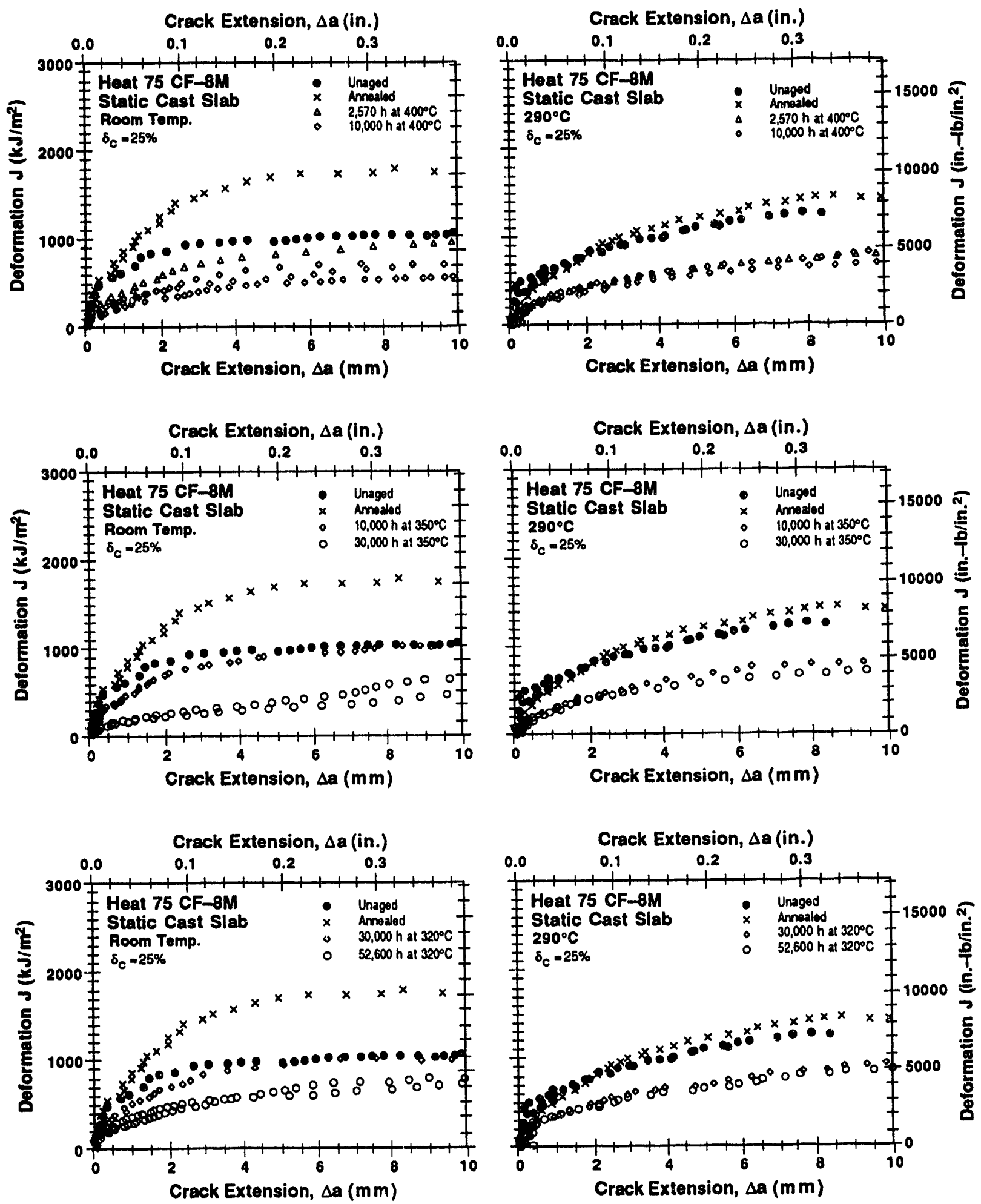

Figure 5. Effect of aging time and temperature on the fracture toughness $J-R$ curves at room temperature and at $290^{\circ} \mathrm{C}$ for static-cast Heat 75 

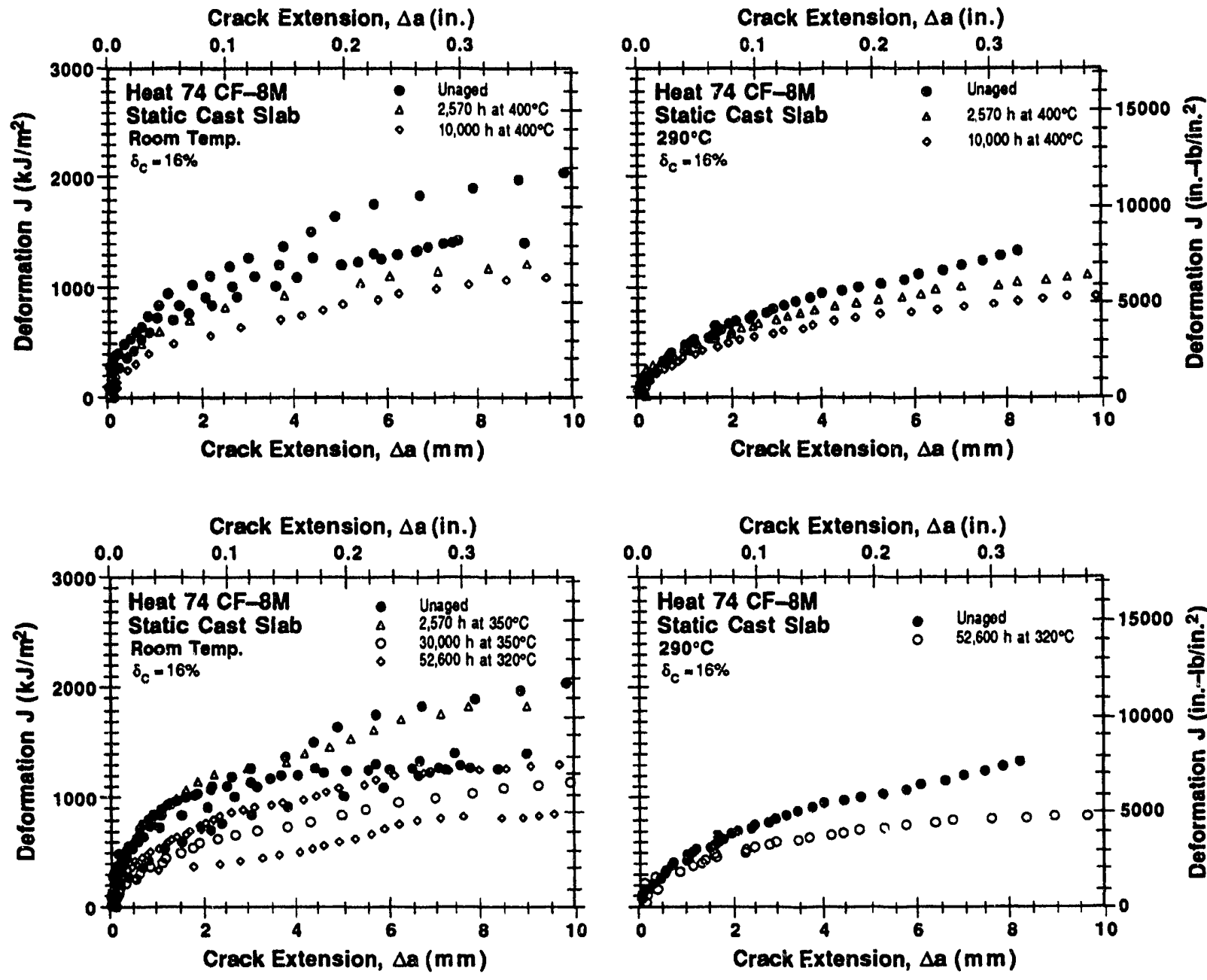

Figure 6. Effect of aging the and temperature on the fracture toughness $J-R$ curves at room temperature and at $290^{\circ} \mathrm{C}$ for static-cast Heat 74
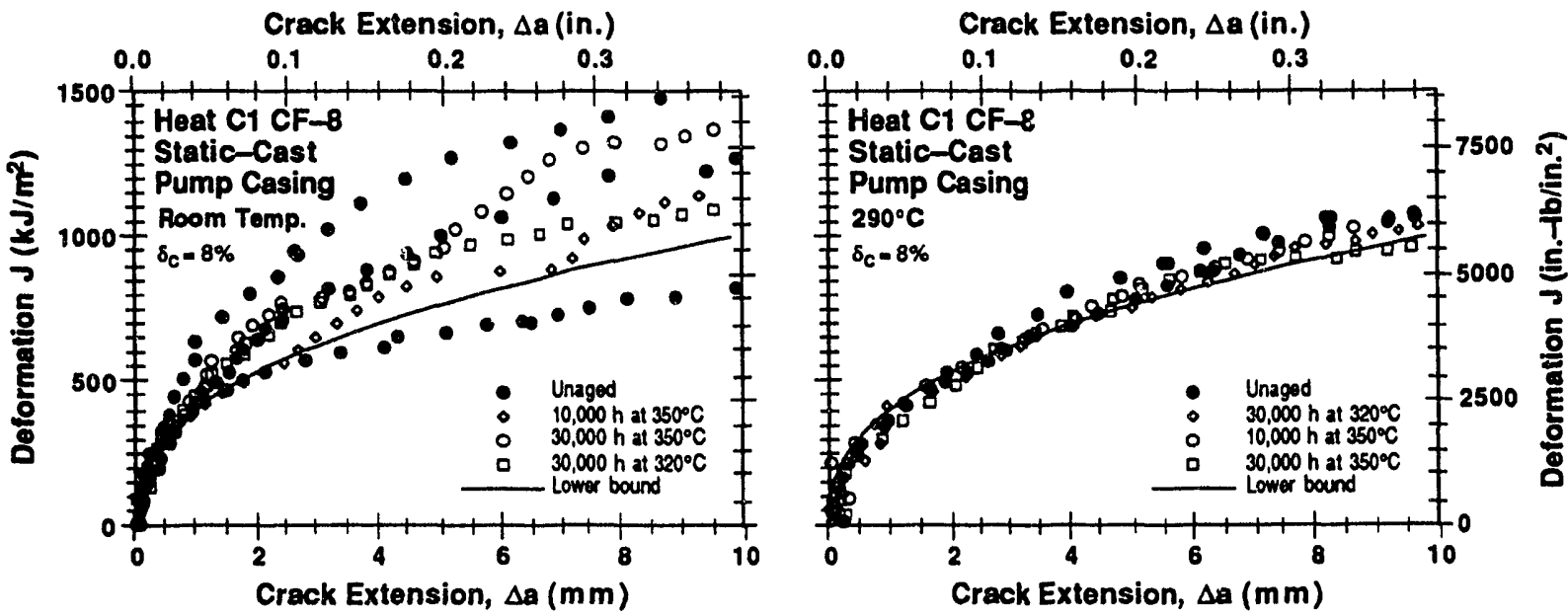

Figure 7. Effect of aging time and temperature on the fracture toughness $J-R$ curves at room temperature and at $290^{\circ} \mathrm{C}$ for static-cast Heat $\mathrm{Cl}$ 

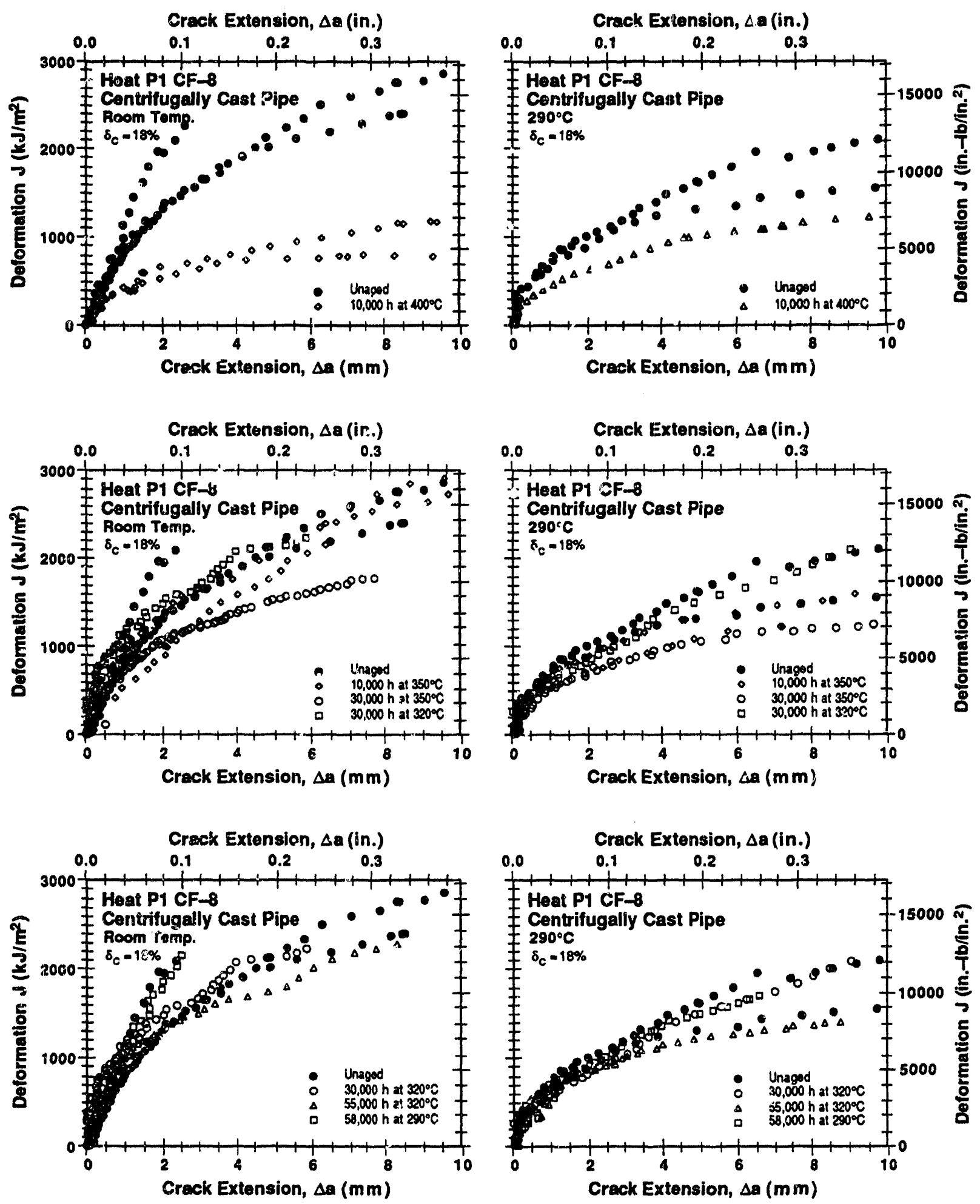

Figure 8. Effect of aging time and temperature on the fracture toughness J-R curves at room temperature and at $290^{\circ} \mathrm{C}$ for centrifugally cast Heat $P 1$ 

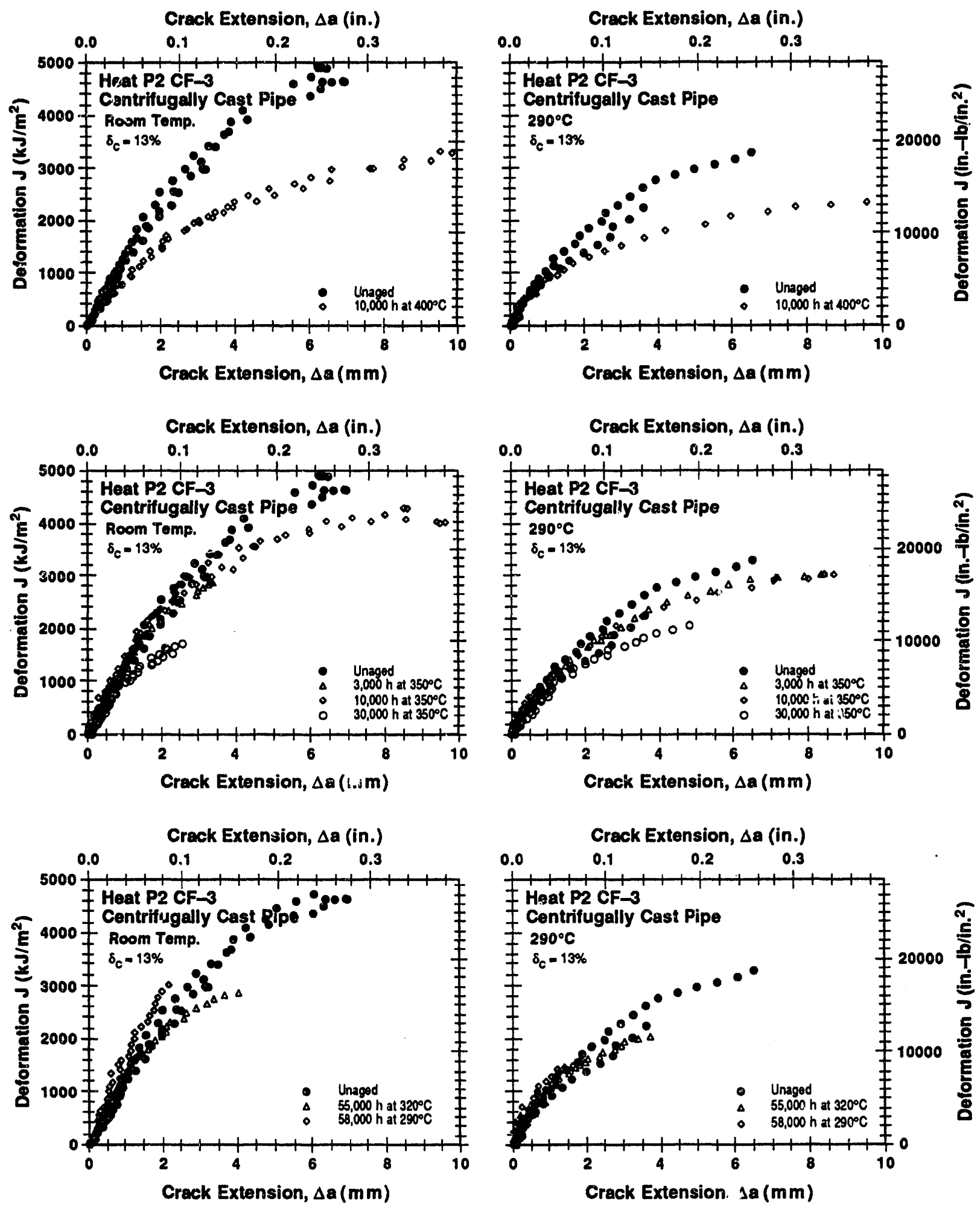

Figure 9. Effect of aging ttme and temperature on the fracture toughness $J-R$ curves at room temperature and at $290^{\circ} \mathrm{C}$ for centrifugally cast Heat $\mathrm{P2}$ 
$10,000 \mathrm{~h}$ at $400^{\circ} \mathrm{C}$ or $30,000 \mathrm{~h}$ at $350^{\circ} \mathrm{C}$. The kinetics for the decrease in fracture toughness are identical to those observed for the change in Charpy-impact energy. In general, loss in toughness increases with an increase in ferrite content. The CF-3 steels show the smallest and CF-8M steels the largest loss in fracture toughness. Also, for a specific steel, the decrease in toughness is larger at room temperature than at $290^{\circ} \mathrm{C}\left(554^{\circ} \mathrm{F}\right)$.

The static-cast slabs (e.g., Heats 68, 69, and 75) exhibit an unusual aging behavior, viz, the room-temperature $J-R$ curves for the static-cast slabs in the unaged condition are exceptionally low, although their Charpy-impact energies are comparable with those for other heats. Also, the room-temperature fracture toughness increased initially after aging, e.g., J-R curves for Heats 68,69 , and 75 aged for $2,570 \mathrm{~h}$ at $400^{\circ} \mathrm{C}\left(752^{\circ} \mathrm{F}\right)$, up to $10,000 \mathrm{~h}$ at $350^{\circ} \mathrm{C}\left(662^{\circ} \mathrm{F}\right)$, or up to $30,000 \mathrm{~h}$ at 320 and $290^{\circ} \mathrm{C}\left(608\right.$ and $\left.554^{\circ} \mathrm{F}\right)$ are generally higher than those for the unaged materials. An initial increase in fracture toughness was not observed at $290^{\circ} \mathrm{C}$ for these heats or for any other product form.

The poor room-temperature fracture toughness of the cast slabs is most likely due to residual stresses introduced in the material either during casting or the production heat treatment. The initial increase in fracture toughness of the aged material is most likely due to relaxation of the residual stresses during aging. Fracture toughness results for recoveryannealed materials support this argument. Annealing studies indicate that thermal embrittlement of cast stainless steels can be reversed by annealing the embrittled material for $1 \mathrm{~h}$ at $550^{\circ} \mathrm{C}$ and then water quenching. ${ }^{1-3,7,12}$ The Charpy-transition curves of recoveryannealed $C F-3, C F-8$, and $C F-8 M$ steels agree very well with those of unaged materials. 7,12 However, fracture toughness J-R curves of recovery-annealed Heats 68 and 75 are significantly higher than those of the unaged materials and are comparable to those of materials that were aged for relatively short times, Figs. 3 and 5. These results suggest that the mechanical test data obtained on unaged static-cast slabs do not represent baseline properties. For the static-cast slabs, fracture toughness should initially increase during reactor service before it decreases because of thermal embrittlement. Fracture toughness J-R curves for the recovery-annealed material most likely represent the baseline properties without the effect of residual stresses.

\subsection{Low-Strength Cast Stainless Steels}

Mechanical-property data on thermally-aged cast stainless steels indicate that cast stainless steels with low impact strength and poor fracture toughness are generally insensitive to thermal aging, e.g., Heat $\mathrm{C} 1$, a static-cast $\mathrm{CF}-8$ steel with $7.3 \%$ ferrite. Static-cast CF-8 steels with 5-10\% ferrite typically have a room-temperature Charpy-impact energy $>150 \mathrm{~J} / \mathrm{cm}^{2}$. The room-temperature Charpy-impact energy for unaged $\mathrm{Heat} \mathrm{Cl}$ is $\approx 60 \mathrm{~J} / \mathrm{cm}^{2}$ and does not change even after aging up to $30,000 \mathrm{~h}$ at $320-400^{\circ} \mathrm{C} .1,12$ The impact strength of Heat $\mathrm{Cl}$ is, in fact, lower than the saturation impact energy of thermally aged cast stainless steels with equivalent ferrite content. The fracture toughness data also show no degradation in properties; $J-R$ curves for aged and unaged Heat $\mathrm{Cl}$ are comparable. Fig 7.

Thermal aging of cast stainless steels at temperatures $<500^{\circ} \mathrm{C}\left(932^{\circ} \mathrm{F}\right)$ affects the fracture processes normally associated with thermal embrittlement of cast stainless steel, viz., cleavage of ferrite and separation of austenite/ferrite phase boundary. The formation of ad- 
ditional phases, such as the chromium-rich $\alpha^{\prime}$ phase, promotes cleavage of the ferrite, and precipitation and/or growth of carbides/nitrides at the phase boundaries causes phaseboundary separation. The extent of thermal embrittlement is controlled by the amount of brittle fracture. A predominantly brittle fallure occurs when either the ferrite phase is continuous, e.g., in cast material with a large ferrite content, or the ferrite/austenite phase boundary provides an easy path for crack propagation, e.g., in high-carbon or high-nitrogen steels that contain phase-boundary carbides or nitrides.

Low-strength cast stainless steels are generally insensitive to thermal aging because failure of these steels is controlled by oxide inclusions or other flaws in the casting. 1.e., by fracture processes other than cleavage of ferrite and phase-boundary separation. Failure processes associated with inclusions or flaws are relatively insensitive to thermal aging. Consequently, cast stainless steels with low impact strength and poor fracture toughness show little or no degradation of mechanical properties.

\subsection{Recovery-Annealed Material}

The influence of annealing on 12 laboratory-aged heats of CF-3, CF-8, and CF-8M steels and service-aged material from the $K R B$ reactor pump cover plate indicate that the mechanical propertics of aged cast stainless steels can be restored by annealing the embrittled material for $1 \mathrm{~h}$ at $550^{\circ} \mathrm{C}$ and water-quenching.7.12 The $\alpha^{\prime}$ phase, which is the primary cause for thermal embrittlement, is not stable at temperatures $>550^{\circ} \mathrm{C}$ and therefore dissolves during the annealing treatment. The material is water-quenched to avoid formation of $\sigma$ and other intermetallic phases that may also degrade mechanical properties. In all cases, the Charpy-transition curves for the annealed materials agree very well with those for the unaged steel. 12

Charpy data for laboratory-aged materials also indicate that the kinetics of embrittlement can be obtained from the reembrittlement of recovery-annealed material. 12 The Charpy-transition curve for recovery-annealed CF-3, CF-8, and CF-8M steels aged for $10,000 \mathrm{~h}$ at $400^{\circ} \mathrm{C}$ is virtually identical to that of the as-received material aged for $10,000 \mathrm{~h}$ at $400^{\circ} \mathrm{C}$. The kinetics of thermal embrittlement for the as-received material and recovery-annealed material are also identical. The activation energies for thermal embrittlement of Heats 68, 69, and 75 are $168 \pm 37,167 \pm 48$, and $146 \pm 21 \mathrm{~kJ} / \mathrm{mole}$, respectively, for the as-received material, and $122 \pm 41,176 \pm 49$, and $130 \pm 28 \mathrm{~kJ} / \mathrm{mole}$, respectively, for recovery-annealed and aged material.12 Fracture toughness data also show similar behavior; $\mathrm{J}-\mathrm{R}$ curves for recovery-annealed Heats 68 and 75 aged for $10,000 \mathrm{~h}$ at $400^{\circ} \mathrm{C}$ are identical to those of the as-received steels aged for $10,000 \mathrm{~h}$ at $400^{\circ} \mathrm{C}$, Fig. 10.

The results indicate that baseline mechanical properties, as well as the kinetics of embrittlement, of aged cast stainless steels can be determined from the recovery-annealed material. This may be very useful for evaluating degradation of mechanical properties of service-aged components, where the baseline mechanical properties of archive material are generally not available. 

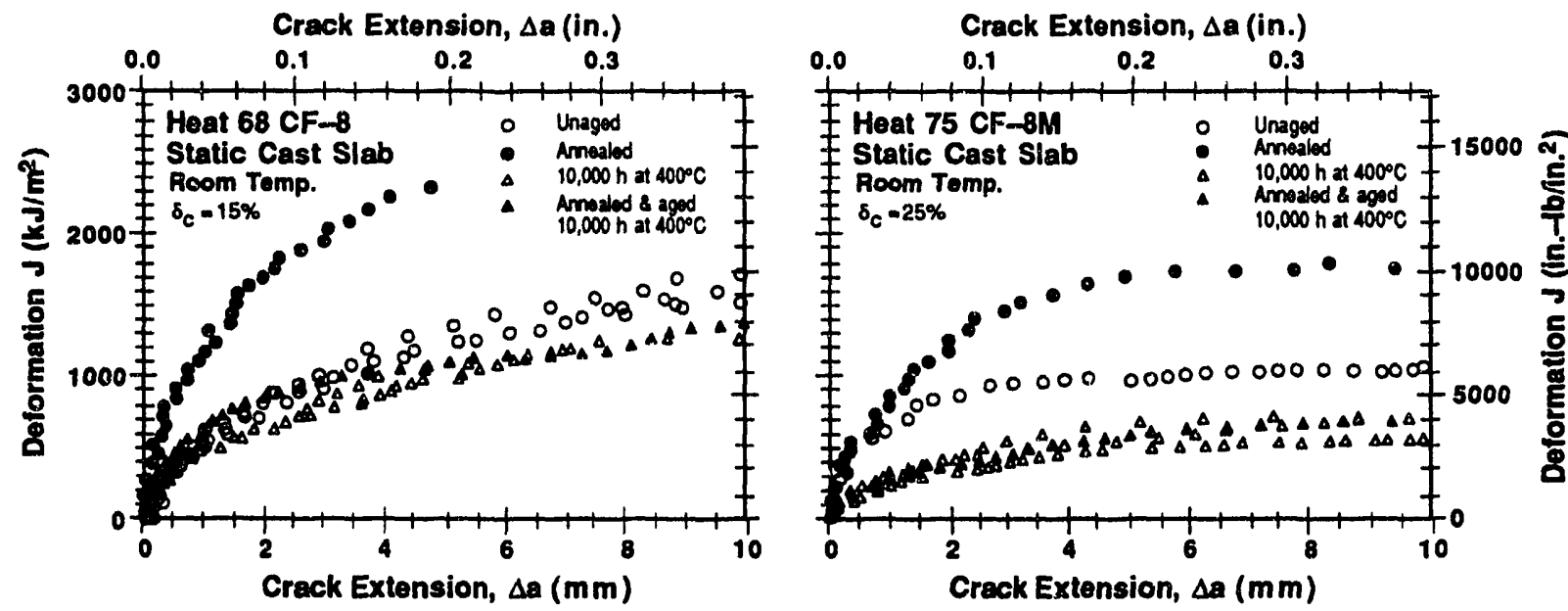

Figure 10. Reembrittlement of static-cast Heats 68 and 75.

\section{Conclusions}

Charpy-impact, tensile, and fracture toughness $J-R$ curve data are presented for several experimental and commercial heats of cast stainless steel that were aged 10,000$58,000 \mathrm{~h}$ at 290,320 , and $350^{\circ} \mathrm{C}$. Thermal aging decreases the fracture toughness of cast stainless steels. The values of fracture toughness $\mathrm{J}_{\mathrm{IC}}$ and average tearing modulus for heats that are sensitive to thermal aging (e.g., CF-8M steels) are as low as $\approx 90 \mathrm{~kJ} / \mathrm{m}^{2}$ and $\approx 60$, respectively. In general, CF-3 steels are the least sensitive to thermal aging and CF-8M steels are the most sensitive. The fracture toughness data are consistent with the Charpyimpact results, 1.e., unaged and aged steels that show low impact energy also exhibit lower fracture toughness. All steels reach a minimum saturation fracture toughness after thermal aging. The time to reach saturation depends on the aging temperature. Mechanical-property data also indicate that the fracture toughness of cast stainless steels can be lower than that of the wrought stainless steels. The low-strength cast stainless steels are generally insensitive to thermal aging.

\section{Acknowledgments}

This work was supported by the Office of the Nuclear Regulatory Research in the U.S. Nuclear Regulatory Commission. The authors are grateful to T. M. Galvin, W. F. Michaud, and W. F. Burke for their contributions to the experimental effort. The authors also thank J. Muscara, W. J. Shack, and T. F. Kassner for their helpful discussions.

\section{References}

1. O. K. Chopra and A. Sather, Initial Assessment of the Mechanisms and Significance of LowTemperature Embrittlement of Cast Stainless Steels in LWR Systems, NUREG/CR-5385, ANL-89/17 (August 1990). 
2. O. K. Chopra and H. M. Chung, "Aging Degradation of Cast Stainless Steels: Effects on Mechanical Properties," in Environmental Degradation of Materials in Nuclear Power Systems-Water Reactors, G. J. Theus and J. R. Weeks, eds., The Metallurgical Society, Warrendale, PA., pp. 737-748 (1988).

3. O. K. Chopra and H. M. Chung, "Effect of Low-Temperature Aging on the Mechanical Properties of Cast Stainless Steels," in Properties of Stainless Steels in Elevated Temperature Service, M. Prager, ed., MPC-Vol. 26, PVP-Vol. 132, ASME, New York, pp. 79-105 (1988).

4. O. K. Chopra, "Thermal Aging of Cast Stainless Steels: Mechanisms and Predictions," in Fatigue, Degradation, and Fracture - 1990, W. H. Bamford, C. Becht, S. Bhandari, J. D. Gilman, L. A. James, and M. Prager, eds., MPC Vol. 30, PVP Vol. 195, ASME, New York, pp. 193-214 (1990).

5. O. K. Chopra, A. Sather, and L. Y. Bush, Long-Term Embrittlement of Cast Duplex Stainless Steels in LWR Systems: Semiannual Report, April-September 1989. NUREG/CR-4744, Vol. 4, No. 2, ANL-90/49 (June 1991).

6. O. K. Chopra and L. Y. Bush, Long-Term Embrittlement of Cast Duplex Stainless Steels in LWR Systems: Semiannual Report, October 1989-March 1990, NUREG/CR-4744, Vol. 5. No. 1, ANL-91/7 (July 1991).

7. O. K. Chopra, Long-Term Embrittlement of Cast Duplex Stainless Steels in LWR Systems: Semiannual Report, April-September 1990, NUREG/CR-4744, Vol. 5, No. 2, ANL-91/10 (July 1991).

8. H. M. Chung and O. K. Chopra, "Kinetics and Mechanism of Thermal Aging Embrittlement of Duplex Stainless Steels," in Environmental Degradation of Materials in Nuclear Power Systems-Water Reactors, G. J. Theus and J. R. Weeks, eds., The Metallurgical Society, Warrendale, PA, pp. 359-370 (1988).

9. H. M. Chung and O. K. Chopra, "Long-Term Aging Embrittlement of Cast Austenitic Stainless Steels - Mechanism and Kinetics," in Properties of Stainless Steels in Elevated Temperature Service, M. Prager, ed., MPC-Vol. 26, PVP-Vol. 132, ASME, New York, pp. 17-34 (1988).

10. H. M. Chung and T. R. Leax, "Embrittlement of Laboratory and Reactor Aged CF3, CF8, and CF8M Duplex Stainless Steels," Mater. Sci. Technol. 6, 249-262 (1990).

11. A. L. Hiser, Tensile and $J-R$ Curve Characterization of Thermally Aged Cast Stainless Steels, NUREG/CR-5024, MEA-2229, Materials Engineering Associates, Inc., (September 1988).

12. O. K. Chopra, Long-Term Embrittlement of Cast Duplex Stainless Steels in LWR Systems: Semiannual Report, October 1990-March 1991, NUREG/CR-4744, Vol. 6, No. 1, ANL 91/22 (August 1992). 
13. O. K. Chopra, Estimation of Fracture Toughness of Cast Stainless Steels During Thermal figing in LWR Systems, NUREG/CR-4513, ANL-90/42 (June 1991).

14. O. K. Chopra, "Thermal Aging of Cast Stainless Steels in LWR Systems: Estimation of Mechanical Properties," in Nuclear Plant Systems/Components Aging Management and Life Extension, I. T. Kisisel, J. Sinnapan, R. W. Carlson, and W. H. Lake, eds., PVP-Vol. 228. ASME, New York, pp. 79-92 (1992).

15. O. K. Chopra, Long-Term Embrittlement of Cast Duplex Stainless Steels in LWR Systems: Semiannual Report. April-September 1991, NUREG/CR-4744, Vol. 6, No. 2, ANL-92/32 (October 1992).

16. A. L. Hiser, Fracture Toughness Characterization of Nuclear Piping Steels, NUREG/CR5118. MEA-2325, Materials Engineering Associates, Inc. (November 1989).

17. G. M. Wilkowskd, et al., Degraded Piping Program - Phase II, Semiannual Report, NUREG/CR-4082, Vol. 2 (June 1985).

18. W. J. Mills, "Heat-to-Heat Variations in the Fracture Toughness of Austenitic Stainless Steels," Eng. Fracture Mech., 30, 469-492 (1988).

19. M. G. Vassilaros, R. A. Hays, and J. P. Gudas, "Investigation of the Ductile Fracture Properties of Type 304 Stainless Steel Plate, Welds, and 4-Inch Pipe," in Proc. 12th Water Reactor Safety Information Meeting, U.S. Nuclear Regulatory Commission, NUREG/CP-0058 Vol. 4, p. 176 (January 1985).

20. P. Balladon, J. Heritier, and P. Rabbe, "Influence of Microstructure on the Ductile Rupture Mechanisms of a 316L Steel at Room and Elevated Temperatures," in Fracture Mechanics: Fourteenth Symposium, ASTM STP 791, II496-II513 (1983).

21. W. H. Bamford and A. J. Bush, "Fracture Behavior of Stainless Steel," Elastic-Plastic Fracture, ASTM STP 668, 553-577 (1979). 


\section{Appendix}

\section{J-R Curve Characterization}

The J-R curve tests were performed according to ASTM Specifications E 813-85 (Standard Test Method for $J_{I C}$, a Measure of Fracture Toughness) and E 1152-87 (Standard Test Method for Determining J-R Curve). Compact-tension (CT) specimens, $25.4 \mathrm{~mm}(1 \mathrm{ln}$.) thick with $10 \%$ side grooves, were used for the tests. The CT specimen design, shown in Fig. A-1, is similar to the specimen of ASTM Specification E 399. the notch region is modified in accordance with $E 813$ and $E 5112$, to permit measurement of load-line displacement by axial extensometer. The extensometer was mounted on razor blades that were screwed onto the specimen along the load line.

Prior to testing, the specimens were fatigue-precracked at room temperature and at load levels within the linear elastic range. The final ratio of crack length to width (a/W) after precracking was $\approx 0.55$. The final $1-\mathrm{mm}(\approx 0.04-\mathrm{in}$.) crack extension was carried out at a load range of $13 \mathrm{kN}(2.92 \mathrm{kip})-1.3 \mathrm{kN}(0.292 \mathrm{kip})$, i.e., during precracking, $\mathrm{K}_{\max }$ was $<25 \mathrm{MPa} \cdot \mathrm{m}^{1 / 2}(22.6 \mathrm{ksi} \cdot \mathrm{in} .1 / 2)$. After precracking, all specimens were side-grooved by $20 \%$ of the total specimen thickness, i.e., $10 \%$ per side, to ensure uniform crack growth during testing.

The J-R curve tests were performed on an Instron testing machine with $90 \mathrm{kN}$ $(20 \mathrm{kdp})$ maximum load capacity. The load and load-line displacement data were digitized with digital voltmeters and stored on a disk for post test analysis and correction of the test data. The single-specimen compliance procedure was used to estimate the crack extension. Rotation and modulus corrections were applied to the compliance data. Both deformation theory and modified forms of the $\mathrm{J}$ integral were evaluated for each test.

After each test, the specimen was heated to $350^{\circ} \mathrm{C}$ to heat-tint the exposed fracture surface. The specimen was then fractured at liquid nitrogen temperature. The initial (1.e., fatigue precrack) and final (test) crack lengths were measured optically for both halves of the fractured specimen. The crack lengths were determined by the $9 / 8$ averaging technique, 1.e., the two near-surface measurements were averaged and the resultant value averaged with the remaining seven measurements.

The fracture toughness $J_{I C}$ values were determined in accordance with ASTM Specifications E 813-81 and E 813-85. For the former, J $J_{I C}$ is defined as the intersection of the blunting line given by $\mathrm{J}=2 \sigma_{\mathrm{f}} \Delta \mathrm{a}$, and the linear fit of the $\mathrm{J}-\mathrm{vs}-\Delta \mathrm{a}$ test data between the $0.15-\mathrm{mm}$ and $1.5-\mathrm{mm}$ exclusion lines. The flow stress, $\sigma_{\mathrm{f}}$, is the average of the $0.2 \%$ yield stress and the ultimate stress. The ASTM Specification E 813-85 procedure defines $\mathrm{J}_{\mathrm{IC}}$ as the intersection of the $0.2-\mathrm{mm}$ offset line with the power-law fit (of the form $\mathrm{J}=$ $C \Delta a^{n}$ ) of the test data between the exclusion lines. J-R curve tests on cast stainless steels indicate that a slope of four times the flow stress $\left(4 \sigma_{f}\right)$ for the blunting line expresses the $J$-vs. $-\Delta a$ data better than the slope of $2 \sigma_{f}$ that is defined in E 813-81 or E 813-85. The fracture toughness $J_{I C}$ values were determined with the $4 \sigma_{f}$ slope for the blunting line or $0.2-\mathrm{mm}$ offset line.

The tearing modulus was also evaluated for each test. The tearing modulus is given by $T=E(d J / d a) / \sigma_{f}^{2}$, where $E$ is the Young's modulus and $\sigma_{\mathrm{f}}$ is the flow stress. The ASTM 
E 813-81 value of tearing modulus is determined from the slope dJ/da of the linear fit to the J-vs. $-\Delta$ a data. For the power law curve fits, an average value of $\mathrm{dJ} / \mathrm{da}$ was calculated $\mathrm{A}^{\mathrm{A}-1}$ to obtain average tearing modulus.

The fracture toughness results for four commercial and four experimental heats of cast stainless steel aged up to $58,000 \mathrm{~h}$ at $290,320,350,400$, and $450^{\circ} \mathrm{C},(554,608,662$, 752, and $842^{\circ} \mathrm{F}$ ) and for the service-aged KBR pump cover plate material, are given in Table A-1. The test data, as well as an analysis and qualification of the data for $71 \mathrm{~J}-\mathrm{R}$ curve tests, have been presented earlier.A-2,A-3 Data analysis and qualification for tests conducted on long-term low-temperature aged materials are presented in this Appendix.

\section{Data Analysis Procedures}

The compliance method was used to determine crack length during the tests. The Hudak-Saxena calibration equation ${ }^{\mathrm{A}-4}$ was used to relate the specimen load line elastic compliance $C_{1}$ on an unloading/loading sequence with the crack length $a_{1}$. The compliance, 1.e., slope $(\Delta \delta / \Delta \mathrm{P})$ of the load line displacement vs. load record obtained during the unloading/loading sequence, is given by

$$
U_{L L}=\frac{1}{\left(B_{e} E_{e} C_{1}\right)^{1 / 2}+1}
$$

and

$$
\begin{aligned}
\mathrm{a}_{1} / \mathrm{W} & =1.000196-4.06319\left(U_{L L}\right)+11.242\left(U_{L L}\right)^{2}-106.043\left(U_{L L}\right)^{3} \\
& +464.335\left(U_{L L}\right)^{4}-650.677\left(U_{L L}\right)^{5}
\end{aligned}
$$

where $E_{e}$ is the effective elastic modulus, $B_{e}$ is the effective specimen thickness expressed as $B-\left(B-B_{N}\right)^{2} / B$, and $W$ is specimen width.

Both rotation and modulus corrections are applied to the compliance data. The modulus correction ${ }^{A-4}$ is used to account for the uncertainties in testing, 1.e., in the values of initial crack length determined by compliance and measured optically. The effective modulus $E_{M}$ is determined from

$$
E_{e}=\frac{1}{C_{0} B_{e}}\left(\frac{W+a_{0}}{W-a_{0}}\right) 1 / 2 f\left(a_{0} / W\right)
$$

and

$$
\begin{aligned}
\mathrm{f}\left(\mathrm{a}_{0} / \mathrm{W}\right)=2.163 & +12.219\left(\mathrm{a}_{0} / \mathrm{W}\right)-20.065\left(\mathrm{a}_{0} / \mathrm{W}\right)^{2}-0.9925\left(\mathrm{a}_{0} / \mathrm{W}\right)^{3} \\
+ & 20.609\left(\mathrm{a}_{0} / \mathrm{W}\right)^{4}-9.9314\left(\mathrm{a}_{0} / \mathrm{W}\right)^{5}
\end{aligned}
$$

where $C_{o}$ is initial compliance, $B_{e}$ is effective specimen thickness, and $a_{0}$ is the initial physical crack size measured optically.

To account for crack opening displacement in CT specimens, the crack size should be corrected for rotation.A-5 The corrected compliance is calculated from 


$$
\theta=\operatorname{Sin}^{-1}\left[\left(\frac{d_{m}}{2}+D\right) /\left(D^{2}+R^{2}\right) 1 / 2\right]-\tan ^{-1}\left(\frac{D}{R}\right)
$$

and

$$
C_{c}=C_{m} /\left[\left(\frac{H^{*}}{R} \operatorname{Sin} \theta-\operatorname{Cos} \theta\right)\left(\frac{D}{R} \operatorname{Sin} \theta-\operatorname{Cos} \theta\right)\right]
$$

where $\mathrm{C}_{c}$ and $\mathrm{C}_{\mathrm{m}}$ are, respectively, the corrected and measured elastic compliance at the load line, $\mathrm{H}^{*}$ represents the initial half-span of load points (1.e., center of pinholes), $R$ is the radius of rotation of the crack centerline $(=(W+a) / 2)$, a is the updated crack length, $D$ is one-half of the initial distance between the displacement points (i.e., half gauge length). $d_{m}$ is the total measured load line displacement, and $\theta$ is the angle of rotation of a rigid body element about the unbroken midsection line.

The $J$ value is calculated at any point on the load-vs.-load line displacement record using the relationship

$$
\mathrm{J}=\mathrm{Jel}_{\mathrm{el}}+\mathrm{J}_{\mathrm{pl}} \text {. }
$$

where $J_{e l}$ is the elastic component of $J$ and $J_{p l}$ is the plastic component of $J$. For a CT specimen, at a point corresponding to the coordinates $P_{1}$ and $\delta_{1}$ on the specimen load-vs.load line displacement record and $a_{1}$ is $\left(a_{0}+\Delta a_{1}\right)$, the deformation $J$ is given by

$$
J_{D(1)}=\left(K_{1}\right)^{2}\left(1-v^{2}\right) / E_{e}+J_{p l(1)}
$$

where from ASTM method E 399,

$$
K_{i}=\left[P_{i} /\left(B B_{N} W_{e}\right)^{1 / 2}\right] f\left(a_{i} / W\right]
$$

with

$$
\begin{gathered}
f\left(a_{1} / W\right)=\left[2+\left(a_{i} / W\right)\right]\left[0.886+4.64\left(a_{1} / W\right)-13.32\left(a_{i} / W\right)^{2}+14.72\left(a_{i} / W\right)^{3}\right. \\
\left.-5.6\left(a_{1} / W\right)^{4}\right] /\left[1-\left(a_{1} / W\right)\right]^{3 / 2}
\end{gathered}
$$

and

$$
J_{p l(1)}=\left[J_{p l(1-1)}+\left(\frac{\eta_{l}}{b_{1}}\right) \frac{A_{p l(1)}-A_{p l(1-1)}}{B_{N}}\right]\left[1-\left(\frac{\gamma_{1}}{b_{1}}\right)\left(a_{1}-a_{1-1}\right)\right]
$$

where $v$ is Poisson's ratio, $\mathrm{b}$ is the uncracked ligament. $A_{\mathrm{pl}}$ is the plastic component of the area under the load-vs.-load line displacement record, and $\eta$ is a factor that accounts for the tensile component of the load as given by

$$
\eta_{1}=2+0.522 b_{1} / W
$$

and $\gamma$ is a factor that accounts for limited crack growth as given by

$$
\gamma_{1}=1+0.76 b_{1} / w
$$


The modified $J$ values $\left(J_{M}\right)$ are calculated from the relationship (from Ref. A-6)

$$
J_{M(1)}=J_{D(1)}+\Delta J_{1}
$$

where

$$
\Delta J_{1}=\Delta J_{1-1}+\left(\frac{\gamma_{1}}{b}\right) J_{p l(1)}\left(a_{1}-a_{1-1}\right)
$$

According to ASTM Specification E 1152-87, the $J_{D}-R$ curves are valid only for crack growth up to $10 \%$ of the initial uncracked ligament. Also, they show a dependence on specimen size. The $J_{M}-R$ curves have been demonstrated to be independent of specimen size and yleld valid results for larger crack growth.

\section{Data Qualification}

The various validity criteria specified in ASTM Specification E 813-85 for $J_{1 C}$ and in ASTM Specification E 1152-87 for the J-R curve were used to qualify the results from each test. The various criteria include maximum values of crack extension and $J$-integral; limits for initial uncracked ligament, effective elastic modulus, optically measured physical crack length, and spacing of $J-\Delta a$ data points. The $\omega$ criterla (from Ref. $A-7$ ) was also used to ensure that a region of $\mathrm{J}$ dominance exists.

For the present investigation, most of the unaged or short-term-aged specimens ydelded invalid $\mathrm{J}_{1 \mathrm{C}}$ values because of the relatively hign toughness of the material. The reasons for the discrepancies are data point spacing. shape of the final crack front, or size of the uncracked ligament. In general, the size of the uncracked ligament or the specimen thickness was inadequate for the unaged or short-term-aged specimens because of the relatively high toughness of the material. The $J_{\max }$ limit for the $J-v s .-\Delta a$ data was ignored in most tests to obtain a good power-law fit of the test data.

The shape of the crack front was also very irregular for most cast stainless steels. This may be attributed to the coarse grain structure of the casting and differences in ferrite morphology. Cast stainless steels with large columnar grains, in particular, showed significant variation in crack length along the width of a specimen. Furthermore, the crack front always had a leading crack near the edges of the specimen. The near-surface measurements of the final physical crack length were often $> \pm 1.02 \mathrm{~mm}$, the maximum value allowed for data qualification.

The fracture surfaces often showed uncracked ridges or ligaments along the direction of crack extension. The uncracked ligaments add significant error to the estimation of crack length by compliance. Therefore, the difference between the crack extension predicted from elastic compliance and the average measured physical crack extension is more than the maximum value allowed by ASTM E 1152.

All tests showed significant load relaxation during the unloading/reloading cycle for estimating crack length by elastic compliance. All unloadings were $25 \%$ of the load. The load at the end of the unloading/reloading cycle is always lower than it was at the start of the unloading cycle. The difference is appreciable for the room-temperature test. 
Therefore, the initial $20-30 \%$ of the unloading curve was ignored in estimating crack length.

\section{References}

A-1. A. L. Hiser, F. J. Loss, and B. H. Menke, J-R Curve Characterlzation of Irradiated Low Upper Shelf Welds, NUREG/CR-3506, MEA-2028, Materlals Engineering Associates, Inc. (April 1984).

A-2. O. K. Chopra. A. Sather, and L. Y. Bush, Long-Term Embrittlement of Cast Duplex Stainless Steels in LWR Systems: Semiannual Report, April-September 1989. NUREG/CR-4744 Vol. 4, No. 2, ANL-90/49 (June 1991).

A-3. O. K. Chopra, Long-Term Embrittlement of Cast Duplex Stainless Steels in LWR Systems: Semiannual Report, October 1990-March 1991, NUREG/CR-4744 Vol. 6. No. 1, ANL-91/22 (June 1992).

A-4. A. Saxena and S. J. Hudak, Jr., "Review and Extention of Compliance Information for Common Crack Growth Specimen," Int. J. Fracture, 5. Vol. 14, 453-468 (1978).

A-5. F. J. Loss, B. H. Menke, and R. A. Gray, Jr., "Development of J-R Curve Procedures," In NRL-EPRI Research Program (RP 886-2), Evaluation and Prediction of Neutron Embrittlement in Reactor Pressure Vessel Materials Annual Progress Report for FY 1978. J. R. Hawthorn, ed., NRL Report 8327, Naval Research Laboratory (August 1979).

A-6. H. A. Ernst, "Material Resistance and Instabllity Beyond J-Controlled Crack Growth," ElastiA-Plastic Fracture: Second Symp., Vol. I: Inelastic Crack Analysis, ASTM STP 803. American Society for Testing and Materials, Philadelphia (1983).

A-7. J. W. Hutchinson and P. C. Paris. "The Theory of Stability Analysis of J-Controlled Crack Growth," Elastic Plastic Fracture, ASTM STP 668, American Society for Testing and Materials, Philadelphia, pp. 37-64 (1983). 

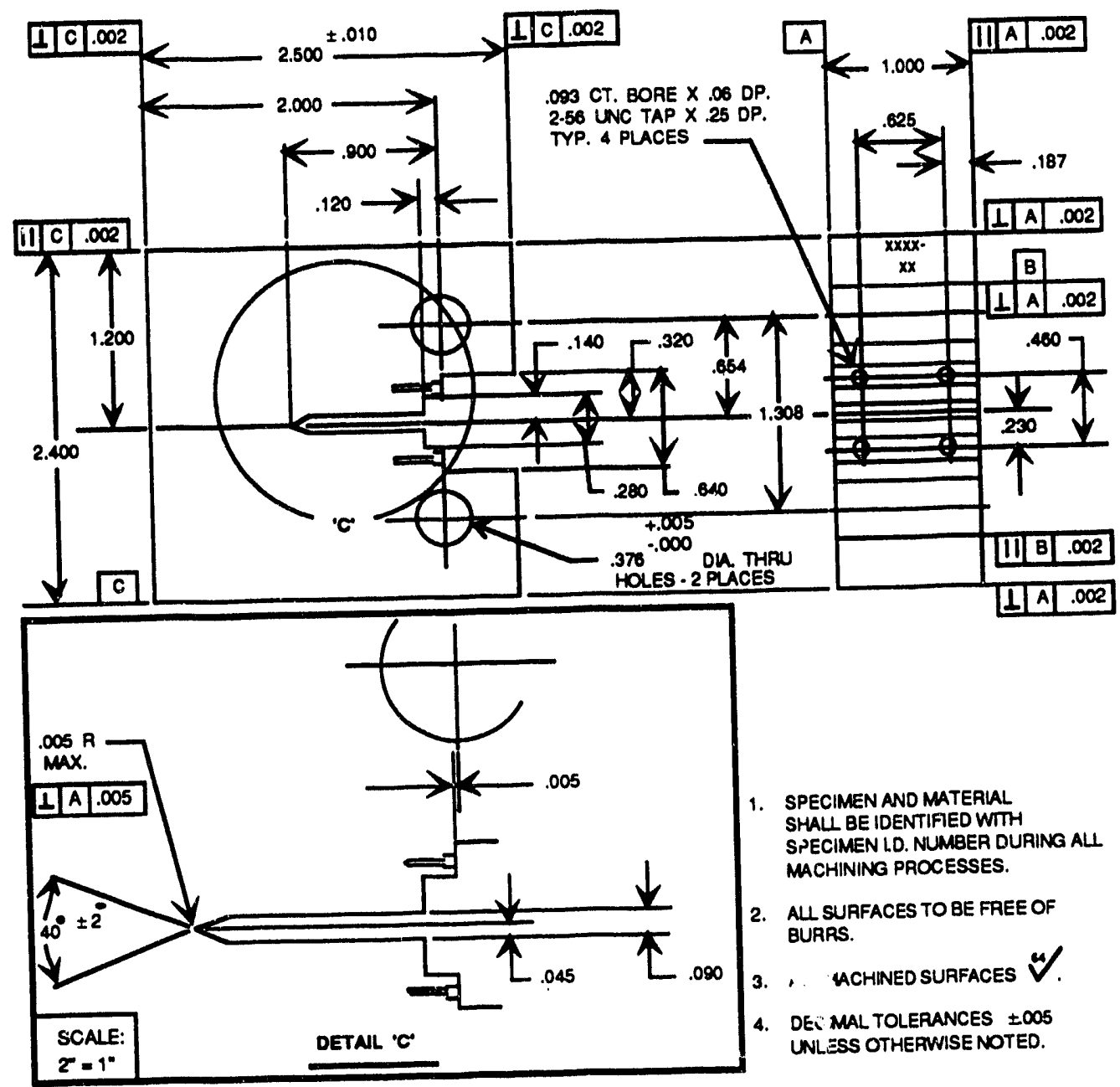

1. SPECIMEN ANO MATERIAL SHALL BE IDENTIFED WITH

SPECIMEN LD. NUMBER DURING ALI MACHINING PROCESSES.

2. ALL SURFACES TO BE FAEE OF BURRS.

3. 1 achined suRfaces $\boldsymbol{v}$.

4. DE: MAL TOLERANCES \pm 005 UNLESS OTHERWISE NOTED.

Fygure A-1. Configuration of compact-tension test specimen 


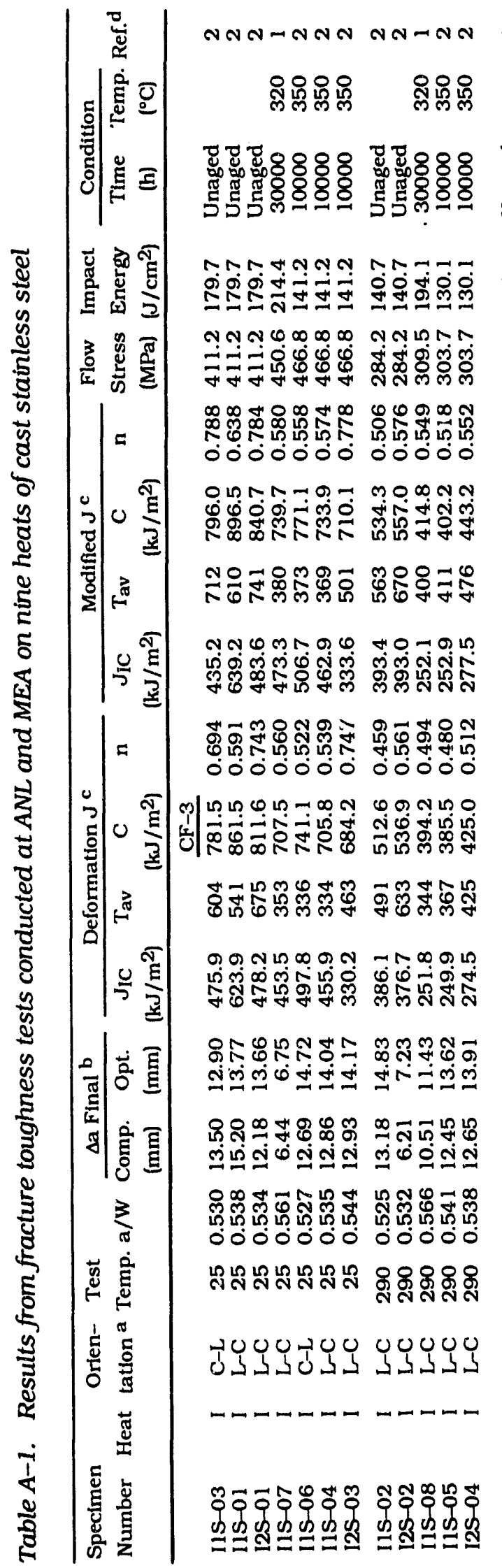

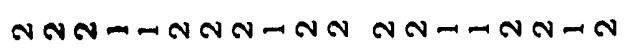

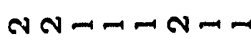

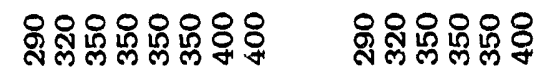

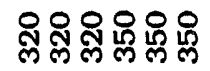

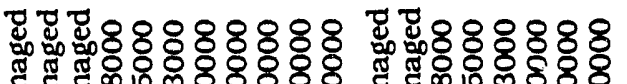

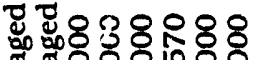

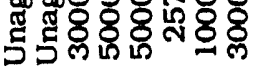

$\infty \infty \infty$ o

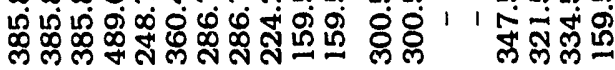
000 ก

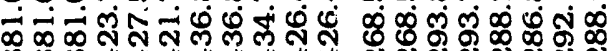

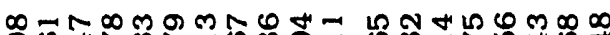

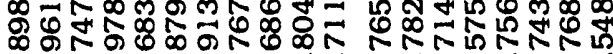
00000000000 00000000

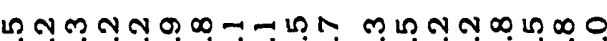

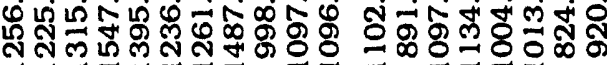
๓

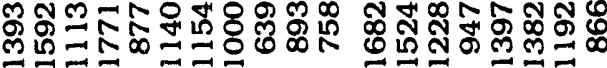

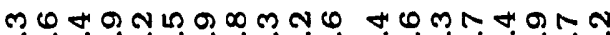

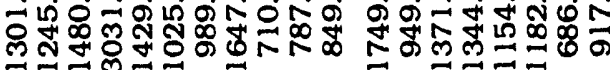

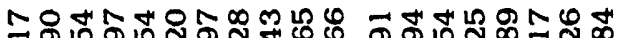

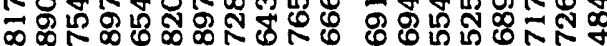
00000000000 00000000

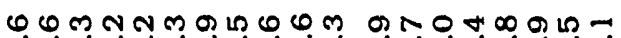

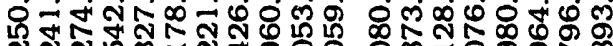

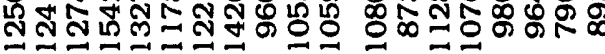

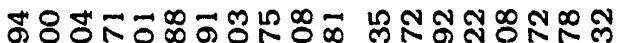

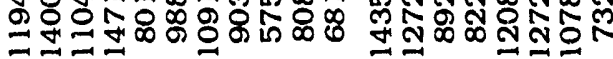

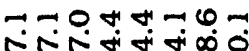

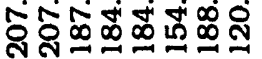
เ ผู่

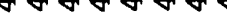
ชูำ 00000000

$00 \ln 10 \ln 4$

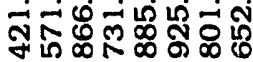

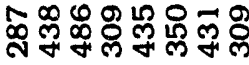

$m \infty 00 \circ 0 \forall-$ นิ่

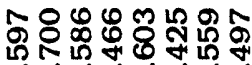
00000000 H R N O $00 \mathrm{~N}$ เท่

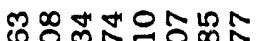

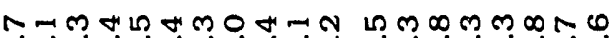
Ћํำ่

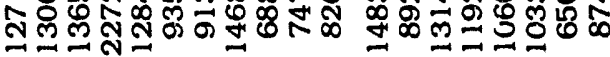

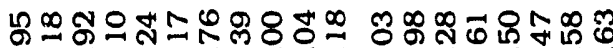

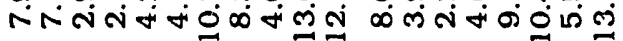

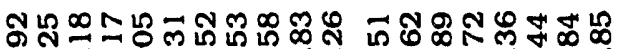

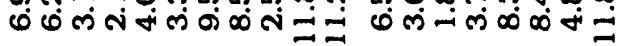

$\infty=0$ เ

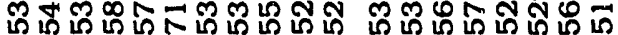
0000000000000000000

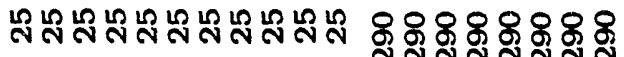

Honดgดั

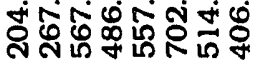

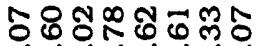
붕ํำ

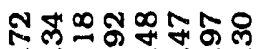
ต่

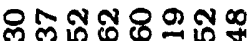

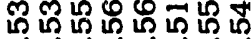
00000000

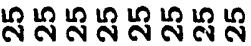

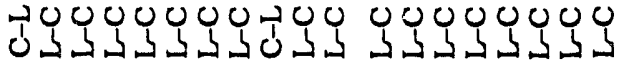

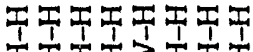

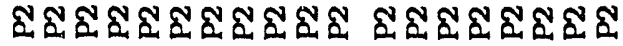

88888888

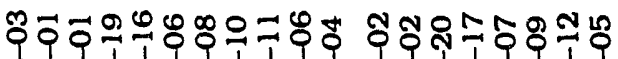

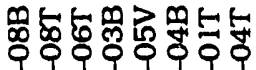

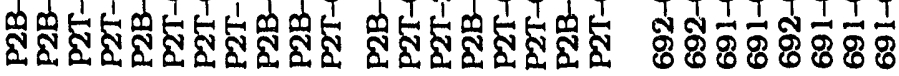




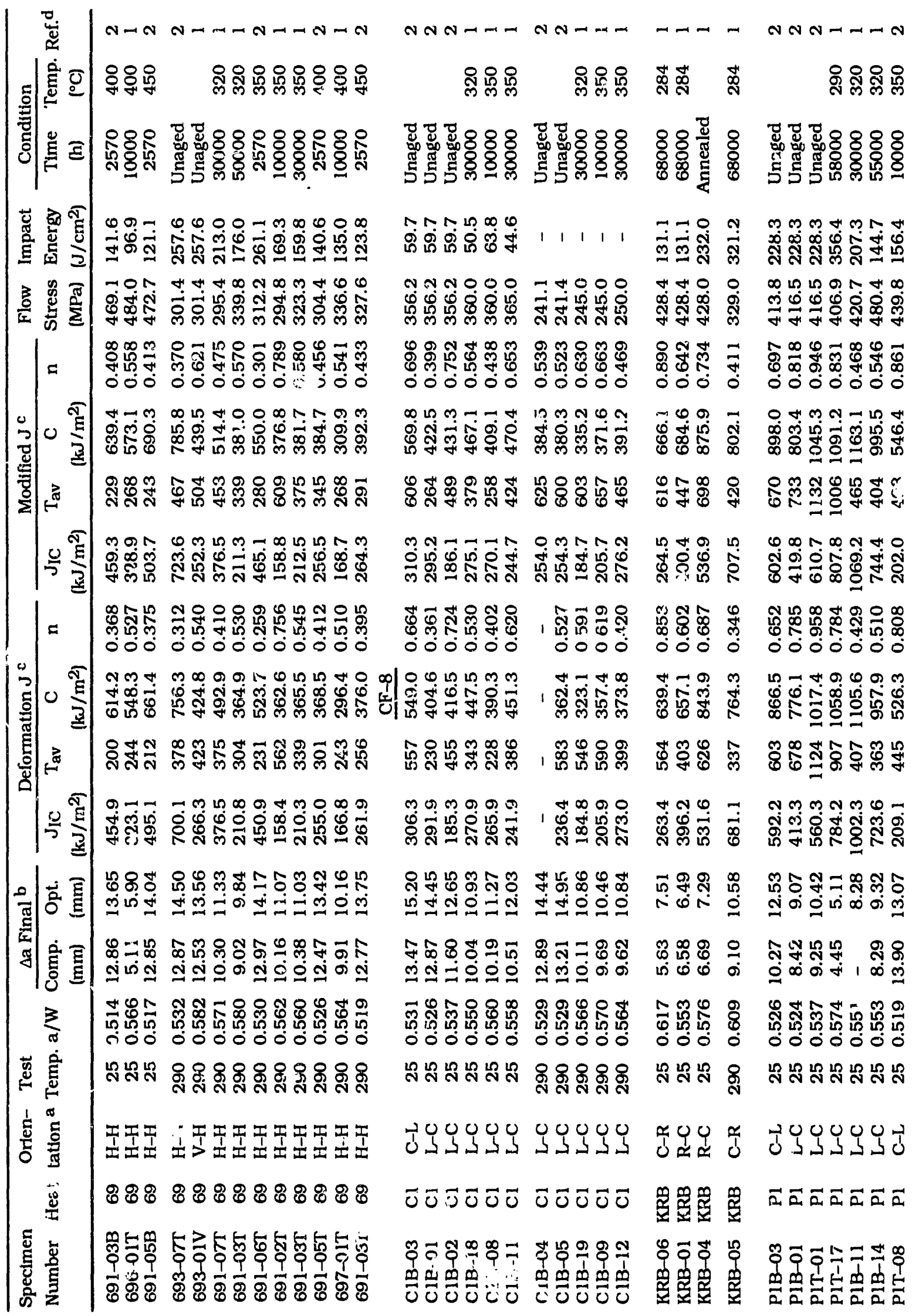




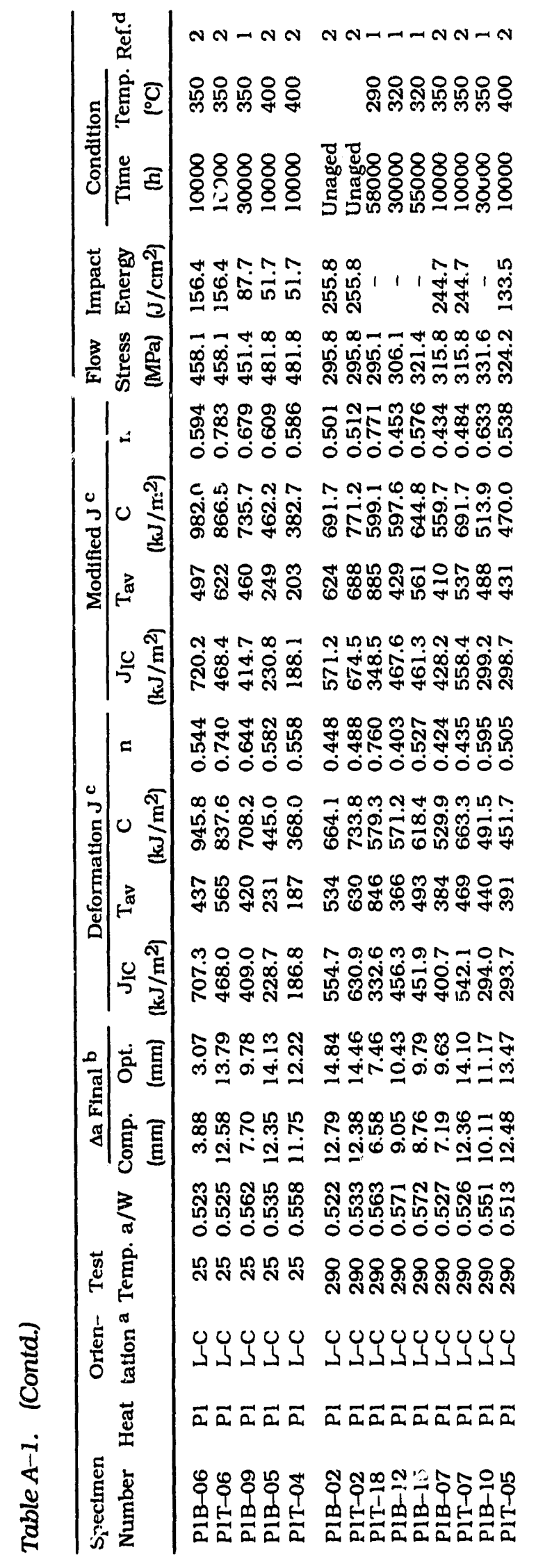

ผ

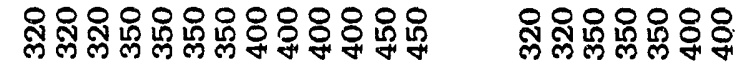

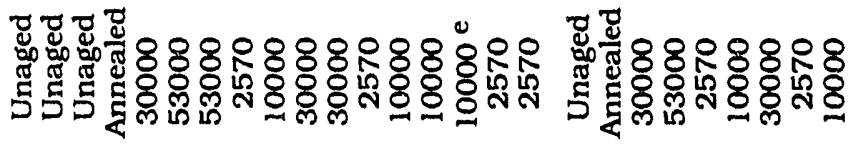
A A th ฝึ่

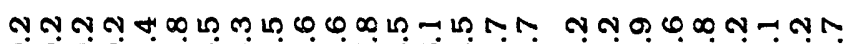

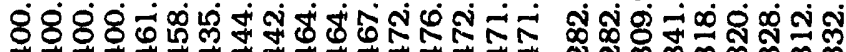

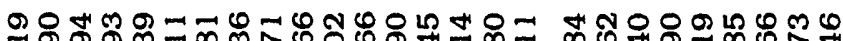

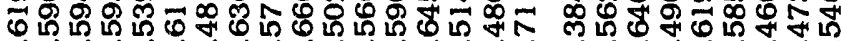
00000000000000000000000000

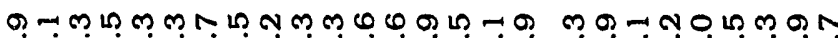

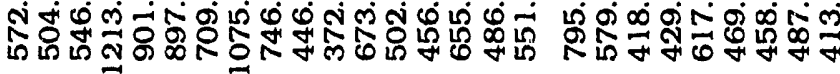

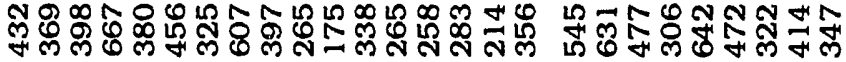

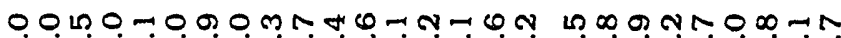
กิ่น

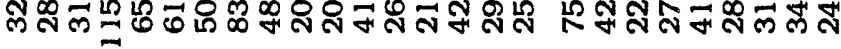

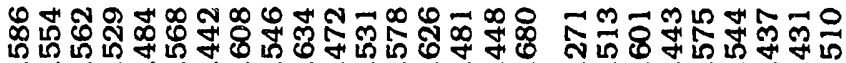
00000000000000000 000000000 m n

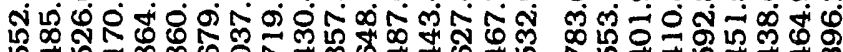

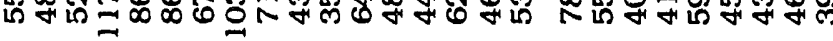

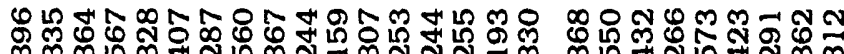
मm สู่

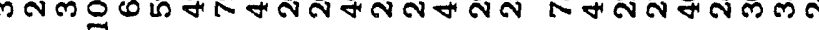

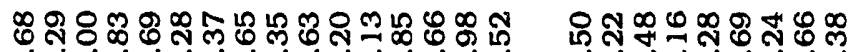
ษ்

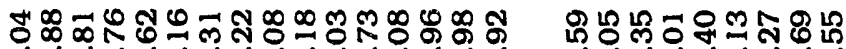
버버 สำง ถูกิ 00000000000000000000000000

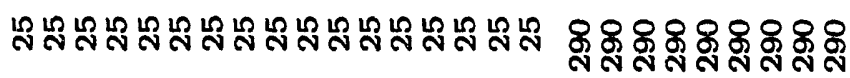

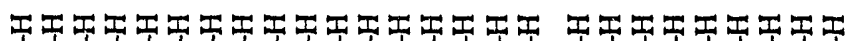

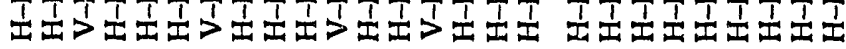

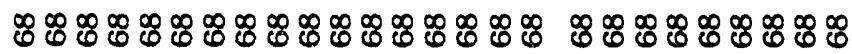

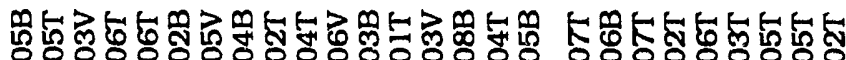

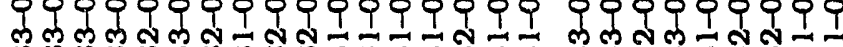

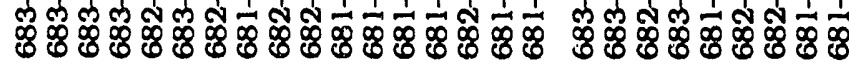




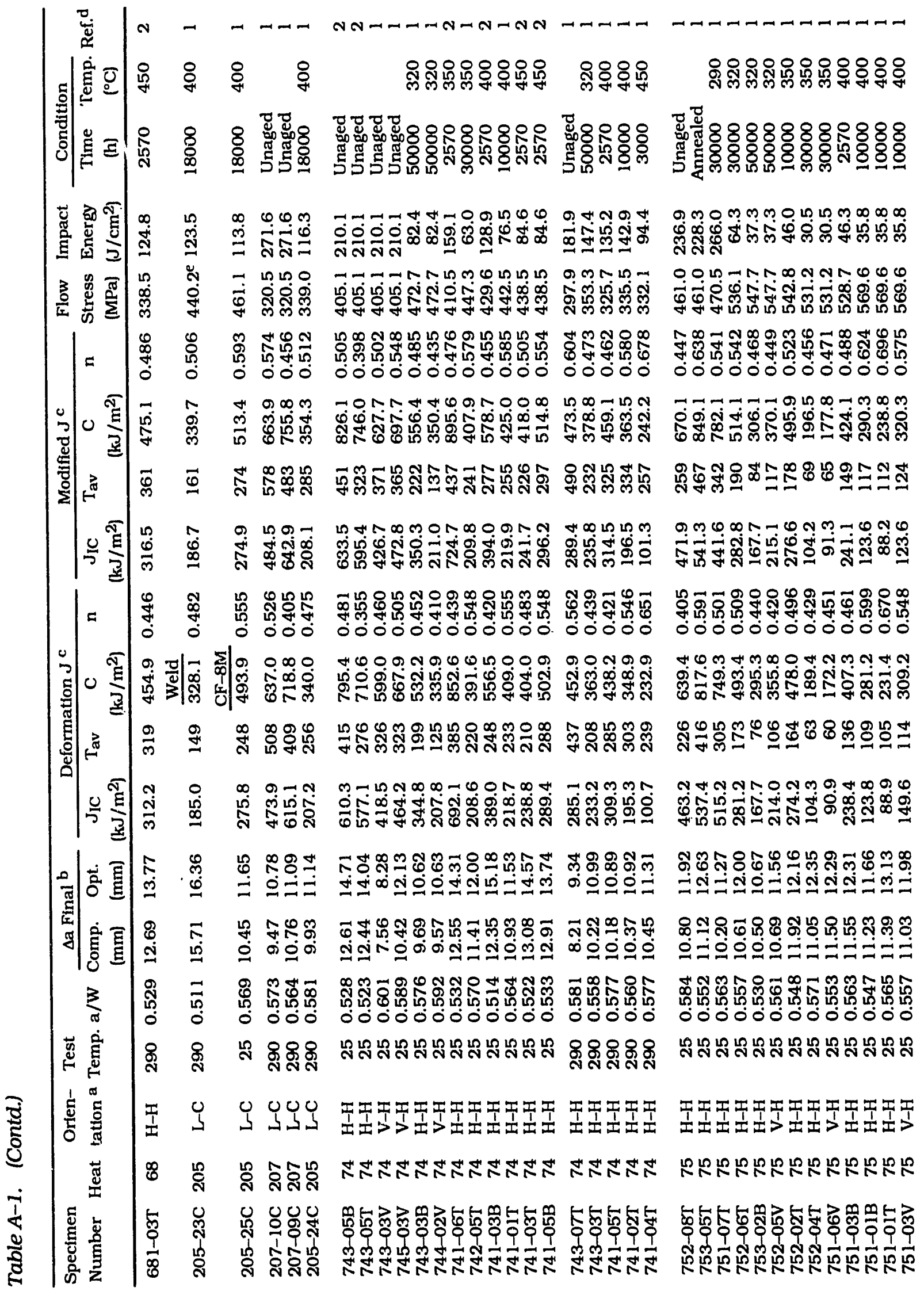




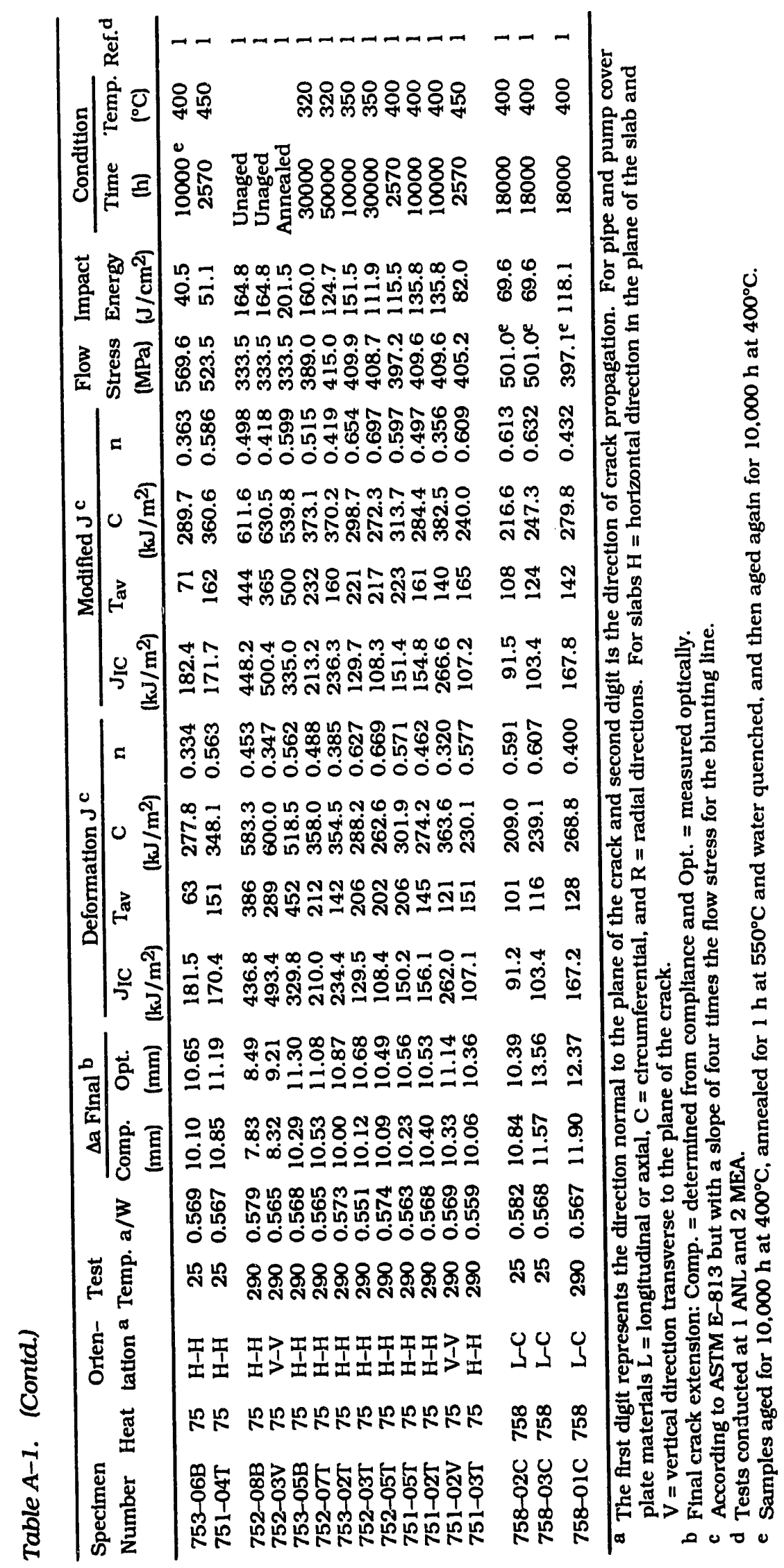


Table A-2. Test data for spectmen P2T-19

$\begin{array}{ll}\text { Test Number } & : 0087 \\ \text { Material Type } & : \text { CF-3 } \\ \text { Aging Temp. } & : 290^{\circ} \mathrm{C} \\ \text { Spec. Thickness } & : 25.36 \mathrm{~mm} \\ \text { Spec. Width } & : 50.78 \mathrm{~mm}\end{array}$

Test Temp. $\quad: 25^{\circ} \mathrm{C}$

Heat Number : P2

Aging Time $: 58,000 \mathrm{~h}$

Net Thickness : $20.27 \mathrm{~mm}$

Flow Stress $\quad: 423.70 \mathrm{MPa}$

\begin{tabular}{crrrrr}
\hline $\begin{array}{c}\text { Unload } \\
\text { Number }\end{array}$ & $\begin{array}{c}J_{\mathrm{d}} \\
\left(\mathrm{kJ} / \mathrm{m}^{2}\right)\end{array}$ & $\begin{array}{c}\mathrm{J}_{\mathrm{m}} \\
\left(\mathrm{kJ} / \mathrm{m}^{2}\right)\end{array}$ & $\begin{array}{c}\Delta \mathbf{a} \\
(\mathrm{mm})\end{array}$ & $\begin{array}{c}\text { Load } \\
(\mathrm{kN})\end{array}$ & $\begin{array}{c}\text { Deflection } \\
(\mathrm{mm})\end{array}$ \\
\hline 1 & 30.19 & 30.24 & 0.0459 & 21.250 & 0.407 \\
2 & 91.85 & 92.33 & 0.1390 & 25.434 & 0.907 \\
3 & 162.09 & 162.56 & 0.1382 & 27.817 & 1.409 \\
4 & 237.45 & 238.47 & 0.1781 & 29.592 & 1.909 \\
5 & 316.63 & 318.53 & 0.2264 & 31.005 & 2.409 \\
6 & 398.94 & 403.01 & 0.3193 & 32.215 & 2.911 \\
7 & 485.94 & 489.02 & 0.2847 & 33.459 & 3.409 \\
8 & 558.51 & 560.97 & 0.2662 & 34.138 & 3.810 \\
9 & 631.19 & 634.80 & 0.2968 & 35.031 & 4.210 \\
10 & 702.68 & 710.41 & 0.3942 & 35.701 & 4.610 \\
11 & 774.39 & 787.64 & 0.5121 & 36.429 & 5.011 \\
12 & 852.64 & 865.03 & 0.4956 & 37.296 & 5.410 \\
13 & 928.30 & 946.08 & 0.5907 & 37.809 & 5.810 \\
14 & 1012.12 & 1027.21 & 0.5472 & 38.445 & 6.213 \\
15 & 1094.79 & 1111.40 & 0.5700 & 39.099 & 6.616 \\
16 & 1172.16 & 1194.96 & 0.6558 & 39.223 & 7.010 \\
17 & 1243.84 & 1281.10 & 0.8435 & 39.871 & 7.408 \\
18 & 1346.67 & 1364.08 & 0.6041 & 40.501 & 7.811 \\
19 & 1417.16 & 1456.81 & 0.8567 & 41.007 & 8.210 \\
20 & 1506.81 & 1542.45 & 0.8138 & 41.548 & 8.609 \\
21 & 1591.19 & 1634.66 & 0.8928 & 42.024 & 9.010 \\
22 & 1663.02 & 1727.32 & 1.0922 & 42.215 & 9.409 \\
23 & 1770.40 & 1841.52 & 1.1532 & 42.627 & 9.906 \\
24 & 1888.24 & 1960.22 & 1.1605 & 43.263 & 10.411 \\
25 & 1997.54 & 2081.01 & 1.2512 & 43.651 & 10.912 \\
26 & 216.74 & 2200.42 & 1.2528 & 44.051 & 11.411 \\
27 & 2218.30 & 2325.89 & 1.4214 & 44.197 & 11.914 \\
28 & 2314.24 & 2449.44 & 1.6066 & 44.580 & 1.412 \\
29 & 2430.70 & 2573.03 & 1.6521 & 45.191 & 12.912 \\
30 & 2538.97 & 2700.96 & 1.7714 & 45.332 & 13.410 \\
31 & 2660.74 & 2828.82 & 1.8066 & 45.837 & 13.912 \\
32 & 2779.87 & 2960.88 & 1.8779 & 46.098 & 14.417 \\
33 & 2889.82 & 3091.41 & 1.9865 & 46.248 & 14.912 \\
34 & 3013.95 & 3251.42 & 2.1668 & 46.596 & 15.510 \\
\hline & & & & & \\
\hline & & & & & \\
\hline
\end{tabular}


Table A-3. Deformation $J_{I C}$ and $J-R$ curve results for spectmen P2T-19

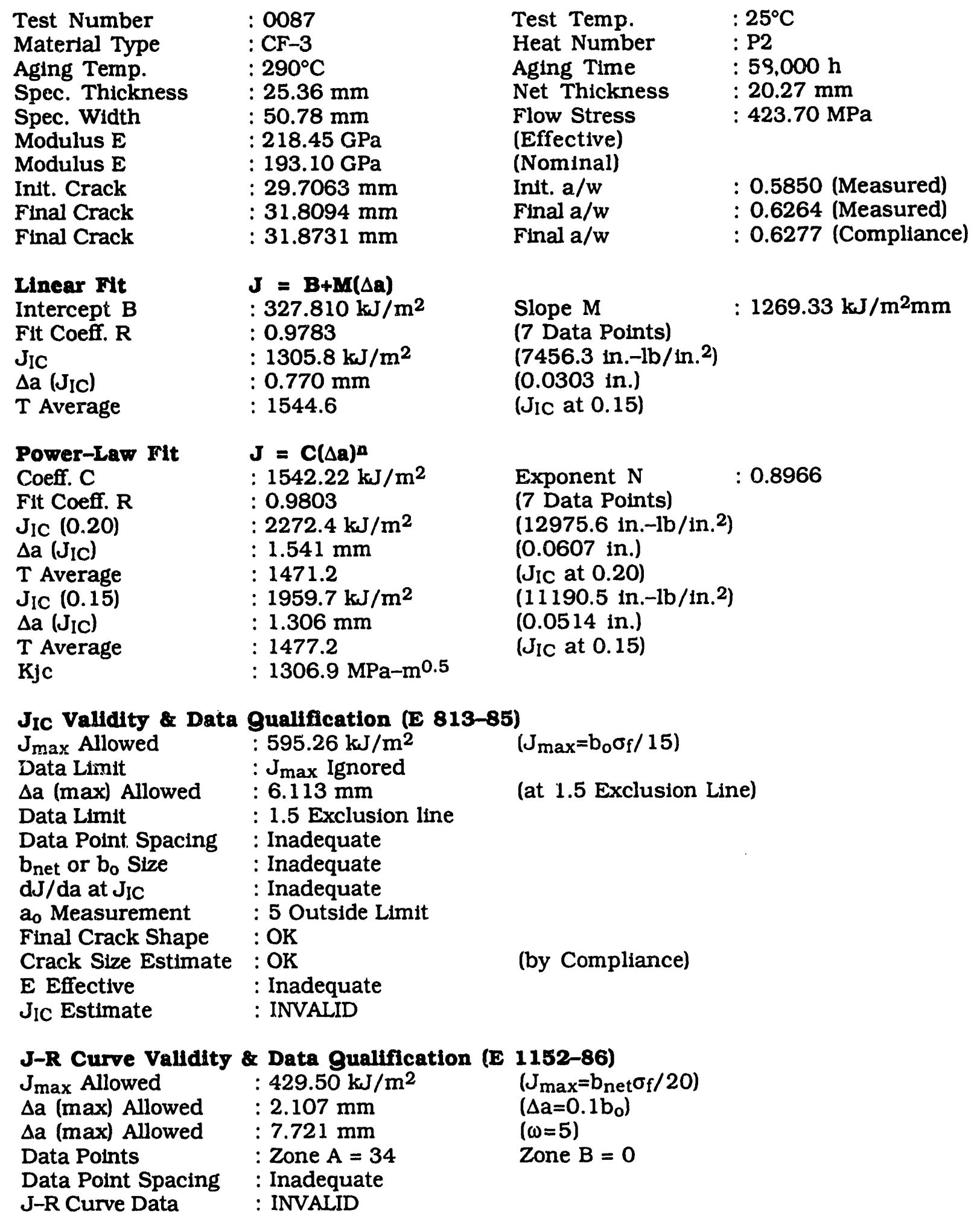


Table A-4. Modifled $J_{I C}$ and $J-R$ curve results for spectmen P2T-19

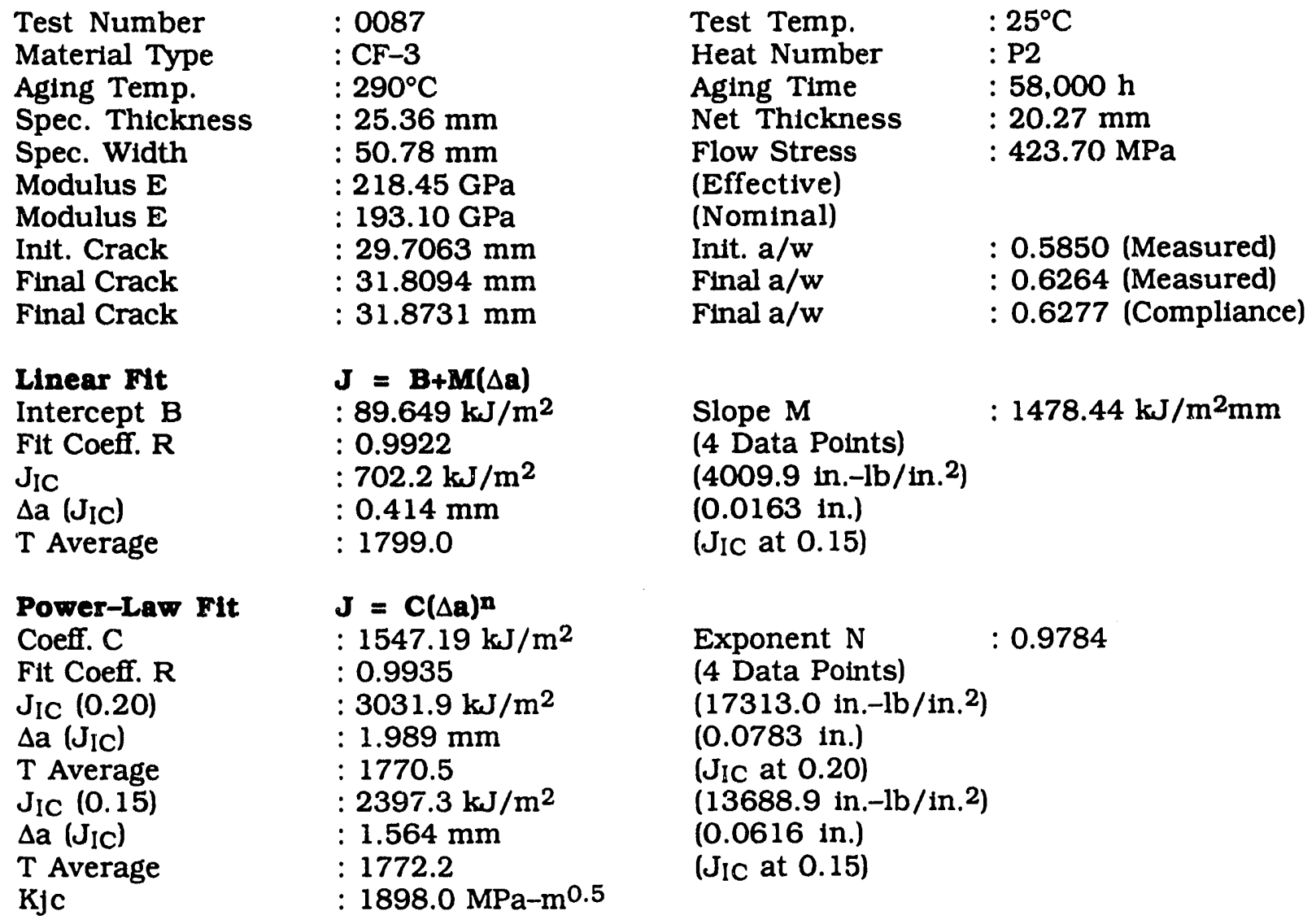

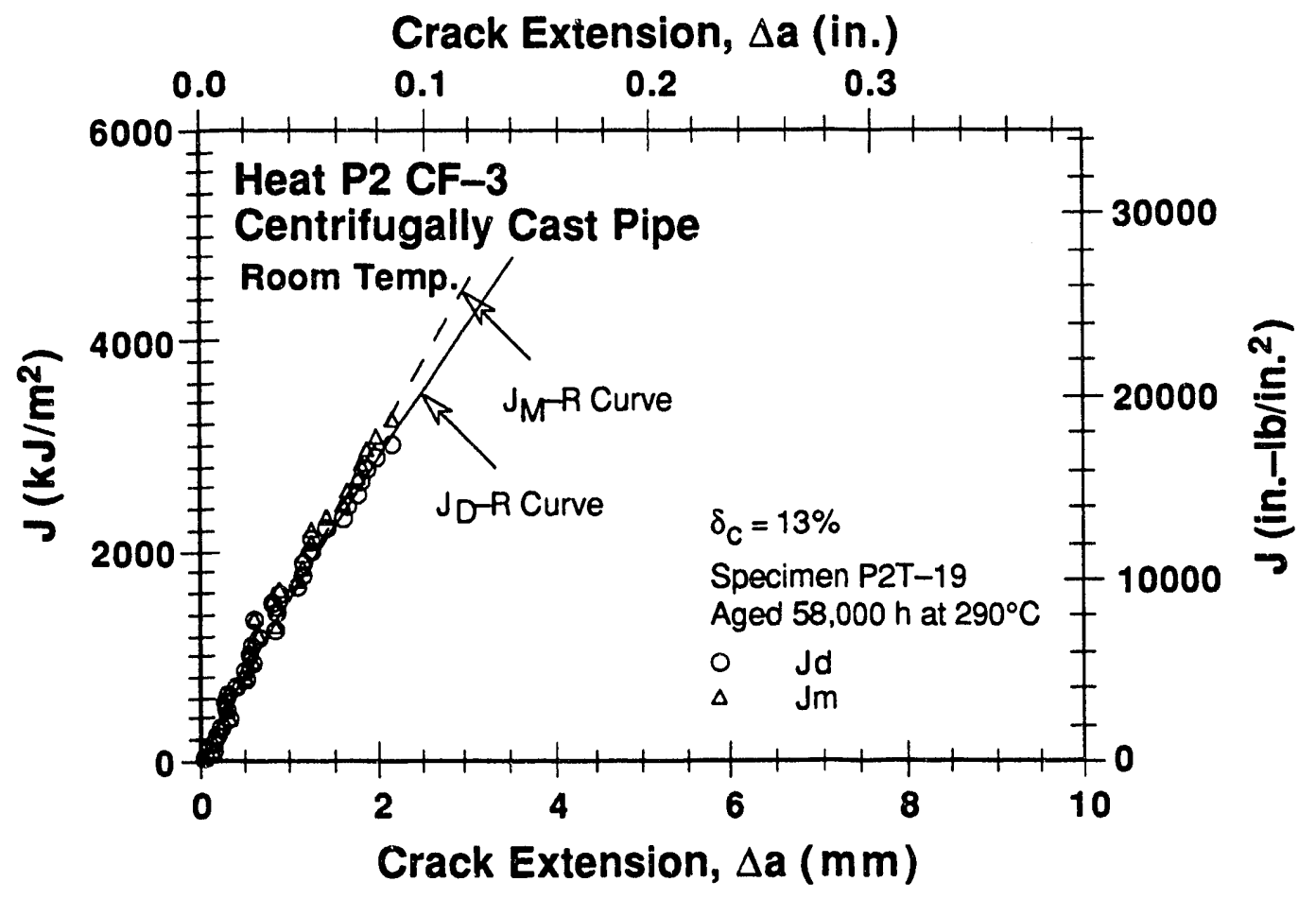

Figure A-2. Deformation and modified $J-R$ curves at room temp. for Heat P2 aged $58,000 \mathrm{~h}$ at $290^{\circ} \mathrm{C}$ 


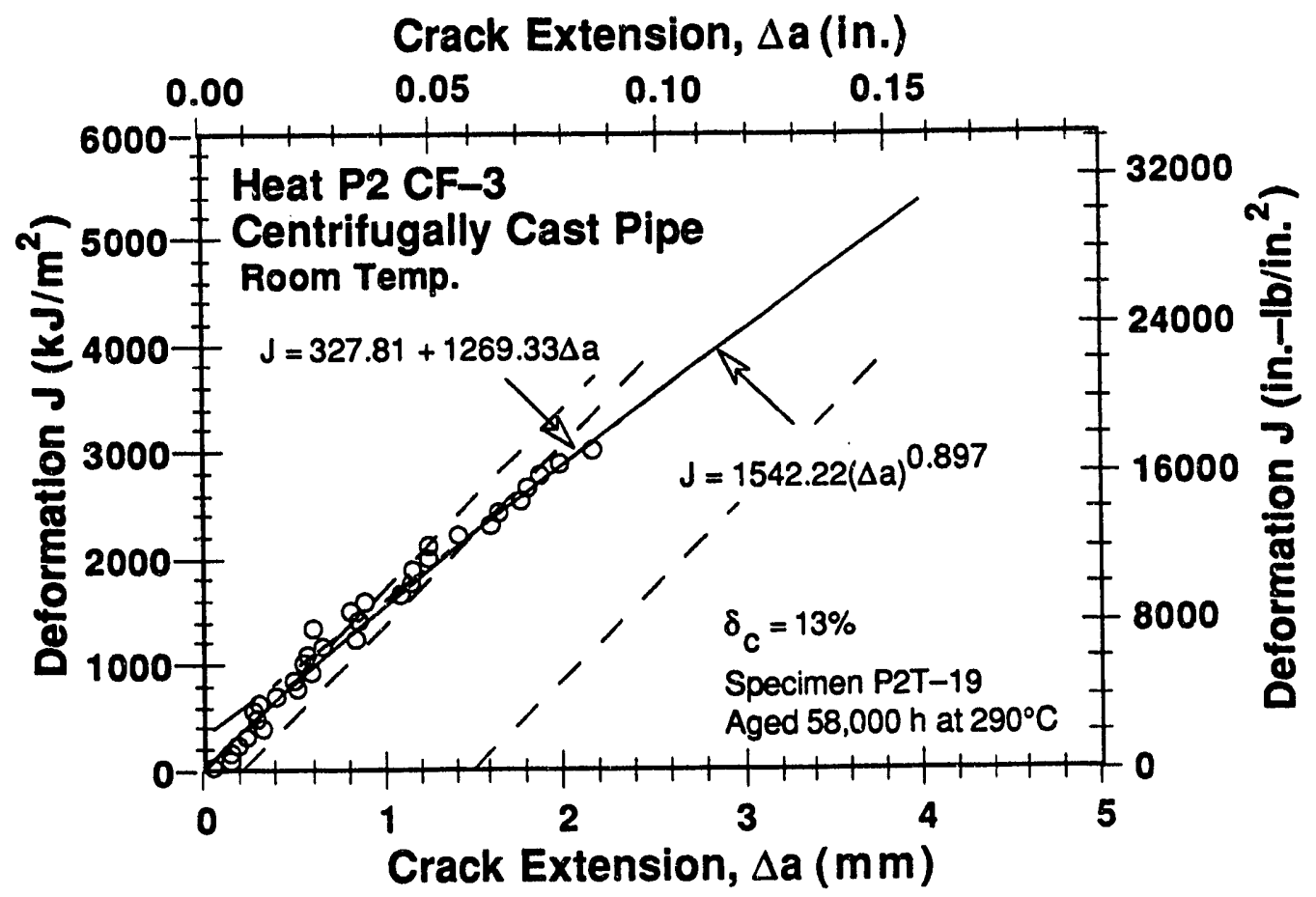

Fygure A-3. Deformation $J_{I C}$ at room temp. for Heat $\mathrm{P2}$ aged 58,000 h at $290^{\circ} \mathrm{C}$

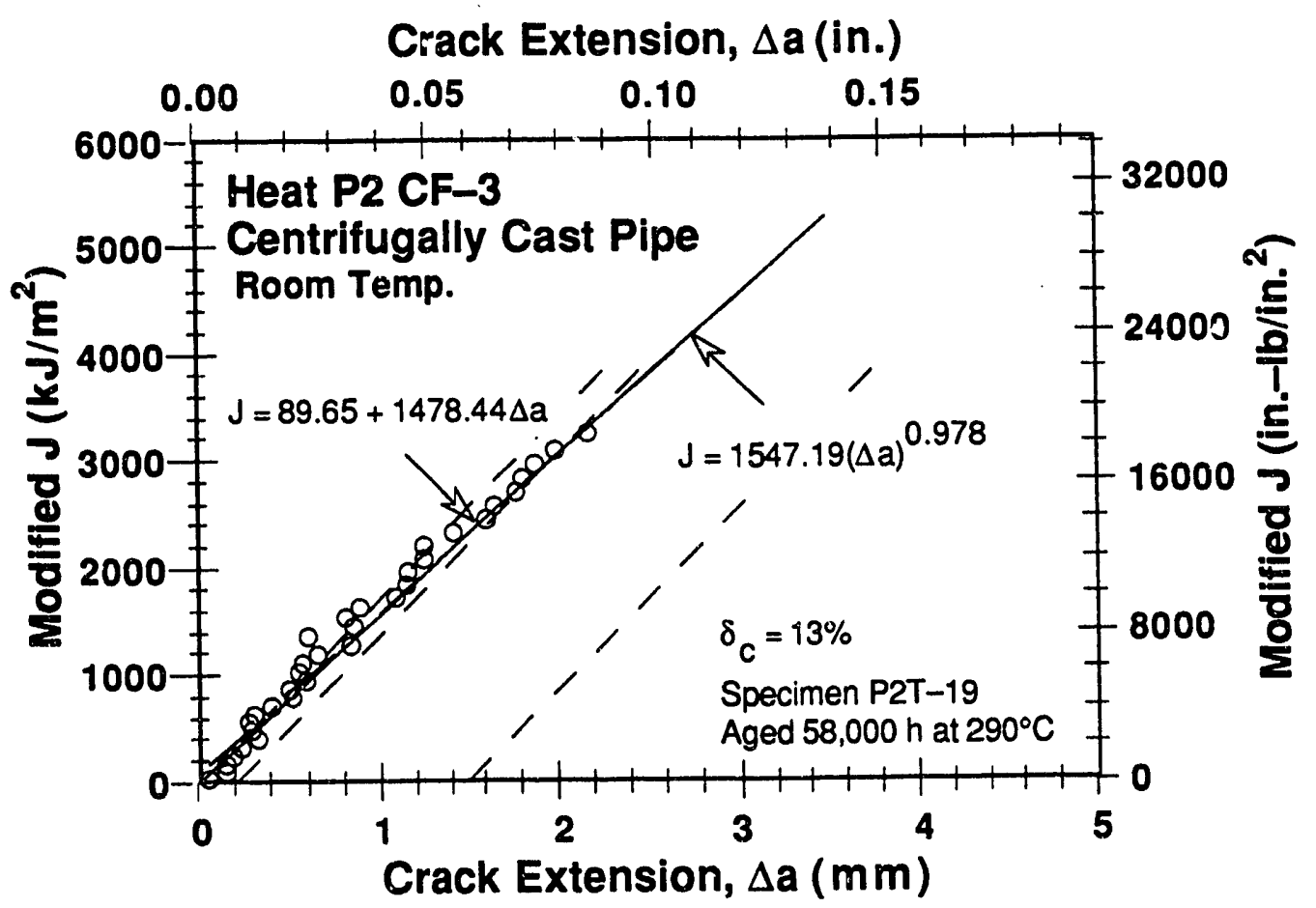

Figure A-4. Modified $J_{I C}$ at room temp. for Heat $P 2$ aged $58,000 \mathrm{~h}$ at $290^{\circ} \mathrm{C}$ 
Table A-5. Test data for specimen P2B-16

\begin{tabular}{|c|c|c|c|c|c|}
\hline \multicolumn{2}{|c|}{$\begin{array}{l}\text { Test Number } \\
\text { Material Type } \\
\text { Aging Temp. } \\
\text { Spec. Thickness } \\
\text { Spec. Width }\end{array}$} & $\begin{array}{l}: 0086 \\
: C F-3 \\
: 320^{\circ} \mathrm{C} \\
: 25.38 \mathrm{~mm} \\
: 50.81 \mathrm{~mm}\end{array}$ & \multicolumn{2}{|c|}{$\begin{array}{l}\text { Test Temp. } \\
\text { Heat Number } \\
\text { Aging Time } \\
\text { Net Thickness } \\
\text { Flow Stress }\end{array}$} & $\begin{array}{l}: 25^{\circ} \mathrm{C} \\
: \mathrm{P} 2 \\
: 55,000 \mathrm{~h} \\
: 20.38 \mathrm{~mm} \\
: 427.45 \mathrm{MPa}\end{array}$ \\
\hline $\begin{array}{l}\text { Unload } \\
\text { Number } \\
\end{array}$ & $\begin{array}{c}\mathrm{Jd}_{\mathrm{d}} \\
\left(\mathrm{kJ} / \mathrm{m}^{2}\right)\end{array}$ & $\begin{array}{c}J_{m} \\
\left(\mathrm{~kJ} / \mathrm{m}^{2}\right)\end{array}$ & $\begin{array}{c}\Delta \mathrm{a} \\
(\mathrm{mm})\end{array}$ & $\begin{array}{l}\text { Load } \\
(\mathrm{kN}) \\
\end{array}$ & $\begin{array}{c}\begin{array}{c}\text { Deflection } \\
(\mathrm{mm})\end{array} \\
\end{array}$ \\
\hline $\begin{array}{l}1 \\
2 \\
3 \\
4 \\
5 \\
6 \\
7 \\
8 \\
9 \\
10 \\
11 \\
12 \\
13 \\
14 \\
15 \\
16 \\
17 \\
18 \\
19 \\
20 \\
21 \\
22 \\
23 \\
24 \\
25 \\
26 \\
27 \\
28 \\
29 \\
30 \\
31 \\
32 \\
33 \\
34 \\
35 \\
36 \\
37\end{array}$ & $\begin{array}{r}31.00 \\
82.91 \\
141.08 \\
204.14 \\
270.49 \\
339.47 \\
409.66 \\
485.14 \\
558.55 \\
634.06 \\
712.46 \\
792.96 \\
868.15 \\
952.26 \\
1035.22 \\
1119.78 \\
1202.77 \\
1291.52 \\
1377.42 \\
1457.83 \\
1552.32 \\
1636.73 \\
1710.14 \\
1790.25 \\
1875.23 \\
1963.94 \\
2040.58 \\
2123.08 \\
2222.88 \\
2309.58 \\
2382.43 \\
2493.94 \\
2579.96 \\
2656.38 \\
2748.47 \\
2820.47 \\
2870.23\end{array}$ & $\begin{array}{r}30.97 \\
83.43 \\
142.13 \\
204.63 \\
272.03 \\
342.09 \\
413.25 \\
487.05 \\
565.30 \\
642.84 \\
722.96 \\
804.19 \\
889.22 \\
972.55 \\
1060.22 \\
1148.34 \\
1237.47 \\
1327.24 \\
1427.86 \\
1512.50 \\
1606.48 \\
1702.99 \\
1800.36 \\
1896.66 \\
1993.14 \\
2091.74 \\
2191.95 \\
2290.50 \\
2391.10 \\
2492.56 \\
2623.32 \\
2746.24 \\
2877.36 \\
3003.69 \\
3129.67 \\
3259.26 \\
3384.43\end{array}$ & $\begin{array}{r}-0.0293 \\
0.1119 \\
0.1846 \\
0.1334 \\
0.2043 \\
0.2610 \\
0.3031 \\
0.2422 \\
0.3922 \\
0.4472 \\
0.4887 \\
0.5042 \\
0.6955 \\
0.6817 \\
0.7579 \\
0.8110 \\
0.8959 \\
0.9088 \\
1.0845 \\
1.1321 \\
1.1267 \\
1.2470 \\
1.4731 \\
1.6181 \\
1.7160 \\
1.7960 \\
1.9783 \\
2.0971 \\
2.1027 \\
2.2024 \\
2.5764 \\
2.6465 \\
2.9111 \\
3.1923 \\
3.3753 \\
3.6743 \\
4.0524\end{array}$ & $\begin{array}{l}23.209 \\
27.610 \\
30.137 \\
31.893 \\
33.362 \\
34.511 \\
35.753 \\
36.675 \\
37.521 \\
38.316 \\
39.271 \\
39.934 \\
40.584 \\
41.443 \\
41.947 \\
42.435 \\
43.010 \\
43.405 \\
43.788 \\
44.130 \\
44.529 \\
44.731 \\
45.102 \\
44.820 \\
45.084 \\
45.215 \\
45.366 \\
45.775 \\
45.690 \\
45.777 \\
45.682 \\
44.864 \\
44.528 \\
44.222 \\
43.979 \\
42.725 \\
41.476\end{array}$ & $\begin{array}{r}0.405 \\
0.806 \\
1.208 \\
1.607 \\
2.009 \\
2.412 \\
2.808 \\
3.210 \\
3.612 \\
4.011 \\
4.411 \\
4.809 \\
5.210 \\
5.610 \\
6.010 \\
6.411 \\
6.808 \\
7.208 \\
7.638 \\
8.007 \\
8.408 \\
8.807 \\
9.209 \\
9.613 \\
10.011 \\
10.412 \\
10.812 \\
1.210 \\
11.616 \\
12.010 \\
12.510 \\
13.010 \\
13.515 \\
14.012 \\
14.512 \\
15.013 \\
15.512\end{array}$ \\
\hline
\end{tabular}


Table A-6. Deformation $J_{I C}$ and $J-R$ curve results for specimen P2B-16

\begin{tabular}{|c|c|c|c|}
\hline $\begin{array}{l}\text { Test Number } \\
\text { Material Type } \\
\text { Aging Temp. } \\
\text { Spec. Thickness } \\
\text { Spec. Width } \\
\text { Modulus E } \\
\text { Modulus E } \\
\text { Init. Crack } \\
\text { Final Crack } \\
\text { Final Crack }\end{array}$ & $\begin{array}{l}: 0086 \\
: \mathrm{CF}-3 \\
: 320^{\circ} \mathrm{C} \\
: 25.38 \mathrm{~mm} \\
: 50.81 \mathrm{~mm} \\
: 213.07 \mathrm{GPa} \\
: 193.10 \mathrm{GPa} \\
: 29.0719 \mathrm{~mm} \\
: 33.3156 \mathrm{~mm} \\
: 33.1243 \mathrm{~mm}\end{array}$ & $\begin{array}{l}\text { Test Temp. } \\
\text { Heat Number } \\
\text { Aging Time } \\
\text { Net Thickness } \\
\text { Flow Stress } \\
\text { (Effective) } \\
\text { (Nominal) } \\
\text { Init. a/w } \\
\text { Final } a / w \\
\text { Final } a / w\end{array}$ & $\begin{array}{l}: 0.5721 \text { (Measured) } \\
: 0.6557 \text { (Measured) } \\
: 0.6519 \text { (Compliance) }\end{array}$ \\
\hline $\begin{array}{l}\text { Linear Fit } \\
\text { Intercept } B \\
\text { Fit Coeff. } R \\
J_{I C} \\
\Delta a\left(J_{I C}\right) \\
T \text { Average }\end{array}$ & $\begin{array}{l}J=B+M(\Delta a) \\
: 636.934 \mathrm{~kJ} / \mathrm{m}^{2} \\
: 0.9868 \\
: 1089.1 \mathrm{~kJ} / \mathrm{m}^{2} \\
: 0.637 \mathrm{~mm} \\
: 827.8\end{array}$ & $\begin{array}{l}\text { Slope } M \\
\text { (19 Data Points) } \\
\left(6219.0 \text { in. }-1 \mathrm{~b} / \mathrm{in}^{2}\right) \\
(0.0251 \text { in.) } \\
\left(J_{\text {IC } \text { at } 0.15)}\right.\end{array}$ & : $709.87 \mathrm{~kJ} / \mathrm{m}^{2} \mathrm{~mm}$ \\
\hline $\begin{array}{l}\text { Power-Law Fit } \\
\text { Coeff. C } \\
\text { Fit Coeff. R } \\
J_{I C ~}(0.20) \\
\Delta a\left(J_{I C}\right) \\
\text { T Average } \\
J_{I C ~}(0.15) \\
\Delta a\left(J_{I C}\right) \\
\text { T Average } \\
\text { Kjc }\end{array}$ & $\begin{array}{l}J=C(\Delta \mathbf{a}) \mathbf{n} \\
: 1327.18 \mathrm{~kJ} / \mathrm{m}^{2} \\
: 0.9914 \\
: 1284.5 \mathrm{~kJ} / \mathrm{m}^{2} \\
: 0.951 \mathrm{~mm} \\
: 801.4 \\
: 1189.4 \mathrm{~kJ} / \mathrm{m}^{2} \\
: 0.846 \mathrm{~mm} \\
: 810.7 \\
: 773.0 \mathrm{MPa}-\mathrm{m}^{0.5}\end{array}$ & $\begin{array}{l}\text { Exponent } N \\
(19 \text { Data Points) } \\
\left(7335.0 \text { in. }-1 \mathrm{~b} / \mathrm{in}^{2}\right) \\
(0.0375 \mathrm{in.}) \\
\left(\mathrm{J}_{\mathrm{IC}} \text { at } 0.20\right) \\
\left(6791.5 \mathrm{in} .-\mathrm{lb} / \mathrm{in}^{2}\right) \\
(0.0333 \mathrm{in.}) \\
\left(\mathrm{J}_{\text {IC }} \text { at } 0.15\right)\end{array}$ & $: 0.6538$ \\
\hline $\begin{array}{l}J_{\text {Ic Valldity \& Data }} \\
J_{\text {max Allowed }} \\
\text { Data Limit } \\
\Delta a \text { (max) Allowed } \\
\text { Data Limit } \\
\text { Data Points } \\
\text { Data Point Spacing } \\
b_{\text {net or } b_{0} \text { Size }} \\
\text { dJ/da at } J_{I C} \\
\text { af Measurement } \\
\text { Initial Crack Shape } \\
\text { Crack Size Estimate } \\
\text { E Effective } \\
J_{I C} \text { Estimate }\end{array}$ & $\begin{array}{l}\text { Qualification (E } 813-85 \\
: 619.55 \mathrm{~kJ} / \mathrm{m}^{2} \\
: J_{\mathrm{max}} \text { Ignored } \\
: 3.140 \mathrm{~mm} \\
: 1.5 \text { Exclusion line } \\
: \text { Zone } \mathrm{A}=9 \\
: \text { OK } \\
: \text { Inadequate } \\
: \text { OK } \\
: \text { Near-Surface } \\
: \text { OK } \\
: \text { OK } \\
: \text { Inadequate } \\
: \text { INVALID }\end{array}$ & $\begin{array}{l}\left(\mathrm{J}_{\max }=b_{o} \sigma_{\mathrm{f}} / 15\right) \\
\text { (at } 1.5 \text { Exclusion Lin } \\
\text { Zone } B=3\end{array}$ & \\
\hline $\begin{array}{l}\text { J-R Curve Valldity } \\
J_{\max } \text { Allowed } \\
\Delta \mathbf{a} \text { (max) Allowed } \\
\Delta \mathbf{a} \text { (max) Allowed } \\
\text { Data Points } \\
\text { Data Point Spacing } \\
\text { J-R Curve Data }\end{array}$ & $\begin{array}{l}\text { Data Qualification } \\
: 435.49 \mathrm{~kJ} / \mathrm{m}^{2} \\
: 2.174 \mathrm{~mm} \\
: 5.876 \mathrm{~mm} \\
: \text { Zone } \mathrm{A}=36 \\
: \text { Inadequate } \\
: \text { INVALID }\end{array}$ & $\begin{array}{l}1152-86) \\
\left(J_{\max }=b_{\text {net }} \sigma_{f} / 20\right) \\
\left(\Delta \mathrm{a}=0.1 b_{0}\right) \\
(\omega=5) \\
\text { Zone } B=0\end{array}$ & \\
\hline
\end{tabular}


Table A-7. Modified $J_{I C}$ and J-R curve results for specimen P2B-16

Test Number

Material Type

Aging Temp.

Spec. Thickness

Spec. Width

Modulus E

Modulus E

Init. Crack

Final Crack

Final Crack

\section{Linear Fit}

Intercept B

Fit Coeff. $\mathbf{R}$

$\mathrm{J}_{\mathrm{IC}}$

$\Delta \mathrm{a}\left(\mathrm{J}_{\mathrm{IC}}\right)$

$T$ Average

Power-Law Fit

Coeff. C

Fit Coeff. R

JIC (0.20)

$\Delta \mathrm{a}\left(\mathrm{J}_{\mathrm{IC}}\right)$

$T$ Average

$J_{I C}(0.15)$

$\Delta \mathrm{a}\left(\mathrm{J}_{\mathrm{IC}}\right)$

$T$ Average

$\mathrm{KJC}$
:0086

: $\mathrm{CF}-3$

: $320^{\circ} \mathrm{C}$

: $25.38 \mathrm{~mm}$

: $50.81 \mathrm{~mm}$

: $213.07 \mathrm{GPa}$

: $193.10 \mathrm{GPa}$

: $29.0719 \mathrm{~mm}$

$33.3156 \mathrm{~mm}$

: $33.1243 \mathrm{~mm}$

$\mathbf{J}=\mathbf{B}+\mathbf{M}(\Delta \mathbf{Q})$

: $674.943 \mathrm{~kJ} / \mathrm{m}^{2}$

: 0.9911

: $1225.0 \mathrm{~kJ} / \mathrm{m}^{2}$

: $0.716 \mathrm{~mm}$

: 895.3

$\mathbf{J}=\mathbf{C}(\Delta \mathbf{a})^{\mathrm{n}}$

: $1395.18 \mathrm{~kJ} / \mathrm{m}^{2}$

: 0.9936

: $1429.2 \mathrm{~kJ} / \mathrm{m}^{2}$

: $1.036 \mathrm{~mm}$

: 876.5

: $1319.7 \mathrm{~kJ} / \mathrm{m}^{2}$

$0.922 \mathrm{~mm}$

: 885.7

: $825.9 \mathrm{MPa}-\mathrm{m}^{0.5}$
Test Temp. $\quad: 25^{\circ} \mathrm{C}$

Heat Number : P2

Aging Time $: 55.000 \mathrm{~h}$

Net Thickness $: 20.38 \mathrm{~mm}$

Flow Stress $\quad: 427.45 \mathrm{MPa}$

(Effective)

(Nominal)

Init. $\mathrm{a} / \mathrm{w} \quad: 0.5721$ (Measured)

Final a/w $\quad: 0.6557$ (Measured)

Final a/w $\quad: 0.6519$ (Compliance)

Slope $M$

$: 767.76 \mathrm{~kJ} / \mathrm{m}^{2} \mathrm{~mm}$

(17 Data Points)

(6995.1 in. $-\mathrm{lb} /$ in. $\left.{ }^{2}\right)$

(0.0282 in.)

( $\mathrm{J}_{\mathrm{IC}}$ at 0.15$)$

Exponent N

: 0.6832

(17 Data Points)

$\left(8160.9\right.$ in. $-\mathrm{lb} /$ in $\left.^{2}\right)$

$(0.0408 \mathrm{in.})$

(JiC at 0.20$)$

(7536.0 in. $-\mathrm{lb} /$ in..$\left.^{2}\right)$

$(0.0363$ in.)

( $\mathrm{JIC}_{\mathrm{IC}}$ at 0.15$)$

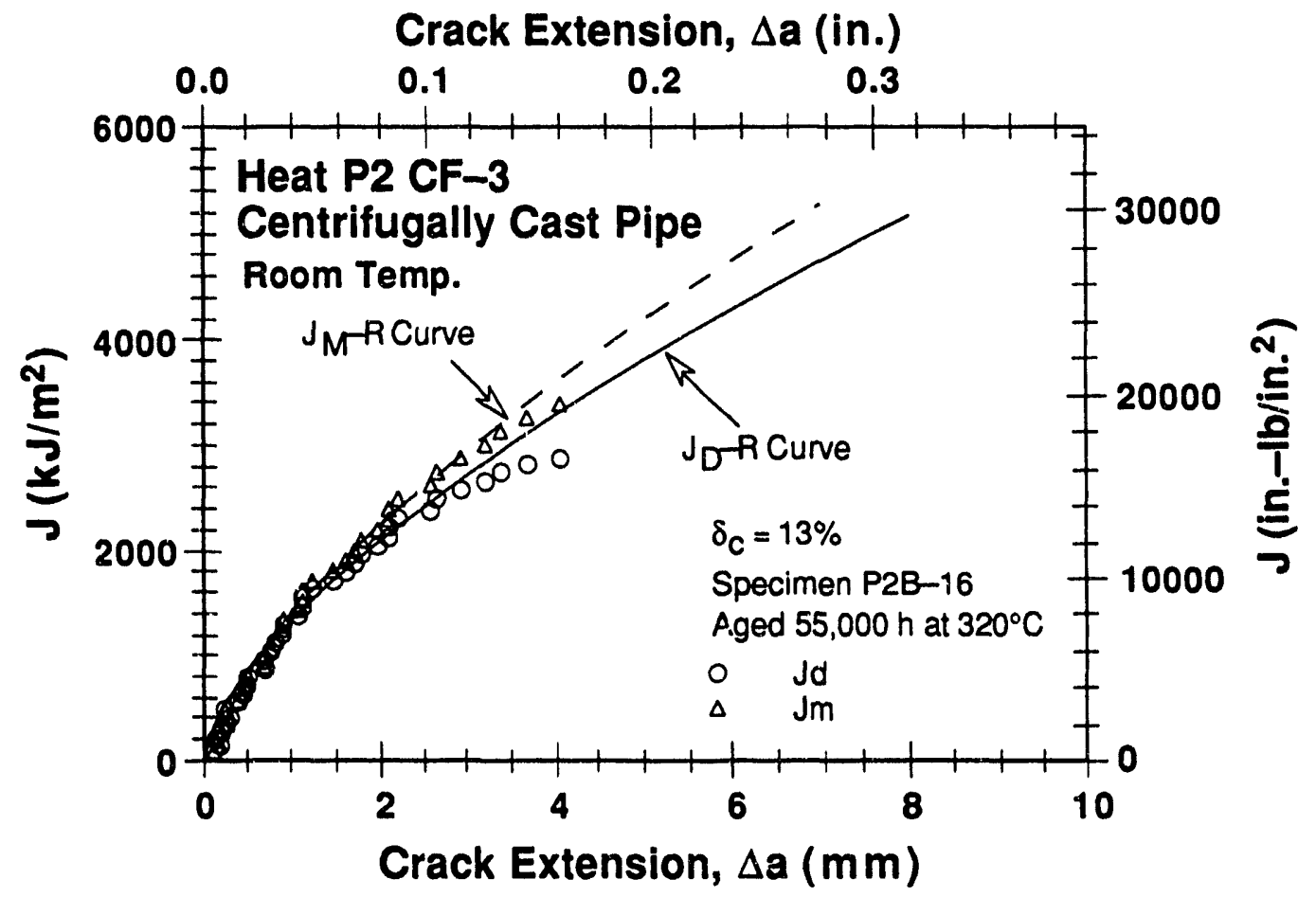

Figure A-5. Deformation and modifled $J-R$ curves at room temp. for Heat P2 aged $55,000 \mathrm{~h}$ at $320^{\circ} \mathrm{C}$ 


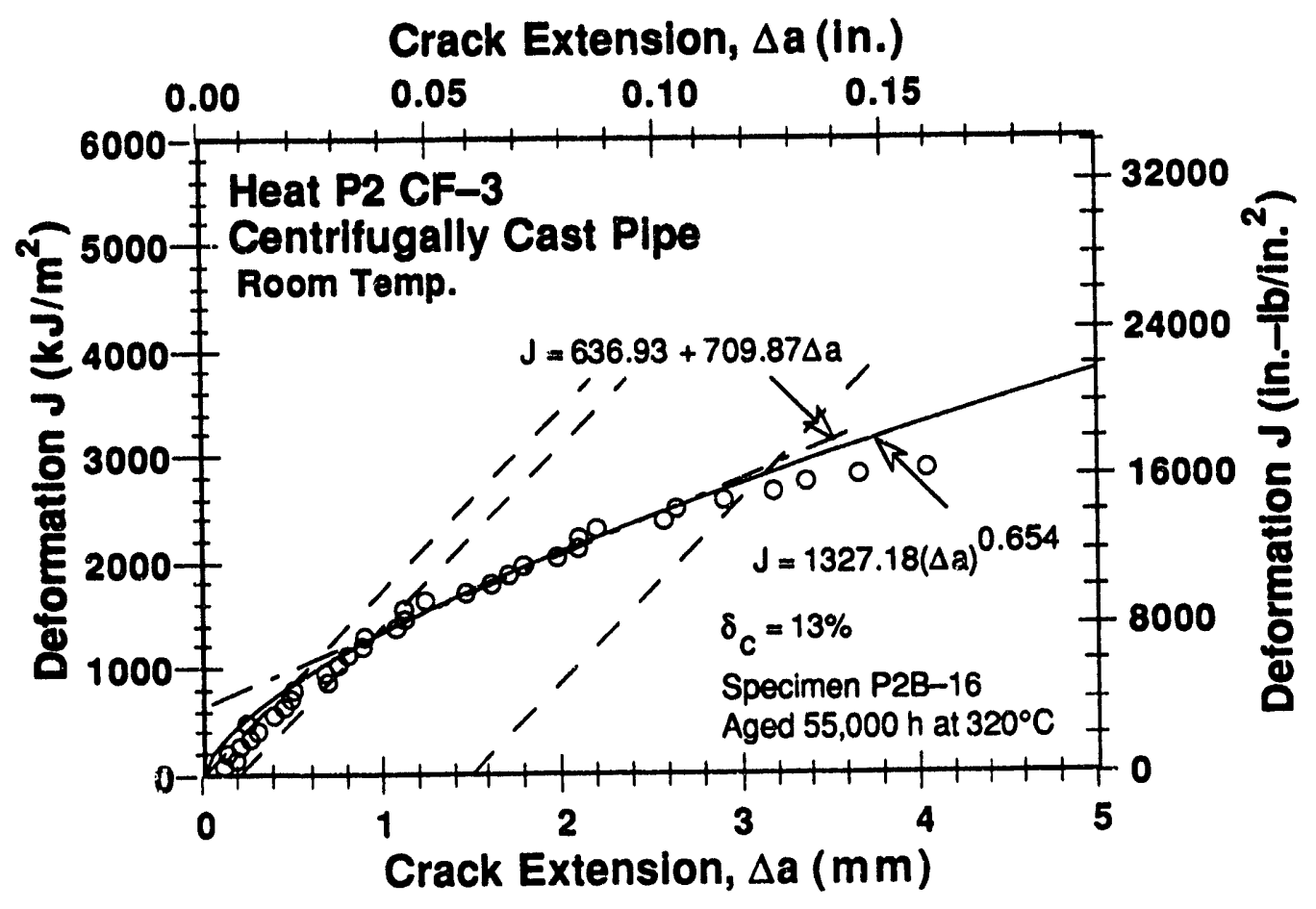

Figure A-6. Deformation $J_{I C}$ at room temp. for Heat $P 2$ aged $55,000 \mathrm{~h}$ at $320^{\circ} \mathrm{C}$

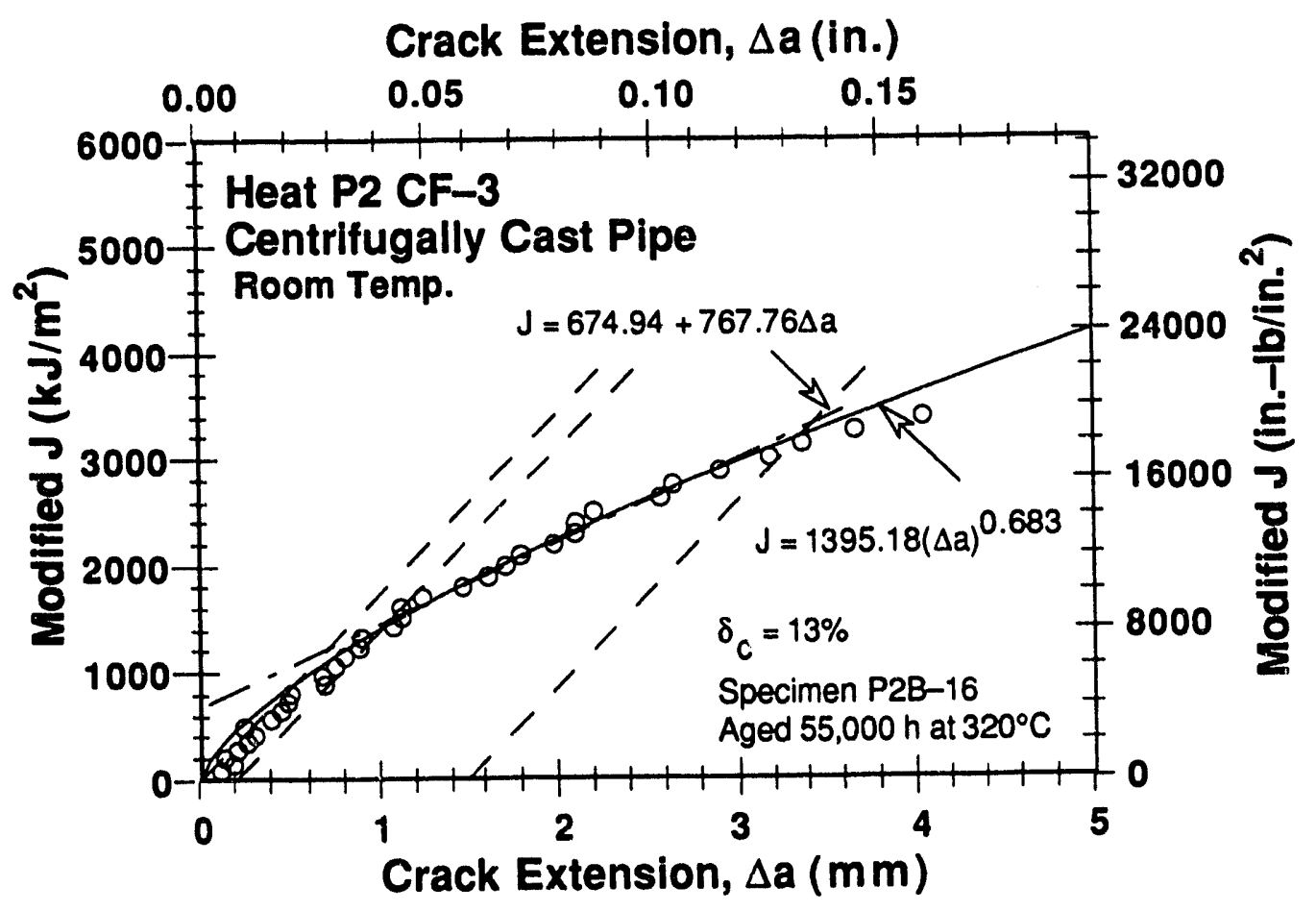

Figure A-7. Modifled $J_{I C}$ at room temp. for Heat $P 2$ aged $55,000 \mathrm{~h}$ at $320^{\circ} \mathrm{C}$ 
Table A-8. Test data for specimen P2T-20

\begin{tabular}{|c|c|c|c|c|c|}
\hline $\begin{array}{l}\text { Test Num } \\
\text { Material } \\
\text { Aging Tes } \\
\text { Spec. Th } \\
\text { Spec. Wic }\end{array}$ & $\begin{array}{ll}\text { er } & : \\
\text { ppe } & : \\
\text { p. } & : \\
\text { kness } & : \\
\text { h } & :\end{array}$ & $\begin{array}{l}\mathrm{mm} \\
\mathrm{mm}\end{array}$ & $\begin{array}{l}\text { Test } \\
\text { Heat } \\
\text { Aging } \\
\text { Net T } \\
\text { Flow }\end{array}$ & & $\begin{array}{l}c \\
20 \mathrm{~h} \\
3 \mathrm{~mm} \\
78 \mathrm{MPa}\end{array}$ \\
\hline $\begin{array}{l}\text { Unload } \\
\text { Number }\end{array}$ & $\begin{array}{c}J_{d} \\
\left(\mathrm{~kJ} / \mathrm{m}^{2}\right)\end{array}$ & $\begin{array}{c}\mathrm{J}_{\mathrm{m}} \\
\left(\mathrm{kJ} / \mathrm{m}^{2}\right)\end{array}$ & $\begin{array}{c}\Delta \mathrm{a} \\
(\mathrm{mm})\end{array}$ & $\begin{array}{l}\text { Load } \\
(\mathrm{kN})\end{array}$ & $\begin{array}{l}\text { Deflection } \\
(\mathrm{mm})\end{array}$ \\
\hline $\begin{array}{l}1 \\
2 \\
3 \\
4 \\
5 \\
6 \\
7 \\
8 \\
9 \\
10 \\
11 \\
12 \\
13 \\
14 \\
15 \\
16 \\
17 \\
18 \\
19 \\
20 \\
21 \\
22 \\
23 \\
24 \\
25 \\
26 \\
27 \\
28 \\
29 \\
30 \\
31 \\
32 \\
33 \\
34 \\
35 \\
36 \\
37 \\
38 \\
39 \\
40 \\
41 \\
42\end{array}$ & $\begin{array}{r}13.99 \\
36.72 \\
62.43 \\
89.11 \\
118.84 \\
147.44 \\
180.36 \\
209.95 \\
244.50 \\
280.21 \\
312.65 \\
350.14 \\
381.49 \\
425.39 \\
457.05 \\
500.77 \\
535.62 \\
576.53 \\
615.35 \\
661.50 \\
711.02 \\
741.50 \\
785.30 \\
826.70 \\
876.49 \\
910.16 \\
964.11 \\
1011.94 \\
1047.78 \\
1105.37 \\
1134.16 \\
1189.43 \\
1216.81 \\
1278.10 \\
1317.75 \\
1365.55 \\
1420.60 \\
1456.56 \\
1487.32 \\
1529.18 \\
1574.63 \\
1570.12\end{array}$ & $\begin{array}{r}14.01 \\
36.69 \\
62.34 \\
89.70 \\
117.21 \\
148.69 \\
178.63 \\
212.45 \\
244.40 \\
279.46 \\
315.56 \\
350.83 \\
389.56 \\
424.99 \\
466.35 \\
503.75 \\
545.99 \\
586.10 \\
628.58 \\
670.76 \\
713.13 \\
759.54 \\
801.80 \\
847.57 \\
892.72 \\
940.56 \\
985.56 \\
1033.74 \\
1082.58 \\
1128.31 \\
1181.52 \\
1226.32 \\
1279.28 \\
1325.69 \\
1378.87 \\
1428.93 \\
1479.74 \\
1533.49 \\
1585.23 \\
1637.17 \\
1690.50 \\
1693.54\end{array}$ & $\begin{array}{r}0.0380 \\
0.0100 \\
-0.0087 \\
0.1317 \\
-0.2078 \\
0.1423 \\
-0.1535 \\
0.2009 \\
0.0145 \\
-0.0258 \\
0.1772 \\
0.0672 \\
0.3988 \\
0.0553 \\
0.4173 \\
0.2010 \\
0.4354 \\
0.4119 \\
0.5124 \\
0.4109 \\
0.2402 \\
0.6007 \\
0.5678 \\
0.6562 \\
0.5676 \\
0.8259 \\
0.6714 \\
0.6772 \\
0.8822 \\
0.7040 \\
1.0575 \\
0.9124 \\
1.2547 \\
1.0642 \\
1.2312 \\
1.2582 \\
1.2096 \\
1.4069 \\
1.6328 \\
1.7380 \\
1.8176 \\
1.8939\end{array}$ & $\begin{array}{l}13.711 \\
15.998 \\
17.457 \\
18.532 \\
19.470 \\
20.381 \\
21.046 \\
21.774 \\
22.421 \\
23.055 \\
23.665 \\
24.182 \\
24.726 \\
25.231 \\
25.724 \\
26.215 \\
26.680 \\
27.100 \\
27.507 \\
27.920 \\
28.295 \\
28.672 \\
29.032 \\
29.296 \\
29.691 \\
30.032 \\
30.275 \\
30.469 \\
30.884 \\
31.129 \\
31.461 \\
31.562 \\
31.798 \\
31.988 \\
32.045 \\
32.166 \\
32.431 \\
32.517 \\
32.718 \\
32.877 \\
33.002 \\
33.438\end{array}$ & $\begin{array}{l}0.307 \\
0.608 \\
0.912 \\
1.209 \\
1.508 \\
1.807 \\
2.111 \\
2.408 \\
2.708 \\
3.010 \\
3.310 \\
3.610 \\
3.910 \\
4.210 \\
4.509 \\
4.810 \\
5.109 \\
5.409 \\
5.708 \\
6.012 \\
6.308 \\
6.611 \\
6.910 \\
7.209 \\
7.511 \\
7.809 \\
8.112 \\
8.410 \\
8.709 \\
9.009 \\
9.317 \\
9.610 \\
9.911 \\
10.211 \\
10.510 \\
10.810 \\
11.110 \\
11.412 \\
11.710 \\
12.010 \\
12.311 \\
12.330\end{array}$ \\
\hline
\end{tabular}


Table A-9. Deformation $J_{I C}$ and $J-R$ curve results for specimen P2T-20

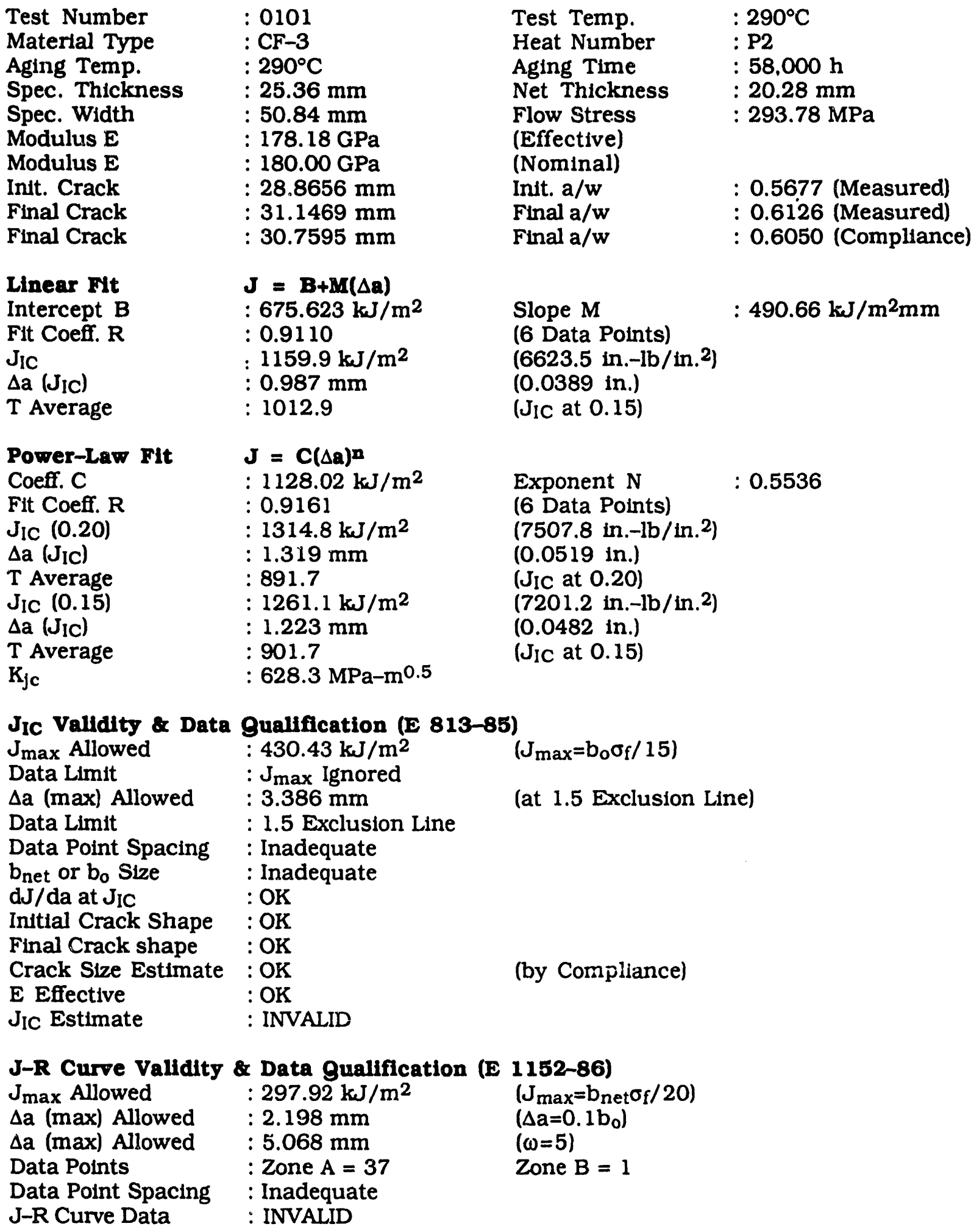


Table A-10. Modified $J_{I C}$ and $J-R$ curve results for specimen P2T-20

\begin{tabular}{|c|c|c|c|}
\hline $\begin{array}{l}\text { Test Number } \\
\text { Material Type } \\
\text { Aging Temp. } \\
\text { Spec. Thickness } \\
\text { Spec. Width } \\
\text { Modulus E } \\
\text { Modilus E } \\
\text { Init. Crack } \\
\text { Final Crack } \\
\text { Final Crack }\end{array}$ & $\begin{array}{l}: 0101 \\
: \mathrm{CF}-3 \\
: 290^{\circ} \mathrm{C} \\
: 25.36 \mathrm{~mm} \\
: 50.84 \mathrm{~mm} \\
: 178.18 \mathrm{GF} \mathrm{d} \\
: 180.00 \mathrm{GPa} \\
: 28.8656 \mathrm{~mm} \\
: 31.1469 \mathrm{~mm} \\
: 30.7595 \mathrm{~mm}\end{array}$ & $\begin{array}{l}\text { Test Temp. } \\
\text { Heat Number } \\
\text { Aging Time } \\
\text { Net Thickness } \\
\text { Flow Stress } \\
\text { (Effective) } \\
\text { (Nominal) } \\
\text { Init. a/w } \\
\text { Final a/w } \\
\text { Final a/w }\end{array}$ & $\begin{array}{l}: 290^{\circ} \mathrm{C} \\
: \mathrm{P2} \\
: 58.000 \mathrm{~h} \\
: 20.28 \mathrm{~mm} \\
: 293.78 \mathrm{MPa}\end{array}$ \\
\hline $\begin{array}{l}\text { Linear Fit } \\
\text { Intercept B } \\
\text { Fit Coeff. } R \\
J_{I C} \\
\Delta a\left(J_{I C}\right) \\
T \text { Average }\end{array}$ & $\begin{array}{l}J=B+M(\Delta \mathbf{a}) \\
: 443.098 \mathrm{~kJ} / \mathrm{m}^{2} \\
: 0.9874 \\
: 1051.9 \mathrm{~kJ} / \mathrm{m}^{2} \\
: 0.895 \mathrm{~mm} \\
: 1404.1\end{array}$ & $\begin{array}{l}\text { Slope } M \\
\text { (5 Data Pinints) } \\
\left(6006.7 \text { in. }-1 \mathrm{~b} / \text { in }^{2}\right) \\
(0.0352 \text { in.) } \\
\left(J_{1 C} \text { at } 0.15\right)\end{array}$ & $: 680.13 \mathrm{~kJ} / \mathrm{m}^{2} \mathrm{~mm}$ \\
\hline $\begin{array}{l}\text { Power-Law Fit } \\
\text { Coeff. C } \\
\text { Fit Coeff. R } \\
\mathrm{J}_{\mathrm{IC}}(0.20) \\
\Delta \mathrm{a}\left(\mathrm{J}_{\mathrm{IC}}\right) \\
\text { T Average } \\
\mathrm{J}_{\mathrm{IC}}(0.15) \\
\Delta \mathrm{a}\left(\mathrm{J}_{\mathrm{IC}}\right) \\
\text { T Average } \\
\mathrm{K}_{\mathrm{jc}}\end{array}$ & $\begin{array}{l}J=C(\Delta a)^{n} \\
: 1097.19 \mathrm{~kJ} / \mathrm{m}^{2} \\
: 0.9914 \\
: 1371.3 \mathrm{~kJ} / \mathrm{m}^{2} \\
: 1.367 \mathrm{~mm} \\
: 1228.4 \\
: 1276.4 \mathrm{~kJ} / \mathrm{m}^{2} \\
: 1.236 \mathrm{~mm} \\
: 1239.1 \\
: 726.3 \mathrm{MPa}-\mathrm{m}^{0.5}\end{array}$ & $\begin{array}{l}\text { Exponent } N \\
(5 \text { Data Points) } \\
\left(7830.7 \text { in. }-1 \mathrm{~b} / \text { in. }^{2}\right) \\
(0.0538 \text { in. }) \\
\left(J_{I C} \text { at } 0.20\right) \\
\left(7288.3 \text { in. }-1 \mathrm{~b} / \text { in }^{2} \text { ) }\right. \\
(0.0487 \text { in. }) \\
\left(J_{I C} \text { at } 0.15\right)\end{array}$ & $: 0.7135$ \\
\hline
\end{tabular}

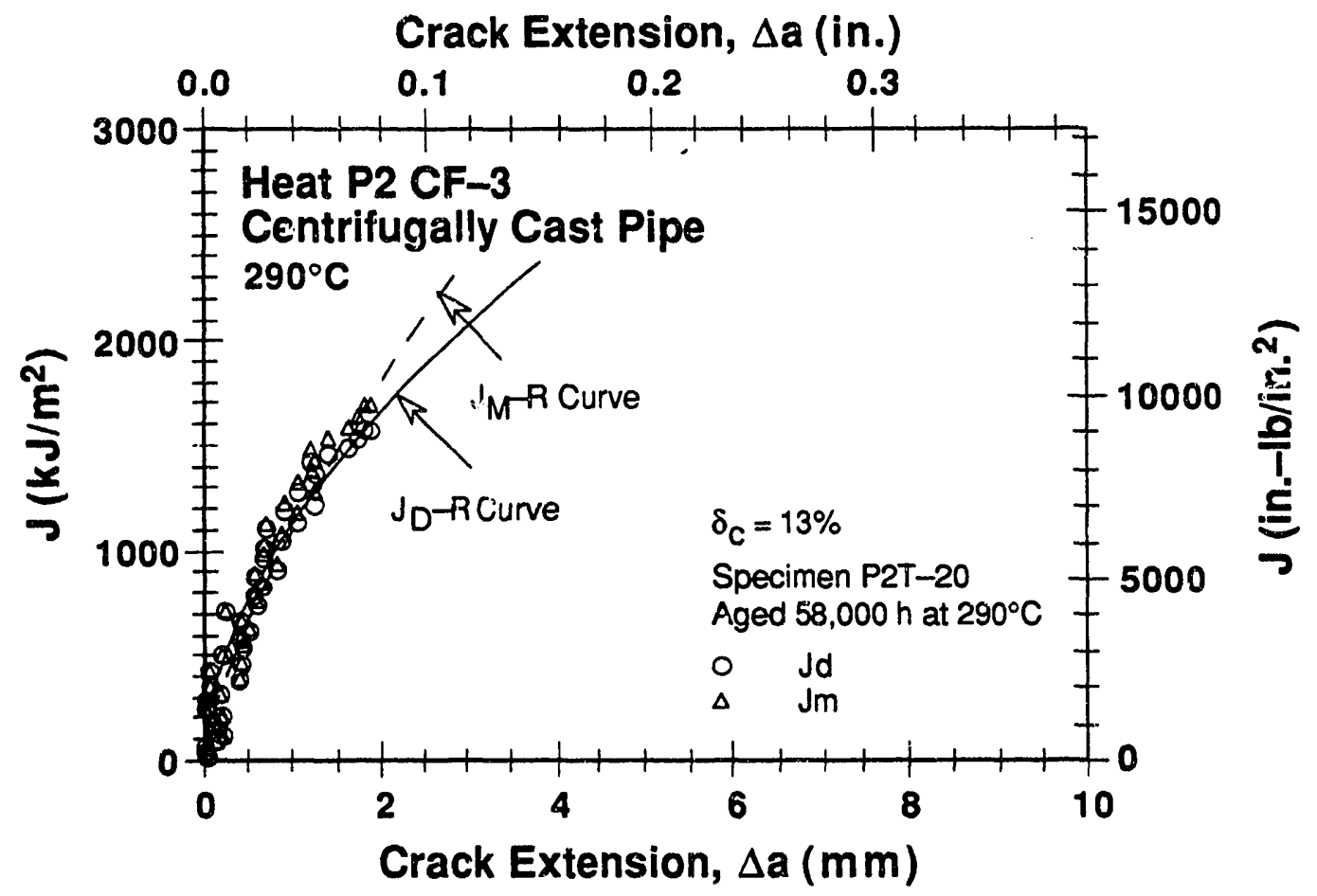

Flgure A-8. Deformatiori and modified $J-R$ curves at $290^{\circ} \mathrm{C}$ for Heat $P 2$ aC $d$ $58,000 \mathrm{~h}$ at $290^{\circ} \mathrm{C}$ 


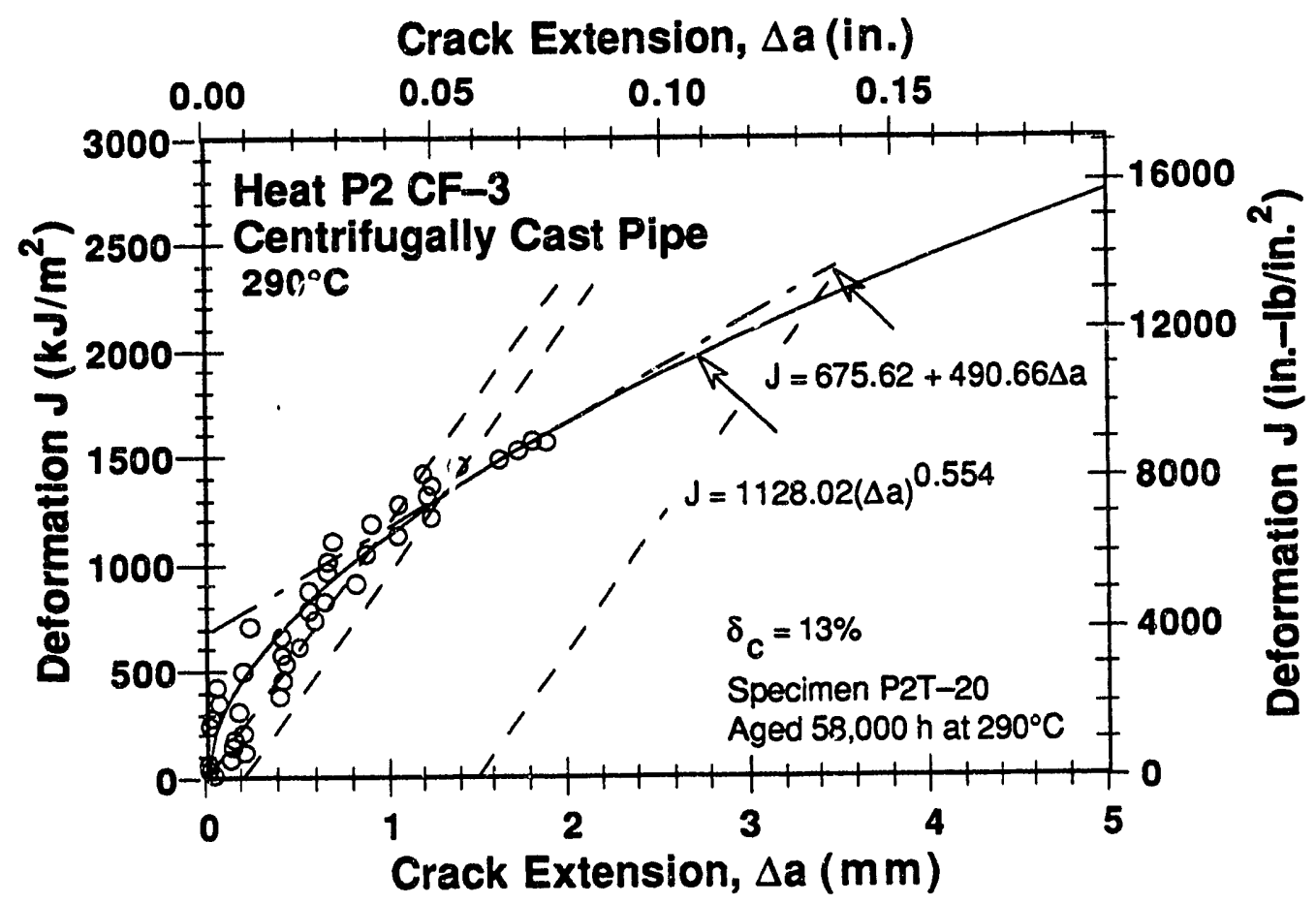

Figure A-9. Deformation $J_{I C}$ at $290^{\circ} \mathrm{C}$ for Heat $\mathrm{P2}$ aged $58,000 \mathrm{~h}$ at $290^{\circ} \mathrm{C}$

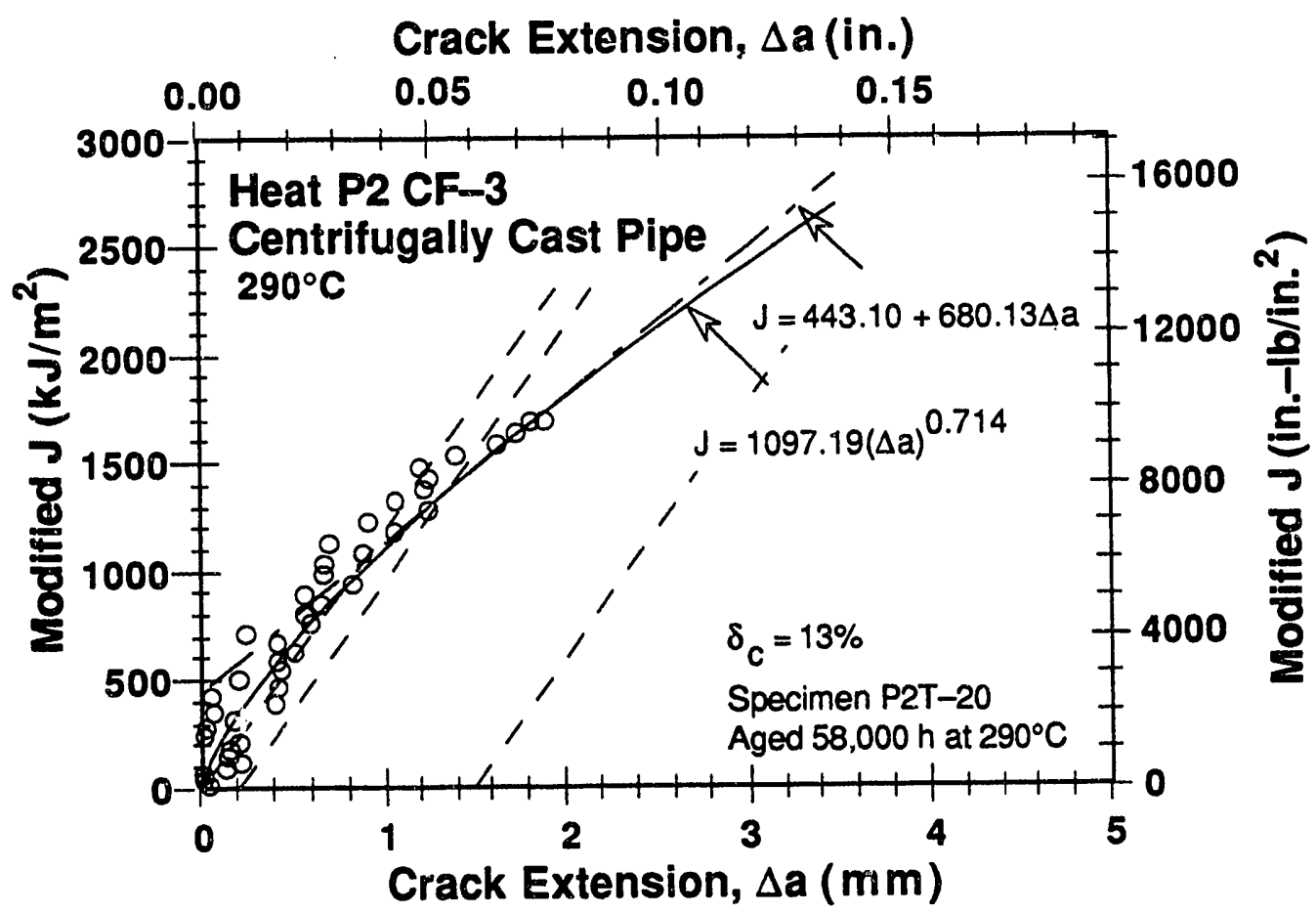

Figure A-10. Modified $J_{I C}$ at $290^{\circ} \mathrm{C}$ for Heat $P 2$ aged $58,000 \mathrm{~h}$ at $290^{\circ} \mathrm{C}$ 
Table A-11. Test data for specimen $P 2 B-17$

\begin{tabular}{|c|c|c|c|c|c|}
\hline \multicolumn{2}{|c|}{$\begin{array}{l}\text { Test Number } \\
\text { Material Type } \\
\text { Aging Temp. } \\
\text { Spec. Thickness } \\
\text { Spec. Width }\end{array}$} & $\begin{array}{l}\mathrm{mm} \\
\mathbf{m m}\end{array}$ & \multicolumn{2}{|c|}{$\begin{array}{l}\text { Test Temp. } \\
\text { Heat Number } \\
\text { Aging Time } \\
\text { Net Thickness } \\
\text { Flow Stress }\end{array}$} & $\begin{array}{l}: 290^{\circ} \mathrm{C} \\
: \mathrm{P} 2 \\
: 55,000 \mathrm{~h} \\
: 20.35 \mathrm{~mm} \\
: 293.65 \mathrm{MPa}\end{array}$ \\
\hline $\begin{array}{c}\text { Unload } \\
\text { Number }\end{array}$ & $\begin{array}{c}\mathrm{Jd}_{\mathrm{d}} \\
\left(\mathrm{ks} / \mathrm{m}^{2}\right)\end{array}$ & $\begin{array}{c}J_{m} \\
\left(k \mathrm{~J} / \mathrm{m}^{2}\right)\end{array}$ & $\begin{array}{c}\Delta \mathbf{a} \\
(\mathrm{mm})\end{array}$ & $\begin{array}{l}\text { Load } \\
(\mathrm{kN}) \\
\end{array}$ & $\begin{array}{l}\text { Deflection } \\
(\mathrm{mm})\end{array}$ \\
\hline $\begin{array}{l}1 \\
2 \\
3 \\
4 \\
5 \\
6 \\
7 \\
8 \\
9 \\
10 \\
11 \\
12 \\
13 \\
14 \\
15 \\
16 \\
17 \\
18 \\
19 \\
20 \\
21 \\
22 \\
23 \\
24 \\
25 \\
26 \\
27 \\
28 \\
29 \\
30 \\
31 \\
32 \\
33 \\
34 \\
35 \\
36 \\
37 \\
38 \\
39 \\
40 \\
41 \\
42\end{array}$ & $\begin{array}{r}14.53 \\
39.37 \\
67.25 \\
97.63 \\
128.40 \\
160.41 \\
194.47 \\
229.53 \\
272.40 \\
315.60 \\
360.58 \\
406.21 \\
455.48 \\
502.28 \\
555.09 \\
593.96 \\
649.00 \\
700.87 \\
756.02 \\
794.59 \\
857.64 \\
907.67 \\
965.00 \\
1011.74 \\
1070.20 \\
1122.04 \\
1179.87 \\
1244.17 \\
1301.78 \\
1339.19 \\
1395.16 \\
1446.48 \\
1499.46 \\
1549.44 \\
1613.34 \\
1656.12 \\
1737.21 \\
1790.58 \\
1861.41 \\
1943.33 \\
1989.39 \\
2036.22\end{array}$ & $\begin{array}{r}14.45 \\
39.51 \\
66.63 \\
97.84 \\
128.13 \\
161.93 \\
195.45 \\
232.68 \\
273.98 \\
319.43 \\
364.48 \\
411.63 \\
459.49 \\
509.27 \\
558.93 \\
612.54 \\
661.54 \\
716.41 \\
770.01 \\
827.62 \\
879.27 \\
938.87 \\
995.72 \\
1055.12 \\
1113.46 \\
1174.45 \\
1233.96 \\
1294.92 \\
1357.46 \\
1420.65 \\
1481.13 \\
1544.95 \\
1609.01 \\
1673.62 \\
1744.45 \\
1821.05 \\
1912.10 \\
2005.65 \\
2096.02 \\
2188.27 \\
2283.58 \\
2376.62\end{array}$ & $\begin{array}{r}-0.1546 \\
-0.0353 \\
-0.2563 \\
-0.0968 \\
-0.1660 \\
0.0353 \\
-0.0151 \\
0.1527 \\
0.0512 \\
0.1751 \\
0.1788 \\
0.2430 \\
0.1899 \\
0.2910 \\
0.1944 \\
0.6116 \\
0.4548 \\
0.5265 \\
0.4923 \\
0.8890 \\
0.6678 \\
0.8422 \\
0.8339 \\
1.0389 \\
1.0371 \\
1.1699 \\
1.1929 \\
1.1492 \\
1.2108 \\
1.5192 \\
1.5709 \\
1.7083 \\
1.8251 \\
1.9735 \\
2.0408 \\
2.3567 \\
2.4450 \\
2.7858 \\
2.9440 \\
3.0238 \\
3.3899 \\
3.7209\end{array}$ & $\begin{array}{l}14.688 \\
17.549 \\
19.166 \\
20.384 \\
21.438 \\
22.337 \\
23.130 \\
23.834 \\
24.485 \\
25.296 \\
26.076 \\
26.732 \\
27.120 \\
27.799 \\
28.475 \\
28.835 \\
29.418 \\
29.642 \\
30.193 \\
30.631 \\
30.864 \\
31.328 \\
31.656 \\
31.965 \\
32.323 \\
32.531 \\
32.761 \\
32.997 \\
33.198 \\
33.382 \\
33.448 \\
33.560 \\
33.441 \\
33.431 \\
33.240 \\
33.250 \\
32.818 \\
32.474 \\
32.371 \\
32.335 \\
31.888 \\
31.550\end{array}$ & $\begin{array}{l}0.305 \\
0.607 \\
0.908 \\
1.214 \\
1.508 \\
1.808 \\
2.107 \\
2.414 \\
2.758 \\
3.110 \\
3.458 \\
3.807 \\
4.159 \\
4.508 \\
4.861 \\
5.210 \\
5.558 \\
5.909 \\
6.259 \\
6.611 \\
6.958 \\
7.308 \\
7.661 \\
8.008 \\
8.361 \\
8.711 \\
9.059 \\
9.411 \\
9.761 \\
10.109 \\
10.459 \\
10.808 \\
11.162 \\
11.514 \\
11.904 \\
12.310 \\
12.816 \\
13.312 \\
13.811 \\
14.312 \\
14.811 \\
15.317\end{array}$ \\
\hline
\end{tabular}


Table A-12. Deformation $J_{I C}$ and $J-R$ curve results for specimen P2B-17

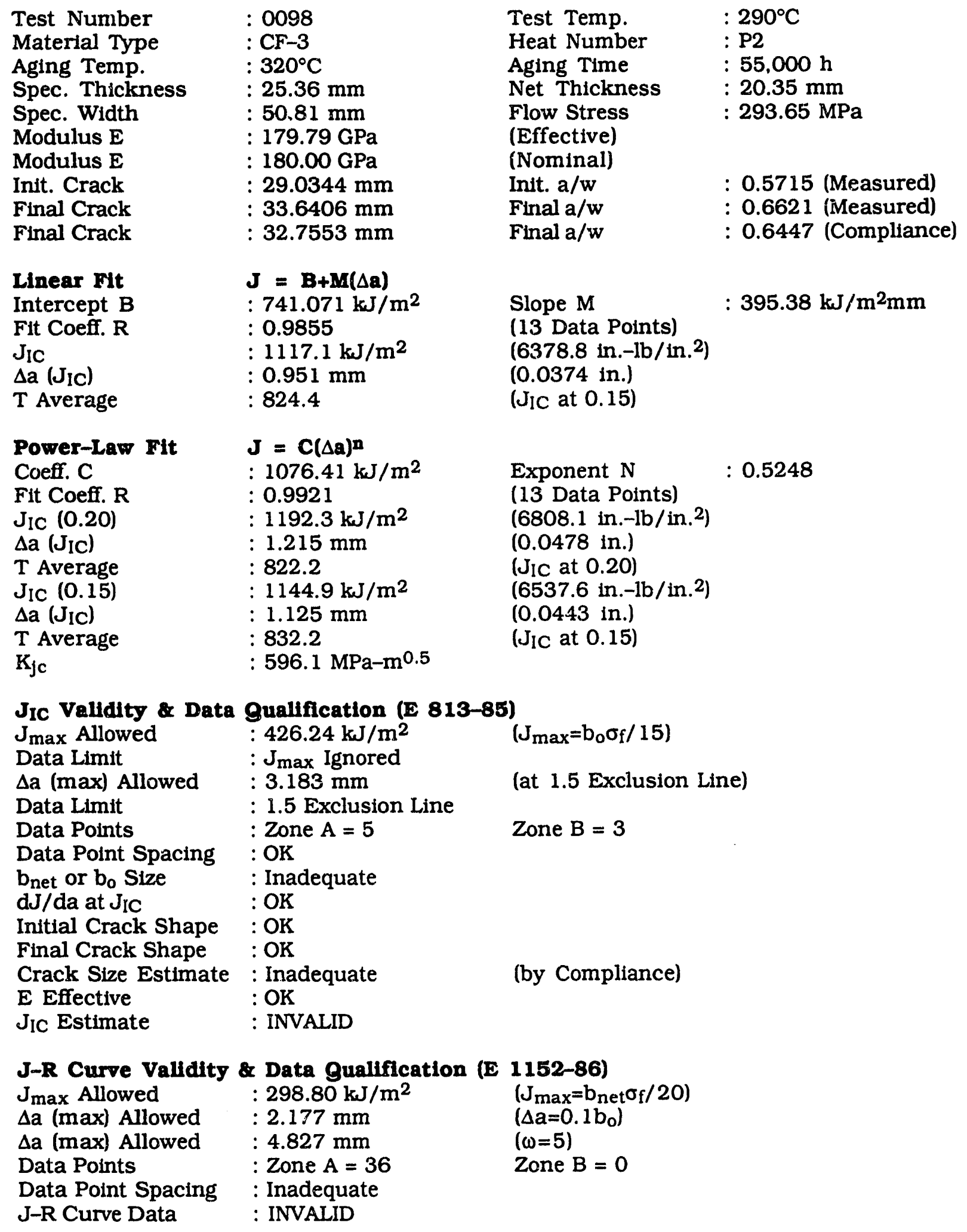


Table A-13. Modified $J_{I C}$ and $J-R$ curve results for specimen P2B-17

\begin{tabular}{|c|c|c|c|}
\hline $\begin{array}{l}\text { Test Number } \\
\text { Material Type } \\
\text { Aging Temp. } \\
\text { Spec. Thickness } \\
\text { Spec. Width } \\
\text { Modulus E } \\
\text { Modulus E } \\
\text { Init. Crack } \\
\text { Final Crack } \\
\text { Final Crack }\end{array}$ & $\begin{array}{l}: 0098 \\
: \mathrm{CF}-3 \\
: 320^{\circ} \mathrm{C} \\
: 25.36 \mathrm{~mm} \\
: 50.81 \mathrm{~mm} \\
: 179.79 \mathrm{GPa} \\
: 180.00 \mathrm{GPa} \\
: 29.0344 \mathrm{~mm} \\
: 33.6406 \mathrm{~mm} \\
: 32.7553 \mathrm{~mm}\end{array}$ & $\begin{array}{l}\text { Test Temp. } \\
\text { Heat Number } \\
\text { Aging Time } \\
\text { Net Thickness } \\
\text { Flow Stress } \\
\text { (Effective) } \\
\text { (Nominal) } \\
\text { Init. a/w } \\
\text { Final a/w } \\
\text { Final a/w }\end{array}$ & $\begin{array}{l}0.5715 \text { (Measured) } \\
: 0.6621 \text { (Measured) } \\
: 0.6447 \text { (Compliance) }\end{array}$ \\
\hline $\begin{array}{l}\text { Linear Fit } \\
\text { Intercept B } \\
\text { Fit Coeff. } R \\
\mathrm{~J}_{\mathrm{IC}} \\
\Delta \mathrm{a}\left(\mathrm{J}_{\mathrm{IC}}\right) \\
\mathrm{T} \text { Average }\end{array}$ & $\begin{array}{l}J=B+M(\Delta a) \\
: 771.288 \mathrm{~kJ} / \mathrm{m}^{2} \\
: 0.9949 \\
: 1257.4 \mathrm{~kJ} / \mathrm{m}^{2} \\
: 1.070 \mathrm{~mm} \\
: 946.8\end{array}$ & $\begin{array}{l}\text { Slope } M \\
\text { (12 Data Points) } \\
\left(7179.8 \text { in. }-1 \mathrm{~b} / \text { in }^{2}\right) \\
(0.0421 \text { in.) } \\
\left(J_{I C} \text { at } 0.15\right)\end{array}$ & $: 454.08 \mathrm{~kJ} / \mathrm{m}^{2} \mathrm{~mm}$ \\
\hline $\begin{array}{l}\text { Power-Law Fit } \\
\text { Coeff. C } \\
\text { Fit Coeff. R } \\
\mathrm{J}_{\mathrm{IC}}(0.20) \\
\Delta \mathrm{a}\left(\mathrm{J}_{\mathrm{IC}}\right) \\
\text { T Average } \\
\mathrm{J}_{\mathrm{IC}}(0.15) \\
\Delta \mathrm{a}\left(\mathrm{J}_{\mathrm{IC}}\right) \\
\text { T Average } \\
\mathrm{K}_{\mathrm{Ic}}\end{array}$ & $\begin{array}{l}J=C(\Delta \mathbf{a})^{\mathbf{n}} \\
: 1134.21 \mathrm{~kJ} / \mathrm{m}^{2} \\
: 0.9963 \\
: 1344.7 \mathrm{~kJ} / \mathrm{m}^{2} \\
: 1.345 \mathrm{~mm} \\
: 946.6 \\
: 1286.7 \mathrm{~kJ} / \mathrm{m}^{2} \\
: 1.245 \mathrm{~mm} \\
: 956.8 \\
: 645.9 \mathrm{MPa}-\mathrm{m}^{0.5}\end{array}$ & $\begin{array}{l}\text { Exponent } N \\
(12 \text { Data Points) } \\
\left(7678.7 \text { in. }-1 \mathrm{~b} / \text { in. }^{2}\right) \\
(0.0529 \text { in. }) \\
\left(J_{1 \mathrm{C}} \text { at } 0.20\right) \\
\left(7347.1 \text { in. }-1 \mathrm{~b} / \text { in. }^{2}\right) \\
(0.0490 \text { in. }) \\
\left(J_{\text {IC }} \text { at } 0.15\right)\end{array}$ & $: 0.5747$ \\
\hline
\end{tabular}

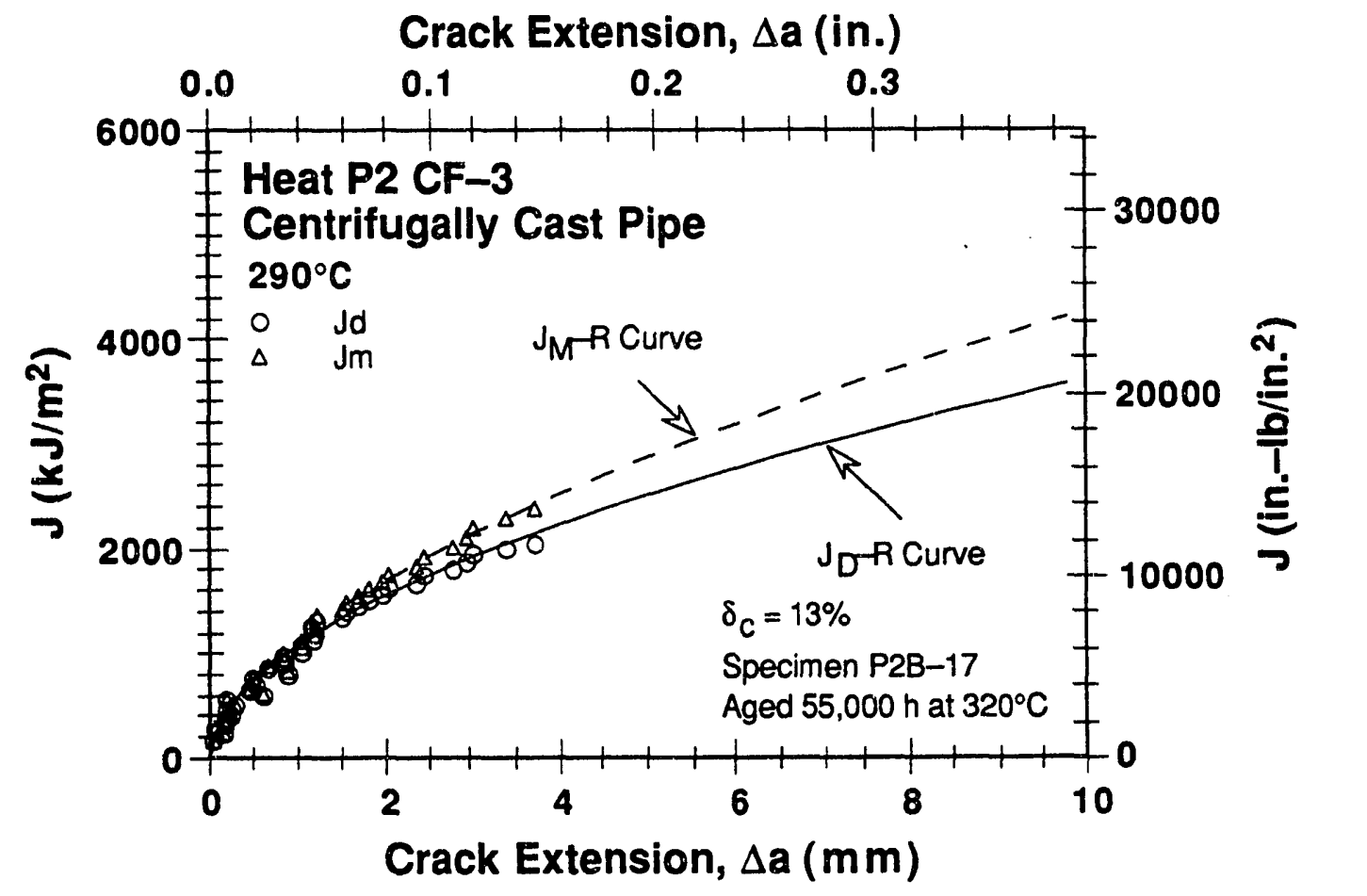

Figure A-11. Deformation and modified $J-R$ curves at $290^{\circ} \mathrm{C}$ for Heat $P 2$ aged $55,000 \mathrm{~h}$ at $320^{\circ} \mathrm{C}$ 
Crack Extension, $\Delta \mathrm{a}$ (in.)

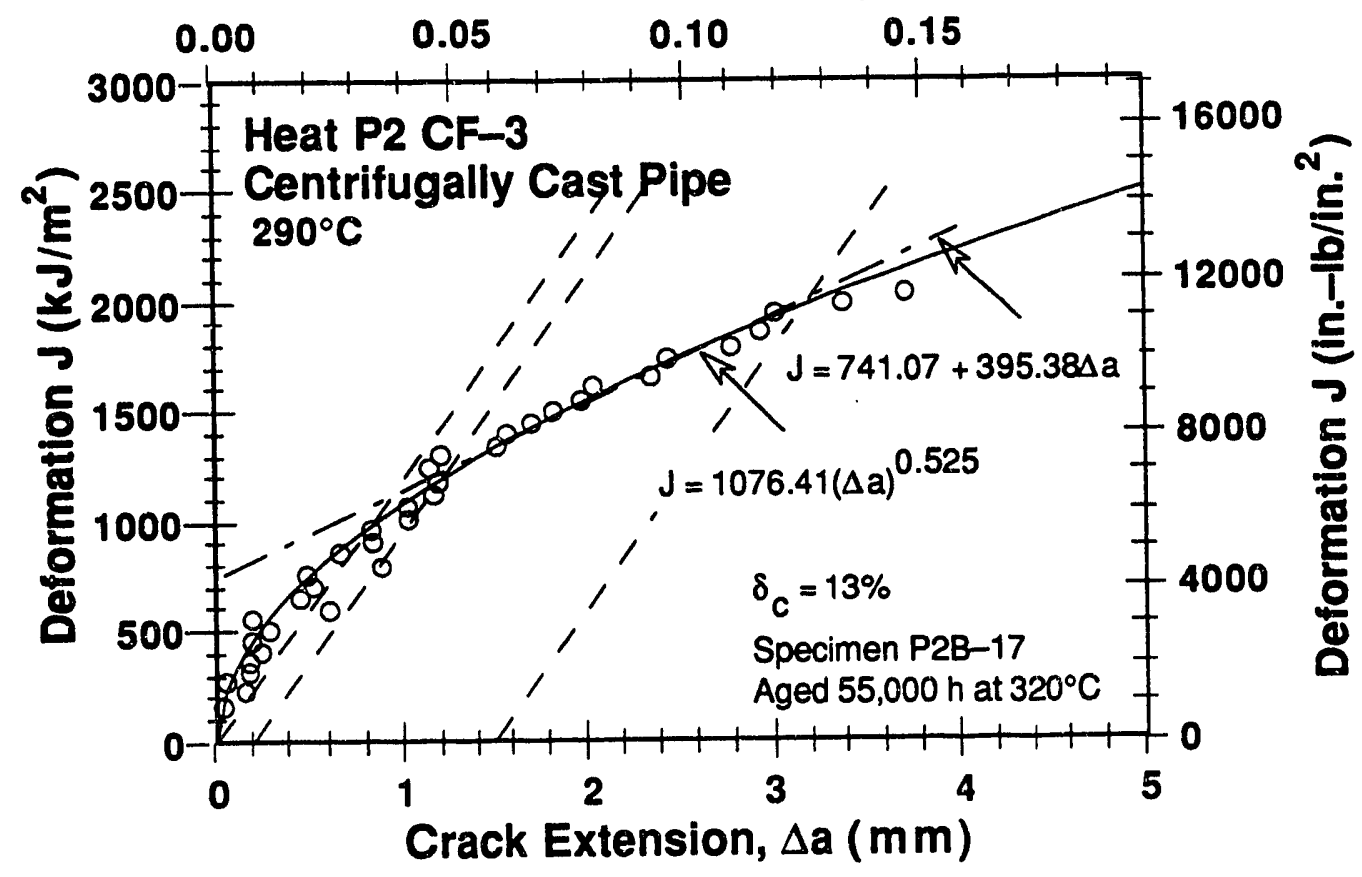

Figure A-12. Deformation $J_{I C}$ at $290^{\circ} \mathrm{C}$ for Heat $\mathrm{P} 2$ aged $55,000 \mathrm{~h}$ at $320^{\circ} \mathrm{C}$

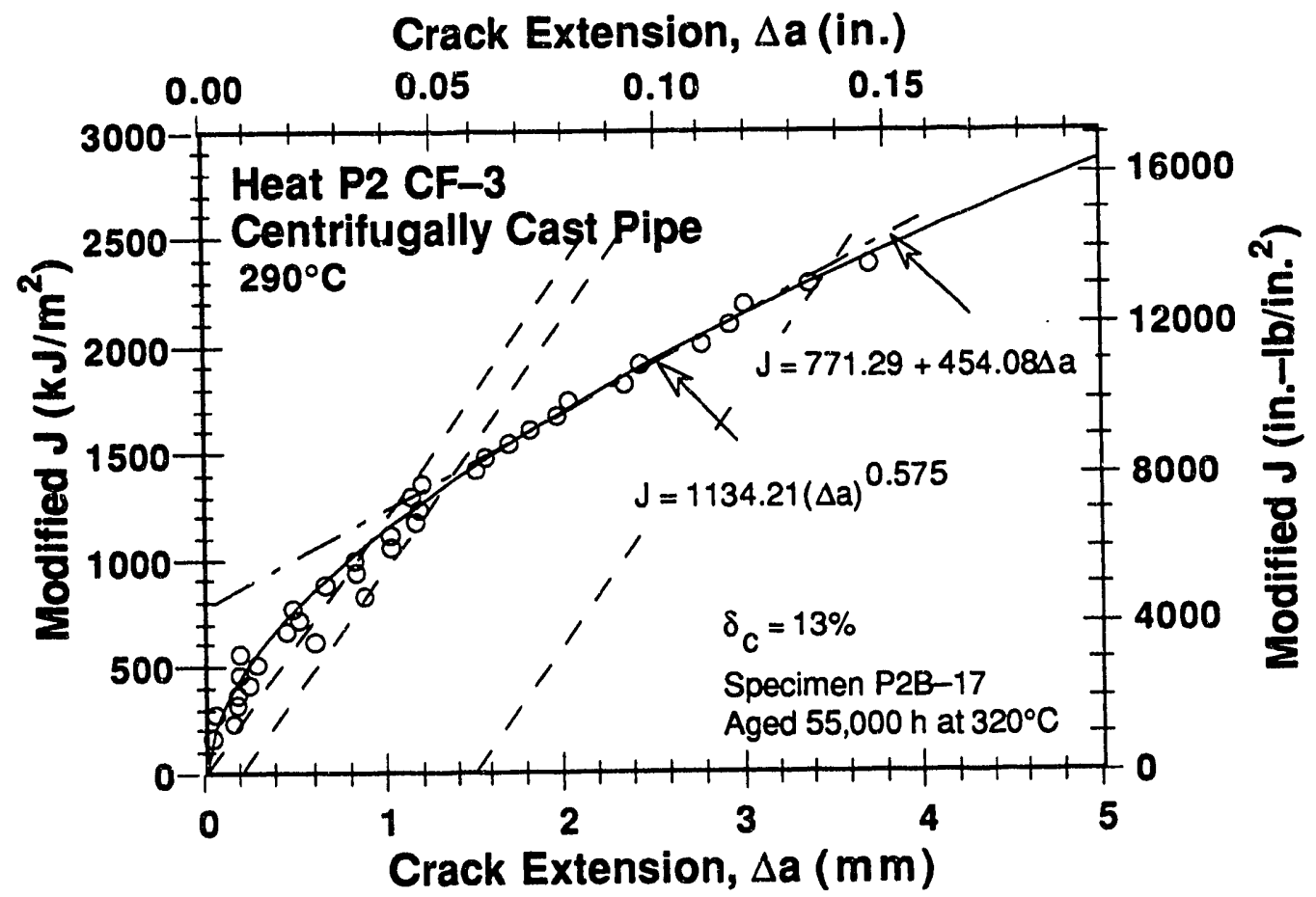

Figure A-13. Modifled $J_{I C}$ at $290^{\circ} \mathrm{C}$ for Heat $P 2$ aged $55,000 \mathrm{~h}$ at $320^{\circ} \mathrm{C}$ 
Table A-14. Test data for spectmen 691-03B

\begin{tabular}{|c|c|c|c|c|c|}
\hline \multicolumn{2}{|c|}{$\begin{array}{l}\text { Test Number } \\
\text { Material Type } \\
\text { Aging Temp. } \\
\text { Spec. Thickness } \\
\text { Spec. Width }\end{array}$} & $\begin{array}{l}: 0093 \\
: \mathrm{CF}-3 \\
: 320^{\circ} \mathrm{C} \\
: 25.39 \mathrm{~mm} \\
: 50.83 \mathrm{~mm}\end{array}$ & \multicolumn{2}{|c|}{$\begin{array}{l}\text { Test Temp. } \\
\text { Heat Number } \\
\text { Aging Time } \\
\text { Net Thickness } \\
\text { Flow Stress }\end{array}$} & $\begin{array}{l}: 25^{\circ} \mathrm{C} \\
: 69 \\
: 50,000 \mathrm{~h} \\
: 20.30 \mathrm{~mm} \\
: 475.52 \mathrm{MPa}\end{array}$ \\
\hline $\begin{array}{l}\text { Unload } \\
\text { Number }\end{array}$ & $\underset{\left(\mathrm{kJ} / \mathrm{m}^{2}\right)}{\mathrm{J}_{\mathrm{d}}}$ & $\begin{array}{c}J_{m} \\
\left(\mathrm{~kJ} / \mathrm{m}^{2}\right)\end{array}$ & $\begin{array}{c}\Delta \mathrm{a} \\
(\mathrm{mm})\end{array}$ & $\begin{array}{l}\text { Load } \\
(\mathrm{kN})\end{array}$ & $\begin{array}{l}\text { Deflection } \\
(\mathrm{mm})\end{array}$ \\
\hline $\begin{array}{l}1 \\
2 \\
3 \\
4 \\
5 \\
6 \\
7 \\
8 \\
9 \\
10 \\
11 \\
12 \\
13 \\
14 \\
15 \\
16 \\
17 \\
18 \\
19 \\
20 \\
21 \\
22 \\
23 \\
24 \\
25 \\
26 \\
27 \\
28 \\
29 \\
30 \\
31 \\
32 \\
33 \\
34 \\
35 \\
36 \\
37 \\
38 \\
39 \\
40 \\
41 \\
42\end{array}$ & $\begin{array}{r}20.96 \\
61.36 \\
108.69 \\
159.49 \\
215.02 \\
270.34 \\
328.56 \\
388.46 \\
447.51 \\
506.84 \\
566.74 \\
626.50 \\
689.82 \\
725.62 \\
773.22 \\
814.86 \\
856.02 \\
889.58 \\
923.02 \\
954.74 \\
988.32 \\
1029.60 \\
1069.55 \\
111.67 \\
1159.16 \\
1208.16 \\
1258.29 \\
1303.37 \\
1355.66 \\
1392.90 \\
1446.22 \\
1480.62 \\
1520.76 \\
1558.73 \\
1586.98 \\
1628.79 \\
1663.07 \\
1692.28 \\
1713.64 \\
1728.92 \\
1768.53 \\
1789.40\end{array}$ & $\begin{array}{r}20.96 \\
61.34 \\
109.29 \\
159.83 \\
215.89 \\
272.43 \\
331.13 \\
391.70 \\
453.60 \\
516.54 \\
581.16 \\
644.55 \\
709.85 \\
754.09 \\
808.60 \\
864.65 \\
905.77 \\
952.32 \\
996.05 \\
1039.82 \\
1083.25 \\
1126.71 \\
1184.40 \\
1238.76 \\
1305.45 \\
1376.22 \\
1447.75 \\
1525.33 \\
1611.64 \\
1697.66 \\
1779.34 \\
1867.79 \\
1942.06 \\
2021.59 \\
2101.87 \\
2197.67 \\
2293.41 \\
2385.09 \\
2475.50 \\
2563.28 \\
2666.77 \\
2771.62\end{array}$ & $\begin{array}{r}0.0001 \\
-0.0080 \\
0.1193 \\
0.0849 \\
0.1338 \\
0.2206 \\
0.2481 \\
0.2801 \\
0.3963 \\
0.5241 \\
0.6724 \\
0.7745 \\
0.8246 \\
1.0261 \\
1.1793 \\
1.4793 \\
1.4786 \\
1.7230 \\
1.9078 \\
2.1154 \\
2.2782 \\
2.3125 \\
2.5795 \\
2.7550 \\
3.0159 \\
3.2961 \\
3.5574 \\
3.9341 \\
4.3065 \\
4.8140 \\
5.0942 \\
5.6030 \\
5.9107 \\
6.2694 \\
6.7010 \\
7.1272 \\
7.5903 \\
8.0404 \\
8.5183 \\
9.0012 \\
9.4062 \\
9.9150\end{array}$ & $\begin{array}{l}23.745 \\
30.200 \\
33.540 \\
35.742 \\
37.483 \\
38.672 \\
39.700 \\
40.652 \\
41.341 \\
41.768 \\
42.099 \\
42.106 \\
42.524 \\
42.410 \\
42.348 \\
42.456 \\
42.186 \\
41.780 \\
41.474 \\
41.256 \\
41.098 \\
41.047 \\
40.668 \\
40.142 \\
39.452 \\
38.875 \\
38.266 \\
37.468 \\
36.286 \\
34.778 \\
33.931 \\
32.545 \\
31.337 \\
30.332 \\
29.433 \\
28.128 \\
26.894 \\
25.396 \\
24.227 \\
23.142 \\
21.997 \\
20.826\end{array}$ & $\begin{array}{r}0.304 \\
0.605 \\
0.905 \\
1.205 \\
1.510 \\
1.808 \\
2.109 \\
2.410 \\
2.708 \\
3.008 \\
3.312 \\
3.608 \\
3.912 \\
4.109 \\
4.361 \\
4.611 \\
4.811 \\
5.010 \\
5.212 \\
5.411 \\
5.610 \\
5.813 \\
6.060 \\
6.311 \\
6.609 \\
6.930 \\
7.258 \\
7.609 \\
8.009 \\
8.409 \\
8.815 \\
9.231 \\
9.612 \\
10.009 \\
10.415 \\
10.909 \\
11.412 \\
11910 \\
12.411 \\
12.911 \\
13.508 \\
14.113\end{array}$ \\
\hline
\end{tabular}


Table A-15. Deformation $J_{I C}$ and $J-R$ curve results for specimen 691-03B

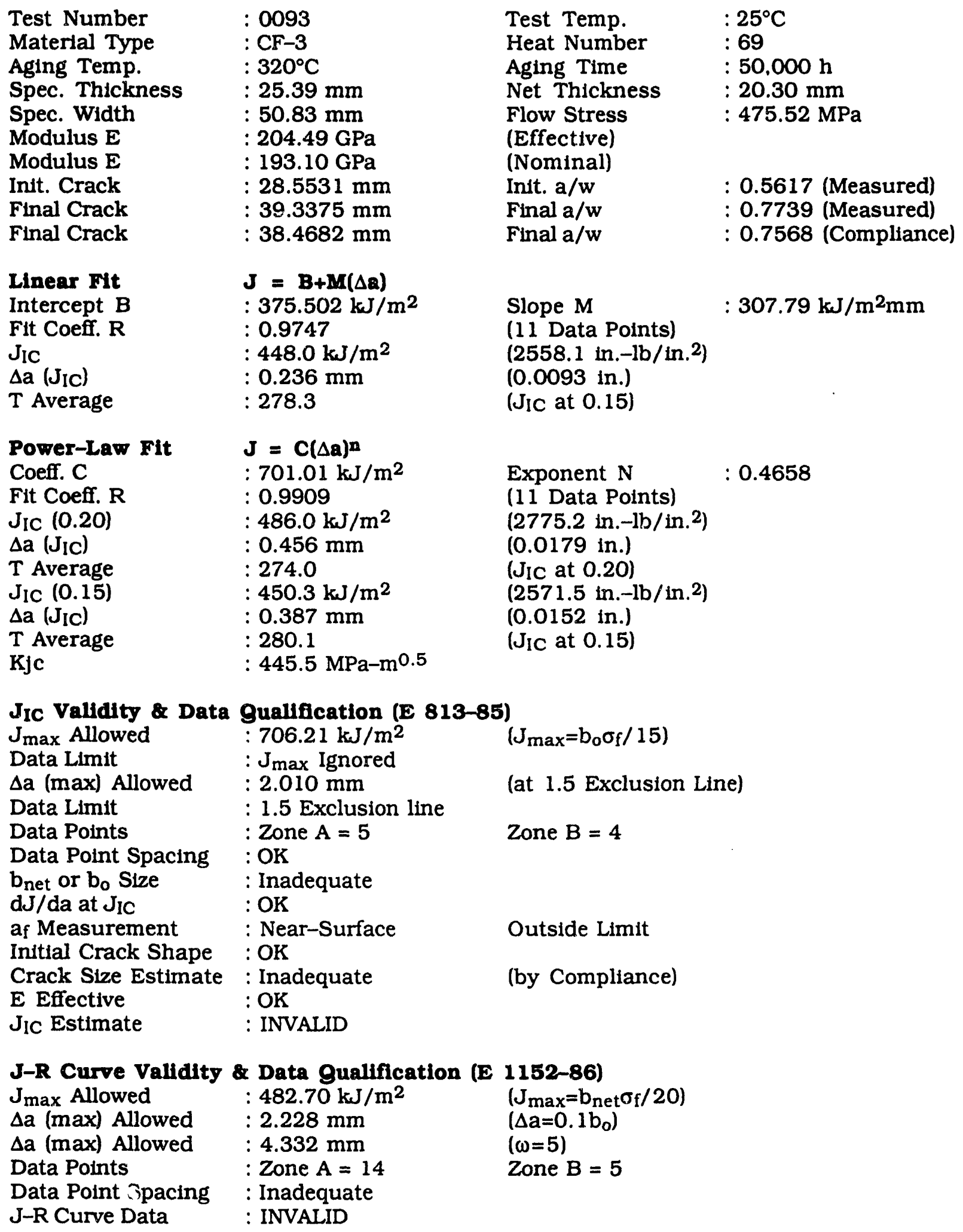


Table A-16. Modified $J_{I C}$ and $J-R$ curve results for specimen 691-03B

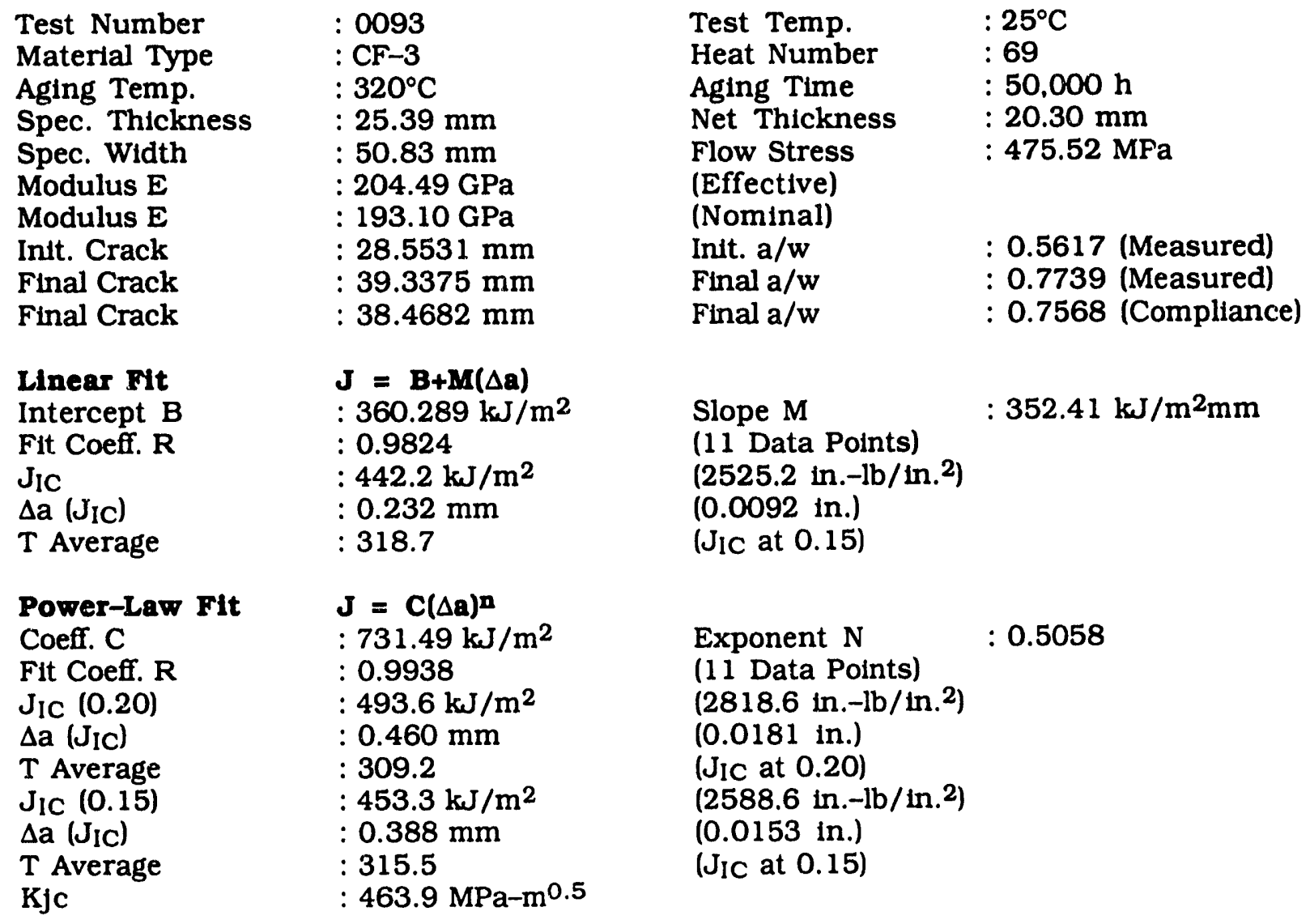

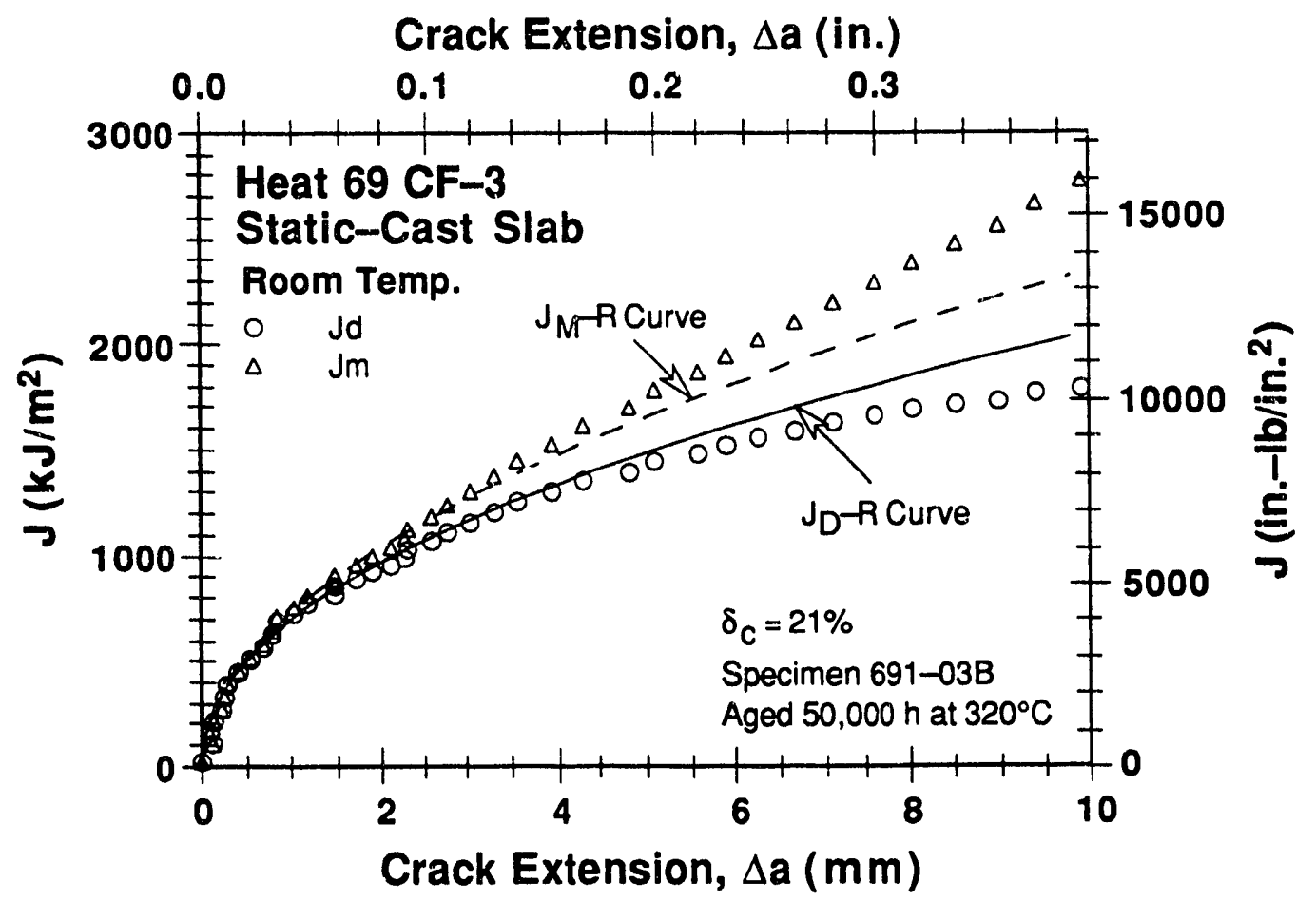

Figure A-14. Deformation and modified $J-R$ curves at room temp. for Heat 69 aged $50,000 \mathrm{~h}$ at $320^{\circ} \mathrm{C}$ 


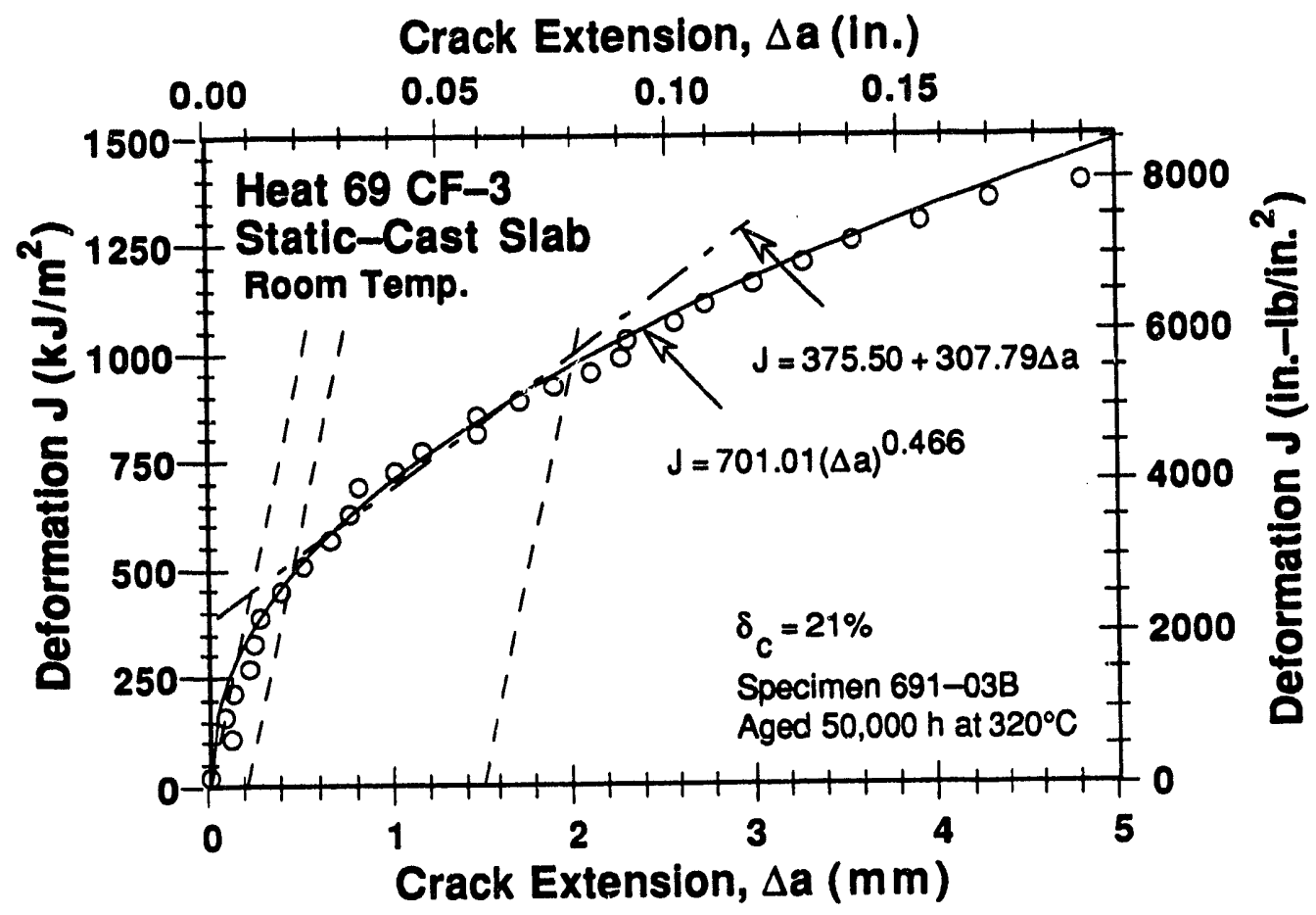

Figure A-15. Deformation $J_{I C}$ at room temp. for Heat 69 aged $50,000 \mathrm{~h}$ at $320^{\circ} \mathrm{C}$

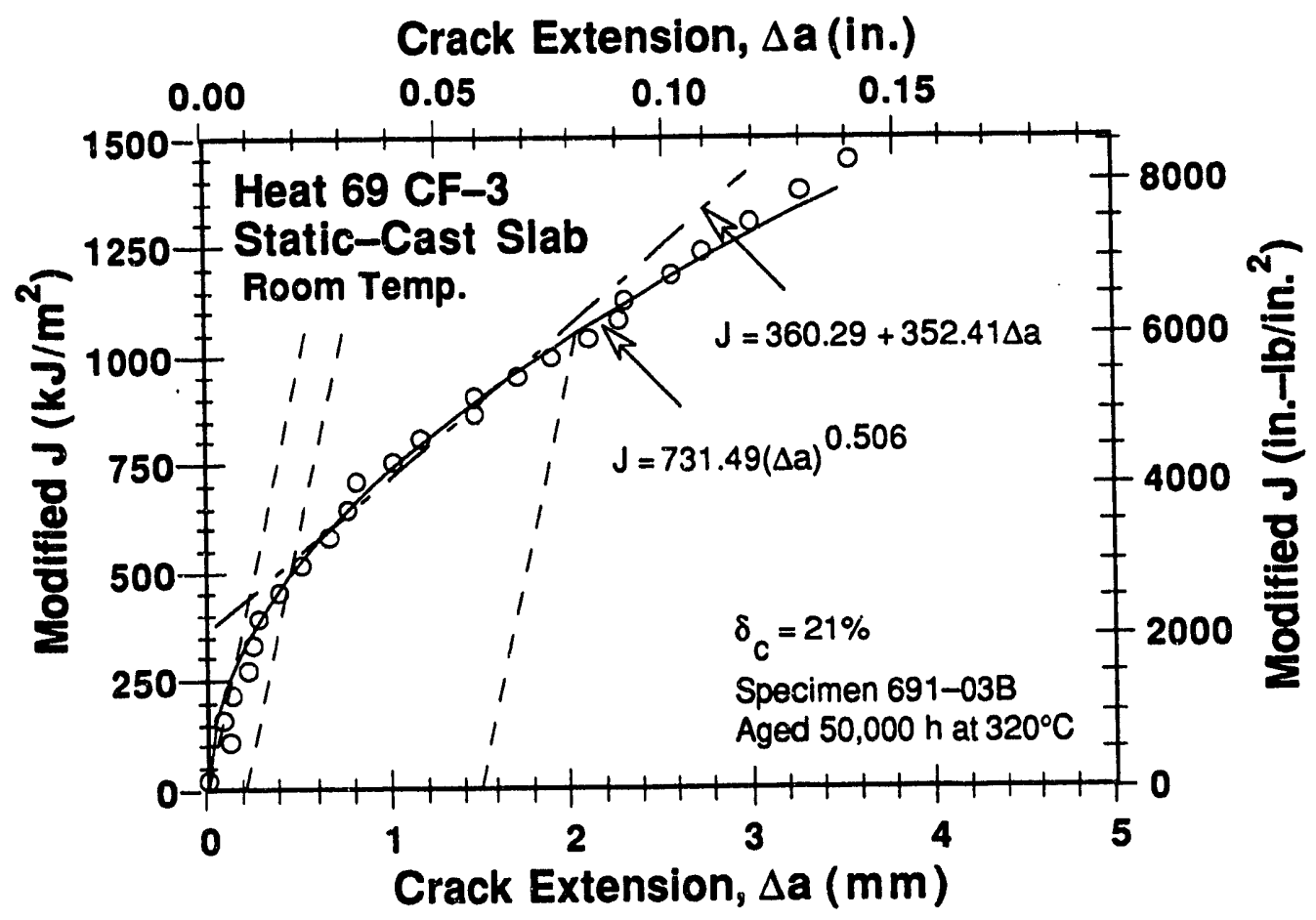

Fygure A-16. Modified $J_{I C}$ at room temp. for Heat 69 aged $50,000 \mathrm{~h}$ at $320^{\circ} \mathrm{C}$ 
Table A-17. Test data for specimen 692-05V

\begin{tabular}{|c|c|c|c|c|c|}
\hline $\begin{array}{l}\text { Test Num } \\
\text { Materlal } \\
\text { Aging Ter } \\
\text { Spec. Th } \\
\text { Spec. Wid }\end{array}$ & $\begin{array}{ll}\text { er } & : \\
\text { pe } & : \\
\text { p. } & : \\
\text { kness } & :\end{array}$ & $\begin{array}{l}\mathrm{mm} \\
\mathrm{mm}\end{array}$ & $\begin{array}{l}\text { Test } \\
\text { Heat } \\
\text { Aging } \\
\text { Net I } \\
\text { Flow }\end{array}$ & & $\begin{array}{l}50 \mathrm{~h} \\
4 \mathrm{~mm} \\
52 \mathrm{MPa}\end{array}$ \\
\hline $\begin{array}{l}\text { Unload } \\
\text { Number }\end{array}$ & $\begin{array}{c}J_{d} \\
\left(k J / m^{2}\right)\end{array}$ & $\begin{array}{c}J_{m} \\
\left(\mathrm{~kJ} / \mathrm{m}^{2}\right)\end{array}$ & $\begin{array}{c}\Delta \mathrm{a} \\
(\mathrm{mm})\end{array}$ & $\begin{array}{l}\text { Load } \\
(\mathrm{kN})\end{array}$ & $\begin{array}{c}\text { Deflection } \\
(\mathrm{mm})\end{array}$ \\
\hline $\begin{array}{l}1 \\
2 \\
3 \\
4 \\
5 \\
6 \\
7 \\
8 \\
9 \\
10 \\
11 \\
12 \\
13 \\
14 \\
15 \\
16 \\
17 \\
18 \\
19 \\
20 \\
21 \\
22 \\
23 \\
24 \\
25 \\
26 \\
27 \\
28 \\
29 \\
30 \\
31 \\
32 \\
33 \\
34 \\
35 \\
36 \\
37 \\
38 \\
39 \\
40 \\
41 \\
42\end{array}$ & $\begin{array}{r}20.07 \\
58.15 \\
102.61 \\
150.51 \\
201.58 \\
254.03 \\
308.93 \\
364.56 \\
423.76 \\
481.36 \\
540.05 \\
601.85 \\
658.77 \\
714.44 \\
777.40 \\
836.54 \\
899.53 \\
958.90 \\
1019.05 \\
1076.78 \\
1119.41 \\
1167.17 \\
1215.89 \\
1248.63 \\
1306.06 \\
1358.87 \\
1401.95 \\
1455.54 \\
1504.42 \\
1552.46 \\
1605.32 \\
1651.91 \\
1698.19 \\
1745.65 \\
1812.71 \\
1864.42 \\
1912.18 \\
1958.09 \\
2012.97 \\
2058.33 \\
2096.83 \\
2140.66\end{array}$ & $\begin{array}{r}20.08 \\
58.03 \\
103.08 \\
151.45 \\
202.26 \\
256.52 \\
311.61 \\
369.44 \\
427.42 \\
486.91 \\
548.09 \\
608.86 \\
673.26 \\
736.94 \\
799.74 \\
865.86 \\
931.10 \\
998.53 \\
1065.76 \\
1131.83 \\
1188.36 \\
1244.50 \\
1299.62 \\
1358.09 \\
1422.62 \\
1490.89 \\
1561.69 \\
1625.76 \\
1693.52 \\
1784.36 \\
1871.38 \\
1964.62 \\
2044.54 \\
2130.19 \\
2238.90 \\
2344.92 \\
2449.03 \\
2574.90 \\
2699.64 \\
2816.54 \\
2956.34 \\
3088.26\end{array}$ & $\begin{array}{r}0.0027 \\
-0.0495 \\
0.0751 \\
0.1395 \\
0.1145 \\
0.2499 \\
0.2621 \\
0.3730 \\
0.3208 \\
0.3915 \\
0.4744 \\
0.4438 \\
0.6438 \\
0.8395 \\
0.8358 \\
0.9797 \\
1.0223 \\
1.1654 \\
1.2828 \\
1.4130 \\
1.6201 \\
1.7389 \\
1.8255 \\
2.1608 \\
2.2488 \\
2.4313 \\
2.7448 \\
2.8583 \\
3.0541 \\
3.4772 \\
3.7985 \\
4.2173 \\
4.5073 \\
4.8229 \\
5.1491 \\
5.5546 \\
5.9567 \\
6.4991 \\
6.9494 \\
7.3898 \\
7.9815 \\
8.4709\end{array}$ & $\begin{array}{l}22.571 \\
28.498 \\
31.578 \\
33.573 \\
35.307 \\
36.363 \\
37.516 \\
38.574 \\
39.401 \\
40.013 \\
40.758 \\
41.152 \\
41.532 \\
42.154 \\
42.195 \\
42.581 \\
42.743 \\
42.985 \\
43.023 \\
43.126 \\
42.995 \\
42.797 \\
42.489 \\
42.205 \\
41.787 \\
41.506 \\
41.182 \\
40.642 \\
40.189 \\
39.375 \\
37.921 \\
37.007 \\
36.236 \\
35.671 \\
34.850 \\
33.647 \\
32.481 \\
31.310 \\
30.269 \\
29.185 \\
27.420 \\
25.831\end{array}$ & $\begin{array}{l}0.304 \\
0.607 \\
0.907 \\
1.209 \\
1.510 \\
1.809 \\
2.112 \\
2.412 \\
2.716 \\
3.010 \\
3.312 \\
3.611 \\
3.910 \\
4.212 \\
4.513 \\
4.811 \\
5.113 \\
5.413 \\
5.716 \\
6.012 \\
6.260 \\
6.514 \\
6.761 \\
7.010 \\
7.310 \\
7.607 \\
7.916 \\
8.213 \\
8.509 \\
8.906 \\
9.307 \\
9.733 \\
10.114 \\
10.511 \\
11.016 \\
11.511 \\
12.010 \\
12.613 \\
13.232 \\
13.814 \\
14.511 \\
15.205\end{array}$ \\
\hline
\end{tabular}


Table A-18. Deformation $J_{I C}$ and $J-R$ curve results for spectmen 692-05V

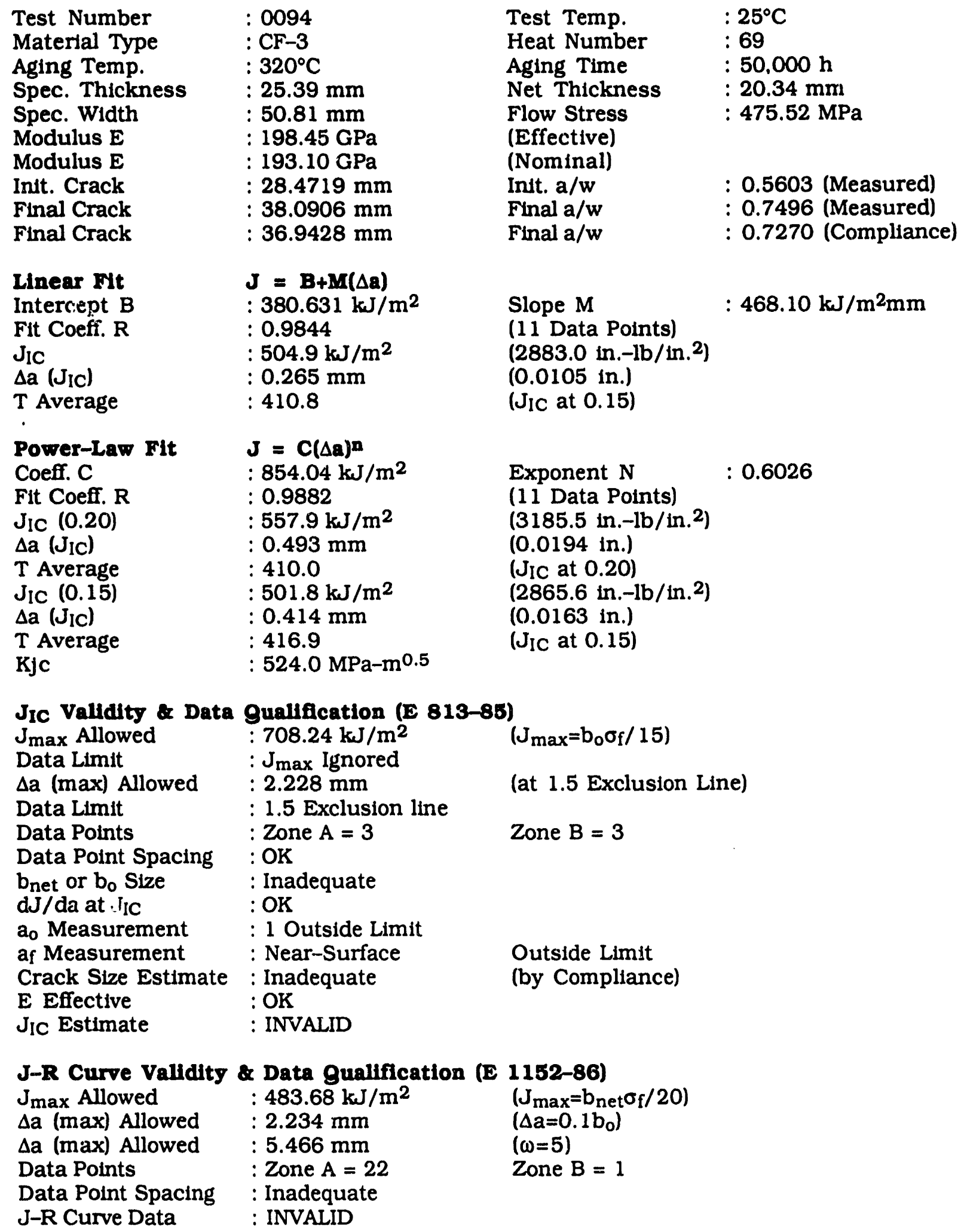


Table A-19. Modifled $J_{I C}$ and $J-R$ curve results for spectmen $692-05 \mathrm{~V}$

\begin{tabular}{|c|c|c|c|}
\hline $\begin{array}{l}\text { Test Number } \\
\text { Material Type } \\
\text { Aging Temp. } \\
\text { Spec. Thickness } \\
\text { Spec. Width } \\
\text { Modulus E } \\
\text { Modulus E } \\
\text { Init. Crack } \\
\text { Final Crack } \\
\text { Final Crack }\end{array}$ & $\begin{array}{l}: 0094 \\
: C F-3 \\
: 320^{\circ} \mathrm{C} \\
: 25.39 \mathrm{~mm} \\
: 50.81 \mathrm{~mm} \\
: 198.45 \mathrm{GPa} \\
: 193.10 \mathrm{GPa} \\
: 28.4719 \mathrm{~mm} \\
: 38.0906 \mathrm{~mm} \\
: 36.9428 \mathrm{~mm}\end{array}$ & $\begin{array}{l}\text { Test Temp. } \\
\text { Heat Number } \\
\text { Aging Time } \\
\text { Net Thickness } \\
\text { Flow Stress } \\
\text { (Effective) } \\
\text { (Nominal) } \\
\text { Init. a/w } \\
\text { Final a/w } \\
\text { Final a/w }\end{array}$ & $\begin{array}{l}: 0.5603 \text { (Measured) } \\
: 0.7496 \text { (Measured) } \\
: 0.7270 \text { (Compliance) }\end{array}$ \\
\hline $\begin{array}{l}\text { Linear Fit } \\
\text { Intercept B } \\
\text { Fit Coeff. } R \\
\mathrm{~J}_{\mathrm{IC}} \\
\Delta \mathrm{a}\left(\mathrm{J}_{\mathrm{IC}}\right) \\
\text { T Average }\end{array}$ & $\begin{array}{l}J=\mathbf{J}+\mathbf{M}(\Delta \mathbf{a}) \\
: 405.072 \mathrm{~kJ} / \mathrm{m}^{2} \\
: 0.9812 \\
: 541.3 \mathrm{~kJ} / \mathrm{m}^{2} \\
: 0.285 \mathrm{~mm} \\
: 420.1\end{array}$ & $\begin{array}{l}\text { Slope } M \\
\text { (12 Data Points) } \\
\left(3090.9 \text { in. }-\mathrm{lb} / \text { in }^{2}\right) \\
(0.0112 \text { in.) } \\
\left(\mathrm{J}_{\text {IC }} \text { at } 0.15\right)\end{array}$ & $: 478.68 \mathrm{~kJ} / \mathrm{m}^{2} \mathrm{~mm}$ \\
\hline $\begin{array}{l}\text { Power-Law Fit } \\
\text { Coeff. C } \\
\text { Fit Coeff. R } \\
J_{I C}(0.20) \\
\Delta a\left(J_{I C}\right) \\
\text { T Average } \\
J_{I C}(0.15) \\
\Delta a\left(J_{I C}\right) \\
\text { T Average } \\
\text { KJc }\end{array}$ & $\begin{array}{l}J=C(\Delta a)^{n} \\
: 885.61 \mathrm{~kJ} / \mathrm{m}^{2} \\
: 0.9894 \\
: 580.0 \mathrm{~kJ} / \mathrm{m}^{2} \\
: 0.505 \mathrm{~mm} \\
: 435.1 \\
: 520.1 \mathrm{~kJ} / \mathrm{m}^{2} \\
: 0.423 \mathrm{~mm} \\
: 442.1 \\
: 540.7 \mathrm{MPa}-\mathrm{m}^{0.5}\end{array}$ & $\begin{array}{l}\text { Exponent } N \\
(12 \text { Data Points) } \\
\left(3311.8 \text { in. }-1 \mathrm{~b} / \text { in. }^{2}\right) \\
(0.0199 \mathrm{in.}) \\
\left(\mathrm{J}_{1 \mathrm{C}} \text { at } 0.20\right) \\
\left(2969.6 \mathrm{in} .-\mathrm{lb} / \mathrm{in}^{2}\right) \\
(0.0167 \mathrm{in.}) \\
\left(\mathrm{J}_{\mathrm{IC}} \text { at } 0.15\right)\end{array}$ & $: 0.6194$ \\
\hline
\end{tabular}

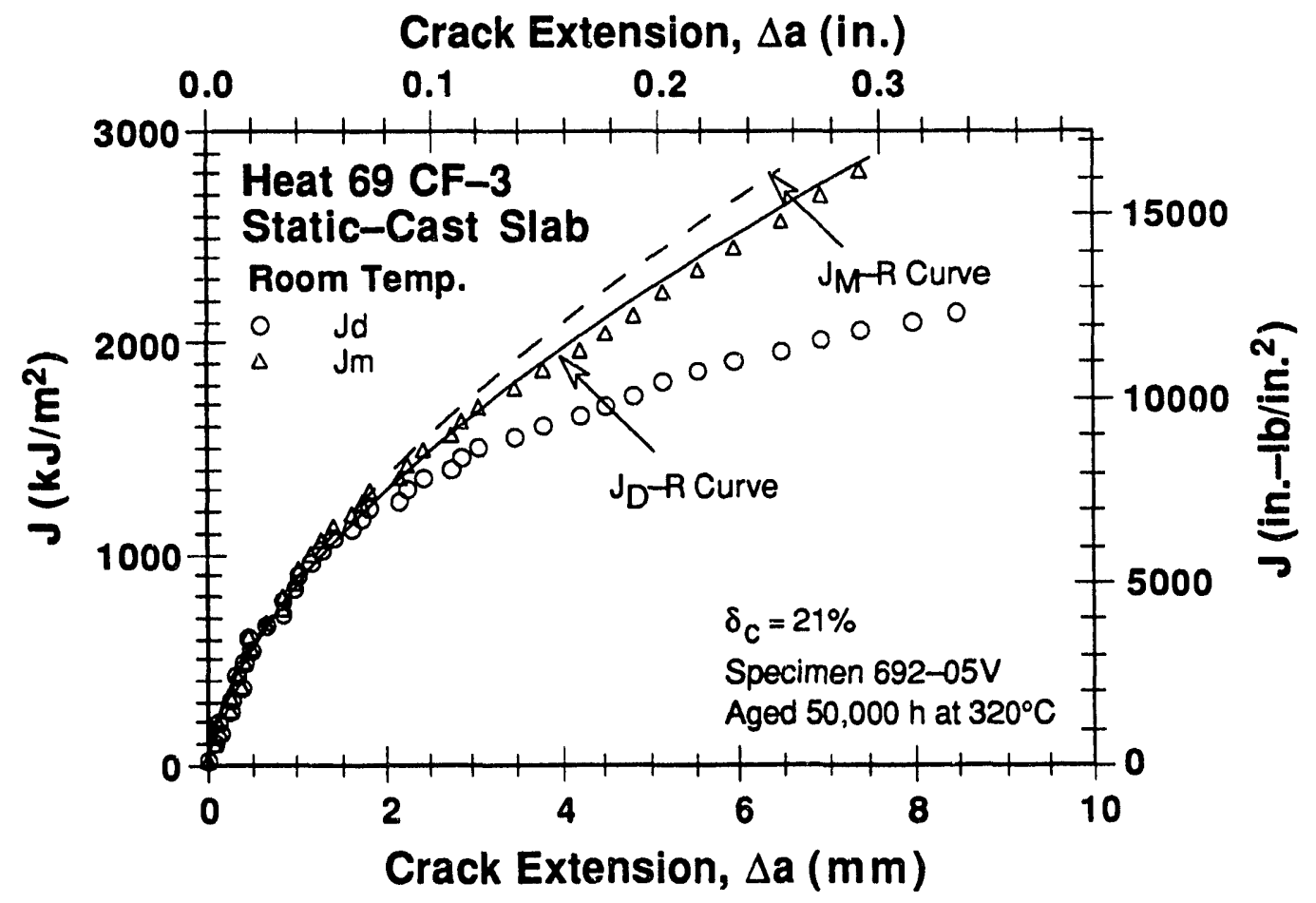

Figure A-17. Deformation and modified $J-R$ curves at room temp. for Heat 69 aged $50,000 \mathrm{~h}$ at $320^{\circ} \mathrm{C}$ 


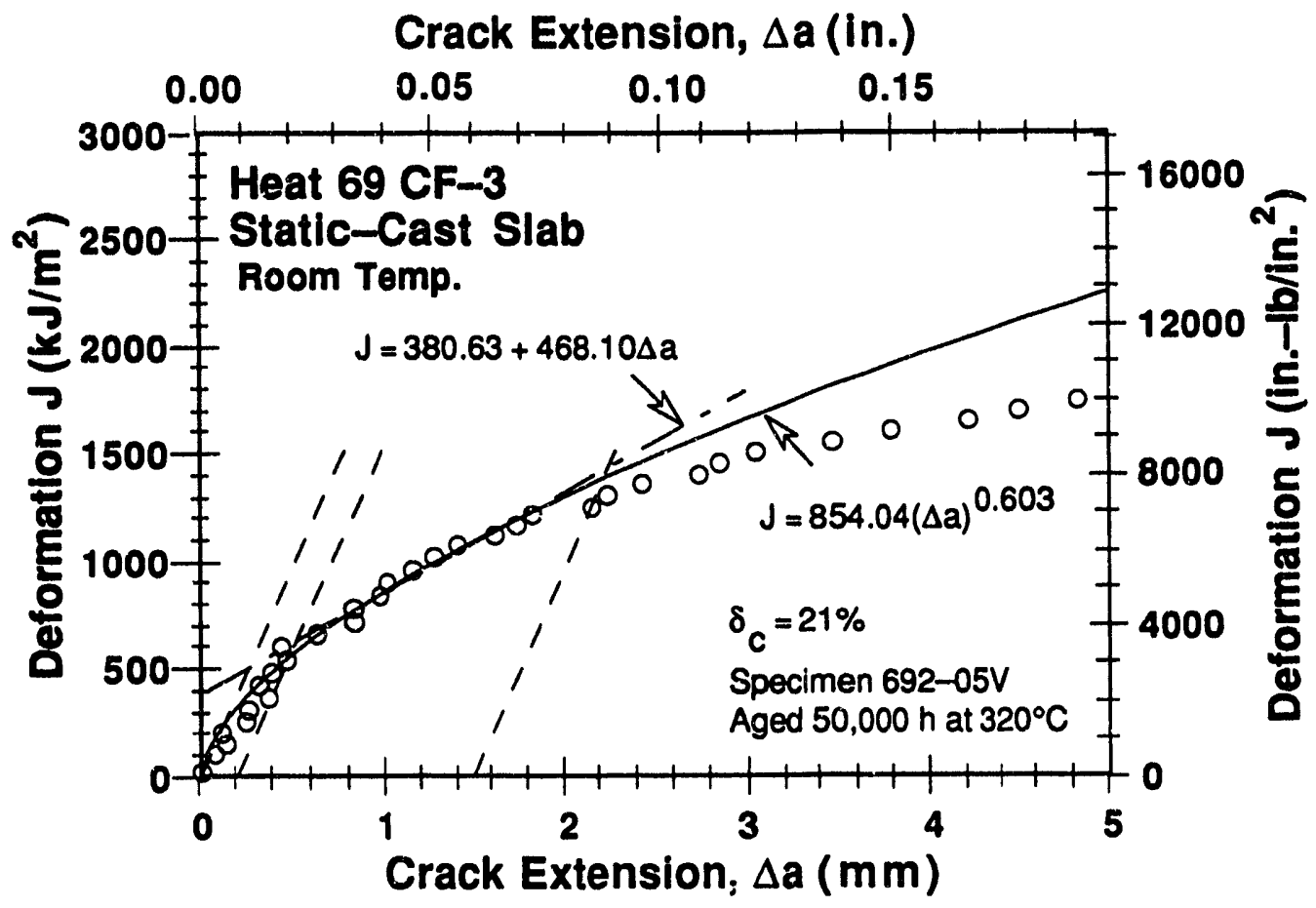

Flgure A-18. Deformation $J_{I C}$ at room temp. for Heat 69 aged 50,000 h at $320^{\circ} \mathrm{C}$

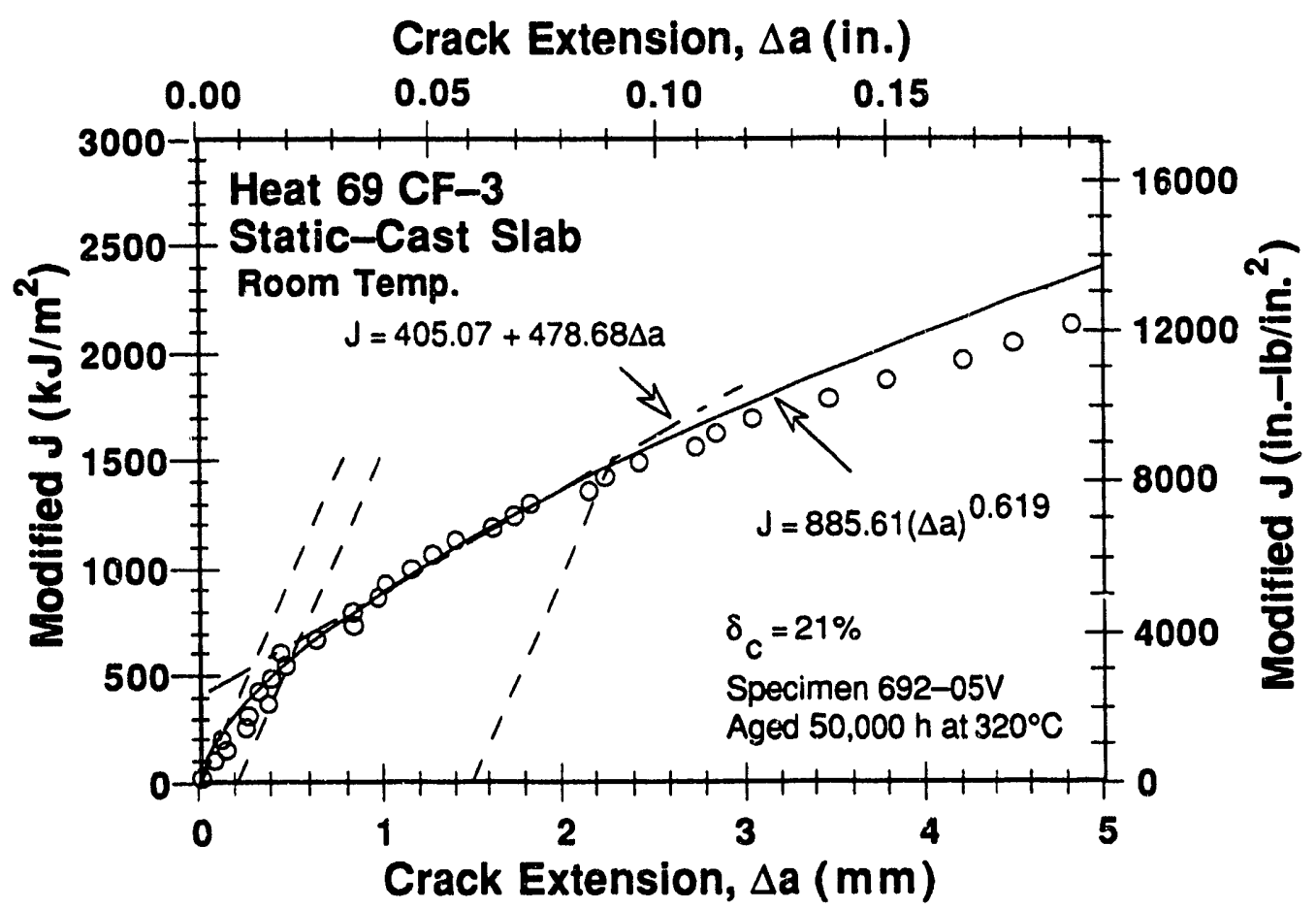

Figure A-19. Modified $J_{I C}$ at room temp. for Heat 69 aged $50,000 \mathrm{~h}$ at $320^{\circ} \mathrm{C}$ 
Table A-20. Test data for specimen 691-03T

\begin{tabular}{|c|c|c|c|c|c|}
\hline $\begin{array}{l}\text { Test Num } \\
\text { Material } \\
\text { Aging Te } \\
\text { Spec. Th } \\
\text { Spec. Wic }\end{array}$ & hess & $\begin{array}{l}\mathrm{mm} \\
\mathrm{mm}\end{array}$ & $\begin{array}{l}\text { Test } \\
\text { Heat } \\
\text { Aging } \\
\text { Net T } \\
\text { Flow }\end{array}$ & & $\begin{array}{l}\mathrm{C} \\
00 \mathrm{~h} \\
2 \mathrm{~mm} \\
84 \mathrm{MPa}\end{array}$ \\
\hline $\begin{array}{l}\text { Unload } \\
\text { Number }\end{array}$ & $\begin{array}{c}\mathrm{J}_{\mathrm{d}} \\
\left(\mathrm{kJJ} / \mathrm{m}^{2}\right)\end{array}$ & $\begin{array}{c}J_{\mathrm{m}} \\
\left(\mathrm{kJ} / \mathrm{m}^{2}\right)\end{array}$ & $\begin{array}{c}\Delta \mathrm{a} \\
(\mathrm{mm})\end{array}$ & $\begin{array}{l}\text { Load } \\
\text { (kN) }\end{array}$ & $\begin{array}{c}\text { Deflection } \\
\text { (mm) }\end{array}$ \\
\hline $\begin{array}{l}1 \\
2 \\
3 \\
4 \\
5 \\
6 \\
7 \\
8 \\
9 \\
10 \\
11 \\
12 \\
13 \\
14 \\
15 \\
16 \\
17 \\
18 \\
19 \\
20 \\
21 \\
22 \\
23 \\
24 \\
25 \\
26 \\
27 \\
28 \\
29 \\
30 \\
31\end{array}$ & $\begin{array}{l}15.55 \\
43.62 \\
75.73 \\
110.16 \\
146.07 \\
184.77 \\
221.17 \\
261.37 \\
298.18 \\
332.13 \\
370.71 \\
400.57 \\
434.34 \\
459.67 \\
490.28 \\
515.46 \\
550.16 \\
593.38 \\
613.81 \\
656.74 \\
691.90 \\
731.76 \\
756.23 \\
781.51 \\
816.91 \\
840.02 \\
874.06 \\
896.09 \\
930.77 \\
947.15 \\
962.55\end{array}$ & $\begin{array}{r}15.56 \\
43.52 \\
76.12 \\
110.43 \\
147.78 \\
185.51 \\
227.01 \\
265.63 \\
310.70 \\
343.49 \\
379.18 \\
418.37 \\
452.59 \\
492.05 \\
526.62 \\
565.79 \\
600.82 \\
646.24 \\
693.87 \\
735.34 \\
797.51 \\
854.71 \\
914.02 \\
968.75 \\
1037.17 \\
1105.60 \\
1169.54 \\
1235.17 \\
1309.70 \\
1382.63 \\
1451.58\end{array}$ & $\begin{array}{r}0.0102 \\
-0.0453 \\
0.0846 \\
0.0641 \\
0.2459 \\
0.1503 \\
0.5570 \\
0.4516 \\
0.9245 \\
0.8658 \\
0.7338 \\
1.1214 \\
1.1386 \\
1.6373 \\
1.7677 \\
2.1974 \\
2.2070 \\
2.2650 \\
2.8142 \\
2.8958 \\
3.4744 \\
3.8189 \\
4.6690 \\
4.9868 \\
5.5267 \\
6.2213 \\
6.6508 \\
7.2406 \\
7.7431 \\
8.4151 \\
9.0167\end{array}$ & $\begin{array}{l}16.217 \\
19.779 \\
21.804 \\
23.093 \\
24.230 \\
25.146 \\
25.731 \\
26.180 \\
25.811 \\
26.884 \\
27.055 \\
27.279 \\
27.246 \\
27.056 \\
27.040 \\
26.901 \\
26.571 \\
26.255 \\
25.975 \\
25.487 \\
24.946 \\
24.013 \\
22.935 \\
21.848 \\
20.854 \\
19.607 \\
18 \text { '10 } \\
17.454 \\
16.308 \\
15.196 \\
14.180\end{array}$ & $\begin{array}{r}0.304 \\
0.606 \\
0.907 \\
1.207 \\
1.506 \\
1.809 \\
2.107 \\
2.407 \\
2.710 \\
2.959 \\
3.208 \\
.460 \\
3.708 \\
3.959 \\
4.207 \\
4.458 \\
4.710 \\
5.009 \\
5.310 \\
5.610 \\
6.007 \\
6.409 \\
6.810 \\
7.211 \\
7.707 \\
8.209 \\
8.708 \\
9.208 \\
9.809 \\
10.410 \\
11.009\end{array}$ \\
\hline
\end{tabular}


Table A-21. Deformation $J_{I C}$ and $J-R$ curve results for specimen 691-03T

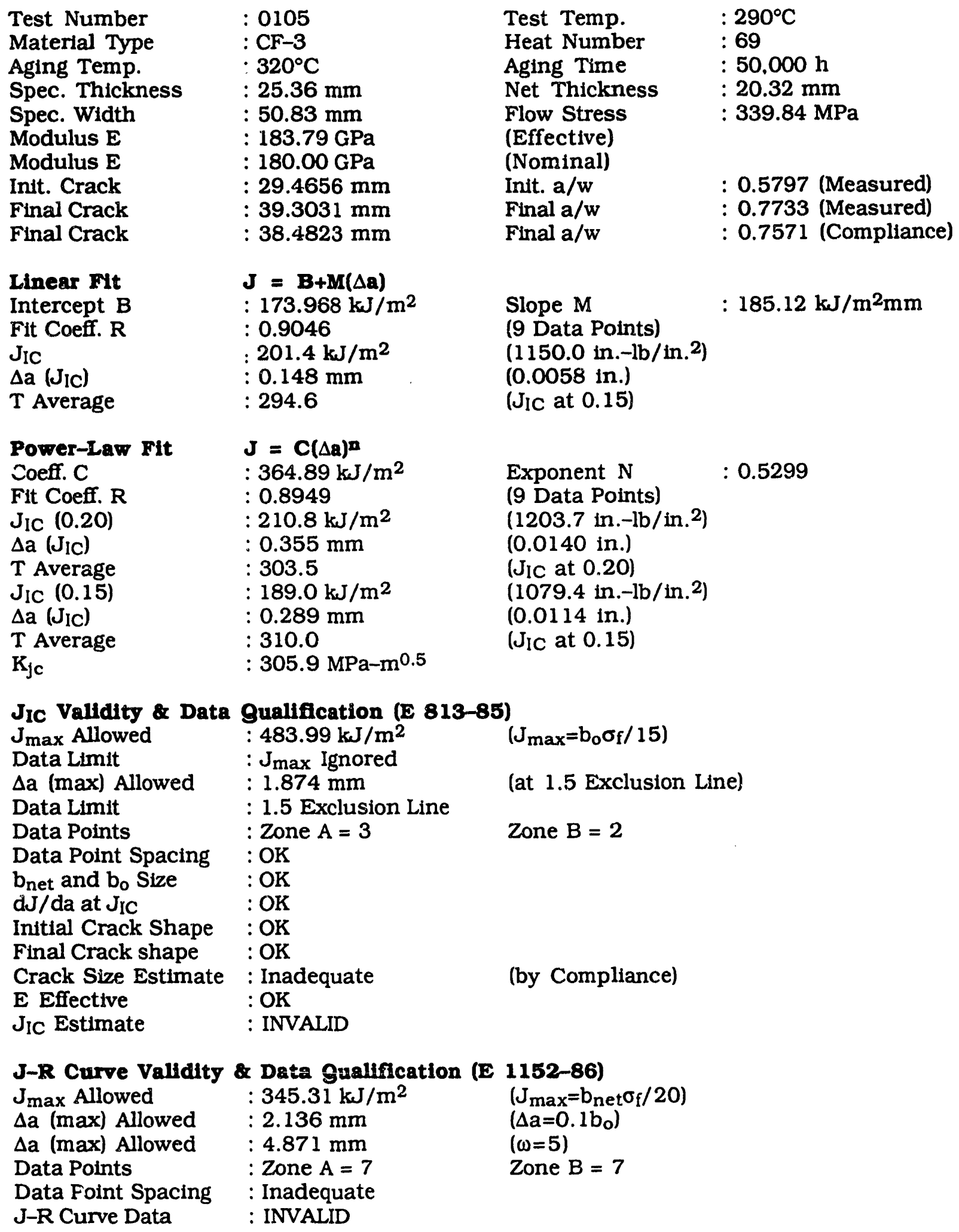


Table A-22. Modified $J_{I C}$ and J-R curve results for specimen 691-03T

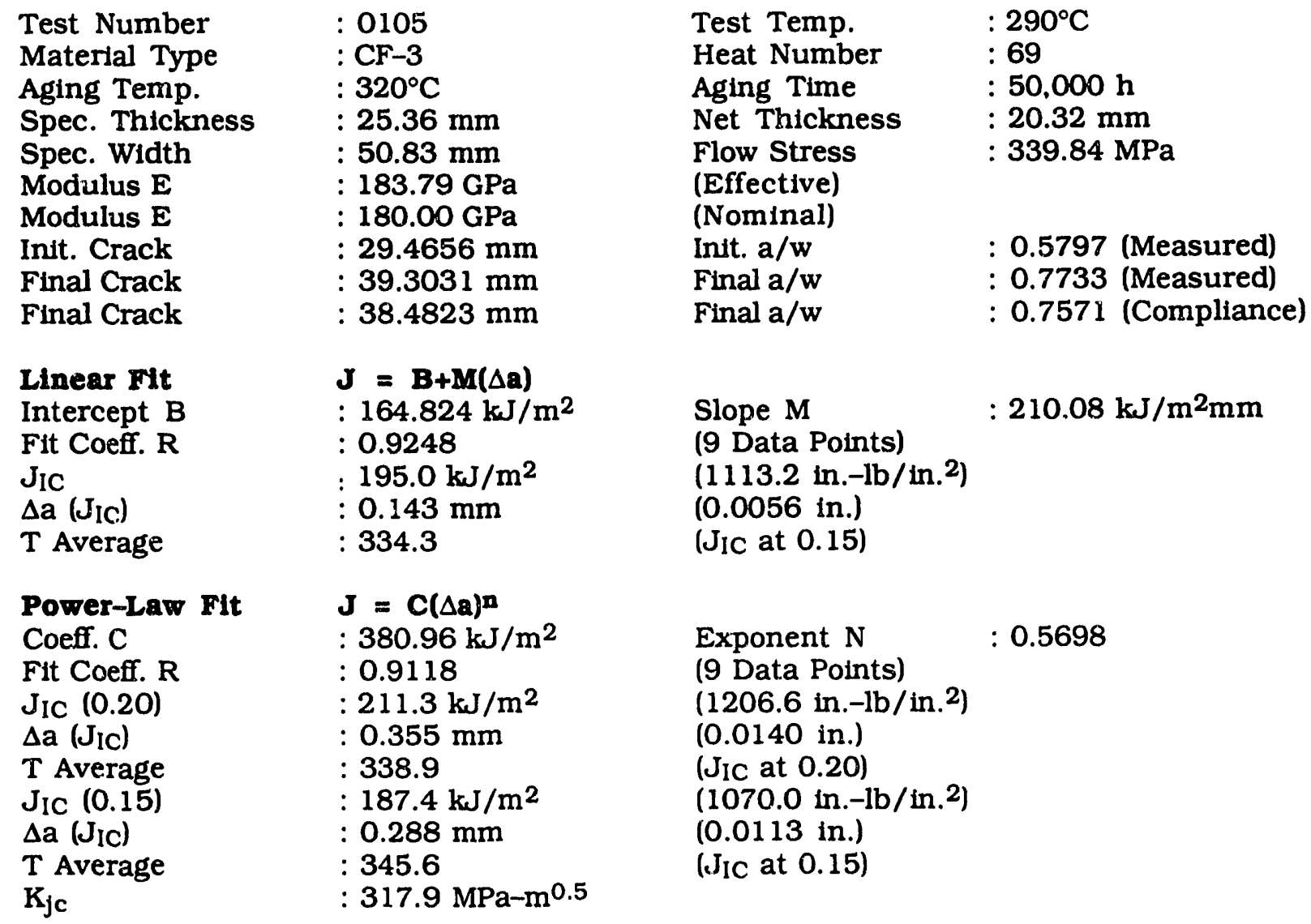

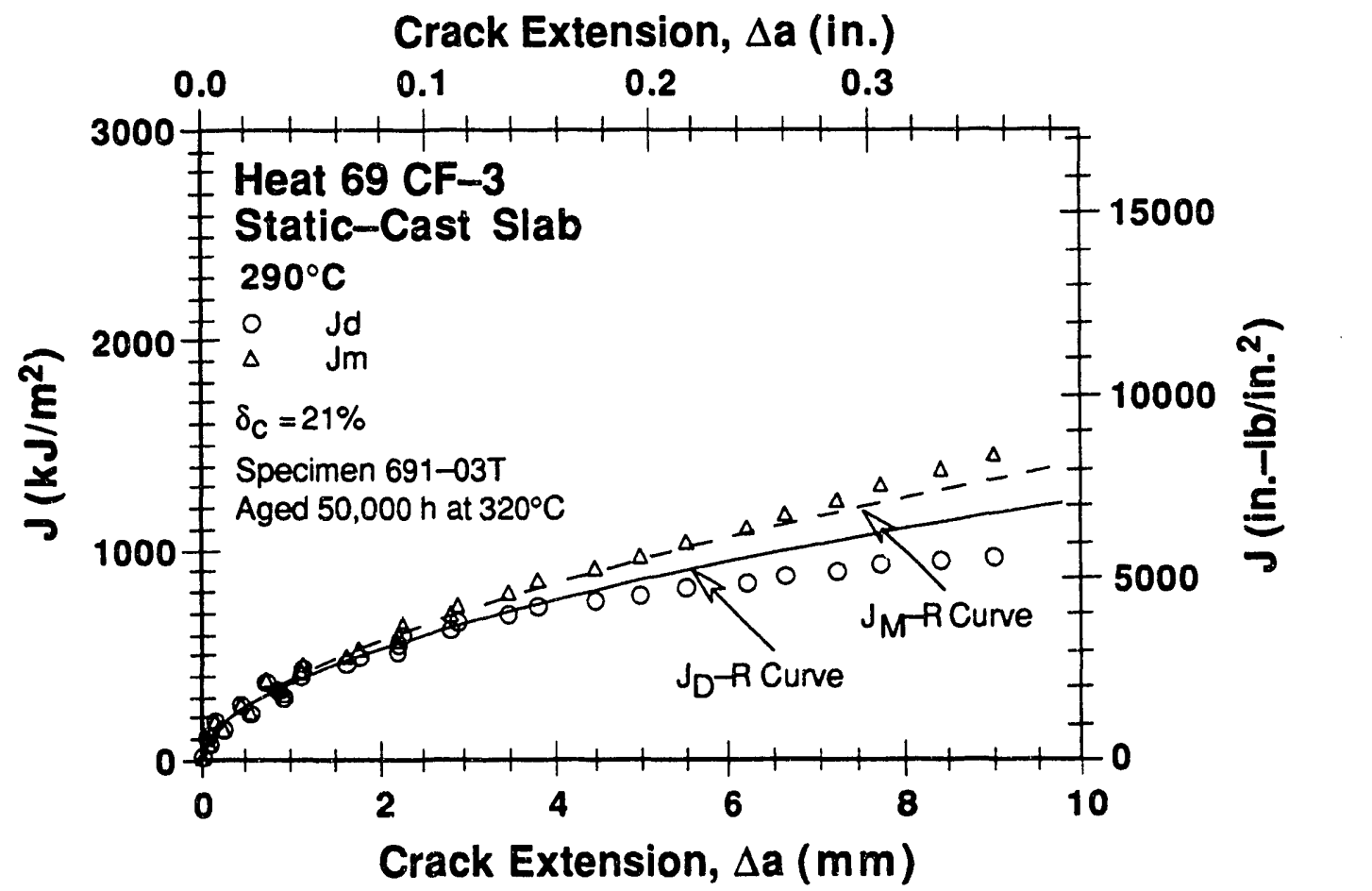

Figure A-20. Deformation and modified $J-R$ curves at $290^{\circ} \mathrm{C}$ for Heat 69 aged $50.000 \mathrm{~h}$ at $320^{\circ} \mathrm{C}$ 


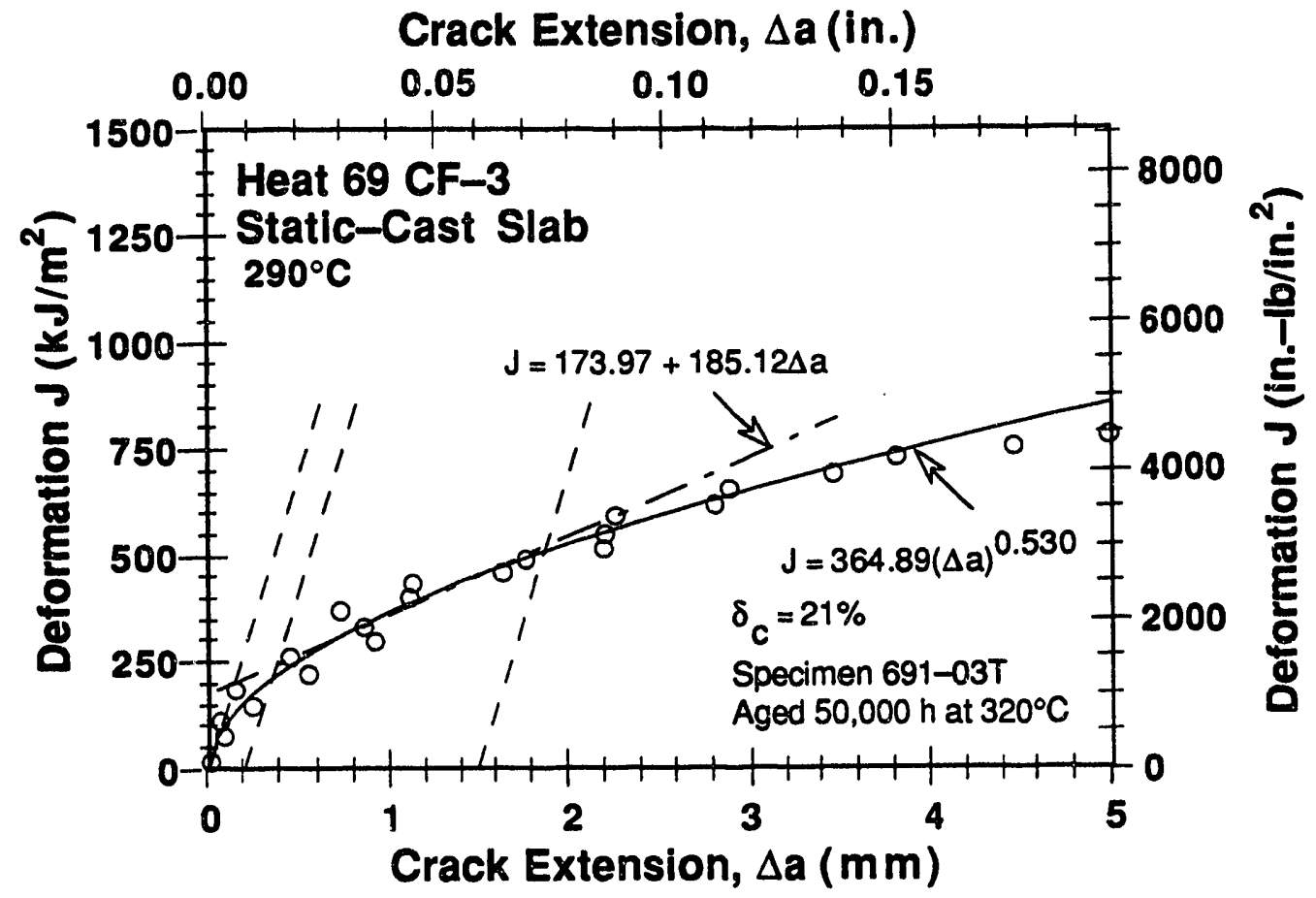

Figure A-21. Deformation $J_{I C}$ at $290^{\circ} \mathrm{C}$ for Heat 69 aged $50,000 \mathrm{~h}$ at $320^{\circ} \mathrm{C}$

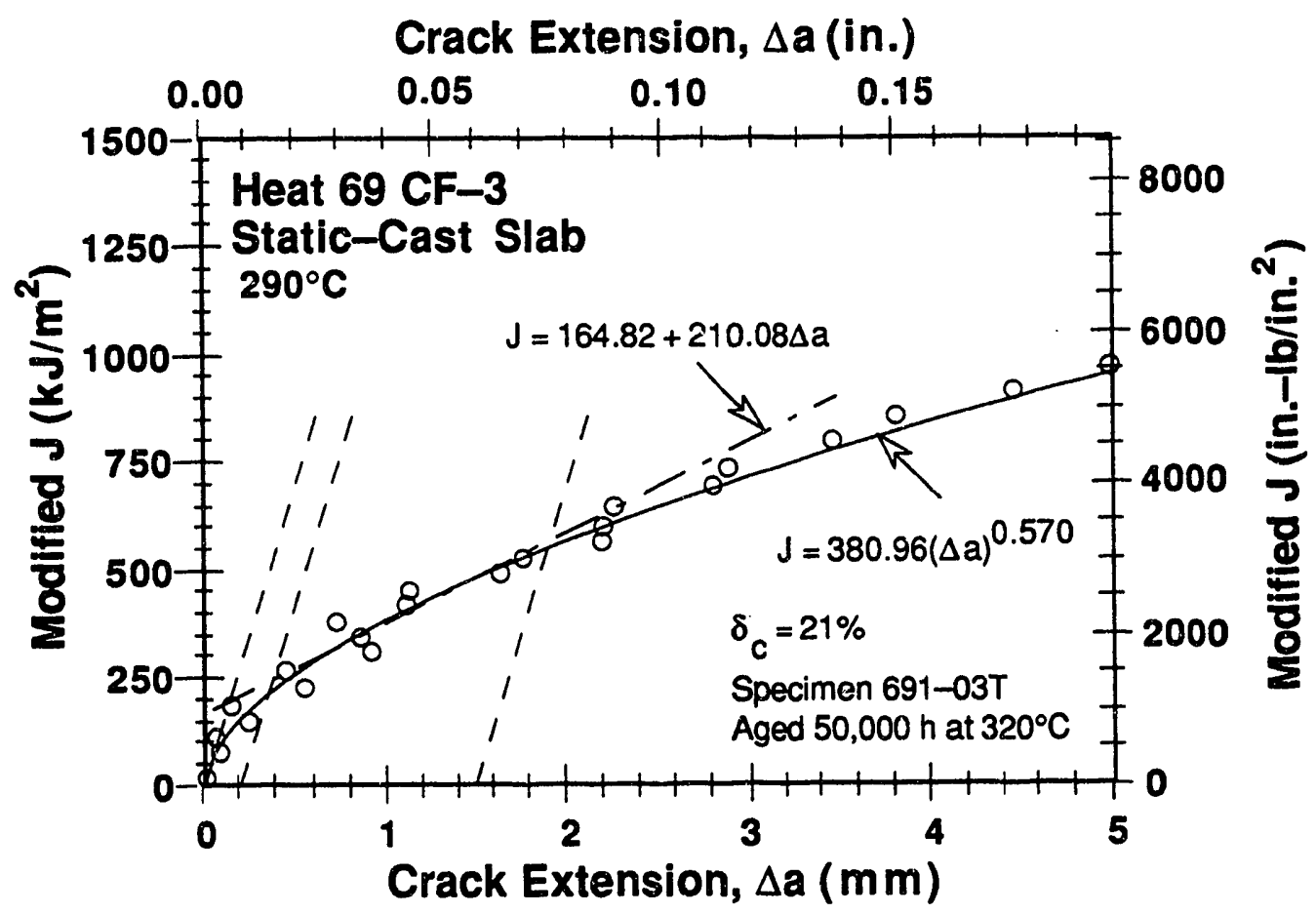

Figure A-22. Modified $J_{I C}$ at $290^{\circ} \mathrm{C}$ for Heat 69 aged $50,000 \mathrm{~h}$ at $320^{\circ} \mathrm{C}$ 
Table A-23. Test data for specimen P1T-17

\begin{tabular}{|c|c|c|c|c|c|}
\hline $\begin{array}{l}\text { Test Num } \\
\text { Material } \\
\text { Aging Ter } \\
\text { Spec. Thi } \\
\text { Spec. Wid }\end{array}$ & $\begin{array}{l}\text { er } \\
\text { pe } \\
\text { p. } \\
\text { kness } \\
\text { h }\end{array}$ & $\begin{array}{l}\mathrm{mm} \\
\mathrm{mm}\end{array}$ & $\begin{array}{l}\text { Test } \\
\text { Heat } \\
\text { Aging } \\
\text { Net } \\
\text { Flow }\end{array}$ & & $\begin{array}{l}00 \mathrm{~h} \\
7 \mathrm{~mm} \\
90 \mathrm{MPa}\end{array}$ \\
\hline $\begin{array}{l}\text { Unload } \\
\text { Number }\end{array}$ & $\begin{array}{c}J_{d} \\
\left(\mathrm{~kJ} / \mathrm{m}^{2}\right)\end{array}$ & $\begin{array}{c}J_{m} \\
\left(\mathrm{~kJ} / \mathrm{m}^{2}\right)\end{array}$ & $\begin{array}{c}\Delta \mathrm{a} \\
(\mathrm{mm})\end{array}$ & $\begin{array}{l}\text { Load } \\
(\mathrm{kN})\end{array}$ & $\begin{array}{c}\text { Deflection } \\
\text { (mm) }\end{array}$ \\
\hline $\begin{array}{l}1 \\
2 \\
3 \\
4 \\
5 \\
6 \\
7 \\
8 \\
9 \\
10 \\
11 \\
12 \\
13 \\
14 \\
15 \\
16 \\
17 \\
18 \\
19 \\
20 \\
21 \\
22 \\
23 \\
24 \\
25 \\
26 \\
27 \\
28 \\
29 \\
30 \\
31 \\
32 \\
33 \\
34 \\
35 \\
36 \\
37 \\
38\end{array}$ & $\begin{array}{r}31.50 \\
85.53 \\
146.94 \\
196.38 \\
247.04 \\
299.19 \\
350.19 \\
405.07 \\
458.99 \\
518.49 \\
575.71 \\
630.50 \\
688.23 \\
750.21 \\
811.30 \\
868.59 \\
923.92 \\
986.27 \\
1053.70 \\
1126.30 \\
1191.51 \\
1264.63 \\
1348.38 \\
1412.88 \\
1474.04 \\
1552.60 \\
1640.31 \\
1711.07 \\
1768.71 \\
1858.81 \\
1930.83 \\
2029.29 \\
2158.48 \\
2250.06 \\
2359.52 \\
2507.01 \\
2679.09 \\
2836.29\end{array}$ & $\begin{array}{r}31.54 \\
85.58 \\
147.73 \\
196.71 \\
247.06 \\
300.41 \\
354.40 \\
408.73 \\
466.11 \\
522.91 \\
583.67 \\
643.68 \\
703.50 \\
764.10 \\
828.29 \\
892.55 \\
954.92 \\
1019.63 \\
1084.20 \\
1163.62 \\
1242.89 \\
1320.71 \\
1400.64 \\
1483.36 \\
1564.95 \\
1644.39 \\
1728.59 \\
1811.85 \\
1896.61 \\
1990.02 \\
2089.85 \\
2209.85 \\
2355.81 \\
2507.82 \\
2676.32 \\
2871.36 \\
3122.19 \\
3370.34\end{array}$ & $\begin{array}{l}0.0360 \\
0.0395 \\
0.1393 \\
0.0948 \\
0.0716 \\
0.1441 \\
0.2977 \\
0.2735 \\
0.4060 \\
0.3151 \\
0.4215 \\
0.5636 \\
0.6157 \\
0.5843 \\
0.6491 \\
0.7841 \\
0.9115 \\
0.9516 \\
0.9063 \\
1.0066 \\
1.2003 \\
1.2611 \\
1.2148 \\
1.4237 \\
1.6466 \\
1.6556 \\
1.6214 \\
1.7378 \\
1.9801 \\
2.0081 \\
2.2327 \\
2.3971 \\
2.5167 \\
2.9231 \\
3.2953 \\
3.5739 \\
3.9976 \\
4.4500\end{array}$ & $\begin{array}{l}24.008 \\
29.018 \\
31.437 \\
32.689 \\
33.898 \\
34.702 \\
35.560 \\
36.288 \\
37.098 \\
37.520 \\
38.246 \\
38.694 \\
39.253 \\
39.939 \\
40.406 \\
40.686 \\
40.810 \\
41.553 \\
41.736 \\
41.901 \\
42.343 \\
42.605 \\
42.936 \\
43.004 \\
43.254 \\
43.317 \\
43.421 \\
43.536 \\
43.722 \\
43.621 \\
43.538 \\
43.506 \\
43.023 \\
42.706 \\
41.805 \\
41.459 \\
41.112 \\
40.193\end{array}$ & $\begin{array}{r}0.405 \\
0.806 \\
1.208 \\
1.513 \\
1.809 \\
2.111 \\
2.409 \\
2.710 \\
3.008 \\
3.312 \\
3.614 \\
3.914 \\
4.213 \\
4.510 \\
4.814 \\
5.115 \\
5.407 \\
5.709 \\
6.007 \\
6.358 \\
6.709 \\
7.059 \\
7.413 \\
7.760 \\
8.111 \\
8.461 \\
8.819 \\
9.161 \\
9.511 \\
9.911 \\
10.312 \\
10.810 \\
11.410 \\
12.017 \\
12.710 \\
13.511 \\
14.514 \\
15.511\end{array}$ \\
\hline
\end{tabular}


Table A-24. Deformation $J_{I C}$ and $J-R$ curve results for specimen P1B-17

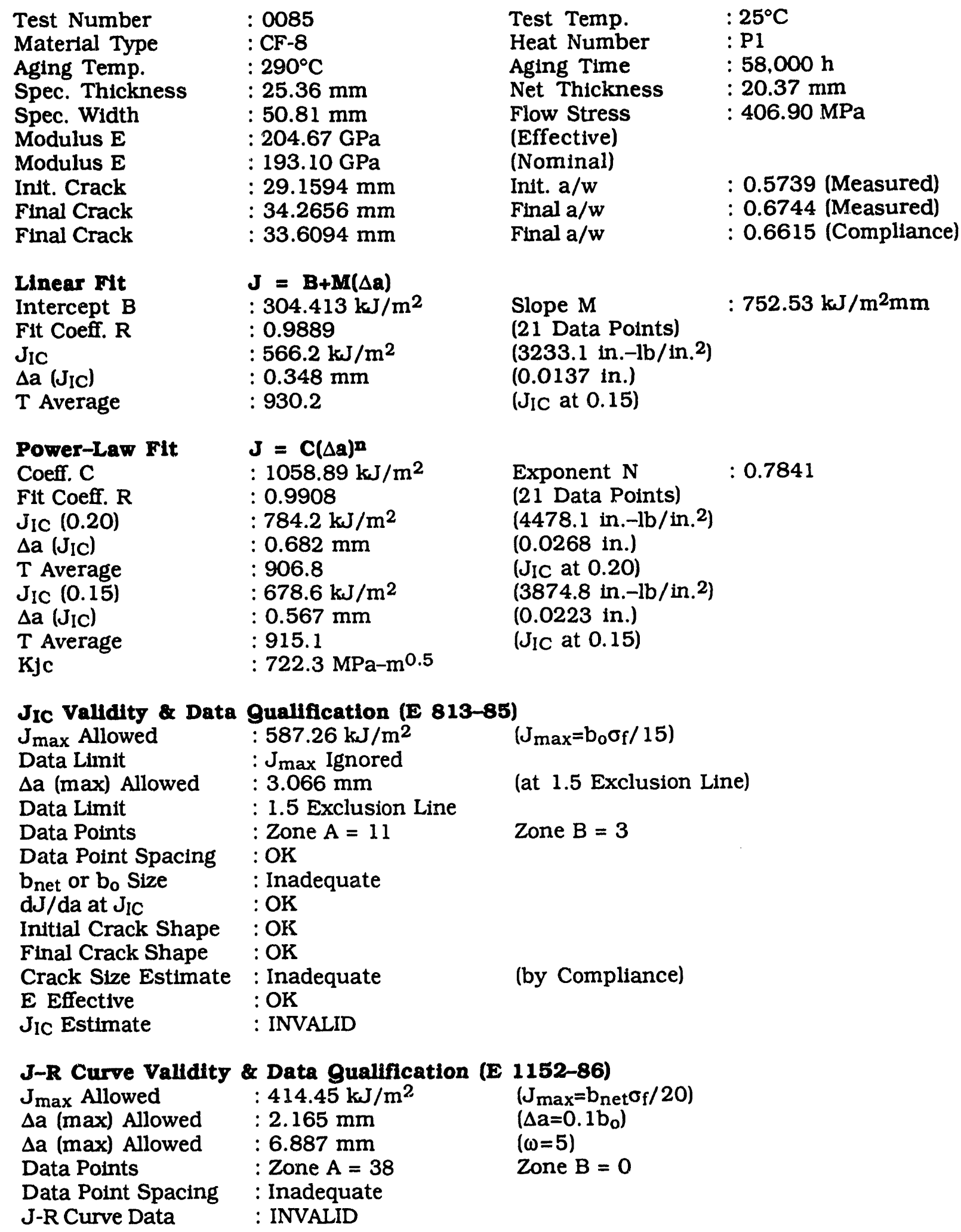


Table A-25. Modified $J_{I C}$ and $J-R$ curve results for specimen P1B-17

\begin{tabular}{|c|c|c|c|}
\hline Test Number & : 0085 & Test Temp. & $: 25^{\circ} \mathrm{C}$ \\
\hline Material Type & : CF-8 & Heat Number & $: \mathrm{P} 1$ \\
\hline Aging Temp. & : $290^{\circ} \mathrm{C}$ & Aging Time & $: 58,000 \mathrm{~h}$ \\
\hline Spec. Thickness & : $25.36 \mathrm{~mm}$ & Net Thickness & $: 20.37 \mathrm{~mm}$ \\
\hline Spec. Width & : $50.81 \mathrm{~mm}$ & Flow Stress & : $406.90 \mathrm{MPa}$ \\
\hline Modulus E & : $204.67 \mathrm{GPa}$ & (Effective) & \\
\hline Modulus E & : $193.10 \mathrm{GPa}$ & (Nominal) & \\
\hline Init. Crack & : $29.1594 \mathrm{~mm}$ & Init. $a / w$ & : 0.5739 (Measured) \\
\hline Final Crack & $: 34.2656 \mathrm{~mm}$ & Final a/w & : 0.6744 (Measured) \\
\hline Final Crack & : $33.6094 \mathrm{~mm}$ & Final a/w & : 0.6615 (Compliance) \\
\hline $\begin{array}{l}\text { Linear Fit } \\
\text { Intercept } B \\
\text { Fit Coeff. } R \\
J_{I C} \\
\Delta a\left(J_{1 C}\right) \\
T \text { Average }\end{array}$ & $\begin{array}{l}J=B+M(\Delta \mathbf{a}) \\
: 288.610 \mathrm{~kJ} / \mathrm{m}^{2} \\
: 0.9903 \\
: 576.5 \mathrm{~kJ} / \mathrm{m}^{2} \\
: 0.354 \mathrm{~mm} \\
: 1004.7\end{array}$ & $\begin{array}{l}\text { Slope } M \\
\text { (21 Data Points) } \\
\left(3291.7 \text { in. }-1 \mathrm{~b} / \mathrm{in}^{2}\right) \\
(0.0139 \mathrm{in} .) \\
\left(\mathrm{J}_{\text {IC }} \text { at } 0.15\right)\end{array}$ & $: 812.73 \mathrm{~kJ} / \mathrm{m}^{2} \mathrm{~mm}$ \\
\hline $\begin{array}{l}\text { Power-Law Fit } \\
\text { Coeff. C } \\
\text { Fit Coeff. R } \\
\mathrm{J}_{I C}(0.20) \\
\Delta \mathrm{a}\left(\mathrm{J}_{\mathrm{IC}}\right) \\
\text { T Average } \\
\mathrm{J}_{I \mathrm{C}}(0.15) \\
\Delta \mathrm{a}\left(\mathrm{J}_{I C}\right) \\
\text { T Average } \\
\text { Kjc }\end{array}$ & $\begin{array}{l}J=C(\Delta \mathbf{a})^{\mathbf{n}} \\
: 1091.18 \mathrm{~kJ} / \mathrm{m}^{2} \\
: 0.9935 \\
: 807.8 \mathrm{~kJ} / \mathrm{m}^{2} \\
: 0.696 \mathrm{~mm} \\
: 1005.5 \\
: 684.8 \mathrm{~kJ} / \mathrm{m}^{2} \\
: 0.571 \mathrm{~mm} \\
: 1012.9 \\
: 777.3 \mathrm{MPa}-\mathrm{m}^{0.5}\end{array}$ & $\begin{array}{l}\text { Exponent } N \\
(21 \text { Data Points) } \\
\left(4612.8 \text { in. }-1 \mathrm{~b} / \text { in. }^{2}\right) \\
(0.0274 \text { in. }) \\
\left(\mathrm{J}_{\text {IC }} \text { at } 0.20\right) \\
\left(3910.3 \text { in. }-1 \mathrm{~b} / \text { in. }^{2}\right) \\
(0.0225 \text { in. }) \\
\left(J_{\text {IC }} \text { at } 0.15\right)\end{array}$ & $: 0.8307$ \\
\hline
\end{tabular}

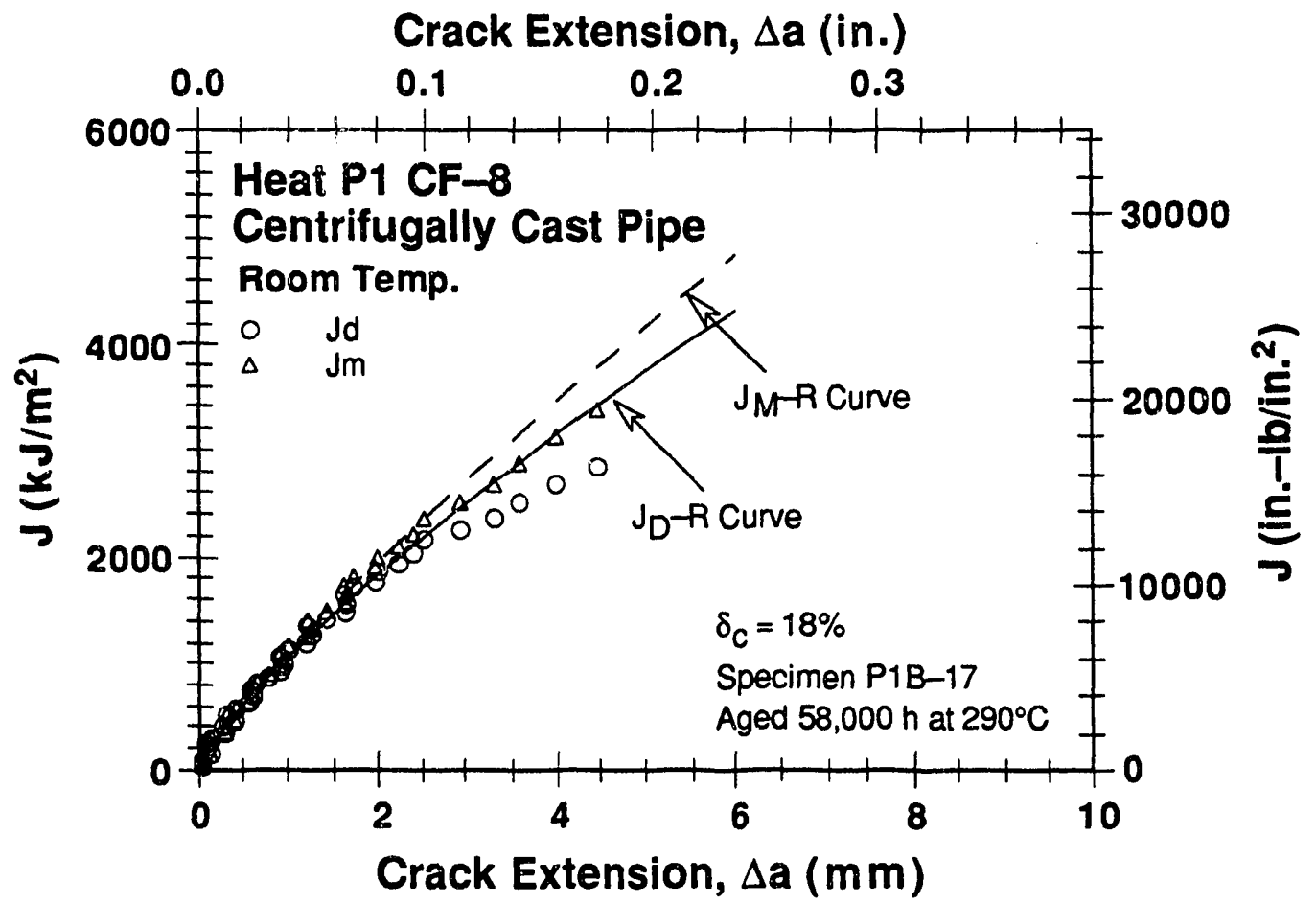

Figure A-23. Deformation and modified $J-R$ curves at room temp. for Heat $P 1$ aged $58,000 \mathrm{~h}$ at $290^{\circ} \mathrm{C}$ 


\section{Crack Extension, $\Delta \mathrm{a}$ (in.)}

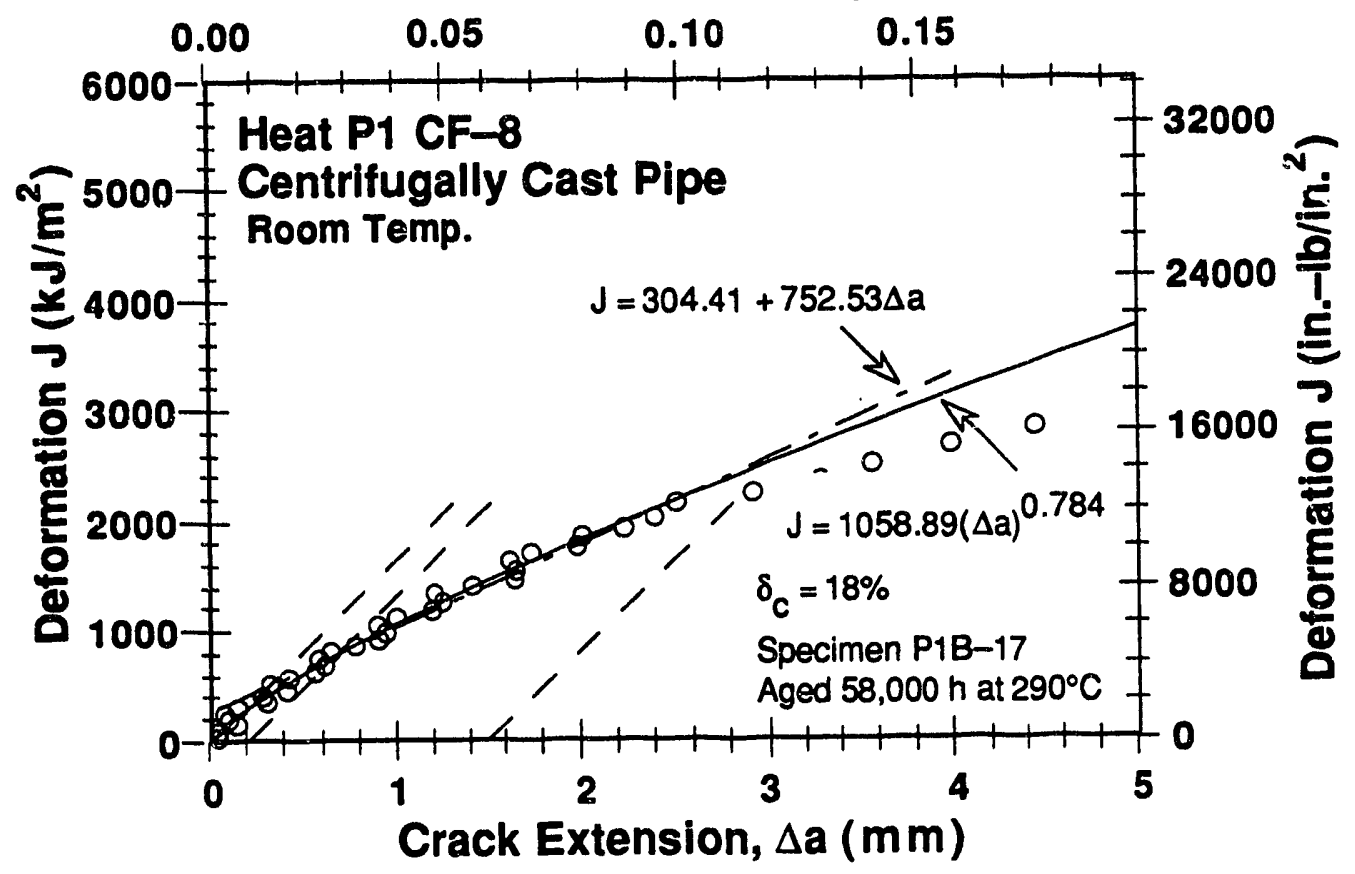

Figure A-24. Deformation $J_{I C}$ at room temp. for Heat $P 1$ aged 58,000 hat $290^{\circ} \mathrm{C}$

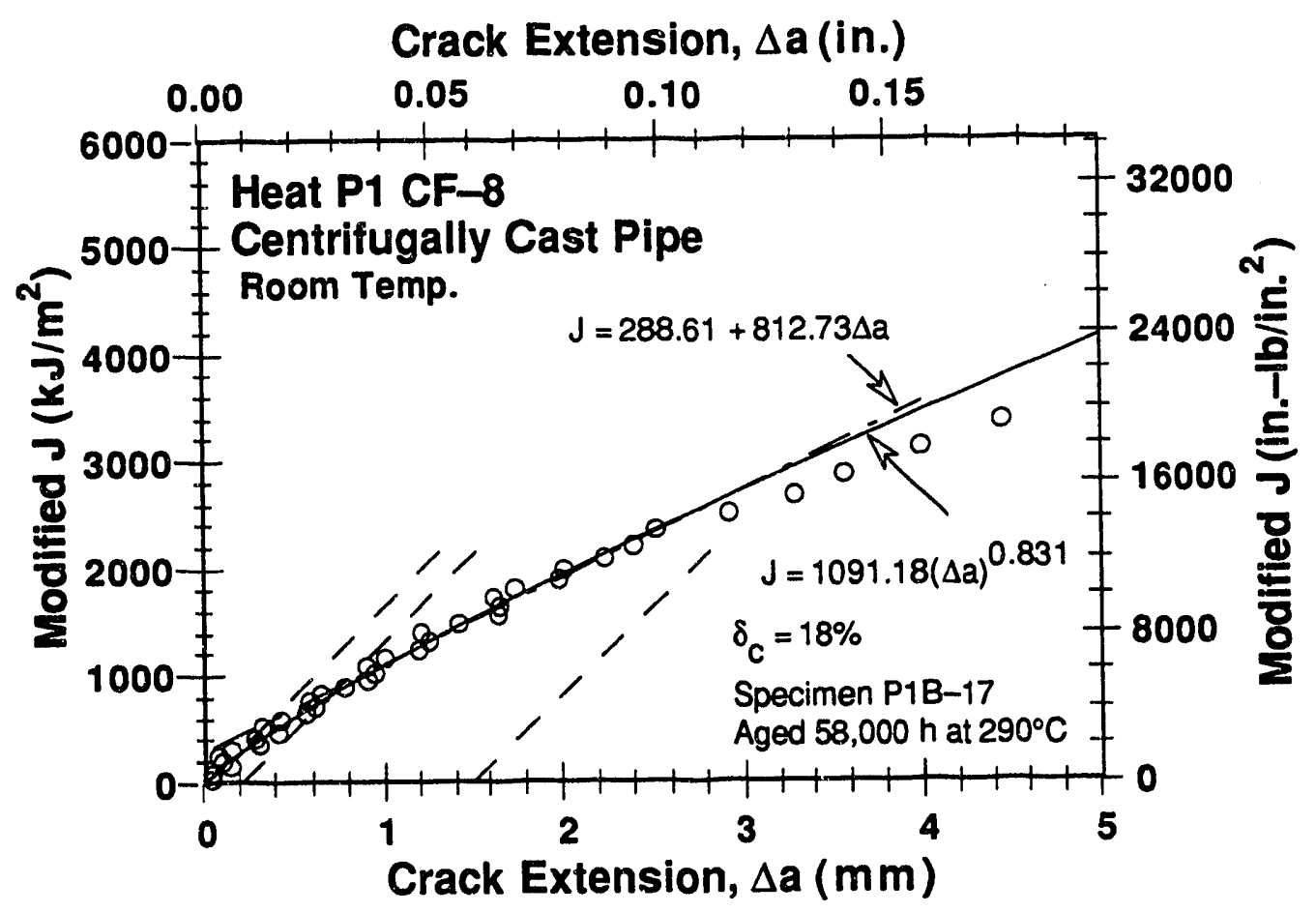

Figure A-25. Modified $J_{I C}$ at room temp. for Heat $P 1$ aged $58,000 \mathrm{~h}$ at $290^{\circ} \mathrm{C}$ 
Table A-26. Test data for specimen P1B-14

$\begin{array}{llll}\text { Test Number } & : 0084 & \text { Test Temp. } & : 25^{\circ} \mathrm{C} \\ \text { Material Type } & : \text { CF-8 } & \text { Heat Number } & : \text { P1 } \\ \text { Aging Temp. } & : 320^{\circ} \mathrm{C} & \text { Aging Time } & : 55,000 \mathrm{~h} \\ \text { Spec. Thickness } & : 25.38 \mathrm{~mm} & \text { Net Thickness } & : 20.37 \mathrm{~mm} \\ \text { Spec. Width } & : 50.84 \mathrm{~mm} & \text { Flow Stress } & : 480.43 \mathrm{MPa}\end{array}$

\begin{tabular}{|c|c|c|c|c|c|}
\hline $\begin{array}{c}\text { Unload } \\
\text { Number }\end{array}$ & $\begin{array}{c}\mathrm{J}_{\mathrm{d}} \\
\left(\mathrm{kJ} / \mathrm{m}^{2}\right)\end{array}$ & $\begin{array}{c}\mathrm{J}_{\mathrm{m}} \\
\left(\mathrm{kJ} / \mathrm{m}^{2}\right)\end{array}$ & $\begin{array}{c}\Delta \mathrm{a} \\
(\mathrm{mm})\end{array}$ & $\begin{array}{r}\text { Load } \\
(\mathrm{kN}) \\
\end{array}$ & $\begin{array}{c}\begin{array}{c}\text { Deflection } \\
(\mathrm{mm})\end{array} \\
\end{array}$ \\
\hline $\begin{array}{l}1 \\
2 \\
3 \\
4 \\
5 \\
6 \\
7 \\
8 \\
9 \\
10 \\
11 \\
12 \\
13 \\
14 \\
15 \\
16 \\
17 \\
18 \\
19 \\
20 \\
21 \\
22 \\
23 \\
24 \\
25 \\
26 \\
27 \\
28 \\
29 \\
30 \\
31 \\
32 \\
33 \\
34 \\
35 \\
36 \\
37 \\
38 \\
39 \\
40 \\
41 \\
42 \\
43 \\
44 \\
45 \\
46 \\
47 \\
48 \\
49 \\
50 \\
51 \\
52\end{array}$ & $\begin{array}{r}10.37 \\
33.14 \\
61.66 \\
92.24 \\
125.45 \\
159.27 \\
194.43 \\
231.14 \\
267.45 \\
305.38 \\
344.38 \\
381.91 \\
421.86 \\
462.07 \\
502.17 \\
540.98 \\
578.78 \\
618.70 \\
662.22 \\
702.12 \\
742.36 \\
787.91 \\
831.05 \\
864.52 \\
903.72 \\
951.77 \\
995.42 \\
1033.67 \\
1074.27 \\
1118.23 \\
1156.26 \\
1191.66 \\
1220.48 \\
1257.66 \\
1294.59 \\
1337.83 \\
1379.53 \\
1418.61 \\
1464.78 \\
1498.98 \\
1549.38 \\
1611.08 \\
1661.60 \\
1693.40 \\
1741.87 \\
1800.77 \\
1903.96 \\
2020.11 \\
2117.35 \\
2184.77 \\
2235.82 \\
2285.95\end{array}$ & $\begin{array}{r}10.38 \\
33.09 \\
61.76 \\
92.05 \\
125.81 \\
159.85 \\
194.88 \\
230.90 \\
269.63 \\
305.71 \\
345.55 \\
385.15 \\
423.70 \\
465.24 \\
505.38 \\
548.23 \\
589.70 \\
631.68 \\
673.93 \\
717.79 \\
760.88 \\
803.97 \\
850.65 \\
895.60 \\
937.14 \\
983.91 \\
1028.77 \\
1074.93 \\
1118.97 \\
1166.22 \\
1214.09 \\
1257.83 \\
1302.69 \\
1346.48 \\
1393.05 \\
1449.30 \\
1506.80 \\
1564.53 \\
1620.26 \\
1690.52 \\
1757.10 \\
1848.04 \\
1938.55 \\
2027.72 \\
2140.52 \\
2261.83 \\
2410.76 \\
2583.79 \\
2756.90 \\
2925.03 \\
3085.45 \\
3237.50\end{array}$ & $\begin{array}{r}0.0479 \\
-0.0146 \\
0.0498 \\
-0.0217 \\
0.0742 \\
0.1021 \\
0.0892 \\
0.0293 \\
0.2058 \\
0.0894 \\
0.1355 \\
0.2369 \\
0.1755 \\
0.2286 \\
0.2299 \\
0.3660 \\
0.4806 \\
0.5405 \\
0.5064 \\
0.6068 \\
0.6750 \\
0.6197 \\
0.6946 \\
0.9272 \\
0.9722 \\
0.9486 \\
0.9698 \\
1.1017 \\
1.1569 \\
1.2072 \\
1.3518 \\
1.4702 \\
1.6906 \\
1.7784 \\
1.9022 \\
2.0626 \\
2.2503 \\
2.4637 \\
2.5691 \\
2.9520 \\
3.1168 \\
3.4001 \\
3.7694 \\
4.2784 \\
4.8199 \\
5.3165 \\
5.6552 \\
6.0447 \\
6.5280 \\
7.1303 \\
7.7481 \\
8.2939\end{array}$ & $\begin{array}{l}19.497 \\
27.195 \\
30.745 \\
32.942 \\
34.456 \\
35.771 \\
36.951 \\
37.706 \\
38.788 \\
39.324 \\
39.997 \\
40.575 \\
40.985 \\
41.258 \\
41.773 \\
42.239 \\
42.689 \\
43.181 \\
43.517 \\
43.824 \\
43.911 \\
44.102 \\
44.392 \\
44.592 \\
44.744 \\
44.982 \\
44.848 \\
44.935 \\
44.882 \\
44.958 \\
44.637 \\
44.145 \\
43.995 \\
43.791 \\
43.687 \\
43.573 \\
43.369 \\
42.961 \\
42.217 \\
41.801 \\
41.163 \\
40.923 \\
39.414 \\
38.134 \\
36.496 \\
35.167 \\
34.692 \\
34.255 \\
32.634 \\
30.834 \\
28.657 \\
27.015\end{array}$ & $\begin{array}{r}0.203 \\
0.405 \\
0.607 \\
0.807 \\
1.009 \\
1.210 \\
1.409 \\
1.609 \\
1.809 \\
2.010 \\
2.210 \\
2.410 \\
2.610 \\
2.811 \\
3.009 \\
3.212 \\
3.412 \\
3.613 \\
3.814 \\
4.011 \\
4.211 \\
4.412 \\
4.618 \\
4.815 \\
5.010 \\
5.220 \\
5.415 \\
5.614 \\
5.811 \\
6.018 \\
6.224 \\
6.418 \\
6.613 \\
6.813 \\
7.016 \\
7.261 \\
7.512 \\
7.763 \\
8.013 \\
8.311 \\
8.618 \\
9.012 \\
9.411 \\
9.813 \\
10.336 \\
10.910 \\
11.613 \\
12.410 \\
13.211 \\
14.013 \\
14.817 \\
15.613\end{array}$ \\
\hline
\end{tabular}


Table A-27. Deformation $J_{I C}$ and $J-R$ curve results for specimen P1B-14

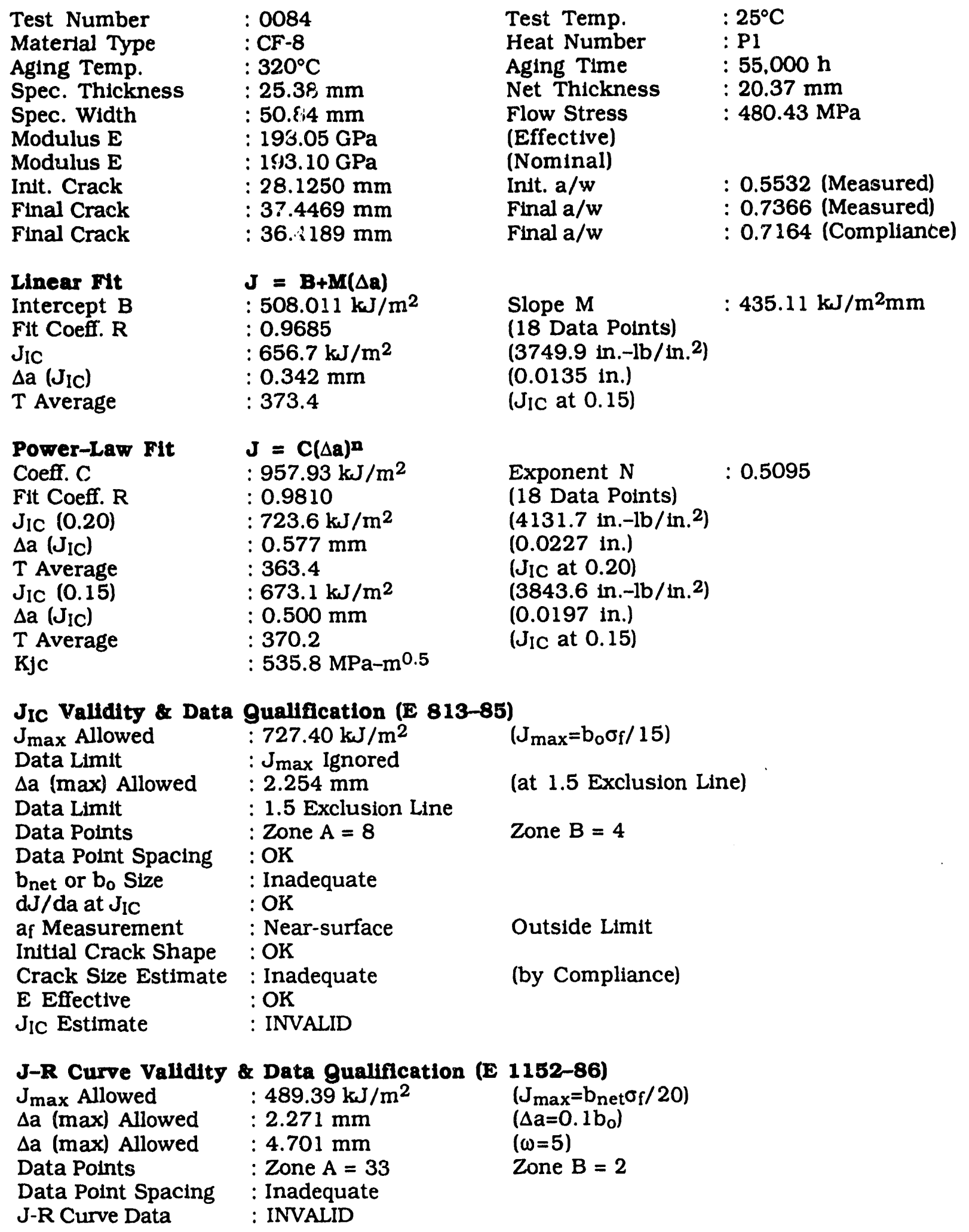


Table A-28. Modifled $J_{I C}$ and $J-R$ curve results for spectmen P1B-14

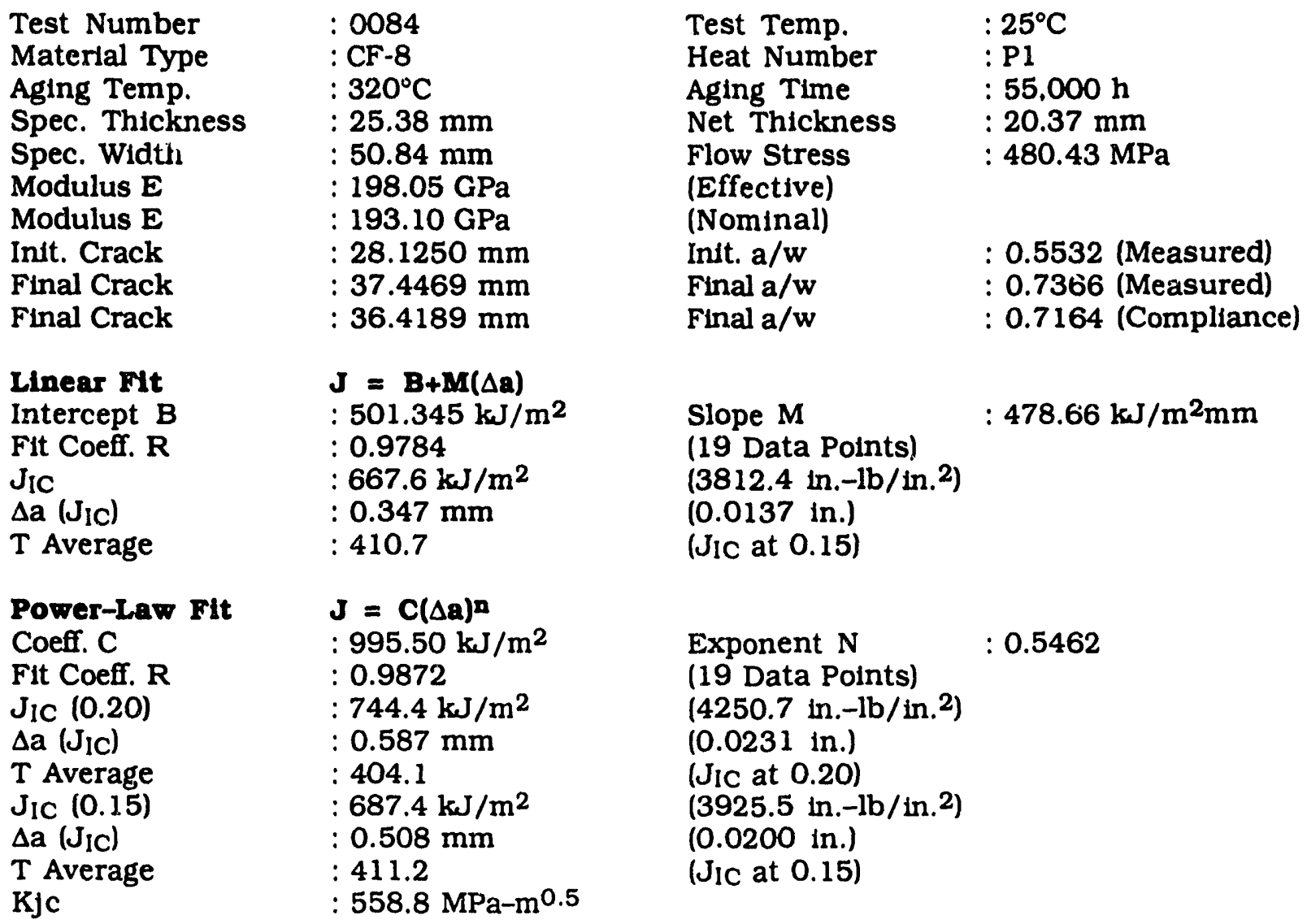

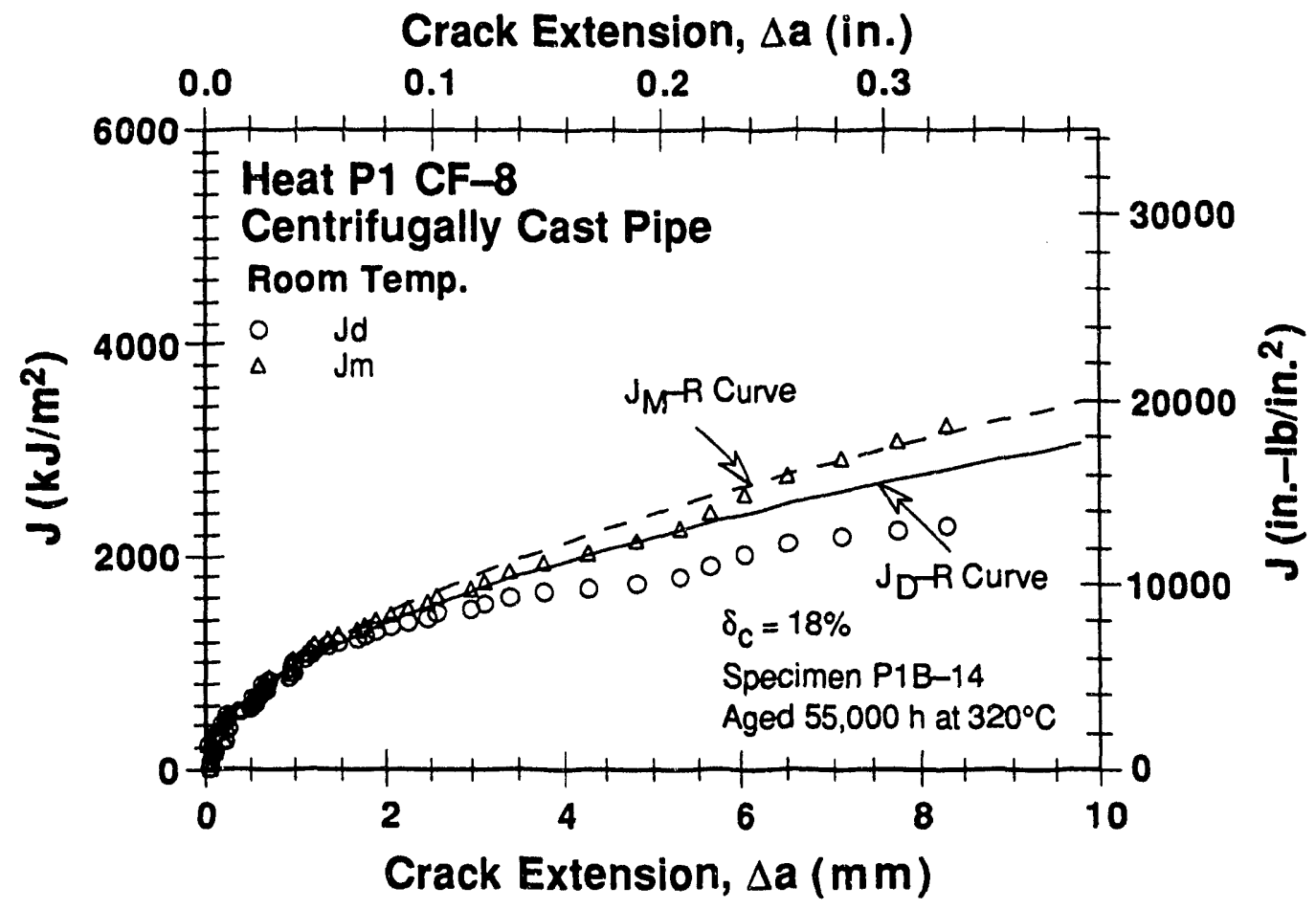

Figure A-26. Deformation and modified $J-R$ curves at room temp. for Heat $P 1$ aged $55,000 \mathrm{~h}$ at $320^{\circ} \mathrm{C}$ 
Crack Extension, $\Delta \mathrm{a}(\mathrm{In}$.

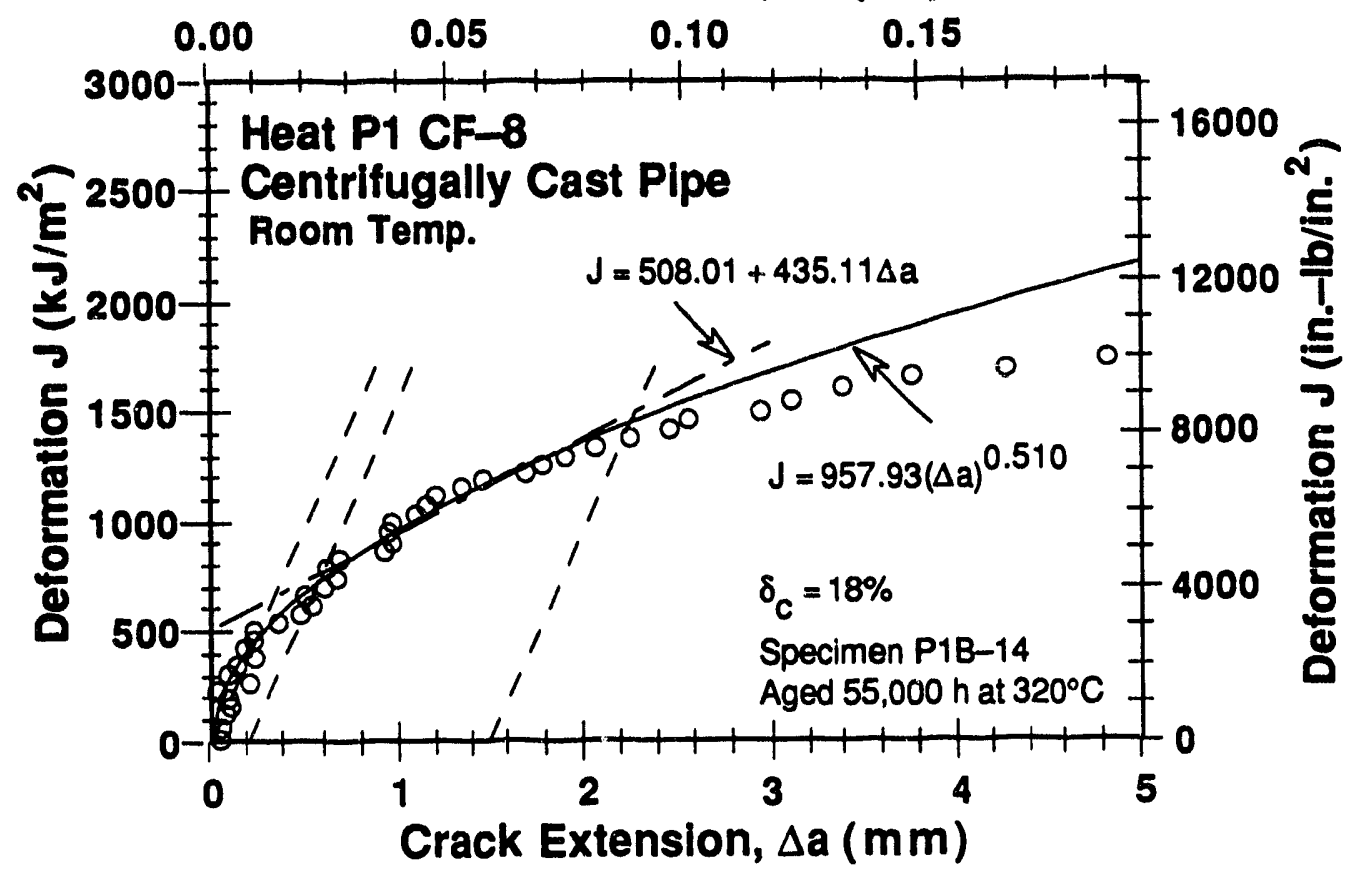

Figure A-27. Deformation JIC at room temp. for Heat P1 aged 55,000 hat $320^{\circ} \mathrm{C}$

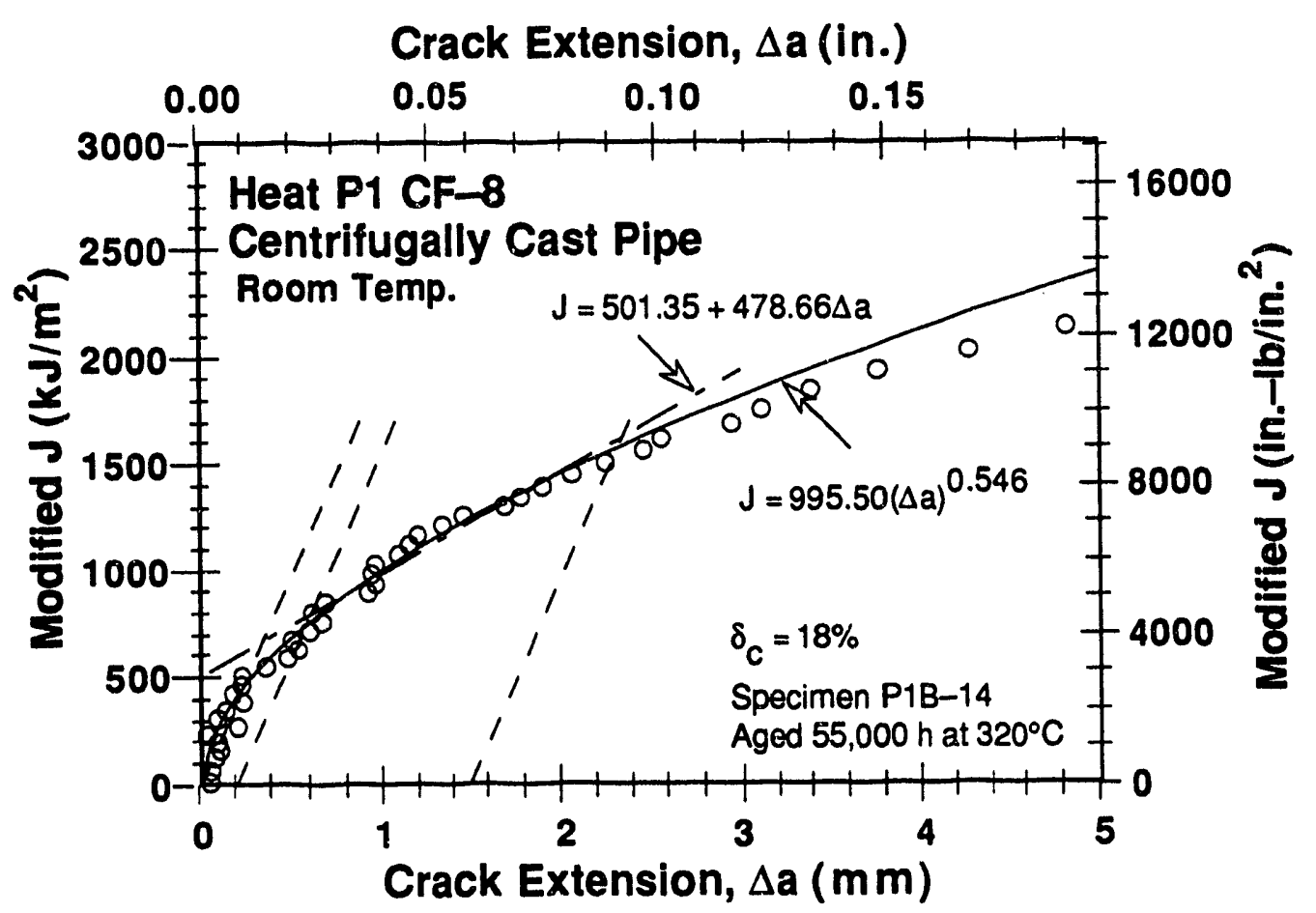

Figure A-28. Modified $J_{I C}$ at room temp. for Heat $P 1$ aged $55,000 \mathrm{~h}$ at $320^{\circ} \mathrm{C}$ 
Table A-29. Test data for spectmen P1T-18

$\begin{array}{ll}\text { Test Number } & : 0100 \\ \text { Material Type } & : \text { CF-8 } \\ \text { Aging Temp. } & : 290^{\circ} \mathrm{C} \\ \text { Spec. Thickness } & : 25.35 \mathrm{~mm} \\ \text { Spec. Width } & : 50.82 \mathrm{~mm}\end{array}$

Test Temp. $: 290^{\circ} \mathrm{C}$

Heat Number : $\mathrm{P} 1$

Aging Time : $58,000 \mathrm{~h}$

Net Thickness : $20.28 \mathrm{~mm}$

Flow Stress $\quad: 295.08 \mathrm{MPa}$

\begin{tabular}{|c|c|c|c|c|c|}
\hline $\begin{array}{c}\text { Unload } \\
\text { Number }\end{array}$ & $\begin{array}{c}J_{d} \\
\left(\mathrm{~kJ} / \mathrm{m}^{2}\right)\end{array}$ & $\begin{array}{c}J_{m} \\
\left(\mathrm{~kJ} / \mathrm{m}^{2}\right)\end{array}$ & $\begin{array}{c}\Delta \mathrm{a} \\
(\mathrm{mm})\end{array}$ & $\begin{array}{l}\text { Load } \\
\text { (kN) }\end{array}$ & $\begin{array}{l}\text { Deflectlon } \\
\text { (mm) }\end{array}$ \\
\hline $\begin{array}{l}1 \\
2 \\
3 \\
4 \\
5 \\
6 \\
7 \\
8 \\
9 \\
10 \\
11 \\
12 \\
13 \\
14 \\
15 \\
16 \\
17 \\
18 \\
19 \\
20 \\
21 \\
22 \\
23 \\
24 \\
25 \\
26 \\
27 \\
28 \\
29 \\
30 \\
31 \\
32 \\
33 \\
34 \\
35 \\
36 \\
37 \\
38 \\
39 \\
40 \\
41 \\
42 \\
43 \\
44 \\
45 \\
46 \\
47 \\
48\end{array}$ & $\begin{array}{r}14.82 \\
40.01 \\
68.61 \\
99.56 \\
132.41 \\
165.94 \\
200.19 \\
238.80 \\
265.24 \\
295.54 \\
323.42 \\
360.61 \\
390.08 \\
426.25 \\
464.73 \\
487.52 \\
519.30 \\
550.17 \\
593.92 \\
625.47 \\
661.50 \\
701.57 \\
731.62 \\
763.47 \\
788.55 \\
825.81 \\
863.57 \\
889.15 \\
920.10 \\
952.36 \\
981.32 \\
1015.58 \\
1050.61 \\
1092.94 \\
1128.47 \\
1181.54 \\
1208.65 \\
1261.08 \\
1305.15 \\
1362.54 \\
1425.72 \\
1458.89 \\
1500.78 \\
1539.65 \\
1575.42 \\
1618.50 \\
1661.00 \\
1703.15\end{array}$ & $\begin{array}{r}14.88 \\
40.58 \\
68.08 \\
100.04 \\
131.49 \\
166.12 \\
200.89 \\
235.53 \\
268.66 \\
298.34 \\
331.87 \\
362.53 \\
398.51 \\
430.64 \\
465.55 \\
502.69 \\
536.48 \\
573.49 \\
607.34 \\
647.13 \\
683.42 \\
720.13 \\
760.13 \\
797.72 \\
837.11 \\
874.45 \\
913.98 \\
954.42 \\
992.95 \\
1032.83 \\
1073.00 \\
1112.70 \\
1161.32 \\
1208.55 \\
1257.17 \\
1312.67 \\
1371.11 \\
1434.14 \\
1500.52 \\
1582.49 \\
1664.13 \\
1746.95 \\
1826.41 \\
1905.58 \\
1984.82 \\
2063.06 \\
2142.26 \\
2219.81\end{array}$ & $\begin{array}{r}0.1173 \\
0.3916 \\
0.0779 \\
0.2681 \\
0.0724 \\
0.1929 \\
0.2388 \\
-0.0581 \\
0.3869 \\
0.3496 \\
0.6538 \\
0.3379 \\
0.6257 \\
0.4620 \\
0.3291 \\
0.8304 \\
0.8962 \\
1.0843 \\
0.8021 \\
1.0232 \\
1.0299 \\
0.9497 \\
1.1760 \\
1.3004 \\
1.5977 \\
1.5993 \\
1.6328 \\
1.9027 \\
2.0351 \\
2.1630 \\
2.3444 \\
2.4287 \\
2.6314 \\
2.7014 \\
2.8810 \\
2.9127 \\
3.3070 \\
3.4340 \\
3.6897 \\
3.9564 \\
4.1459 \\
4.6336 \\
4.9866 \\
5.3493 \\
5.7246 \\
6.0160 \\
6.3080 \\
6.5786\end{array}$ & $\begin{array}{l}15.075 \\
18.246 \\
19.871 \\
21.060 \\
21.969 \\
22.746 \\
23.570 \\
24.245 \\
24.849 \\
25.250 \\
25.810 \\
26.134 \\
26.534 \\
27.046 \\
27.245 \\
27.667 \\
27.983 \\
28.308 \\
28.464 \\
28.822 \\
29.024 \\
29.004 \\
29.289 \\
29.419 \\
29.329 \\
29.448 \\
29.609 \\
29.486 \\
29.458 \\
29.440 \\
29.200 \\
29.087 \\
29.004 \\
28.781 \\
28.737 \\
28.657 \\
28.349 \\
28.284 \\
28.150 \\
28.024 \\
27.525 \\
26.740 \\
26.073 \\
25.291 \\
24.642 \\
24.302 \\
23.897 \\
23.076\end{array}$ & $\begin{array}{l}0.305 \\
0.606 \\
0.907 \\
1.207 \\
1.509 \\
1.809 \\
2.109 \\
2.408 \\
2.659 \\
2.908 \\
3.158 \\
3.409 \\
3.659 \\
3.909 \\
4.161 \\
4.410 \\
4.661 \\
4.912 \\
5.159 \\
5.410 \\
5.661 \\
5.907 \\
6.160 \\
6.410 \\
6.660 \\
6.911 \\
7.161 \\
7.410 \\
7.660 \\
7.910 \\
8.160 \\
8.413 \\
8.711 \\
9.011 \\
9.308 \\
9.659 \\
10.008 \\
10.409 \\
10.810 \\
11.310 \\
11.811 \\
12.310 \\
12.811 \\
13.310 \\
13.812 \\
14.313 \\
14.815 \\
15.311\end{array}$ \\
\hline
\end{tabular}


Table A-30. Deformation $J_{I C}$ and $J-R$ curve results for spectmen P1T-18

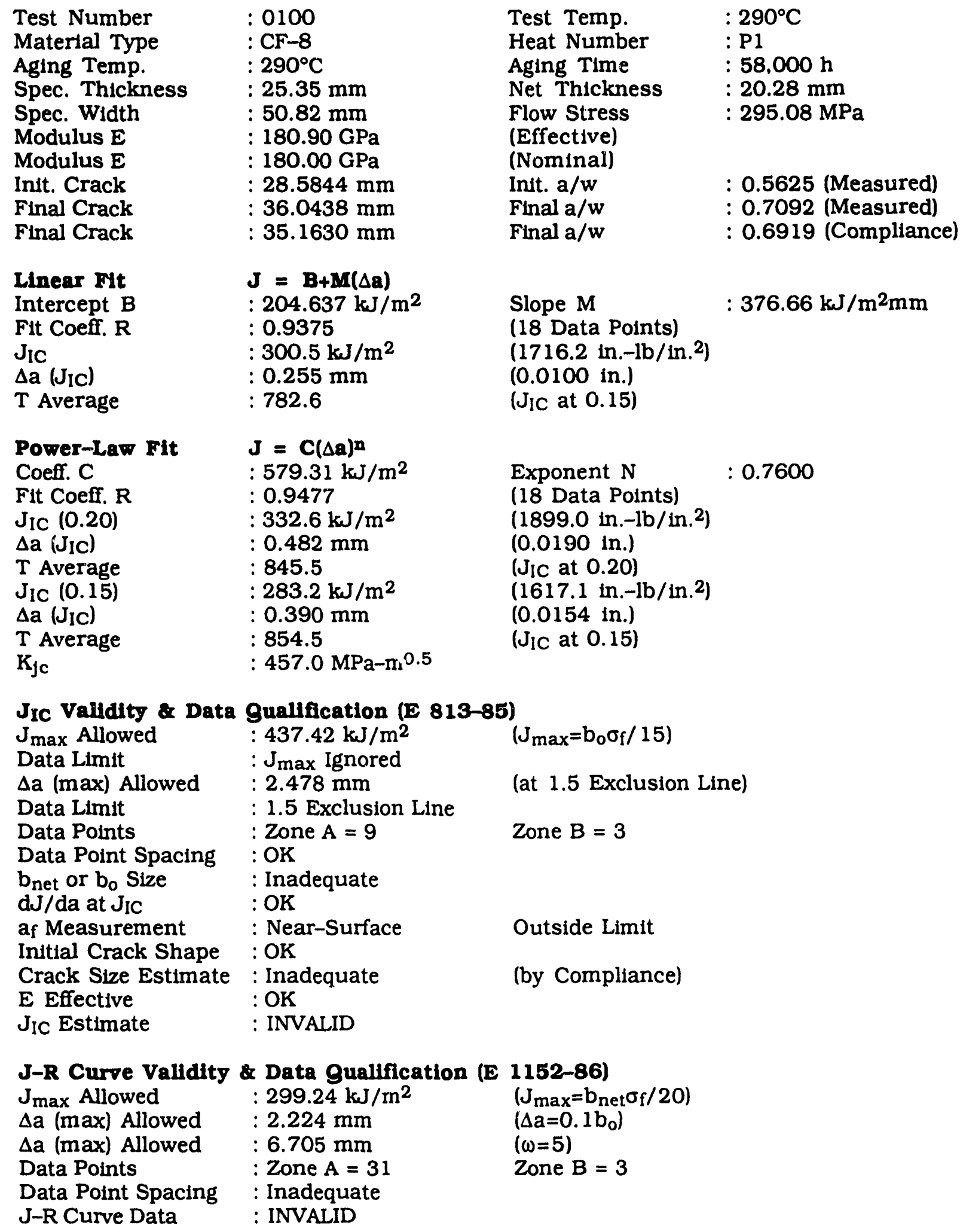


Table A-31. Modified $J_{I C}$ and J-R curve results for specimen P1T-18

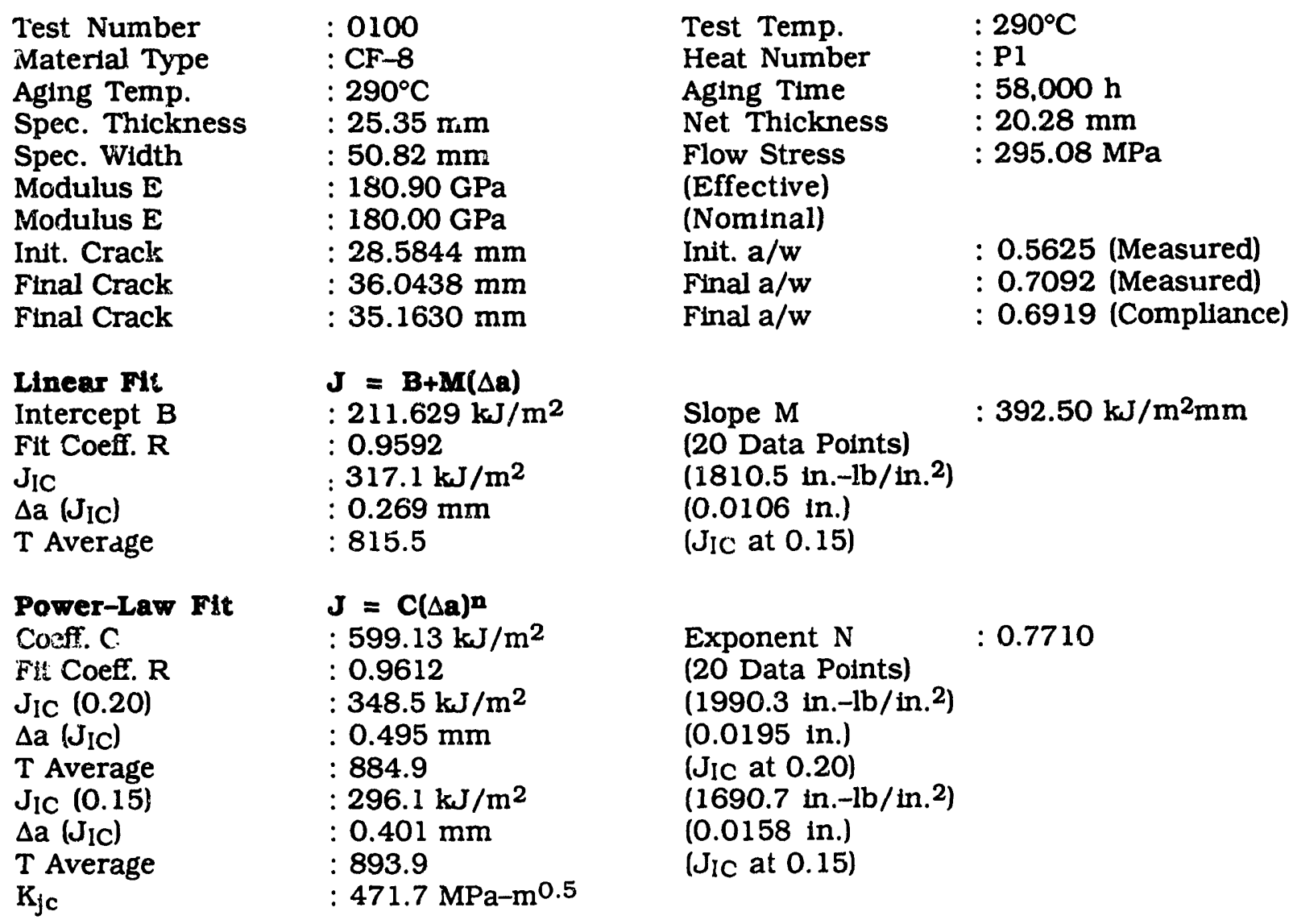

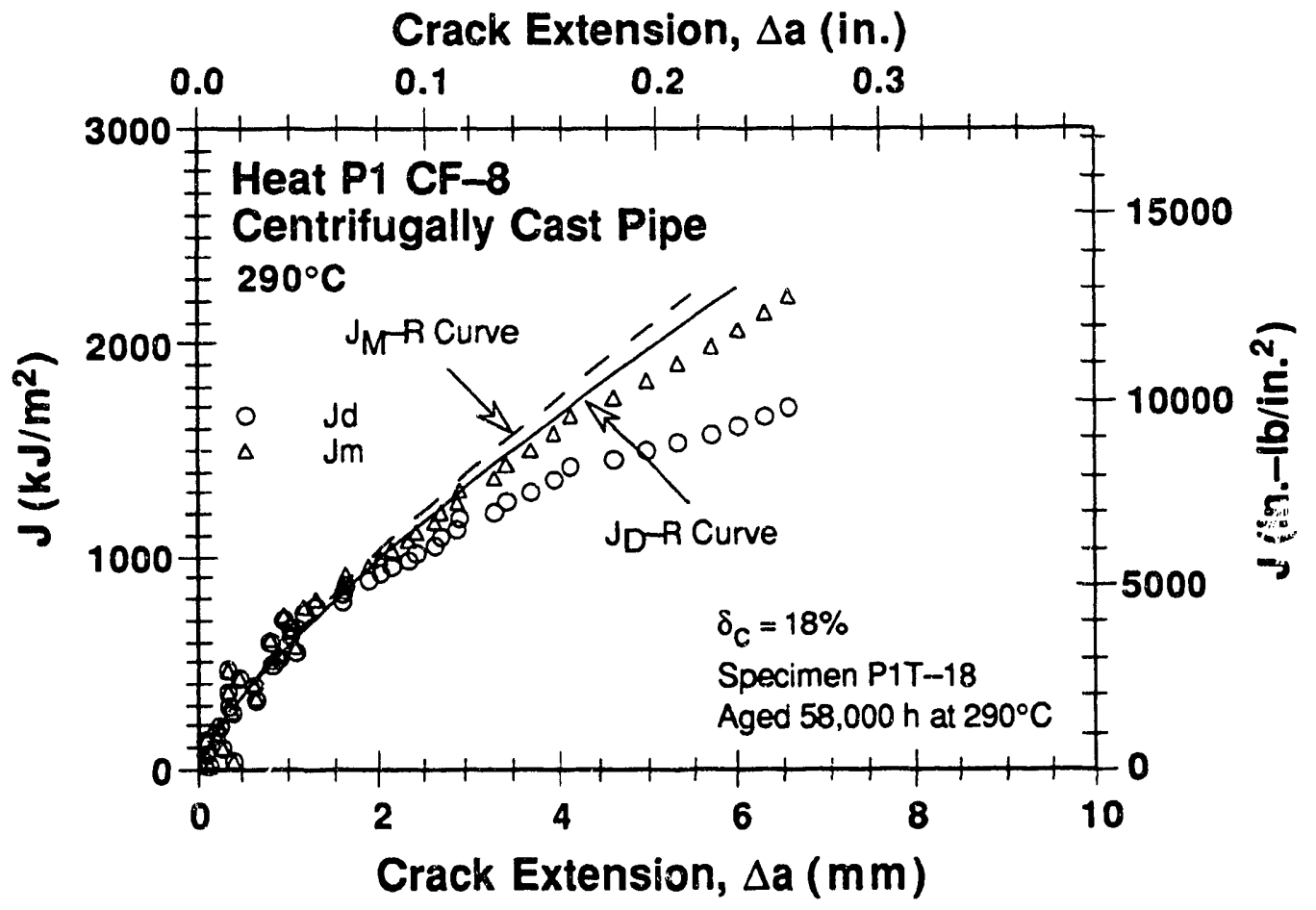

Figure A-29. Deformation and modified $J-R$ curves at $290^{\circ} \mathrm{C}$ for Heat $P 1$ aged $58,000 \mathrm{~h}$ at $290^{\circ} \mathrm{C}$ 
Crack Extension, $\Delta \mathrm{a}$ (in.)

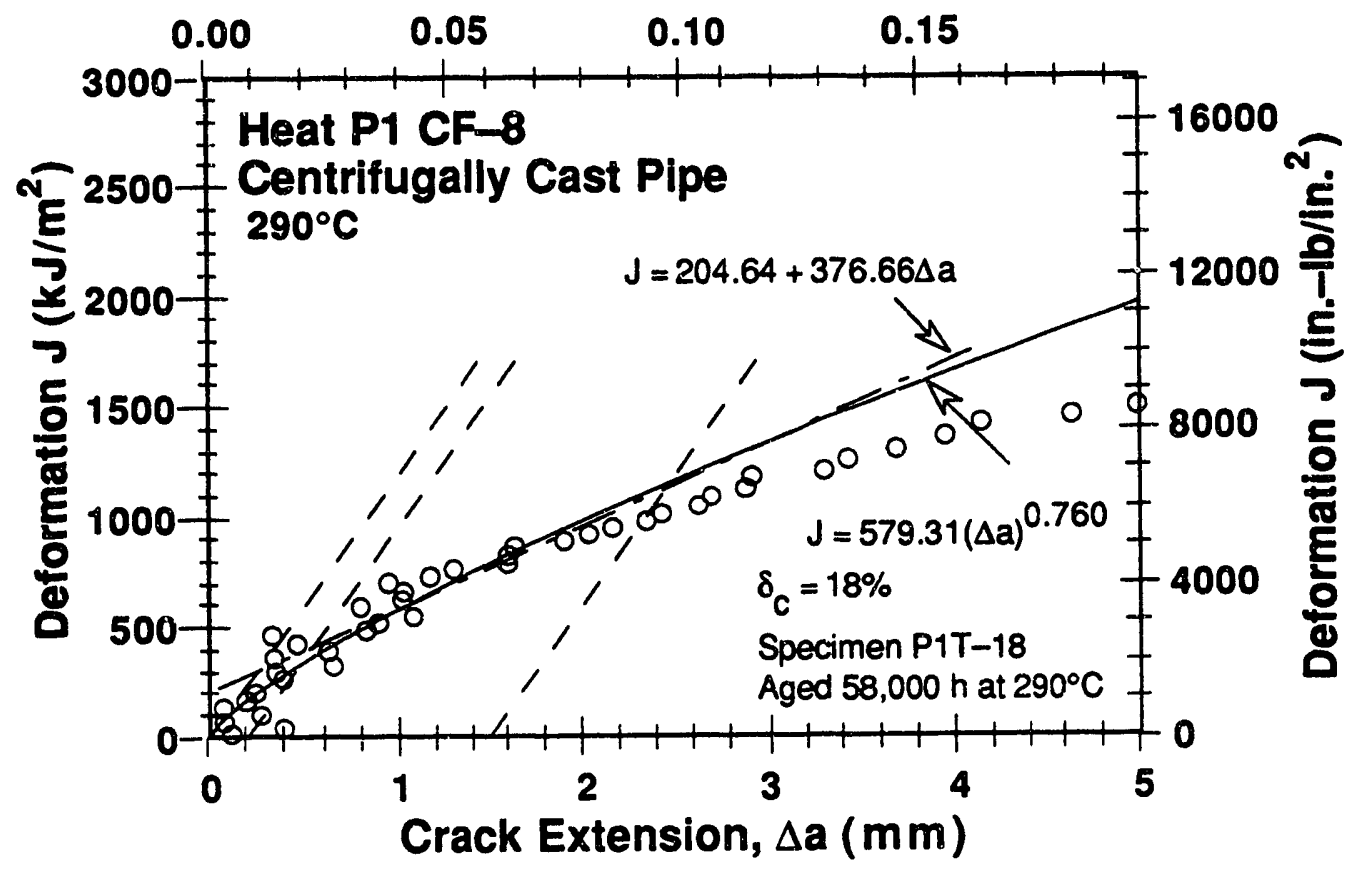

Figure A-30. Deformation $U_{I C}$ at $290^{\circ} \mathrm{C}$ for Heat $\mathrm{P} 1$ aged $58,000 \mathrm{~h}$ at $290^{\circ} \mathrm{C}$

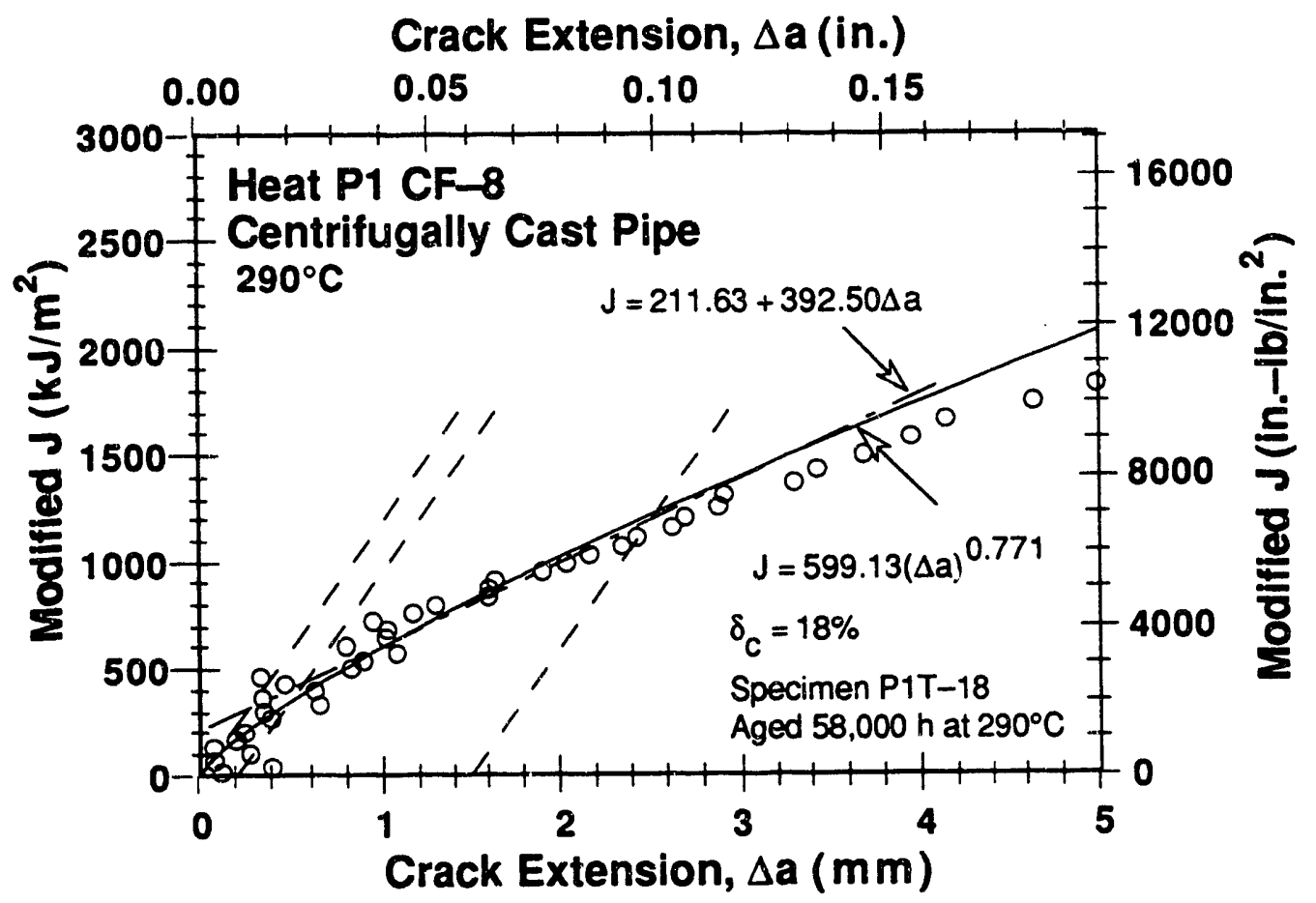

Figure A-31. Modified $J_{I C}$ at $290^{\circ} \mathrm{C}$ for Heat PI aged $58,000 \mathrm{~h}$ at $290^{\circ} \mathrm{C}$ 
Table A-32. Test data for specimen P1B-15

\begin{tabular}{|c|c|c|c|c|c|}
\hline $\begin{array}{l}\text { Test Num } \\
\text { Material } \\
\text { Aging Ter } \\
\text { Spec. Th } \\
\text { Spec. Wic }\end{array}$ & $\begin{array}{l}\text { pe } \\
\text { ness }\end{array}$ & $\mathrm{mm}$ & $\begin{array}{l}\text { Test T } \\
\text { Heat } 1 \\
\text { Aging } \\
\text { Net T] } \\
\text { Flow S }\end{array}$ & & $\begin{array}{l}\mathrm{C} \\
00 \mathrm{~h} \\
7 \mathrm{~mm} \\
35 \mathrm{MPa}\end{array}$ \\
\hline $\begin{array}{l}\text { Unload } \\
\text { Number } \\
\end{array}$ & $\begin{array}{c}\mathrm{Jd}_{\mathrm{d}} \\
\left(\mathrm{kJ} / \mathrm{m}^{2}\right) \\
\end{array}$ & $\begin{array}{c}J_{m} \\
\left(\mathrm{~N} J / \mathrm{m}^{2}\right)\end{array}$ & $\begin{array}{c}\Delta \mathrm{a} \\
(\mathrm{mm})\end{array}$ & $\begin{array}{l}\text { Load } \\
(\mathrm{kN})\end{array}$ & $\begin{array}{l}\text { Deflectiort } \\
(\mathrm{mm})\end{array}$ \\
\hline $\begin{array}{l}1 \\
2 \\
3 \\
4 \\
5 \\
6 \\
7 \\
8 \\
9 \\
10 \\
11 \\
12 \\
13 \\
14 \\
15 \\
16 \\
17 \\
18 \\
19 \\
20 \\
21 \\
22 \\
23 \\
24 \\
25 \\
26 \\
27 \\
28 \\
29 \\
30 \\
31 \\
32 \\
33 \\
34 \\
35 \\
36 \\
37 \\
38 \\
39 \\
41 \\
42 \\
43 \\
44 \\
45 \\
46 \\
48 \\
49 \\
50 \\
51 \\
52\end{array}$ & $\begin{array}{r}15.13 \\
41.40 \\
72.19 \\
104.84 \\
138.70 \\
175.97 \\
212.12 \\
250.14 \\
280.17 \\
314.78 \\
341.03 \\
371.45 \\
403.41 \\
426.54 \\
454.98 \\
474.28 \\
507.00 \\
545.05 \\
564.98 \\
594.70 \\
615.76 \\
651.12 \\
682.65 \\
698.82 \\
731.00 \\
755.91 \\
782.26 \\
805.72 \\
830.33 \\
865.52 \\
871.54 \\
899.32 \\
914.97 \\
931.24 \\
970.89 \\
997.28 \\
1026.44 \\
1052.12 \\
1091.19 \\
1154.13 \\
1182.24 \\
1218.07 \\
1251.27 \\
1267.53 \\
1288.47 \\
1315.93 \\
1331.29 \\
1364.32 \\
1369.59 \\
1394.84 \\
1406.40\end{array}$ & $\begin{array}{r}15.19 \\
40.97 \\
72.59 \\
104.51 \\
139.87 \\
174.56 \\
213.67 \\
250.77 \\
285.00 \\
316.96 \\
353.89 \\
376.91 \\
406.75 \\
436.88 \\
463.68 \\
495.05 \\
521.16 \\
550.77 \\
584.03 \\
611.08 \\
643.67 \\
671.03 \\
707.11 \\
734.81 \\
764.17 \\
796.85 \\
828.09 \\
859.39 \\
890.69 \\
920.25 \\
954.87 \\
982.17 \\
1015.64 \\
1045.92 \\
1083.10 \\
1124.42 \\
1163.12 \\
1209.74 \\
1255.87 \\
1362.24 \\
1423.84 \\
1498.55 \\
1574.08 \\
1645.71 \\
1710.78 \\
1779.78 \\
1860.00 \\
191.95 \\
1981.54 \\
2044.37 \\
2109.55\end{array}$ & $\begin{array}{r}0.1330 \\
-0.1305 \\
0.0999 \\
-0.0323 \\
0.1676 \\
-0.0996 \\
0.1497 \\
0.0846 \\
0.3466 \\
0.2002 \\
0.7372 \\
0.3945 \\
0.3039 \\
0.5835 \\
0.5219 \\
0.9498 \\
0.7299 \\
0.4677 \\
0.8621 \\
0.7869 \\
1.0968 \\
0.8927 \\
1.0031 \\
1.2730 \\
1.2101 \\
1.3772 \\
1.4785 \\
1.6350 \\
1.7637 \\
1.6596 \\
2.1755 \\
2.1672 \\
2.4696 \\
2.7010 \\
2.6620 \\
2.8898 \\
3.0304 \\
3.3273 \\
3.4233 \\
3.9870 \\
4.3895 \\
4.8333 \\
5.2930 \\
5.8698 \\
6.3113 \\
6.7097 \\
7.3050 \\
7.4725 \\
8.0226 \\
8.3318 \\
8.7577\end{array}$ & $\begin{array}{l}15.586 \\
18.870 \\
20.873 \\
22.125 \\
23.181 \\
24.024 \\
24.701 \\
25.241 \\
25.900 \\
26.350 \\
26.757 \\
26.983 \\
27.210 \\
27.494 \\
27.770 \\
27.988 \\
28.217 \\
28.490 \\
28.580 \\
28.762 \\
28.942 \\
28.940 \\
28.998 \\
29.172 \\
29.157 \\
29.307 \\
29.198 \\
28.945 \\
28.697 \\
28.637 \\
28.338 \\
28.159 \\
28.039 \\
27.726 \\
27.670 \\
27.390 \\
26.872 \\
26.439 \\
26.213 \\
25.139 \\
24.602 \\
23.692 \\
22.634 \\
21.552 \\
20.407 \\
19.805 \\
18.903 \\
18.380 \\
17.576 \\
16.755 \\
16.030\end{array}$ & $\begin{array}{l}0.305 \\
0.606 \\
0.907 \\
1.209 \\
1.507 \\
1.810 \\
2.110 \\
2.409 \\
2.661 \\
2.912 \\
3.161 \\
3.357 \\
3.559 \\
3.760 \\
3.959 \\
4.159 \\
4.360 \\
4.560 \\
4.761 \\
4.959 \\
5.161 \\
5.360 \\
5.582 \\
5.758 \\
5.960 \\
6.159 \\
6.362 \\
6.559 \\
6.760 \\
6.959 \\
7.160 \\
7.360 \\
7.562 \\
7.760 \\
8.009 \\
8.259 \\
8.512 \\
8.808 \\
9.117 \\
9.814 \\
10.211 \\
10.710 \\
11.224 \\
11.726 \\
12.203 \\
12.708 \\
13.290 \\
13.708 \\
14.213 \\
14.714 \\
15.220\end{array}$ \\
\hline
\end{tabular}


Table A-33. Deformation $J_{I C}$ and $J-R$ curve results for spectmen P1B-15

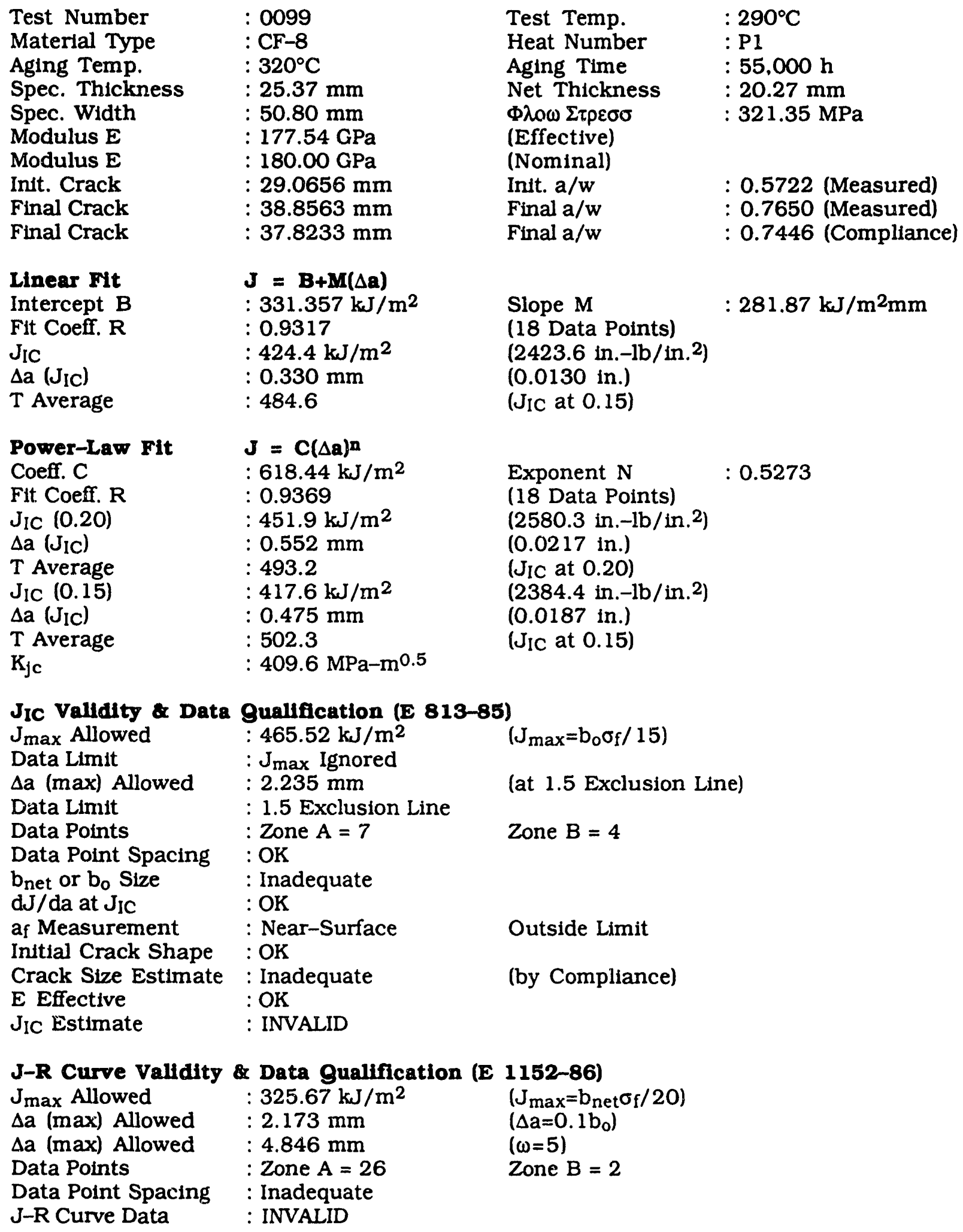


Table A-34. Modified $J_{I C}$ and J-R curve results for specimen P1B-15

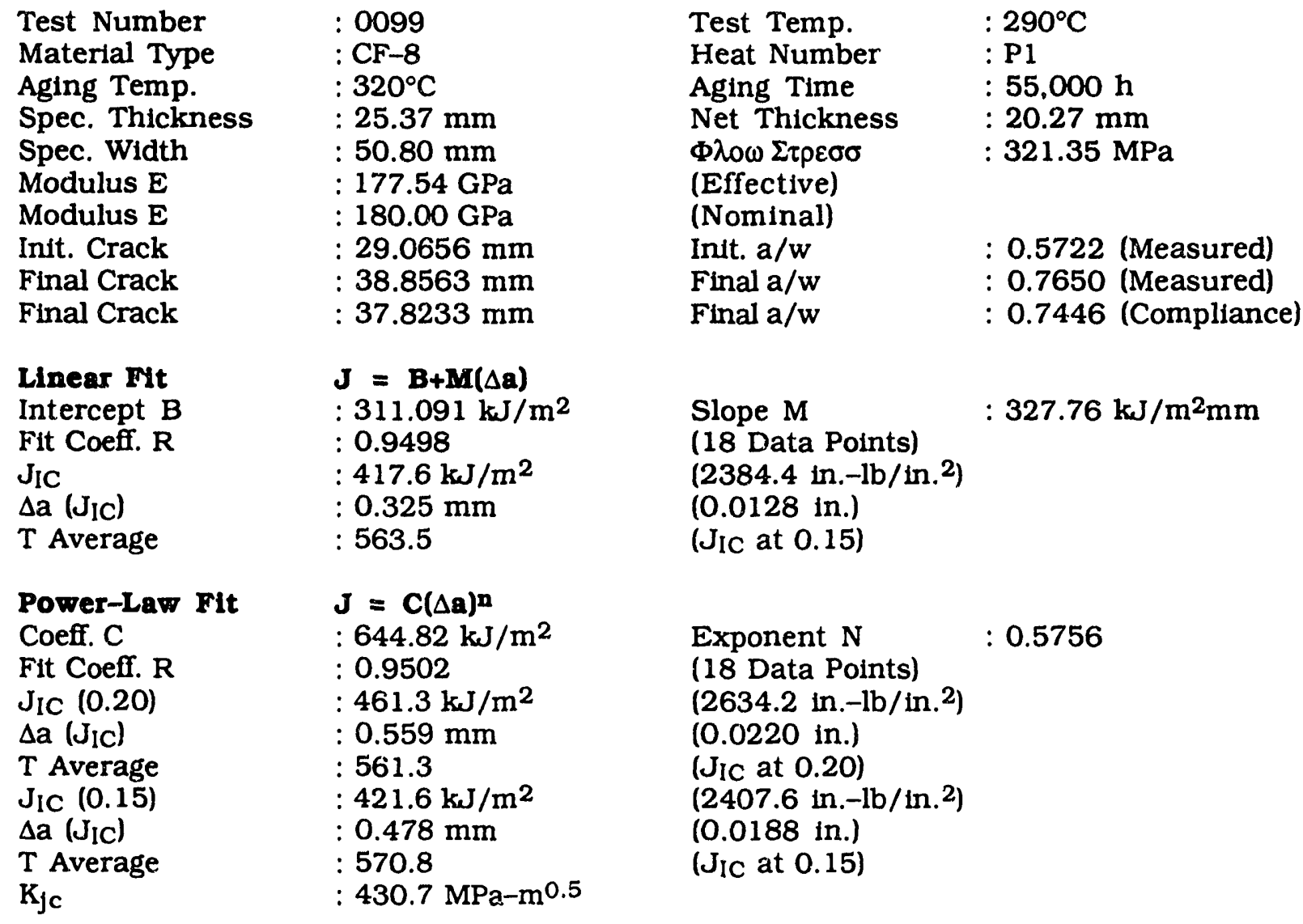

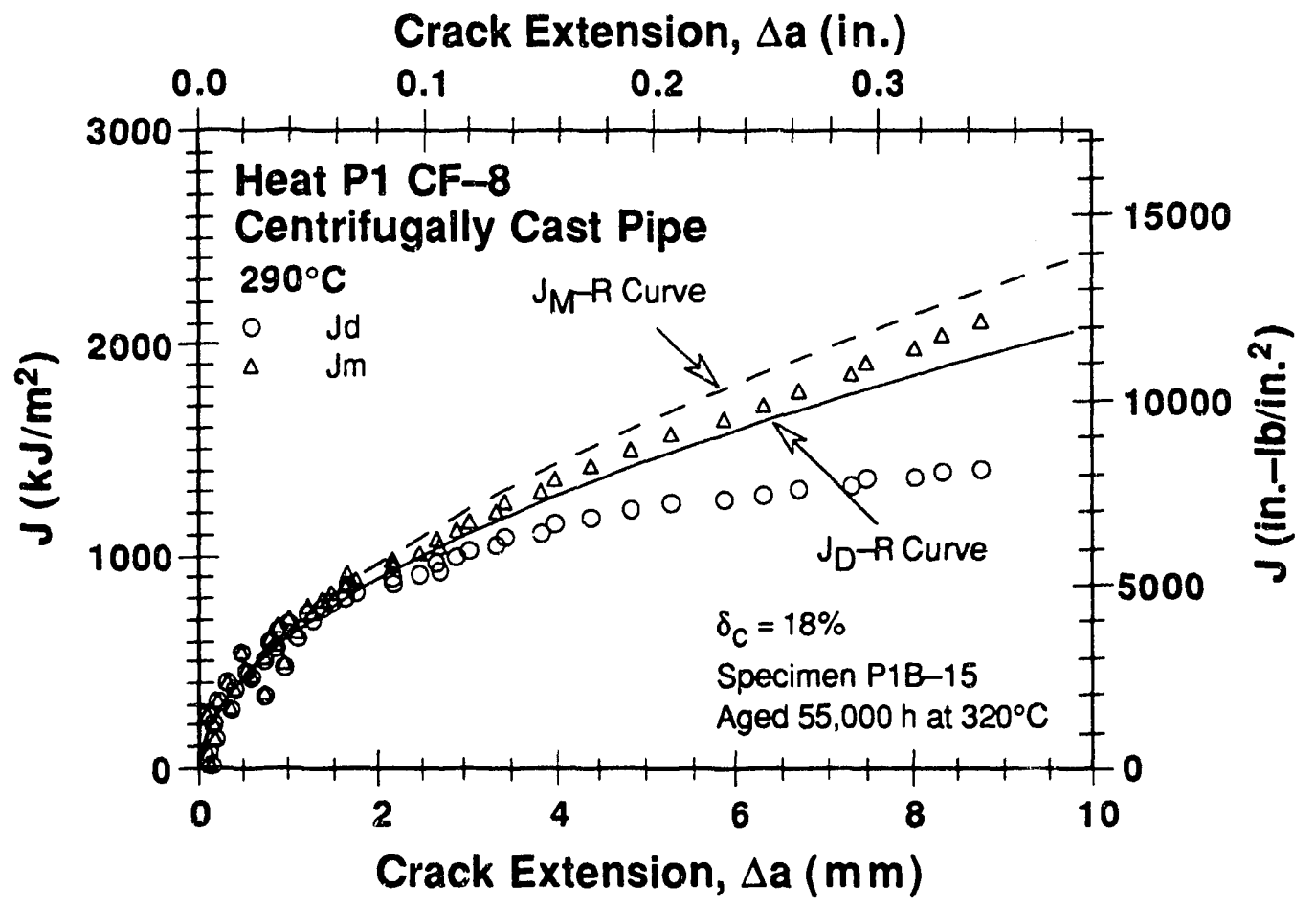

Figure A-32. Deformation and modifled $J-R$ curves at $290^{\circ} \mathrm{C}$ for Heat $P 1$ aged $55.000 \mathrm{~h}$ at $320^{\circ} \mathrm{C}$ 


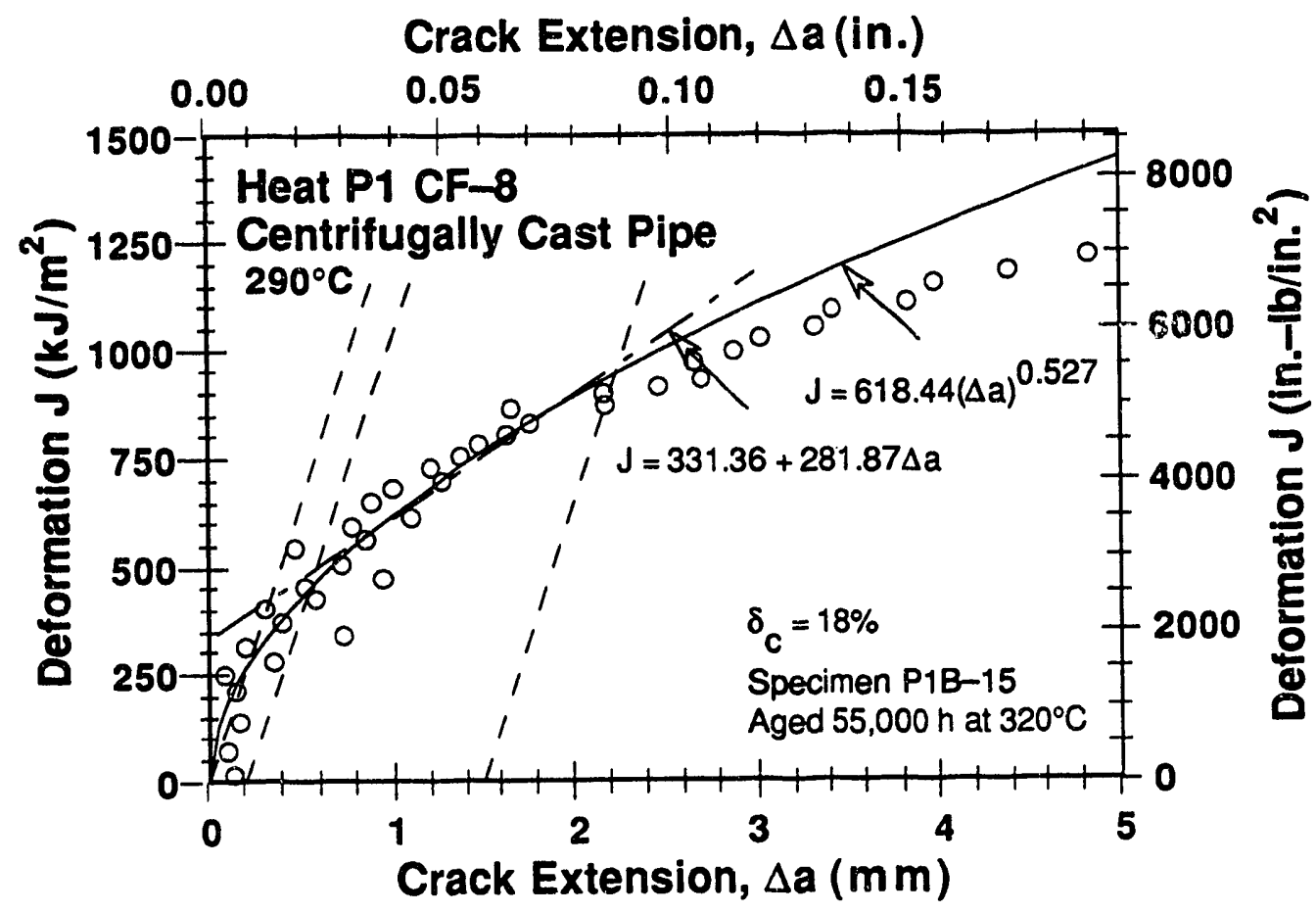

Figure A-33. Deformation $J_{I C}$ at $290^{\circ} \mathrm{C}$ for Heat $\mathrm{PI}$ aged $55.000 \mathrm{~h}$ at $320^{\circ} \mathrm{C}$

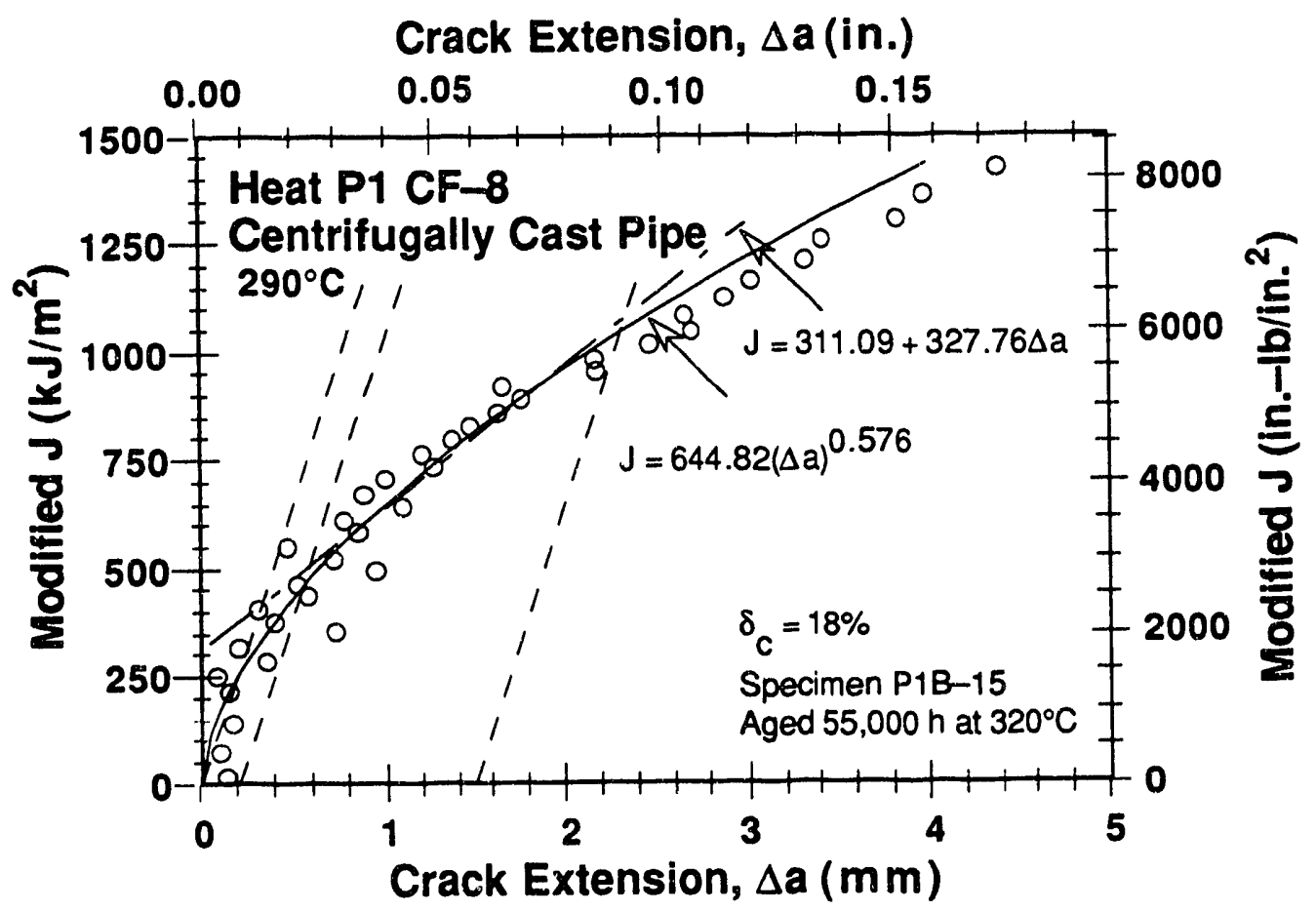

Figure A-34. Modified $J_{I C}$ at $290^{\circ} \mathrm{C}$ for Heat $P 1$ aged $55,000 \mathrm{~h}$ at $320^{\circ} \mathrm{C}$ 
Table A-35. Test data for spectmen C1B-18

\begin{tabular}{|c|c|c|c|c|c|}
\hline \multicolumn{2}{|c|}{$\begin{array}{l}\text { Test Number } \\
\text { Materlal Type } \\
\text { Aging Temp. } \\
\text { Spec. Thickness } \\
\text { Spec. Width }\end{array}$} & $\begin{array}{l}: 0110 \\
: \mathrm{CF}-8 \\
: 320^{\circ} \mathrm{C} \\
: 25.40 \mathrm{~mm} \\
: 50.79 \mathrm{~mm}\end{array}$ & \multicolumn{2}{|c|}{$\begin{array}{l}\text { Test Temp. } \\
\text { Heat Number } \\
\text { Aging Time } \\
\text { Net Thickness } \\
\text { of }\end{array}$} & $\begin{array}{l}: 25^{\circ} \mathrm{C} \\
: \mathrm{C} 1 \\
: 30,000 \mathrm{~h} \\
: 20.25 \mathrm{~mm} \\
: 360.00 \mathrm{MPa}\end{array}$ \\
\hline $\begin{array}{c}\text { Unload } \\
\text { Number }\end{array}$ & $\underset{\left(\mathrm{kJ} / \mathrm{m}^{2}\right)}{\mathrm{J}_{\mathrm{d}}}$ & $\frac{J_{m}}{\left(k J / m^{2}\right)}$ & $\begin{array}{c}\Delta \mathrm{a} \\
(\mathrm{mm})\end{array}$ & $\begin{array}{l}\text { Load } \\
(\mathrm{kN})\end{array}$ & $\begin{array}{l}\text { Deflection } \\
(\mathrm{mm})\end{array}$ \\
\hline $\begin{array}{l}1 \\
2 \\
3 \\
4 \\
5 \\
6 \\
7 \\
8 \\
9 \\
10 \\
11 \\
12 \\
13 \\
14 \\
15 \\
16 \\
17 \\
18 \\
19 \\
20 \\
21 \\
22 \\
23 \\
24 \\
25 \\
26 \\
27 \\
28 \\
29 \\
30 \\
31 \\
32 \\
33 \\
34\end{array}$ & $\begin{array}{r}19.52 \\
53.78 \\
92.22 \\
132.53 \\
174.86 \\
218.95 \\
264.71 \\
310.56 \\
356.64 \\
400.93 \\
445.73 \\
482.44 \\
521.38 \\
556.89 \\
589.26 \\
629.08 \\
658.00 \\
699.52 \\
739.02 \\
771.84 \\
798.10 \\
829.53 \\
866.93 \\
901.26 \\
944.43 \\
970.11 \\
988.22 \\
1006.79 \\
1041.02 \\
1046.95 \\
1056.47 \\
1075.98 \\
1091.49 \\
1101.76\end{array}$ & $\begin{array}{r}19.50 \\
53.82 \\
92.43 \\
134.30 \\
176.66 \\
221.43 \\
267.82 \\
314.88 \\
363.60 \\
413.35 \\
463.31 \\
505.13 \\
546.50 \\
589.86 \\
632.33 \\
673.19 \\
717.48 \\
767.56 \\
818.72 \\
870.18 \\
920.77 \\
967.86 \\
1026.25 \\
1084.18 \\
1149.51 \\
1213.88 \\
1274.55 \\
1332.51 \\
1405.57 \\
1476.96 \\
1539.83 \\
1603.77 \\
1666.64 \\
1727.06\end{array}$ & $\begin{array}{r}-0.0391 \\
-0.0120 \\
0.0247 \\
0.2593 \\
0.2625 \\
0.3204 \\
0.3648 \\
0.4363 \\
0.5699 \\
0.8131 \\
1.0173 \\
1.2015 \\
1.2823 \\
1.5239 \\
1.8142 \\
1.8421 \\
2.2298 \\
2.4307 \\
2.6875 \\
3.0729 \\
3.5507 \\
3.8431 \\
4.2115 \\
4.6034 \\
4.9482 \\
5.5187 \\
6.1172 \\
6.6468 \\
7.1390 \\
7.9279 \\
8.5433 \\
9.0323 \\
9.5301 \\
10.0357\end{array}$ & $\begin{array}{l}21.239 \\
25.337 \\
27.115 \\
28.540 \\
29.758 \\
30.665 \\
31.493 \\
32.204 \\
32.718 \\
33.249 \\
33.104 \\
32.946 \\
33.081 \\
32.922 \\
32.772 \\
32.482 \\
32.042 \\
31.841 \\
31.685 \\
30.467 \\
29.879 \\
29.451 \\
28.764 \\
28.245 \\
26.943 \\
25.594 \\
24.001 \\
22.961 \\
21.969 \\
19.456 \\
18.202 \\
17.363 \\
16.233 \\
15.284\end{array}$ & $\begin{array}{l}0.304 \\
0.605 \\
0.907 \\
1.208 \\
1.510 \\
1.808 \\
2.111 \\
2.409 \\
2.710 \\
3.010 \\
3.312 \\
3.562 \\
3.811 \\
4.062 \\
4.312 \\
4.562 \\
4.810 \\
5.113 \\
5.410 \\
5.711 \\
6.015 \\
6.309 \\
6.600 \\
7.011 \\
7.411 \\
7.811 \\
8.212 \\
8.611 \\
9.109 \\
9.612 \\
10.110 \\
10.611 \\
11.110 \\
11.609\end{array}$ \\
\hline
\end{tabular}


Table A-36. Deformation $J_{I C}$ and $J-R$ curve results for specimen C1B-18

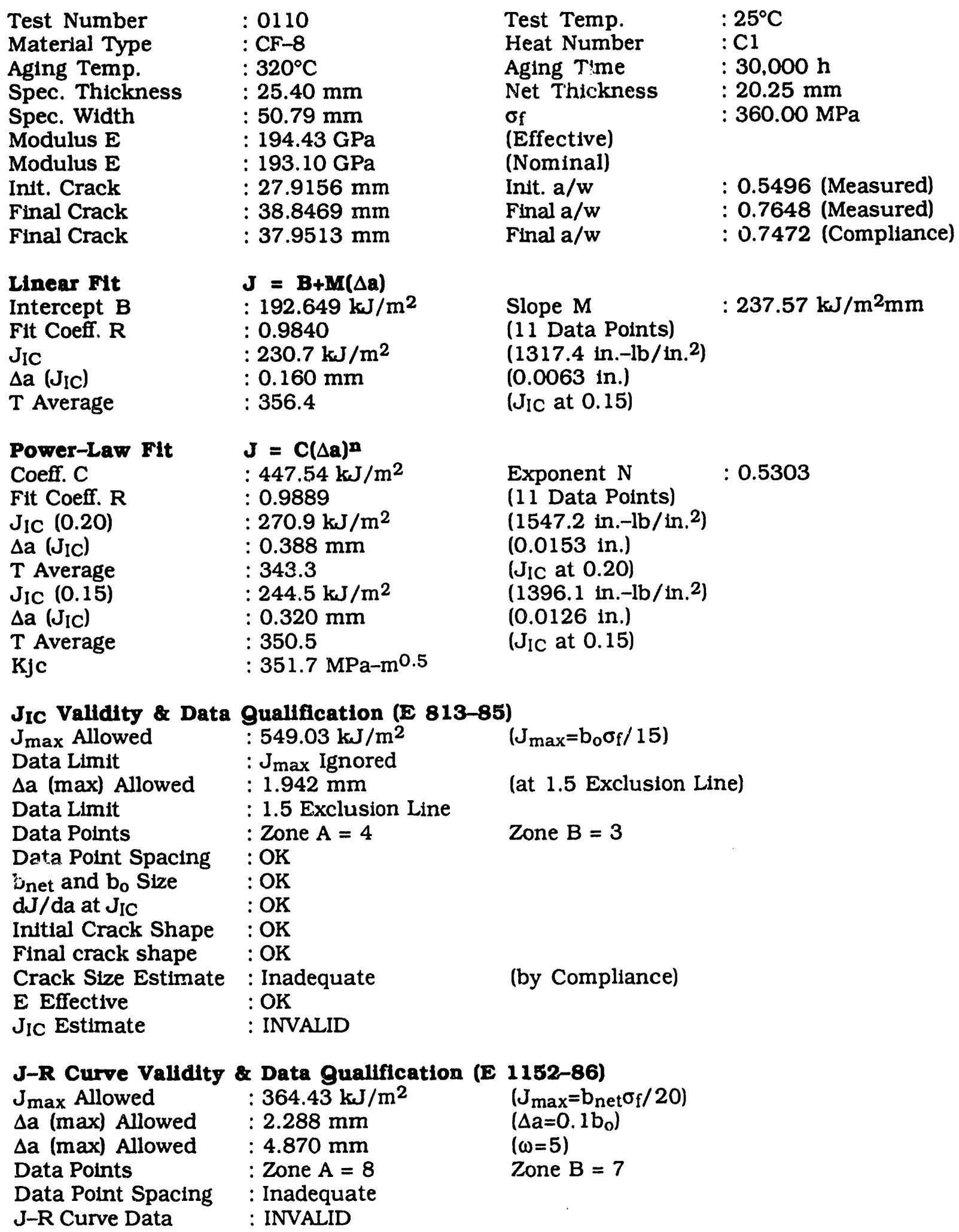


Table A-37. Modified $J_{I C}$ and $J-R$ curve results for spectmen C1B-18

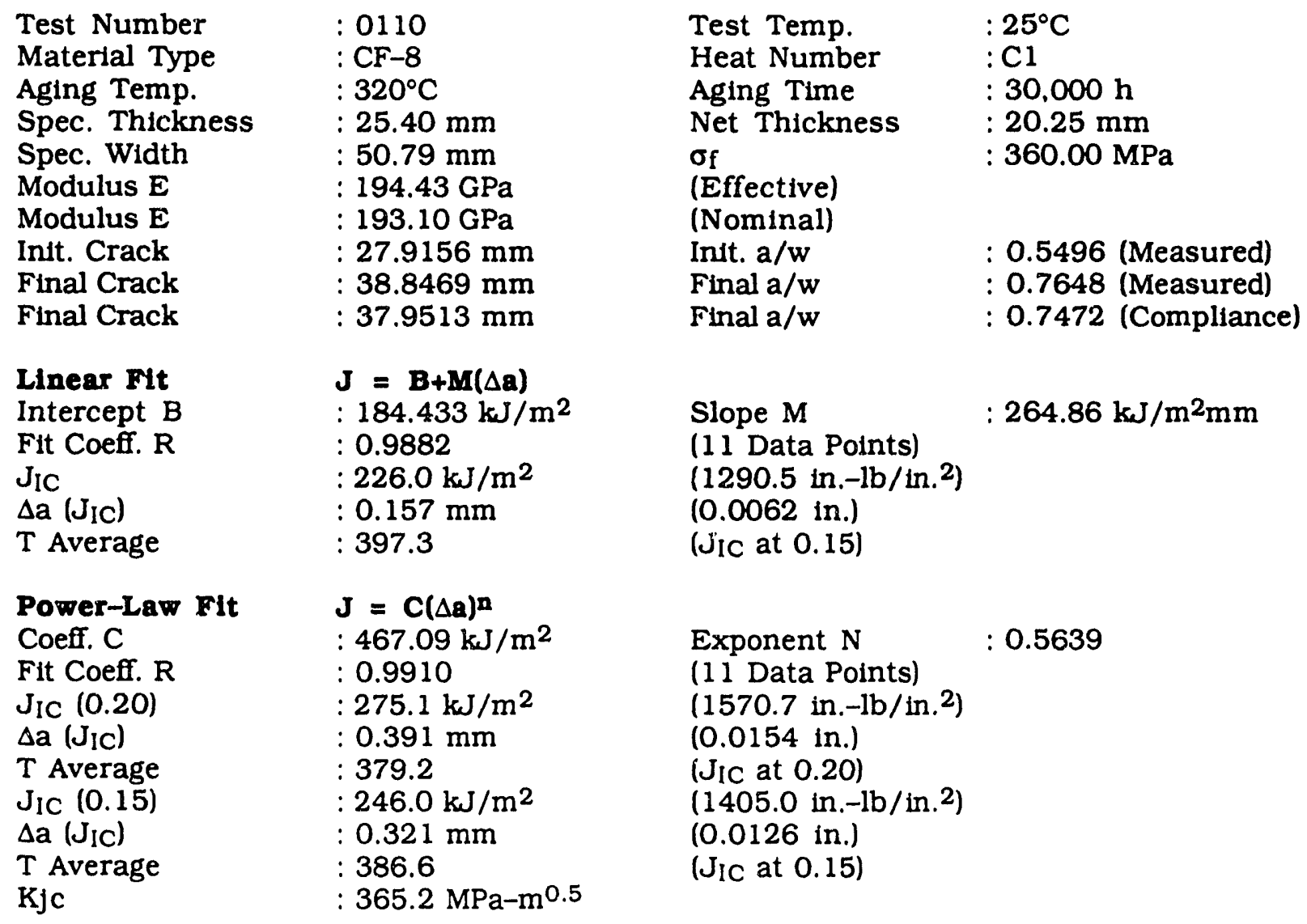

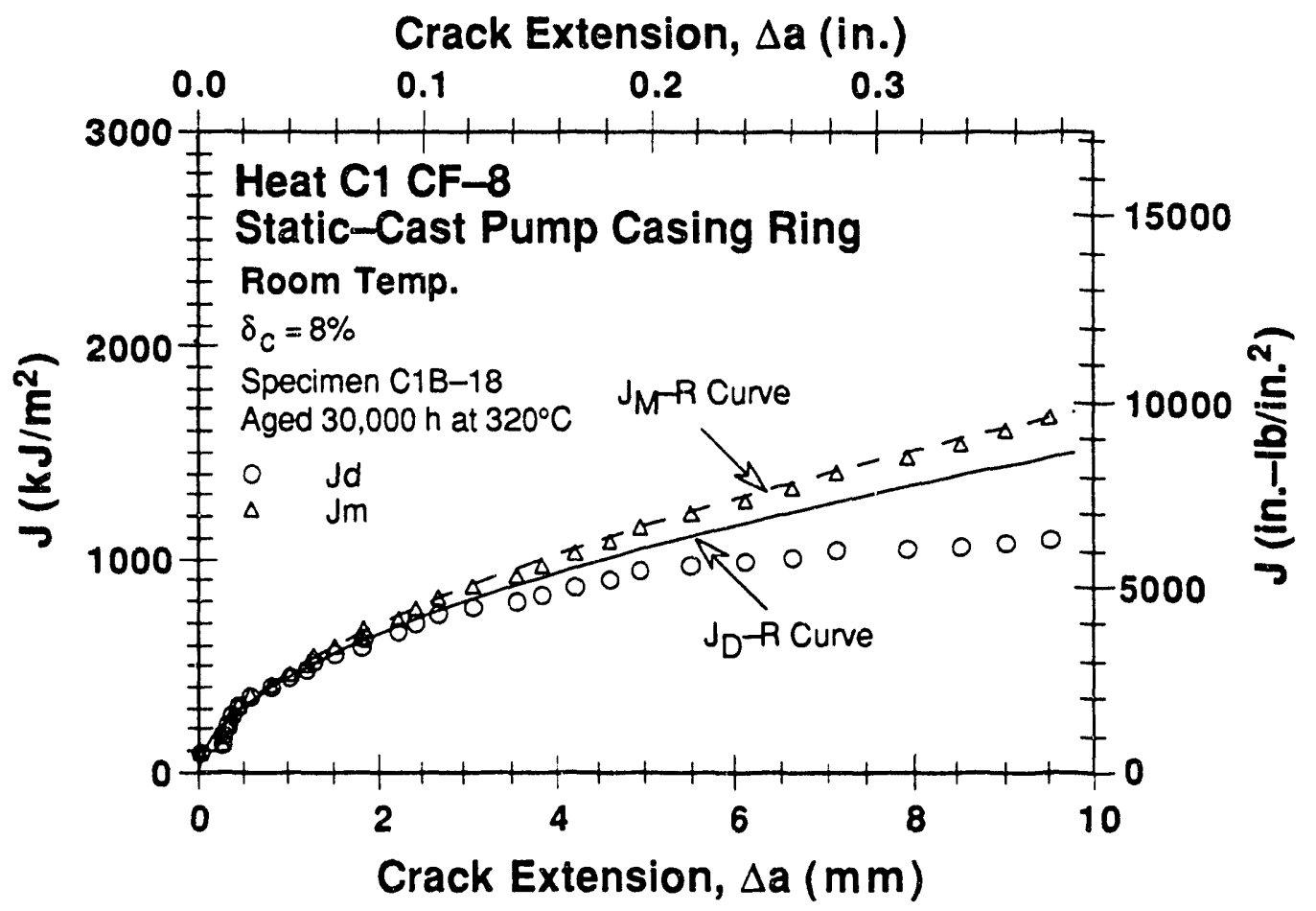

Fygure A-35. Deformation and modified $J-R$ curves at room temp. for Heat $C 1$ aged $30,000 \mathrm{~h}$ at $320^{\circ} \mathrm{C}$ 
Crack Extension, $\Delta \mathrm{a}$ (in.)

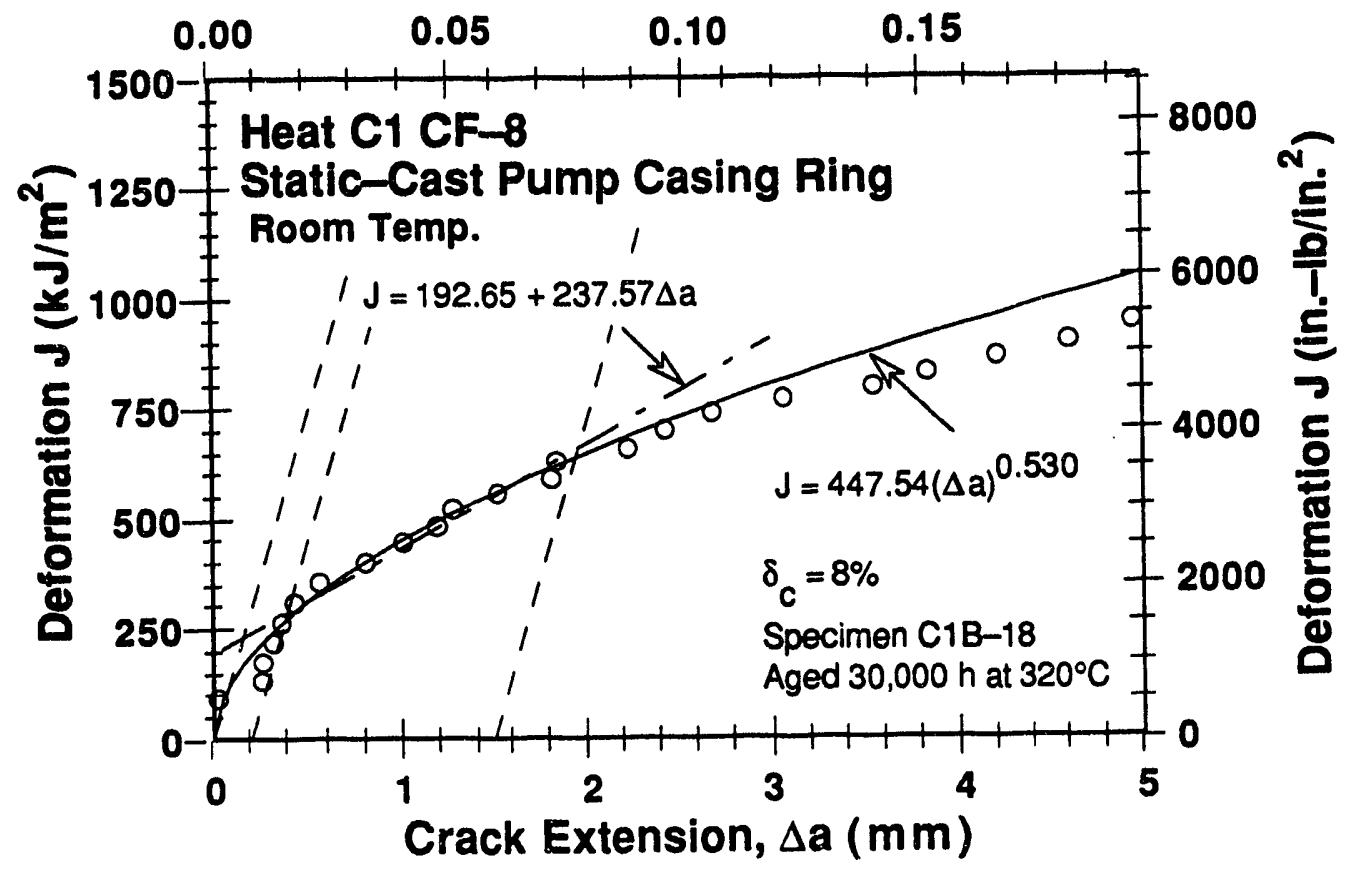

Figure A-36. Deformation $J_{I C}$ at room temp. for Heat $\mathrm{Cl}$ aged $30,000 \mathrm{~h}$ at $320^{\circ} \mathrm{C}$

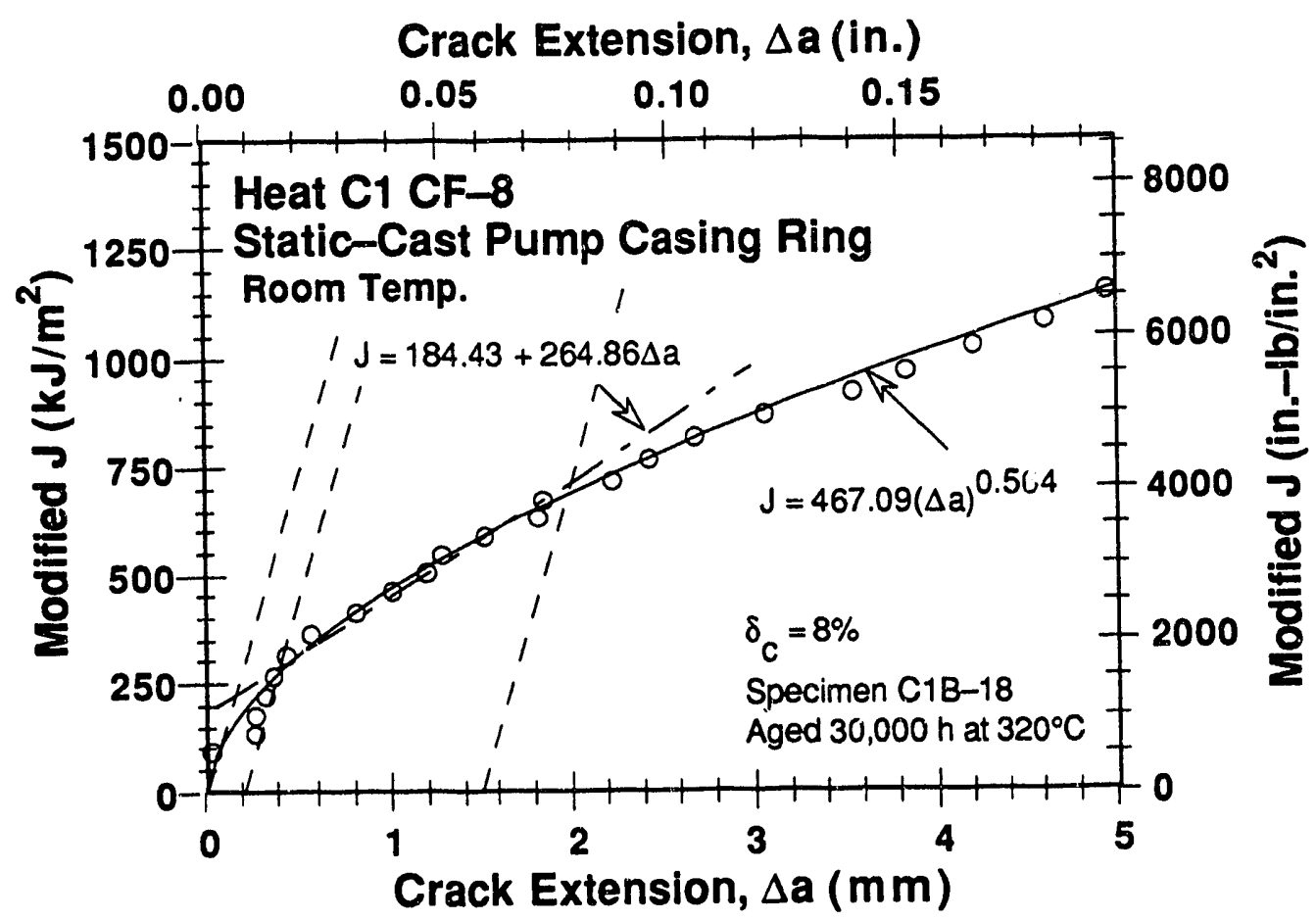

Figure A-37. Modified $J_{I C}$ at room temp. for Heat $\mathrm{Cl}$ aged $30,000 \mathrm{~h}$ at $320^{\circ} \mathrm{C}$ 
Table A-38. Test data for spectmen C1B-08

\begin{tabular}{|c|c|c|c|c|c|}
\hline $\begin{array}{l}\text { Test Nun } \\
\text { Material } \\
\text { Aging Te } \\
\text { Spec. Th } \\
\text { Spec. Wi }\end{array}$ & $\begin{array}{ll}\text { er } & : \\
\text { pe } & : \\
\text { cness } & : \\
& :\end{array}$ & $\underset{\mathrm{mm}}{\mathrm{mm}}$ & $\begin{array}{l}\text { Test } \\
\text { Heat } \\
\text { Aging } \\
\text { Net T } \\
\text { Flow }\end{array}$ & $\begin{array}{l}: 2 \\
: \mathrm{C} \\
: 1 \\
: 2 \\
: 3\end{array}$ & $\begin{array}{l}00 \mathrm{~h} \\
0 \mathrm{~mm} \\
0 \mathrm{MPa}\end{array}$ \\
\hline $\begin{array}{c}\text { Unload } \\
\text { Number } \\
\end{array}$ & $\begin{array}{c}\mathrm{Jd} \\
\left(\mathrm{kJ} / \mathrm{m}^{2}\right)\end{array}$ & $\begin{array}{c}\mathrm{J}_{\mathrm{m}} \\
\left(\mathrm{kJ} / \mathrm{m}^{2}\right)\end{array}$ & $\begin{array}{c}\Delta \mathrm{a} \\
(\mathrm{mm})\end{array}$ & $\begin{array}{l}\text { Load } \\
(\mathrm{kN}) \\
\end{array}$ & $\begin{array}{c}\text { Deflection } \\
\text { (mm) }\end{array}$ \\
\hline $\begin{array}{l}1 \\
2 \\
3 \\
4 \\
5 \\
6 \\
7 \\
8 \\
9 \\
10 \\
11 \\
12 \\
13 \\
14 \\
15 \\
16 \\
17 \\
18 \\
19 \\
20 \\
21 \\
22 \\
23 \\
24 \\
25 \\
26 \\
27 \\
28 \\
29 \\
30 \\
31\end{array}$ & $\begin{array}{r}18.65 \\
51.80 \\
88.88 \\
128.62 \\
168.77 \\
210.35 \\
252.46 \\
294.96 \\
337.06 \\
377.48 \\
417.96 \\
456.66 \\
493.49 \\
528.02 \\
561.53 \\
606.50 \\
650.04 \\
698.09 \\
744.22 \\
788.62 \\
825.77 \\
860.56 \\
878.42 \\
885.31 \\
922.02 \\
990.01 \\
1036.26 \\
1079.36 \\
1117.43 \\
1138.43 \\
1114.03\end{array}$ & $\begin{array}{r}18.67 \\
51.65 \\
89.08 \\
129.33 \\
169.27 \\
212.26 \\
256.03 \\
301.56 \\
346.48 \\
392.95 \\
439.14 \\
485.28 \\
532.51 \\
577.29 \\
623.35 \\
677.11 \\
732.09 \\
795.24 \\
857.69 \\
921.00 \\
983.89 \\
1047.28 \\
1132.35 \\
1197.54 \\
1260.33 \\
1342.58 \\
1428.47 \\
1509.42 \\
1589.06 \\
1667.63 \\
1736.04\end{array}$ & $\begin{array}{r}0.0273 \\
-0.0436 \\
0.0367 \\
0.1125 \\
0.0900 \\
0.2142 \\
0.3341 \\
0.5184 \\
0.6662 \\
0.9458 \\
1.1798 \\
1.4551 \\
1.8062 \\
2.1253 \\
2.4860 \\
2.7176 \\
2.9951 \\
3.3310 \\
3.6662 \\
4.0269 \\
4.4858 \\
4.9634 \\
6.0040 \\
6.8632 \\
7.2257 \\
7.4083 \\
7.8803 \\
8.3018 \\
8.7375 \\
9.3077 \\
10.1919\end{array}$ & $\begin{array}{l}20.167 \\
23.879 \\
25.638 \\
26.999 \\
27.971 \\
28.781 \\
29.492 \\
29.865 \\
29.747 \\
30.170 \\
29.573 \\
29.164 \\
28.988 \\
28.739 \\
28.301 \\
28.087 \\
27.979 \\
27.681 \\
27.236 \\
26.859 \\
26.046 \\
24.774 \\
20.777 \\
19.794 \\
19.842 \\
19.804 \\
19.035 \\
18.123 \\
17.494 \\
16.006 \\
13.759\end{array}$ & $\begin{array}{l}0.303 \\
0.606 \\
0.907 \\
1.214 \\
1.509 \\
1.808 \\
2.109 \\
2.411 \\
2.709 \\
3.010 \\
3.311 \\
3.610 \\
3.917 \\
4.210 \\
4.508 \\
4.860 \\
5.210 \\
5.610 \\
6.008 \\
6.411 \\
6.810 \\
7.225 \\
7.788 \\
8.310 \\
8.807 \\
9.408 \\
10.009 \\
10.610 \\
11.207 \\
11.808 \\
12.408\end{array}$ \\
\hline
\end{tabular}


Table A-39. Deformation $J_{I C}$ and $J-R$ curve results for specimen $C 1 B-08$

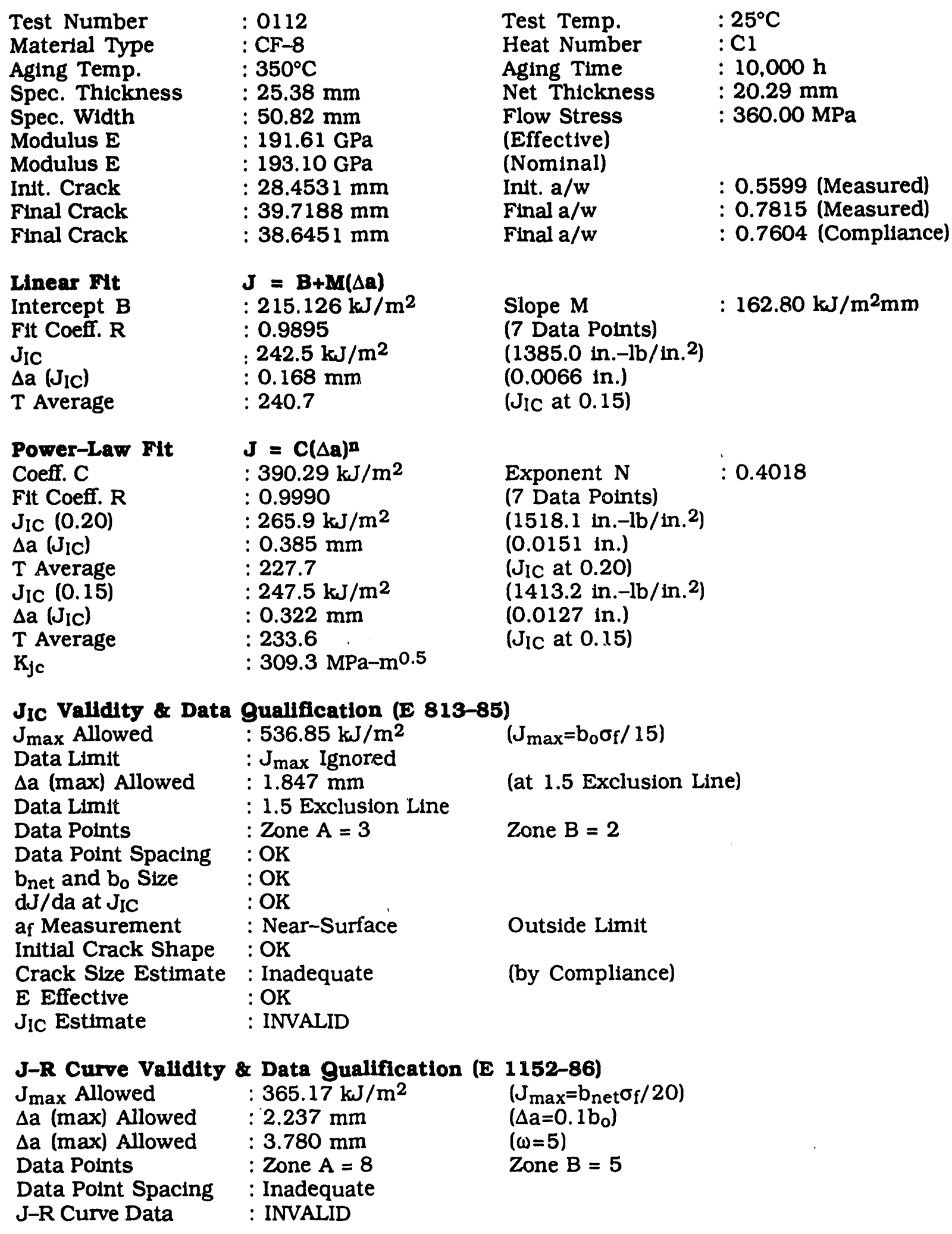

Slope $M:: 162.80 \mathrm{~kJ} / \mathrm{m}^{2} \mathrm{~mm}$
(7 Data Points)
$\left(1385.0 \mathrm{in} .-\mathrm{lb} / \mathrm{in}^{2}\right)$
$(0.0066$ in.)
$\left(\mathrm{J}_{\mathrm{IC}}\right.$ at 0.15$)$

Exponent $\mathrm{N} \quad: 0.4018$

(1518.1 in. $-\mathrm{lb} /$ in. $^{2}$ )

(0.0151 in.)

(JIC at 0.20 )

(1413.2 in. $-\mathrm{lb} /$ in. $\left.{ }^{2}\right)$

(J)

(JIC at 0.15 )

Jic Valldity Data Qualification (E 813-85) 
Table A-40. Modifled $J_{I C}$ and $J-R$ curve results for spectmen C1B-08

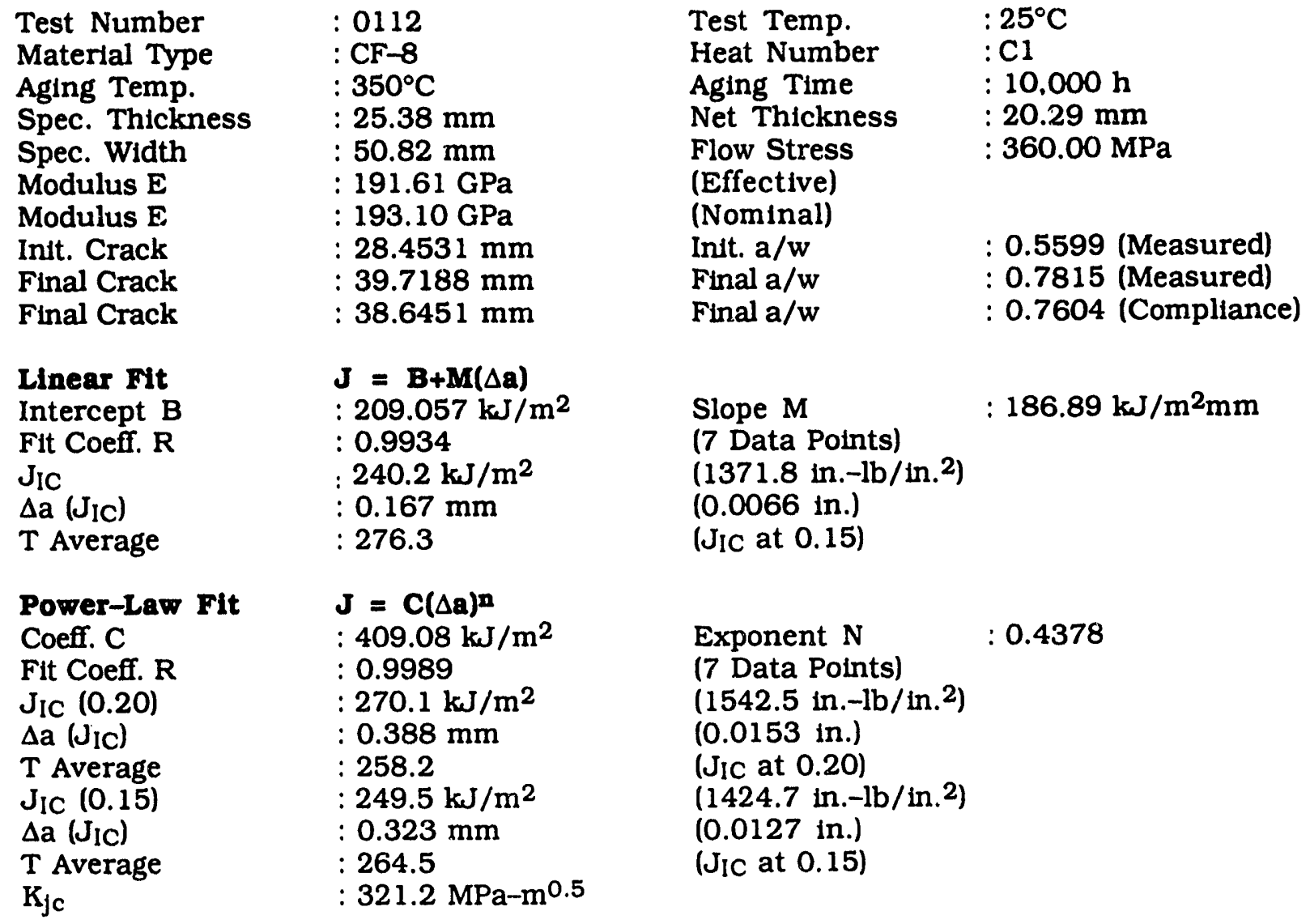

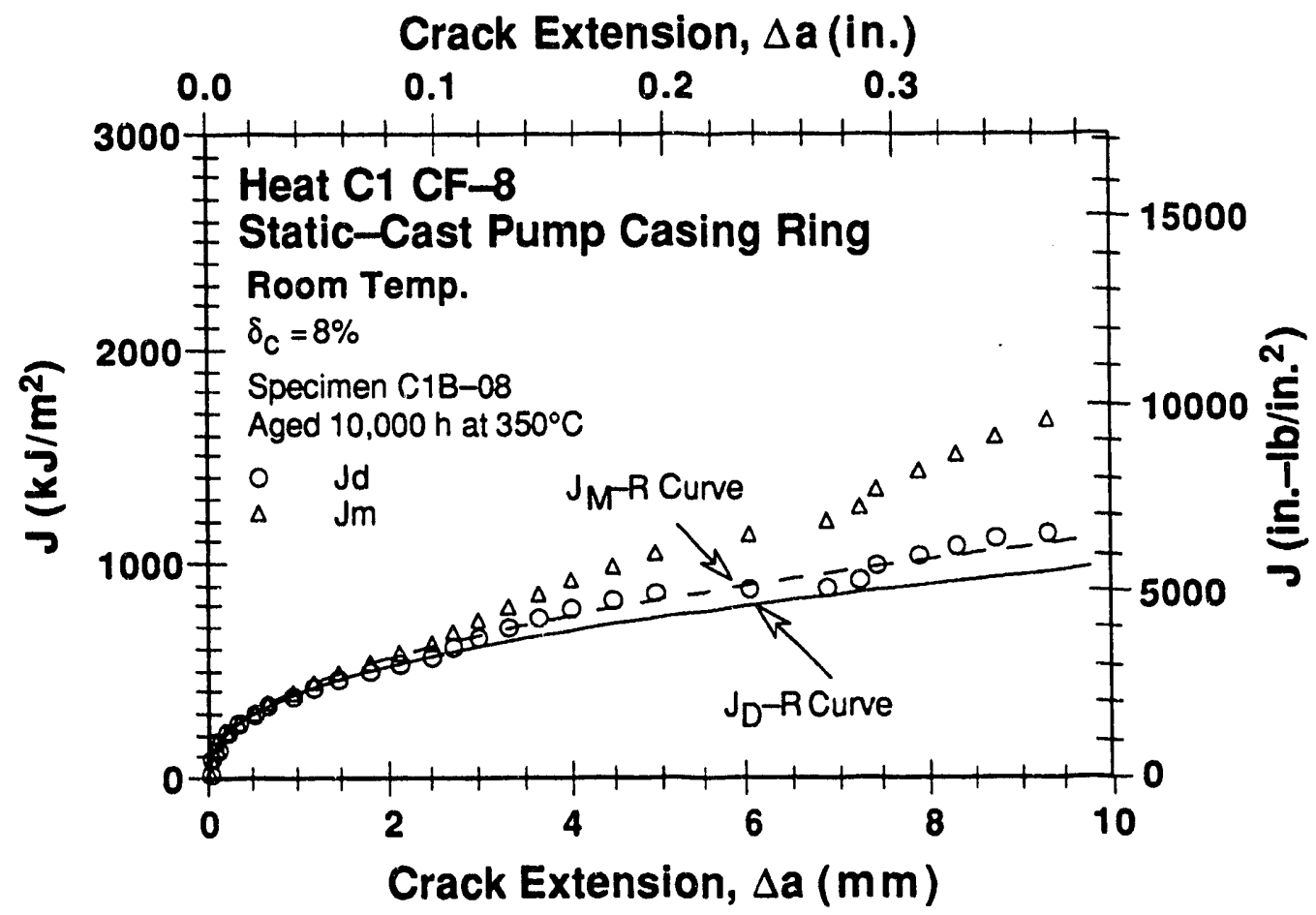

Figure A-38. Deformation and modified $J-R$ curves at room temp. for Heat $C 1$ aged $10.000 \mathrm{~h}$ at $350^{\circ} \mathrm{C}$ 


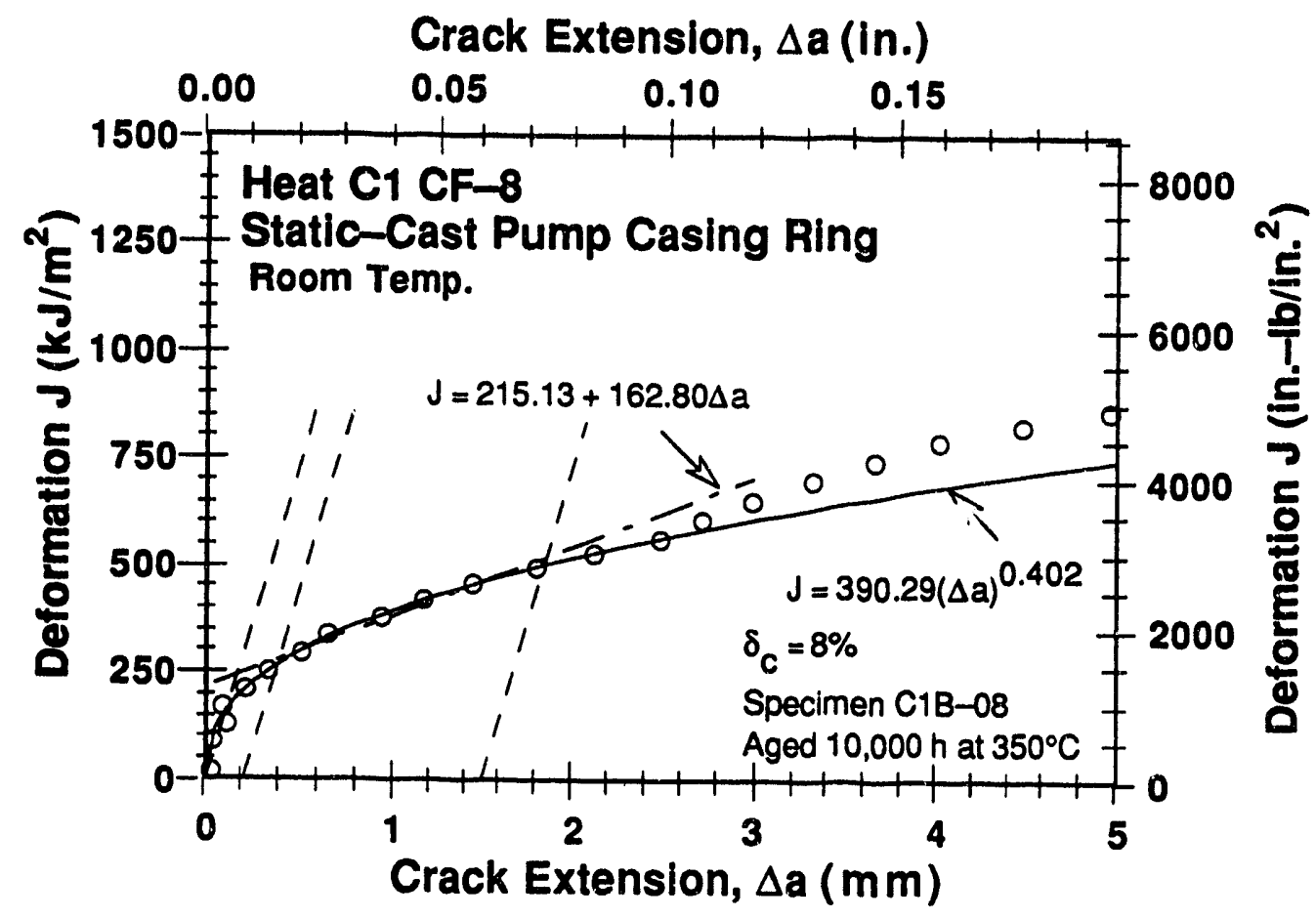

Figure A-39. Deformation $J_{I C}$ at room temp. for Heat $C 1$ aged 10,000 $\mathrm{h}$ at $350^{\circ} \mathrm{C}$

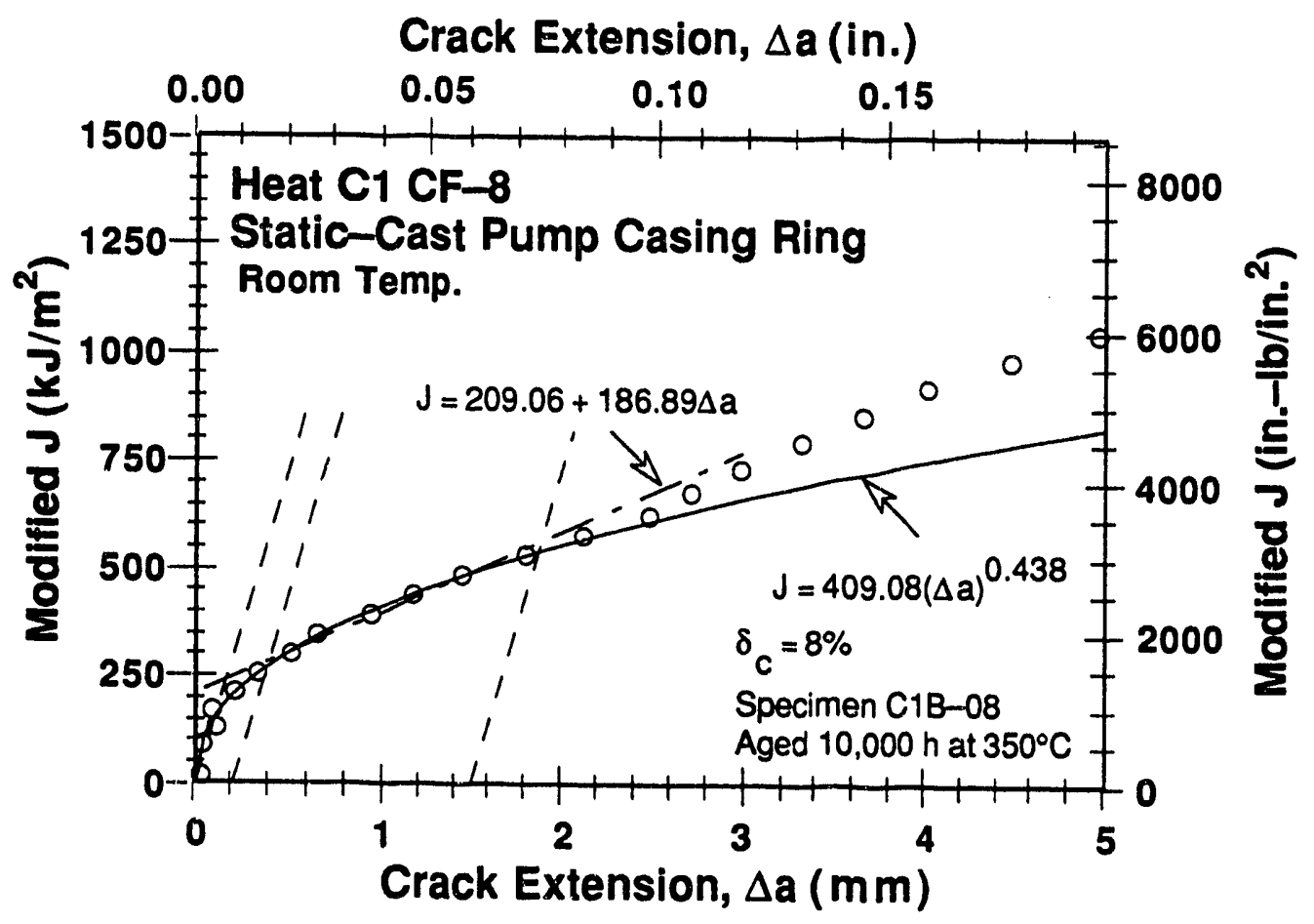

Figure A-40. Modified $J_{I C}$ at room temp. for Heat $\mathrm{Cl}$ aged $10,000 \mathrm{~h}$ at $350^{\circ} \mathrm{C}$ 

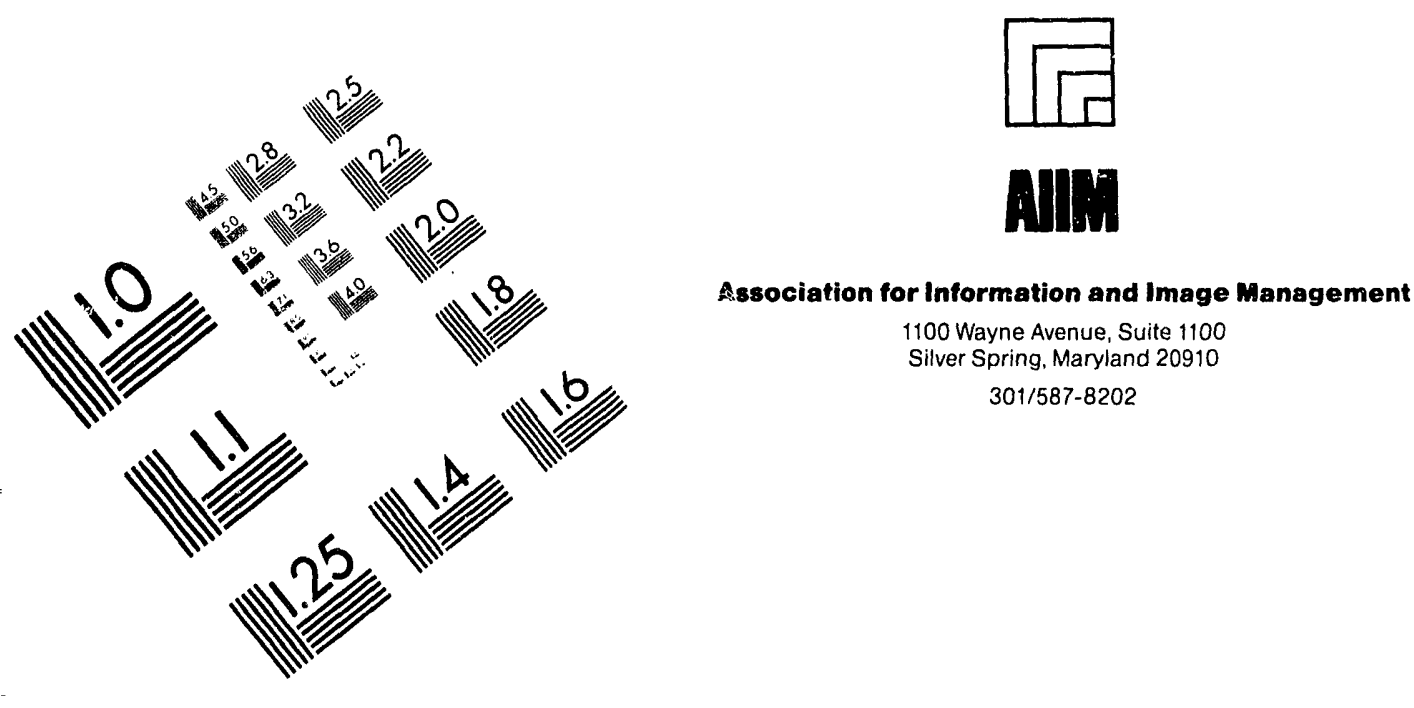

1100 Wayne Avenue, Suite 1100

Silver Spring, Maryland 20910

301/587-8202

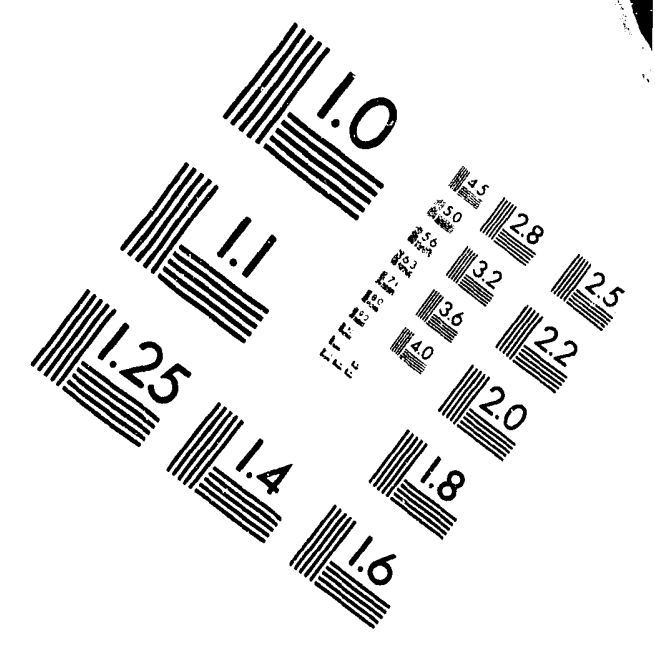

Centimeter

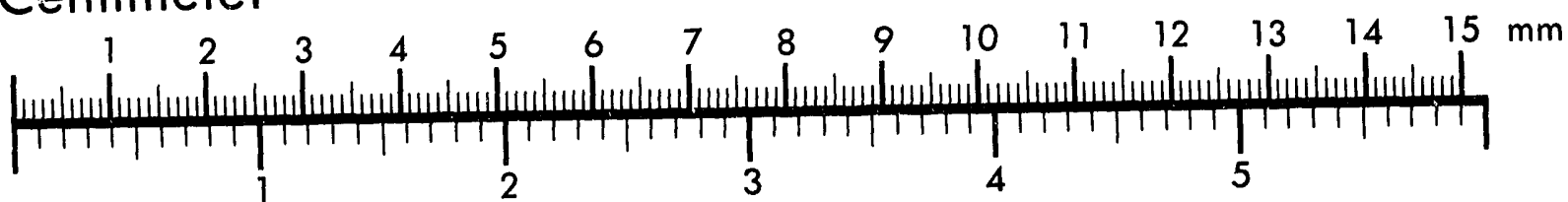
Inches

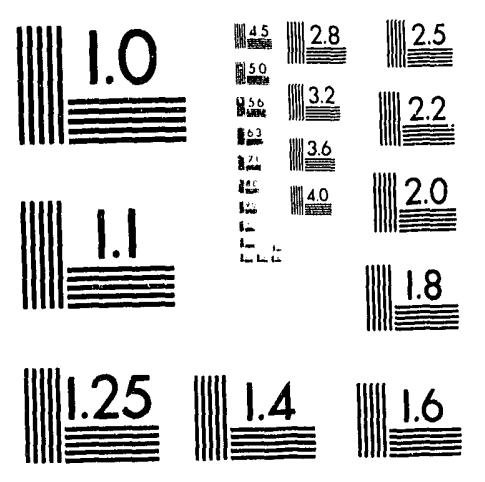

$\equiv$

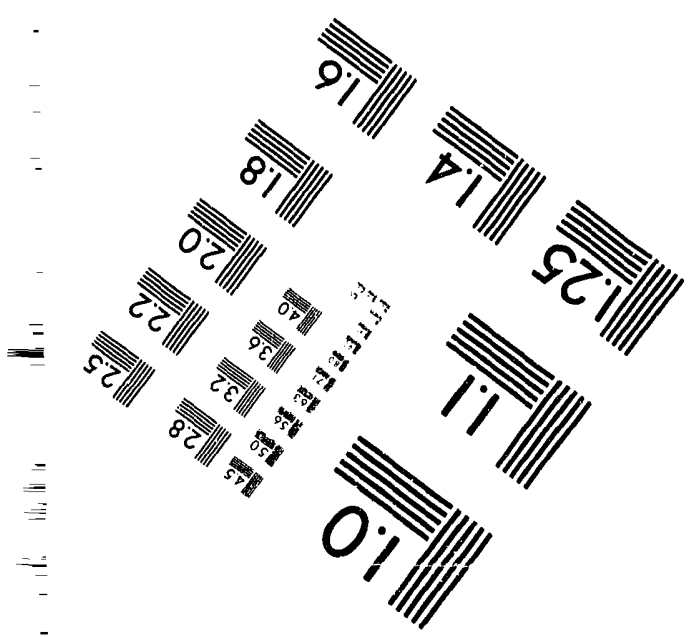

MANUFACTURED TO AIIM STANDARDS BY APPLIED IMAGE. INC.

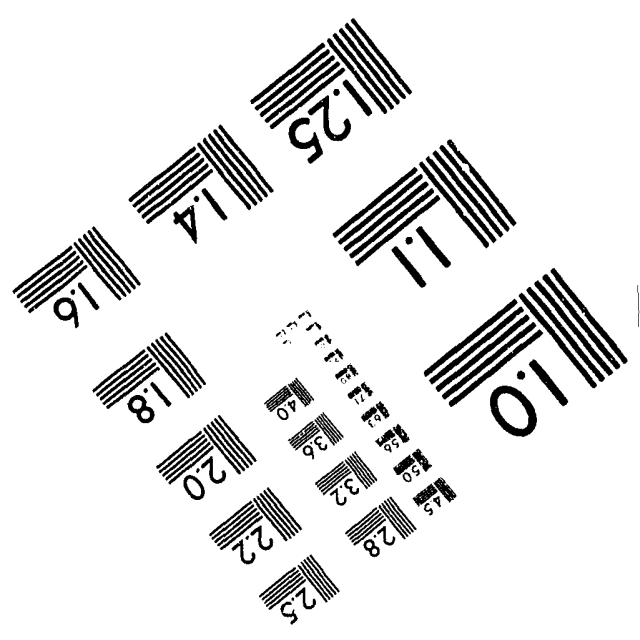



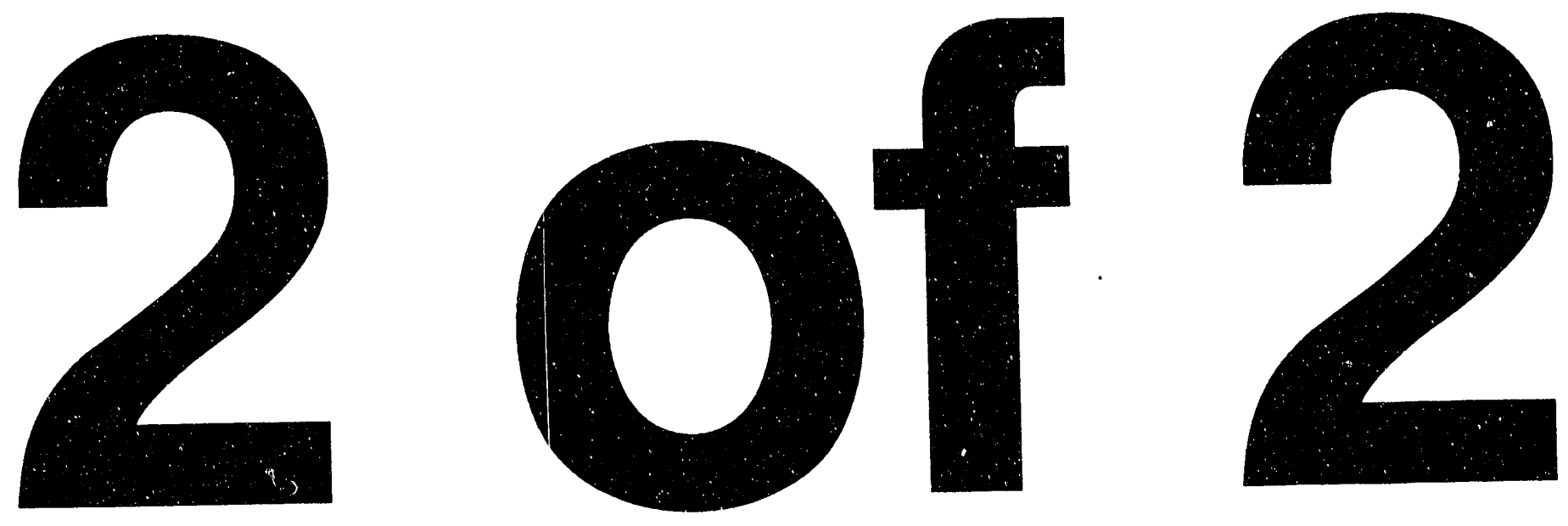
Table A-41. Test data for specimen $C 1 B-11$

\begin{tabular}{|c|c|c|c|c|c|}
\hline $\begin{array}{l}\text { Test Num } \\
\text { Material } \\
\text { Aging Te } \\
\text { Spec. T } \\
\text { Spec. Wi }\end{array}$ & $\begin{array}{r}\text { e } \\
\text { e } \\
\text { hess } \\
\vdots \\
\vdots\end{array}$ & $\frac{\mathrm{mm}}{\mathrm{mm}}$ & $\begin{array}{l}\text { Test T } \\
\text { Heat I } \\
\text { Aging } \\
\text { Net TI } \\
\text { Flow S }\end{array}$ & & $\begin{array}{l}00 \mathrm{~h} \\
9 \mathrm{~mm} \\
00 \mathrm{MPa}\end{array}$ \\
\hline $\begin{array}{l}\text { Unload } \\
\text { Number }\end{array}$ & $\begin{array}{c}\mathrm{J}_{\mathrm{d}} \\
\left(\mathrm{kJ} / \mathrm{m}^{2}\right) \\
\end{array}$ & $\begin{array}{c}J_{1 \mathrm{~m}} \\
\left(\mathrm{~kJ} / \mathrm{m}^{2}\right) \\
\end{array}$ & $\begin{array}{c}\Delta \mathrm{a} \\
(\mathrm{mm})\end{array}$ & $\begin{array}{l}\text { Load } \\
(\mathrm{kN}) \\
\end{array}$ & $\begin{array}{c}\text { Deflection } \\
\text { (mm) }\end{array}$ \\
\hline $\begin{array}{l}1 \\
2 \\
3 \\
4 \\
5 \\
6 \\
7 \\
8 \\
9 \\
10 \\
11 \\
12 \\
13 \\
14 \\
15 \\
16 \\
17 \\
18 \\
19 \\
20 \\
21 \\
22 \\
23 \\
24 \\
25 \\
26 \\
27 \\
28 \\
29 \\
30 \\
31 \\
32 \\
33 \\
34 \\
35 \\
36 \\
37\end{array}$ & $\begin{array}{r}18.56 \\
52.08 \\
89.10 \\
128.18 \\
169.77 \\
211.69 \\
254.22 \\
297.41 \\
340.34 \\
383.72 \\
429.48 \\
472.38 \\
518.69 \\
566.22 \\
603.07 \\
649.07 \\
691.05 \\
729.10 \\
768.58 \\
786.50 \\
808.60 \\
837.77 \\
878.48 \\
915.36 \\
961.58 \\
1024.79 \\
1086.55 \\
1146.60 \\
1207.23 \\
1263.90 \\
1302.96 \\
1323.89 \\
1318.53 \\
1346.45 \\
1368.74 \\
1382.71 \\
1392.33\end{array}$ & $\begin{array}{r}18.54 \\
52.11 \\
89.69 \\
128.76 \\
170.43 \\
214.17 \\
258.01 \\
303.24 \\
349.98 \\
396.41 \\
444.24 \\
494.03 \\
541.68 \\
591.43 \\
642.71 \\
689.99 \\
742.03 \\
792.36 \\
842.03 \\
892.80 \\
938.11 \\
983.37 \\
1046.39 \\
1108.57 \\
1185.96 \\
1262.36 \\
1359.19 \\
1452.51 \\
1544.83 \\
1638.14 \\
1735.86 \\
1812.71 \\
1891.99 \\
1968.01 \\
2046.80 \\
2123.14 \\
2197.19\end{array}$ & $\begin{array}{r}-0.0421 \\
-0.0177 \\
0.1113 \\
0.1102 \\
0.1188 \\
0.2788 \\
0.3724 \\
0.4963 \\
0.6955 \\
0.8346 \\
0.9188 \\
1.1697 \\
1.2139 \\
1.2806 \\
1.6812 \\
1.7139 \\
1.9538 \\
2.2281 \\
2.4416 \\
3.0952 \\
3.5361 \\
3.8274 \\
4.2061 \\
4.6105 \\
5.0752 \\
5.2578 \\
5.7060 \\
6.1007 \\
6.4514 \\
6.8306 \\
7.4009 \\
7.9196 \\
8.6742 \\
9.0838 \\
9.5433 \\
10.0297 \\
10.5117\end{array}$ & $\begin{array}{l}20.286 \\
24.232 \\
25.831 \\
27.351 \\
28.458 \\
29.002 \\
29.790 \\
30.281 \\
30.699 \\
31.086 \\
31.428 \\
31.456 \\
31.624 \\
31.729 \\
31.695 \\
31.686 \\
31.579 \\
31.243 \\
30.630 \\
28.399 \\
27.613 \\
27.281 \\
26.489 \\
25.810 \\
25.477 \\
25.431 \\
24.763 \\
24.077 \\
23.519 \\
22.719 \\
21.091 \\
19.230 \\
17.834 \\
17.081 \\
16.330 \\
15.481 \\
14.301\end{array}$ & $\begin{array}{l}0.302 \\
0.606 \\
0.906 \\
1.205 \\
1.507 \\
1.808 \\
2.109 \\
2.408 \\
2.710 \\
3.008 \\
3.310 \\
3.612 \\
3.910 \\
4.211 \\
4.510 \\
4.808 \\
5.111 \\
5.409 \\
5.709 \\
6.011 \\
6.312 \\
6.609 \\
7.009 \\
7.411 \\
7.908 \\
8.408 \\
9.009 \\
9.609 \\
10.207 \\
10.809 \\
11.453 \\
12.008 \\
12.608 \\
13.209 \\
13.811 \\
14.408 \\
15.015\end{array}$ \\
\hline
\end{tabular}


Table A-42. Deformation $J_{I C}$ and J-R curve results for specimen C1B-11

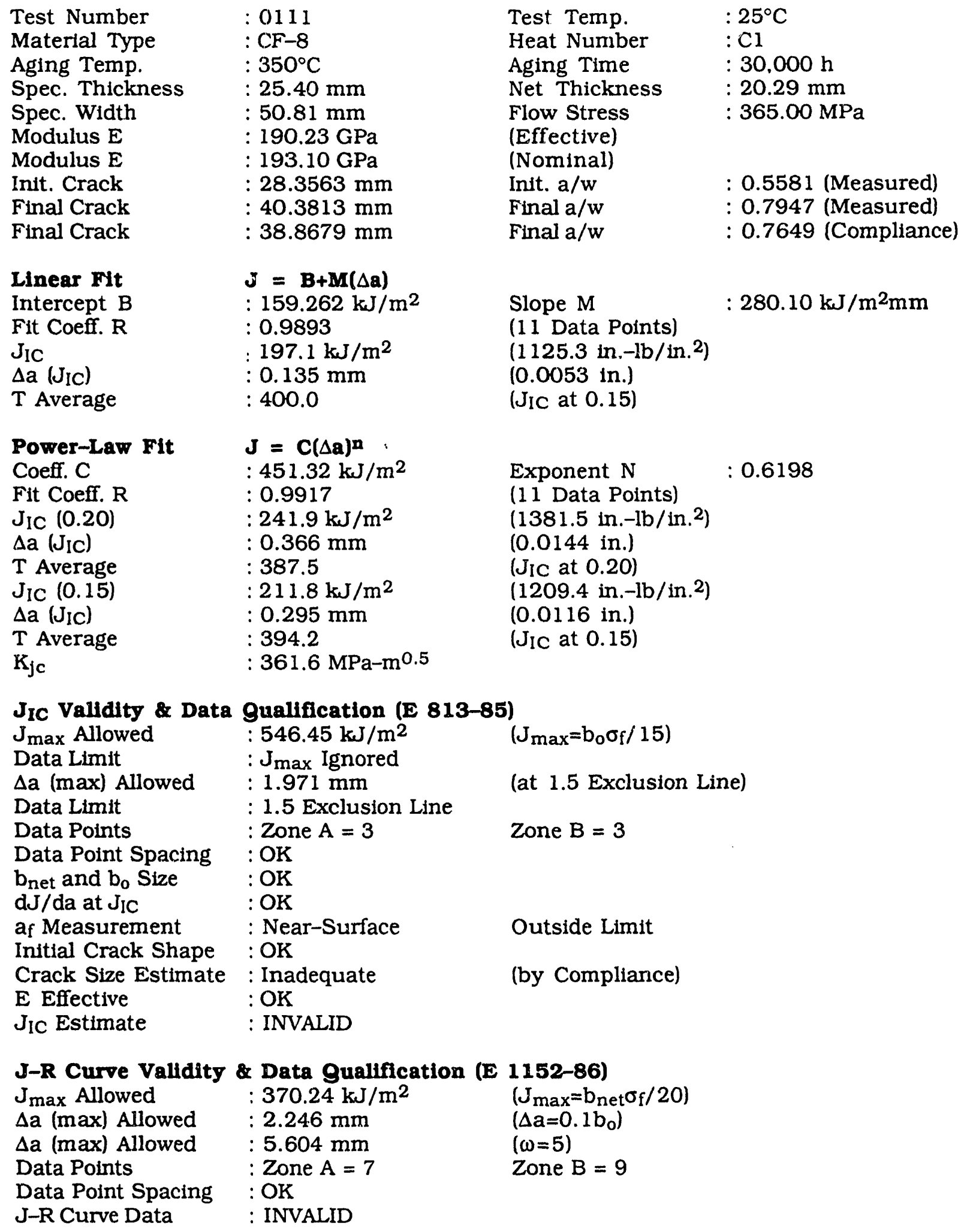


Table A-43. Modified $J_{I C}$ and $J-R$ curve results for specimen C1B-1 1

\begin{tabular}{|c|c|c|c|}
\hline Test Number & $: 0111$ & Test Temp. & $: 25^{\circ} \mathrm{C}$ \\
\hline Material Type & : CF-8 & Heat Number & $: \mathrm{Cl}$ \\
\hline Aging Temp. & $: 350^{\circ} \mathrm{C}$ & Aging Time & $: 30,000 \mathrm{~h}$ \\
\hline Spec. Thickness & $: 25.40 \mathrm{~mm}$ & Net Thickness & : $20.29 \mathrm{~mm}$ \\
\hline Spec. Width & $: 50.81 \mathrm{~mm}$ & Flow Stress & $: 365.00 \mathrm{MPa}$ \\
\hline Modulus $\mathrm{E}$ & $: 190.23 \mathrm{GPa}$ & (Effective) & \\
\hline Modulus E & $: 193.10 \mathrm{GPa}$ & (Nominal) & \\
\hline Init. Crack & $: 28.3563 \mathrm{~mm}$ & Init. $a / w$ & : 0.5581 (Measured) \\
\hline Final Crack & : $40.3813 \mathrm{~mm}$ & Final a/w & : 0.7947 (Measured) \\
\hline Final Crack & : $38.8679 \mathrm{~mm}$ & Final $a / w$ & : 0.7649 (Compliance) \\
\hline $\begin{array}{l}\text { Linear FIt } \\
\text { Intercept } B \\
\text { Fit Coeff. } R \\
\mathrm{~J}_{\mathrm{IC}} \\
\Delta \mathrm{a}\left(\mathrm{J}_{\mathrm{IC}}\right) \\
\mathrm{T} \text { Average }\end{array}$ & $\begin{array}{l}J=B+M(\Delta \mathbf{a}) \\
: 148.422 \mathrm{~kJ} / \mathrm{m}^{2} \\
: 0.9920 \\
: 188.4 \mathrm{~kJ} / \mathrm{m}^{2} \\
: 0.129 \mathrm{~mm} \\
: 442.5\end{array}$ & $\begin{array}{l}\text { Slope } M \\
\text { (11 Data Points) } \\
\left(1075.9 \text { in. }-1 \mathrm{~b} / \text { in. }{ }^{2}\right) \\
(0.0051 \text { in.) } \\
\left(\mathrm{JIC}_{\mathrm{IC}} 0.15\right)\end{array}$ & $: 309.89 \mathrm{~kJ} / \mathrm{m}^{2} \mathrm{~mm}$ \\
\hline $\begin{array}{l}\text { Power-Law Fit } \\
\text { Coeff. C } \\
\text { Fit Coeff. R } \\
\mathrm{J}_{I C}(0.20) \\
\Delta \mathrm{a}\left(\mathrm{J}_{\mathrm{IC}}\right) \\
\mathrm{T} \text { Average } \\
\mathrm{J}_{\mathrm{IC}}(0.15) \\
\Delta \mathrm{a}\left(\mathrm{J}_{\mathrm{IC}}\right) \\
\mathrm{T} \text { Average } \\
\mathrm{K}_{\mathrm{jc}}\end{array}$ & $\begin{array}{l}J=C(\Delta \mathbf{a})^{\mathbf{n}} \\
: 470.42 \mathrm{~kJ} / \mathrm{m}^{2} \\
: 0.9924 \\
: 244.7 \mathrm{~kJ} / \mathrm{m}^{2} \\
: 0.368 \mathrm{~mm} \\
: 424.1 \\
: 212.0 \mathrm{~kJ} / \mathrm{m}^{2} \\
: 0.295 \mathrm{~mm} \\
: 430.8 \\
: 375.6 \mathrm{MPa}-\mathrm{m}^{0.5}\end{array}$ & $\begin{array}{l}\text { Exponent } N \\
(11 \text { Data Points) } \\
\left(1397.1 \text { in. }-\mathrm{lb} / \text { in. }{ }^{2}\right) \\
(0.0145 \text { in. }) \\
\left(J_{I C} \text { at } 0.20\right) \\
\left(1210.7 \text { in. }-1 \mathrm{~b} / \text { in. }^{2}\right) \\
(0.0116 \text { in.) } \\
\left(J_{I C} \text { at } 0.15\right)\end{array}$ & $: 0.6532$ \\
\hline
\end{tabular}

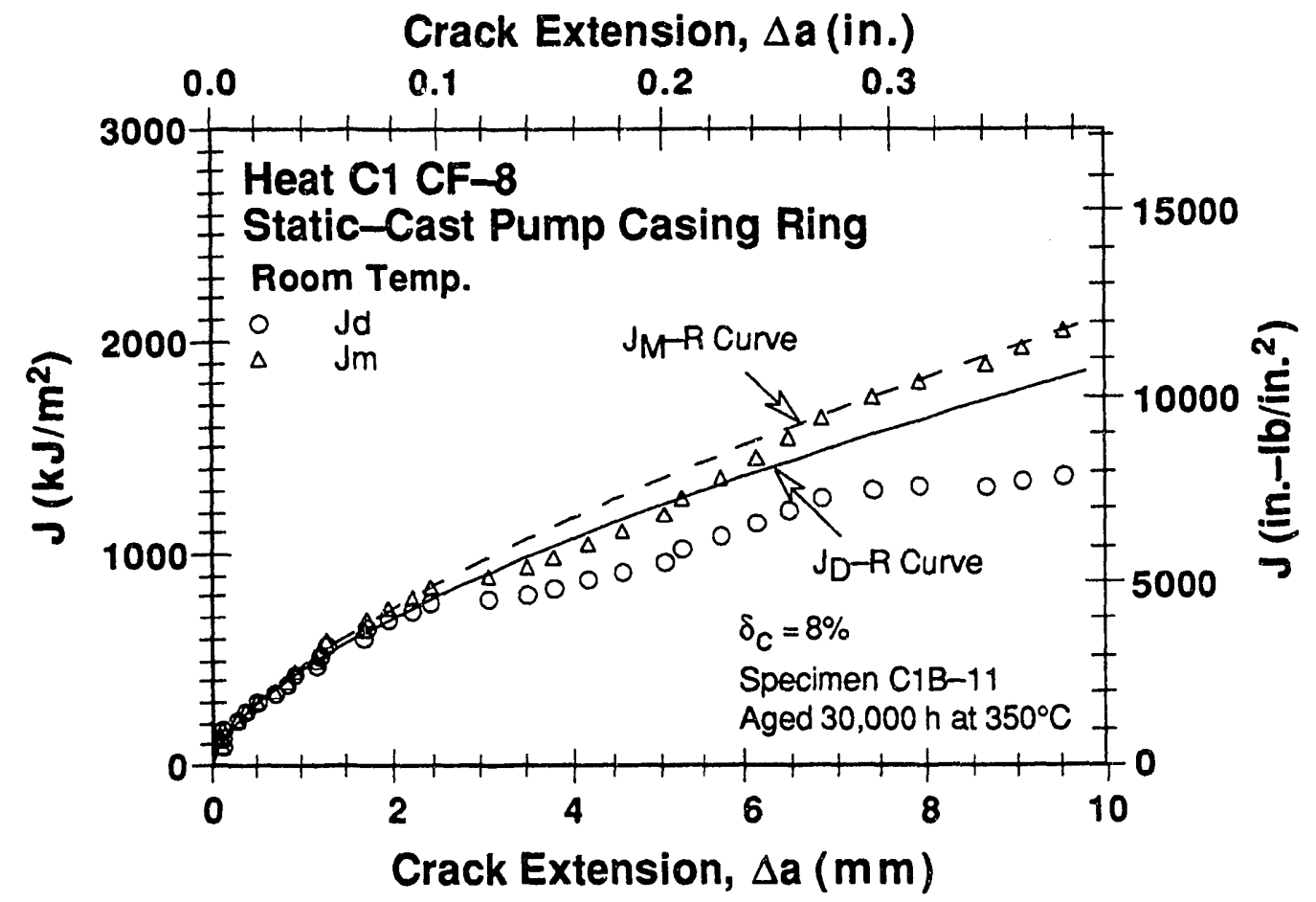

Figure A-41. Deformation and modified $J-R$ curves at room temp. for Heat $C 1$ aged $30,000 \mathrm{~h}$ at $350^{\circ} \mathrm{C}$ 


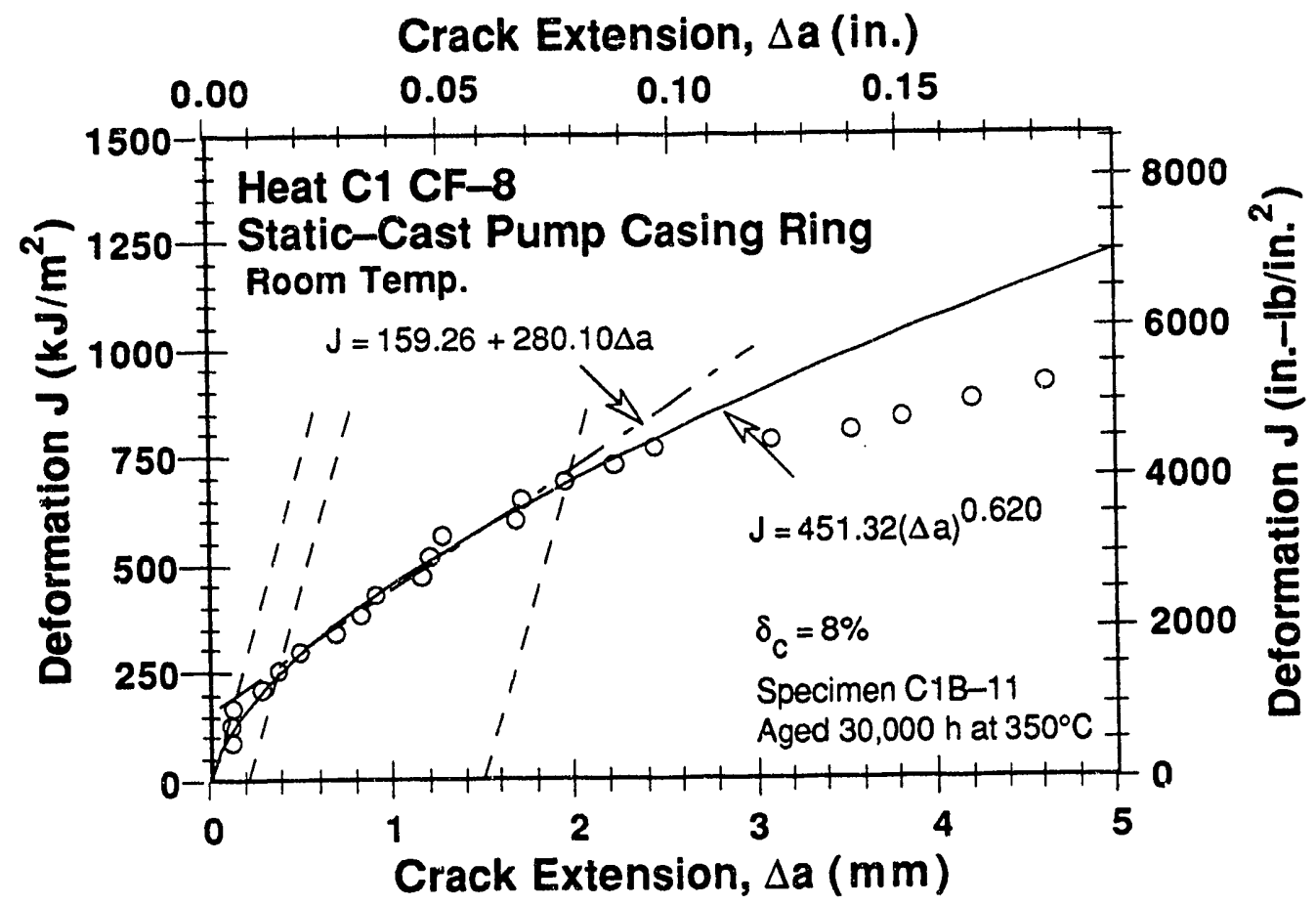

Figure A-42. Deformation $J_{I C}$ at room temp. for Heat $C 1$ aged $30,000 \mathrm{~h}$ at $350^{\circ} \mathrm{C}$

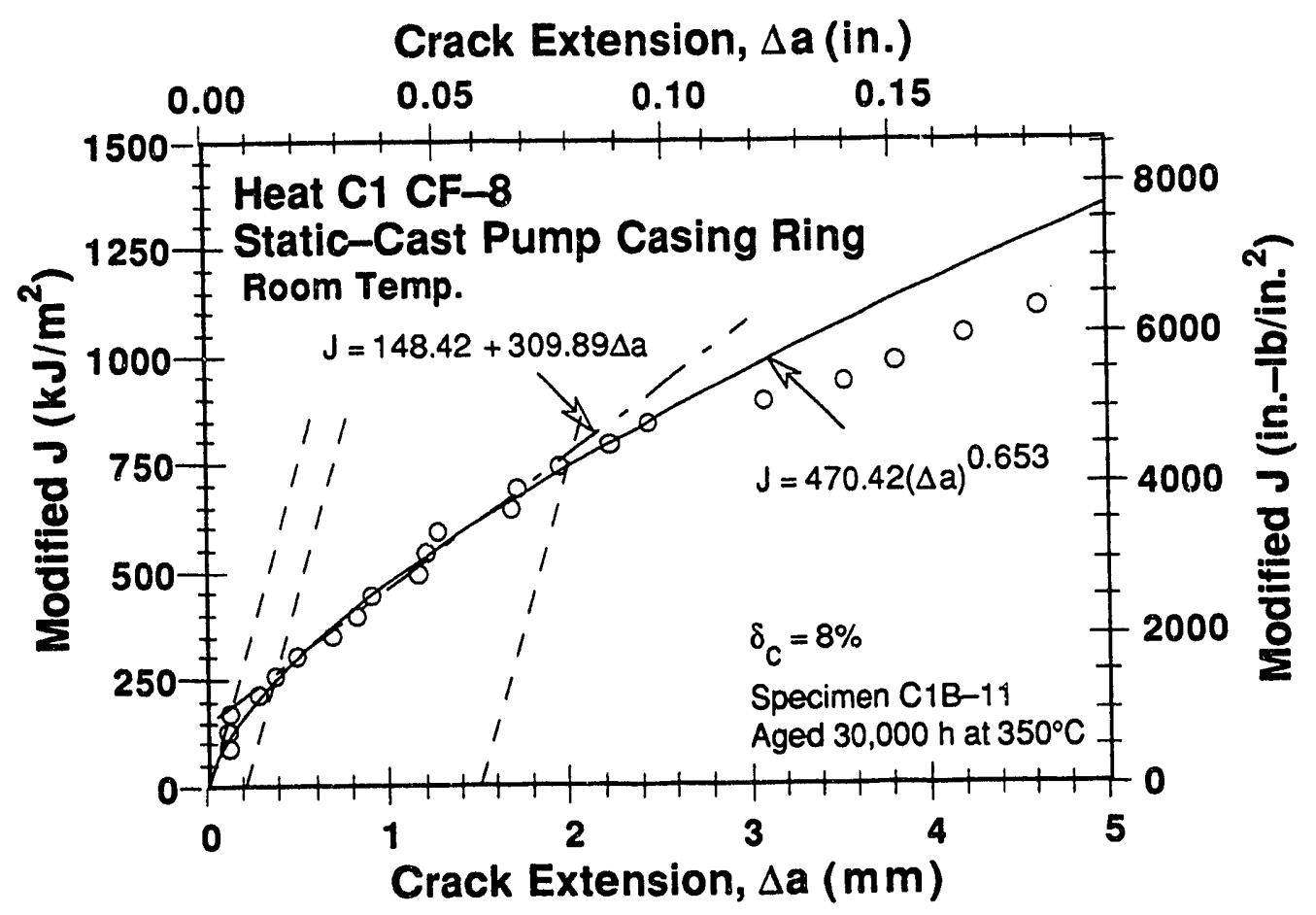

Figure A-43. Modified $J_{I C}$ at room temp. for Heat $C 1$ aged 30,000 h at $350^{\circ} \mathrm{C}$ 
Table A-44. 'Test data for specimen $C 1 B-19$

\begin{tabular}{|c|c|c|c|c|c|}
\hline $\begin{array}{l}\text { Test Num } \\
\text { Material } \\
\text { Aging Te } \\
\text { Spec. Th } \\
\text { Spec. Wic }\end{array}$ & $\begin{array}{ll}\mathrm{r} & : \\
\text { he } & \vdots \\
\text { hess } & : \\
& :\end{array}$ & $\mathrm{mm}$ & $\begin{array}{l}\text { Test } \\
\text { Heat } \\
\text { Aging } \\
\text { Net } \mathrm{T} \\
\sigma_{\mathrm{f}}\end{array}$ & & $\begin{array}{l}0 \mathrm{~h} \\
\mathrm{~mm}\end{array}$ \\
\hline $\begin{array}{c}\text { Unload } \\
\text { Number } \\
\end{array}$ & $\begin{array}{c}\mathrm{Jd}_{\mathrm{d}} \\
\left(\mathrm{kJ} / \mathrm{m}^{2}\right)\end{array}$ & $\begin{array}{c}J_{m} \\
\left(\mathrm{~kJ} / \mathrm{m}^{2}\right)\end{array}$ & $\begin{array}{c}\Delta \mathrm{a} \\
(\mathrm{mm})\end{array}$ & $\begin{array}{l}\text { Load } \\
(\mathrm{kN}) \\
\end{array}$ & $\begin{array}{c}\text { Deflection } \\
(\mathrm{mm})\end{array}$ \\
\hline $\begin{array}{l}1 \\
2 \\
3 \\
4 \\
5 \\
6 \\
7 \\
8 \\
9 \\
10 \\
11 \\
12 \\
13 \\
14 \\
15 \\
16 \\
17 \\
18 \\
19 \\
20 \\
21 \\
22 \\
23 \\
24 \\
25 \\
26 \\
27 \\
28 \\
29 \\
30 \\
31 \\
32 \\
33 \\
34 \\
35 \\
35 \\
37 \\
38\end{array}$ & $\begin{array}{r}14.88 \\
37.39 \\
62.49 \\
89.77 \\
117.92 \\
145.99 \\
177.30 \\
205.42 \\
239.10 \\
268.05 \\
299.93 \\
332.49 \\
362.96 \\
397.81 \\
423.83 \\
458.37 \\
483.08 \\
518.26 \\
543.78 \\
576.25 \\
607.31 \\
632.15 \\
663.69 \\
688.35 \\
720.56 \\
739.27 \\
783.18 \\
819.02 \\
850.82 \\
875.76 \\
905.25 \\
917.63 \\
927.12 \\
924.03 \\
948.74 \\
951.03 \\
963.48 \\
960.67\end{array}$ & $\begin{array}{r}14.96 \\
37.75 \\
62.62 \\
89.79 \\
117.88 \\
148.28 \\
177.76 \\
210.73 \\
241.13 \\
275.88 \\
308.77 \\
343.58 \\
378.79 \\
413.88 \\
451.35 \\
485.90 \\
523.32 \\
558.33 \\
597.06 \\
632.98 \\
670.89 \\
714.60 \\
757.07 \\
801.17 \\
843.20 \\
893.43 \\
939.88 \\
1003.14 \\
1063.52 \\
1122.19 \\
1178.81 \\
1234.82 \\
1287.93 \\
1337.67 \\
1386.79 \\
1436.03 \\
1482.72 \\
1529.57\end{array}$ & $\begin{array}{l}0.1278 \\
0.2832 \\
0.2165 \\
0.1907 \\
0.1815 \\
0.4655 \\
0.2839 \\
0.6921 \\
0.4554 \\
0.8242 \\
0.8811 \\
0.9951 \\
1.2121 \\
1.2222 \\
1.6632 \\
1.6633 \\
2.0847 \\
2.0793 \\
2.4619 \\
2.5556 \\
2.7306 \\
3.1851 \\
3.4333 \\
3.8509 \\
4.0503 \\
4.6583 \\
4.7045 \\
5.1695 \\
5.6255 \\
6.1346 \\
6.5226 \\
7.1185 \\
7.6887 \\
8.3551 \\
8.6494 \\
9.1949 \\
9.5776 \\
10.1143\end{array}$ & $\begin{array}{l}13.872 \\
15.887 \\
17.268 \\
18.145 \\
19.047 \\
19.724 \\
20.215 \\
20.671 \\
21.121 \\
21.513 \\
21.738 \\
22.185 \\
22.258 \\
22.428 \\
22.427 \\
22.403 \\
22.375 \\
22.335 \\
22.333 \\
22.116 \\
21.994 \\
21.717 \\
21.346 \\
20.956 \\
20.433 \\
20.082 \\
19.763 \\
19.338 \\
18.437 \\
17.555 \\
16.746 \\
15.727 \\
14.433 \\
13.417 \\
12.901 \\
12.244 \\
11.512 \\
10.912\end{array}$ & $\begin{array}{r}0.306 \\
0.606 \\
0.906 \\
1.207 \\
1.505 \\
1.807 \\
2.108 \\
2.407 \\
2.707 \\
3.007 \\
3.306 \\
3.608 \\
3.906 \\
4.209 \\
4.511 \\
4.811 \\
5.107 \\
5.407 \\
5.710 \\
6.010 \\
6.312 \\
6.657 \\
7.007 \\
7.358 \\
7.708 \\
8.107 \\
8.509 \\
9.006 \\
9.509 \\
10.008 \\
10.506 \\
11.005 \\
11.509 \\
12.006 \\
12.517 \\
13.010 \\
13.509 \\
14.010\end{array}$ \\
\hline
\end{tabular}


Table A-45. Deformation $J_{I C}$ and $J-R$ curve results for specimen C1B-19

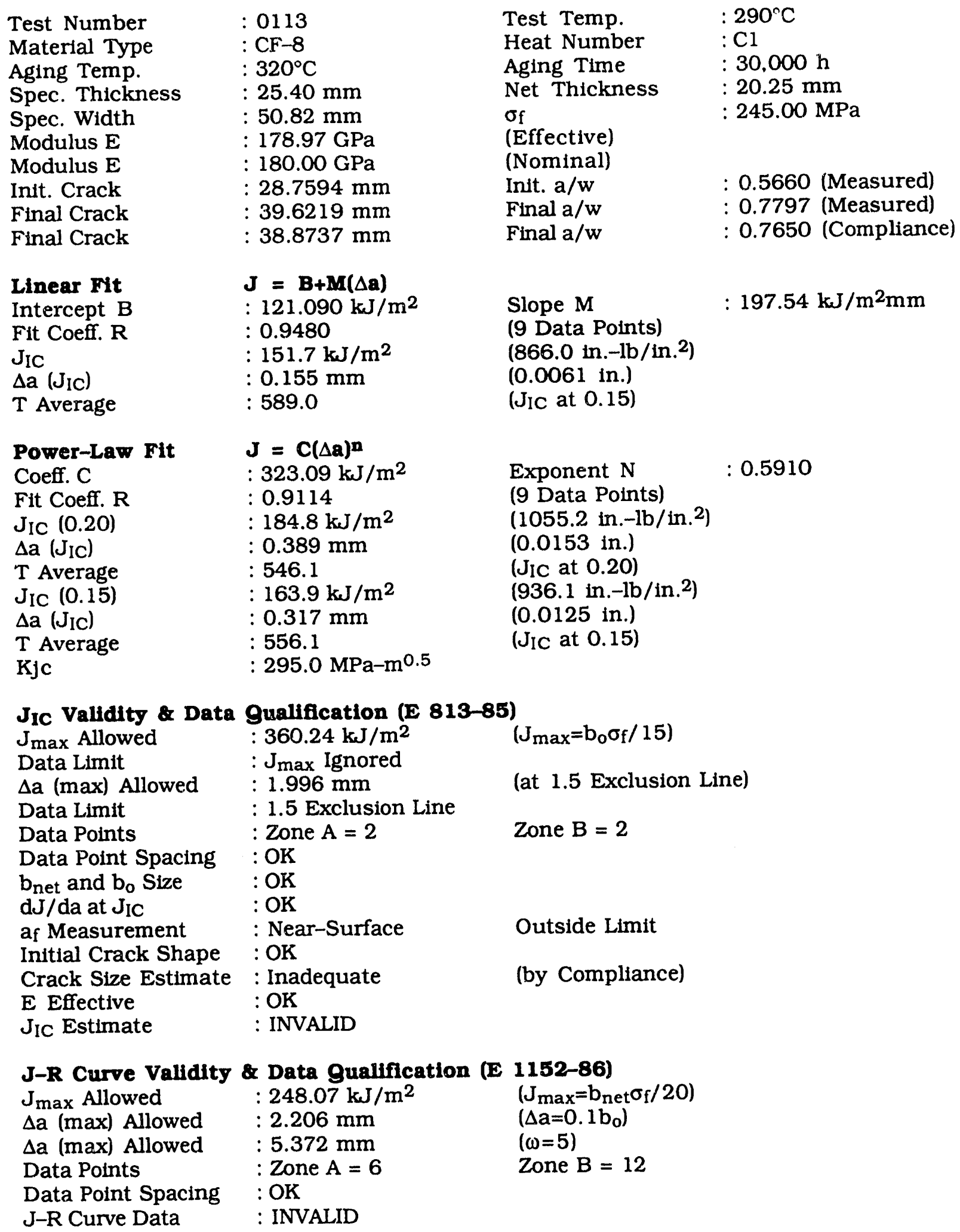


Table A-46. Modified $J_{I C}$ and $J-R$ curve results for specimen C1B-19

\begin{tabular}{|c|c|c|c|}
\hline Test Number & $: 0113$ & Test Temp. & $: 290^{\circ} \mathrm{C}$ \\
\hline Material Type & $: C F-8$ & Heat Number & : 1 \\
\hline Aging Temp. & $: 320^{\circ} \mathrm{C}$ & Aging Time & $: 30,000 \mathrm{~h}$ \\
\hline Spec. Thickness & $: 25.40 \mathrm{~mm}$ & Net Thickness & : $20.25 \mathrm{~mm}$ \\
\hline Spec. Width & $: 50.82 \mathrm{~mm}$ & & $: 245.00 \mathrm{MPa}$ \\
\hline $\begin{array}{l}\text { Modulus E } \\
\text { Modulus E }\end{array}$ & : $178.97 \mathrm{GPa}$ & (Effective) & \\
\hline $\begin{array}{l}\text { Modulus E } \\
\text { Init. Crack }\end{array}$ & $: 180.00 \mathrm{GPa}$ & (Nominal) & \\
\hline $\begin{array}{l}\text { Init. Crack } \\
\text { Final Crack }\end{array}$ & : $28.7594 \mathrm{~mm}$ & Init. a/w & : 0.5660 (Measured) \\
\hline $\begin{array}{l}\text { Final Crack } \\
\text { Final Crack }\end{array}$ & : $39.6219 \mathrm{~mm}$ & Final a/w & $\begin{array}{l}0.7797 \text { (Measured) } \\
0.7650 \text { (Compliance) }\end{array}$ \\
\hline Final Crack & $: 38.8737 \mathrm{~mm}$ & Final a/w & \\
\hline $\begin{array}{l}\text { Linear Fit } \\
\text { Intercept B }\end{array}$ & $J=\mathbf{B}+\mathbf{M}(\Delta \mathbf{a})$ & Slope $\mathrm{M}$ & $: 219.42 \mathrm{~kJ} / \mathrm{m}^{2} \mathrm{~mm}$ \\
\hline $\begin{array}{l}\text { Intercept } B \\
\text { Fit Coeff. } R\end{array}$ & $: 0.9573$ & (9 Data Points) & \\
\hline $\mathrm{J}_{\mathrm{IC}}$ & $: 143.4 \mathrm{~kJ} / \mathrm{m}^{2}$ & $\left(818.8\right.$ in. $-\mathrm{lb} /$ in $\left.^{2}{ }^{2}\right)$ & \\
\hline$\Delta \mathrm{a}\left(\mathrm{J}_{\mathrm{IC}}\right)$ & $: 0.146 \mathrm{~mm}$ & (0.0058 in.) & \\
\hline T Average & $: 654.2$ & $\left(\mathrm{~J}_{\mathrm{IC}}\right.$ at 0.15$)$ & \\
\hline Power-Law Fit & $J=C(\Delta \mathbf{a})^{\mathbf{n}}$ & & \\
\hline $\begin{array}{l}\text { Coeff. C } \\
\text { Fit Coeff. R }\end{array}$ & $: 335.18 \mathrm{~kJ} / \mathrm{m}^{2}$ & $\begin{array}{l}\text { Exponent } \mathrm{N} \\
\text { (9 Data Points) }\end{array}$ & $: 0.6302$ \\
\hline $\begin{array}{l}\text { Fit Coeff. } R \\
J_{I C}(0.20)\end{array}$ & $: 0.9222$ & $\begin{array}{l}\text { (9 Data Points) } \\
\left(1054.8 \text { in. }-1 \mathrm{~b} / \text { in }^{2}\right)\end{array}$ & \\
\hline $\begin{array}{l}J_{I C}(0.20) \\
\Delta a\left(J_{I C}\right)\end{array}$ & $\begin{array}{l}: 184.7 \mathrm{~kJ} / \mathrm{m}^{2} \\
: 0.388 \mathrm{~mm}\end{array}$ & $\begin{array}{l}(1054.8 \text { in. }-1 b / i n .4) \\
(0.0153 \text { in. })\end{array}$ & \\
\hline T Average & $: 602.6$ & $\left(\mathrm{JIC}_{\mathrm{IC}}\right.$ at 0.20$)$ & \\
\hline $\mathrm{J}_{\mathrm{IC}}(0.15)$ & $: 161.9 \mathrm{~kJ} / \mathrm{m}^{2}$ & (924.7 in.-lb/in. $\left.{ }^{2}\right)$ & \\
\hline$\Delta \mathrm{a}\left(\mathrm{J}_{\mathrm{IC}}\right)$ & $: 0.315 \mathrm{~mm}$ & (0.0124 in.) & \\
\hline T Average & $: 612.7$ & $\left(\mathrm{~J}_{\mathrm{IC}}\right.$ at 0.15$)$ & \\
\hline $\mathrm{KJC}$ & $: 306.4 \mathrm{MPa}-\mathrm{m}$ & & \\
\hline
\end{tabular}

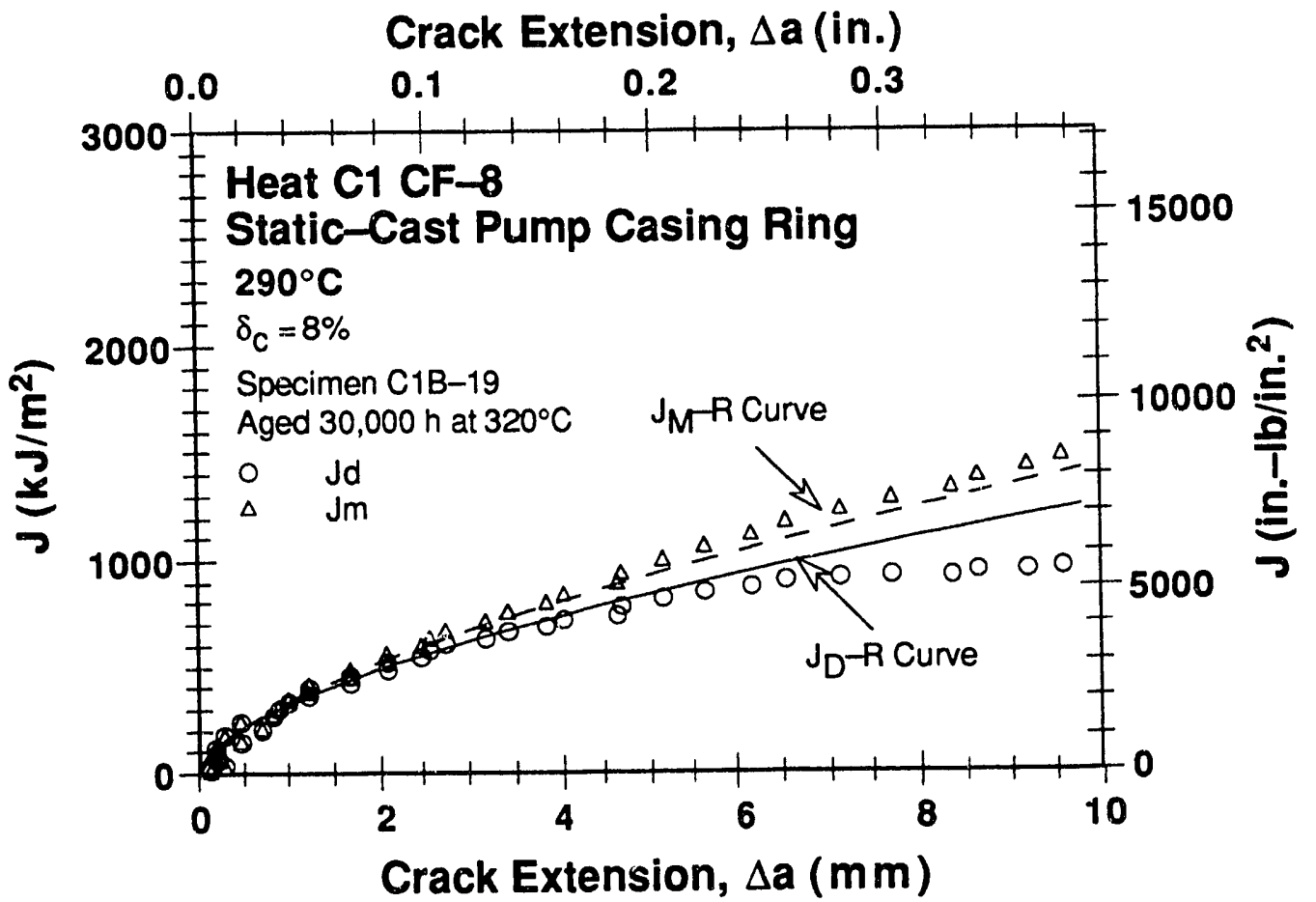

Figure A-44. Deformation and modified $J-R$ curves at $290^{\circ} \mathrm{C}$ for Heat C1 aged $30,000 \mathrm{~h}$ at $320^{\circ} \mathrm{C}$ 


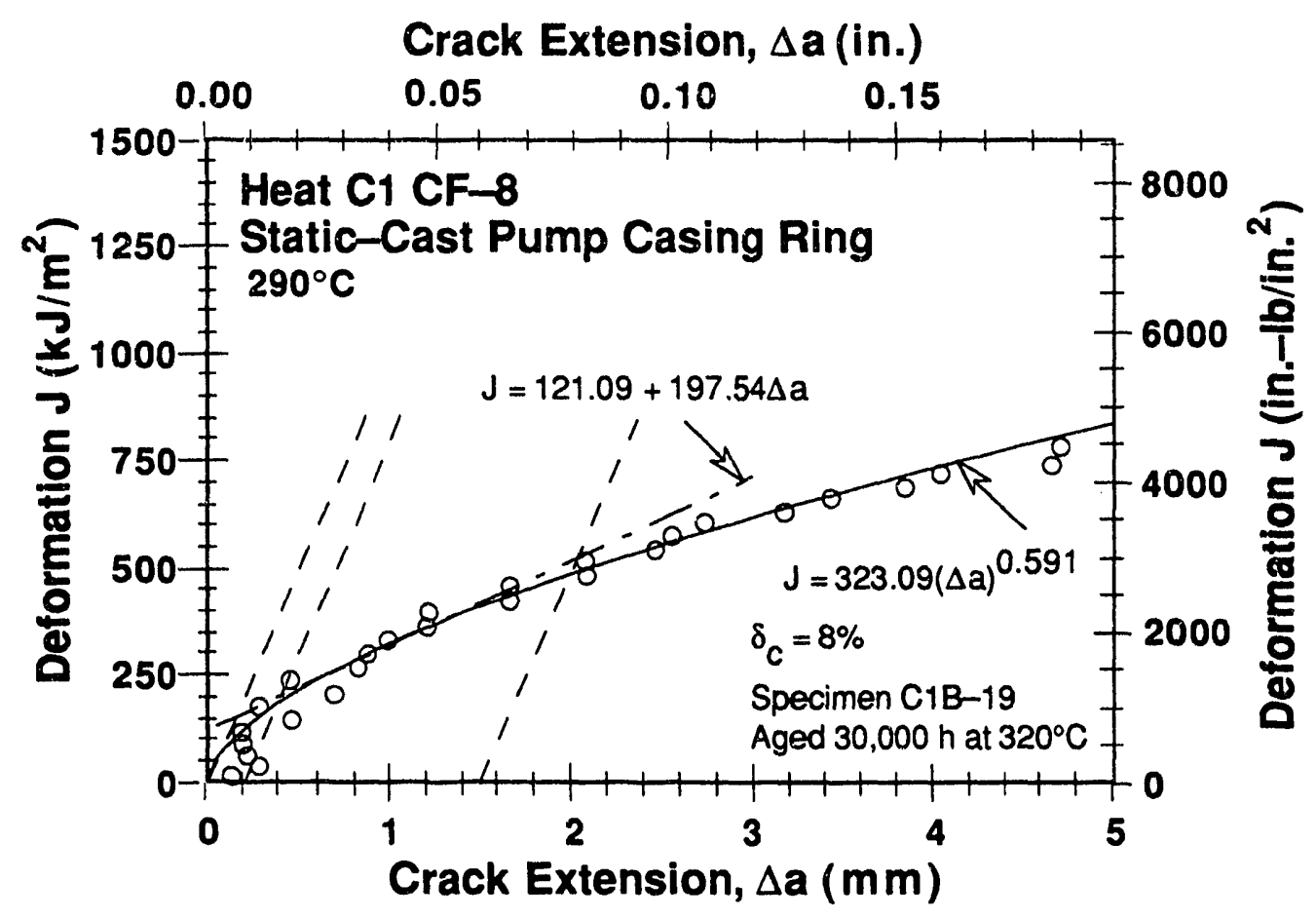

Figure A-45. Deformation $J_{I C}$ at $290^{\circ} \mathrm{C}$ for Heat $\mathrm{Cl}$ aged $30,000 \mathrm{~h}$ at $320^{\circ} \mathrm{C}$

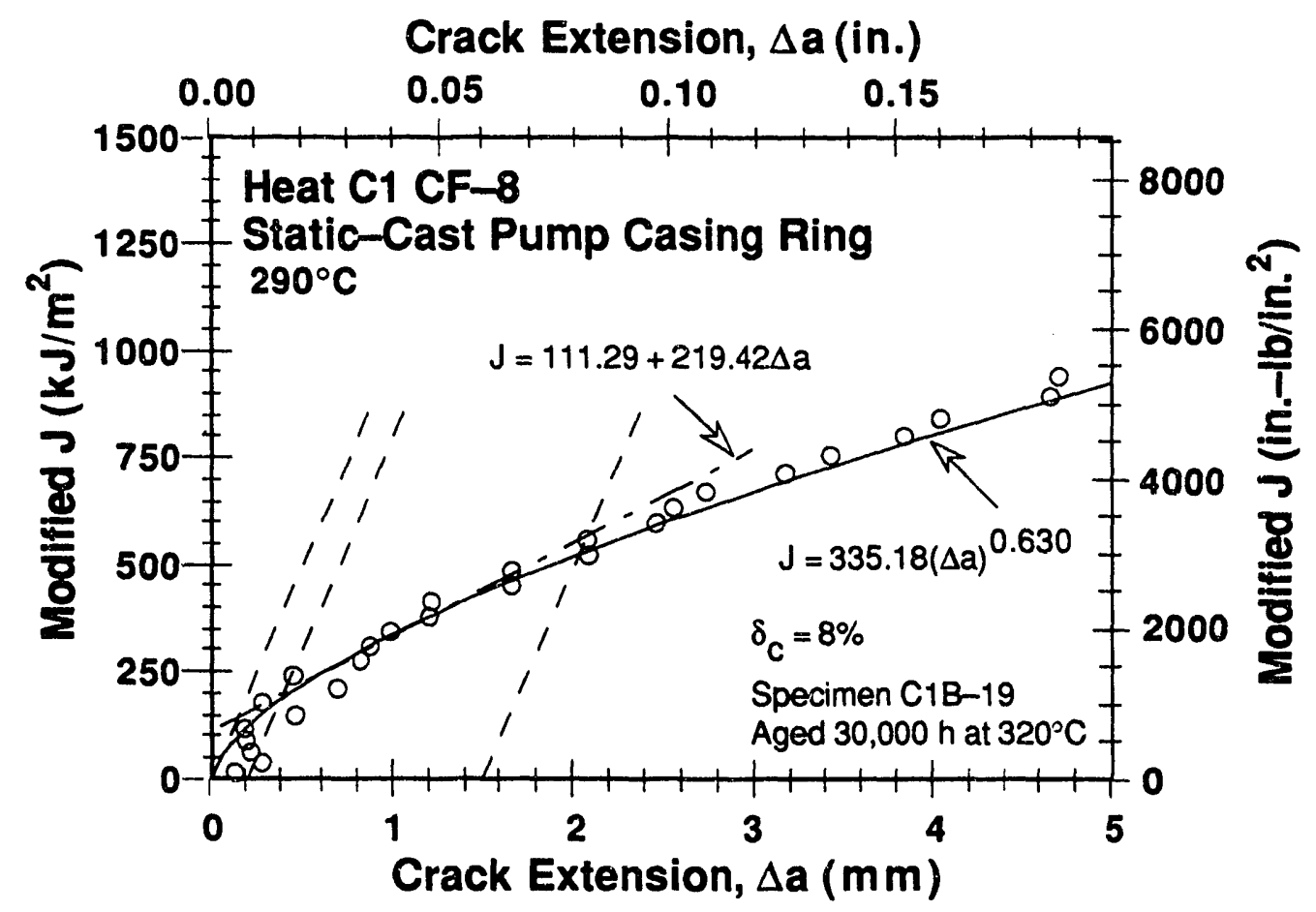

Figure A-46. Modifled $J_{I C}$ at $290^{\circ} \mathrm{C}$ for Heat $\mathrm{Cl}$ aged $30,000 \mathrm{~h}$ at $320^{\circ} \mathrm{C}$ 
Table A-47. Test data for specimen C1B-09

\begin{tabular}{|c|c|c|c|c|c|}
\hline $\begin{array}{l}\text { Test Num } \\
\text { Material } \\
\text { Aging Te } \\
\text { Spec. Th } \\
\text { Spec. Wid }\end{array}$ & $\begin{array}{ll}\text { ype } & : \\
\text { p. } & : \\
\text { kness } & \text { : } \\
\text { h } & \text { : }\end{array}$ & $\mathrm{mm}$ & $\begin{array}{l}\text { Test } \\
\text { Heat } \\
\text { Aging } \\
\text { Net } \\
\sigma_{f}\end{array}$ & $:$ & $\begin{array}{l}\mathrm{C} \\
00 \mathrm{~h} \\
2 \mathrm{~mm} \\
00 \mathrm{MPa}\end{array}$ \\
\hline $\begin{array}{l}\text { Unload } \\
\text { Number }\end{array}$ & $\begin{array}{c}J_{d} \\
\left(k J / m^{2}\right)\end{array}$ & $\begin{array}{c}\mathrm{J}_{\mathrm{m}} \\
\left(\mathrm{kJ} / \mathrm{m}^{2}\right)\end{array}$ & $\begin{array}{c}\Delta \mathrm{a} \\
(\mathrm{mm})\end{array}$ & $\begin{array}{l}\text { Load } \\
(\mathrm{kN})\end{array}$ & $\begin{array}{c}\text { Deflection } \\
\text { (mm) }\end{array}$ \\
\hline $\begin{array}{l}1 \\
2 \\
3 \\
4 \\
5 \\
6 \\
7 \\
8 \\
9 \\
10 \\
11 \\
12 \\
13 \\
14 \\
15 \\
16 \\
17 \\
18 \\
19 \\
20 \\
21 \\
22 \\
23 \\
24 \\
25 \\
26 \\
27 \\
28 \\
29 \\
30 \\
31 \\
32 \\
33 \\
34 \\
35 \\
36 \\
37 \\
38\end{array}$ & $\begin{array}{r}13.73 \\
34.98 \\
58.57 \\
82.83 \\
109.16 \\
136.28 \\
165.83 \\
194.72 \\
222.02 \\
252.38 \\
281.13 \\
314.55 \\
348.51 \\
378.30 \\
412.01 \\
434.41 \\
460.74 \\
482.29 \\
512.34 \\
545.20 \\
585.54 \\
620.27 \\
655.09 \\
686.18 \\
724.93 \\
751.99 \\
789.19 \\
816.15 \\
842.88 \\
870.51 \\
901.43 \\
931.44 \\
959.50 \\
971.79 \\
982.90 \\
1007.70 \\
1018.59 \\
1035.23\end{array}$ & $\begin{array}{r}13.75 \\
34.98 \\
58.50 \\
83.99 \\
110.02 \\
137.86 \\
166.71 \\
196.33 \\
227.14 \\
257.59 \\
290.50 \\
322.47 \\
356.07 \\
390.49 \\
424.05 \\
459.98 \\
493.38 \\
528.47 \\
561.88 \\
609.87 \\
655.83 \\
703.84 \\
751.05 \\
811.02 \\
868.23 \\
926.37 \\
982.62 \\
1039.47 \\
1094.70 \\
1150.47 \\
1205.50 \\
1260.66 \\
1315.18 \\
1368.99 \\
1420.65 \\
1471.08 \\
1523.43 \\
1570.64\end{array}$ & $\begin{array}{l}0.0474 \\
0.0346 \\
0.0108 \\
0.2824 \\
0.2340 \\
0.3279 \\
0.2539 \\
0.3188 \\
0.5904 \\
0.6033 \\
0.8484 \\
0.7706 \\
0.7530 \\
0.9574 \\
0.9512 \\
1.4599 \\
1.7080 \\
2.1537 \\
2.2572 \\
2.6877 \\
2.8356 \\
3.1601 \\
3.4433 \\
4.0574 \\
4.4220 \\
4.9981 \\
5.3290 \\
5.8189 \\
6.2609 \\
6.6747 \\
7.0106 \\
7.3432 \\
7.6765 \\
8.1778 \\
8.6480 \\
8.9324 \\
9.3747 \\
9.6885\end{array}$ & $\begin{array}{l}13.000 \\
14.931 \\
16.062 \\
17.047 \\
17.799 \\
18.456 \\
19.010 \\
19.517 \\
20.008 \\
20.422 \\
20.893 \\
21.193 \\
21.495 \\
21.658 \\
21.782 \\
21.602 \\
21.493 \\
21.178 \\
20.970 \\
20.959 \\
20.784 \\
20.539 \\
20.257 \\
19.804 \\
19.128 \\
18.214 \\
17.899 \\
17.080 \\
16.618 \\
16.292 \\
15.781 \\
15.295 \\
14.801 \\
14.105 \\
13.413 \\
12.854 \\
12.292 \\
11.724\end{array}$ & $\begin{array}{r}0.304 \\
0.605 \\
0.907 \\
1.205 \\
1.506 \\
1.805 \\
2.110 \\
2.408 \\
2.706 \\
3.006 \\
3.307 \\
3.608 \\
3.908 \\
4.207 \\
4.509 \\
4.810 \\
5.110 \\
5.409 \\
5.709 \\
6.109 \\
6.508 \\
6.908 \\
7.310 \\
7.810 \\
8.309 \\
8.808 \\
9.311 \\
9.808 \\
10.307 \\
10.809 \\
11.308 \\
11.809 \\
12.308 \\
12.808 \\
13.309 \\
13.811 \\
14.323 \\
14.812\end{array}$ \\
\hline
\end{tabular}


Table A-48. Deformation $J_{I C}$ and $J-R$ curve results for specimen $C 1 B-09$

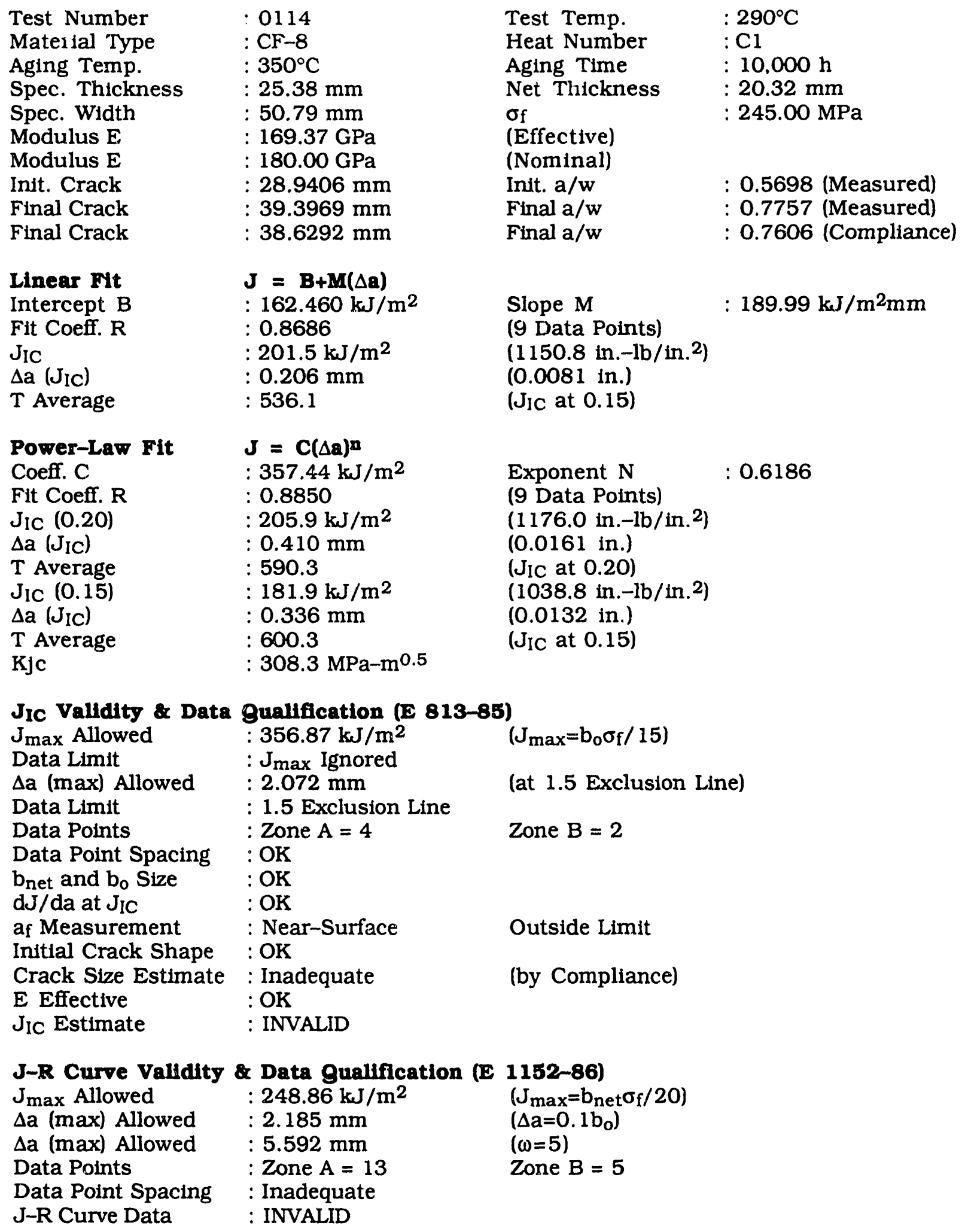


Table A-49. Modified $J_{I C}$ and $J-R$ curve results for specimen $C 1 B-09$

\begin{tabular}{|c|c|c|c|}
\hline Test Number & $: 0114$ & Test Temp. & : $290^{\circ} \mathrm{C}$ \\
\hline Material Type & $: C F-8$ & Heat Number & $: \mathrm{Cl}$ \\
\hline Aging Temip. & $: 350^{\circ} \mathrm{C}$ & Aging Time & $: 10,000 \mathrm{~h}$ \\
\hline Spec. Thickness & $: 25.38 \mathrm{~mm}$ & Net Thickness & $20.32 \mathrm{~mm}$ \\
\hline Spec. Width & : $50.79 \mathrm{~mm}$ & & $245.00 \mathrm{MPa}$ \\
\hline Modulus E & $: 169.37 \mathrm{GPa}$ & (Effective) & \\
\hline Modulus E & $: 180.00 \mathrm{GPa}$ & (Nominal) & \\
\hline Init. Crack & : $28.9406 \mathrm{~mm}$ & Init. $a / w$ & : 0.5698 (Measured) \\
\hline Final Crack & : $39.3969 \mathrm{~mm}$ & Final a/w & : 0.7757 (Measured) \\
\hline Final Crack & : $38.6292 \mathrm{~mm}$ & Final $a / w$ & : 0.7606 (Compliance) \\
\hline $\begin{array}{l}\text { Linear Fit } \\
\text { Intercept B } \\
\text { Fit Coeff. R } \\
J_{\text {IC }} \\
\Delta \text { a }\left(J_{I C}\right) \\
T \text { Average }\end{array}$ & $\begin{array}{l}J=B+M(\Delta \mathbf{Q}) \\
: 151.518 \mathrm{~kJ} / \mathrm{m}^{2} \\
: 0.8954 \\
: 194.1 \mathrm{~kJ} / \mathrm{m}^{2} \\
: 0.198 \mathrm{~mm} \\
: 606.7\end{array}$ & $\begin{array}{l}\text { Slope M } \\
\text { (9 Data Points) } \\
\left.\text { (1108.4 in.-lb/in. }{ }^{2}\right) \\
(0.0078 \text { in.) } \\
\text { (JIC at } 0.15 \text { ) }\end{array}$ & $: 215.01 \mathrm{~kJ} / \mathrm{m}^{2} \mathrm{~mm}$ \\
\hline $\begin{array}{l}\text { Power-Law Fit } \\
\text { Coeff. C } \\
\text { Fit Coeff. R } \\
\mathrm{J}_{I C}(0.20) \\
\Delta \mathrm{a}\left(\mathrm{J}_{\mathrm{IC}}\right) \\
\text { T Average } \\
\mathrm{J}_{1 \mathrm{C}}(0.15) \\
\Delta \mathrm{a}\left(\mathrm{J}_{\mathrm{IC}}\right) \\
\text { T Average } \\
\text { Kjc }\end{array}$ & $\begin{array}{l}J=C(\Delta \mathbf{a})^{\mathbf{n}} \\
: 371.61 \mathrm{~kJ} / \mathrm{m}^{2} \\
: 0.9047 \\
: 205.7 \mathrm{~kJ} / \mathrm{m}^{2} \\
: 0.410 \mathrm{~mm} \\
: 657.2 \\
: 179.2 \mathrm{~kJ} / \mathrm{m}^{2} \\
: 0.333 \mathrm{~mm} \\
: 667.2 \\
: 322.1 \mathrm{MPa}-\mathrm{m}^{0.5}\end{array}$ & $\begin{array}{l}\text { Exponent } \mathrm{N} \\
\text { (9 Data Points) } \\
\left(1174.7 \text { in.- }-\mathrm{lb} / \text { in. }{ }^{2}\right) \\
(0.0161 \mathrm{in.}) \\
\left(\mathrm{J}_{\mathrm{IC}} \text { at } 0.20\right) \\
\left(1023.2 \mathrm{in} .-\mathrm{lb} / \text { in. }^{2}\right) \\
(0.0131 \mathrm{in.}) \\
\left(\mathrm{J}_{\text {IC }} \text { at } 0.15\right)\end{array}$ & $: 0.6631$ \\
\hline
\end{tabular}

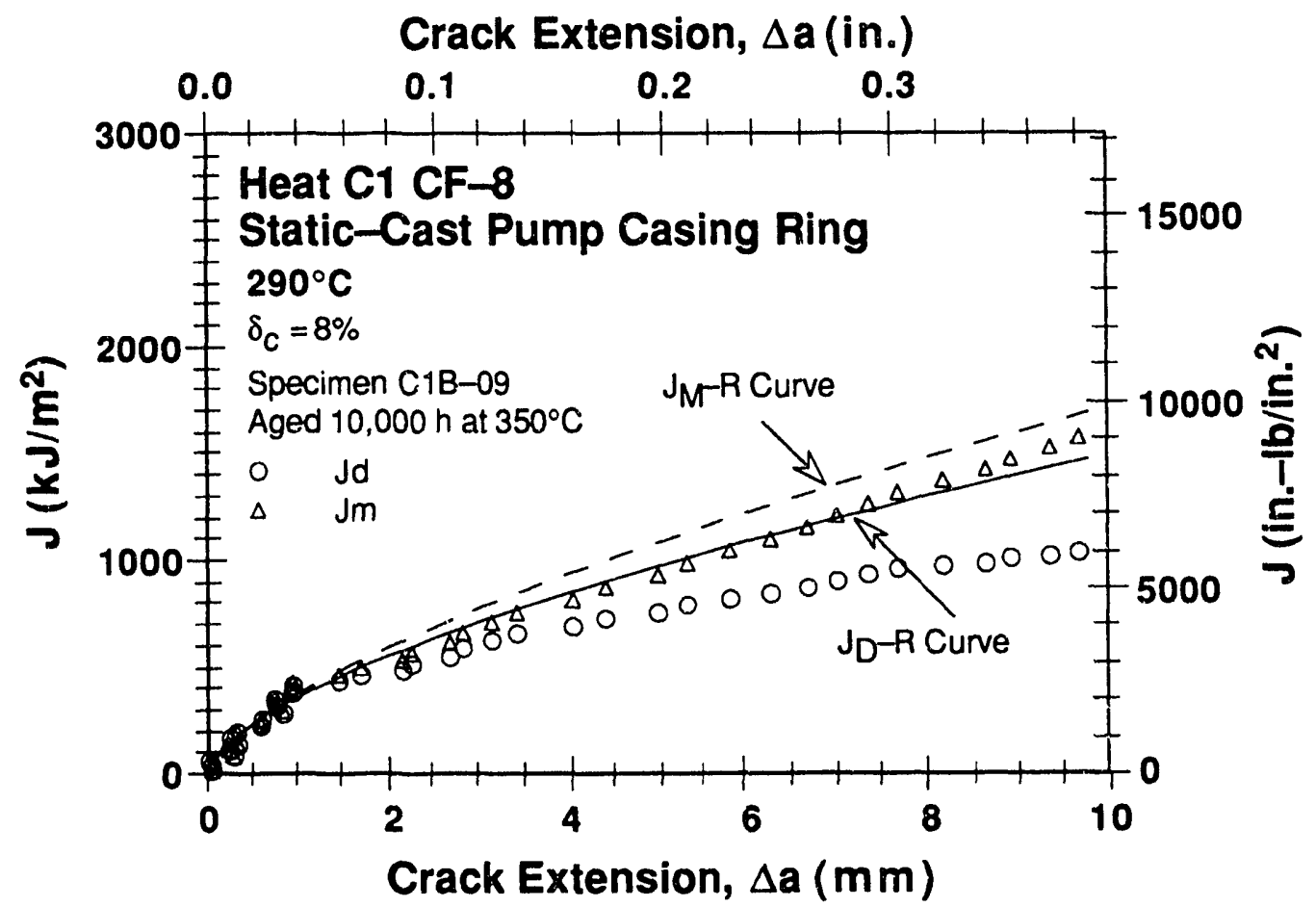

Figure A-47. Deformation and modified $J-R$ curves at $290^{\circ} \mathrm{C}$ for Heat $\mathrm{Cl}$ aged $10,000 \mathrm{~h}$ at $350^{\circ} \mathrm{C}$ 


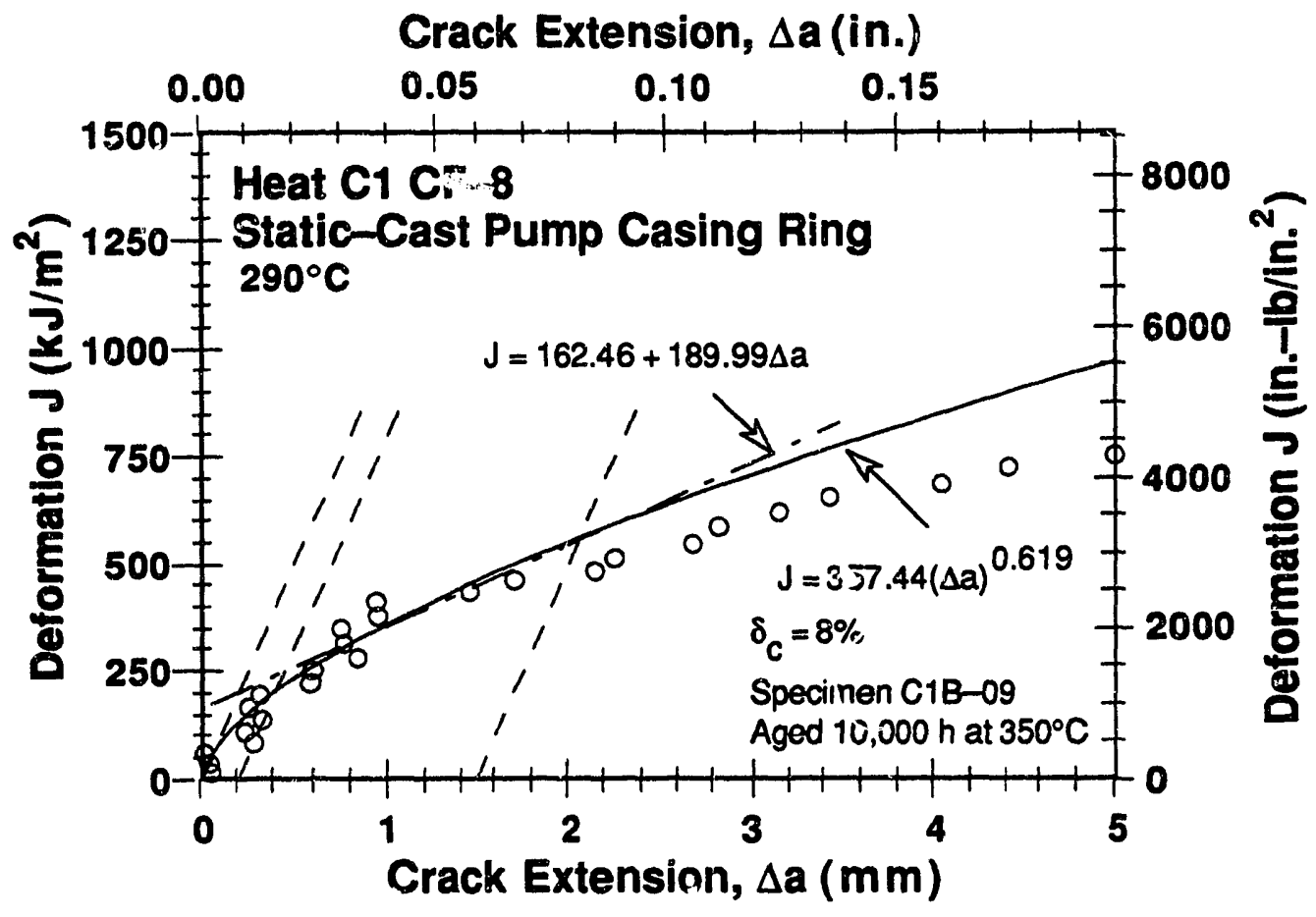

Figure A-48. Deformation $J_{I C}$ at $290^{\circ} \mathrm{C}$ for Heat $\mathrm{Cl}$ aged $10,000 \mathrm{~h}$ at $350^{\circ} \mathrm{C}$

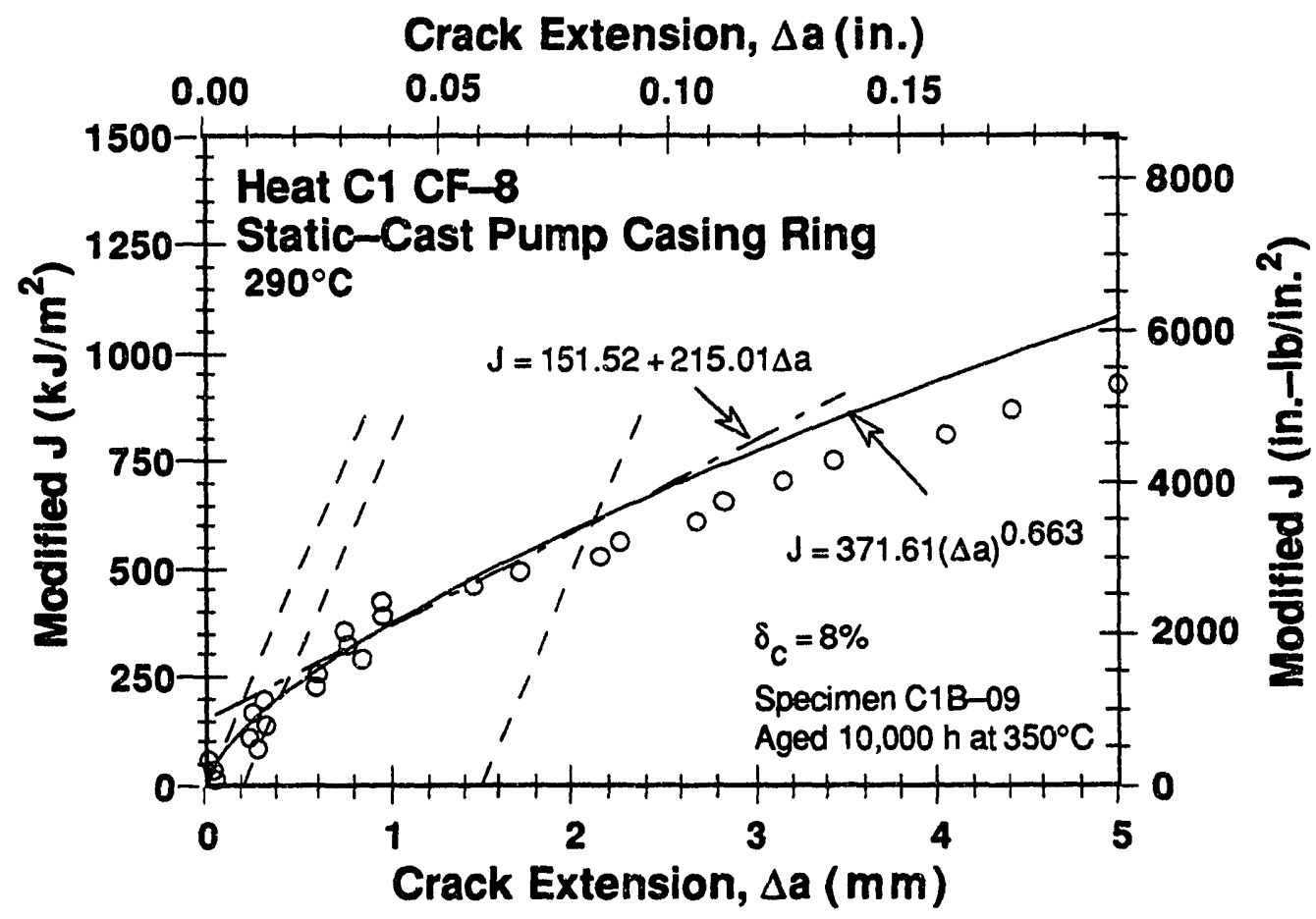

Figure A-49. Modified $J_{I C}$ at $290^{\circ} \mathrm{C}$ for Heat $\mathrm{Cl}$ aged $10,000 \mathrm{~h}$ at $350^{\circ} \mathrm{C}$ 
Table A-50. Test data for specimen C1B-12

\begin{tabular}{|c|c|c|c|c|c|}
\hline $\begin{array}{l}\text { Test Nun } \\
\text { Material } \\
\text { Aging Te } \\
\text { Spec. Th } \\
\text { Spec. Wi }\end{array}$ & $\begin{array}{l}\text { ype } \\
\text { p. } \\
\text { kness } \\
\text { h }\end{array}$ & $\mathrm{mm}$ & $\begin{array}{l}\text { Test } \\
\text { Heat } \\
\text { Aging } \\
\text { Net } 1 \\
\sigma_{f}\end{array}$ & & $\begin{array}{l}\mathrm{C} \\
00 \mathrm{~h} \\
7 \mathrm{~mm} \\
00 \mathrm{MPa}\end{array}$ \\
\hline $\begin{array}{l}\text { Unload } \\
\text { Number }\end{array}$ & $\begin{array}{c}J_{d} \\
\left(\mathrm{~kJ} / \mathrm{m}^{2}\right)\end{array}$ & $\begin{array}{c}J_{m} \\
\left(\mathrm{~kJ} / \mathrm{m}^{2}\right)\end{array}$ & $\begin{array}{c}\Delta a \\
(\mathrm{~mm})\end{array}$ & $\begin{array}{l}\text { Load } \\
(\mathrm{kN})\end{array}$ & $\begin{array}{l}\text { Deflection } \\
\text { (mm) }\end{array}$ \\
\hline $\begin{array}{l}1 \\
2 \\
3 \\
4 \\
5 \\
6 \\
7 \\
8 \\
9 \\
10 \\
11 \\
12 \\
13 \\
14 \\
15 \\
16 \\
17 \\
18 \\
19 \\
20 \\
21 \\
22 \\
23 \\
24 \\
25 \\
26 \\
27 \\
28 \\
29 \\
30 \\
31 \\
32 \\
33 \\
34 \\
35\end{array}$ & $\begin{array}{r}21.42 \\
43.94 \\
68.48 \\
94.10 \\
122.53 \\
150.52 \\
180.12 \\
216.05 \\
249.64 \\
283.57 \\
316.40 \\
351.75 \\
387.56 \\
422.15 \\
438.09 \\
480.59 \\
506.26 \\
545.13 \\
572.14 \\
611.43 \\
643.99 \\
678.44 \\
712.27 \\
757.39 \\
791.82 \\
834.12 \\
860.83 \\
892.48 \\
922.57 \\
949.61 \\
979.97 \\
1000.80 \\
1029.02 \\
1048.07 \\
1075.36\end{array}$ & $\begin{array}{r}21.31 \\
44.45 \\
68.59 \\
95.59 \\
122.06 \\
151.12 \\
180.21 \\
215.28 \\
251.96 \\
288.82 \\
327.06 \\
365.52 \\
404.98 \\
444.95 \\
474.68 \\
512.68 \\
556.64 \\
595.88 \\
639.52 \\
686.55 \\
736.13 \\
783.91 \\
844.95 \\
903.98 \\
965.22 \\
1023.84 \\
1095.88 \\
1164.36 \\
1231.75 \\
1298.72 \\
1363.84 \\
1416.73 \\
1480.85 \\
1553.63 \\
1623.58\end{array}$ & $\begin{array}{r}-0.1193 \\
0.1647 \\
0.0517 \\
0.3201 \\
0.0312 \\
0.1579 \\
0.1080 \\
0.0379 \\
0.2534 \\
0.4314 \\
0.7223 \\
0.8713 \\
1.0292 \\
1.2399 \\
1.7527 \\
1.6001 \\
2.1775 \\
2.1880 \\
2.6434 \\
2.8396 \\
3.2425 \\
3.5381 \\
4.0991 \\
4.3651 \\
4.8452 \\
5.1186 \\
5.8303 \\
6.3723 \\
6.8890 \\
7.4110 \\
7.8405 \\
8.2198 \\
8.6225 \\
9.1935 \\
9.6229\end{array}$ & $\begin{array}{l}14.295 \\
15.921 \\
16.929 \\
17.866 \\
18.554 \\
19.137 \\
19.730 \\
20.208 \\
20.780 \\
21.006 \\
21.331 \\
21.662 \\
21.709 \\
21.801 \\
21.782 \\
21.892 \\
21.804 \\
21.762 \\
21.644 \\
21.482 \\
21.337 \\
20.801 \\
20.415 \\
19.854 \\
19.526 \\
18.955 \\
18.225 \\
17.164 \\
16.433 \\
15.684 \\
14.972 \\
14.327 \\
13.596 \\
12.951 \\
12.287\end{array}$ & $\begin{array}{r}0.407 \\
0.706 \\
1.007 \\
1.307 \\
1.609 \\
1.906 \\
2.208 \\
2.558 \\
2.907 \\
3.257 \\
3.607 \\
3.958 \\
4.308 \\
4.658 \\
4.910 \\
5.256 \\
55.609 \\
5.958 \\
6.309 \\
6.707 \\
7.109 \\
7.508 \\
8.006 \\
8.507 \\
9.010 \\
9.508 \\
10.107 \\
10.709 \\
11.308 \\
11.908 \\
12.508 \\
13.004 \\
13.609 \\
14.308 \\
15.007\end{array}$ \\
\hline
\end{tabular}


Table A-51. Deformation $J_{I C}$ and $J-R$ curve results for specimen C1B-12

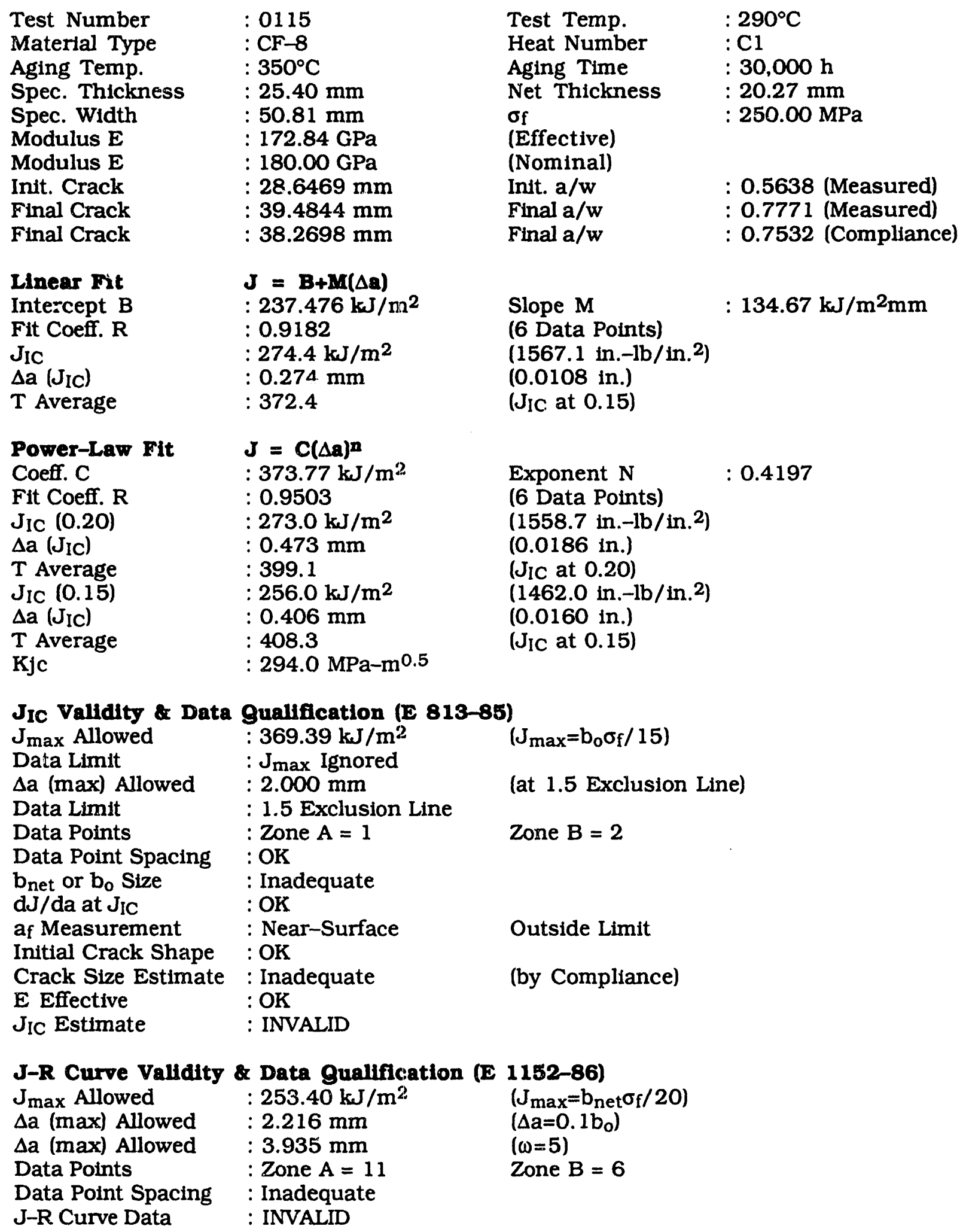


Table A-52. Modified. $J_{I C}$ and $J-R$ curve results for spectmen C1B-12

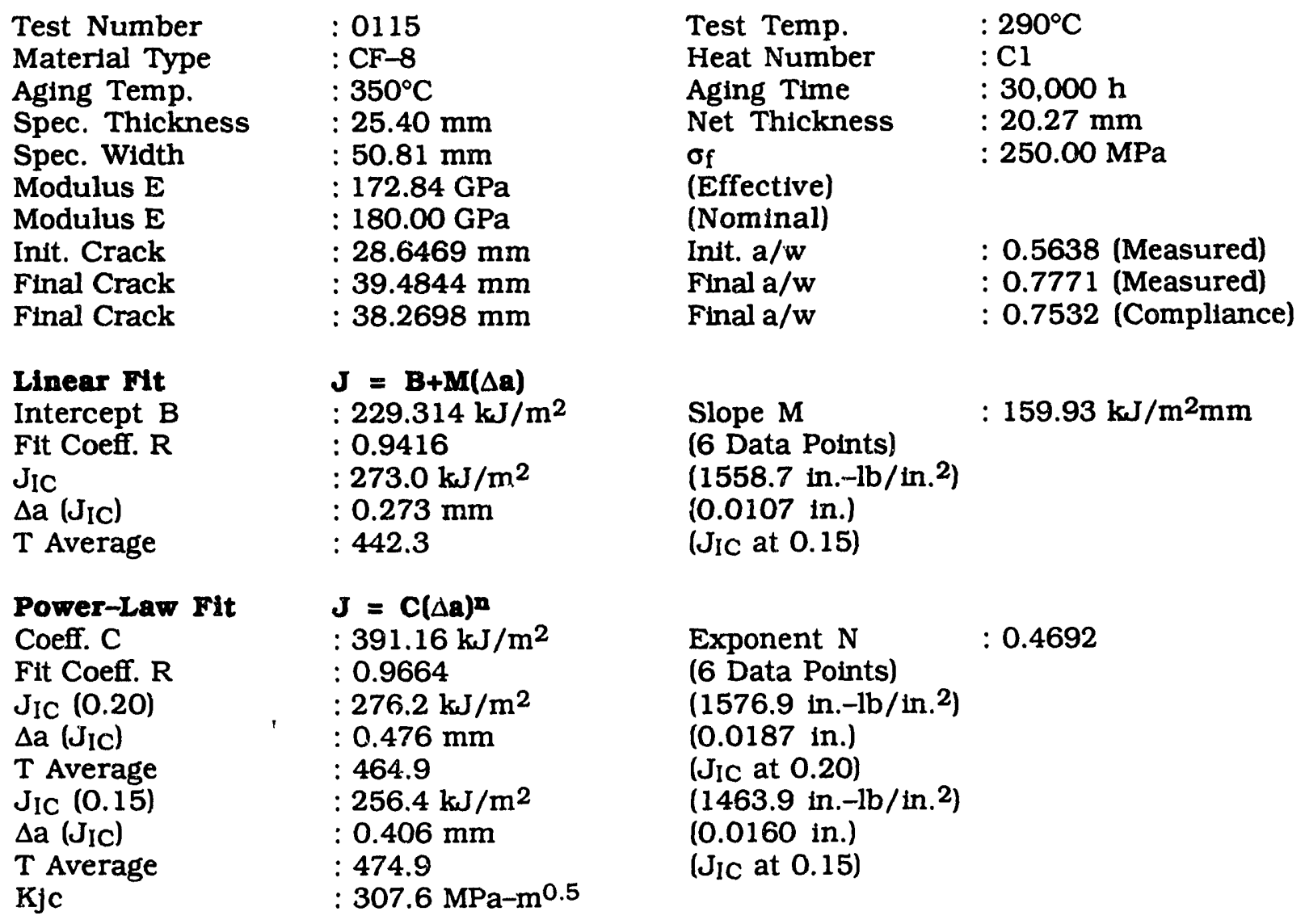

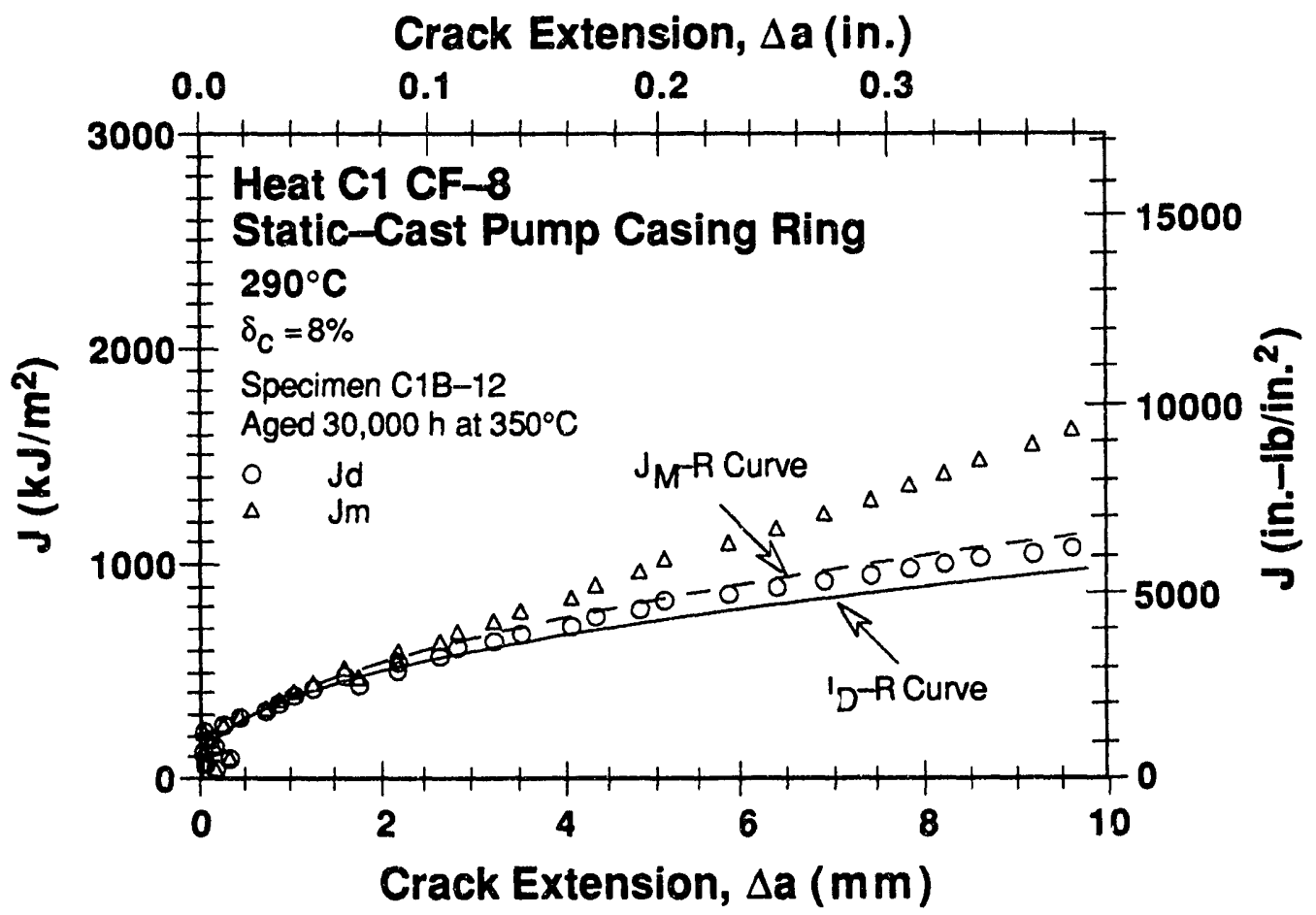

Figure A-50. Deformation and modified $J-R$ curves at $290^{\circ} \mathrm{C}$ for Heat $\mathrm{Cl}$ aged 30,000 h at $350^{\circ} \mathrm{C}$ 


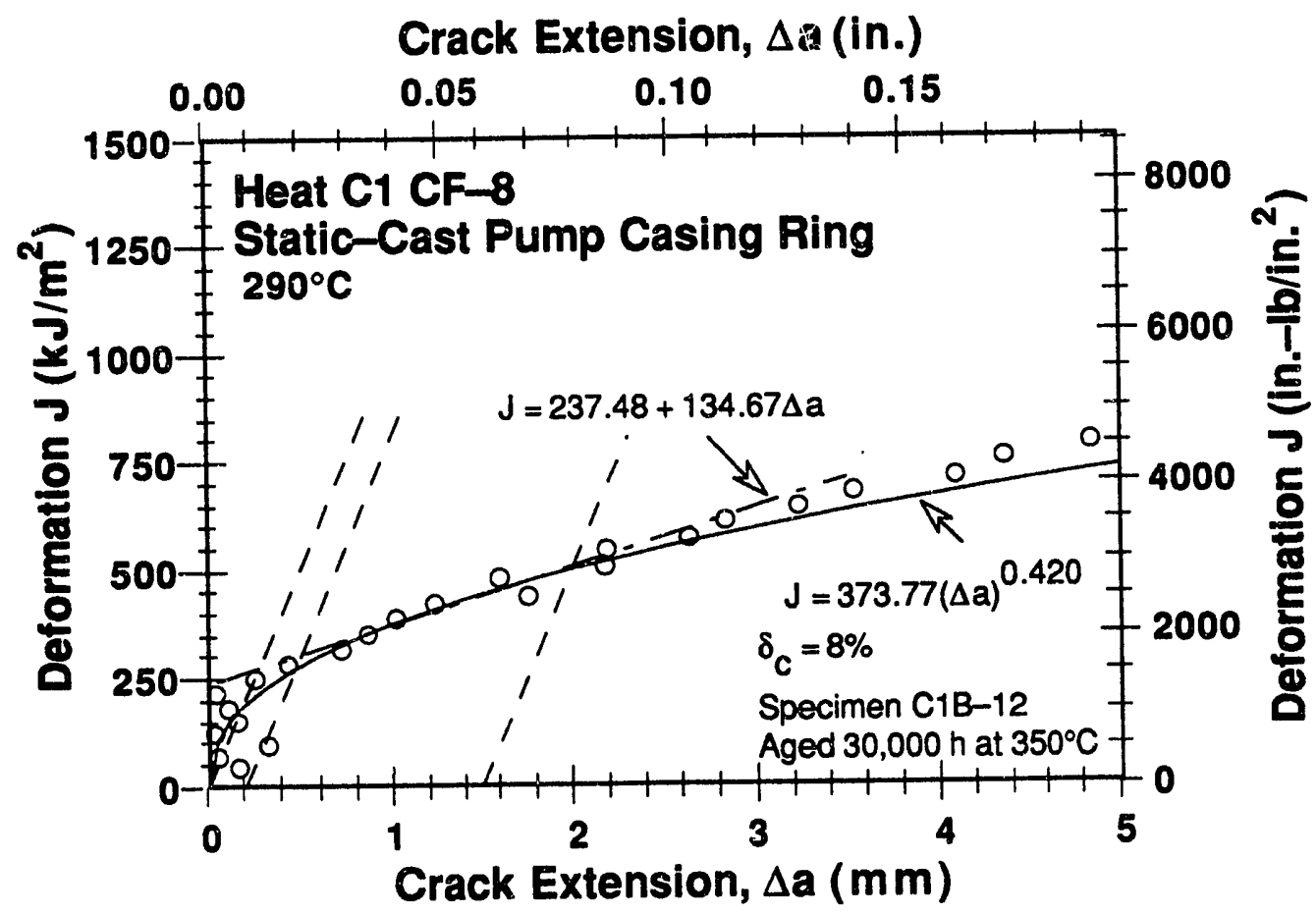

Fygure A-51. Deformation $\mathrm{J}_{\mathrm{IC}}$ at $290^{\circ} \mathrm{C}$ for Heat $\mathrm{Cl}$ aged $30,000 \mathrm{~h}$ at $350^{\circ} \mathrm{C}$

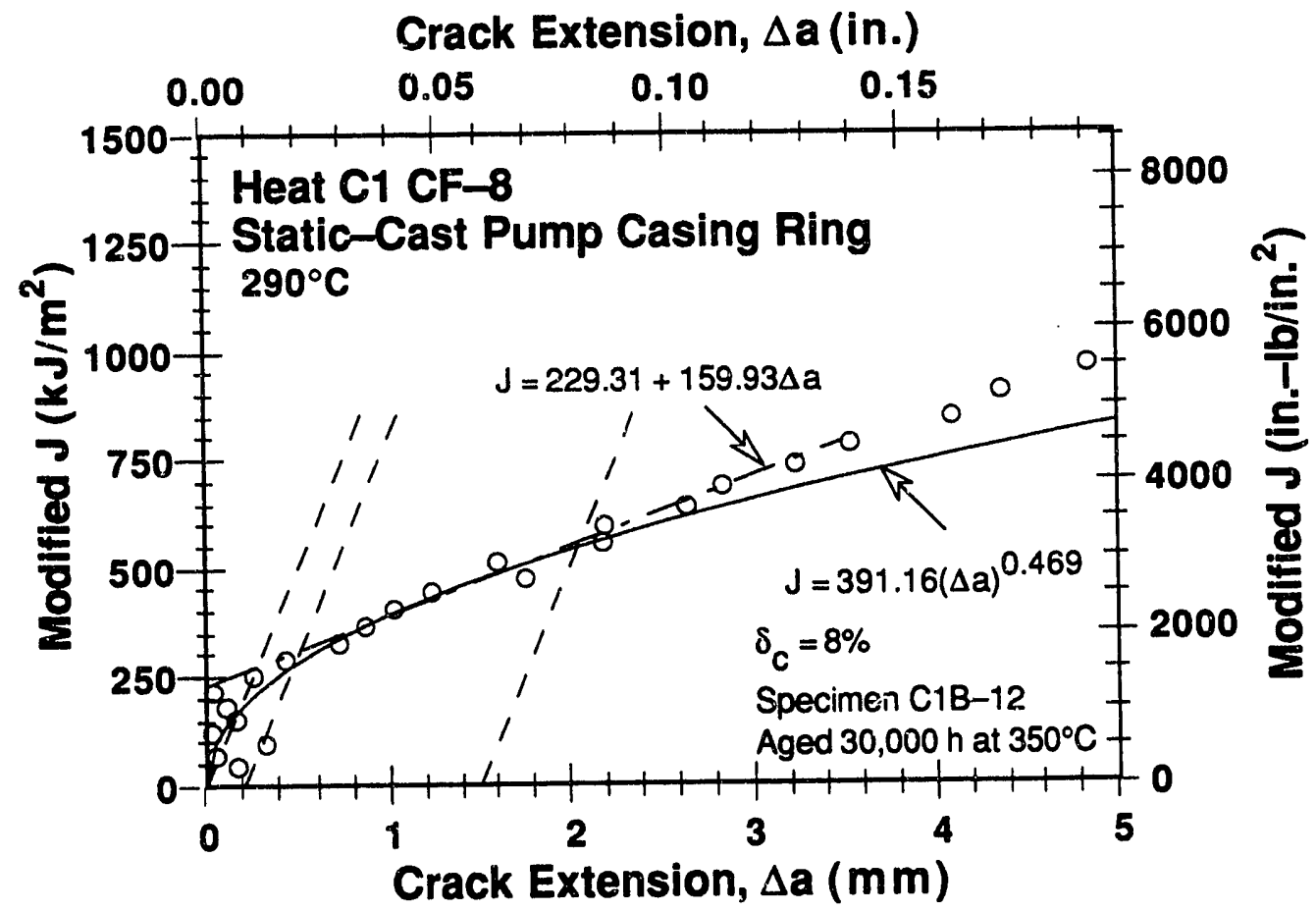

Figure A-52. Modifled $J_{I C}$ at $290^{\circ} \mathrm{C}$ for Heat $\mathrm{Cl}$ aged $30,000 \mathrm{~h}$ at $350^{\circ} \mathrm{C}$ 
Table A-53. Test data for spectmen 683-02B

\begin{tabular}{|c|c|c|c|c|c|}
\hline $\begin{array}{l}\text { Test Nun } \\
\text { Material } \\
\text { Aging TeI } \\
\text { Spec. Th } \\
\text { Spec. Wic }\end{array}$ & $\begin{array}{l}\text { er } \\
\text { pe } \\
\text { mess }\end{array}$ & $\mathrm{mm}$ & $\begin{array}{l}\text { Test } \\
\text { Heat } \\
\text { Aging } \\
\text { Net } 1 \\
\text { Flow }\end{array}$ & $\mathbf{S}$ & $\begin{array}{l}20 \mathrm{~h} \\
3 \mathrm{~mm} \\
30 \mathrm{MPa}\end{array}$ \\
\hline $\begin{array}{l}\text { Unload } \\
\text { Number }\end{array}$ & $\begin{array}{c}J_{d} \\
\left(\mathrm{~kJ} / \mathrm{m}^{2}\right)\end{array}$ & $\begin{array}{c}J_{\mathrm{m}} \\
\left(\mathrm{kJ} / \mathrm{m}^{2}\right)\end{array}$ & $\begin{array}{c}\Delta \mathrm{a} \\
(\mathrm{mm})\end{array}$ & $\begin{array}{l}\text { Load } \\
(\mathrm{kN}) \\
\end{array}$ & $\begin{array}{l}\text { Deflection } \\
(\mathrm{mm})\end{array}$ \\
\hline $\begin{array}{l}1 \\
2 \\
3 \\
4 \\
5 \\
6 \\
7 \\
8 \\
9 \\
10 \\
11 \\
12 \\
13 \\
14 \\
15 \\
16 \\
17 \\
18 \\
19 \\
20 \\
21 \\
22 \\
23 \\
24 \\
25 \\
26 \\
27 \\
28 \\
29 \\
30 \\
31 \\
32 \\
33 \\
34 \\
35 \\
36 \\
37 \\
38\end{array}$ & $\begin{array}{r}32.47 \\
92.54 \\
161.57 \\
215.93 \\
272.93 \\
332.28 \\
391.39 \\
454.65 \\
514.06 \\
571.95 \\
632.26 \\
695.70 \\
758.05 \\
816.45 \\
879.57 \\
944.67 \\
1004.41 \\
1059.50 \\
1114.68 \\
1171.11 \\
1239.70 \\
1281.11 \\
1325.13 \\
1375.07 \\
1414.02 \\
1474.46 \\
1542.38 \\
1597.09 \\
1665.22 \\
1740.29 \\
1790.61 \\
1842.65 \\
1888.23 \\
1905.78 \\
1933.26 \\
1943.92 \\
1976.07 \\
2023.84\end{array}$ & $\begin{array}{r}32.48 \\
92.48 \\
162.19 \\
217.16 \\
274.08 \\
333.12 \\
394.52 \\
455.07 \\
520.12 \\
584.61 \\
647.96 \\
713.82 \\
781.64 \\
847.39 \\
913.73 \\
982.42 \\
1050.57 \\
1119.82 \\
1188.16 \\
1256.08 \\
1331.21 \\
1389.81 \\
1459.48 \\
1522.58 \\
1589.77 \\
1677.81 \\
1763.83 \\
1875.47 \\
1981.02 \\
2087.17 \\
2219.01 \\
2340.33 \\
2459.60 \\
2592.45 \\
2716.07 \\
2839.40 \\
2959.61 \\
3079.90\end{array}$ & $\begin{array}{r}0.0076 \\
-0.0087 \\
0.0779 \\
0.1348 \\
0.1287 \\
0.1117 \\
0.2202 \\
0.1349 \\
0.3123 \\
0.5190 \\
0.6043 \\
0.6657 \\
0.7913 \\
0.9466 \\
1.0096 \\
1.0744 \\
1.2162 \\
1.4406 \\
1.6368 \\
1.7980 \\
1.8843 \\
2.1016 \\
2.4113 \\
2.5630 \\
2.8758 \\
3.1653 \\
3.3451 \\
3.8787 \\
4.2103 \\
4.4704 \\
5.1141 \\
5.6325 \\
6.1550 \\
6.9323 \\
7.5501 \\
8.2427 \\
8.7593 \\
9.1641\end{array}$ & $\begin{array}{l}26.797 \\
32.788 \\
36.013 \\
37.372 \\
38.723 \\
39.890 \\
40.589 \\
41.368 \\
41.939 \\
42.417 \\
42.946 \\
43.276 \\
43.157 \\
43.393 \\
43.459 \\
43.657 \\
43.789 \\
43.392 \\
43.337 \\
41.849 \\
41.794 \\
41.220 \\
40.647 \\
39.894 \\
39.353 \\
38.806 \\
38.143 \\
36.777 \\
36.481 \\
35.702 \\
34.040 \\
32.611 \\
29.760 \\
27.264 \\
25.762 \\
24.225 \\
23.317 \\
22.305\end{array}$ & $\begin{array}{r}0.405 \\
0.806 \\
1.208 \\
1.508 \\
1.808 \\
2.109 \\
2.409 \\
2.711 \\
3.011 \\
3.313 \\
3.612 \\
3.913 \\
4.216 \\
4.510 \\
4.810 \\
5.113 \\
5.410 \\
5.710 \\
6.010 \\
6.312 \\
6.651 \\
6.907 \\
7.217 \\
7.512 \\
7.810 \\
8.213 \\
8.612 \\
9.110 \\
9.615 \\
10.111 \\
10.711 \\
11.311 \\
11.911 \\
12.611 \\
13.311 \\
14.010 \\
14.711 \\
15.404\end{array}$ \\
\hline
\end{tabular}


Table A-54. Deformation $J_{I C}$ and $J-R$ curve results for specimen $683-02 B$

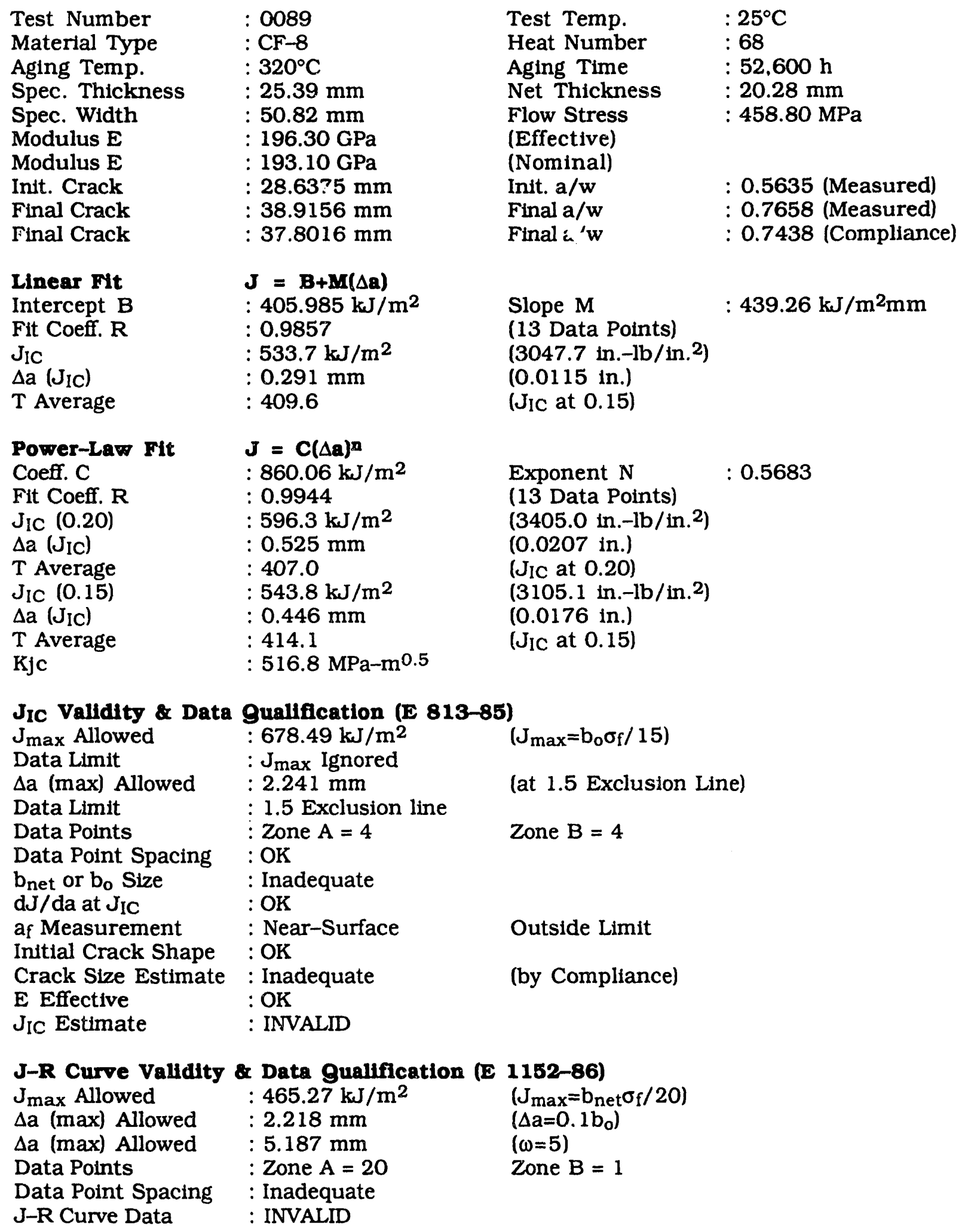


Table A-55. Modified $J_{I C}$ and $J-R$ curve results for spectmen 683-02B

\begin{tabular}{|c|c|c|c|}
\hline Test Number & : 0089 & Test Temp. & $: 25^{\circ} \mathrm{C}$ \\
\hline Material Type & $: C F-8$ & Heat Number & $: 68$ \\
\hline Aging Temp. & $: 320^{\circ} \mathrm{C}$ & Aging Time & $: 52,600 \mathrm{~h}$ \\
\hline Spec. Thickness & $: 25.39 \mathrm{~mm}$ & Net Thickness & $20.28 \mathrm{~mm}$ \\
\hline Spec. Width & $: 50.82 \mathrm{~mm}$ & Flow Stress & $: 458.80 \mathrm{MPa}$ \\
\hline Modulus E & $: 196.30 \mathrm{GPa}$ & (Effective) & \\
\hline Modulus E & $: 193.10 \mathrm{GPa}$ & (Nominal) & \\
\hline Init. Crack & $: 28.6375 \mathrm{~mm}$ & Init. $a / w$ & : 0.5635 (Measured) \\
\hline Final Crack & $: 38.9156 \mathrm{~mm}$ & Final $a / w$ & : 0.7658 (Measured) \\
\hline Final Crack & : $37.8016 \mathrm{~mm}$ & Final a/w & : 0.7438 (Compliance) \\
\hline $\begin{array}{l}\text { Linear Fit } \\
\text { Intercept B } \\
\text { Fit Coeff. } R \\
J_{I C} \\
\Delta A\left(J_{I C}\right) \\
T \text { Average }\end{array}$ & $\begin{array}{l}J=B+M(\Delta Q) \\
: 382.067 \mathrm{~kJ} / \mathrm{m}^{2} \\
: 0.9904 \\
: 525.0 \mathrm{~kJ} / \mathrm{m}^{2} \\
: 0.286 \mathrm{~mm} \\
: 466.0\end{array}$ & $\begin{array}{l}\text { Slope } M \\
\text { (13 Data Points) } \\
\left(2998.1 \text { in.-lb/in. }{ }^{2}\right) \\
(0.0113 \text { in.) } \\
\left(J_{I C} \text { at } 0.15\right)\end{array}$ & $: 499.75 \mathrm{~kJ} / \mathrm{m}^{2} \mathrm{~mm}$ \\
\hline $\begin{array}{l}\text { Power-Law Fit } \\
\text { Coeff. C } \\
\text { Fit Coeff. R } \\
\mathrm{J}_{\mathrm{IC}}(0.20) \\
\Delta \mathrm{a}\left(\mathrm{J}_{\mathrm{IC}} \mathrm{C}\right) \\
\text { T Average } \\
\mathrm{J}_{\mathrm{IC}}(0.15) \\
\Delta \mathrm{a}\left(\mathrm{J}_{\mathrm{IC}}\right) \\
\text { T Average } \\
\text { Kjc }\end{array}$ & $\begin{array}{l}J=C(\Delta a)^{\mathbf{n}} \\
: 897.33 \mathrm{~kJ} / \mathrm{m}^{2} \\
: 0.9962 \\
: 611.0 \mathrm{~kJ} / \mathrm{m}^{2} \\
: 0.533 \mathrm{~mm} \\
: 455.9 \\
: 551.4 \mathrm{~kJ} / \mathrm{m}^{2} \\
: 0.450 \mathrm{~mm} \\
: 463.3 \\
: 542.4 \mathrm{MPa}-\mathrm{m}^{0.5}\end{array}$ & $\begin{array}{l}\text { Exponent } N \\
(13 \text { Datc Points) } \\
\left(3488.9 \text { in.-lb/in. }{ }^{2}\right) \\
(0.0210 \mathrm{in.}) \\
\left(\mathrm{J}_{\mathrm{IC}} \text { at } 0.20\right) \\
\left(3148.3 \mathrm{in} .-\mathrm{lb} / \mathrm{in}^{2}\right) \\
(0.0177 \mathrm{in.}) \\
\left(\mathrm{J}_{\mathrm{IC}} \text { at } 0.15\right)\end{array}$ & $: 0.6107$ \\
\hline
\end{tabular}

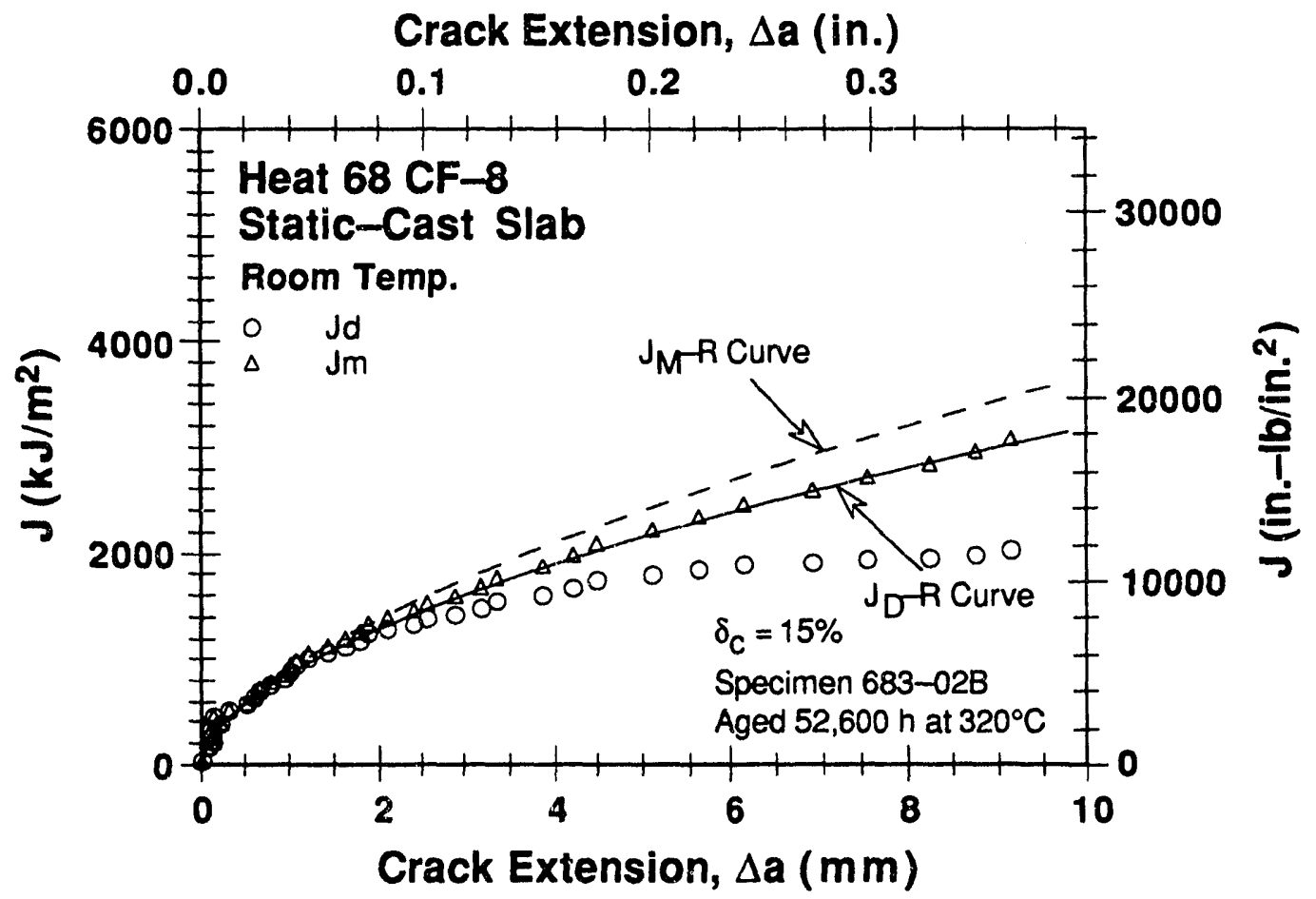

Figure A-53. Deformation and modified $J-R$ curves at room temp. for Heat 68 aged $52,600 \mathrm{~h}$ at $320^{\circ} \mathrm{C}$ 


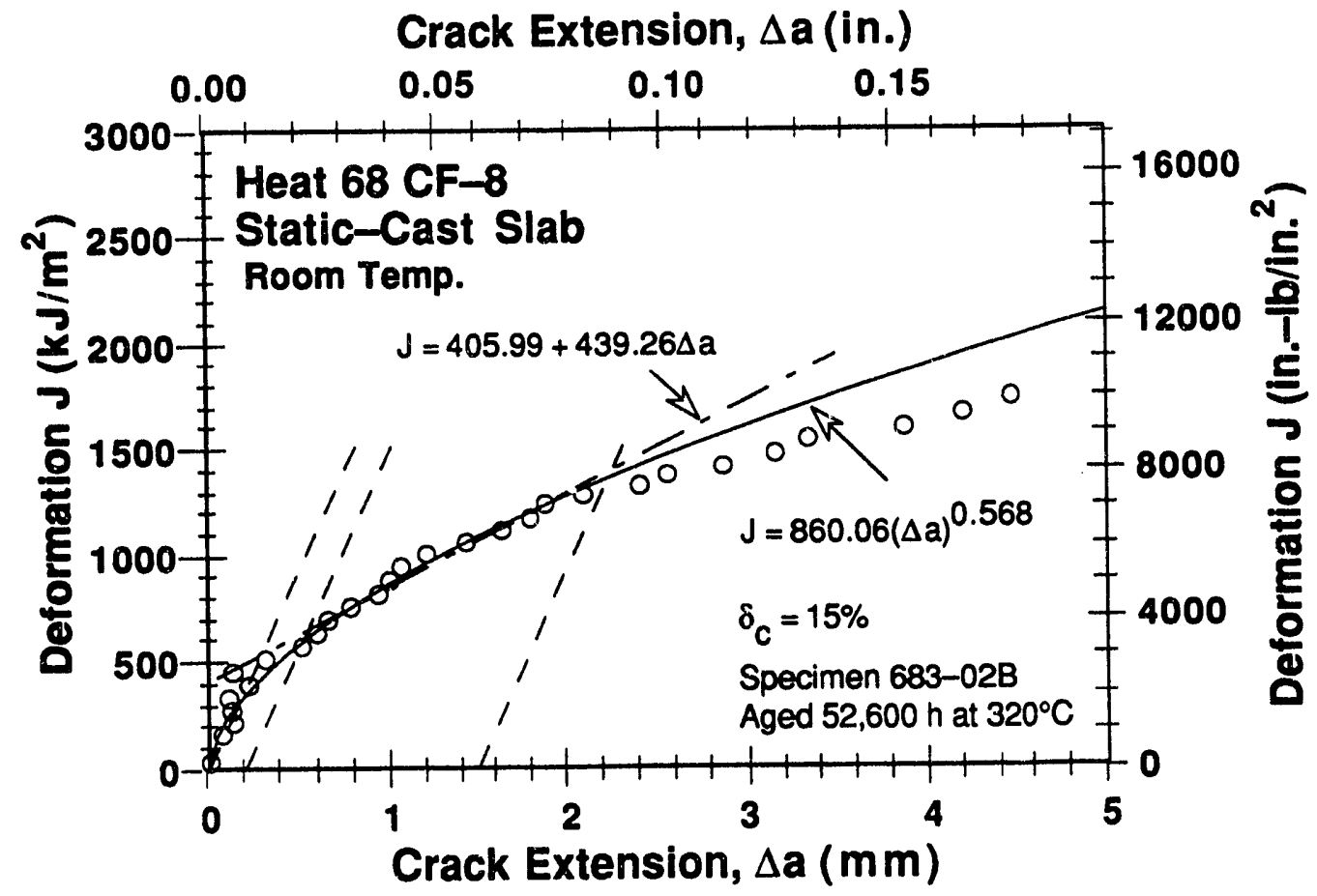

Figure A-54. Deformation $J_{I C}$ at room temp. for Heat 68 aged 52,600 $\mathrm{h}$ at $320^{\circ} \mathrm{C}$

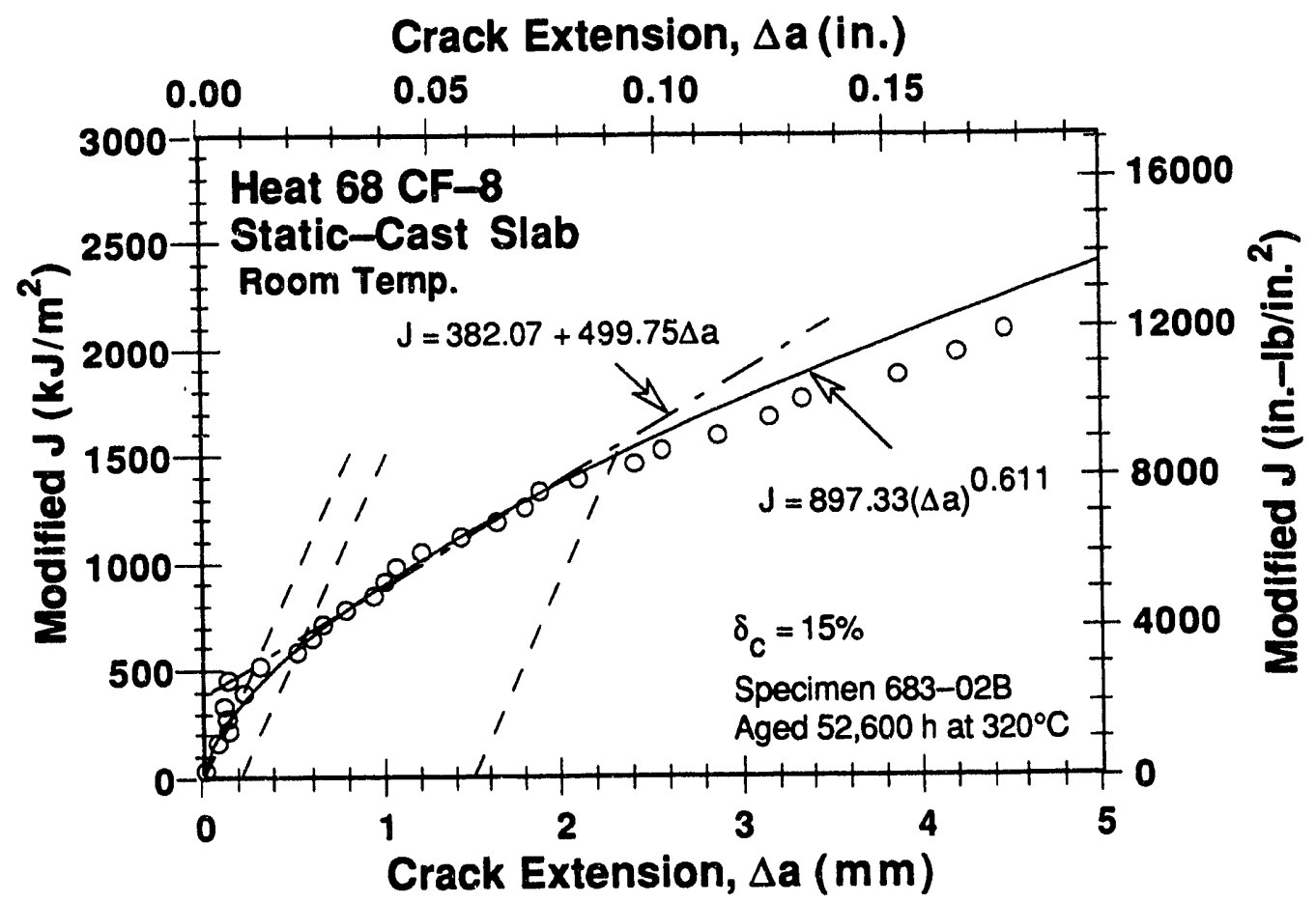

Figure A-55. Modified $J_{I C}$ at room temp. for Heat 68 aged $52,600 \mathrm{~h}$ at $320^{\circ} \mathrm{C}$ 
Table A-56. Test data for spectmen 682-05V

\begin{tabular}{|c|c|c|c|c|c|}
\hline $\begin{array}{l}\text { Test Nun } \\
\text { Material } \\
\text { Aging Te } \\
\text { Spec. Th } \\
\text { Spec. Wid }\end{array}$ & $\begin{array}{ll}\text { yper } & : \\
\text { ype } & : \\
\text { kness } & : \\
\text { h } & :\end{array}$ & $\begin{array}{l}\mathrm{mm} \\
\mathrm{mm}\end{array}$ & $\begin{array}{l}\text { Test } \\
\text { Heat } \\
\text { Aging } \\
\text { Net } \\
\text { Flow }\end{array}$ & & $\begin{array}{l}00 \mathrm{~h} \\
0 \mathrm{~mm} \\
48 \mathrm{MPa}\end{array}$ \\
\hline $\begin{array}{l}\text { Unload } \\
\text { Number }\end{array}$ & $\begin{array}{c}J_{d} \\
\left(\mathrm{~kJ} / \mathrm{m}^{2}\right)\end{array}$ & $\begin{array}{c}\mathrm{J}_{\mathrm{m}} \\
\left(\mathrm{kJ} / \mathrm{m}^{2}\right)\end{array}$ & $\begin{array}{c}\Delta \mathrm{a} \\
(\mathrm{mm})\end{array}$ & $\begin{array}{l}\text { Load } \\
(\mathrm{kN}) \\
\end{array}$ & $\begin{array}{c}\text { Deflection } \\
\text { (mm) }\end{array}$ \\
\hline $\begin{array}{l}1 \\
2 \\
3 \\
4 \\
5 \\
6 \\
7 \\
8 \\
9 \\
10 \\
11 \\
12 \\
13 \\
14 \\
15 \\
16 \\
17 \\
18 \\
19 \\
20 \\
21 \\
22 \\
23 \\
24 \\
25 \\
26 \\
27 \\
28 \\
29 \\
30 \\
31 \\
32 \\
33\end{array}$ & $\begin{array}{r}31.80 \\
89.50 \\
155.19 \\
206.40 \\
260.66 \\
316.10 \\
370.89 \\
427.08 \\
485.09 \\
541.86 \\
596.70 \\
652.14 \\
701.41 \\
753.75 \\
809.34 \\
863.92 \\
901.02 \\
942.56 \\
986.14 \\
1049.49 \\
1107.72 \\
1151.42 \\
1215.69 \\
1288.92 \\
1343.84 \\
1362.39 \\
1385.51 \\
1437.06 \\
1509.38 \\
1552.05 \\
1563.69 \\
1558.02 \\
1583.92\end{array}$ & $\begin{array}{r}31.78 \\
89.50 \\
155.97 \\
208.16 \\
261.38 \\
318.53 \\
376.45 \\
433.49 \\
494.11 \\
554.06 \\
614.65 \\
674.67 \\
737.34 \\
796.37 \\
858.46 \\
920.45 \\
984.64 \\
1040.86 \\
1099.63 \\
1179.07 \\
1259.67 \\
1337.90 \\
1435.09 \\
1531.34 \\
1630.83 \\
1722.78 \\
1806.54 \\
1911.57 \\
2016.92 \\
2127.77 \\
2243.96 \\
2345.68 \\
2447.37\end{array}$ & $\begin{array}{r}-0.0270 \\
-0.0224 \\
0.0811 \\
0.1717 \\
0.0975 \\
0.1964 \\
0.3485 \\
0.3838 \\
0.4783 \\
0.5797 \\
0.7450 \\
0.8644 \\
1.1838 \\
1.3307 \\
1.4627 \\
1.6023 \\
2.0806 \\
2.3255 \\
2.5652 \\
2.8008 \\
3.1063 \\
3.5512 \\
3.9457 \\
4.2022 \\
4.6679 \\
5.3949 \\
5.9698 \\
6.4464 \\
6.7222 \\
7.2584 \\
8.0343 \\
8.7978 \\
9.3096\end{array}$ & $\begin{array}{l}25.250 \\
30.714 \\
33.393 \\
34.523 \\
35.799 \\
36.496 \\
37.241 \\
37.855 \\
38.081 \\
38.201 \\
38.209 \\
38.271 \\
38.091 \\
38.106 \\
37.938 \\
37.769 \\
35.740 \\
35.123 \\
35.049 \\
34.620 \\
33.586 \\
32.916 \\
32.325 \\
31.714 \\
30.661 \\
27.261 \\
26.745 \\
25.950 \\
25.451 \\
23.838 \\
20.633 \\
19.333 \\
18.245\end{array}$ & $\begin{array}{r}0.405 \\
0.806 \\
1.208 \\
1.508 \\
1.809 \\
2.109 \\
2.411 \\
2.709 \\
3.013 \\
3.312 \\
3.611 \\
3.910 \\
4.211 \\
4.509 \\
4.812 \\
5.112 \\
5.416 \\
5.714 \\
6.012 \\
6.410 \\
6.812 \\
7.208 \\
7.710 \\
8.210 \\
8.713 \\
9.217 \\
9.711 \\
10.307 \\
10.907 \\
11.518 \\
12.216 \\
12.909 \\
13.609\end{array}$ \\
\hline
\end{tabular}


Table A-57. Deformation $J_{I C}$ and $J-R$ curve results for specimen $682-05 \mathrm{~V}$

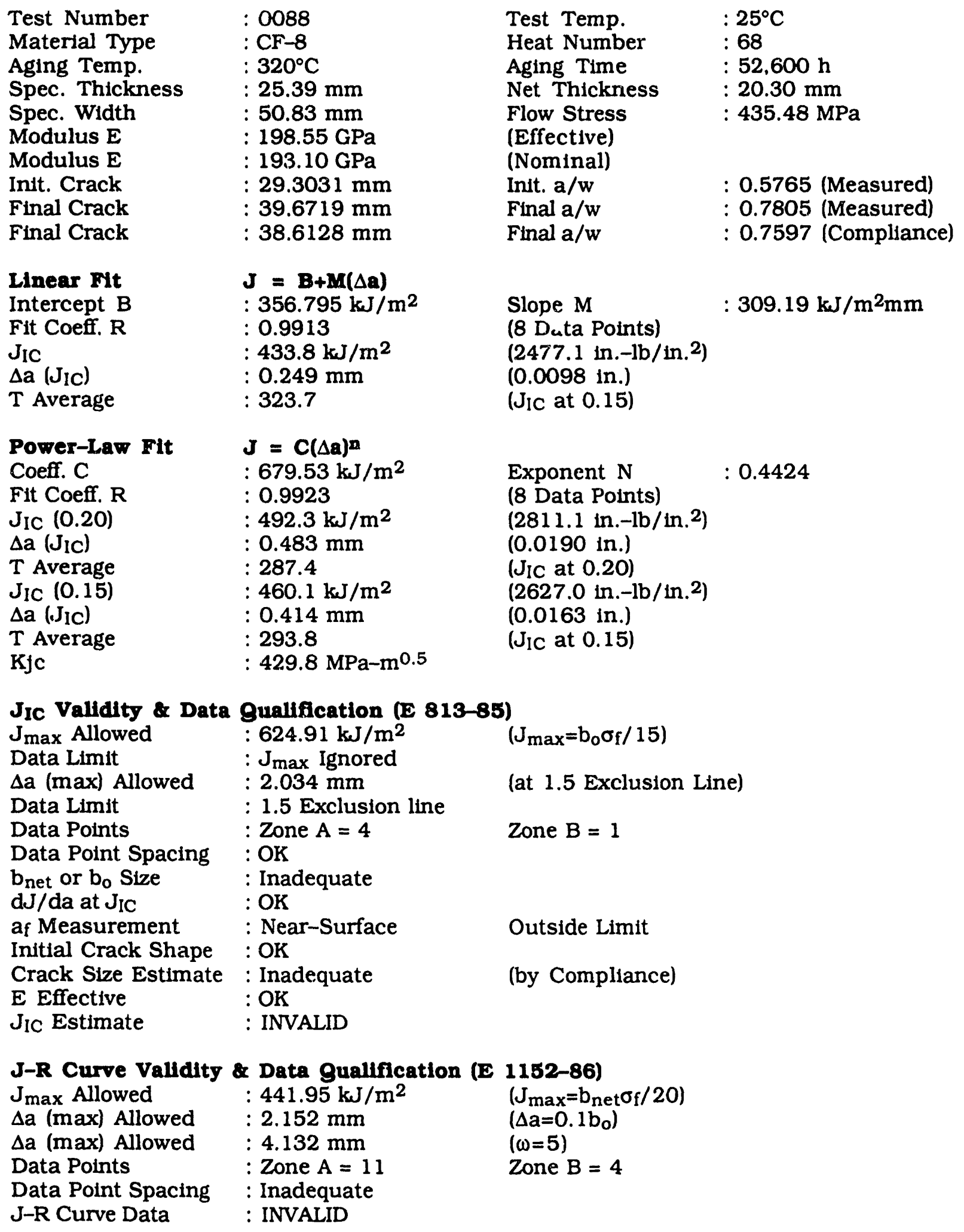


Table A-58. Modified $J_{I C}$ and J-R curve results for specimen $682-05 \mathrm{~V}$

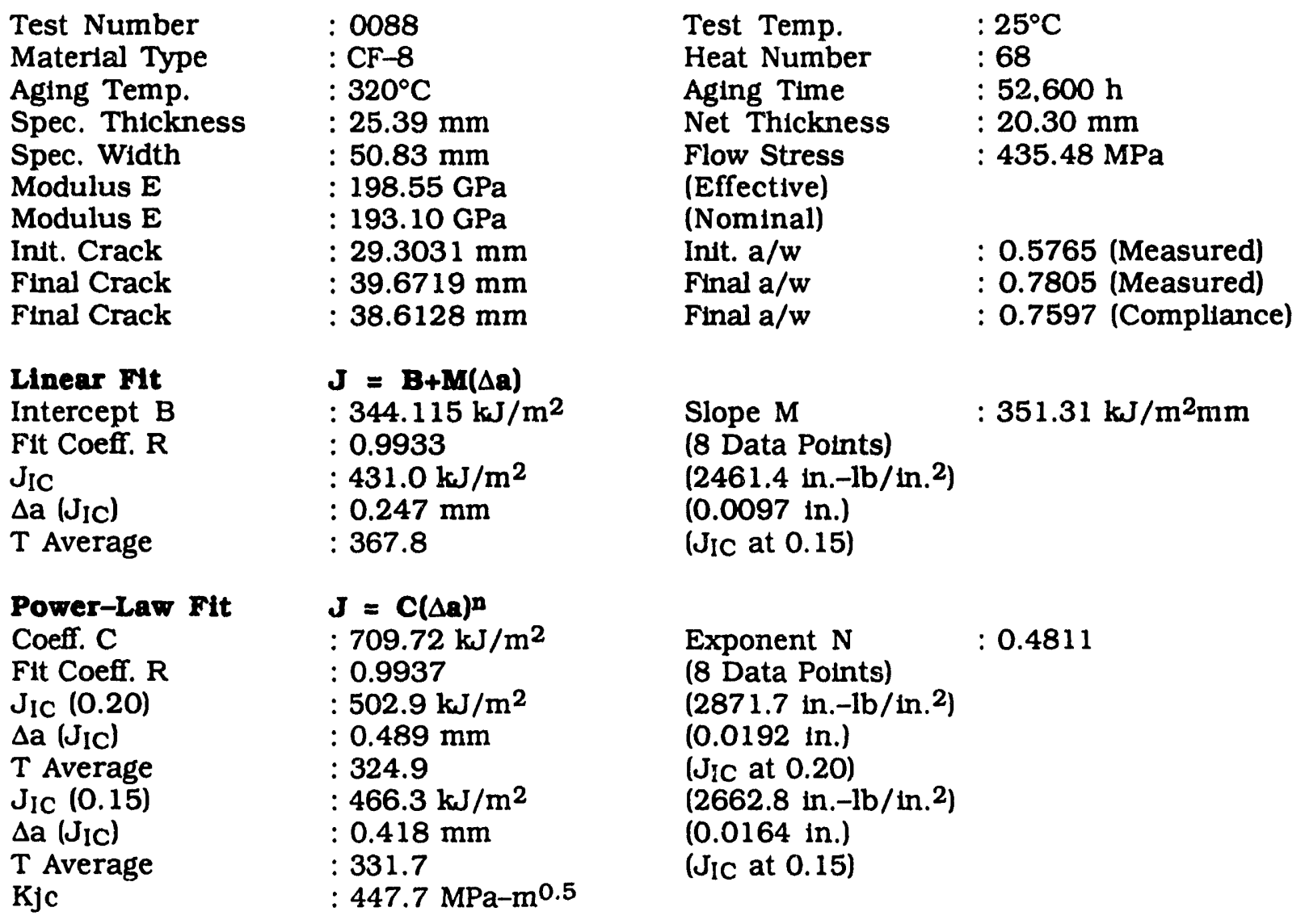

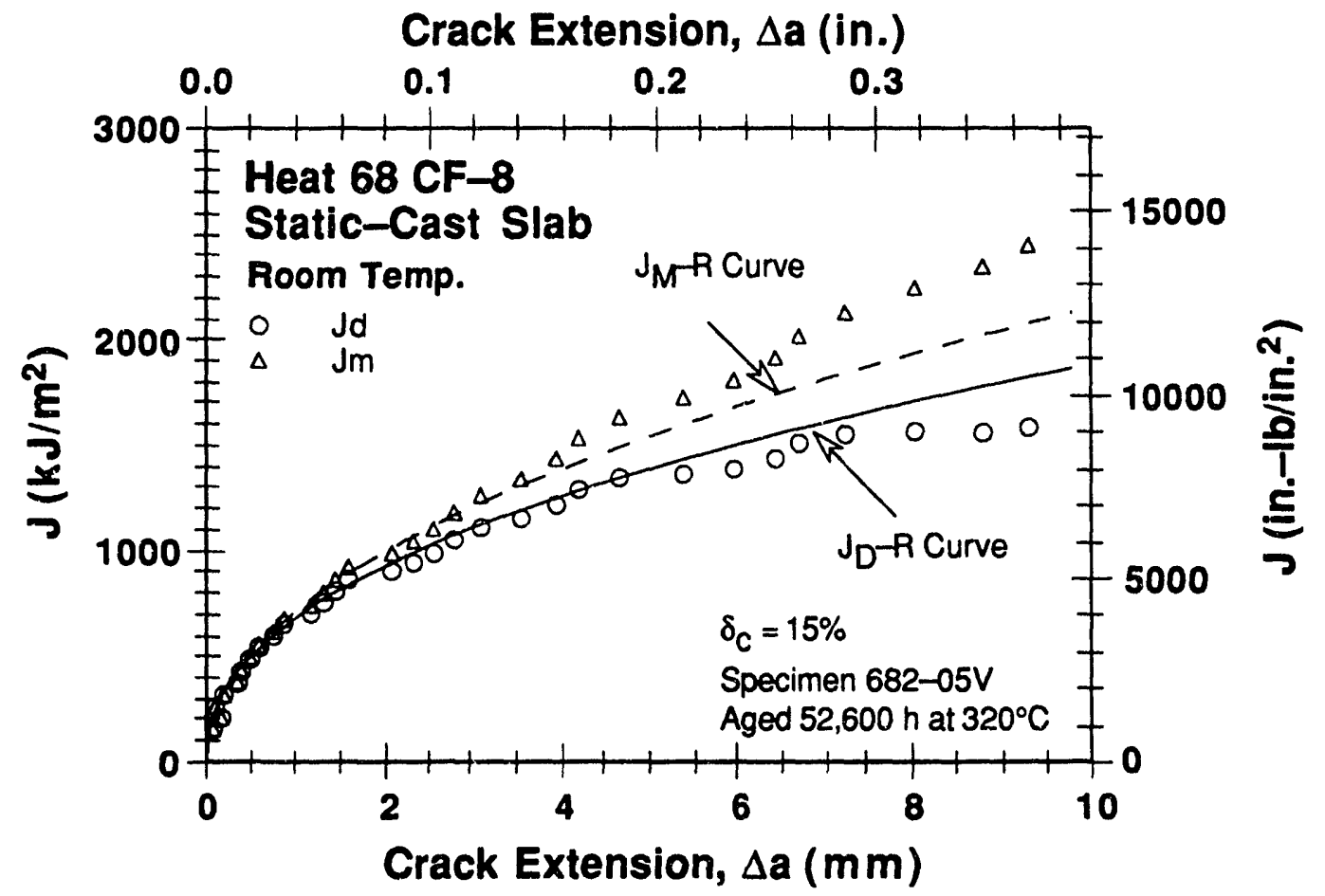

Figure A-56. Deformation and modifted J-R curves at room temp. for Heat 68 aged $52,600 \mathrm{~h}$ at $320^{\circ} \mathrm{C}$ 


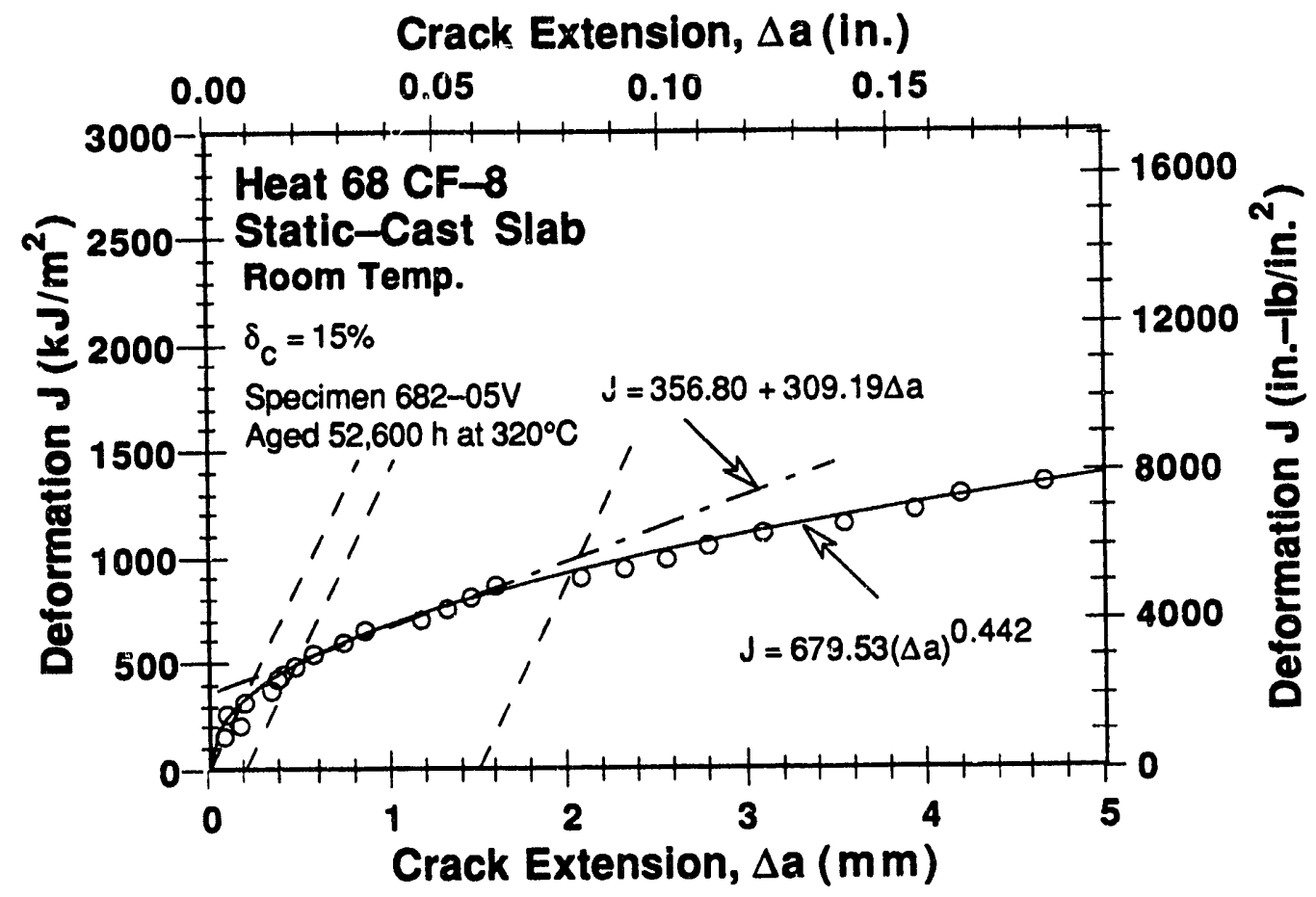

Figure A-57. Deformation $J_{I C}$ at room temp. for Heat 68 aged $52,600 \mathrm{~h}$ at $320^{\circ} \mathrm{C}$

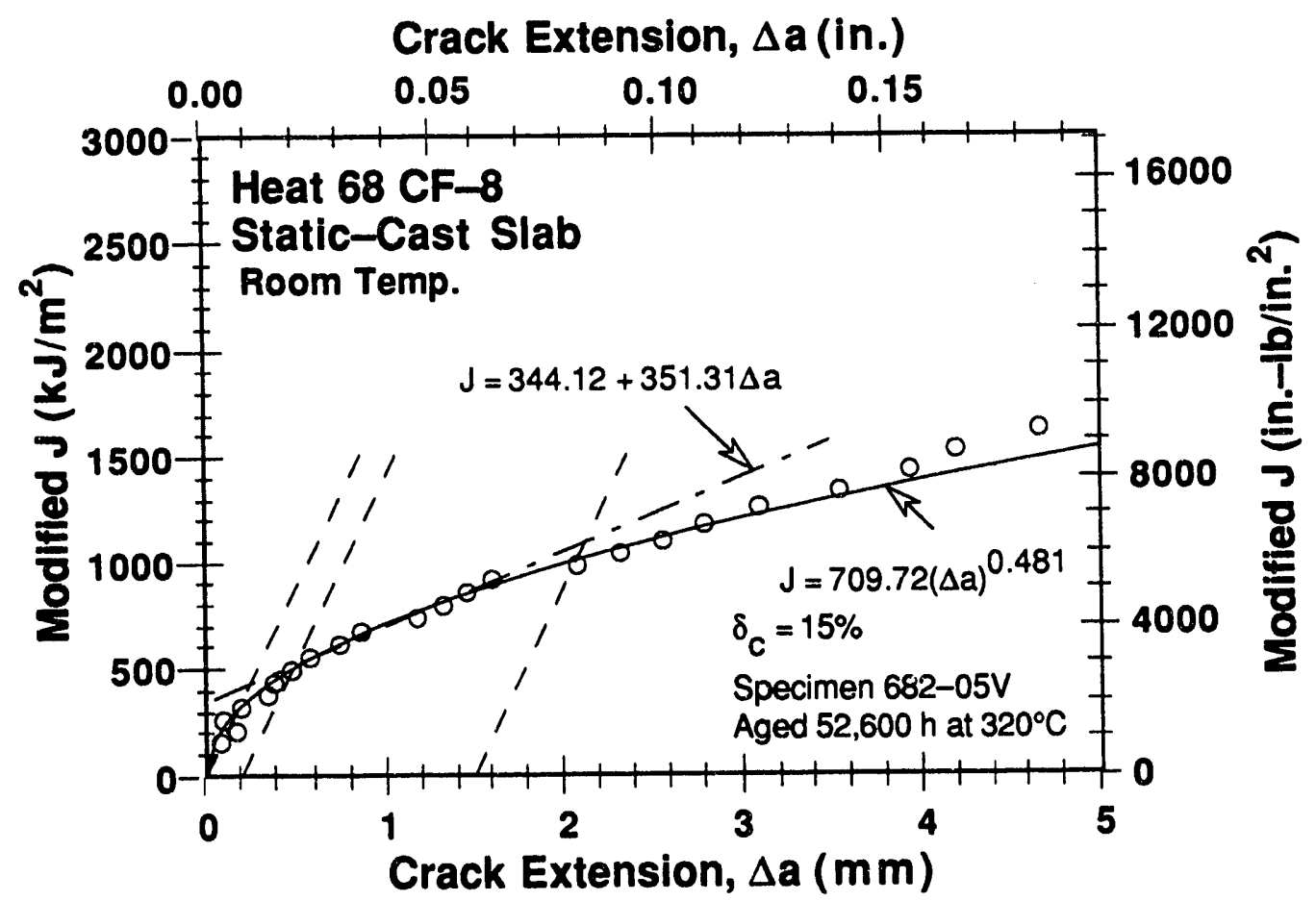

Figure A-58. Modified $J_{I C}$ ac room temp. for Heat 68 aged $52,600 \mathrm{~h}$ at $320^{\circ} \mathrm{C}$ 
Table A-59. Test data for specimen 682-08B

\begin{tabular}{|c|c|c|c|c|c|}
\hline $\begin{array}{l}\text { Test Num } \\
\text { Material } \\
\text { Aging Te } \\
\text { Spec. Th } \\
\text { Spec. Wid }\end{array}$ & $\begin{array}{ll}\text { ber } & : \\
\text { pe } & : \\
\text { p. } & : \\
\text { kness } & : \\
\text { h } & :\end{array}$ & $\mathrm{mm}$ & $\begin{array}{l}\text { Test } \\
\text { Heat } \\
\text { Aging } \\
\text { Net I } \\
\text { Flow }\end{array}$ & & $\begin{array}{l}00 \mathrm{~h} \\
9 \mathrm{~mm} \\
50 \mathrm{MPa}\end{array}$ \\
\hline $\begin{array}{l}\text { Unload } \\
\text { Number }\end{array}$ & $\begin{array}{c}J_{d} \\
\left(k J / m^{2}\right)\end{array}$ & $\begin{array}{c}\mathrm{J}_{\mathrm{m}} \\
\left(\mathrm{kJJ} / \mathrm{m}^{2}\right)\end{array}$ & $\begin{array}{c}\Delta \mathrm{a} \\
(\mathrm{mm})\end{array}$ & $\begin{array}{l}\text { Load } \\
(\mathrm{kN}) \\
\end{array}$ & $\begin{array}{c}\text { Deflection } \\
(\mathrm{mm})\end{array}$ \\
\hline $\begin{array}{l}1 \\
2 \\
3 \\
4 \\
5 \\
6 \\
7 \\
8 \\
9 \\
10 \\
11 \\
12 \\
13 \\
14 \\
15 \\
16 \\
17 \\
18 \\
19 \\
20 \\
21 \\
22 \\
23 \\
24 \\
25 \\
26 \\
27 \\
28 \\
29 \\
30 \\
31 \\
32 \\
33 \\
34 \\
35 \\
36 \\
37\end{array}$ & $\begin{array}{r}20.88 \\
62.85 \\
112.17 \\
166.21 \\
222.41 \\
280.77 \\
340.26 \\
400.09 \\
459.72 \\
509.82 \\
559.53 \\
606.50 \\
645.57 \\
684.52 \\
722.86 \\
768.11 \\
813.25 \\
850.51 \\
889.03 \\
921.00 \\
962.75 \\
1002.70 \\
1032.45 \\
1054.78 \\
1072.99 \\
1099.97 \\
1132.26 \\
1149.92 \\
1147.77 \\
1157.90 \\
1177.94 \\
1216.80 \\
1260.83 \\
1304.64 \\
1338.93 \\
1353.07 \\
1371.69\end{array}$ & $\begin{array}{r}20.86 \\
62.88 \\
112.19 \\
166.32 \\
224.22 \\
282.13 \\
344.47 \\
407.13 \\
470.47 \\
523.82 \\
577.18 \\
632.67 \\
674.97 \\
716.95 \\
761.96 \\
814.68 \\
870.19 \\
924.72 \\
976.36 \\
1029.56 \\
1090.25 \\
1152.97 \\
1212.62 \\
1272.52 \\
1324.03 \\
1378.10 \\
1443.10 \\
1509.81 \\
1571.25 \\
1629.79 \\
1690.73 \\
1769.62 \\
1848.38 \\
1927.06 \\
2005.91 \\
2081.54 \\
2150.07\end{array}$ & $\begin{array}{r}-0.0537 \\
-0.0347 \\
-0.0343 \\
-0.0242 \\
0.1287 \\
0.0979 \\
0.2552 \\
0.3858 \\
0.5322 \\
0.6463 \\
0.7617 \\
1.0070 \\
1.0931 \\
1.1692 \\
1.3263 \\
1.4900 \\
1.7023 \\
2.0359 \\
2.2749 \\
2.6423 \\
2.9515 \\
3.3014 \\
3.7389 \\
4.2626 \\
4.7100 \\
5.0594 \\
5.4611 \\
6.0342 \\
6.7501 \\
7.2756 \\
7.7019 \\
8.0971 \\
8.4209 \\
8.7291 \\
9.1037 \\
9.5968 \\
9.9810\end{array}$ & $\begin{array}{l}23.728 \\
30.934 \\
34.471 \\
36.817 \\
38.471 \\
39.398 \\
40.468 \\
40.945 \\
41.541 \\
41.604 \\
41.671 \\
41.532 \\
40.905 \\
40.725 \\
40.829 \\
40.591 \\
39.883 \\
39.619 \\
38.293 \\
37.416 \\
36.777 \\
34.714 \\
33.644 \\
31.160 \\
30.357 \\
29.747 \\
28.867 \\
25.740 \\
23.350 \\
22.467 \\
21.781 \\
21.428 \\
20.607 \\
20.117 \\
19.401 \\
17.428 \\
16.622\end{array}$ & $\begin{array}{r}0.302 \\
0.605 \\
0.906 \\
1.207 \\
1.507 \\
1.808 \\
2.108 \\
2.411 \\
2.711 \\
2.962 \\
3.210 \\
3.462 \\
3.665 \\
3.861 \\
4.067 \\
4.310 \\
4.565 \\
4.815 \\
5.064 \\
5.315 \\
5.611 \\
5.914 \\
6.214 \\
6.525 \\
6.812 \\
7.112 \\
7.461 \\
7.828 \\
8.217 \\
8.611 \\
9.009 \\
9.509 \\
10.009 \\
10.509 \\
11.007 \\
11.510 \\
12.008\end{array}$ \\
\hline
\end{tabular}


Table A-6C. Deformation $J_{I C}$ and $J-R$ curve results for specimen 682-08B

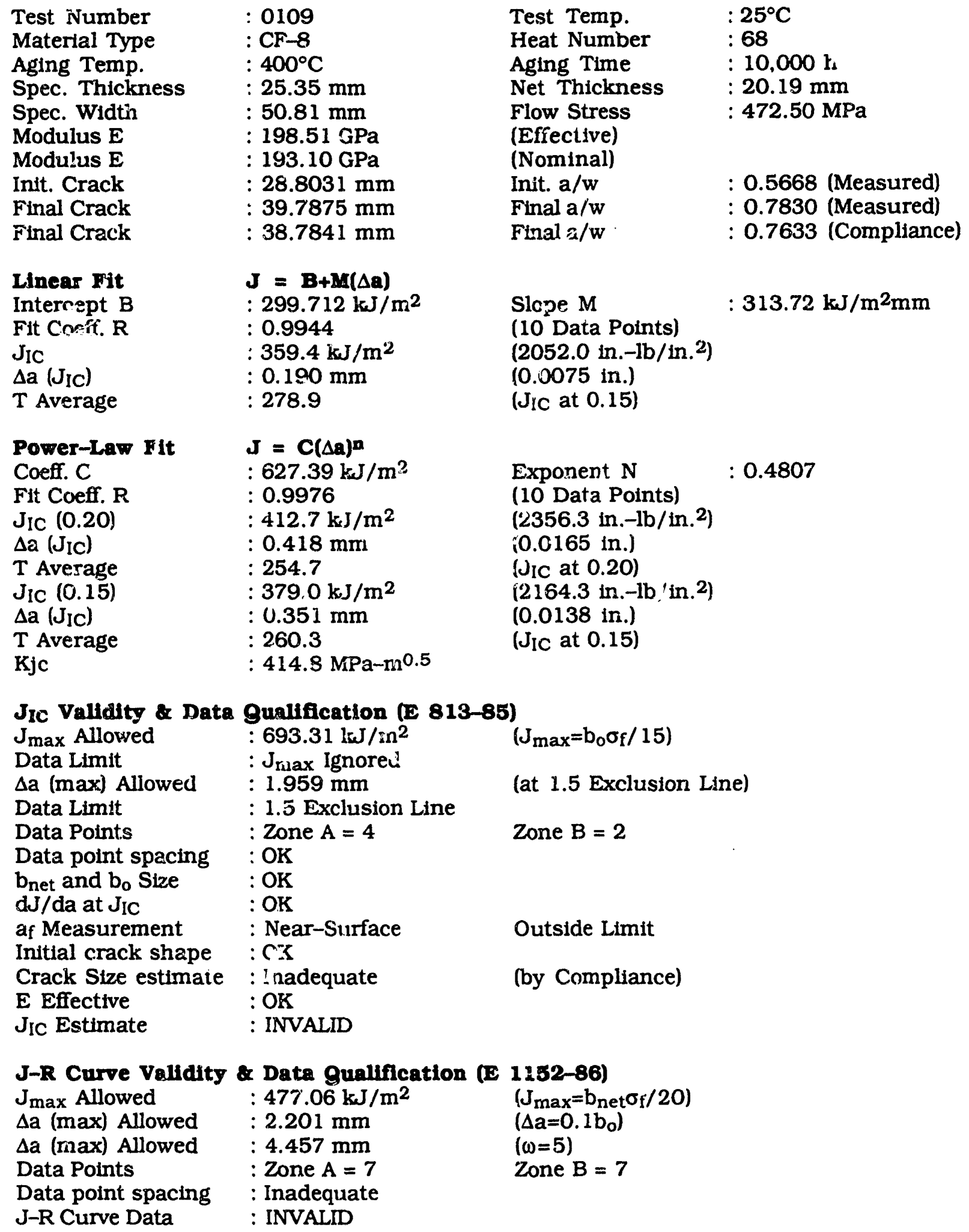


Table A-61. Modified $J_{I C}$ and $J-R$ curve results for specimen $682-08 B$

\begin{tabular}{|c|c|c|c|}
\hline $\begin{array}{l}\text { Test Niamber } \\
\text { Material Type }\end{array}$ & $\begin{array}{l}: 0109 \\
: C F-8\end{array}$ & $\begin{array}{l}\text { Test Temp. } \\
\text { Heat Number }\end{array}$ & $\begin{array}{l}: 25^{\circ} \mathrm{C} \\
: 68\end{array}$ \\
\hline Aging Temp. & $: 400^{\circ} \mathrm{C}$ & Aging Time & $10,000 \mathrm{~h}$ \\
\hline Spec. Thickness & $: 25.35 \mathrm{~mm}$ & Net Thickness & $20.19 \mathrm{~mm}$ \\
\hline Spec. Width & : $50.81 \mathrm{~mm}$ & Flow Stress & : $472.50 \mathrm{MPa}$ \\
\hline Modulus E & : $19,8.51 \mathrm{GPa}$ & (Effective) & \\
\hline Modulus E & : $193.10 \mathrm{GPa}$ & (Nominal) & \\
\hline Init. Crack & $: 28.8031 \mathrm{~mm}$ & Init. $a / w$ & : 0.5668 (Measured) \\
\hline Final Crack & : $39.7875 \mathrm{mn}_{\iota}$ & Final a/w & : 0.7830 (Measured) \\
\hline Final Crack & $: 38.7841 \mathrm{~mm}$ & Final a/w & : 0.7633 (Compliance) \\
\hline $\begin{array}{l}\text { Linear Fit } \\
\text { Intercept B } \\
\text { Fit Coeff. } R \\
\mathrm{~J}_{\mathrm{IC}} \\
\Delta \mathrm{a}\left(\mathrm{J}_{\mathrm{IC}}\right) \\
\text { T Average }\end{array}$ & $\begin{array}{l}J=B+M(\Delta Q) \\
: 289.634 \mathrm{~kJ} / \mathrm{m}^{2} \\
: 0.9962 \\
: 355.8 \mathrm{~kJ} / \mathrm{m}^{2} \\
: 0.188 \mathrm{~mm} \\
: 312.4\end{array}$ & $\begin{array}{l}\text { Slope } M \\
\text { (10 Data Points) } \\
\left(2031.6 \text { in.-lb/in. }{ }^{2}\right) \\
(0.0074 \text { in. }) \\
\left(J_{1 C} \text { at } 0.15\right)\end{array}$ & $: 351.37 \mathrm{~kJ} / \mathrm{m}^{2} \mathrm{~mm}$ \\
\hline $\begin{array}{l}\text { Power-Law Fit } \\
\text { Coeff. C } \\
\text { Fit Coeff. R } \\
\mathrm{J}_{I C}(0.20) \\
\Delta \mathrm{a}\left(\mathrm{J}_{\mathrm{IC}}\right) \\
\text { T Average } \\
\mathrm{J}_{\mathrm{IC}}(0.15) \\
\Delta \mathrm{a}\left(\mathrm{J}_{\mathrm{IC}}\right) \\
\text { T Average } \\
\text { Kjc }\end{array}$ & $\begin{array}{l}J=C(\Delta a)^{n} \\
: 655.51 \mathrm{~kJ} / \mathrm{m}^{2} \\
: 0.9977 \\
: 421.1 \mathrm{~kJ} / \mathrm{m}^{2} \\
: 0.423 \mathrm{~mm} \\
: 282.9 \\
: 383.9 \mathrm{~kJ} / \mathrm{m}^{2} \\
: 0.353 \mathrm{~mm} \\
: 288.8 \\
: 430.8 \mathrm{MPa}-\mathrm{m}^{0.5}\end{array}$ & $\begin{array}{l}\text { Exponent } N \\
\text { (10 Data Points) } \\
\left(2404.8 \mathrm{in} .-\mathrm{lb} / \text { in. }^{2}\right) \\
(0.0166 \mathrm{in.}) \\
\left(\mathrm{J}_{\mathrm{IC}} \text { at } 0.20\right) \\
\left(2192.1 \mathrm{in.}-\mathrm{lb} / \mathrm{in}^{2}{ }^{2}\right) \\
(0.0139 \mathrm{in.}) \\
\left(\mathrm{J}_{\mathrm{IC}} \text { at } 0.15\right)\end{array}$ & $: 0.5140$ \\
\hline
\end{tabular}

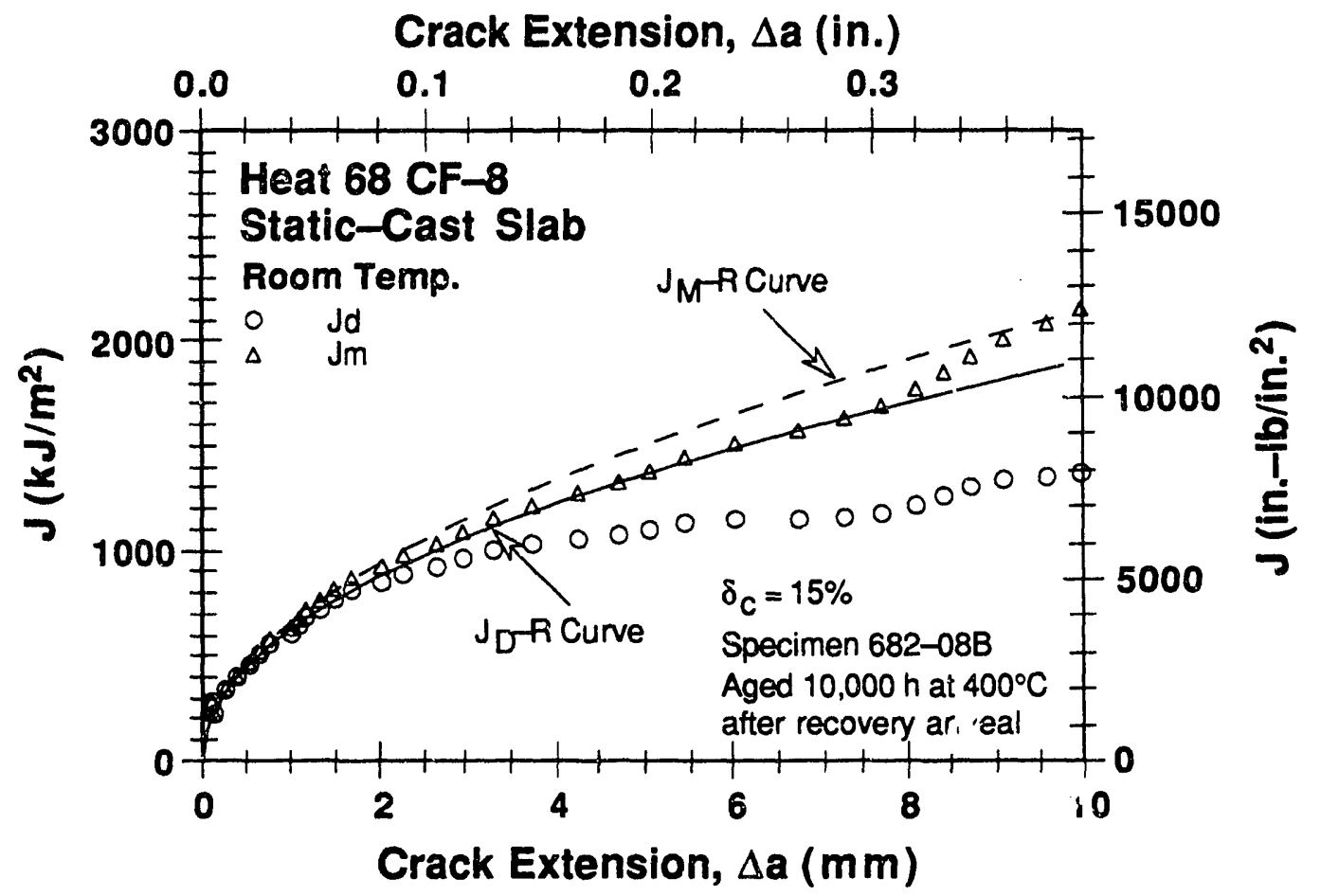

Figure A-59. Deformation and modified J-R cirves at room temp. for Heat 68 aged $10,000 \mathrm{~h}$ at $400^{\circ} \mathrm{C}$, then recovery-annealed and aged again for $10,000 \mathrm{~h}$ at $400^{\circ} \mathrm{C}$ 


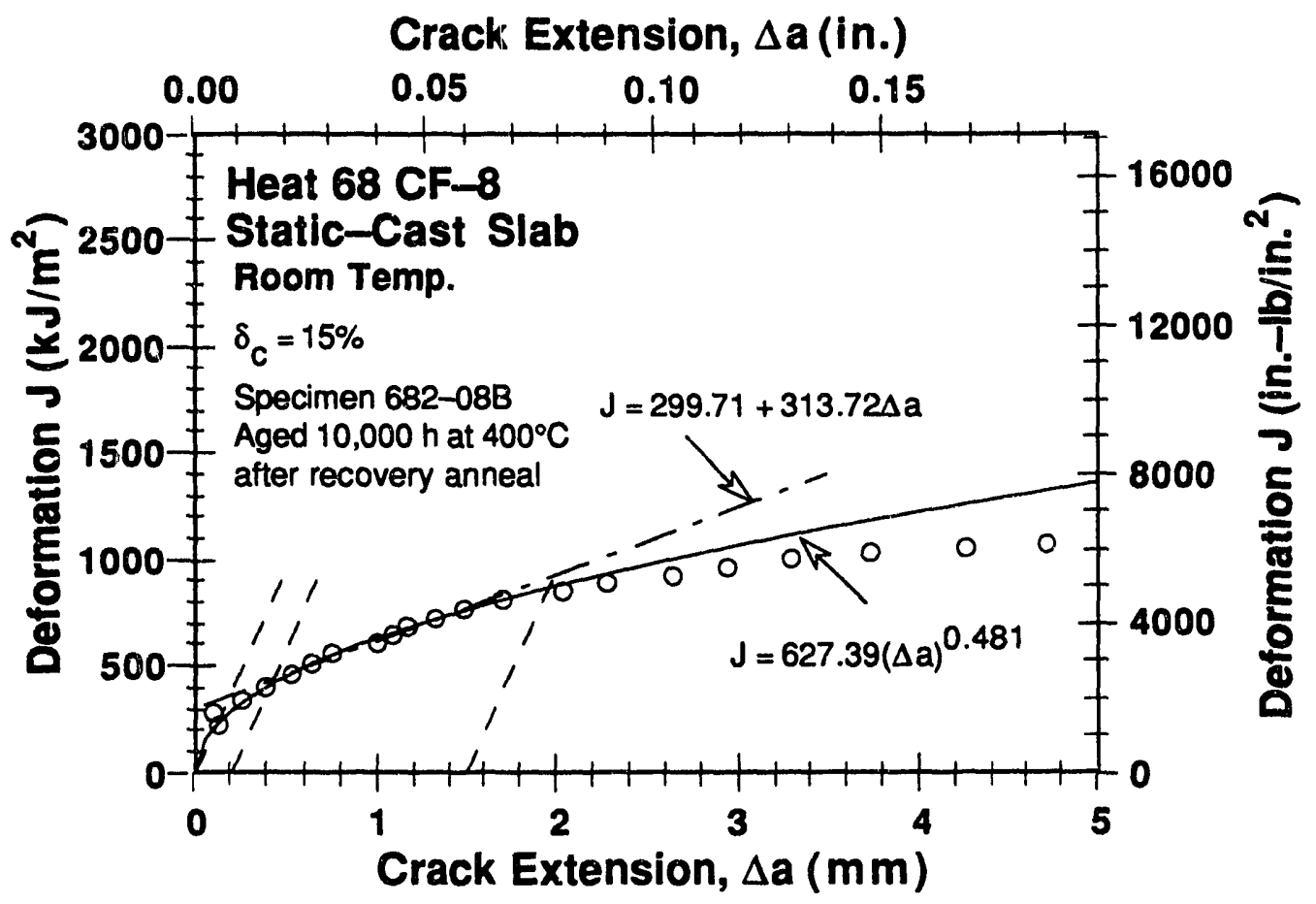

Figure A-60. Deformation $J_{I C}$ at room temp. for Heat 68 aged 10,000 h at $400^{\circ} \mathrm{C}$, then recovery-annealed and aged again for $10,000 \mathrm{~h}$ at $400^{\circ} \mathrm{C}$

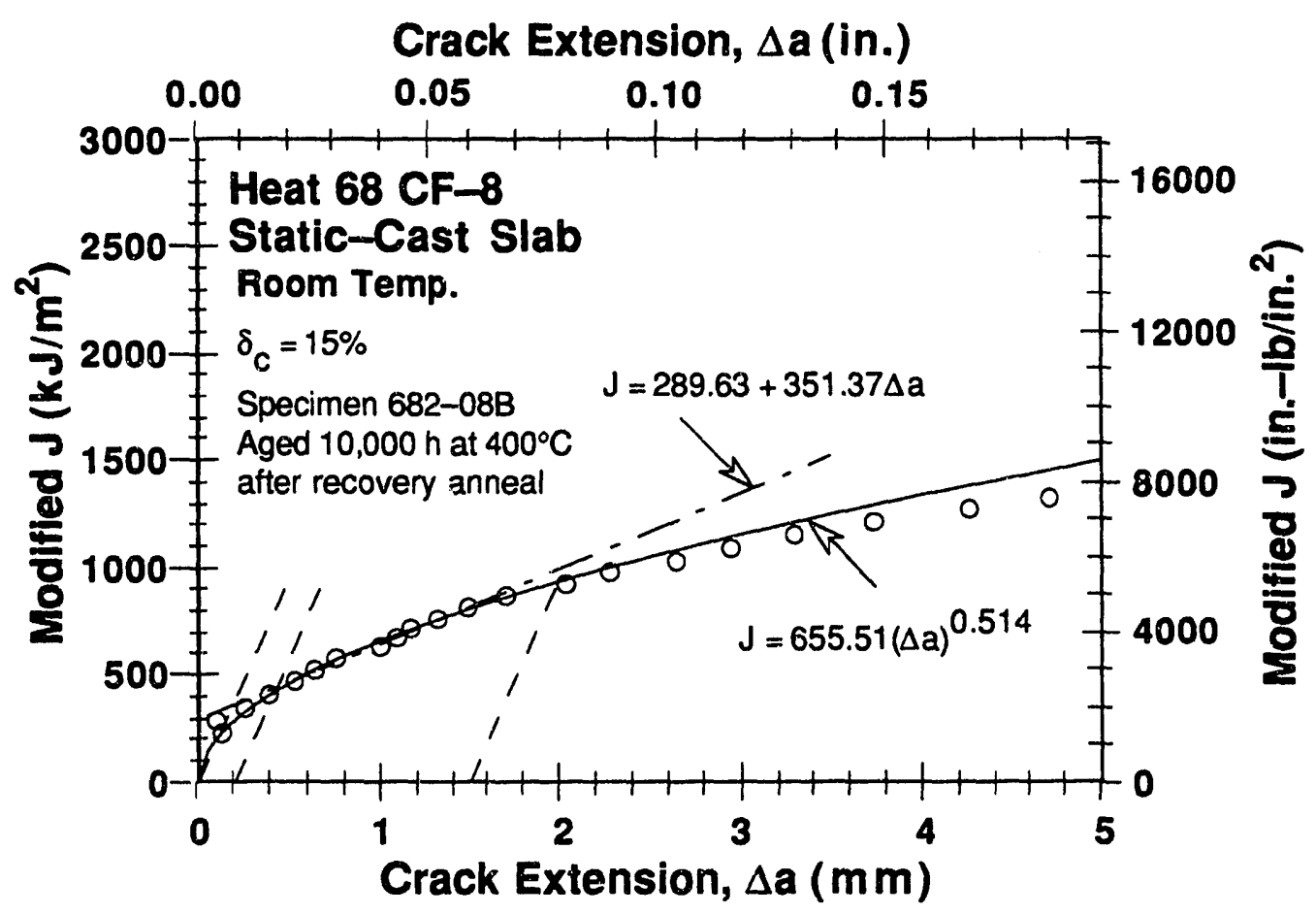

Figure A-61. Modified $J_{I C}$ at room temp. for Heat 68 aged $10,000 \mathrm{~h}$ at $400^{\circ} \mathrm{C}$, then recovery-annealed and aged again for $10.000 \mathrm{~h}$ at $400^{\circ} \mathrm{C}$ 
Table A-62. Test data for spectmen 683-02T

\begin{tabular}{|c|c|c|c|c|c|}
\hline $\begin{array}{l}\text { Test Nun } \\
\text { Material } \\
\text { Aging Te } \\
\text { Spec. Th } \\
\text { Spec. WI }\end{array}$ & $\begin{array}{ll}\text { ber } & : \\
\text { ype } & : \\
\text { lp. } & : \\
\text { :kness } & : \\
\text { h } & :\end{array}$ & $\begin{array}{l}\mathrm{mm} \\
\mathrm{mm}\end{array}$ & $\begin{array}{l}\text { Test } \\
\text { Heat } \\
\text { Aging } \\
\text { Net } \\
\text { Flow }\end{array}$ & & $\begin{array}{l}20 \mathrm{~h} \\
2 \mathrm{~mm} \\
2 \mathrm{MPa}\end{array}$ \\
\hline $\begin{array}{l}\text { Unload } \\
\text { Number }\end{array}$ & $\frac{J_{d}}{\left(k J / m^{2}\right)}$ & $\frac{J_{m}}{\left(\mathrm{~kJ} / \mathrm{m}^{2}\right)}$ & $\begin{array}{c}\Delta a \\
(\mathrm{~mm})\end{array}$ & $\begin{array}{l}\text { Load } \\
(\mathrm{kN})\end{array}$ & $\begin{array}{l}\text { Deflection } \\
\text { (mm) }\end{array}$ \\
\hline $\begin{array}{l}1 \\
2 \\
3 \\
4 \\
5 \\
6 \\
7 \\
8 \\
9 \\
10 \\
11 \\
12 \\
13 \\
14 \\
15 \\
16 \\
17 \\
18 \\
19 \\
20 \\
21 \\
22 \\
23 \\
24 \\
25 \\
26 \\
27 \\
28 \\
29 \\
30 \\
31 \\
32 \\
33 \\
34 \\
35 \\
36 \\
37 \\
38 \\
39\end{array}$ & $\begin{array}{r}16.15 \\
44.63 \\
77.17 \\
112.34 \\
148.94 \\
192.19 \\
239.91 \\
280.74 \\
329.66 \\
356.03 \\
387.75 \\
421.39 \\
449.90 \\
477.18 \\
496.62 \\
532.89 \\
554.23 \\
577.72 \\
609.06 \\
630.01 \\
649.53 \\
684.58 \\
709.19 \\
734.79 \\
765.09 \\
791.34 \\
818.51 \\
843.18 \\
866.78 \\
885.33 \\
912.33 \\
923.83 \\
947.04 \\
953.02 \\
985.90 \\
990.13 \\
1000.05 \\
1014.85 \\
1024.11\end{array}$ & $\begin{array}{r}16.34 \\
43.98 \\
78.08 \\
111.09 \\
150.98 \\
192.05 \\
243.44 \\
283.34 \\
323.16 \\
362.84 \\
395.93 \\
433.42 \\
470.68 \\
507.73 \\
537.29 \\
572.97 \\
603.99 \\
633.23 \\
662.02 \\
701.88 \\
737.60 \\
780.25 \\
825.10 \\
866.92 \\
916.67 \\
965.50 \\
1018.78 \\
1072.57 \\
1124.47 \\
1176.77 \\
1226.67 \\
1277.35 \\
1323.80 \\
1372.67 \\
1416.98 \\
1466.22 \\
1510.00 \\
1554.37 \\
1597.74\end{array}$ & $\begin{array}{r}0.4039 \\
-0.0232 \\
0.3890 \\
0.0152 \\
0.4306 \\
0.2221 \\
0.4973 \\
0.4381 \\
-0.0542 \\
0.5997 \\
0.6612 \\
0.8183 \\
1.1486 \\
1.4920 \\
1.8294 \\
1.8110 \\
2.0955 \\
2.2566 \\
2.1889 \\
2.6647 \\
3.0539 \\
3.2252 \\
3.6572 \\
3.9864 \\
4.3589 \\
4.7681 \\
5.2160 \\
5.6897 \\
6.1274 \\
6.6259 \\
6.9479 \\
7.4762 \\
7.7764 \\
8.3105 \\
8.4467 \\
8.9644 \\
9.3406 \\
9.6573 \\
10.0105\end{array}$ & $\begin{array}{l}16.910 \\
20.742 \\
22.607 \\
24.063 \\
25.225 \\
26.129 \\
27.000 \\
27.576 \\
27.836 \\
28.176 \\
28.379 \\
28.469 \\
28.393 \\
28.316 \\
28.123 \\
27.896 \\
27.689 \\
27.394 \\
27.105 \\
26.817 \\
26.334 \\
25.577 \\
24.921 \\
24.282 \\
23.502 \\
22.445 \\
21.617 \\
20.655 \\
20.083 \\
19.195 \\
18.394 \\
17.372 \\
16.648 \\
16.023 \\
15.575 \\
14.821 \\
14.180 \\
13.450 \\
12.829\end{array}$ & $\begin{array}{l}0.305 \\
0.613 \\
0.906 \\
1.208 \\
1.508 \\
1.844 \\
2.210 \\
2.509 \\
2.808 \\
3.054 \\
3.306 \\
3.560 \\
3.809 \\
4.060 \\
4.261 \\
4.513 \\
4.709 \\
4.910 \\
5.112 \\
5.361 \\
5.610 \\
5.910 \\
6.211 \\
6.509 \\
6.859 \\
7.210 \\
7.602 \\
8.006 \\
8.406 \\
8.807 \\
9.208 \\
9.608 \\
10.007 \\
10.408 \\
10.809 \\
11.210 \\
11.610 \\
12.012 \\
12.411\end{array}$ \\
\hline
\end{tabular}


Table A-63. Deformation $J_{I C}$ and $J-R$ curve resilts for spectmen 683-02T

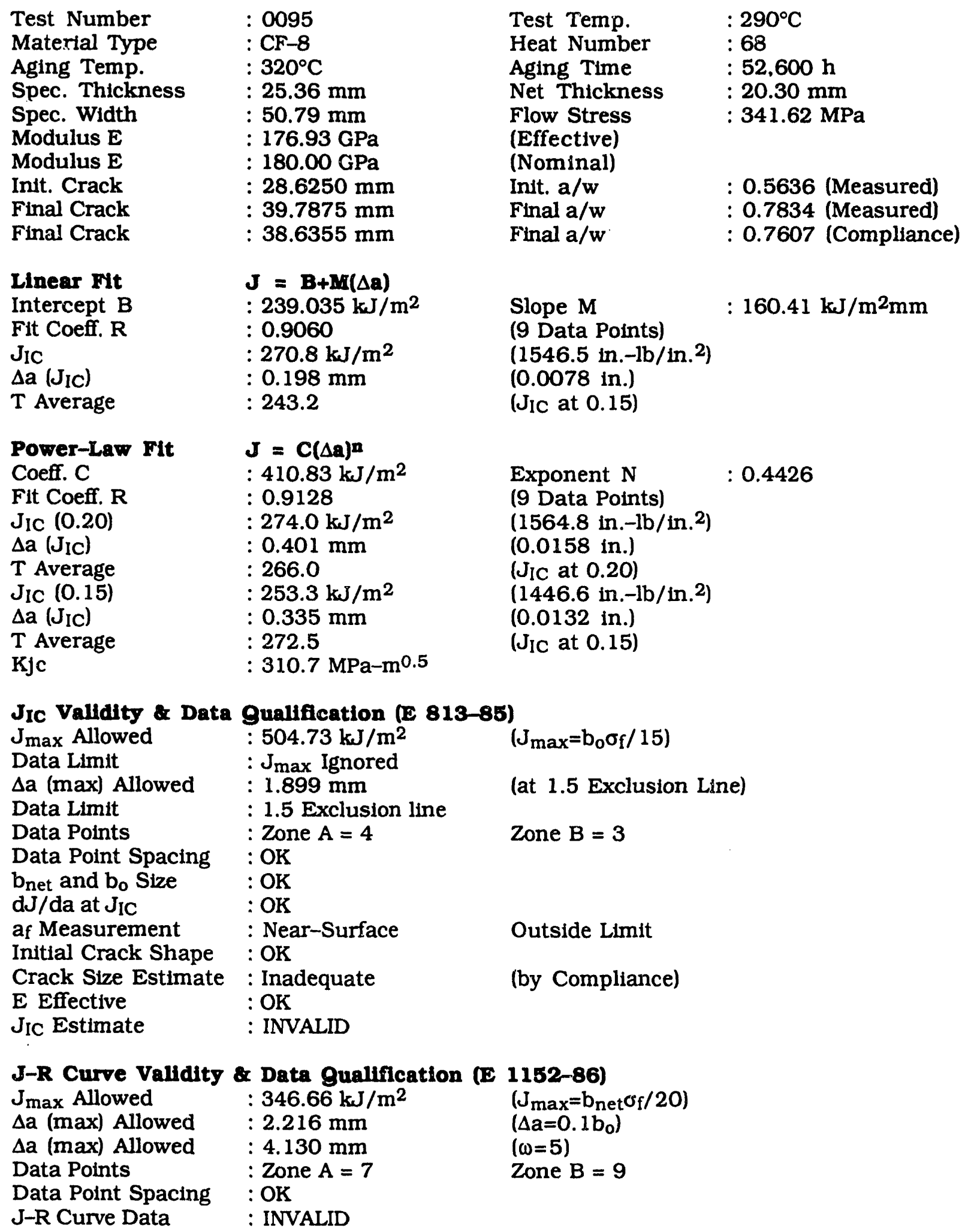


Table A-64. Modified $J_{I C}$ and J-R curve results for specimen 683-02T

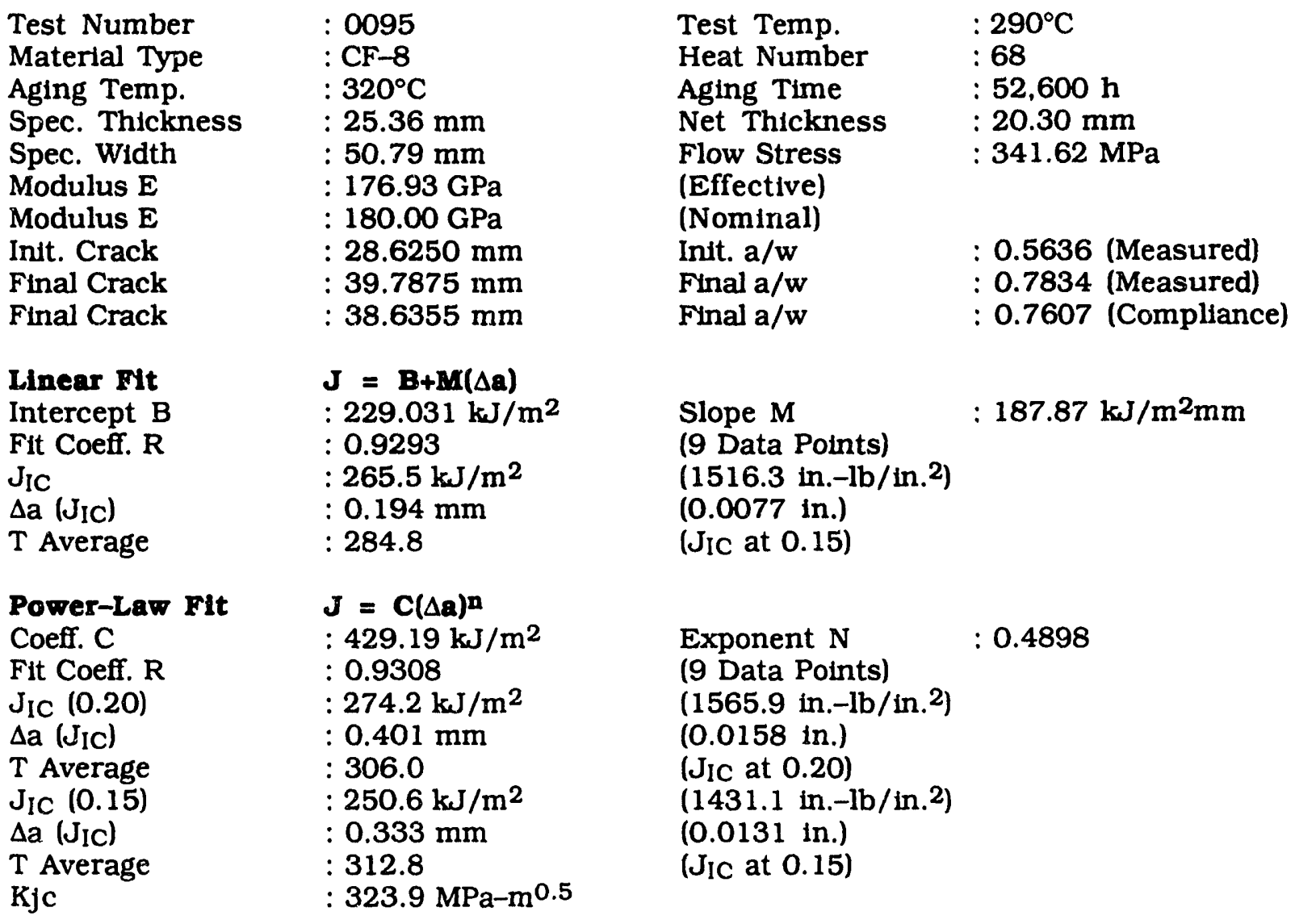

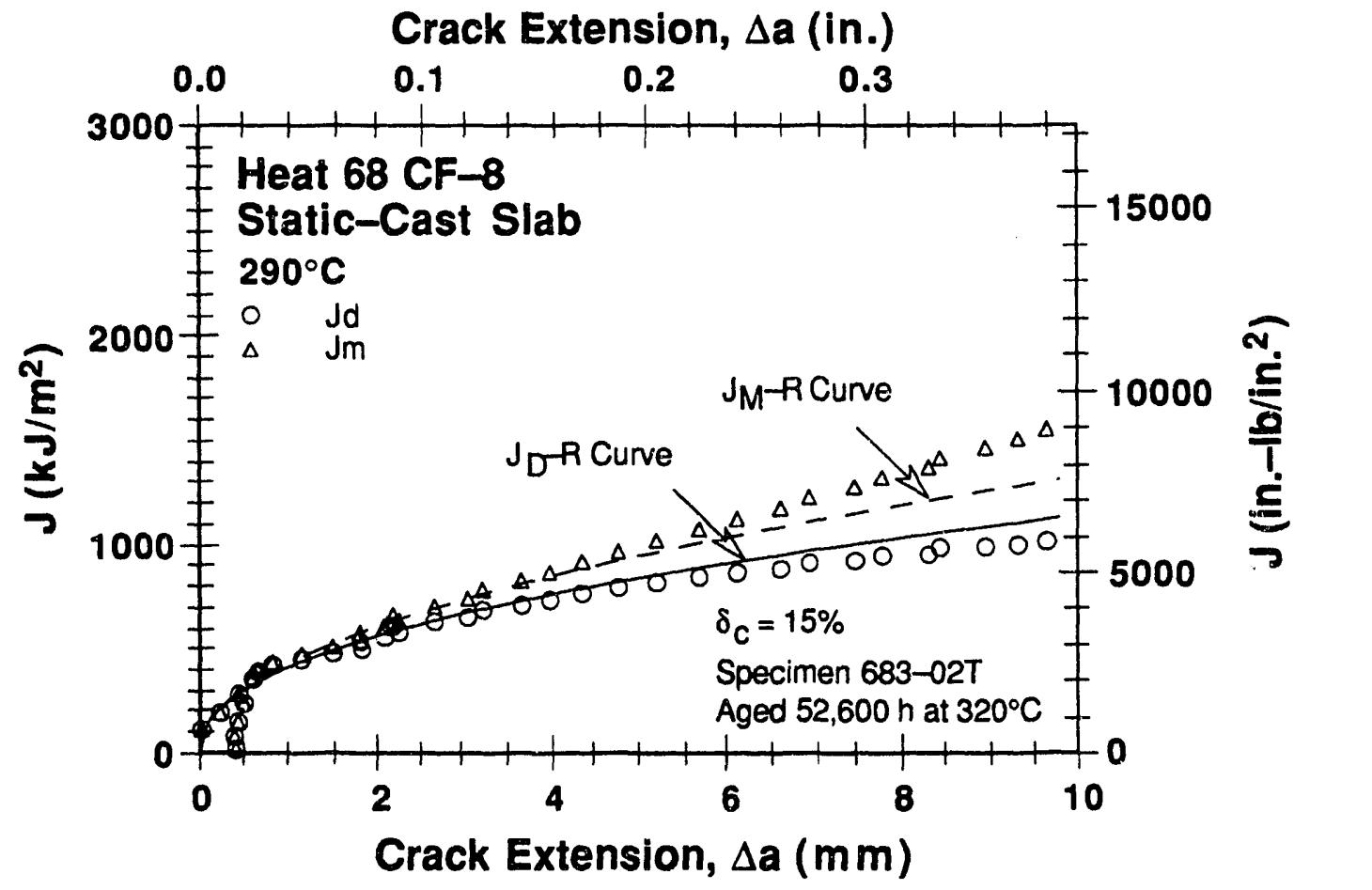

Figure A-62. Deformation and modified $J-R$ curves at $290^{\circ} \mathrm{C}$ for Heat 68 aged $52,600 \mathrm{~h}$ at $320^{\circ} \mathrm{C}$ 


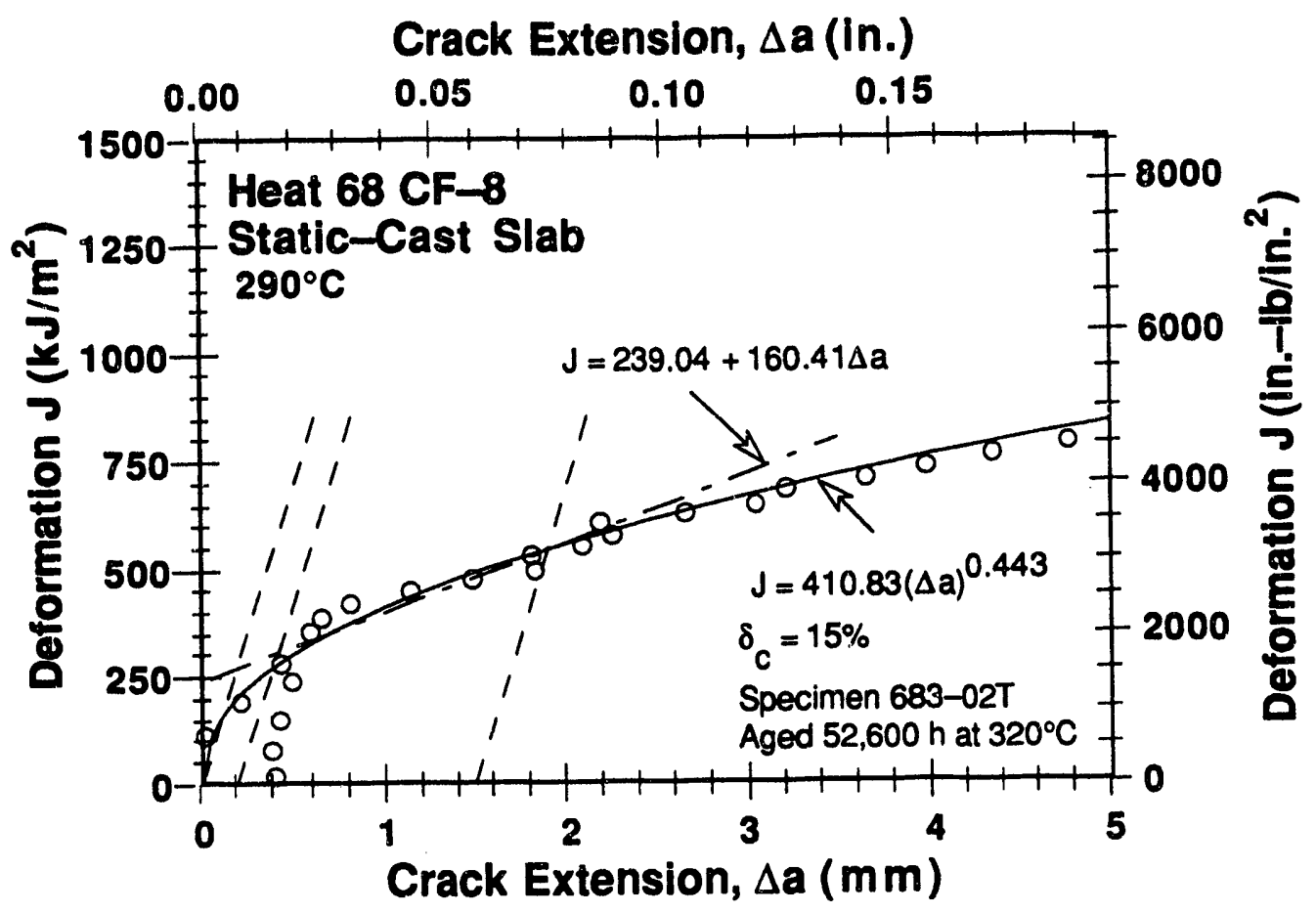

Figure A-63. Deformation $J_{I C}$ at $290^{\circ} \mathrm{C}$ for Heat 68 aged $52,600 \mathrm{~h}$ at $320^{\circ} \mathrm{C}$

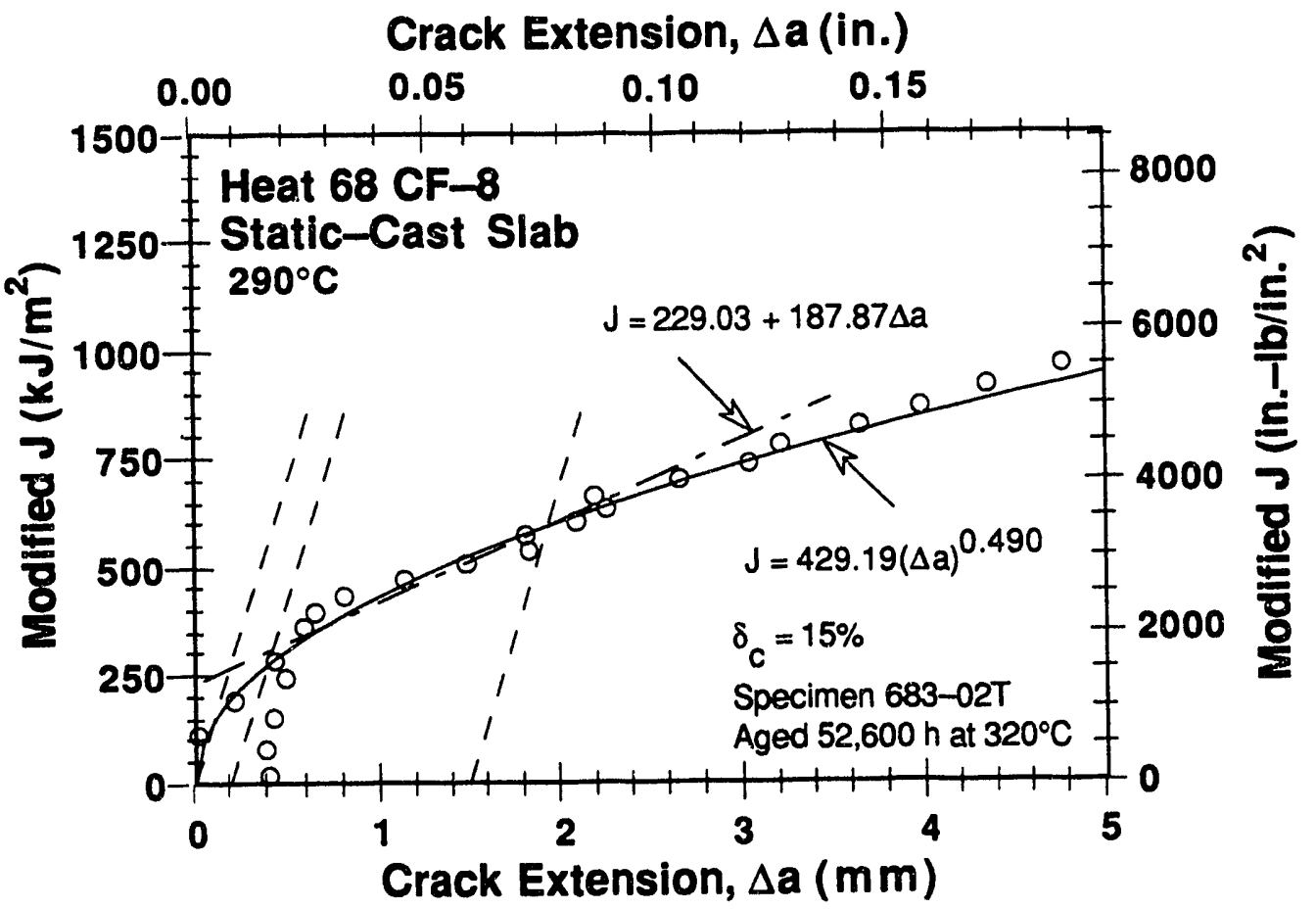

Figure A-64. Modified $J_{I C}$ at $290^{\circ} \mathrm{C}$ for Heat 68 aged $52,600 \mathrm{~h}$ at $320^{\circ} \mathrm{C}$ 
Table A-65. Test data for specumen 745-03V

$\begin{array}{ll}\text { Test Number } & : 0108 \\ \text { Material Type } & : \text { CF-8M } \\ \text { Aging Temp. } & : 25^{\circ} \mathrm{C} \\ \text { Spec. Thickness } & : 25.39 \mathrm{~mm} \\ \text { Spec. Width } & : 50.82 \mathrm{~mm}\end{array}$

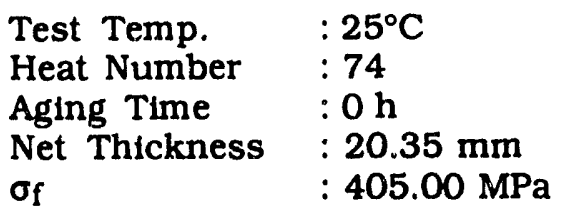

\begin{tabular}{|c|c|c|c|c|c|}
\hline $\begin{array}{l}\text { Unload } \\
\text { Number }\end{array}$ & $\begin{array}{c}J_{d} \\
\left(\mathrm{~kJ} / \mathrm{m}^{2}\right)\end{array}$ & $\begin{array}{c}J_{m} \\
\left(\mathrm{~kJ} / \mathrm{m}^{2}\right)\end{array}$ & $\begin{array}{c}\Delta \mathbf{a} \\
(\mathrm{mm})\end{array}$ & $\begin{array}{l}\text { Load } \\
(\mathrm{kN})\end{array}$ & $\begin{array}{l}\text { Deflection } \\
(\mathrm{mm})\end{array}$ \\
\hline $\begin{array}{l}1 \\
2 \\
3 \\
4 \\
5 \\
6 \\
7 \\
8 \\
9 \\
10 \\
11 \\
12 \\
13 \\
14 \\
15 \\
16 \\
17 \\
18 \\
19 \\
20 \\
21 \\
22 \\
23 \\
24 \\
25 \\
26 \\
27 \\
28 \\
29 \\
30 \\
31 \\
32 \\
33 \\
34 \\
35 \\
36 \\
37 \\
38 \\
39 \\
40\end{array}$ & $\begin{array}{r}16.35 \\
51.75 \\
86.16 \\
122.60 \\
152.39 \\
191.71 \\
230.27 \\
270.14 \\
320.06 \\
367.34 \\
403.66 \\
444.55 \\
485.90 \\
518.60 \\
553.36 \\
586.59 \\
625.29 \\
664.35 \\
709.45 \\
756.05 \\
799.37 \\
842.55 \\
890.24 \\
933.42 \\
970.17 \\
1004.39 \\
1038.74 \\
1078.40 \\
1107.00 \\
1142.30 \\
1175.46 \\
1204.59 \\
1228.34 \\
1251.02 \\
1253.46 \\
1259.69 \\
1270.74 \\
1276.93 \\
1274.97 \\
1267.61\end{array}$ & $\begin{array}{r}16.31 \\
51.74 \\
86.44 \\
123.68 \\
153.33 \\
193.36 \\
233.67 \\
274.44 \\
321.19 \\
372.24 \\
409.30 \\
453.85 \\
496.61 \\
531.70 \\
565.94 \\
601.90 \\
645.54 \\
688.62 \\
742.20 \\
794.59 \\
847.68 \\
900.64 \\
963.00 \\
1024.29 \\
1084.35 \\
1152.14 \\
1216.65 \\
1301.91 \\
1376.42 \\
1451.18 \\
1528.23 \\
1600.82 \\
1673.18 \\
1758.56 \\
1836.90 \\
1910.33 \\
1982.10 \\
2052.03 \\
2119.18 \\
2183.93\end{array}$ & $\begin{array}{r}-0.1431 \\
-0.1285 \\
-0.0537 \\
0.0811 \\
0.0638 \\
0.1344 \\
0.2741 \\
0.3348 \\
0.1599 \\
0.3400 \\
0.3715 \\
0.5122 \\
0.5616 \\
0.6392 \\
0.6235 \\
0.7010 \\
0.8312 \\
0.9305 \\
1.1240 \\
1.2470 \\
1.4416 \\
1.6247 \\
1.8810 \\
2.1785 \\
2.5407 \\
3.0329 \\
3.4518 \\
4.0447 \\
4.6101 \\
5.0697 \\
5.5536 \\
6.0090 \\
6.4949 \\
7.0887 \\
7.7753 \\
8.3570 \\
8.8598 \\
9.3658 \\
9.8938 \\
10.4250\end{array}$ & $\begin{array}{l}19.135 \\
25.293 \\
27.385 \\
28.772 \\
29.570 \\
30.232 \\
31.634 \\
31.354 \\
30.713 \\
32.240 \\
32.544 \\
32.639 \\
32.618 \\
32.469 \\
32.421 \\
32.452 \\
32.255 \\
32.291 \\
32.007 \\
31.958 \\
31.602 \\
31.552 \\
30.954 \\
30.027 \\
29.254 \\
28.066 \\
26.766 \\
25.643 \\
24.389 \\
23.336 \\
22.206 \\
21.026 \\
20.000 \\
18.630 \\
16.899 \\
15.532 \\
14.410 \\
13.358 \\
12.448 \\
11.546\end{array}$ & $\begin{array}{l}0.303 \\
0.604 \\
0.855 \\
1.107 \\
1.308 \\
1.559 \\
1.807 \\
2.059 \\
2.350 \\
2.636 \\
2.859 \\
3.111 \\
3.361 \\
3.560 \\
3.761 \\
3.963 \\
4.211 \\
4.459 \\
4.759 \\
5.061 \\
5.358 \\
5.660 \\
6.010 \\
6.362 \\
6.711 \\
7.111 \\
7.510 \\
8.031 \\
8.511 \\
9.002 \\
9.510 \\
10.007 \\
10.509 \\
11.112 \\
11.708 \\
12.308 \\
12.909 \\
13.511 \\
14.108 \\
14.709\end{array}$ \\
\hline
\end{tabular}


Table A-66. Deformation $J_{I C}$ and $J-R$ curve results for spectmen 745-03V

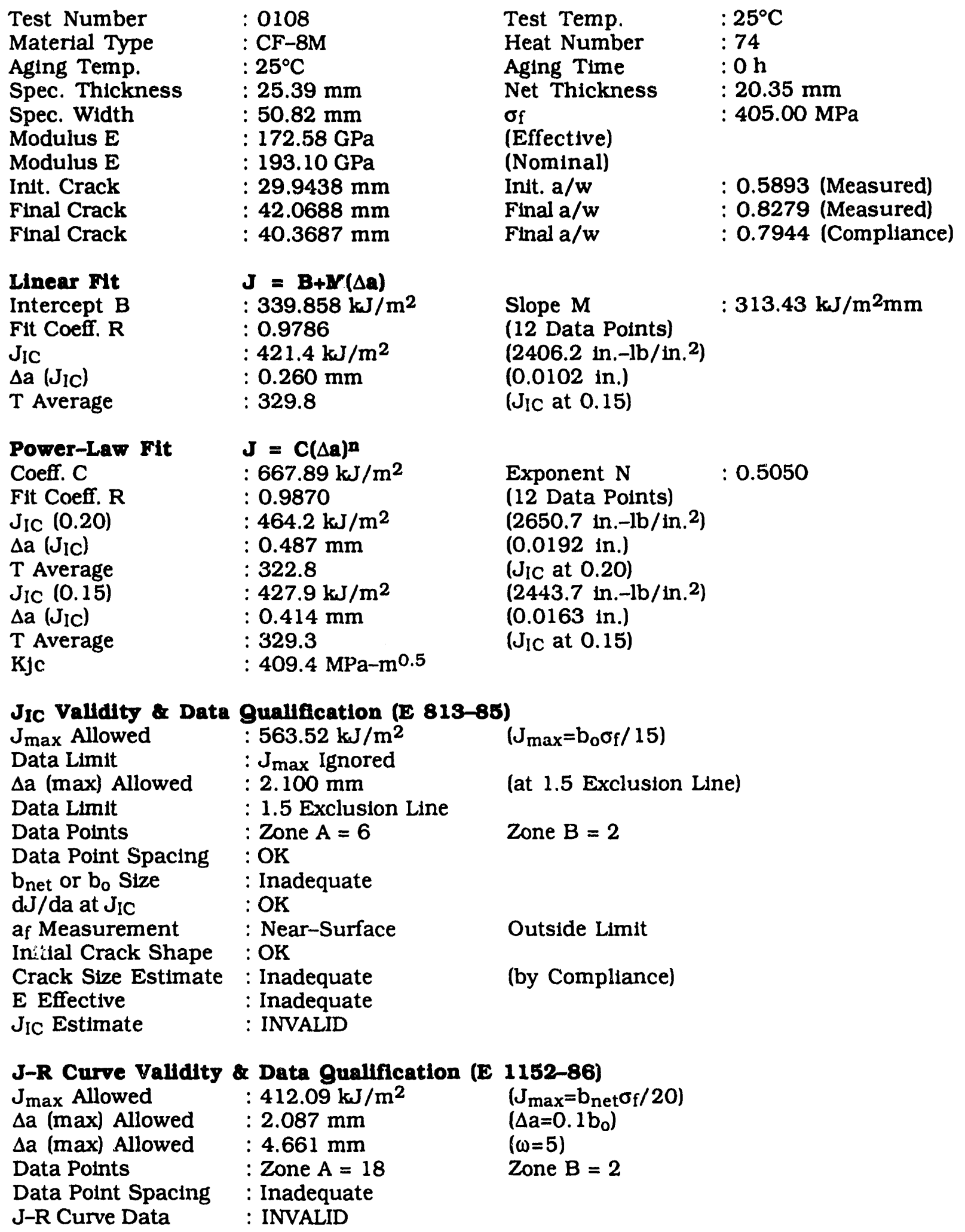


Table A-67. Modified $J_{I C}$ and J-R curve results for specimen 745-03V

Test Number

Material Type

Aging Temp.

Spec. Thickness

Spec. Width

Modulus E

Modulus E

Init. Crack

Final Crack

Final Crack

\section{Linear Fit}

Intercept $B$

Fit Coeff. $R$

JIC

$\Delta \mathrm{a}\left(\mathrm{J}_{\mathrm{IC}}\right)$

$T$ Average

Power-Law Fit

Coeff. C

Fit Coeff. $R$

$J_{I C}(0.20)$

$\Delta \mathrm{a}\left(\mathrm{J}_{\mathrm{lC}}\right)$

$T$ Average

$\mathrm{J}_{\text {IC }}(0.15)$

$\Delta \mathrm{a}\left(\mathrm{J}_{1 \mathrm{C}}\right)$

$\mathrm{T}$ Average

$\mathrm{KJC}$
: 0108

: CF-8M

: $25^{\circ} \mathrm{C}$

: $25.39 \mathrm{~mm}$

: $50.82 \mathrm{~mm}$

: $172.58 \mathrm{GPa}$

: $193.10 \mathrm{GPa}$

: $29.9438 \mathrm{~mm}$

: $42.0688 \mathrm{~mm}$

: $40.3687 \mathrm{~mm}$

$\mathbf{J}=\mathbf{B}+\mathbf{M}(\Delta \mathbf{q})$

: $323.332 \mathrm{~kJ} / \mathrm{m}^{2}$

: 0.9852

: $415.4 \mathrm{~kJ} / \mathrm{m}^{2}$

$0.256 \mathrm{~mm}$

: 377.9

$\mathbf{J}=\mathbf{C}(\Delta \mathbf{a})^{\mathbf{n}}$

: $697.69 \mathrm{~kJ} / \mathrm{m}^{2}$

: 0.9907

: $472.8 \mathrm{~kJ} / \mathrm{m}^{2}$

: $0.492 \mathrm{~mm}$

: 365.2

: $431.5 \mathrm{~kJ} / \mathrm{m}^{2}$

$0.416 \mathrm{~mm}$

: 372.0

: $428.4 \mathrm{MPa}-\mathrm{m}^{0.5}$
Test Temp. $\quad: 25^{\circ} \mathrm{C}$

Heat Number $: 74$

Aging Time $: 0 \mathrm{~h}$

Net Thickness : $20.35 \mathrm{~mm}$

of $\quad: 405.00 \mathrm{MPa}$

(Effective)

(Nominal)

Init. $a / w \quad: 0.5893$ (Measured)

Final $a / w \quad: 0.8279$ (Measured)

Final $a / w \quad: 0.7944$ (Compliance)

Slope $M$

: $359.17 \mathrm{~kJ} / \mathrm{m}^{2} \mathrm{~mm}$

(12 Data Points)

(2372.2 in. -lb/tn. ${ }^{2}$ )

(0.0101 in.)

(JIC at 0.15 )

Exponent N

: 0.5484

(12 Data Points)

(2699.5 in.-lb/in. ${ }^{2}$ )

(0.0194 in.)

( $\mathrm{JIC}$ at 0.20 )

(2463.8 in. $-\mathrm{lb} /$ in. $^{2}$ )

(0.0164 in.)

( $\mathrm{JIC}_{\mathrm{C}}$ at 0.15$)$

Crack Extension, $\Delta a$ (in.)

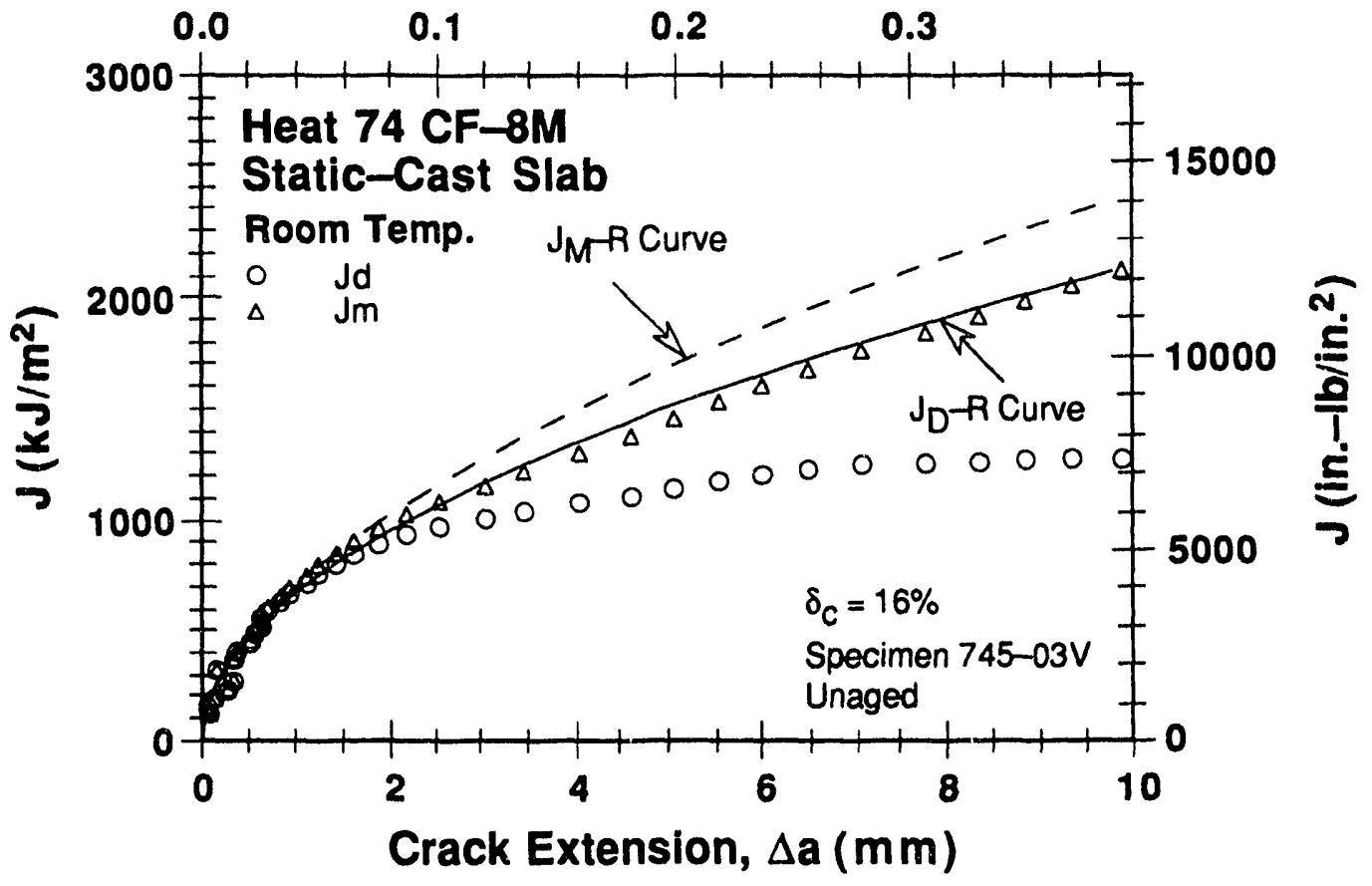

Figure A-65. Deformation and modifled $J-R$ curves at room temp. for unaged Heat 74 


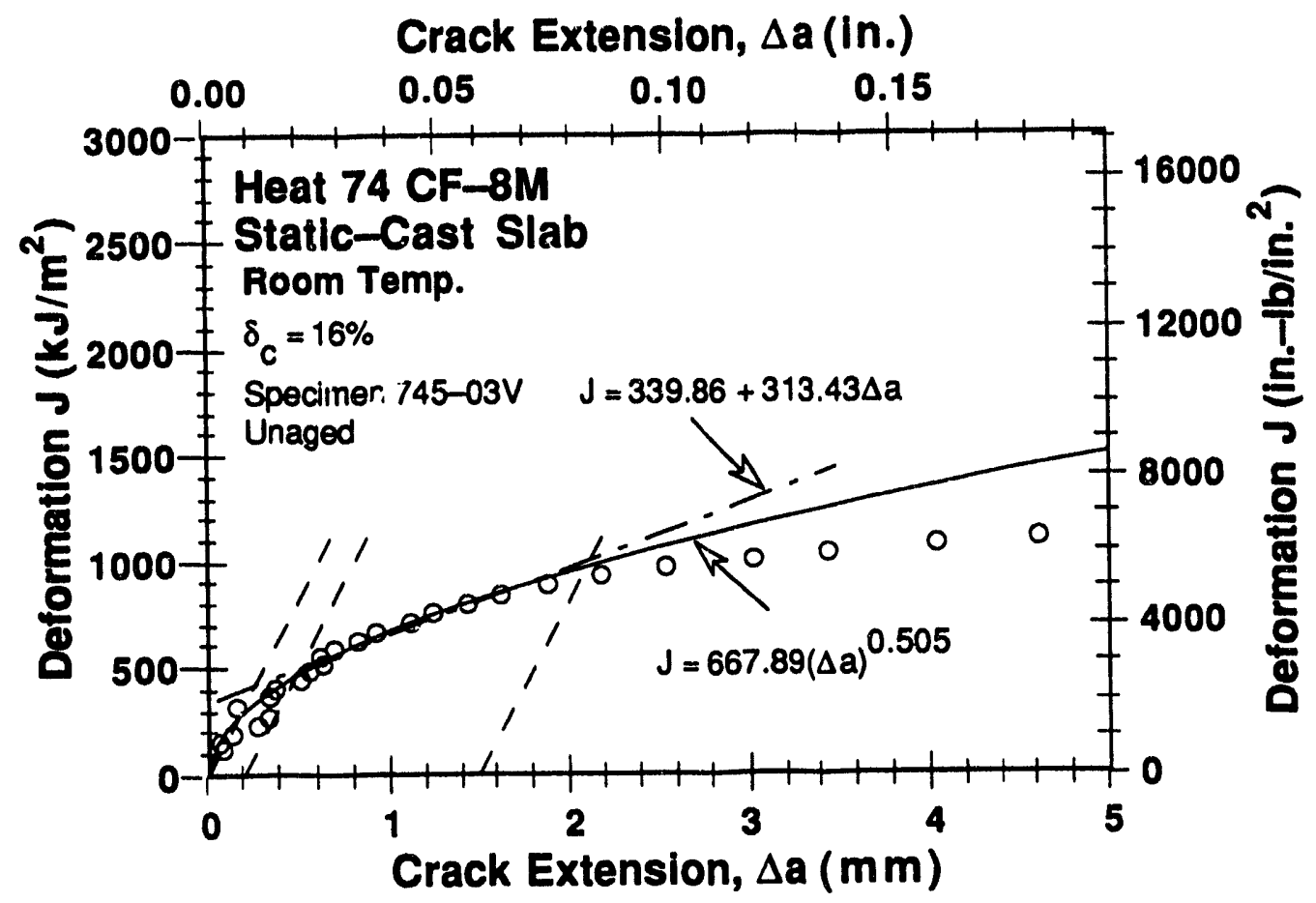

Figure A-66. Deformation $J_{I C}$ at room temp. for unaged Heat 74

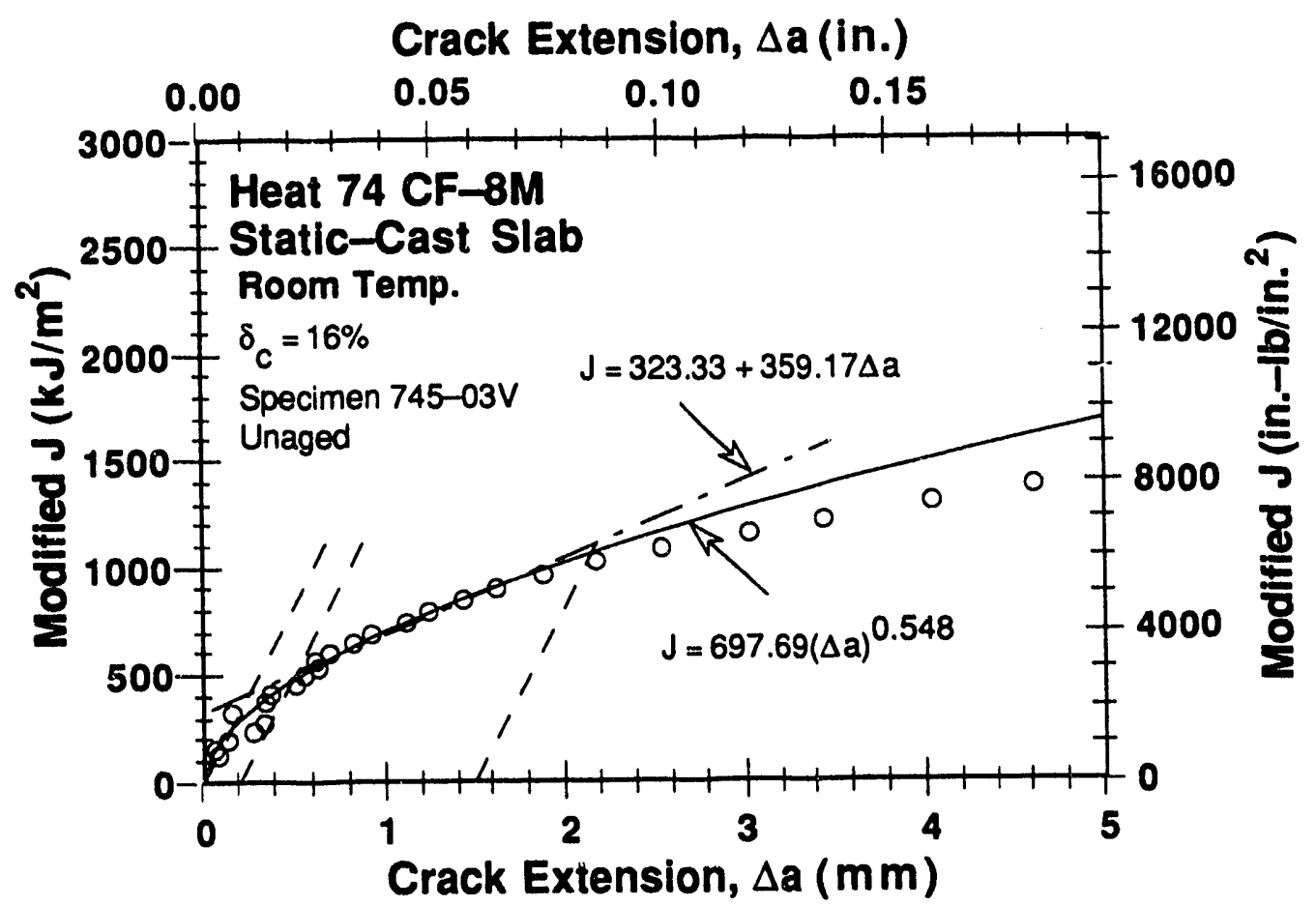

Fygure A-67. Modified $J_{I C}$ at room temp. for unaged Heat 74 
Table A-68. Test data for spectmen 743-03B

\begin{tabular}{|c|c|c|c|c|c|}
\hline $\begin{array}{l}\text { Test Nur } \\
\text { Material } \\
\text { Aging Te } \\
\text { Spec. Th } \\
\text { Spec. WI }\end{array}$ & $\begin{array}{l}\text { er } \\
\text { pe } \\
\text { o. } \\
\text { aness }\end{array}$ & $\mathrm{mm}$ & $\begin{array}{l}\text { Test } \\
\text { Heat } \\
\text { Aging } \\
\text { Net T } \\
\text { Flow }\end{array}$ & & $\begin{array}{l}00 \mathrm{~h} \\
6 \mathrm{~mm} \\
73 \mathrm{MPa}\end{array}$ \\
\hline $\begin{array}{l}\text { Unload } \\
\text { Number }\end{array}$ & $\begin{array}{c}J_{d} \\
\left(\mathrm{~kJ} / \mathrm{m}^{2}\right)\end{array}$ & $\begin{array}{c}J_{m} \\
\left(\mathrm{~kJ} / \mathrm{m}^{2}\right)\end{array}$ & $\begin{array}{c}\Delta a \\
(\mathrm{~mm})\end{array}$ & $\begin{array}{l}\text { Load } \\
(\mathrm{kN})\end{array}$ & $\begin{array}{c}\text { Deflection } \\
\text { (mm) }\end{array}$ \\
\hline $\begin{array}{l}1 \\
2 \\
3 \\
4 \\
5 \\
6 \\
7 \\
8 \\
9 \\
10 \\
11 \\
12 \\
13 \\
14 \\
15 \\
16 \\
17 \\
18 \\
19 \\
20 \\
21 \\
22 \\
23 \\
24 \\
25 \\
26 \\
27 \\
28 \\
29 \\
30 \\
31 \\
32 \\
33 \\
34 \\
35 \\
36 \\
37 \\
38 \\
39 \\
40 \\
41 \\
42 \\
43 \\
44 \\
45 \\
46\end{array}$ & $\begin{array}{r}19.24 \\
58.74 \\
88.89 \\
121.87 \\
156.15 \\
191.88 \\
227.04 \\
264.12 \\
301.57 \\
337.77 \\
364.76 \\
392.44 \\
422.08 \\
450.43 \\
476.80 \\
504.94 \\
530.77 \\
556.63 \\
584.94 \\
612.89 \\
639.35 \\
662.43 \\
688.89 \\
710.57 \\
739.50 \\
765.98 \\
798.99 \\
832.56 \\
862.35 \\
886.66 \\
911.93 \\
930.65 \\
950.05 \\
978.73 \\
1011.61 \\
1051.38 \\
1087.76 \\
1118.61 \\
1163.74 \\
1202.31 \\
1228.02 \\
1250.48 \\
1256.55 \\
1266.06 \\
1289.55 \\
1303.10\end{array}$ & $\begin{array}{r}19.22 \\
58.81 \\
88.82 \\
121.91 \\
156.57 \\
191.68 \\
228.47 \\
265.54 \\
304.21 \\
343.50 \\
372.32 \\
402.08 \\
430.85 \\
463.28 \\
492.92 \\
523.03 \\
554.86 \\
585.04 \\
614.77 \\
645.95 \\
676.85 \\
707.74 \\
737.20 \\
769.58 \\
797.36 \\
829.79 \\
871.51 \\
912.13 \\
956.30 \\
994.53 \\
1033.84 \\
1074.26 \\
1109.22 \\
1168.28 \\
1220.78 \\
1275.89 \\
1332.70 \\
1407.84 \\
1475.89 \\
1549.92 \\
1636.81 \\
1717.18 \\
1793.71 \\
1867.01 \\
1954.22 \\
2042.55\end{array}$ & $\begin{array}{l}-0.0434 \\
-0.0021 \\
-0.0400 \\
-0.0202 \\
0.0307 \\
0.0489 \\
0.1213 \\
0.1198 \\
0.1956 \\
0.3648 \\
0.4566 \\
0.5524 \\
0.5155 \\
0.6763 \\
0.7971 \\
0.8655 \\
1.0612 \\
1.1947 \\
1.2360 \\
1.3252 \\
1.4422 \\
1.6387 \\
1.7108 \\
1.9577 \\
1.9324 \\
2.0586 \\
2.2344 \\
2.3694 \\
2.6323 \\
2.8766 \\
3.1133 \\
3.4653 \\
3.7100 \\
4.1632 \\
4.4424 \\
4.6501 \\
4.9137 \\
5.4544 \\
5.7195 \\
6.1079 \\
6.7399 \\
7.3079 \\
7.9690 \\
8.5420 \\
9.0840 \\
9.6872\end{array}$ & $\begin{array}{l}21.880 \\
28.826 \\
31.310 \\
33.022 \\
34.392 \\
35.462 \\
36.274 \\
36.825 \\
37.346 \\
37.904 \\
38.342 \\
38.478 \\
38.648 \\
38.679 \\
38.752 \\
38.803 \\
38.673 \\
38.662 \\
38.389 \\
38.201 \\
38.018 \\
37.932 \\
37.591 \\
37.421 \\
37.362 \\
37.284 \\
37.116 \\
36.512 \\
35.822 \\
34.980 \\
34.114 \\
32.598 \\
32.117 \\
30.883 \\
30.282 \\
29.675 \\
29.044 \\
27.753 \\
27.355 \\
26.207 \\
23.904 \\
22.249 \\
20.619 \\
19.300 \\
18.112 \\
16.656\end{array}$ & $\begin{array}{l}0.303 \\
0.606 \\
0.806 \\
1.007 \\
1.208 \\
1.407 \\
1.606 \\
1.807 \\
2.006 \\
2.206 \\
2.357 \\
2.507 \\
2.657 \\
2.809 \\
2.958 \\
3.109 \\
3.260 \\
3.412 \\
3.561 \\
3.711 \\
3.861 \\
4.010 \\
4.161 \\
4.311 \\
4.462 \\
4.610 \\
4.810 \\
5.010 \\
5.221 \\
5.414 \\
5.614 \\
5.818 \\
6.011 \\
6.312 \\
6.607 \\
6.908 \\
7.211 \\
7.609 \\
8.008 \\
8.412 \\
8.909 \\
9.413 \\
9.910 \\
10.411 \\
11.009 \\
11.625\end{array}$ \\
\hline
\end{tabular}


Table A-69. Deformation $J_{I C}$ and $J-R$ curve results for spectmen 743-03B

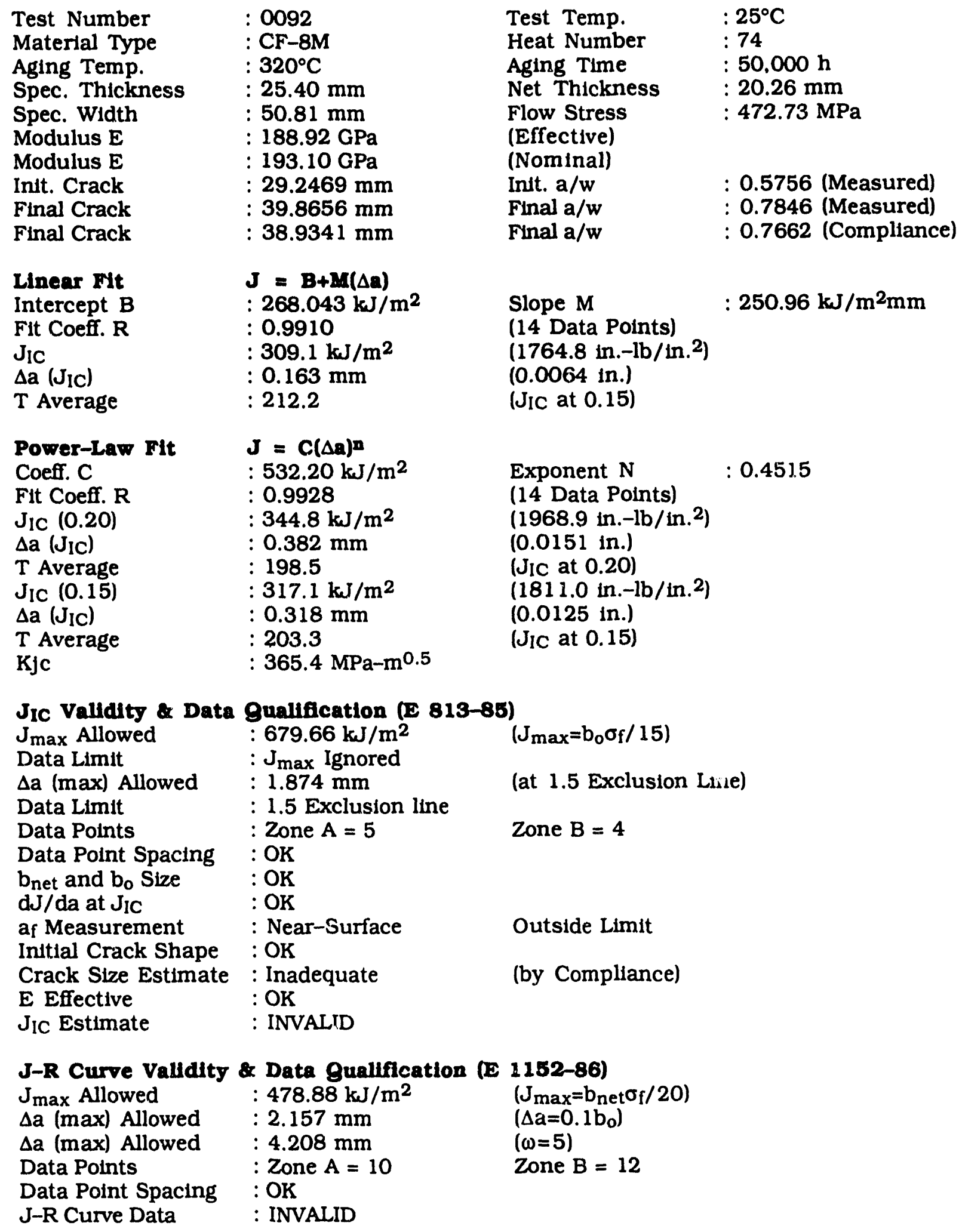


Table A-70. Modified $J_{I C}$ and $J-R$ curve results for spectmen 743-03B

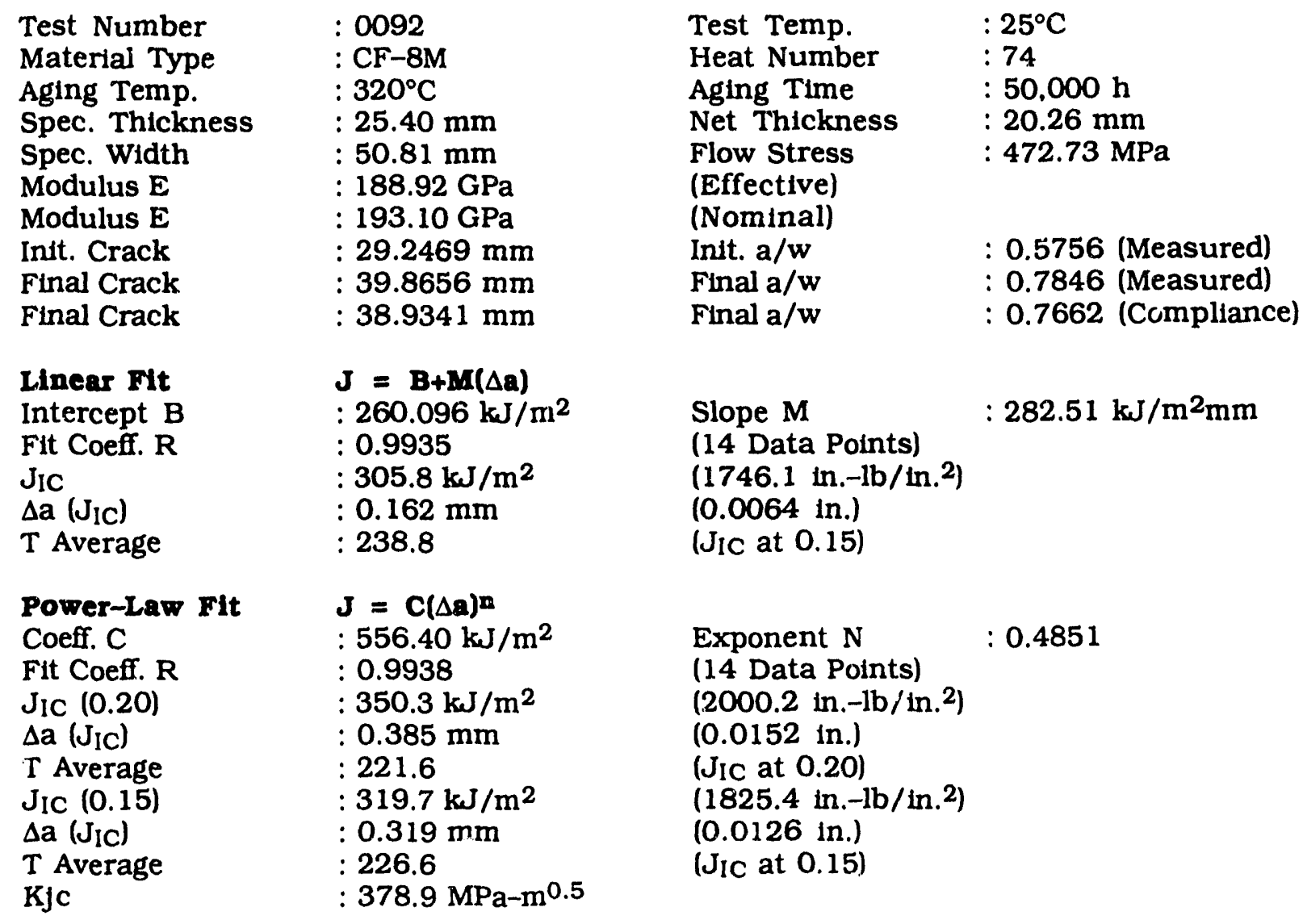

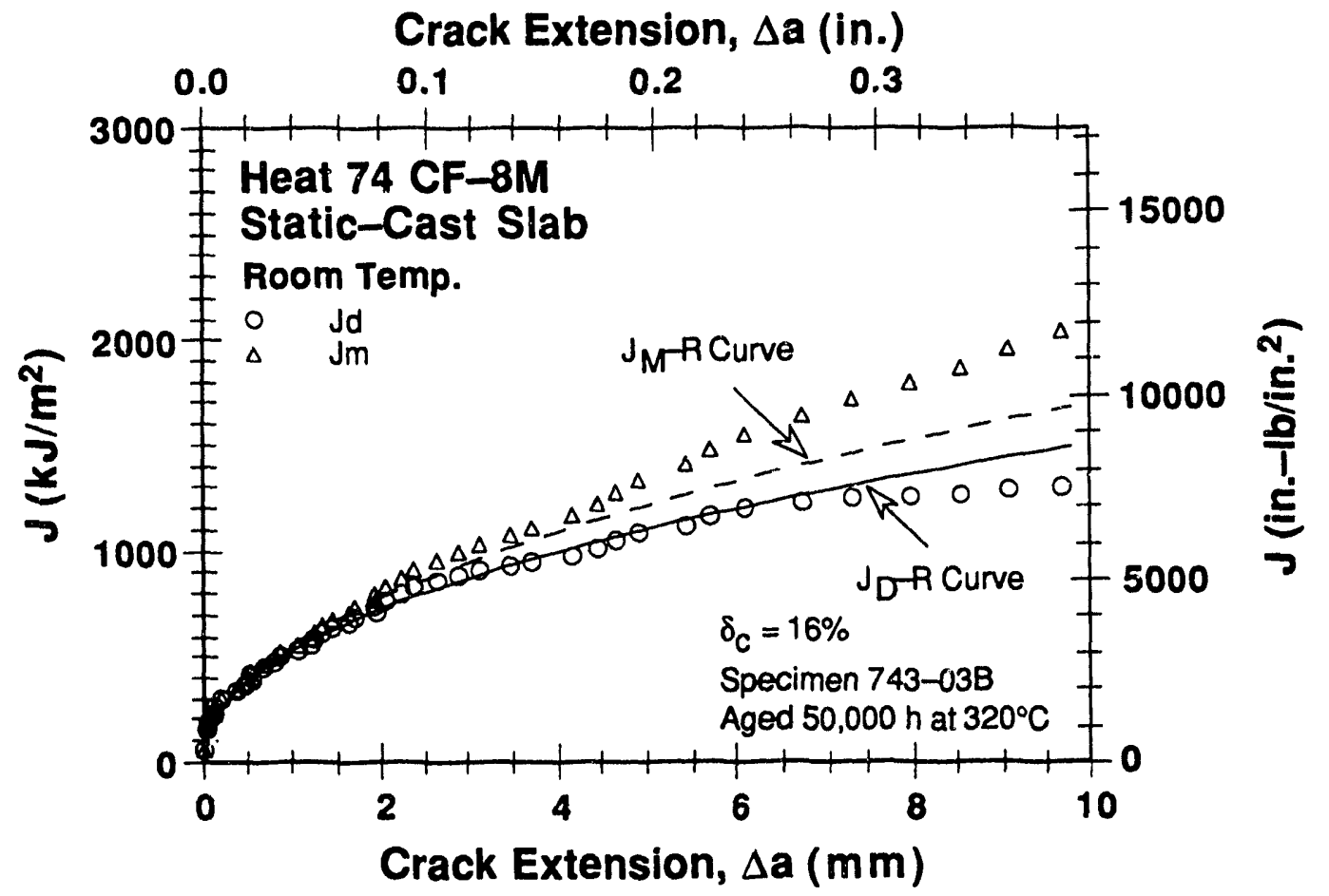

Figure A-68. Deformation and modified $J-R$ curves at roorn temp. for Heat 74 aged $50,000 \mathrm{~h}$ at $320^{\circ} \mathrm{C}$ 


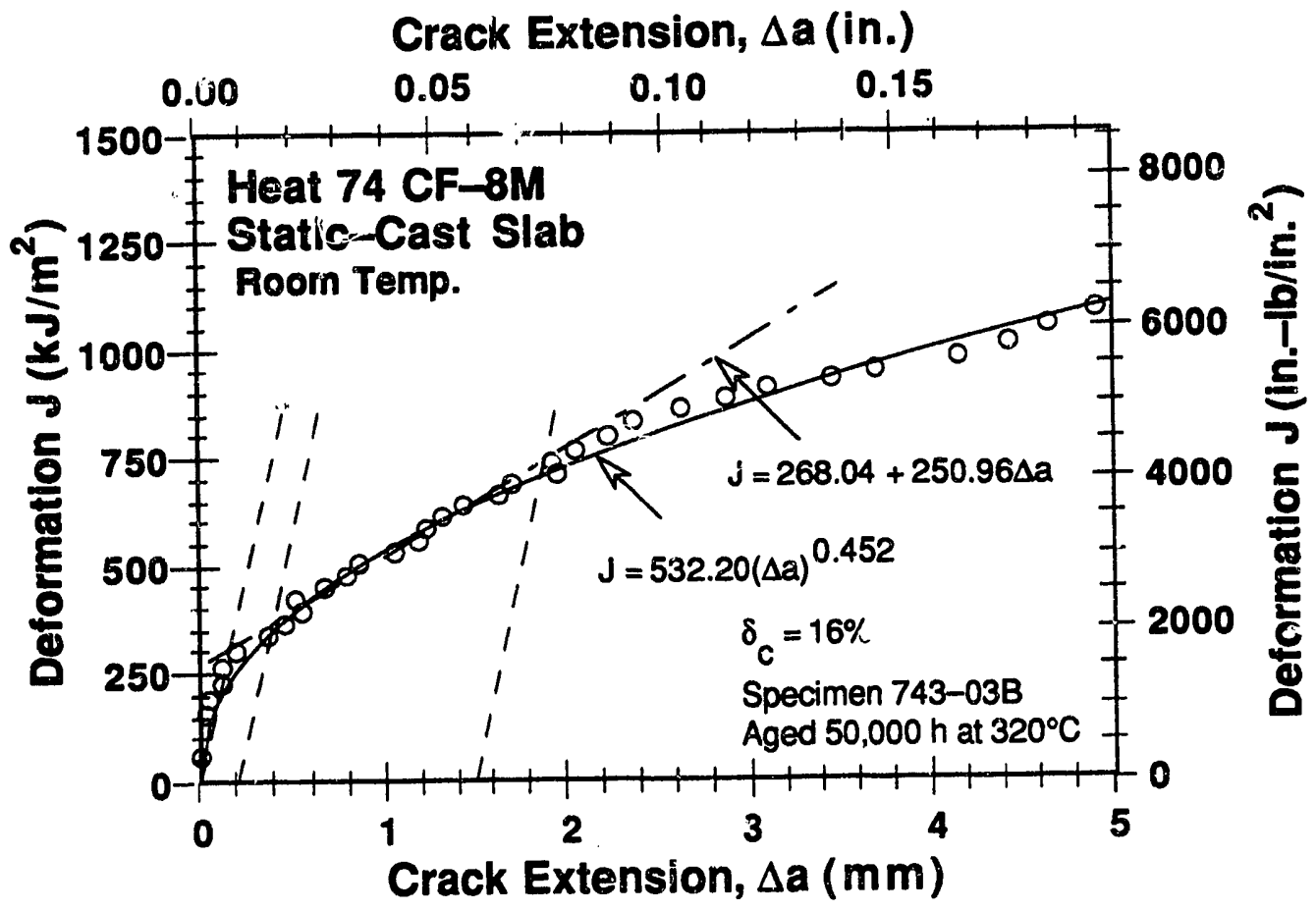

Figure A-69. Deformation $J_{I C}$ at room temp. for Heat 74 aged $5^{\prime} .000 \mathrm{~h}$ at $320^{\circ} \mathrm{C}$

Crack Extension, $\Delta a$ (in.)

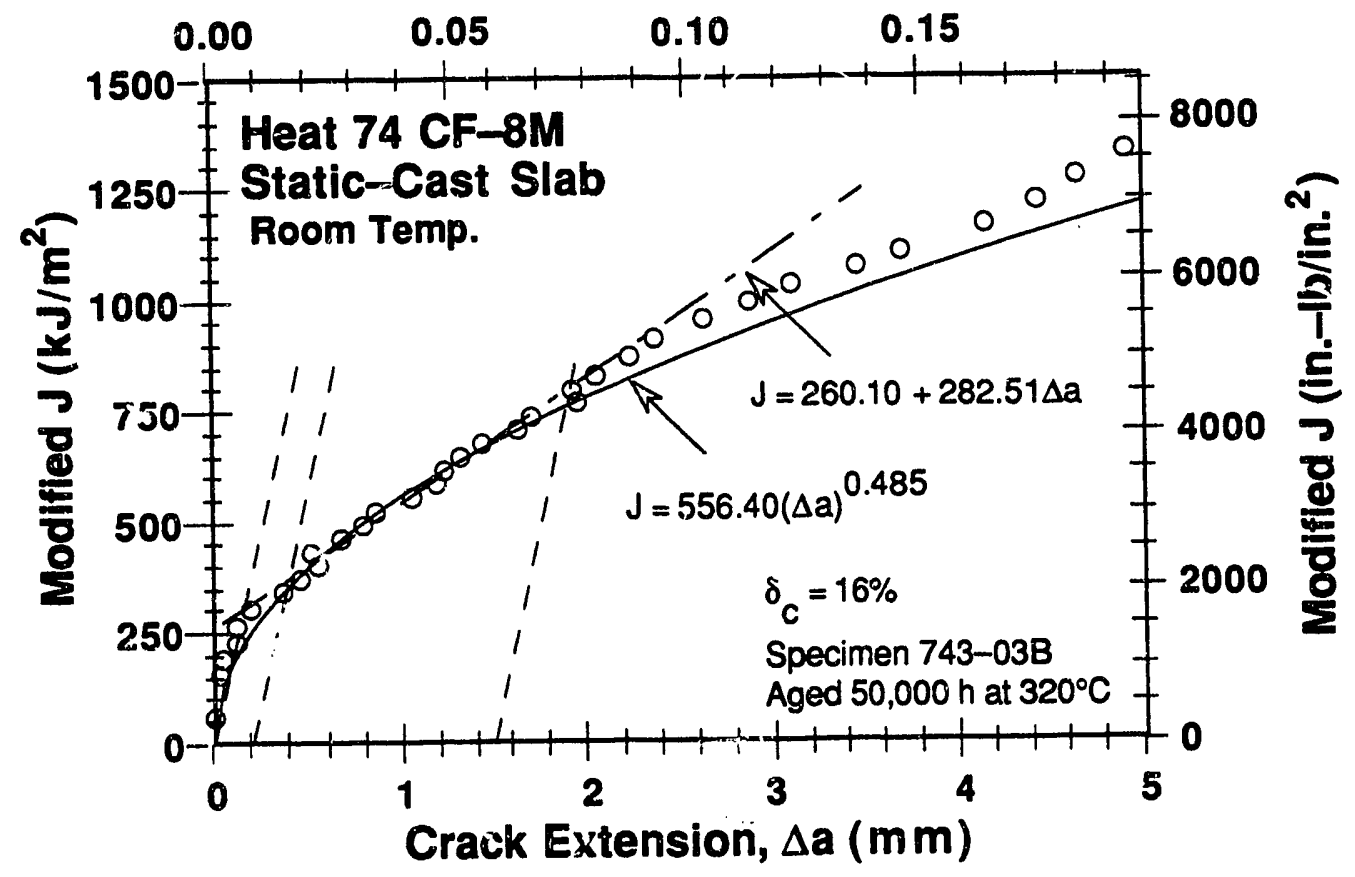

Figure A-70. Modified $J_{I C}$ at room temp. for He'at $i 1$ aged $50,000 \mathrm{~h}$ at $320^{\circ} \mathrm{C}$ 
Table A-71. Test data for specimen 744-02V

\begin{tabular}{|c|c|c|c|c|c|}
\hline $\begin{array}{l}\text { Test Nur } \\
\text { Material } \\
\text { Aging Te } \\
\text { Spec. Th } \\
\text { Slec. Wi }\end{array}$ & $\begin{array}{ll} & : \\
\text { pe } & : \\
\text { ness } & \vdots \\
& :\end{array}$ & $\begin{array}{l}\mathrm{mm} \\
\mathrm{mm}\end{array}$ & $\begin{array}{l}\text { Test } \\
\text { Heat } \\
\text { Aging } \\
\text { Net } \\
\text { Flow }\end{array}$ & & $\begin{array}{l}00 \mathrm{~h} \\
6 \mathrm{~mm} \\
73 \mathrm{MPa}\end{array}$ \\
\hline $\begin{array}{c}\text { Unload } \\
\text { Number }\end{array}$ & $\underset{\left(\mathrm{ke}^{1} / \mathrm{m}^{2}\right)}{\mathrm{J}_{\mathrm{d}}}$ & $\begin{array}{c}J_{m} \\
\left(\mathrm{~kJ} / \mathrm{m}^{2}\right)\end{array}$ & $\begin{array}{c}\Delta \mathrm{a} \\
(\mathrm{mm})\end{array}$ & $\begin{array}{l}\text { Load } \\
\text { (kN) }\end{array}$ & $\begin{array}{c}\text { Deflection } \\
\text { (mm) }\end{array}$ \\
\hline $\begin{array}{l}1 \\
2 \\
3 \\
4 \\
5 \\
6 \\
7 \\
8 \\
9 \\
10 \\
11 \\
12 \\
13 \\
14 \\
15 \\
16 \\
17 \\
18 \\
19 \\
20 \\
21 \\
22 \\
23 \\
24 \\
25 \\
26 \\
27 \\
28 \\
29\end{array}$ & $\begin{array}{r}18.39 \\
50.58 \\
86.31 \\
126.91 \\
169.31 \\
211.58 \\
253.47 \\
296.77 \\
336.36 \\
366.40 \\
392.55 \\
419.44 \\
447.10 \\
475.86 \\
500.34 \\
528.58 \\
557.96 \\
591.13 \\
622.46 \\
666.05 \\
711.55 \\
753.34 \\
788.53 \\
808.01 \\
824.12 \\
810.35 \\
815.13 \\
830.50 \\
848.14\end{array}$ & $\begin{array}{r}18.34 \\
50.82 \\
86.55 \\
127.17 \\
170.47 \\
215.14 \\
259.65 \\
305.62 \\
352.37 \\
398.81 \\
439.45 \\
477.92 \\
519.18 \\
559.38 \\
599.19 \\
637.73 \\
676.70 \\
723.65 \\
770.52 \\
832.38 \\
893.23 \\
953.32 \\
102.93 \\
1069.04 \\
1121.16 \\
1157.98 \\
1209.16 \\
1252.94 \\
1297.50\end{array}$ & $\begin{array}{l}-0.1568 \\
0.0038 \\
0.0059 \\
0.0084 \\
0.1129 \\
0.3286 \\
0.5182 \\
0.6787 \\
1.0470 \\
1.7874 \\
2.3776 \\
2.8090 \\
3.2724 \\
3.6301 \\
4.0750 \\
4.3533 \\
4.5942 \\
4.9151 \\
5.2521 \\
5.6142 \\
5.8932 \\
6.2008 \\
6.5834 \\
7.1230 \\
7.6246 \\
8.4359 \\
8.9050 \\
9.2555 \\
9.5729\end{array}$ & $\begin{array}{l}20.953 \\
26.695 \\
29.721 \\
31.663 \\
32.928 \\
33.535 \\
33.904 \\
33.860 \\
33.184 \\
30.694 \\
28.954 \\
28.217 \\
27.388 \\
26.429 \\
25.374 \\
24.914 \\
24.064 \\
23.479 \\
23.094 \\
22.475 \\
21.684 \\
20.848 \\
19.882 \\
18.118 \\
16.367 \\
14.162 \\
13.447 \\
12.963 \\
12.553\end{array}$ & $\begin{array}{l}0.302 \\
0.554 \\
0.803 \\
1.057 \\
1.309 \\
1.559 \\
1.809 \\
2.062 \\
2.310 \\
2.564 \\
2.815 \\
3.058 \\
3.308 \\
3.562 \\
3.808 \\
4.062 \\
4.311 \\
4.609 \\
4.912 \\
5.308 \\
5.711 \\
6.107 \\
6.507 \\
6.904 \\
7.308 \\
7.706 \\
8.106 \\
8.505 \\
8.904\end{array}$ \\
\hline
\end{tabular}


Table A-72. Deformation $J_{I C}$ and $J-R$ curve results for specimen 744-02V

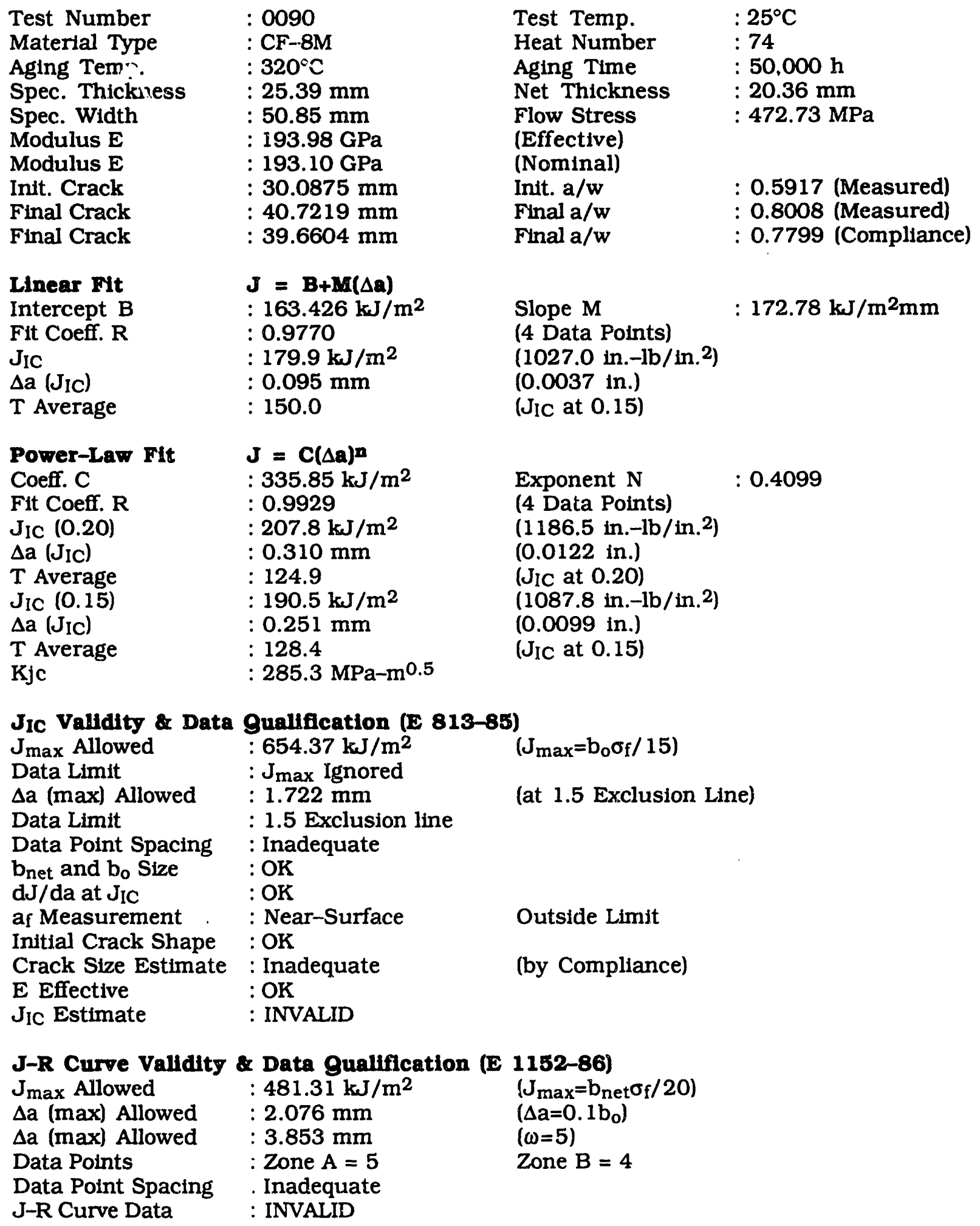


Table A-73. Modified $J_{I C}$ and $J-R$ curve results for spectmen 744-02V

\begin{tabular}{|c|c|c|c|}
\hline Test Number & $: 0090$ & Test Temp. & $: 25^{\circ} \mathrm{C}$ \\
\hline Material Type & : CF-8M & Heat Number & $: 74$ \\
\hline Aging Temp. & $: 320^{\circ} \mathrm{C}$ & Aging Time & $: 50,000 \mathrm{~h}$ \\
\hline Spec. Thickness & : $25.39 \mathrm{~mm}$ & Net Thickness & $20.36 \mathrm{~mm}$ \\
\hline Spec. Width & : $50.85 \mathrm{~mm}$ & Flow Stress & : $472.73 \mathrm{MPa}$ \\
\hline Modulus E & : $193.98 \mathrm{GPa}$ & (Effective) & \\
\hline Modulus E & $193.10 \mathrm{GPa}$ & (Nominal) & \\
\hline Init. Crack & : $30.0875 \mathrm{~mm}$ & Init. $a / w$ & : 0.5917 (Measured) \\
\hline Final Crack & : $40.7219 \mathrm{~mm}$ & Final a/w & : 0.8008 (Measured) \\
\hline Final Crack & : $39.6604 \mathrm{~mm}$ & Final $a / w$ & : 0.7799 (Compliance) \\
\hline $\begin{array}{l}\text { Linear Fit } \\
\text { Intercept B } \\
\text { Fit Coeff. R } \\
J_{\text {IC }} \\
\Delta \text { a (JIC) } \\
T \text { Average }\end{array}$ & $\begin{array}{l}J=B+M(\Delta \mathbf{a}) \\
: 160.803 \mathrm{~kJ} / \mathrm{m}^{2} \\
: 0.9821 \\
: 178.8 \mathrm{~kJ} / \mathrm{m}^{2} \\
: 0.095 \mathrm{~mm} \\
: 165.2\end{array}$ & $\begin{array}{l}\text { Slope } M \\
\text { (4 Data Points) } \\
\left(1021.0 \text { in. }-1 \mathrm{~b} / \text { in. }^{2}\right) \\
(0.0037 \text { in.) } \\
\left(J_{\text {IC } \text { at } 0.15)}\right.\end{array}$ & $: 190.31 \mathrm{~kJ} / \mathrm{m}^{2} \mathrm{~mm}$ \\
\hline $\begin{array}{l}\text { Power-Law Fit } \\
\text { Coeff. C } \\
\text { Fit Coeff. } \mathrm{R} \\
\mathrm{J}_{\text {IC }(0.20)} \\
\Delta \mathrm{a}\left(\mathrm{J}_{\mathrm{IC}}\right) \\
\mathrm{T} \text { Average } \\
\mathrm{J}_{\mathrm{IC}}(0.15) \\
\Delta \mathrm{a}\left(\mathrm{J}_{\mathrm{IC}}\right) \\
\mathrm{T} \text { Average } \\
\text { KjC }\end{array}$ & $\begin{array}{l}J=C(\Delta a)^{\mathbf{n}} \\
: 350.44 \mathrm{~kJ} / \mathrm{m}^{2} \\
: 0.9947 \\
: 211.0 \mathrm{~kJ} / \mathrm{m}^{2} \\
: 0.312 \mathrm{~mm} \\
: 137.4 \\
: 192.2 \mathrm{~kJ} / \mathrm{m}^{2} \\
: 0.252 \mathrm{~mm} \\
: 141.1 \\
: 294.0 \mathrm{MPa}-\mathrm{m}^{0.5}\end{array}$ & $\begin{array}{l}\text { Exponent } N \\
(4 \text { Data Points }) \\
\left(1204.7 \text { in. }-\mathrm{lb} / \text { in. }^{2}\right) \\
(0.0123 \text { in. }) \\
\left(J_{\text {IC }} \text { at } 0.20\right) \\
\left(1097.8 \mathrm{in.}-\mathrm{lb} / \text { in. }^{2}\right) \\
(0.0099 \text { in. }) \\
\left(J_{\text {IC }} \text { at } 0.15\right)\end{array}$ & $: 0.4352$ \\
\hline
\end{tabular}

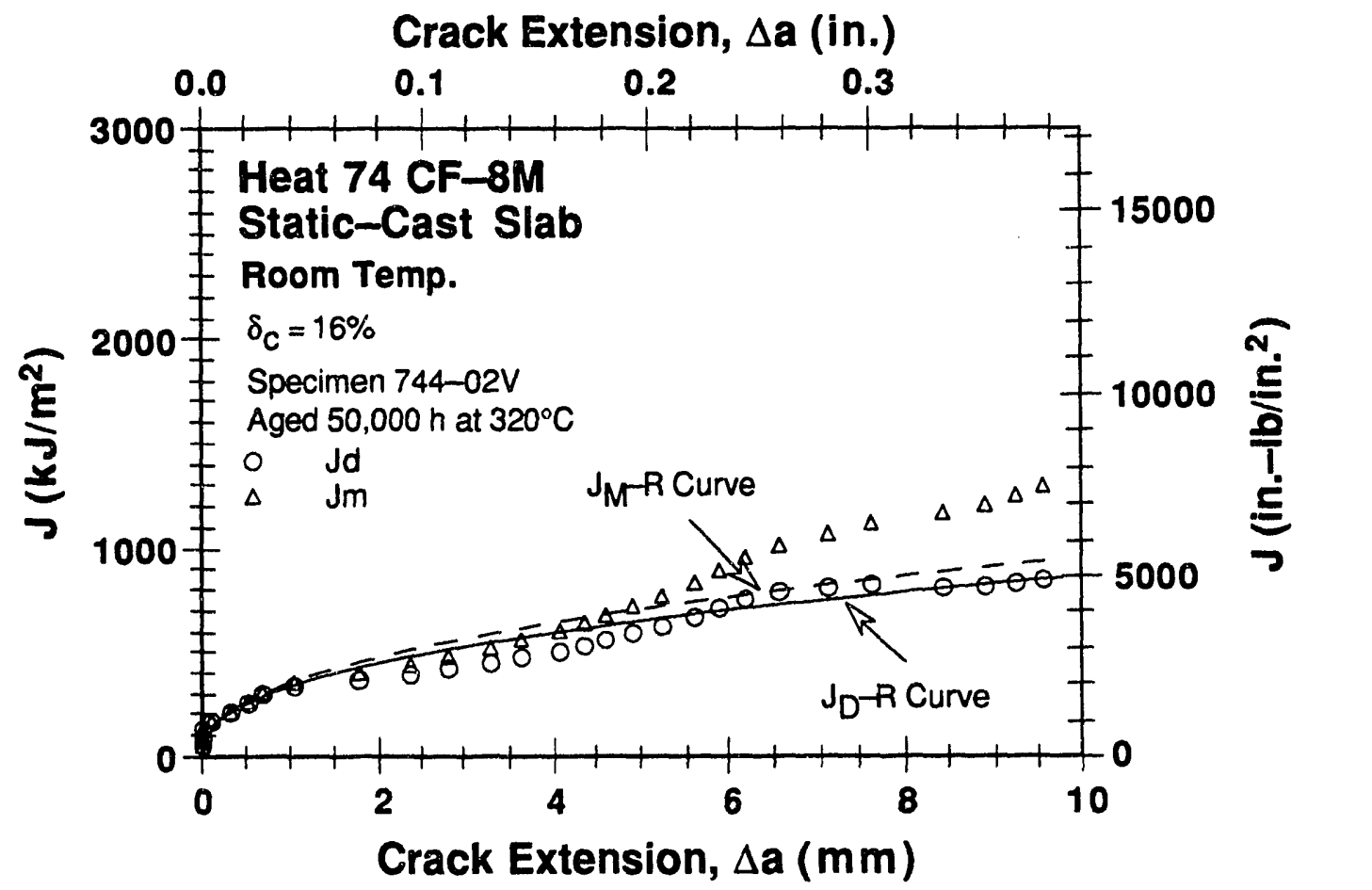

Figure A-71. Deformation and modified $J-R$ curves at room temp. for Heat 74 aged $50.000 \mathrm{~h}$ at $320^{\circ} \mathrm{C}$ 


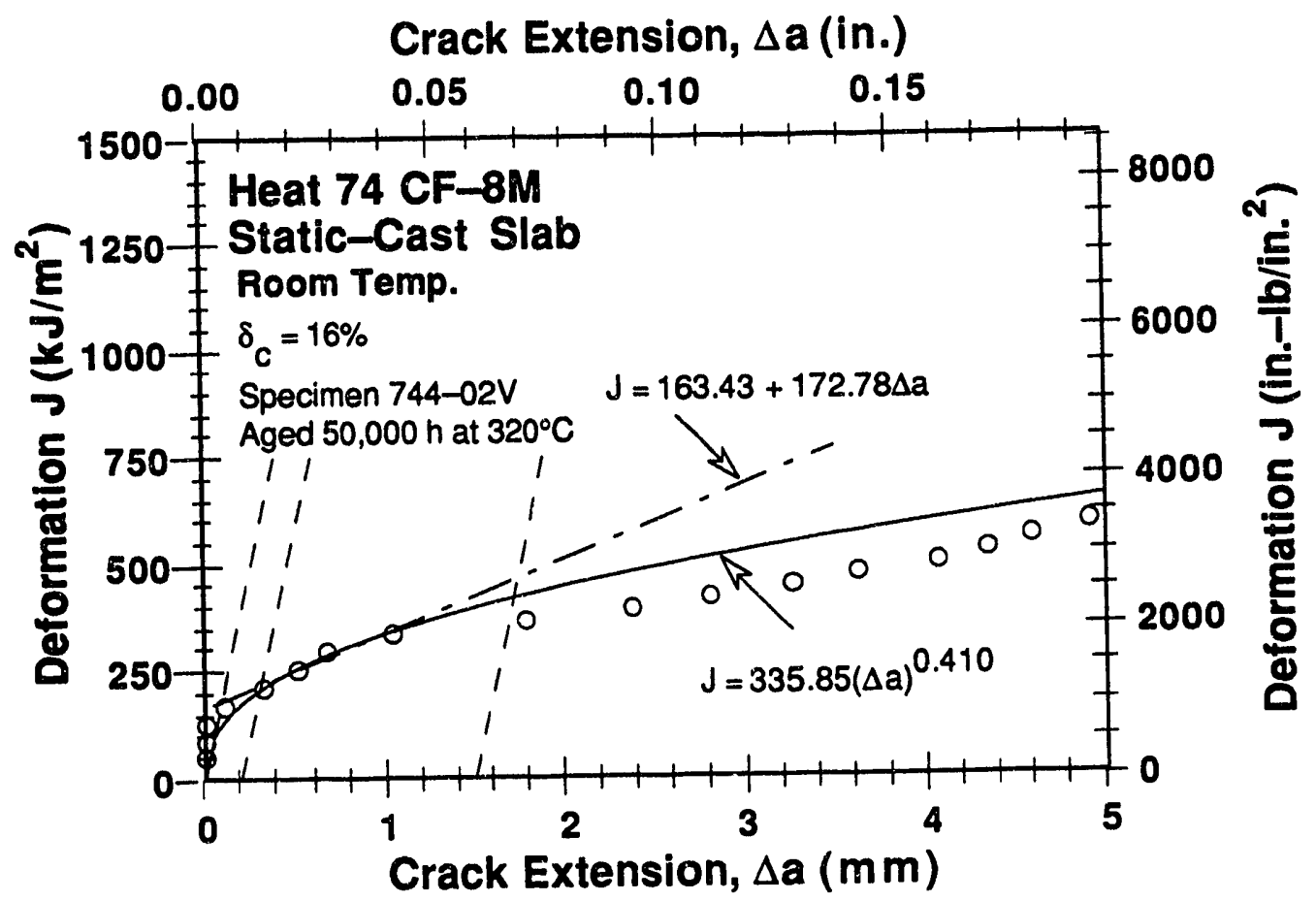

Figure A-72. Deformation $J_{I C}$ at room temp. for Heat 74 aged $50,000 \mathrm{~h}$ at $320^{\circ} \mathrm{C}$

Crack Extension, $\Delta \mathrm{a}$ (in.)

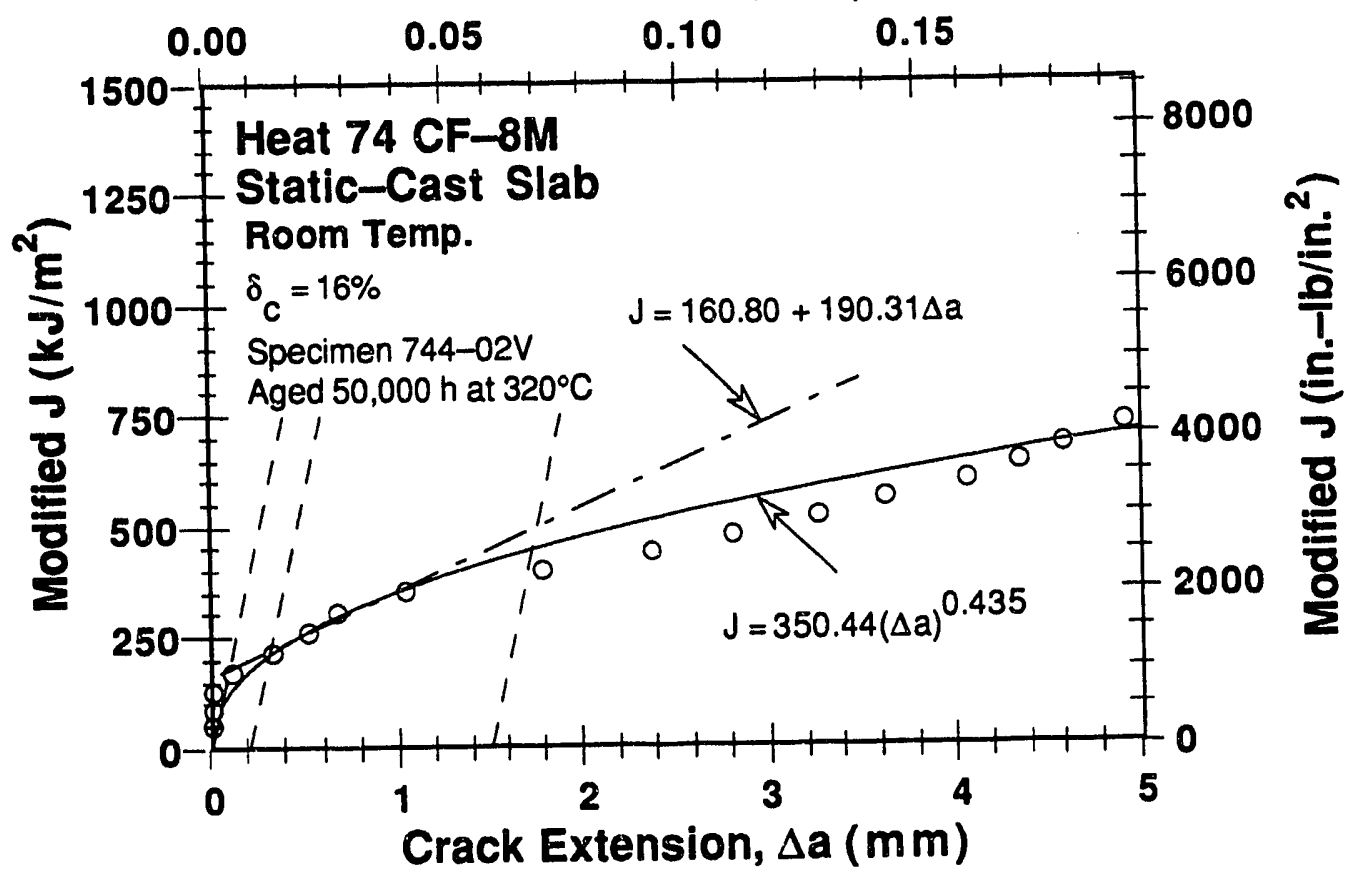

Figure A-73. Modified $\mathrm{J}_{\mathrm{IC}}$ at room temp. for Heat 74 aged $50,000 \mathrm{~h}$ at $320^{\circ} \mathrm{C}$ 
Table A-74. Test data for specimen 743-07T

\begin{tabular}{|c|c|c|c|c|c|}
\hline $\begin{array}{l}\text { Test Nun } \\
\text { Material } \\
\text { Aging Te } \\
\text { Spec. Th } \\
\text { Spec. Wt }\end{array}$ & $\begin{array}{ll}\text { er } & : \\
\text { ype } & : \\
\text { p. } & : \\
\text { heness } & :\end{array}$ & $\mathrm{mm}$ & $\begin{array}{l}\text { Test } \\
\text { Heat } \\
\text { Aging } \\
\text { Net I } \\
\text { Flow }\end{array}$ & & $\begin{array}{l}\mathrm{C} \\
90 \mathrm{mPa}\end{array}$ \\
\hline $\begin{array}{c}\text { Unload } \\
\text { Number } \\
\end{array}$ & $\begin{array}{c}J_{d} \\
\left(\mathrm{~kJ} / \mathrm{m}^{2}\right)\end{array}$ & $\begin{array}{c}J_{m} \\
\left(k J / m^{2}\right)\end{array}$ & $\begin{array}{c}\Delta \mathrm{a} \\
(\mathrm{mm})\end{array}$ & $\begin{array}{l}\text { Load } \\
(\mathrm{kN})\end{array}$ & $\begin{array}{c}\text { Deflection } \\
(\mathrm{mm})\end{array}$ \\
\hline $\begin{array}{l}1 \\
2 \\
3 \\
4 \\
5 \\
6 \\
7 \\
8 \\
9 \\
10 \\
11 \\
12 \\
13 \\
14 \\
15 \\
16 \\
17 \\
18 \\
19 \\
20 \\
21 \\
22 \\
23 \\
24 \\
25 \\
26 \\
27 \\
28 \\
29 \\
30 \\
31 \\
32 \\
33 \\
34 \\
35 \\
36 \\
37 \\
38 \\
39 \\
40 \\
41 \\
42 \\
43 \\
44 \\
45 \\
46 \\
47 \\
48\end{array}$ & $\begin{array}{r}13.96 \\
39.99 \\
59.47 \\
79.52 \\
100.75 \\
122.53 \\
144.62 \\
167.24 \\
191.03 \\
214.53 \\
239.89 \\
261.47 \\
285.44 \\
309.42 \\
334.04 \\
363.94 \\
384.23 \\
408.40 \\
428.34 \\
452.68 \\
480.10 \\
504.35 \\
529.53 \\
546.54 \\
570.23 \\
594.72 \\
619.09 \\
650.91 \\
669.22 \\
696.96 \\
719.31 \\
750.45 \\
771.41 \\
805.57 \\
835.43 \\
877.31 \\
913.52 \\
951.65 \\
976.70 \\
1004.26 \\
1035.55 \\
1072.96 \\
1122.94 \\
1155.88 \\
1204.42 \\
1244.59 \\
1287.40 \\
1331.36\end{array}$ & $\begin{array}{r}13.93 \\
40.05 \\
59.97 \\
79.74 \\
101.54 \\
122.73 \\
146.89 \\
168.28 \\
192.32 \\
216.50 \\
240.00 \\
266.22 \\
289.80 \\
315.76 \\
341.00 \\
366.06 \\
394.38 \\
419.32 \\
446.94 \\
472.56 \\
499.10 \\
527.02 \\
554.52 \\
582.47 \\
609.30 \\
636.82 \\
664.48 \\
691.76 \\
722.45 \\
756.58 \\
793.15 \\
827.48 \\
864.36 \\
906.08 \\
949.08 \\
1006.17 \\
1063.01 \\
1118.57 \\
1173.96 \\
1227.46 \\
1294.58 \\
1374.23 \\
1452.51 \\
1532.14 \\
1620.13 \\
1709.44 \\
1795.77 \\
1882.55\end{array}$ & $\begin{array}{r}-0.0853 \\
-0.0312 \\
0.1191 \\
0.0505 \\
0.1589 \\
0.0699 \\
0.3291 \\
0.1973 \\
0.2202 \\
0.2751 \\
0.1400 \\
0.4463 \\
0.4223 \\
0.5313 \\
0.5628 \\
0.3375 \\
0.6878 \\
0.7191 \\
1.0148 \\
1.0612 \\
1.0310 \\
1.1496 \\
1.2206 \\
1.5414 \\
1.6296 \\
1.7103 \\
1.7944 \\
1.6839 \\
1.9736 \\
2.1163 \\
2.4201 \\
2.4851 \\
2.7969 \\
2.9374 \\
3.1703 \\
3.4239 \\
3.7494 \\
4.0094 \\
4.4418 \\
4.7948 \\
5.2568 \\
5.7691 \\
6.0909 \\
6.5926 \\
6.9898 \\
7.4556 \\
7.8449 \\
8.2067\end{array}$ & $\begin{array}{l}14.768 \\
18.202 \\
19.339 \\
20.146 \\
20.810 \\
21.360 \\
21.802 \\
22.314 \\
22.679 \\
23.056 \\
23.378 \\
23.652 \\
23.841 \\
24.066 \\
24.319 \\
24.519 \\
24.735 \\
24.733 \\
24.876 \\
24.942 \\
25.084 \\
25.023 \\
25.071 \\
25.044 \\
25.072 \\
25.043 \\
25.136 \\
25.289 \\
25.342 \\
25.259 \\
25.007 \\
24.765 \\
24.568 \\
24.159 \\
23.926 \\
23.542 \\
23.139 \\
22.267 \\
21.579 \\
20.928 \\
20.147 \\
19.691 \\
18.960 \\
18.119 \\
17.436 \\
16.697 \\
16.123 \\
15.620\end{array}$ & $\begin{array}{l}0.303 \\
0.605 \\
0.808 \\
1.007 \\
1.207 \\
1.406 \\
1.611 \\
1.808 \\
2.007 \\
2.208 \\
2.408 \\
2.607 \\
2.807 \\
3.008 \\
3.207 \\
3.409 \\
3.607 \\
3.810 \\
4.009 \\
4.210 \\
4.409 \\
4.608 \\
4.811 \\
5.007 \\
5.213 \\
5.411 \\
5.608 \\
5.810 \\
6.010 \\
6.257 \\
6.508 \\
6.760 \\
7.008 \\
7.309 \\
7.608 \\
8.009 \\
8.408 \\
8.809 \\
9.207 \\
9.610 \\
10.108 \\
10.708 \\
11.310 \\
11.914 \\
12.609 \\
13.311 \\
14.009 \\
14.710\end{array}$ \\
\hline
\end{tabular}


Table A-75. Deformation $J_{I C}$ and $J-R$ curve results for specimen 743-07T

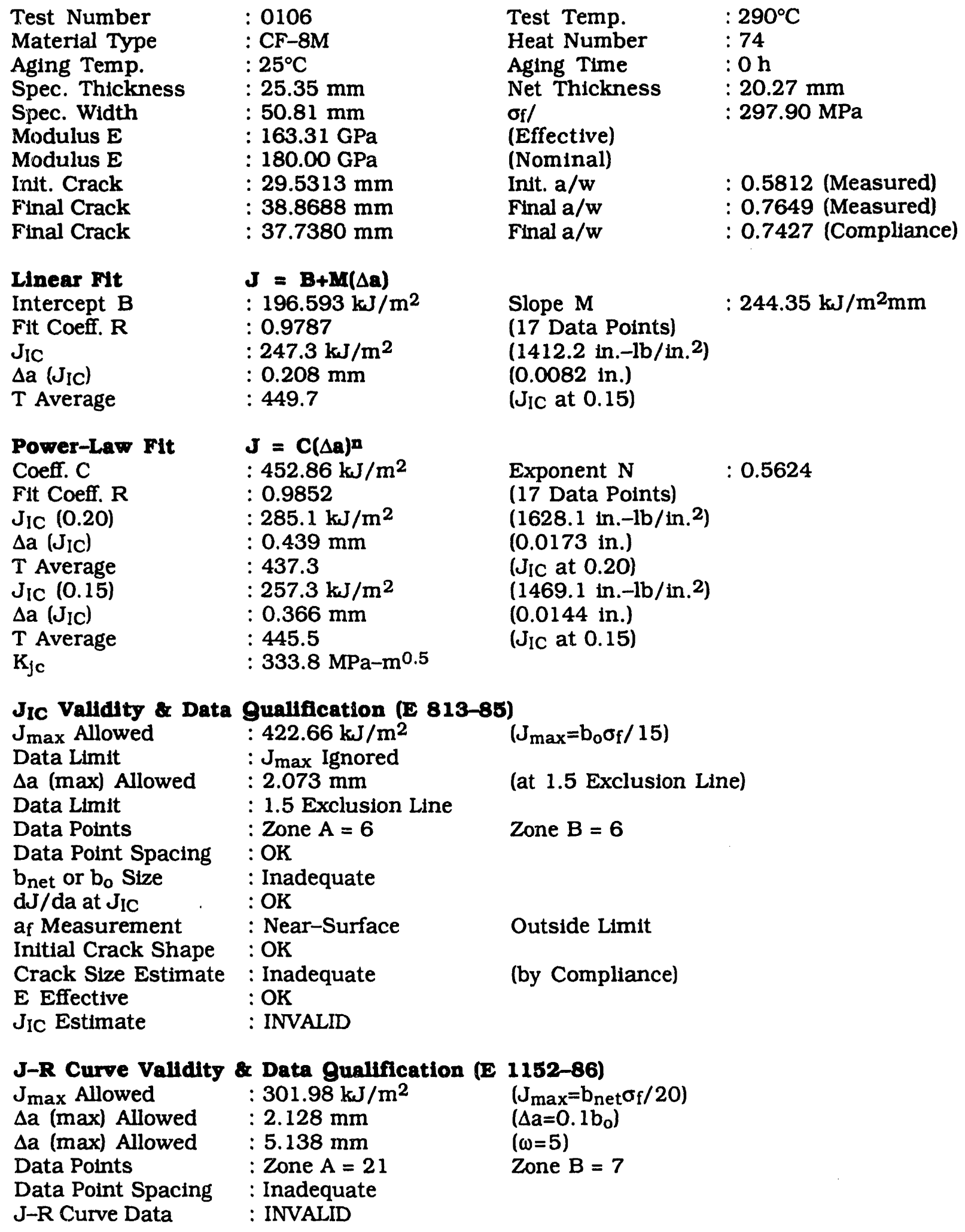


Table A-76. Modified $J_{I C}$ and $J-R$ curve results for specimen 743-07T

\begin{tabular}{|c|c|c|c|}
\hline Test Number & $: 0106$ & Test Temp. & $: 290^{\circ} \mathrm{C}$ \\
\hline Material Type & : CF-8M & Heat Number & $: 74$ \\
\hline Aging Temp. & $: 25^{\circ} \mathrm{C}$ & Aging Time & $: 0 \mathrm{~h}$ \\
\hline Spec. Thickness & : $25.35 \mathrm{~mm}$ & Net Thickness & : $20.27 \mathrm{~mm}$ \\
\hline Spec. Width & $: 50.81 \mathrm{~mm}$ & $\sigma_{\mathrm{f}} /$ & $: 297.90 \mathrm{MPa}$ \\
\hline Modulus E & $: 163.31 \mathrm{GPa}$ & (Effective) & \\
\hline Modulus E & $: 180.00 \mathrm{GPa}$ & (Nominal) & \\
\hline Init. Crack & : $29.5313 \mathrm{~mm}$ & Init. $a / w$ & : 0.5812 (Measured) \\
\hline Final Crack & : $38.8688 \mathrm{~mm}$ & Final $a / w$ & : 0.7649 (Measured) \\
\hline Final Crack & $37.7380 \mathrm{~mm}$ & Final $a / w$ & : 0.7427 (Compliance) \\
\hline $\begin{array}{l}\text { Linear Fit } \\
\text { Intercept B } \\
\text { Fit Coeff. } R \\
J_{I C} \\
\Delta a\left(J_{I C}\right) \\
T \text { Average }\end{array}$ & $\begin{array}{l}J=B+M(\Delta a) \\
: 187.460 \mathrm{~kJ} / \mathrm{m}^{2} \\
: 0.9864 \\
: 243.2 \mathrm{~kJ} / \mathrm{m}^{2} \\
: 0.204 \mathrm{~mm} \\
: 502.6\end{array}$ & $\begin{array}{l}\text { Slope } M \\
\text { (18 Data Points) } \\
\left(1388.7 \text { in. }-1 \mathrm{~b} / \text { in. }{ }^{2}\right) \\
(0.0080 \text { in.) } \\
\left(\mathrm{J}_{\mathrm{IC}} \text { at } 0.15\right)\end{array}$ & $: 273.11 \mathrm{~kJ} / \mathrm{m}^{2} \mathrm{~mm}$ \\
\hline $\begin{array}{l}\text { Power-Law Fit } \\
\text { Coeff. C } \\
\text { Fit Coeff. } R \\
\mathrm{~J}_{\mathrm{IC}}(0.20) \\
\Delta \mathrm{a}\left(\mathrm{J}_{\mathrm{IC}}\right) \\
\mathrm{T} \text { Average } \\
\mathrm{J}_{\mathrm{IC}}(0.15) \\
\Delta \mathrm{a}\left(\mathrm{J}_{\mathrm{IC}}\right) \\
\mathrm{T} \text { Average } \\
\mathrm{K}_{\mathrm{Jc}}\end{array}$ & $\begin{array}{l}J=C(\Delta \Omega)^{n} \\
: 473.52 \mathrm{~kJ} / \mathrm{m}^{2} \\
: 0.9896 \\
: 289.4 \mathrm{~kJ} / \mathrm{m}^{2} \\
: 0.443 \mathrm{~mm} \\
: 490.0 \\
: 258.2 \mathrm{~kJ} / \mathrm{m}^{2} \\
: 0.367 \mathrm{~mm} \\
: 498.4 \\
: 349.3 \mathrm{MPa}-\mathrm{m}^{0.5}\end{array}$ & 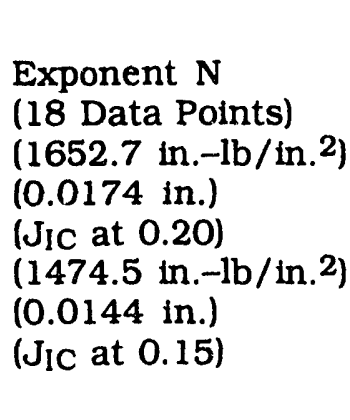 & $: 0.6044$ \\
\hline
\end{tabular}

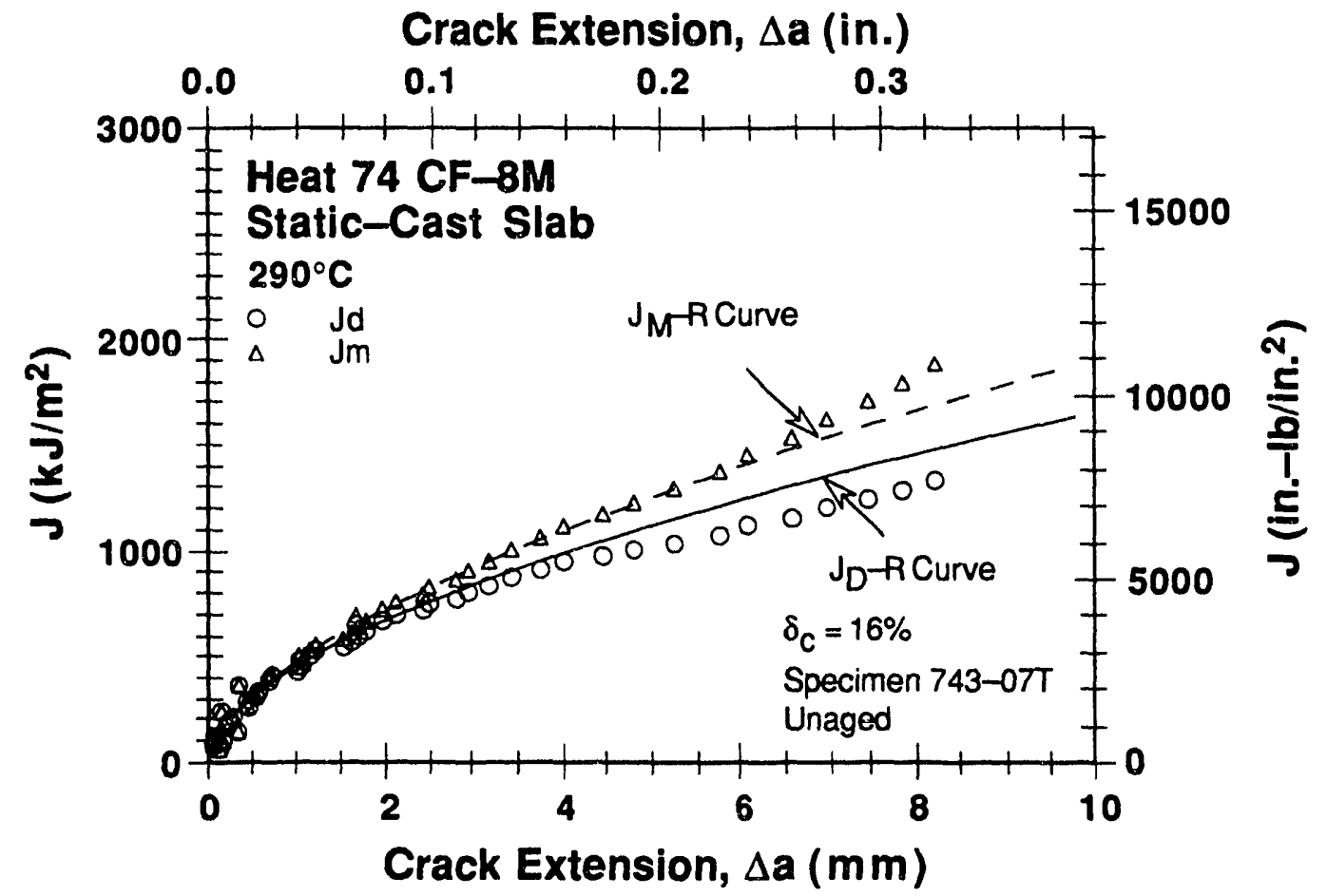

Figure A-74. Deformation and modifled $J-R$ curves at $290^{\circ} \mathrm{C}$ for unaged Heat 74 


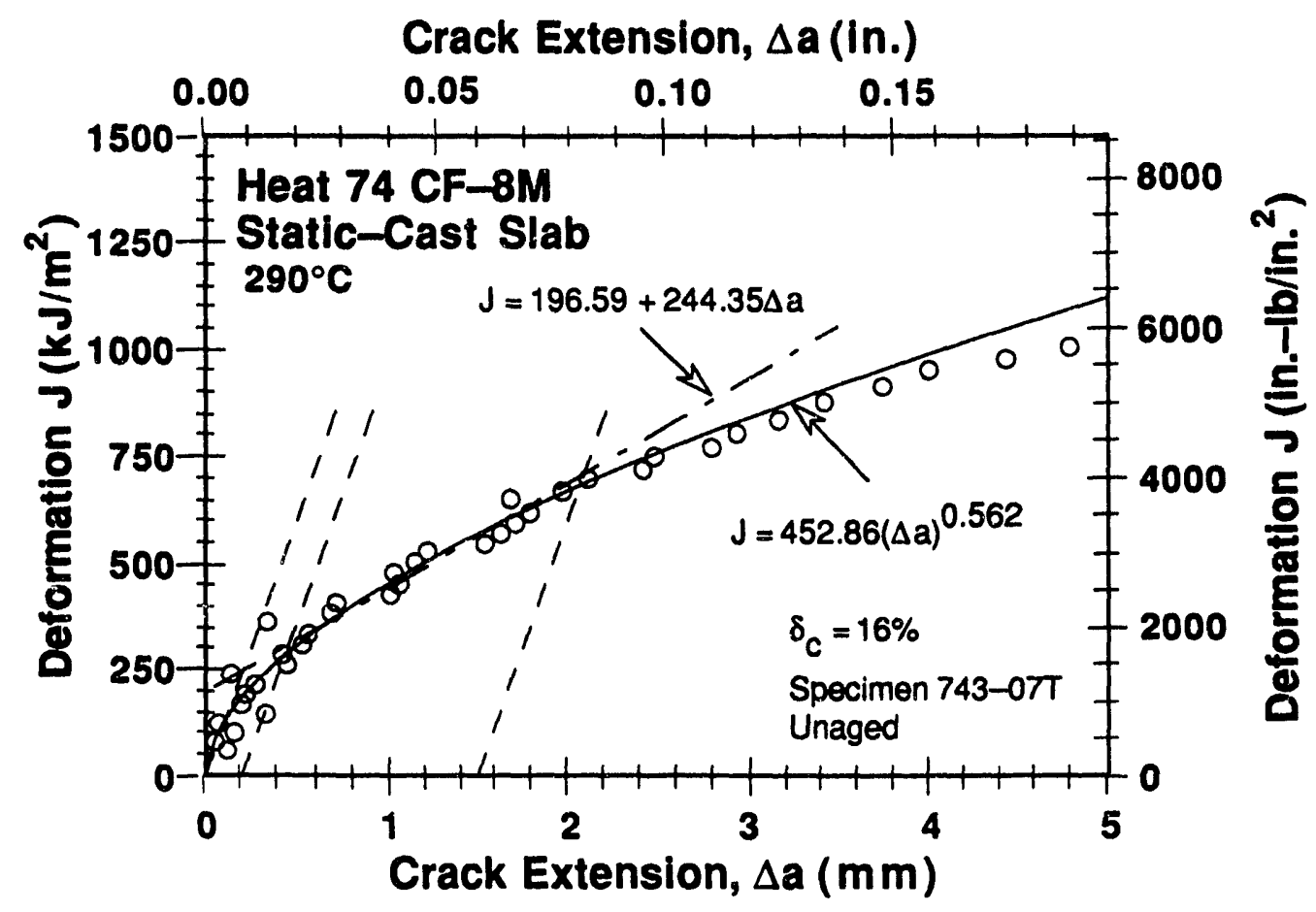

Figure A-75. Deformation $J_{I C}$ at $290^{\circ} \mathrm{C}$ for unaged Heat 74

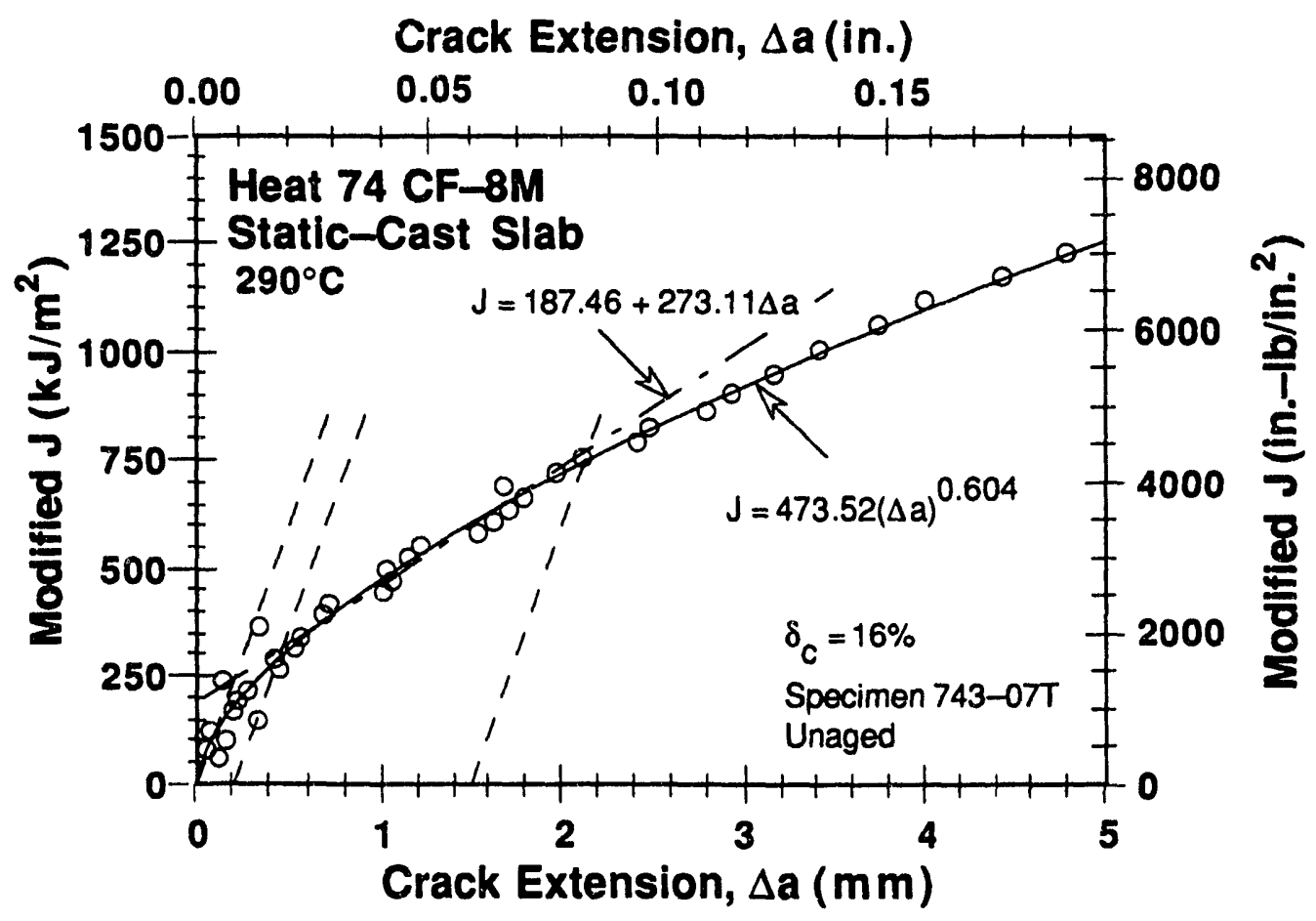

Fugure A-76. Modifled $J_{I C}$ at $290^{\circ} \mathrm{C}$ for unaged Heat 74 
Table A-77. Test data for specimen 743-03T

\begin{tabular}{|c|c|c|c|c|c|}
\hline $\begin{array}{l}\text { Test Num } \\
\text { Material } \\
\text { Aging Te } \\
\text { Spec. Th } \\
\text { Spec. Wic }\end{array}$ & $\begin{array}{ll}\text { er } & : \\
\text { pe } & : \\
\text { p. } & : \\
\text { kness } & : \\
\text { h } & :\end{array}$ & $\mathrm{mm}$ & $\begin{array}{l}\text { Test } \\
\text { Heat } \\
\text { Aging } \\
\text { Net } \\
\text { Flow }\end{array}$ & & $\begin{array}{l}00 \mathrm{~h} \\
8 \mathrm{~mm} \\
25 \mathrm{MPa}\end{array}$ \\
\hline $\begin{array}{l}\text { Unload } \\
\text { Number }\end{array}$ & $\begin{array}{c}J_{d} \\
\left(k J / m^{2}\right)\end{array}$ & $\begin{array}{c}J_{m} \\
\left(k J / m^{2}\right)\end{array}$ & $\begin{array}{c}\Delta \mathbf{a} \\
(\mathrm{mm})\end{array}$ & $\begin{array}{l}\text { Load } \\
\text { (kN) }\end{array}$ & $\begin{array}{l}\text { Deflection } \\
\text { (mm) }\end{array}$ \\
\hline $\begin{array}{l}1 \\
2 \\
3 \\
4 \\
5 \\
6 \\
7 \\
8 \\
9 \\
10 \\
11 \\
12 \\
13 \\
14 \\
15 \\
16 \\
17 \\
18 \\
19 \\
20 \\
21 \\
22 \\
23 \\
24 \\
25 \\
26 \\
27 \\
28 \\
29 \\
30 \\
31 \\
32 \\
33 \\
34 \\
35 \\
36 \\
37 \\
38\end{array}$ & $\begin{array}{r}16.02 \\
44.58 \\
65.99 \\
89.74 \\
114.02 \\
138.37 \\
163.50 \\
190.35 \\
219.73 \\
246.59 \\
274.10 \\
298.18 \\
323.60 \\
352.76 \\
377.89 \\
402.76 \\
430.22 \\
455.46 \\
485.46 \\
500.38 \\
524.89 \\
550.48 \\
570.11 \\
593.66 \\
614.16 \\
638.49 \\
656.31 \\
678.99 \\
705.84 \\
720.94 \\
749.92 \\
767.76 \\
795.14 \\
805.56 \\
813.87 \\
827.11 \\
827.80 \\
836.09\end{array}$ & $\begin{array}{r}16.01 \\
44.88 \\
66.06 \\
88.76 \\
115.00 \\
139.55 \\
166.25 \\
191.79 \\
219.36 \\
249.71 \\
276.82 \\
307.93 \\
335.23 \\
364.76 \\
395.86 \\
425.22 \\
454.47 \\
485.99 \\
514.86 \\
549.64 \\
574.98 \\
606.73 \\
637.43 \\
666.43 \\
705.99 \\
740.72 \\
778.97 \\
813.53 \\
856.72 \\
897.97 \\
952.65 \\
1005.89 \\
1055.25 \\
1119.94 \\
1177.21 \\
1232.99 \\
1287.24 \\
1339.38\end{array}$ & $\begin{array}{r}-0.0134 \\
0.1477 \\
0.0711 \\
-0.1695 \\
0.1738 \\
0.2022 \\
0.3862 \\
0.2566 \\
0.1019 \\
0.3635 \\
0.3367 \\
0.7614 \\
0.8647 \\
0.8833 \\
1.1601 \\
1.3531 \\
1.4249 \\
1.6595 \\
1.6197 \\
2.2783 \\
2.3045 \\
2.4873 \\
2.8005 \\
2.9472 \\
3.4341 \\
3.6860 \\
4.1582 \\
4.4199 \\
4.7596 \\
5.2797 \\
5.7592 \\
6.3840 \\
6.7506 \\
7.6050 \\
8.3359 \\
8.9377 \\
9.6601 \\
10.2241\end{array}$ & $\begin{array}{l}17.067 \\
21.098 \\
22.860 \\
24.102 \\
25.181 \\
26.100 \\
26.924 \\
27.498 \\
28.024 \\
28.555 \\
28.805 \\
28.964 \\
29.085 \\
29.131 \\
29.169 \\
29.196 \\
29.181 \\
29.101 \\
28.973 \\
28.624 \\
28.336 \\
27.893 \\
27.570 \\
27.156 \\
26.587 \\
25.873 \\
25.237 \\
24.214 \\
23.227 \\
22.524 \\
21.435 \\
20.194 \\
19.215 \\
17.780 \\
16.251 \\
14.995 \\
13.535 \\
12.760\end{array}$ & $\begin{array}{r}0.305 \\
0.607 \\
0.807 \\
1.008 \\
1.208 \\
1.411 \\
1.610 \\
1.808 \\
2.007 \\
2.210 \\
2.409 \\
2.610 \\
2.809 \\
3.011 \\
3.210 \\
3.410 \\
3.608 \\
3.810 \\
4.010 \\
4.215 \\
4.410 \\
4.611 \\
4.810 \\
5.011 \\
5.262 \\
5.508 \\
5.761 \\
6.012 \\
6.315 \\
6.608 \\
7.013 \\
7.412 \\
7.811 \\
8.312 \\
8.809 \\
9.311 \\
9.809 \\
10.325\end{array}$ \\
\hline
\end{tabular}


Table A-78. Deformation $J_{I C}$ and $J-R$ curve results for spectmen 743-03T

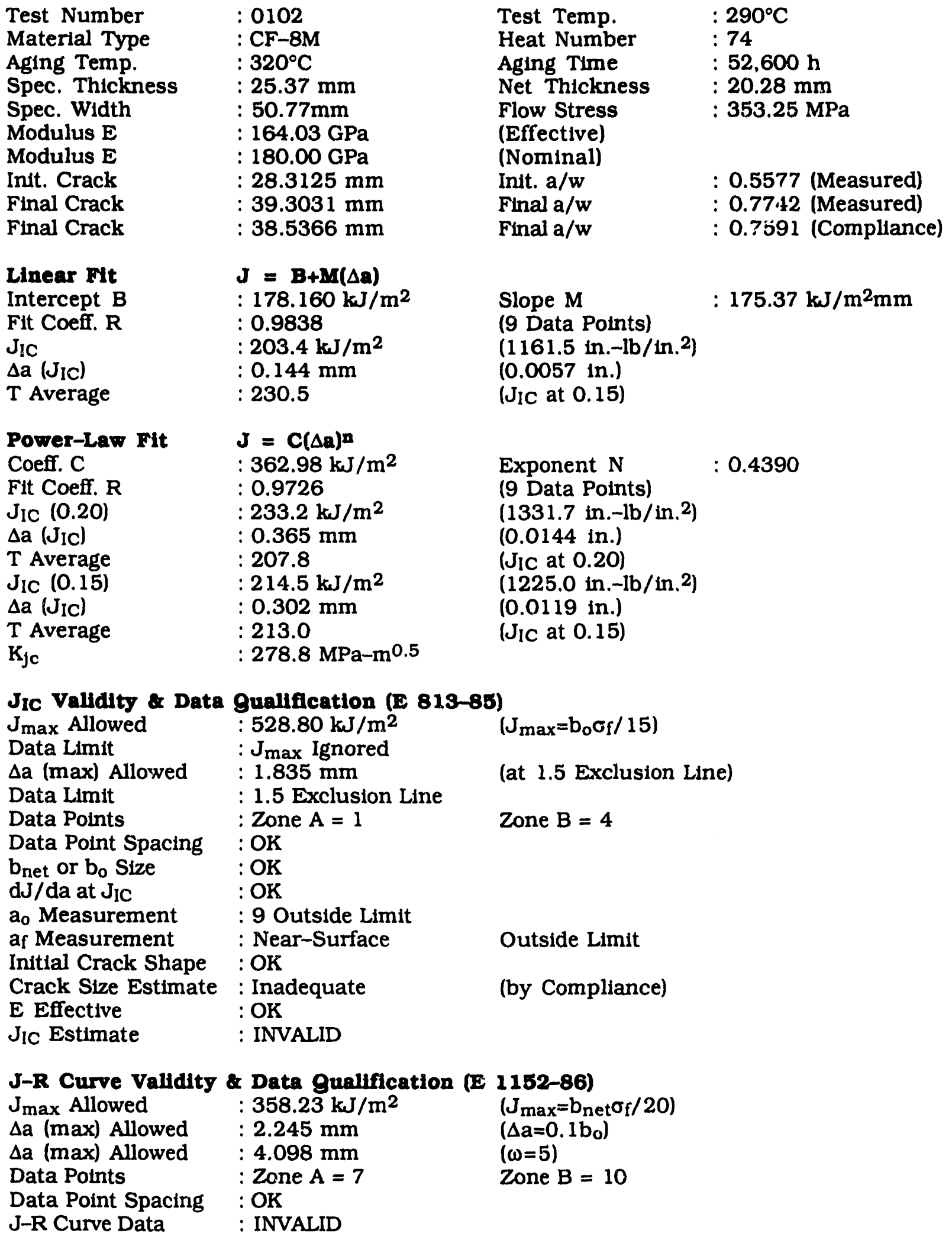


Table A-79. Modified $J_{I C}$ and $J-R$ curve results for specimen 743-O3T

\begin{tabular}{|c|c|c|c|}
\hline Test Number & : 0102 & Test Temp. & $: 290^{\circ} \mathrm{C}$ \\
\hline Material Type & : CF-8M & Heat Number & $: 74$ \\
\hline Aging Temp. & $: 320^{\circ} \mathrm{C}$ & Aging Time & $: 52,600 \mathrm{~h}$ \\
\hline Spec. Thickness & : $25.37 \mathrm{~mm}$ & Net Thickness & $: 20.28 \mathrm{~mm}$ \\
\hline Spec. Width & $: 50.77 \mathrm{~mm}$ & Flow Stress & : $353.25 \mathrm{MPa}$ \\
\hline Modulus E & $: 164.03 \mathrm{GPa}$ & (Effective) & \\
\hline Modulus E & $: 180.00 \mathrm{GPa}$ & (Nominal) & \\
\hline Intt. Crack & $28.3125 \mathrm{~mm}$ & Indt. $a / w$ & : 0.5577 (Measured) \\
\hline Final Crack & $: 39.3031 \mathrm{~mm}$ & Final a/w & : 0.7742 (Measured) \\
\hline Final Crack & $: 38.5366 \mathrm{~mm}$ & Final a/w & : 0.7591 (Compliance) \\
\hline Linear Fit & $J=B+M(\Delta a)$ & & \\
\hline Intercept $B$ & $: 171.837 \mathrm{~kJ} / \mathrm{m}^{2}$ & Slope M & $: 196.97 \mathrm{~kJ} / \mathrm{m}^{2} \mathrm{~mm}$ \\
\hline Fit Coeff. R & $\begin{array}{l}: 0.9869 \\
: 1997 \mathrm{~kJ} / \mathrm{m}^{2}\end{array}$ & (9 Data Poirlidi & \\
\hline $\begin{array}{l}J_{I C} \\
\Delta a\left(J_{I C}\right)\end{array}$ & $0.141 \mathrm{~mm}$ & $(0.0056$ in.) & \\
\hline T Average & : 258.9 & $\left(\mathrm{~J}_{\mathrm{IC}}\right.$ at 0.15$)$ & \\
\hline Power-Law Fit & $\mathbf{J}=\mathbf{C}(\Delta \mathbf{a})^{\mathbf{n}}$ & & \\
\hline Coeff. C & $: 378.83 \mathrm{~kJ} / \mathrm{m}^{2}$ & Exponent $\mathrm{N}$ & $: 0.4728$ \\
\hline Fit Coeff. R & $: 0.9754$ & (9 Data Points) & \\
\hline $\begin{array}{l}\mathrm{J}_{\mathrm{IC}}(0.20) \\
\Delta \mathrm{a}\left(\mathrm{J}_{\mathrm{IC}}\right)\end{array}$ & $\begin{array}{l}: 235.8 \mathrm{~kJ} / \mathrm{m}^{2} \\
: 0.367 \mathrm{~mm}\end{array}$ & $\begin{array}{l}\left(1346.5 \text { in. }-1 \mathrm{~b} / \text { in }^{2}\right) \\
(0.0144 \text { in. })\end{array}$ & \\
\hline T Average & $: 232.0$ & $\left(\mathrm{~J}_{\mathrm{IC}}\right.$ at 0.20$)$ & \\
\hline$J_{I C}(0.15)$ & $: 215.2 \mathrm{~kJ} / \mathrm{m}^{2}$ & (1228.7 in. $-\mathrm{lb}^{\prime}$ 'in. $\left.{ }^{2}\right)$ & \\
\hline$\Delta \mathrm{a}\left(\mathrm{J}_{\mathrm{IC}}\right)$ & $0.302 \mathrm{~mm}$ & (0.0119 in.) & \\
\hline $\begin{array}{l}\text { T Average } \\
\mathrm{K}_{\mathrm{jc}}\end{array}$ & $288.6 \mathrm{MPa}-\mathrm{m}^{0.5}$ & $\left(J_{I C}\right.$ at 0.15$)$ & \\
\hline
\end{tabular}

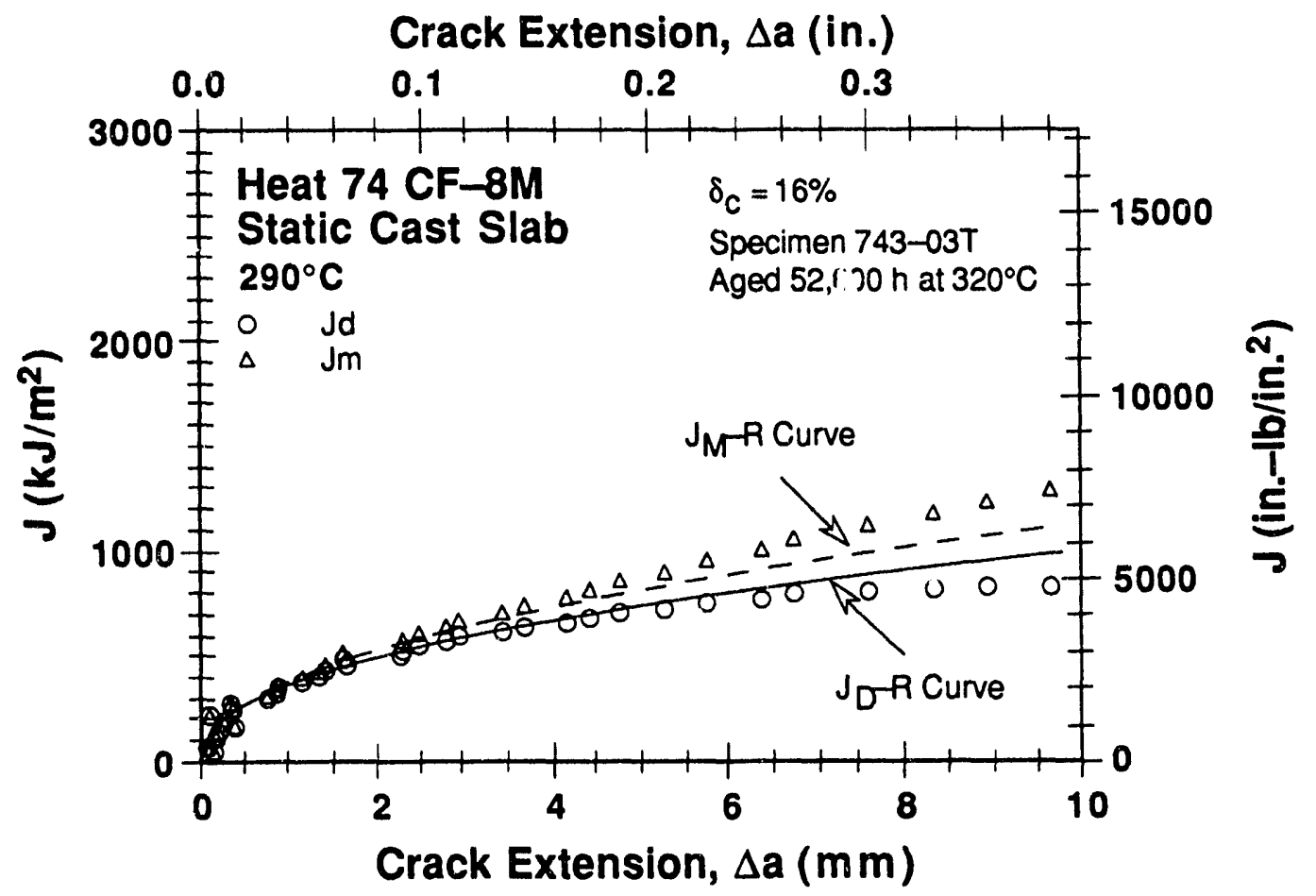

Figure A-77. Deformation and modified $J-R$ curves at $290^{\circ} \mathrm{C}$ for Heat i 4 aged $52,600 \mathrm{~h}$ at $320^{\circ} \mathrm{C}$ 


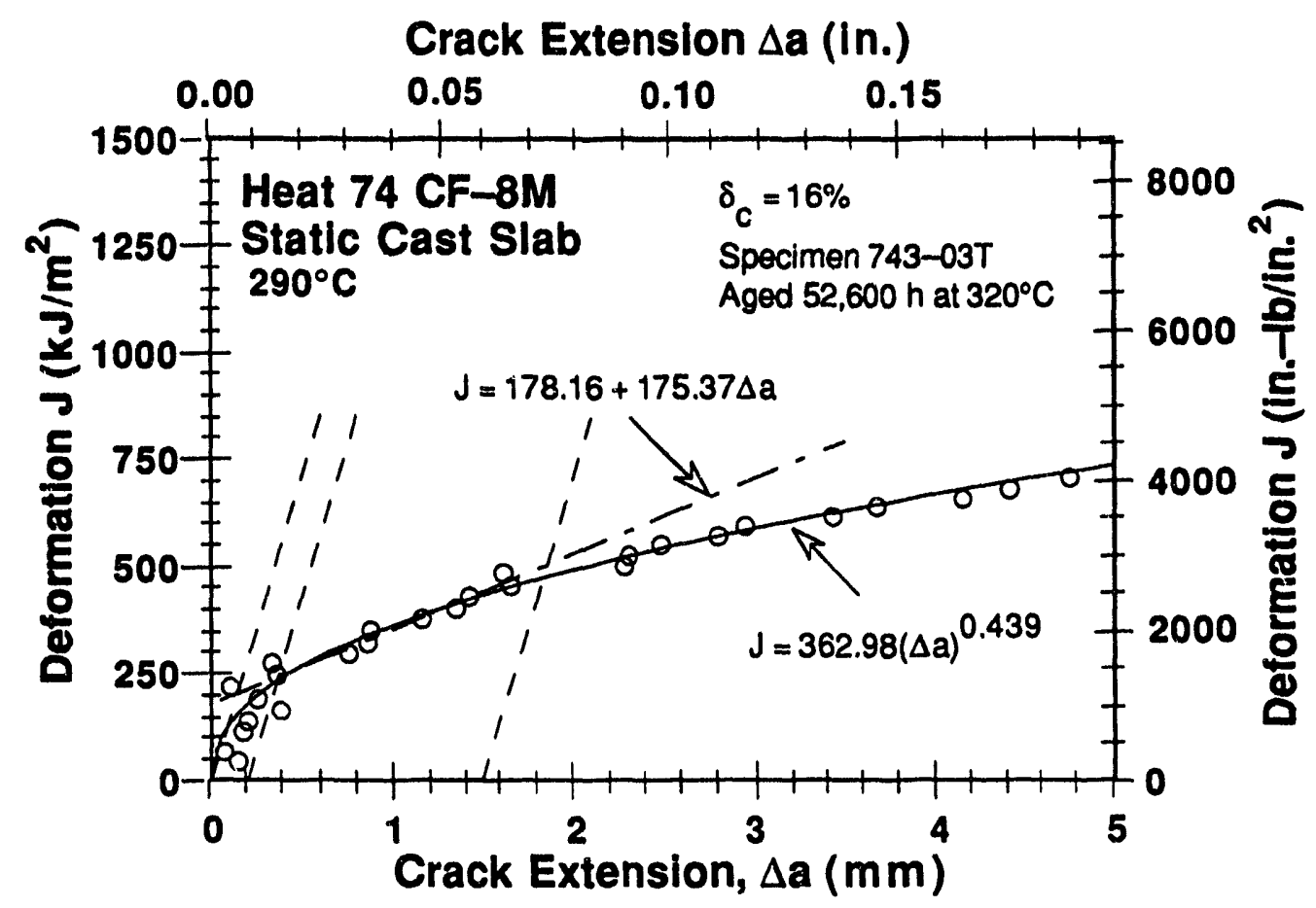

Figure A-78. Deformation $J_{I C}$ at $290^{\circ} \mathrm{C}$ for Heat 74 aged $52.600 \mathrm{~h}$ at $320^{\circ} \mathrm{C}$

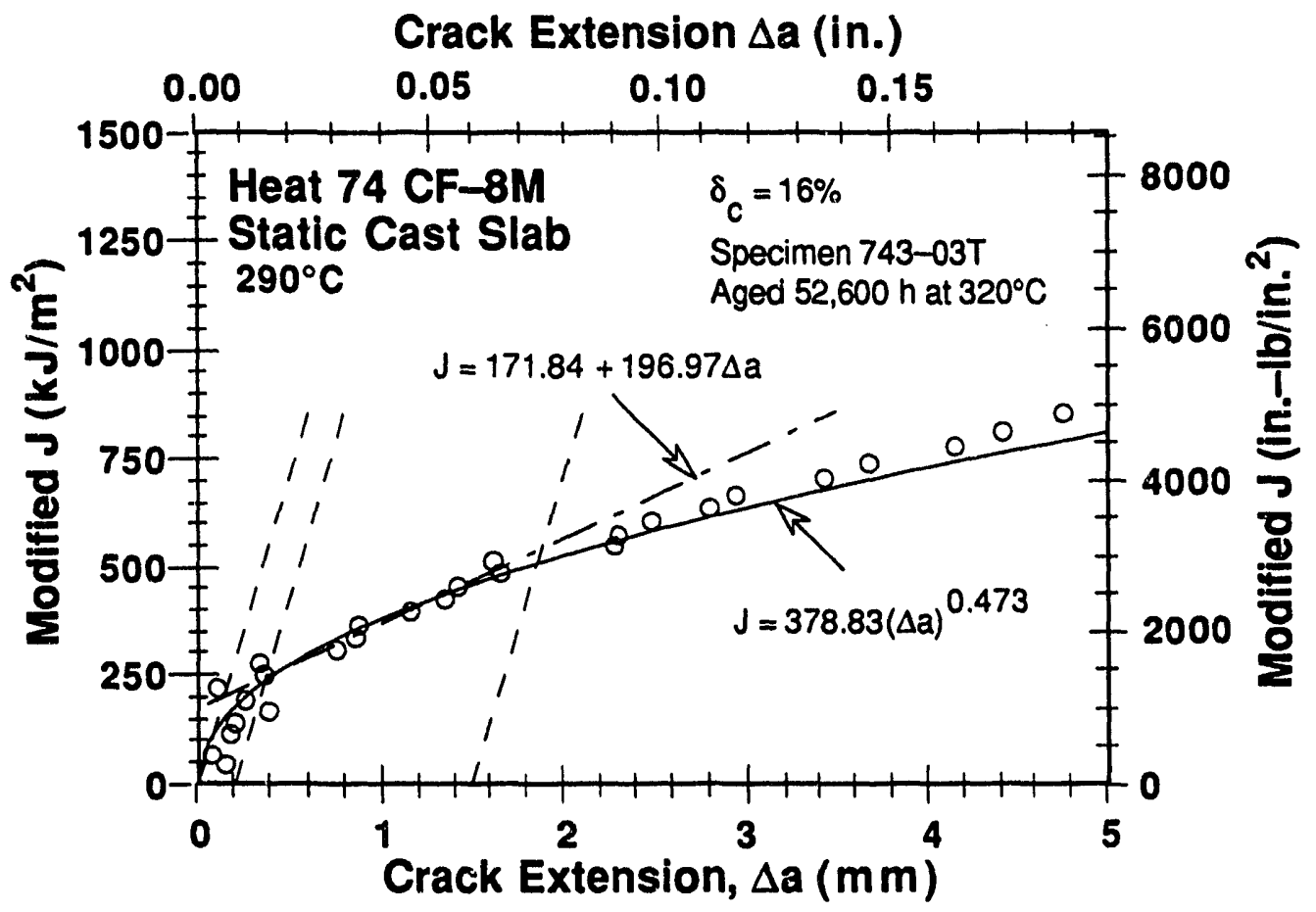

Figure A-79. Modified $J_{I C}$ at $290^{\circ} \mathrm{C}$ for Heat 74 aged $52,600 \mathrm{~h}$ at $320^{\circ} \mathrm{C}$ 
Table A-80. Test data for spectmen 753-02B

\begin{tabular}{|c|c|c|c|c|c|}
\hline $\begin{array}{l}\text { Test Num } \\
\text { Material } \\
\text { Aging TeI } \\
\text { Spec. Th } \\
\text { Spec. Wic }\end{array}$ & $\begin{array}{ll}\text { er } & : \\
\text { pe } & : \\
\text { p. } & : \\
\text { hness } & : \\
\text { h } & :\end{array}$ & $\mathrm{mm}$ & $\begin{array}{l}\text { Test } \\
\text { Heat } \\
\text { Aging } \\
\text { Net T } \\
\text { Flow }\end{array}$ & & $\begin{array}{l}20 \mathrm{~h} \\
3 \mathrm{MPa}\end{array}$ \\
\hline $\begin{array}{l}\text { Unload } \\
\text { Number }\end{array}$ & $\begin{array}{c}J_{d} \\
\left(\mathrm{~kJ} / \mathrm{m}^{2}\right)\end{array}$ & $\begin{array}{c}J_{m} \\
\left(\mathrm{~kJ} / \mathrm{m}^{2}\right)\end{array}$ & $\begin{array}{c}\Delta \mathrm{a} \\
(\mathrm{mm})\end{array}$ & $\begin{array}{l}\text { Load } \\
\text { (kN) }\end{array}$ & $\begin{array}{l}\text { Deflection } \\
(\mathrm{mm})\end{array}$ \\
\hline $\begin{array}{l}1 \\
2 \\
3 \\
4 \\
5 \\
6 \\
7 \\
8 \\
9 \\
10 \\
11 \\
12 \\
13 \\
14 \\
15 \\
16 \\
17 \\
18 \\
19 \\
20 \\
21 \\
22 \\
23 \\
24 \\
25 \\
26 \\
27 \\
28 \\
29 \\
30 \\
31 \\
32 \\
33 \\
34 \\
35\end{array}$ & $\begin{array}{r}19.17 \\
45.41 \\
76.09 \\
101.36 \\
128.43 \\
155.89 \\
184.73 \\
202.25 \\
221.70 \\
240.67 \\
259.42 \\
277.12 \\
296.03 \\
314.44 \\
332.46 \\
349.82 \\
367.48 \\
385.35 \\
405.76 \\
429.56 \\
453.86 \\
475.58 \\
497.27 \\
529.54 \\
556.94 \\
576.37 \\
594.01 \\
598.71 \\
623.00 \\
644.81 \\
662.49 \\
684.39 \\
708.36 \\
728.05 \\
742.14\end{array}$ & $\begin{array}{r}19.16 \\
45.52 \\
76.19 \\
101.55 \\
129.01 \\
156.17 \\
187.20 \\
204.65 \\
225.44 \\
244.88 \\
266.41 \\
285.18 \\
306.77 \\
326.25 \\
347.84 \\
367.38 \\
387.43 \\
407.87 \\
431.71 \\
460.43 \\
490.41 \\
522.02 \\
551.10 \\
590.64 \\
632.22 \\
671.51 \\
725.52 \\
755.11 \\
803.46 \\
851.30 \\
915.43 \\
971.01 \\
1027.67 \\
1084.28 \\
1136.61\end{array}$ & $\begin{array}{r}-0.0128 \\
0.0729 \\
0.0724 \\
0.0937 \\
0.1709 \\
0.1247 \\
0.3936 \\
0.3874 \\
0.5197 \\
0.5620 \\
0.7886 \\
0.8693 \\
1.0553 \\
1.1245 \\
1.3396 \\
1.4629 \\
1.5902 \\
1.7196 \\
1.8812 \\
2.0965 \\
2.3287 \\
2.7075 \\
2.9748 \\
3.2180 \\
3.6582 \\
4.2371 \\
5.2116 \\
5.8559 \\
6.4381 \\
7.0274 \\
8.0017 \\
8.6615 \\
9.2587 \\
9.8888 \\
10.5036\end{array}$ & $\begin{array}{l}24.484 \\
31.431 \\
35.600 \\
37.851 \\
39.663 \\
40.976 \\
41.765 \\
42.248 \\
42.967 \\
43.084 \\
43.229 \\
43.303 \\
43.274 \\
42.965 \\
42.762 \\
42.814 \\
42.486 \\
42.318 \\
42.034 \\
41.304 \\
40.829 \\
39.887 \\
39.487 \\
38.833 \\
37.412 \\
35.236 \\
30.481 \\
29.092 \\
27.873 \\
26.094 \\
23.741 \\
22.296 \\
20.875 \\
19.103 \\
17.447\end{array}$ & $\begin{array}{l}0.301 \\
0.504 \\
0.706 \\
0.855 \\
1.007 \\
1.157 \\
1.307 \\
1.408 \\
1.508 \\
1.609 \\
1.709 \\
1.808 \\
1.910 \\
2.011 \\
2.111 \\
2.212 \\
2.310 \\
2.410 \\
2.525 \\
2.663 \\
2.811 \\
2.963 \\
3.116 \\
3.314 \\
3.515 \\
3.718 \\
4.003 \\
4.211 \\
4.511 \\
4.811 \\
5.210 \\
5.610 \\
6.008 \\
6.414 \\
6.816\end{array}$ \\
\hline
\end{tabular}


Table A-81. Deformation $J_{I C}$ and $J-R$ curve results for specimen 753-02B

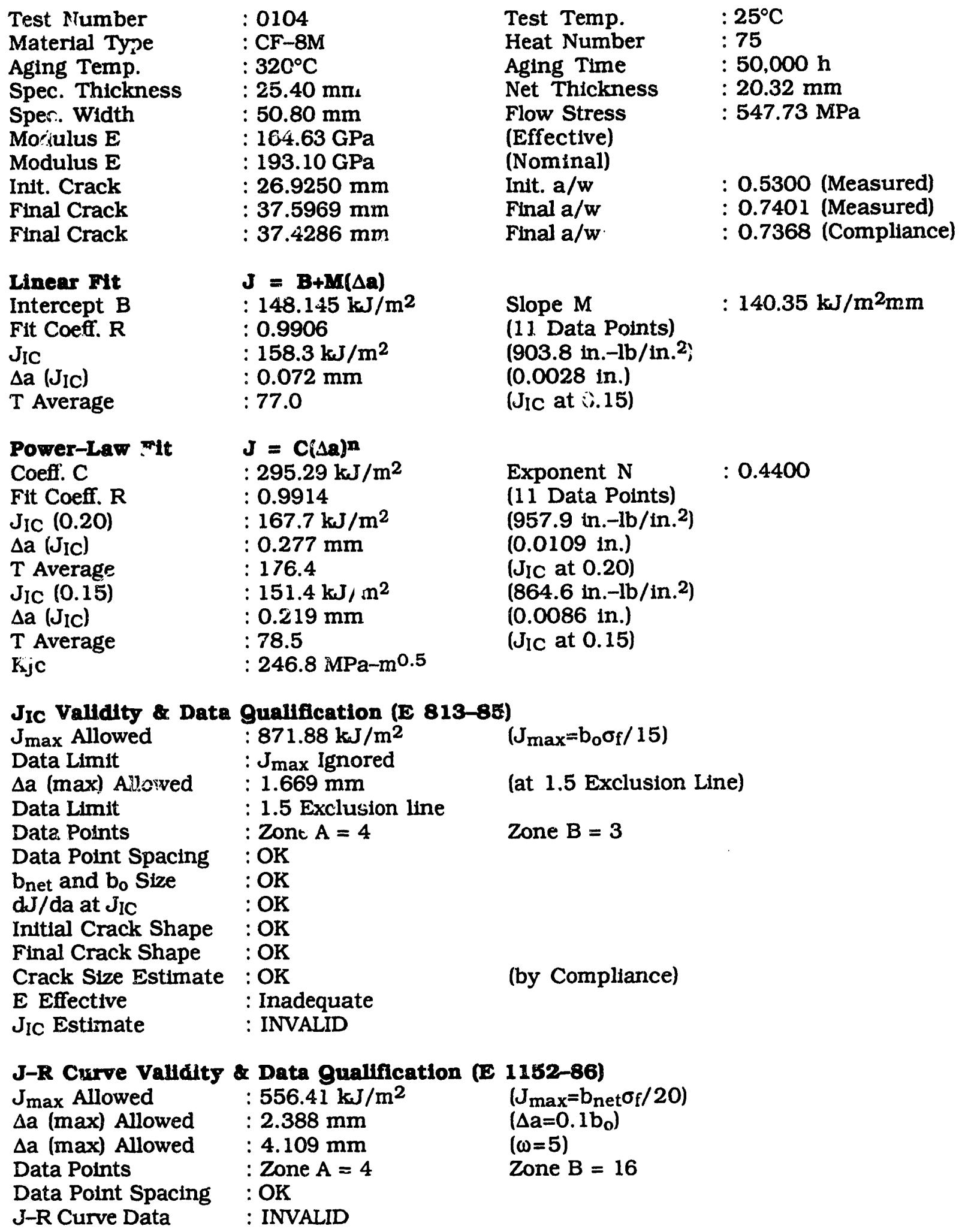


Table A-82. Modified $J_{I C}$ and $J-R$ curve results for spectmen 753-02B

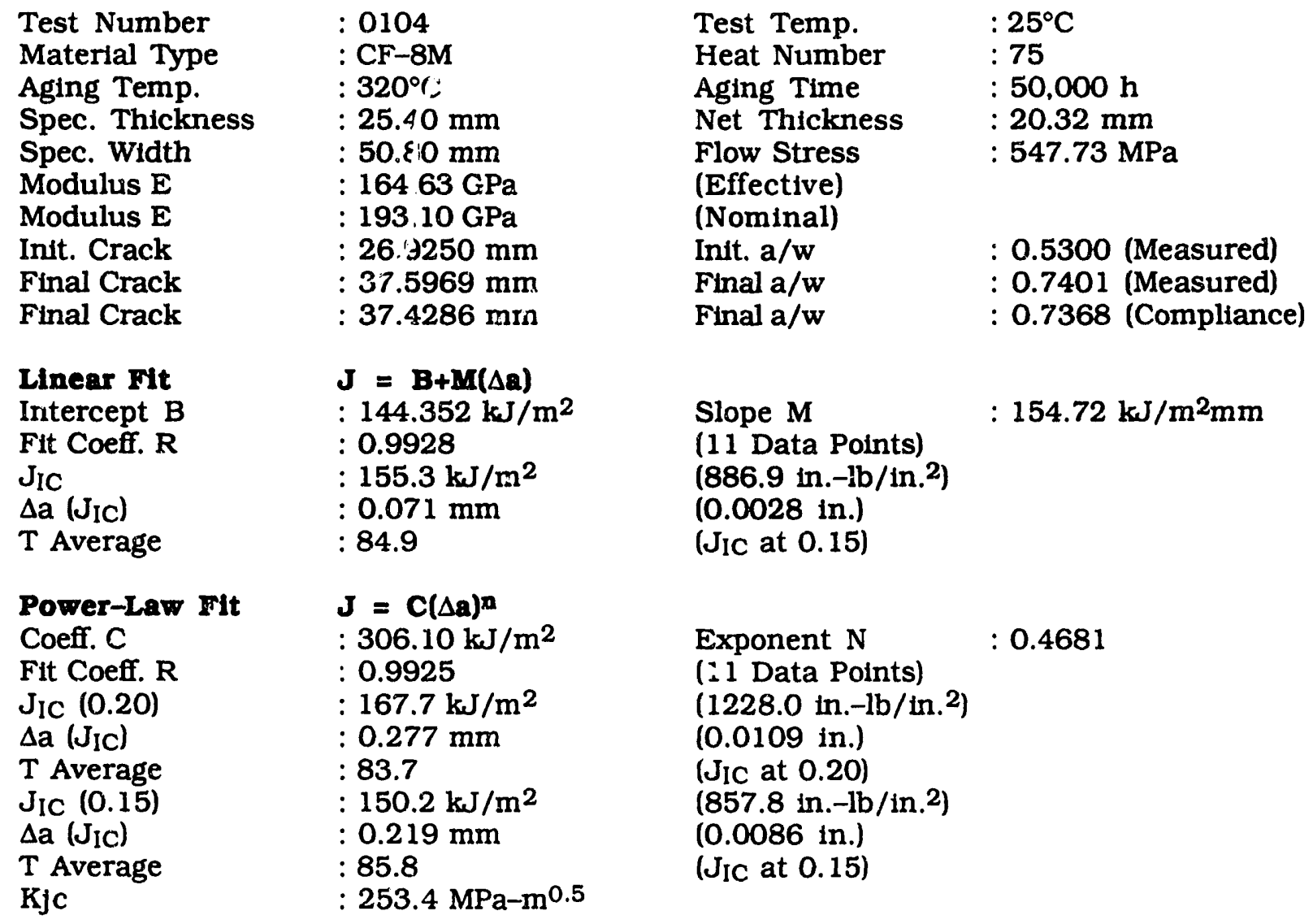

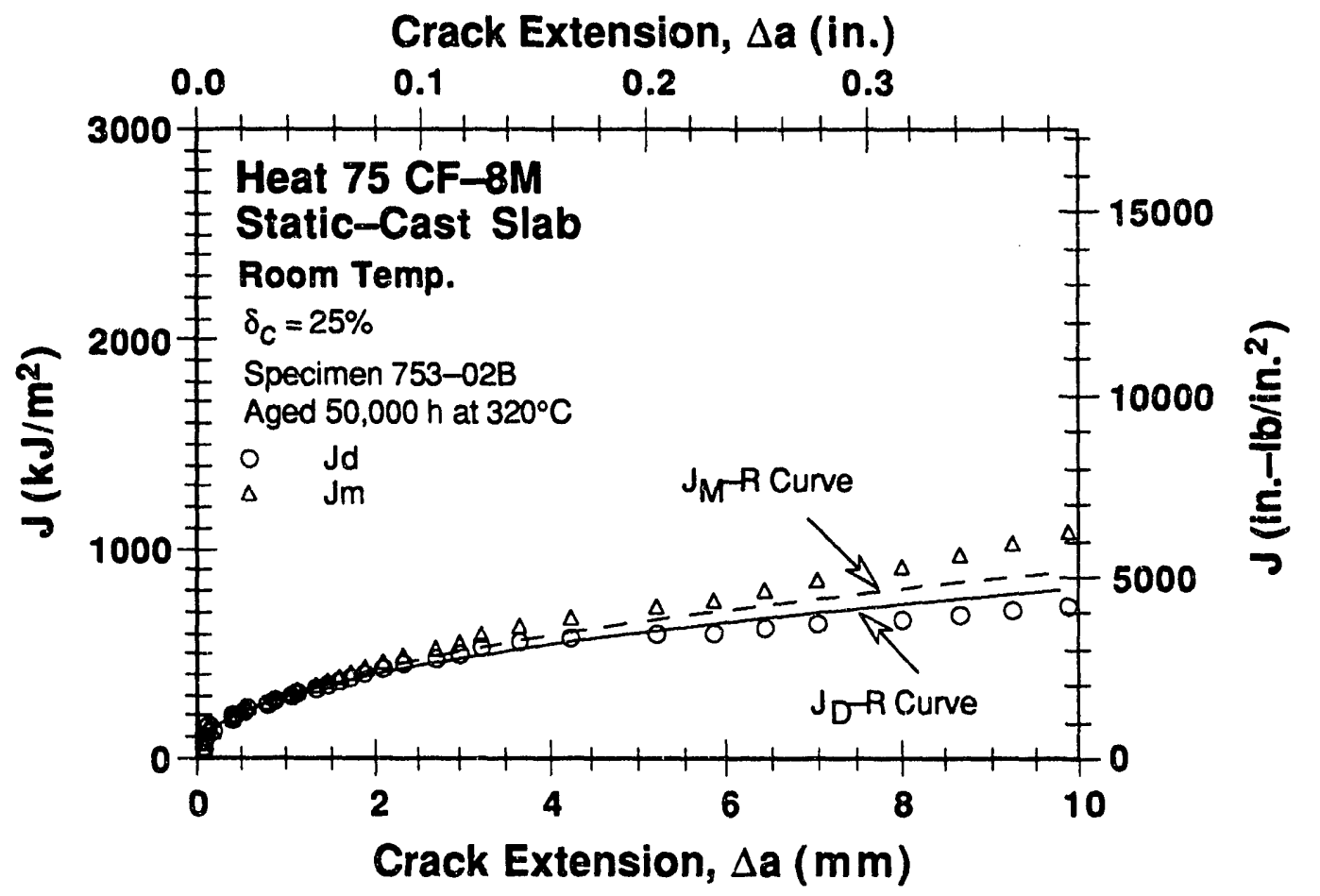

Figure A-80. Deformation and modified $J-R$ curves at room temp. for Heat 75 aged $50.000 \mathrm{~h}$ at $320^{\circ} \mathrm{C}$ 


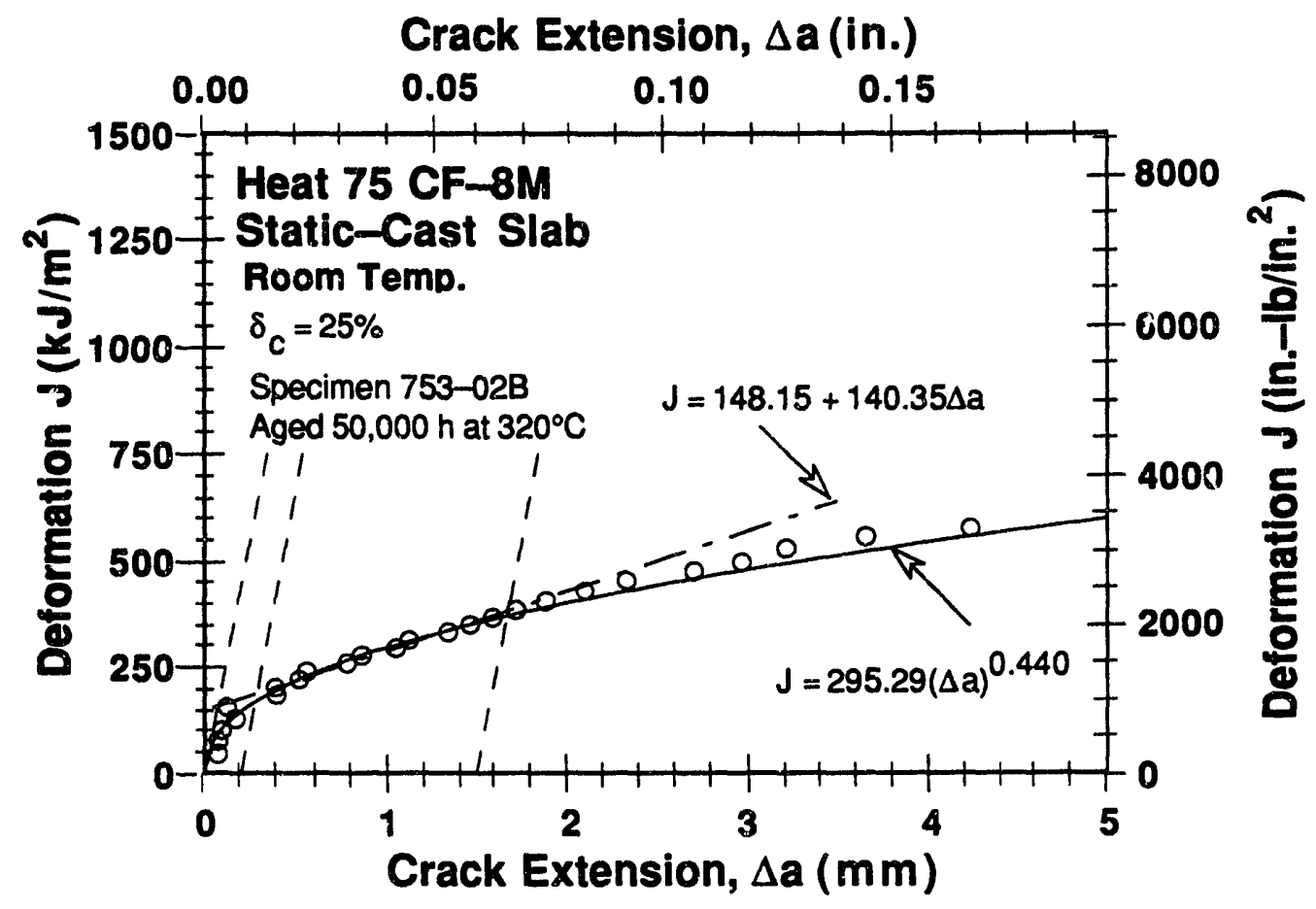

Figure A-81. Deformation $J_{I C}$ at room temp. for Heat 75 aged $50,000 \mathrm{~h}$ at $320^{\circ} \mathrm{C}$

Crack Extension, $\Delta \mathbf{a}($ in.)

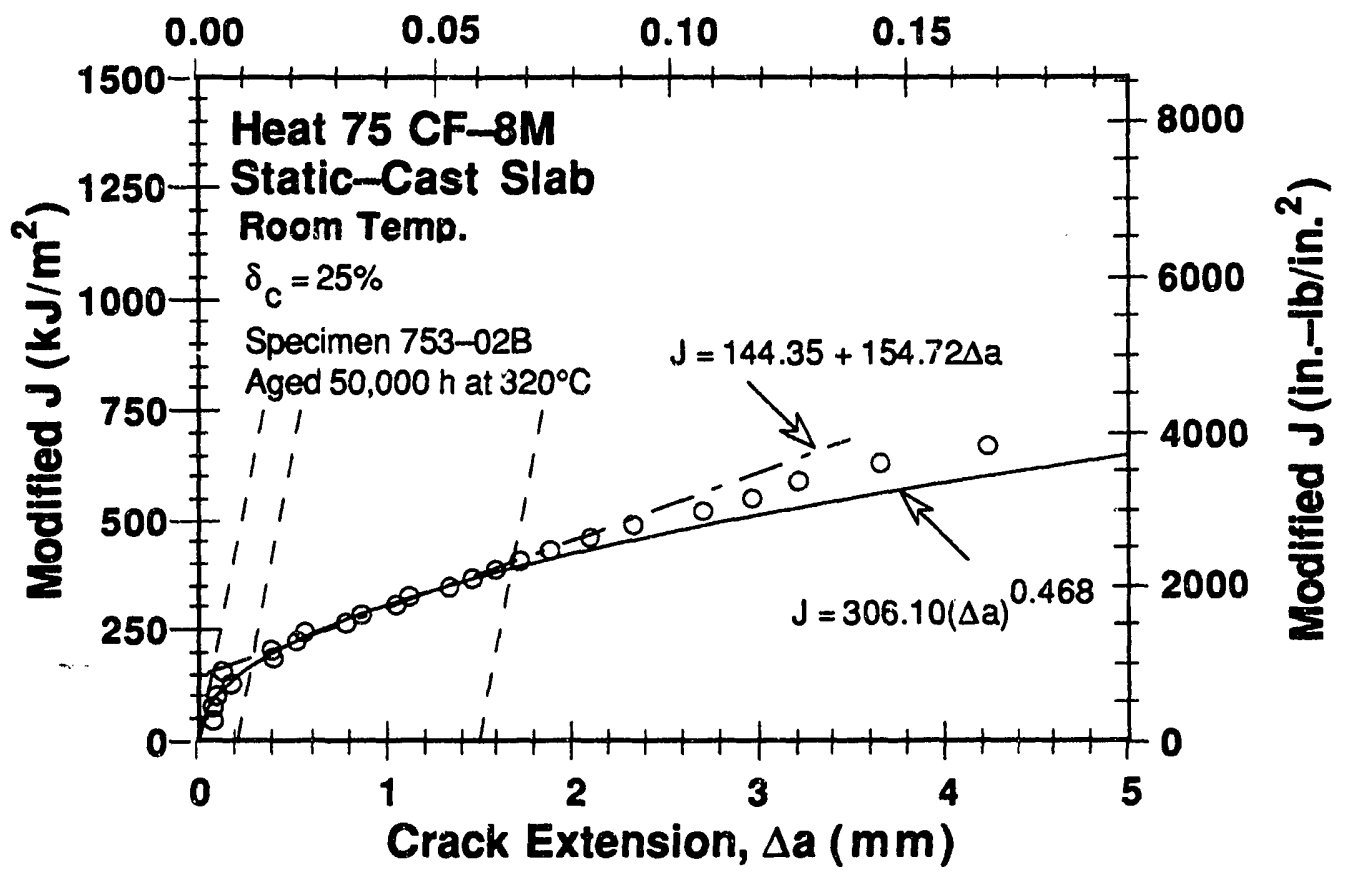

Figure A-82. Modified $J_{I C}$ at room temp. for Heat 75 aged $50,000 \mathrm{~h}$ at $320^{\circ} \mathrm{C}$ 
Table A-83. Test data for specimen 752-05V

$\begin{array}{llll}\text { Test Number } & : 0091 & \text { Test Temp. } & : 25^{\circ} \mathrm{C} \\ \text { Material Type } & : \text { CF-8M } & \text { Heat Number } & : 75 \\ \text { Aging Temp. } & : 320^{\circ} \mathrm{C} & \text { Aging Time } & : 50.000 \mathrm{~h} \\ \text { Spec. Thickness } & : 25.38 \mathrm{~mm} & \text { Net Thickness } & : 20.36 \mathrm{~mm} \\ \text { Spec. Width } & : 50.82 \mathrm{~mm} & \text { Flow Stress } & : 547.73 \mathrm{MPa}\end{array}$

\begin{tabular}{|c|c|c|c|c|c|}
\hline $\begin{array}{l}\text { Unload } \\
\text { Number }\end{array}$ & $\begin{array}{c}J_{d} \\
\left(\mathrm{~kJ} / \mathrm{m}^{2}\right)\end{array}$ & $\underset{\left(\mathrm{kJ} / \mathrm{m}^{2}\right)}{J_{\mathrm{m}}}$ & $\begin{array}{c}\Delta \mathrm{a} \\
(\mathrm{mm})\end{array}$ & $\begin{array}{l}\text { Load } \\
(\mathrm{kN})\end{array}$ & $\begin{array}{l}\text { Deflectior } \\
\text { (mm) }\end{array}$ \\
\hline $\begin{array}{l}1 \\
2 \\
3 \\
4 \\
5 \\
6 \\
7 \\
8 \\
9 \\
10 \\
11 \\
12 \\
13 \\
14 \\
15 \\
16 \\
17 \\
18 \\
19 \\
20 \\
21 \\
22 \\
23 \\
24 \\
25 \\
26 \\
27 \\
28 \\
29 \\
30 \\
31 \\
32 \\
33 \\
34 \\
35 \\
36 \\
37\end{array}$ & $\begin{array}{r}21.85 \\
51.52 \\
85.59 \\
114.96 \\
144.98 \\
176.34 \\
207.83 \\
239.43 \\
261.44 \\
293.99 \\
314.75 \\
335.63 \\
355.76 \\
375.22 \\
394.58 \\
413.03 \\
432.03 \\
451.01 \\
469.48 \\
486.04 \\
502.96 \\
527.02 \\
544.33 \\
559.44 \\
576.63 \\
613.80 \\
635.89 \\
658.24 \\
680.73 \\
714.88 \\
739.79 \\
748.42 \\
746.23 \\
768.77 \\
791.74 \\
781.21 \\
769.95\end{array}$ & $\begin{array}{r}21.84 \\
51.64 \\
85.51 \\
114.95 \\
145.58 \\
177.60 \\
210.06 \\
242.62 \\
265.91 \\
299.92 \\
323.24 \\
345.78 \\
368.84 \\
391.42 \\
413.15 \\
436.92 \\
457.97 \\
481.06 \\
504.44 \\
526.12 \\
549.40 \\
581.78 \\
614.04 \\
642.92 \\
671.85 \\
734.40 \\
770.87 \\
807.35 \\
843.60 \\
901.00 \\
955.36 \\
1004.89 \\
1049.37 \\
1105.75 \\
1165.64 \\
1223.43 \\
1266.10\end{array}$ & $\begin{array}{r}-0.0217 \\
0.0621 \\
-0.0015 \\
0.0146 \\
0.1132 \\
0.1965 \\
0.2978 \\
0.3827 \\
0.4838 \\
0.5834 \\
0.7446 \\
0.8407 \\
0.9978 \\
1.1554 \\
1.2677 \\
1.5046 \\
1.5915 \\
1.7556 \\
1.9417 \\
2.1271 \\
2.3455 \\
2.6130 \\
3.0690 \\
3.4697 \\
3.7952 \\
4.4340 \\
4.7768 \\
5.0964 \\
5.3922 \\
5.8552 \\
6.4025 \\
7.1211 \\
7.9110 \\
8.4484 \\
8.9962 \\
9.9599 \\
10.6930\end{array}$ & $\begin{array}{l}26.301 \\
33.616 \\
37.822 \\
40.104 \\
41.645 \\
43.243 \\
44.341 \\
44.854 \\
45.564 \\
45.684 \\
45.483 \\
45.241 \\
44.927 \\
44.682 \\
44.421 \\
43.871 \\
43.742 \\
43.263 \\
42.524 \\
41.921 \\
40.748 \\
38.978 \\
37.848 \\
36.604 \\
35.411 \\
33.451 \\
32.367 \\
31.361 \\
30.343 \\
28.892 \\
26.431 \\
23.521 \\
22.021 \\
20.714 \\
18.942 \\
16.545 \\
14.905\end{array}$ & $\begin{array}{l}0.303 \\
0.504 \\
0.703 \\
0.854 \\
1.004 \\
1.158 \\
1.307 \\
1.455 \\
1.559 \\
1.708 \\
1.809 \\
1.912 \\
2.011 \\
2.111 \\
2.210 \\
2.310 \\
2.412 \\
2.511 \\
2.615 \\
2.714 \\
2.819 \\
2.968 \\
3.116 \\
3.264 \\
3.414 \\
3.712 \\
3.921 \\
4.115 \\
4.311 \\
4.610 \\
4.913 \\
5.213 \\
5.512 \\
5.904 \\
6.308 \\
6.727 \\
7.106\end{array}$ \\
\hline
\end{tabular}


Table A-84. Deformation $J_{I C}$ and $J-R$ curve results for specimen 752-05V

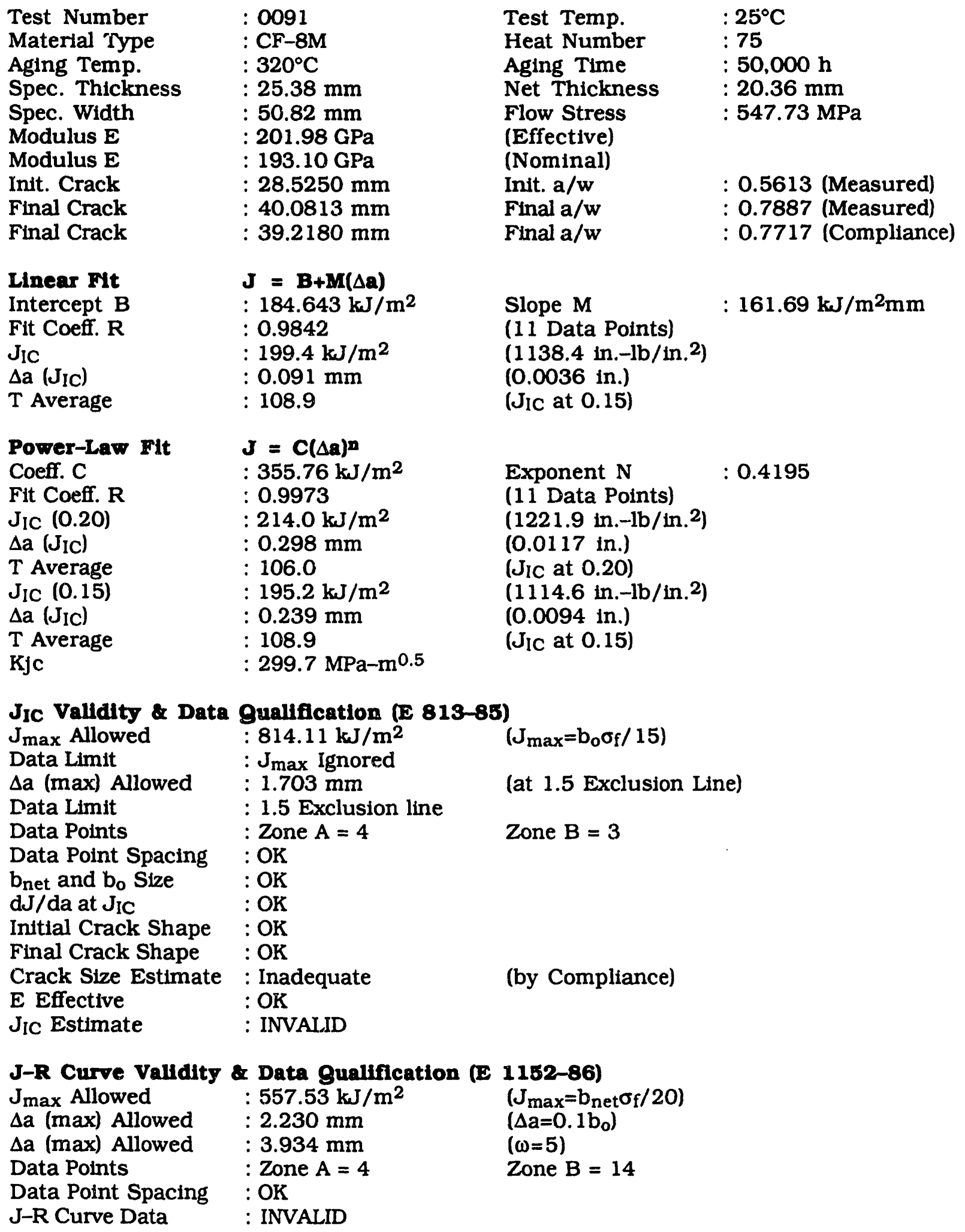


Table A-85. Modified $J_{I C}$ and J-R curve results for specimen 752-05V

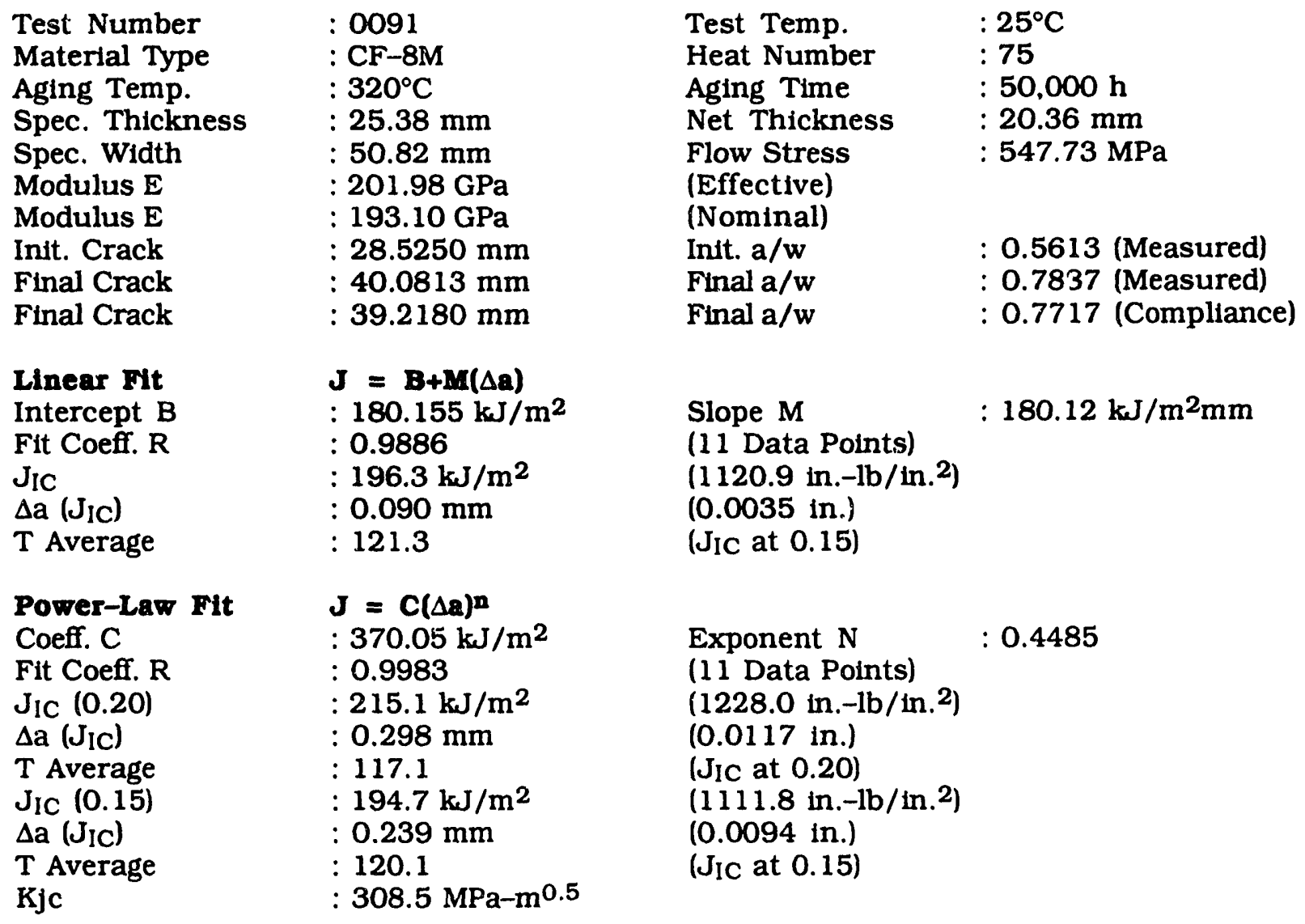

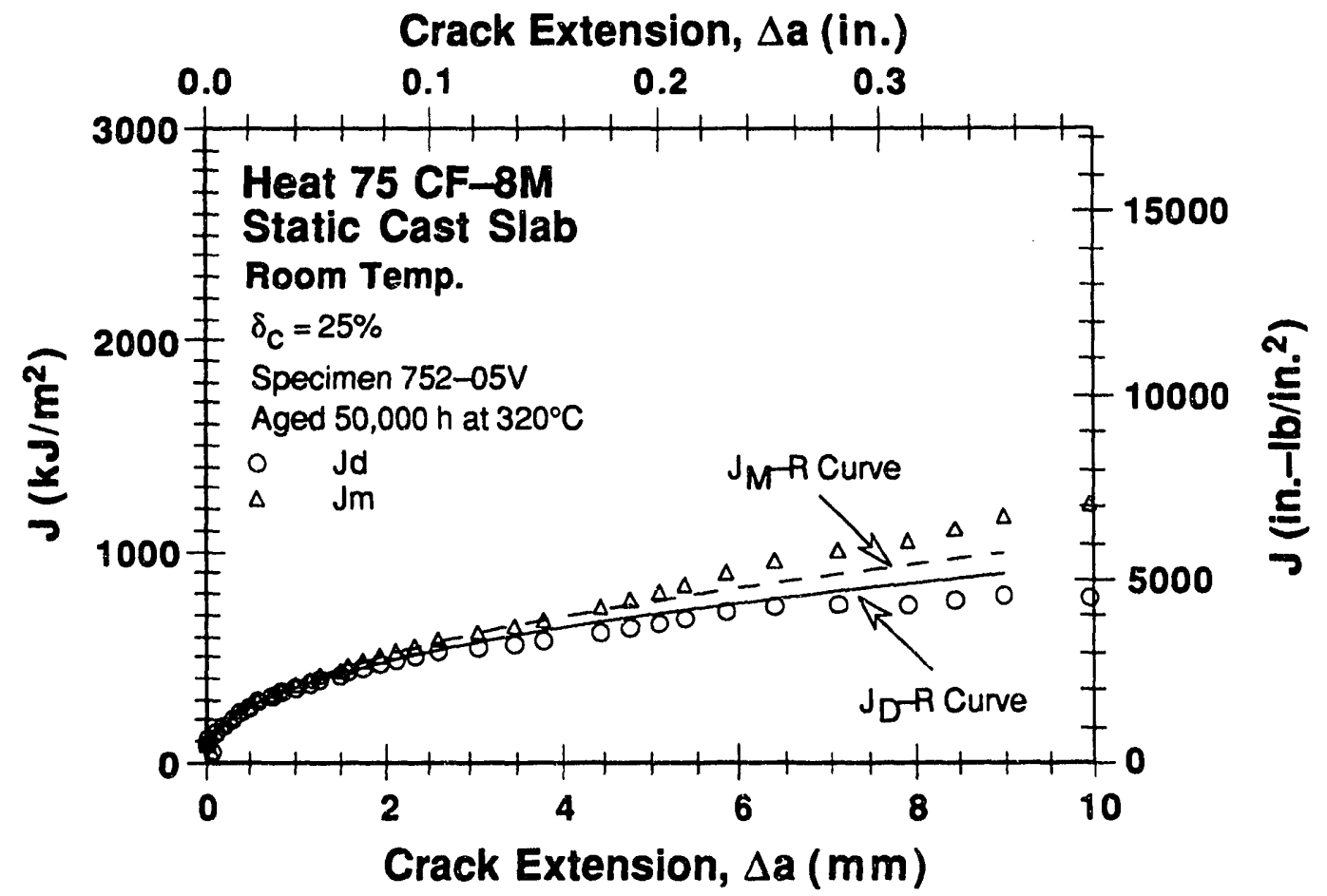

Figure A-83. Deformation and modified $J-R$ curves at room temp. for Heat 75 aged $50,000 \mathrm{~h}$ at $320^{\circ} \mathrm{C}$ 


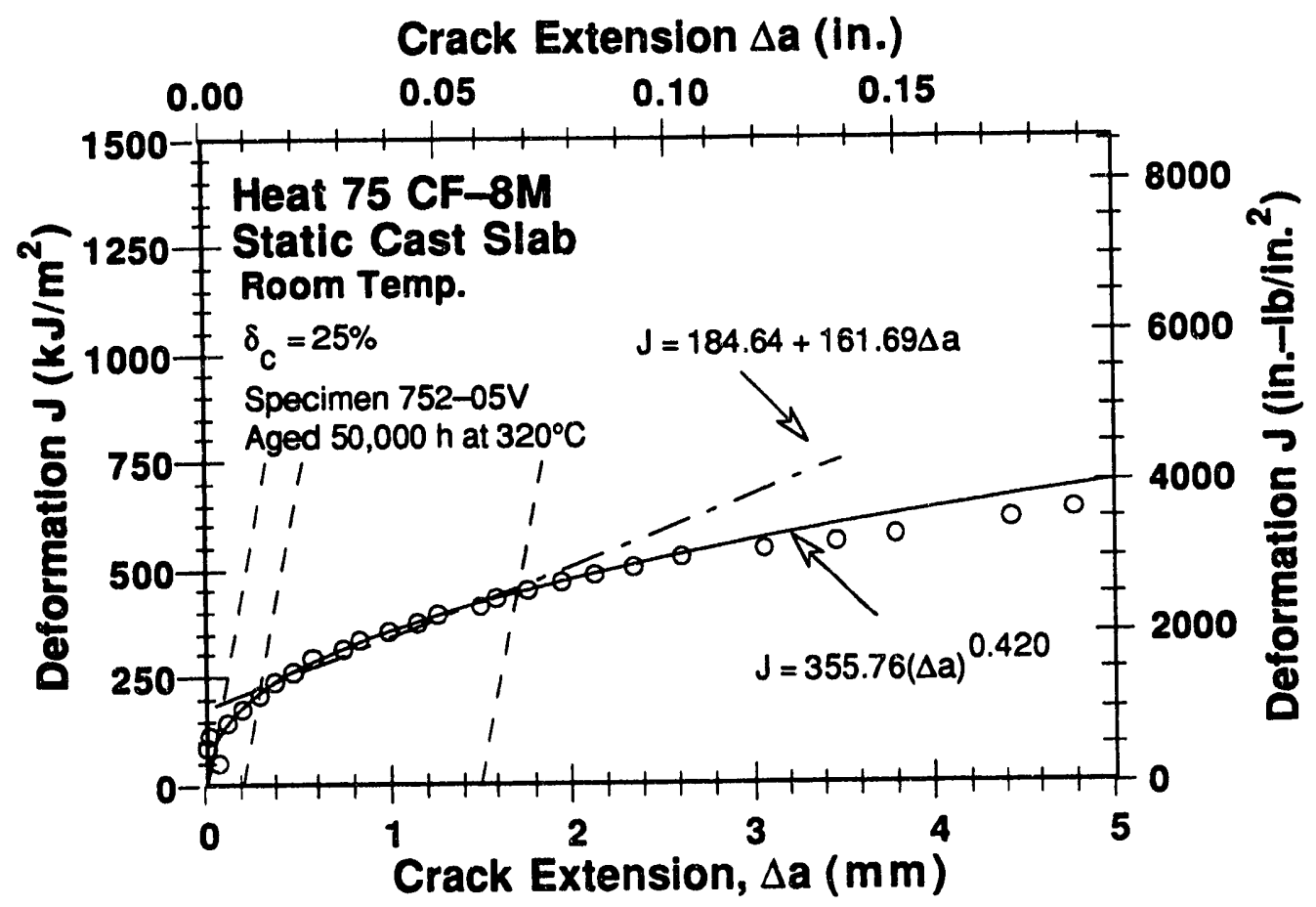

Figure A-84. Deformation $J_{I C}$ at room temp. for Heat 75 aged $50,000 \mathrm{~h}$ at $320^{\circ} \mathrm{C}$

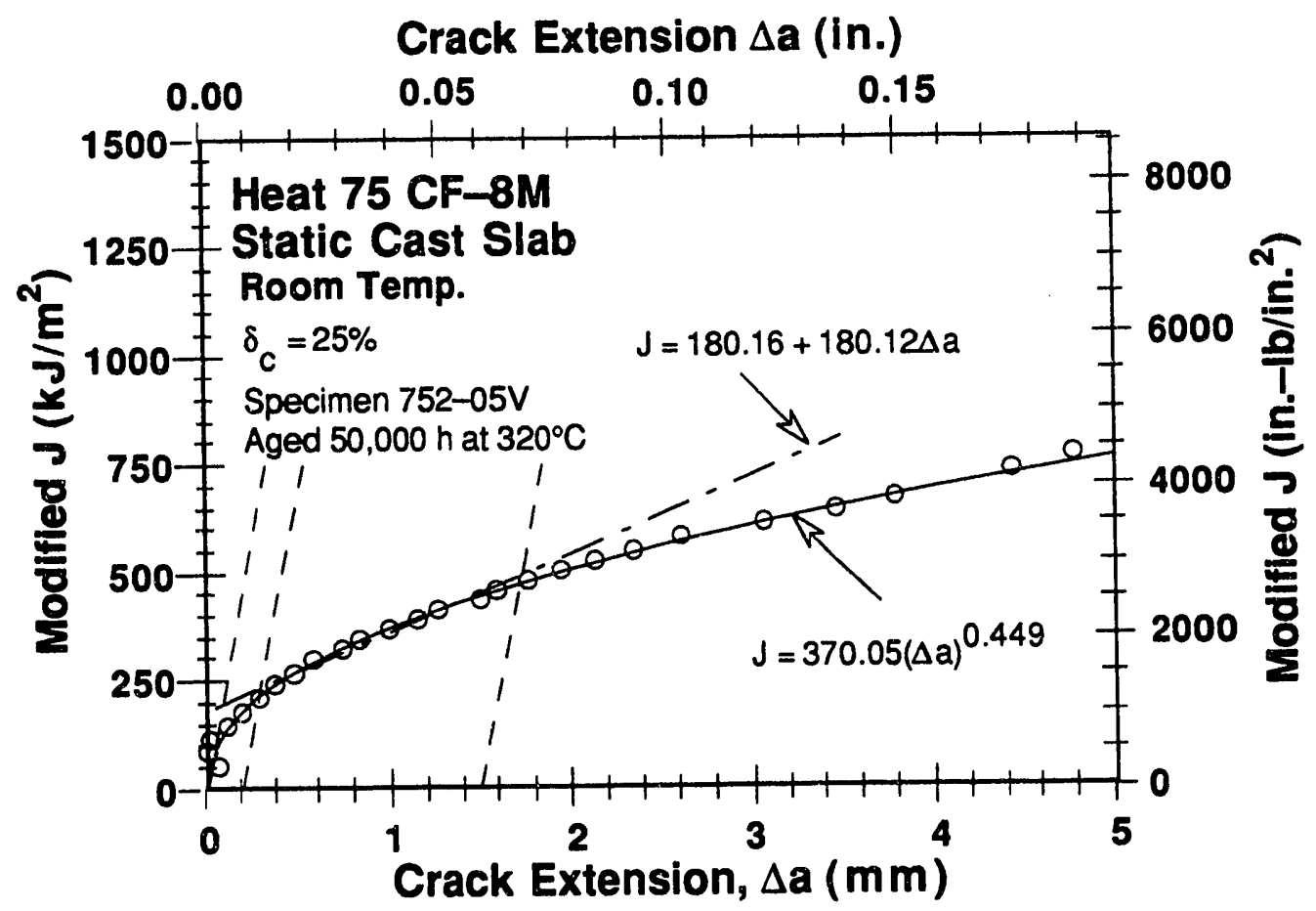

Figure A-85. Modifled $J_{I C}$ at room temp. for Heat 75 aged $50,000 \mathrm{~h}$ at $320^{\circ} \mathrm{C}$ 
Table A-86. Test data for specimen 753-06B

\begin{tabular}{|c|c|c|c|c|c|}
\hline $\begin{array}{l}\text { Test Nur } \\
\text { Material } \\
\text { Aging Te } \\
\text { Spec. Th } \\
\text { Spec. Wi }\end{array}$ & $\begin{array}{l}\text { r } \\
\text { le } \\
\text { ness } \\
\text { ne }\end{array}$ & $\mathrm{mm}$ & $\begin{array}{l}\text { Test } \\
\text { Heat } \\
\text { Agin } \\
\text { Net } \\
\text { Flow }\end{array}$ & & $\begin{array}{l}00 \mathrm{~h} \\
7 \mathrm{~mm} \\
60 \mathrm{MPa}\end{array}$ \\
\hline $\begin{array}{c}\text { Unload } \\
\text { Number }\end{array}$ & $\begin{array}{c}J_{d} \\
\left(\mathrm{~kJ} / \mathrm{m}^{2}\right)\end{array}$ & $\begin{array}{c}J_{m} \\
\left(\mathrm{~kJ} / \mathrm{m}^{2}\right)\end{array}$ & $\begin{array}{c}\Delta \mathrm{a} \\
(\mathrm{mm})\end{array}$ & $\begin{array}{l}\text { Load } \\
(\mathrm{kN})\end{array}$ & $\begin{array}{c}\text { Deflection } \\
\text { (mm) }\end{array}$ \\
\hline $\begin{array}{l}1 \\
2 \\
3 \\
4 \\
5 \\
6 \\
7 \\
8 \\
9 \\
10 \\
11 \\
12 \\
13 \\
14 \\
15 \\
16 \\
17 \\
18 \\
19 \\
20 \\
21 \\
22 \\
23 \\
24 \\
25 \\
26 \\
27 \\
28\end{array}$ & $\begin{array}{r}21.00 \\
63.41 \\
106.64 \\
154.36 \\
204.34 \\
233.73 \\
249.68 \\
279.85 \\
307.30 \\
335.07 \\
361.77 \\
387.02 \\
410.96 \\
435.10 \\
457.28 \\
491.46 \\
522.98 \\
544.19 \\
566.93 \\
587.48 \\
610.56 \\
632.49 \\
642.12 \\
661.06 \\
670.78 \\
683.43 \\
682.87 \\
683.81\end{array}$ & $\begin{array}{r}21.00 \\
63.43 \\
106.77 \\
155.08 \\
207.18 \\
240.63 \\
258.05 \\
291.30 \\
323.78 \\
354.70 \\
387.82 \\
420.50 \\
451.65 \\
483.21 \\
513.11 \\
555.66 \\
600.22 \\
639.01 \\
675.49 \\
712.60 \\
749.45 \\
798.42 \\
840.18 \\
886.78 \\
934.32 \\
984.95 \\
1032.13 \\
1082.23\end{array}$ & $\begin{array}{r}0.0144 \\
0.0177 \\
0.0457 \\
0.1290 \\
0.3481 \\
0.7004 \\
0.8172 \\
1.0307 \\
1.3419 \\
1.5168 \\
1.8411 \\
2.1824 \\
2.4878 \\
2.7801 \\
3.0642 \\
3.3448 \\
3.7439 \\
4.2452 \\
4.6133 \\
5.0321 \\
5.3603 \\
5.9609 \\
6.6364 \\
7.1816 \\
7.8848 \\
8.5457 \\
9.3361 \\
10.1029\end{array}$ & $\begin{array}{l}23.861 \\
32.436 \\
36.827 \\
39.629 \\
41.330 \\
41.241 \\
41.372 \\
41.277 \\
41.344 \\
41.097 \\
40.867 \\
39.626 \\
38.933 \\
38.361 \\
37.546 \\
37.008 \\
35.044 \\
33.028 \\
31.803 \\
30.878 \\
29.676 \\
27.663 \\
25.406 \\
23.484 \\
21.376 \\
19.011 \\
17.334 \\
15.091\end{array}$ & $\begin{array}{l}0.304 \\
0.605 \\
0.855 \\
1.106 \\
1.357 \\
1.514 \\
1.610 \\
1.762 \\
1.911 \\
2.063 \\
2.210 \\
2.363 \\
2.513 \\
2.665 \\
2.809 \\
3.011 \\
3.220 \\
3.413 \\
3.613 \\
3.808 \\
4.012 \\
4.266 \\
4.512 \\
4.810 \\
5.109 \\
5.465 \\
5.811 \\
6.210\end{array}$ \\
\hline
\end{tabular}


Table A-87. Deformation $J_{I C}$ and $J-R$ curve results for specimen 753-O6B

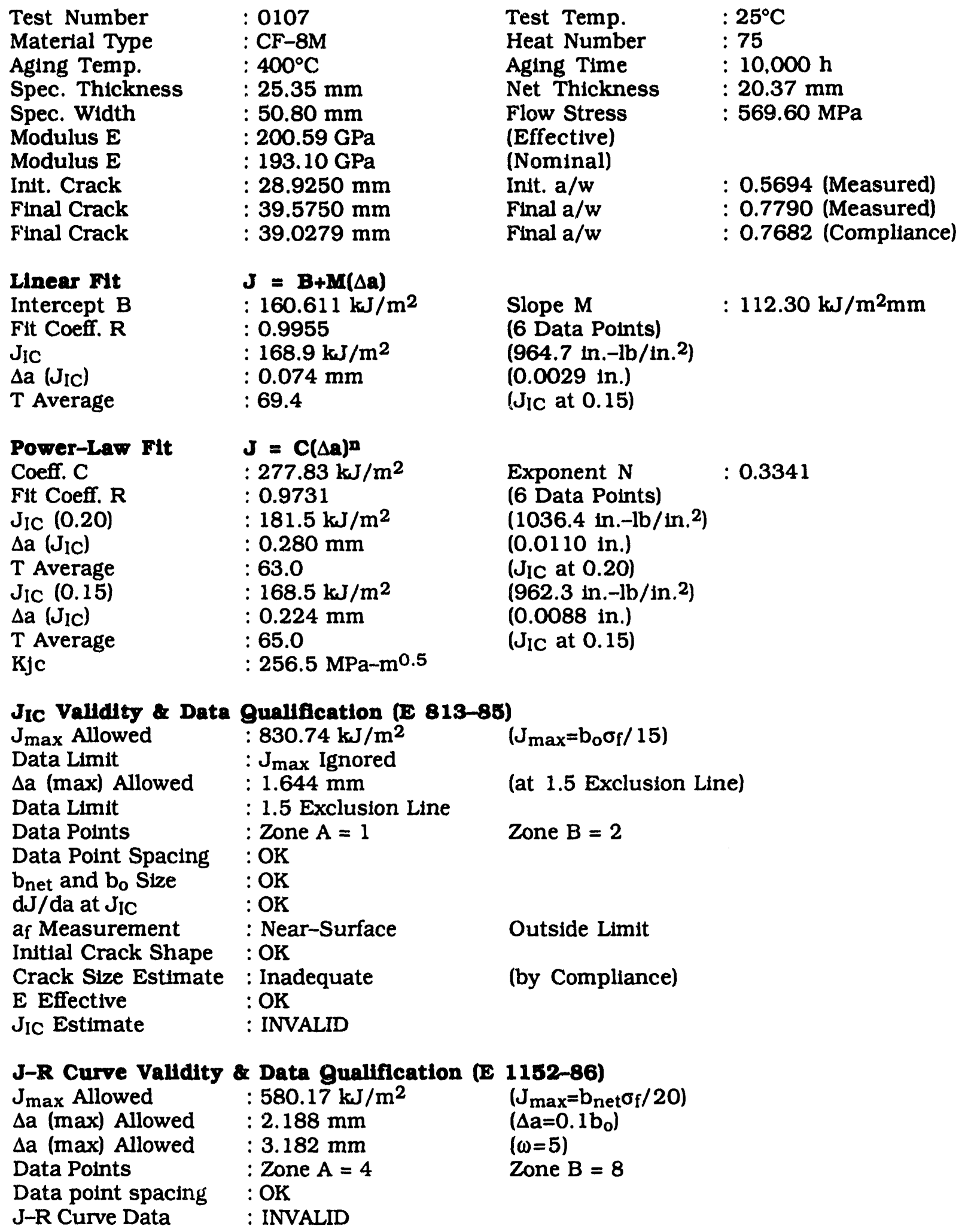


Table A-88. Modifled $J_{I C}$ and $J-R$ curve results for spectmen 753-06B

\begin{tabular}{|c|c|c|c|}
\hline Test Number & : 0107 & Test Temp. & $: 25^{\circ} \mathrm{C}$ \\
\hline Material Type & : CF-8M & Heat Number & $: 75$ \\
\hline Aging Temp. & $: 400^{\circ} \mathrm{C}$ & Aging Time & $: 10,000 \mathrm{~h}$ \\
\hline Spec. Thickness & $: 25.35 \mathrm{~mm}$ & Net Thickness & : $20.37 \mathrm{~mm}$ \\
\hline Spec. Width & $: 50.80 \mathrm{~mm}$ & Flow Stress & : $569.60 \mathrm{MPa}$ \\
\hline Modulus E & $: 200.59 \mathrm{GPa}$ & (Effective) & \\
\hline Modulus E & $: 193.10 \mathrm{GPa}$ & (Nominal) & \\
\hline Init. Crack & : $28.9250 \mathrm{~mm}$ & Init. $a / w$ & : 0.5694 (Measured) \\
\hline Final Crack & : $39.5750 \mathrm{~mm}$ & Final $a / w$ & : 0.7790 (Measured) \\
\hline Final Crack & : $39.0279 \mathrm{~mm}$ & Final $a / w$ & : 0.7682 (Compliance) \\
\hline $\begin{array}{l}\text { Linear Fit } \\
\text { Intercept } B \\
\text { Fit Coeff. } R \\
J_{I C} \\
\Delta a\left(J_{1 C}\right) \\
T \text { Average }\end{array}$ & $\begin{array}{l}J=\mathbf{J}+\mathbf{M}(\Delta \mathrm{a}) \\
: 157.670 \mathrm{~kJ} / \mathrm{m}^{2} \\
: 0.9960 \\
: 167.0 \mathrm{~kJ} / \mathrm{m}^{2} \\
: 0.073 \mathrm{~mm} \\
: 78.4\end{array}$ & $\begin{array}{l}\text { Slope M } \\
\text { (6 Data Points) } \\
(953.4 \mathrm{In} .-\mathrm{lb} / \mathrm{ln} .2) \\
(0.0029 \mathrm{in.}) \\
\left(J_{\text {IC }} \text { at } 0.15\right)\end{array}$ & $: 126.78 \mathrm{~kJ} / \mathrm{m}^{2} \mathrm{~mm}$ \\
\hline $\begin{array}{l}\text { Power-Law Fit } \\
\text { Coeff. C } \\
\text { Fit Coeff. R } \\
J_{I C}(0.20) \\
\Delta a\left(J_{I C}\right) \\
\text { T Average } \\
J_{I C}(0.15) \\
\Delta a\left(J_{I C}\right) \\
\text { T Average } \\
\text { Kjc }\end{array}$ & $\begin{array}{l}J=C(\Delta a)^{n} \\
: 289.68 \mathrm{~kJ} / \mathrm{m}^{2} \\
: 0.9745 \\
: 182.4 \mathrm{~kJ} / \mathrm{m}^{2} \\
: 0.280 \mathrm{~mm} \\
: 70.8 \\
: 168.1 \mathrm{~kJ} / \mathrm{m}^{2} \\
: 0.224 \mathrm{~mm} \\
: 73.0 \\
: 264.1 \mathrm{MPa}-\mathrm{m}^{0.5}\end{array}$ & $\begin{array}{l}\text { Exponent } \mathrm{N} \\
\text { (6 Data Points) } \\
\left(1041.6 \mathrm{in} .-\mathrm{lb} / \mathrm{in} .{ }^{2}\right) \\
(0.0110 \mathrm{in.}) \\
\left(\mathrm{J}_{\mathrm{IC}} \text { at } 0.20\right) \\
\left(960.1 \mathrm{in} .-\mathrm{lb} / \mathrm{in} .{ }^{2}\right) \\
(0.0088 \mathrm{in} .) \\
\left(\mathrm{J}_{\mathrm{IC}} \text { at } 0.15\right)\end{array}$ & : 0.3634 \\
\hline
\end{tabular}

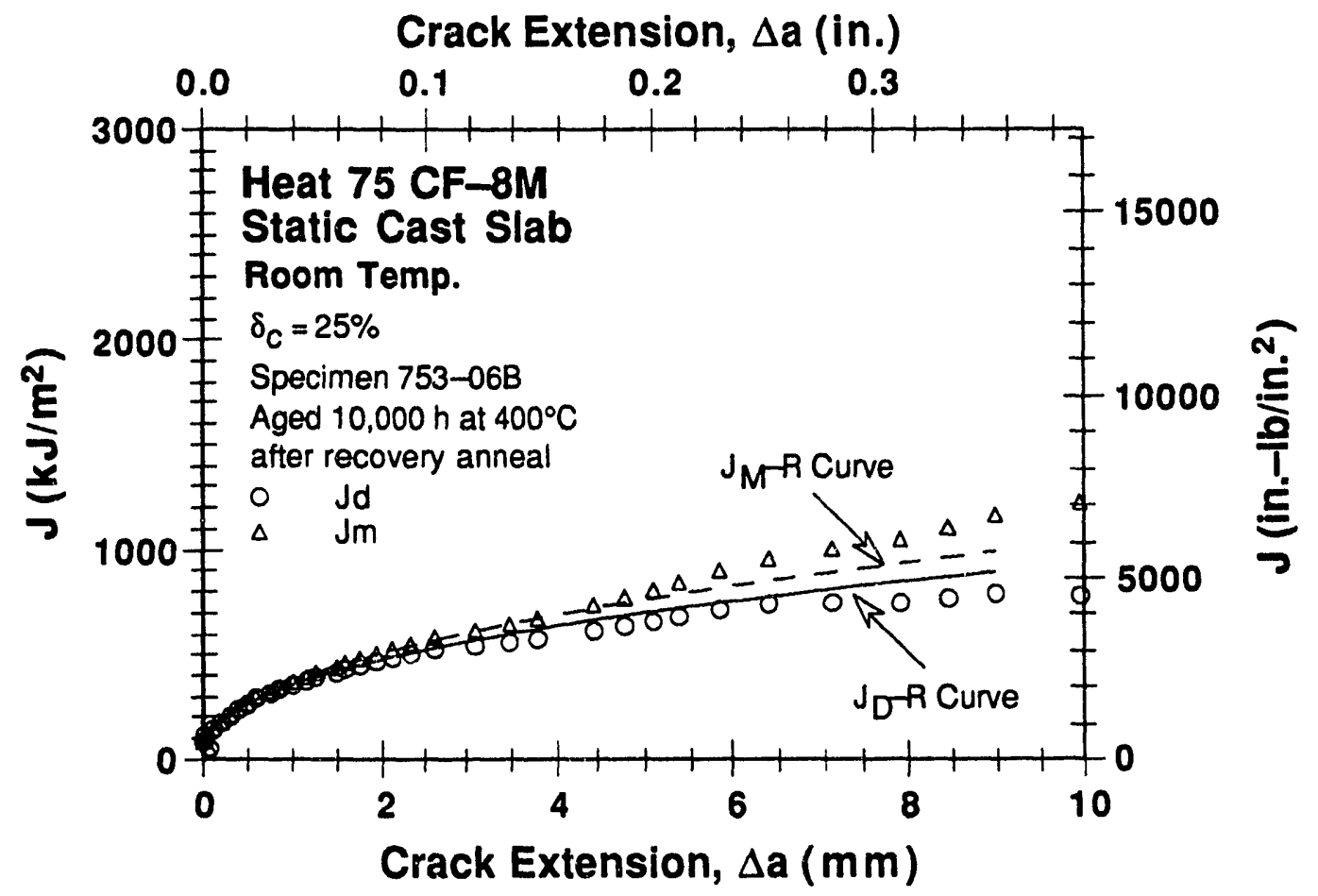

Figure A-86. Deformation and modified $J-R$ curves at room temp. for Heat 75 aged $10,000 \mathrm{~h}$ at $400^{\circ} \mathrm{C}$, then recovery-annealed and aged again for $10,000 \mathrm{~h}$ at $400^{\circ} \mathrm{C}$ 
Crack Extension $\Delta$ a (in.)

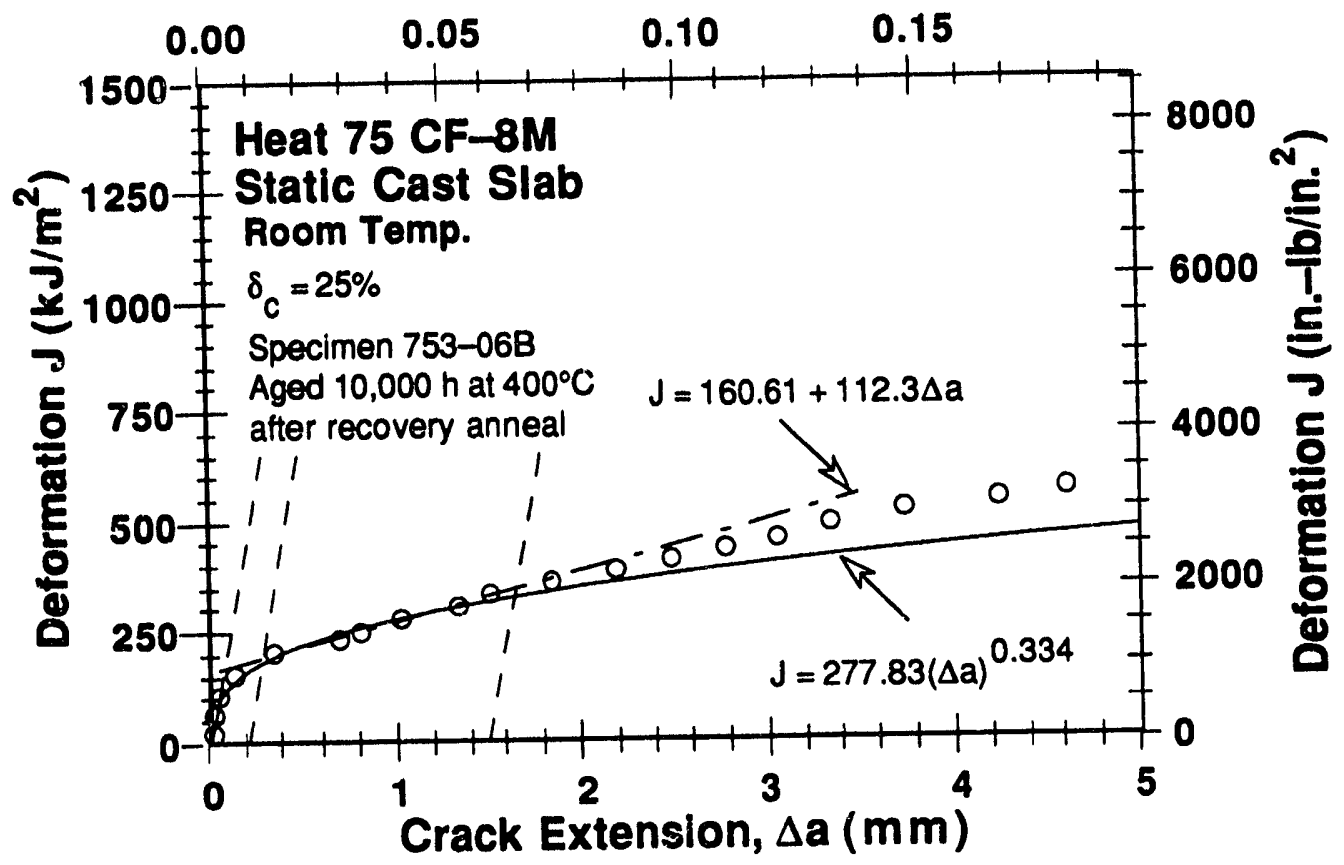

Figure A-87. Deformation $J_{I C}$ at room temp. for Heat 75 aged $10,000 \mathrm{~h}$ at $400^{\circ} \mathrm{C}$, then recovery-annealed and aged again for $10.000 \mathrm{~h}$ at $400^{\circ} \mathrm{C}$

Crack Extension $\Delta \mathrm{a}$ (in.)

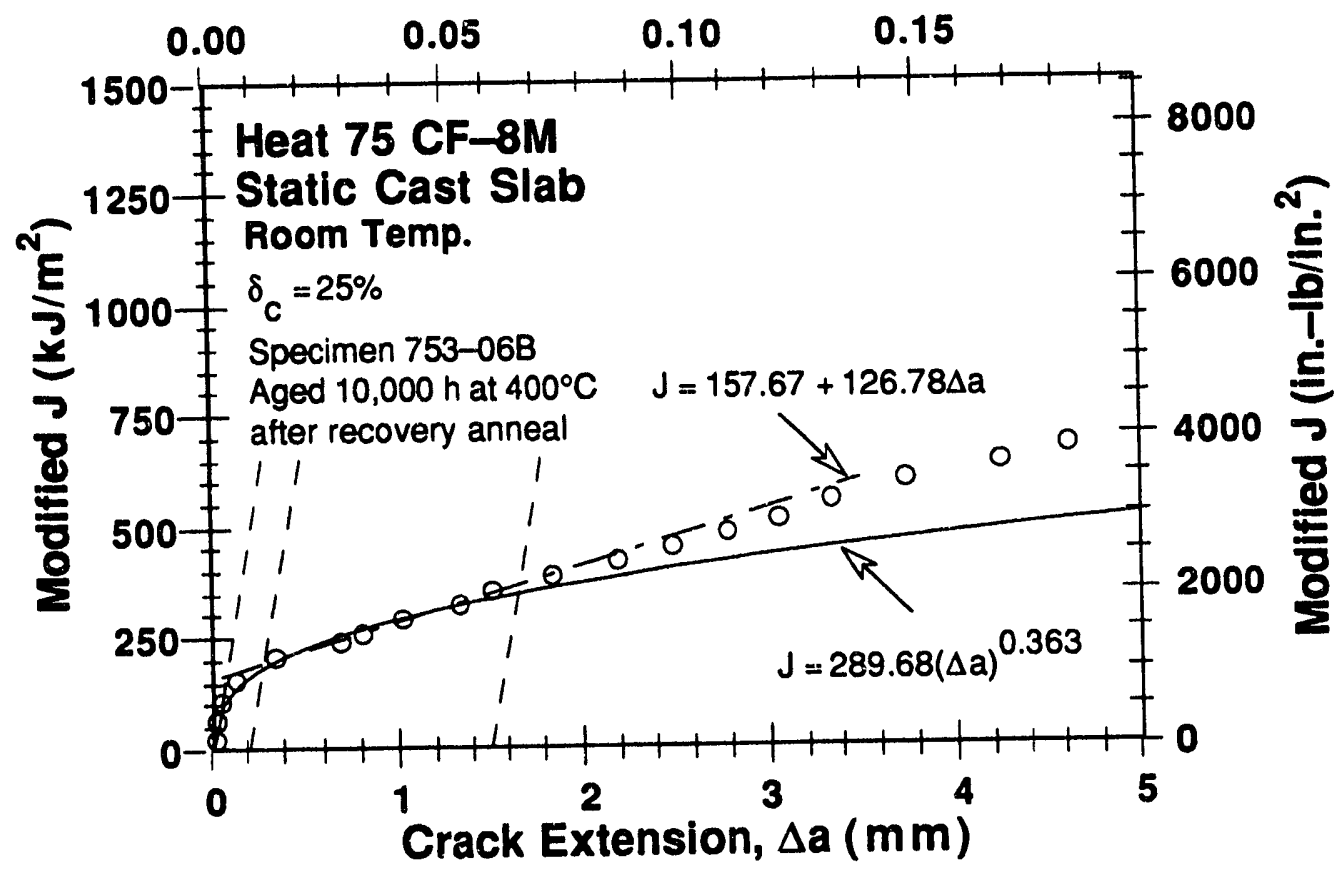

Figure A-88. Modified $J_{I C}$ at room temp. for Heat 75 aged $10,000 \mathrm{~h}$ at $400^{\circ} \mathrm{C}$. then recovery-annealed and aged again for $10,000 \mathrm{~h}$ at $400^{\circ} \mathrm{C}$ 
Table A-89. Test data for spectmen 753-02T

\begin{tabular}{|c|c|c|c|c|c|}
\hline $\begin{array}{l}\text { Test Num } \\
\text { Material } \\
\text { Aging Te } \\
\text { Spec. Th } \\
\text { Spec. Wi }\end{array}$ & $\begin{array}{l}\mathrm{r} \\
\text { ness }\end{array}$ & $\mathrm{mm}$. & $\begin{array}{l}\text { Test } \\
\text { Heat } \\
\text { Aging } \\
\text { Net } \\
\text { Flow }\end{array}$ & & $\begin{array}{l}\mathrm{C} \\
00 \mathrm{~h} \\
8 \mathrm{~mm} \\
00 \mathrm{MPa}\end{array}$ \\
\hline $\begin{array}{l}\text { Unload } \\
\text { Number }\end{array}$ & $\begin{array}{c}\mathrm{Jd}_{\mathrm{d}} \\
\left(\mathrm{m} / / \mathrm{m}^{2}\right)\end{array}$ & $\begin{array}{c}J_{m} \\
\left(\mathrm{~kJ} / \mathrm{m}^{2}\right)\end{array}$ & $\begin{array}{c}\Delta \mathrm{a} \\
(\mathrm{mm})\end{array}$ & $\begin{array}{l}\text { Load } \\
\text { (kN) }\end{array}$ & $\begin{array}{c}\text { Deflection } \\
\text { (mm) }\end{array}$ \\
\hline $\begin{array}{l}1 \\
2 \\
3 \\
4 \\
5 \\
6 \\
7 \\
8 \\
9 \\
10 \\
11 \\
12 \\
13 \\
14 \\
15 \\
16 \\
17 \\
18 \\
19 \\
20 \\
21 \\
22 \\
23 \\
24 \\
25 \\
26 \\
27 \\
28 \\
29 \\
30 \\
31 \\
32 \\
33 \\
34\end{array}$ & $\begin{array}{r}16.15 \\
46.43 \\
72.47 \\
98.65 \\
127.87 \\
156.27 \\
185.06 \\
216.97 \\
246.65 \\
280.81 \\
309.91 \\
338.79 \\
368.06 \\
396.26 \\
423.51 \\
444.60 \\
474.04 \\
499.91 \\
526.82 \\
552.82 \\
580.61 \\
612.96 \\
629.59 \\
656.80 \\
672.58 \\
699.30 \\
720.62 \\
751.08 \\
774.51 \\
803.49 \\
818.31 \\
844.98 \\
848.22 \\
863.25\end{array}$ & $\begin{array}{r}16.30 \\
45.81 \\
72.46 \\
98.04 \\
125.90 \\
158.75 \\
184.87 \\
219.61 \\
250.66 \\
283.79 \\
318.24 \\
350.64 \\
384.69 \\
418.53 \\
451.78 \\
487.23 \\
516.57 \\
554.78 \\
585.11 \\
620.40 \\
671.98 \\
718.47 \\
768.58 \\
810.41 \\
858.50 \\
898.91 \\
945.81 \\
985.61 \\
1046.93 \\
1101.90 \\
1169.36 \\
1230.07 \\
1292.01 \\
1347.55\end{array}$ & $\begin{array}{r}0.3897 \\
-0.0211 \\
0.1634 \\
0.0351 \\
-0.1788 \\
0.3804 \\
0.1019 \\
0.3478 \\
0.4503 \\
0.3839 \\
0.6937 \\
0.8780 \\
1.1046 \\
1.3500 \\
1.5898 \\
2.1280 \\
2.1245 \\
2.5246 \\
2.6289 \\
2.8948 \\
3.5261 \\
3.8738 \\
4.6490 \\
4.9670 \\
5.6299 \\
5.8959 \\
6.3659 \\
6.5285 \\
7.1465 \\
7.5446 \\
8.3008 \\
8.7591 \\
9.5066 \\
9.9959\end{array}$ & $\begin{array}{l}17.670 \\
23.121 \\
25.325 \\
27.083 \\
28.336 \\
29.433 \\
30.455 \\
31.152 \\
31.631 \\
32.000 \\
32.118 \\
32.118 \\
31.974 \\
31.796 \\
31.305 \\
31.218 \\
30.829 \\
30.205 \\
29.974 \\
29.347 \\
28.341 \\
27.023 \\
25.862 \\
24.589 \\
23.119 \\
22.523 \\
21.543 \\
21.082 \\
19.829 \\
18.849 \\
17.289 \\
16.075 \\
14.391 \\
13.502\end{array}$ & $\begin{array}{l}0.304 \\
0.606 \\
0.805 \\
1.007 \\
1.208 \\
1.407 \\
1.608 \\
1.809 \\
2.008 \\
2.216 \\
2.409 \\
2.609 \\
2.810 \\
3.111 \\
3.209 \\
3.409 \\
3.609 \\
3.814 \\
4.010 \\
4.212 \\
4.509 \\
4.811 \\
5.110 \\
5.408 \\
5.709 \\
6.009 \\
6.314 \\
6.611 \\
7.008 \\
7.422 \\
7.910 \\
8.409 \\
8.909 \\
9.414\end{array}$ \\
\hline
\end{tabular}


Table A-90. Deformation $J_{I C}$ and $J-R$ curve results for specimen 753-02T

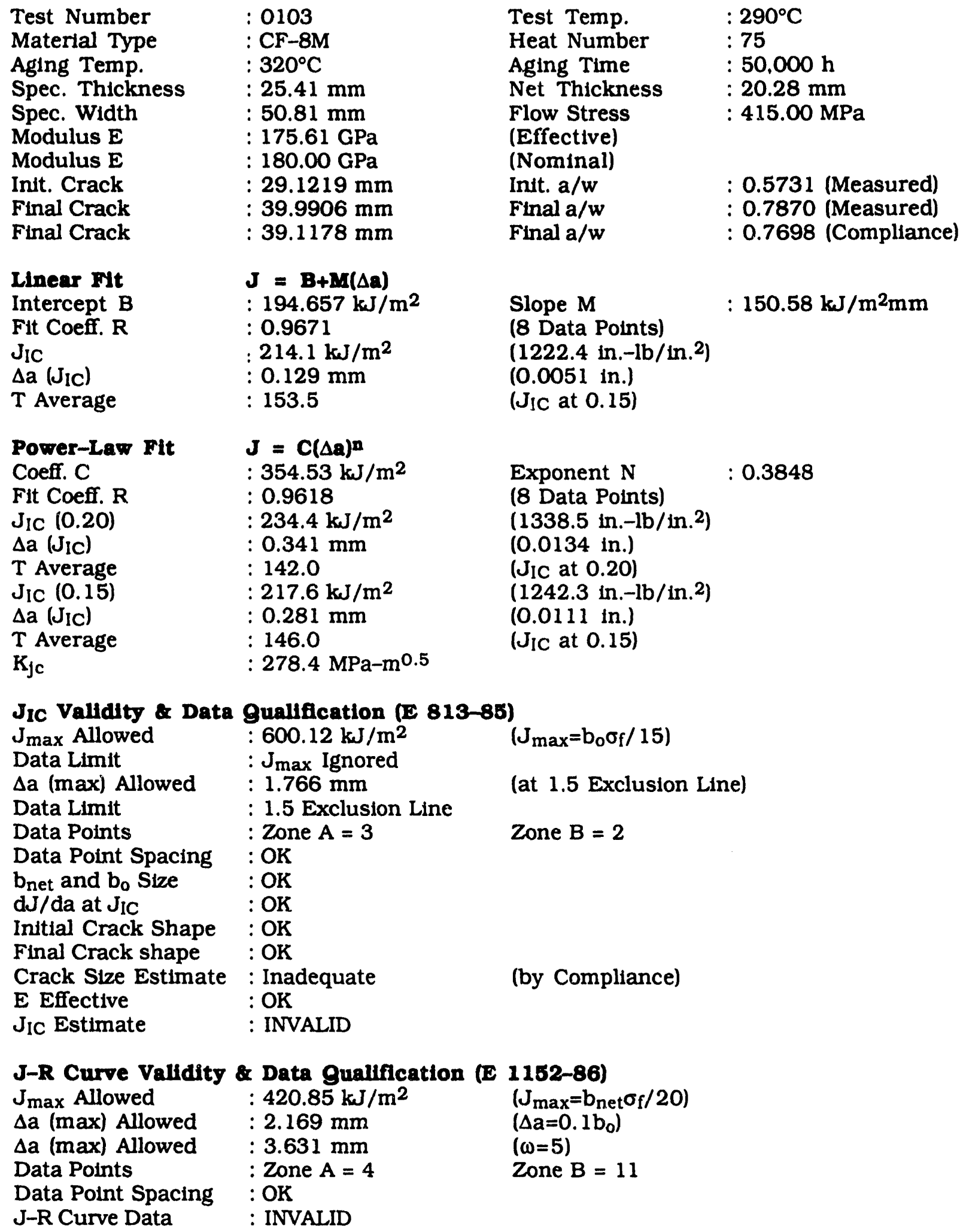


Table A-91. Modifled $J_{I C}$ and $J-R$ curve results for spectmen 753-02T

\begin{tabular}{|c|c|c|c|}
\hline $\begin{array}{l}\text { Test Number } \\
\text { Material Type } \\
\text { Aging Temp. } \\
\text { Spec. Thickness } \\
\text { Spec. Width } \\
\text { Modulus E } \\
\text { Modulus E } \\
\text { Init. Crack } \\
\text { Final Crack } \\
\text { Final Crack }\end{array}$ & $\begin{array}{l}: 0103 \\
: \mathrm{CF}-8 \mathrm{M} \\
: 320^{\circ} \mathrm{C} \\
: 25.41 \mathrm{~mm} \\
: 50.81 \mathrm{~mm} \\
: 175.61 \mathrm{GPa} \\
: 180.00 \mathrm{GPa} \\
: 29.1219 \mathrm{~mm} \\
: 39.9906 \mathrm{~mm} \\
: 39.1178 \mathrm{~mm}\end{array}$ & $\begin{array}{l}\text { Test Temp. } \\
\text { Heat Number } \\
\text { Aging Time } \\
\text { Net Thickness } \\
\text { Flow Stress } \\
\text { (Effective) } \\
\text { (Nominal) } \\
\text { Init. a/w } \\
\text { Final } a / w \\
\text { Final } a / w\end{array}$ & $\begin{array}{l}: 0.5731 \text { (Measured) } \\
: 0.7870 \text { (Measured) } \\
: 0.7698 \text { (Compliance) }\end{array}$ \\
\hline $\begin{array}{l}\text { Linear Fit } \\
\text { Intercept } B \\
\text { Fit Coeff. } R \\
\mathrm{~J}_{I C} \\
\Delta \mathrm{a}\left(\mathrm{J}_{\mathrm{IC}}\right) \\
\mathrm{T} \text { Average }\end{array}$ & $\begin{array}{l}J=B+M(\Delta Q) \\
: 189.400 \mathrm{~kJ} / \mathrm{m}^{2} \\
: 0.9751 \\
211.2 \mathrm{~kJ} / \mathrm{m}^{2} \\
: 0.127 \mathrm{~mm} \\
: 174.4\end{array}$ & $\begin{array}{l}\text { Slope } M \\
\text { (8 Data Points) } \\
\left(1205.7 \text { in. }-1 \mathrm{~b} / \mathrm{in} .{ }^{2}\right) \\
(0.0050 \text { in.) } \\
\left(\mathrm{J}_{1 \mathrm{C}} \text { at } 0.15\right)\end{array}$ & $: 171.04 \mathrm{~kJ} / \mathrm{m}^{2} \mathrm{~mm}$ \\
\hline $\begin{array}{l}\text { Power-Law Fit } \\
\text { Coeff. C } \\
\text { Fit Coeff. } \mathrm{R} \\
\mathrm{J}_{\mathrm{IC}}(0.20) \\
\Delta \mathrm{a}\left(\mathrm{J}_{\mathrm{IC}}\right) \\
\mathrm{T} \text { Average } \\
\mathrm{J}_{\mathrm{IC}}(0.15) \\
\Delta \mathrm{a}\left(\mathrm{J}_{\mathrm{IC}}\right) \\
\mathrm{T} \text { Average } \\
\mathrm{K}_{\mathrm{Jc}}\end{array}$ & $\begin{array}{l}J=C(\Delta a)^{n} \\
: 370.21 \mathrm{~kJ} / \mathrm{m}^{2} \\
: 0.9684 \\
: 236.3 \mathrm{~kJ} / \mathrm{m}^{2} \\
: 0.342 \mathrm{~mm} \\
: 160.3 \\
: 217.6 \mathrm{~kJ} / \mathrm{m}^{2} \\
: 0.281 \mathrm{~mm} \\
: 164.5 \\
: 287.8 \mathrm{MPa}-\mathrm{m}^{0.5}\end{array}$ & $\begin{array}{l}\text { Exponent } N \\
(8 \text { Data Points) } \\
\left(1349.4 \text { in.-lb/in. }{ }^{2}\right) \\
(0.0139 \text { in. }) \\
\left(J_{1 C} \text { at } 0.20\right) \\
\left(1242.5 \text { in.-lb/in. }{ }^{2}\right) \\
(0.0111 \text { in. }) \\
\left(J_{l C} \text { at } 0.15\right)\end{array}$ & $: 0.4188$ \\
\hline
\end{tabular}

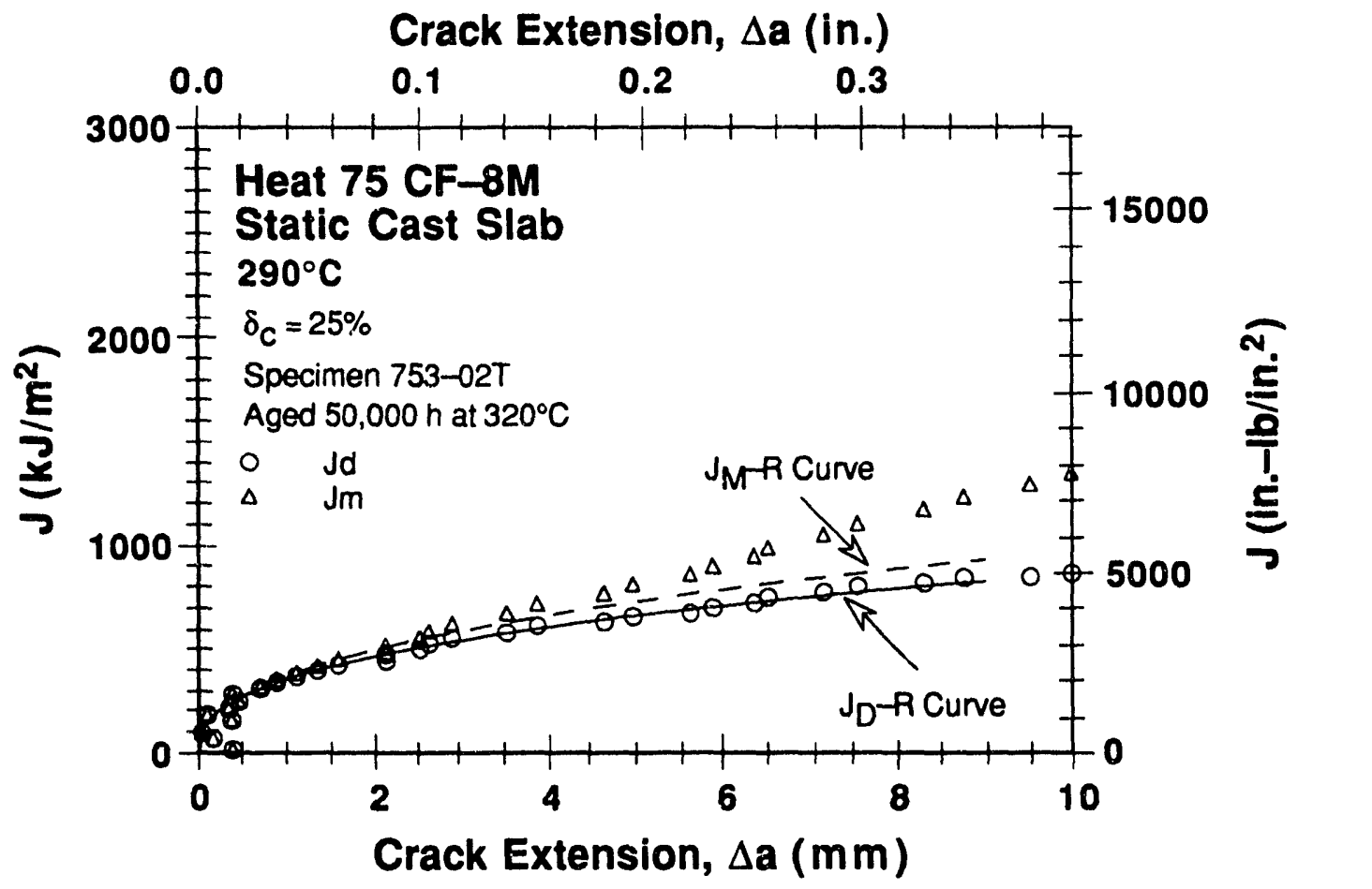

Figure A-89. Deformation and modified $J-R$ curves at room temp. for Heat 75 aged $50,000 \mathrm{~h}$ at $320^{\circ} \mathrm{C}$ 
Crack Extension $\Delta \mathrm{a}$ (in.)

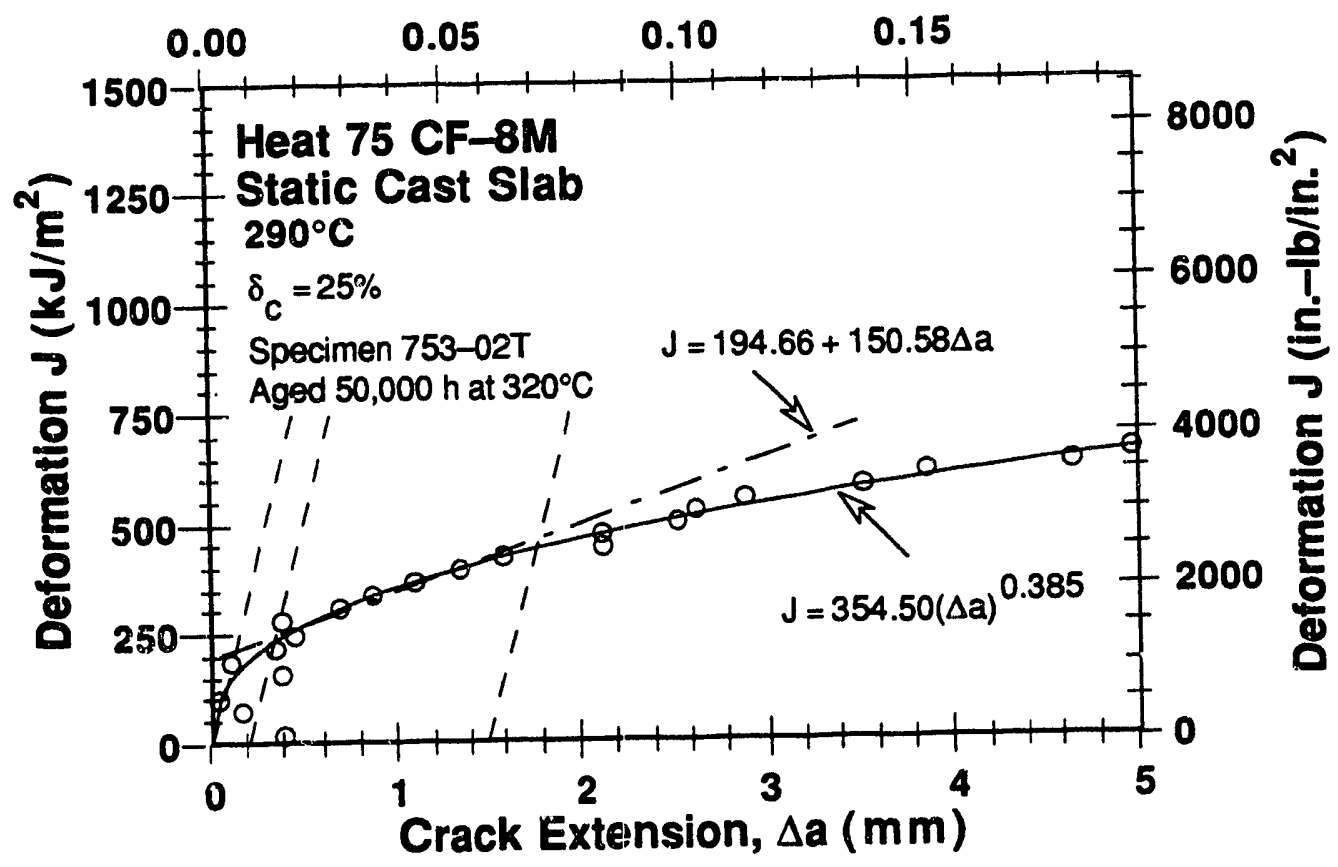

Figure A-90. Deformation $J_{I C}$ at room temp. for Heat 75 aged 50,000 $\mathrm{h}$ at $320^{\circ} \mathrm{C}$

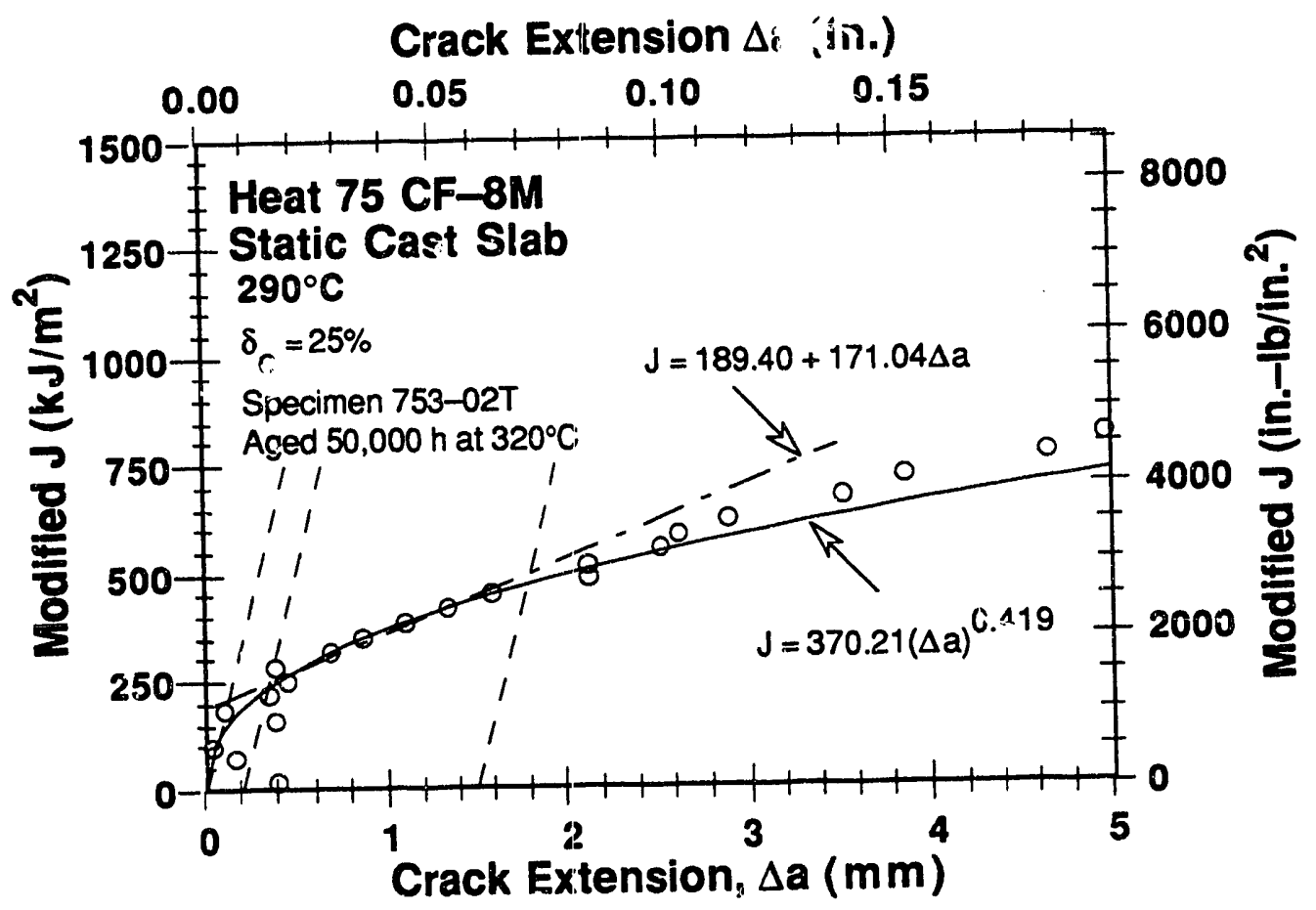

Figure A-91. Modified $J_{I C}$ at room temp. for Heat 75 aged $50,000 \mathrm{~h}$ at $320^{\circ} \mathrm{C}$ 
Distribution for NUREG/CR-4744 Vol. 7, No. 1 (ANL-92/42)

Internal:
O. K. Chopra (25)
W. J. Shack
TIS Files
H. M. Chung
C. E. Till
ANL Patent File
T. F. Kassner
R. W. Weeks
C. Malefyt (2)

\section{External:}

NRC, for distribution per R5

ANL Libraries

ANL-E

ANL-W

Manager, Chicago Operations Office, DOE

Materials and Components Technology Division Review Committee

H. K. Birnbaum, University of Illinois, Urbana, IL

R. C. Buchanan, University of Cincinnati, Cincinnati, $\mathrm{OH}$

M. S. Dresselhaus, Massachusetts Institute of Technology, Cambridge, MA

B. G. Jones, University of Illinois, Urbana, IL

C.-Y. LI, Cornell U., Ithaca, NY

S.-N. Liu, Electric Power Research Institute, Palo Alto, CA

R. E. Smith, Engineering Applied Sciences, Inc., Trafford, PA

D. Atteridge, Battelle Pacific Northwest Laboratory

W. H. Bamford, Westinghouse Electric Corp., Pittsburgh

N. G. Cofie, Nutech, San Jose, CA

A. Cowan, Risley Nuclear Power Development Labs., Risley, Warrington, UK

E. L. Creamer, Shell Oil Co., Houston

W. H. Cullen, Materials Engineering Associates, Inc., Lanham, MD

B. J. L. Darlaston, Berkeley Nuclear Laboratories, Berkeley, Gloucestershire, UK

H. Domian, Alliance Research Center, Babcock \& Wilcox Co., Alliance, $\mathrm{OH}$

G. Gage, AEA Technology, Harwell Laboratory, Oxfordshire, UK

J. Gilman, Electric Power Research Inst., Palo Alto, CA

M. Guttmann, Electricité de France, Les Renardieres Roule de Sens, France

W. Gysel, Georg Fischer, Ltd., Schaffhausen, Switzerland

G. E. Hale, The Welding Institute, Abington, Cambridge, UK

P. Hedgecock, APTECH Engineering Services, Inc., Palo Alto, CA

B. Hemsworth, HM Nuclear Installations Inspectorate, London

C. G. Interrante, Center for Materials Science. National Institute of Standards and Technology. Gaithersburg, MD

J. Jansky, Buro für Technische Beratung, Leonberg, Germany

C. E. Jaske, CC Technologies, Cortest, Columbus, $\mathrm{OH}$

C. Kim, Westinghouse Electric Corp., Pittsburgh

P. M. Lang, Office of Converter Reactor Deployment, U.S. Dept. of Energy, Washington, DC

G. J. Licina, Structural Integrity Associates, San Jose, CA

T. R. Mager. Westinghouse Electric Corp., Pittsburgh

Y. Meyzaud, Framatome, Paris La Defense, France 
M. Prager, Materials Properties Council, Inc., New York

P. H. Pumphrey, National Power, Technology and Environment Center, Leatherhead, Surrey, UK

D. Quiñones, Robert Cloud \& Associates, Berkeley, CA

V. N. Shah, EG\&G Idaho. Inc., P. O. Box 1625, Idaho Falls, Idaho

V. K. Sikka, Oak Ridge National Laboratory

A. Singh. Unical Science \& Technology Division, Brea, CA

G. Slama, Framatome, Parts La Defense, France

G. D. W. Smith, Oxford University, Oxford, UK

H. D. Solomon, General Electric Co., Schenectady, NY

D. M. Stevens, Lynchburg Research Center, Babcock \& Wilcox Co., Lynchburg, VA

L. Taylor, Nuclear Electric plc., Chelsford Rd., Knutsford. Cheshire, UK

J. M. Vitek, Oak Ridge National Laboratory

J. Wilks, AMOCO, Naperville, IL 


\begin{tabular}{|c|c|}
\hline $\begin{array}{l}\text { BIBLIOGRAPHIC DATA SHEET } \\
\text { (Se日 instructions on the reverse) }\end{array}$ & $\begin{array}{l}\text { 1. PEPORT NUMBER } \\
\text { (Assignod by NRC. Add Vol., Supp., Rov., } \\
\text { and Addondum Numbers, if any.) } \\
\text { NUREG/CR-4744 } \\
\text { Vol. 7. No. } 1\end{array}$ \\
\hline \multirow{3}{*}{$\begin{array}{l}\text { 2. TTLE AND SUBTME } \\
\text { Long-Term Embrittlement of Cast Duplex Stainless Steels } \\
\text { in LWR Systems }\end{array}$} & ANL-92/42 \\
\hline & 3. DATE REPORT PUBLISHED \\
\hline & \begin{tabular}{l|r} 
MONTH & YEAR \\
May & 19.93 \\
\end{tabular} \\
\hline $\begin{array}{l}\text { Semiannual Report } \\
\text { October 1991-March } 1992\end{array}$ & $\begin{array}{l}\text { 4. FN OR GRANT NUMBER } \\
\text { A2243 }\end{array}$ \\
\hline \multirow[t]{2}{*}{$\begin{array}{l}\text { 5. AUTHOR(S) } \\
\text { O. K Chopra }\end{array}$} & $\begin{array}{l}\text { 6. TYPE OF REPOAT } \\
\text { Technical; Semiannual }\end{array}$ \\
\hline & $\begin{array}{l}\text { 7. PERIOD COVERED (Inchusive Datos) } \\
\text { October } 1991 \text {-March } 1992\end{array}$ \\
\hline
\end{tabular}

8. PERFORMING ORGANIRATION - NAME AND ADORESS (II NRC, provido Division, Offico or Region, U.S. Nuclaar Regulabry Commission, and mailing address; if contracior, provide nemo and maling adctess)

Argonne National Laboratory

9700 South Cass Avenue

Argonne, Il 60439

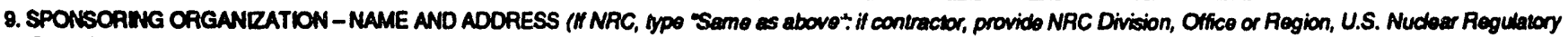

Commiseion, and maiting adthess.)

Division of Engineering

Office of Nuclear Regulatory Research

U. S. Nuclear Regulatory Commission

Washington, DC 20555

10. SUPPLEMENTARY NOTES

11. ABSTRACT (200 words or lees)

This progress report summarizes work performed by Argonne National Laboratory on long-term thermal embrittlement of cast duplex stainless steels in LWR systems during the six months from October 1991 to March 1992. Charpy-impact, tensile, and fracture toughness J-R curve data are presented for several heats of cast stainless steel that were aged $10,000-58,000 \mathrm{~h}$ at 290,320 , and $350^{\circ} \mathrm{C}$. The results indicate that thermal aging decreases the fracture toughness of cast stainless steels. In general, CF-3 steels are the least sensitive to thermal aging and CF-8M steels are the most sensitive. The values of fracture toughness $J_{I C}$ and tearing modulus for $C F-8 M$ steels can be as $10 w$ as $\approx 90 \mathrm{~kJ} / \mathrm{m}^{2}$ and $\approx 60$, respectively. The fracture toughness data are consistent with the Charpy-impact results, l.e., unaged and aged steels that show low impact energy also exhlbit lower fracture toughness. All steels reach a minimum saturation fracture toughness after thermal aging; the time to reach saturation depends on the aging temperature. The results also indicate that low-strength cast stainless steels are generally insensittve to thermal aging.

Cast duplex stainless steel

Thermal aging

Embrittlement

Fracture toughness

J-R curve

Impact strength

\begin{tabular}{|c|}
\hline $\begin{array}{l}\text { 13. AVALABUTY STATEMENT } \\
\text { Unlimited }\end{array}$ \\
\hline 14. SECUARTY CLASSIFICATION \\
\hline $\begin{array}{l}\text { This Paod } \\
\text { Unclassified }\end{array}$ \\
\hline $\begin{array}{l}\text { (This Roporn) } \\
\text { Unclassified }\end{array}$ \\
\hline 15. NUMBER OF PAGES \\
\hline 16. PRICE \\
\hline
\end{tabular}



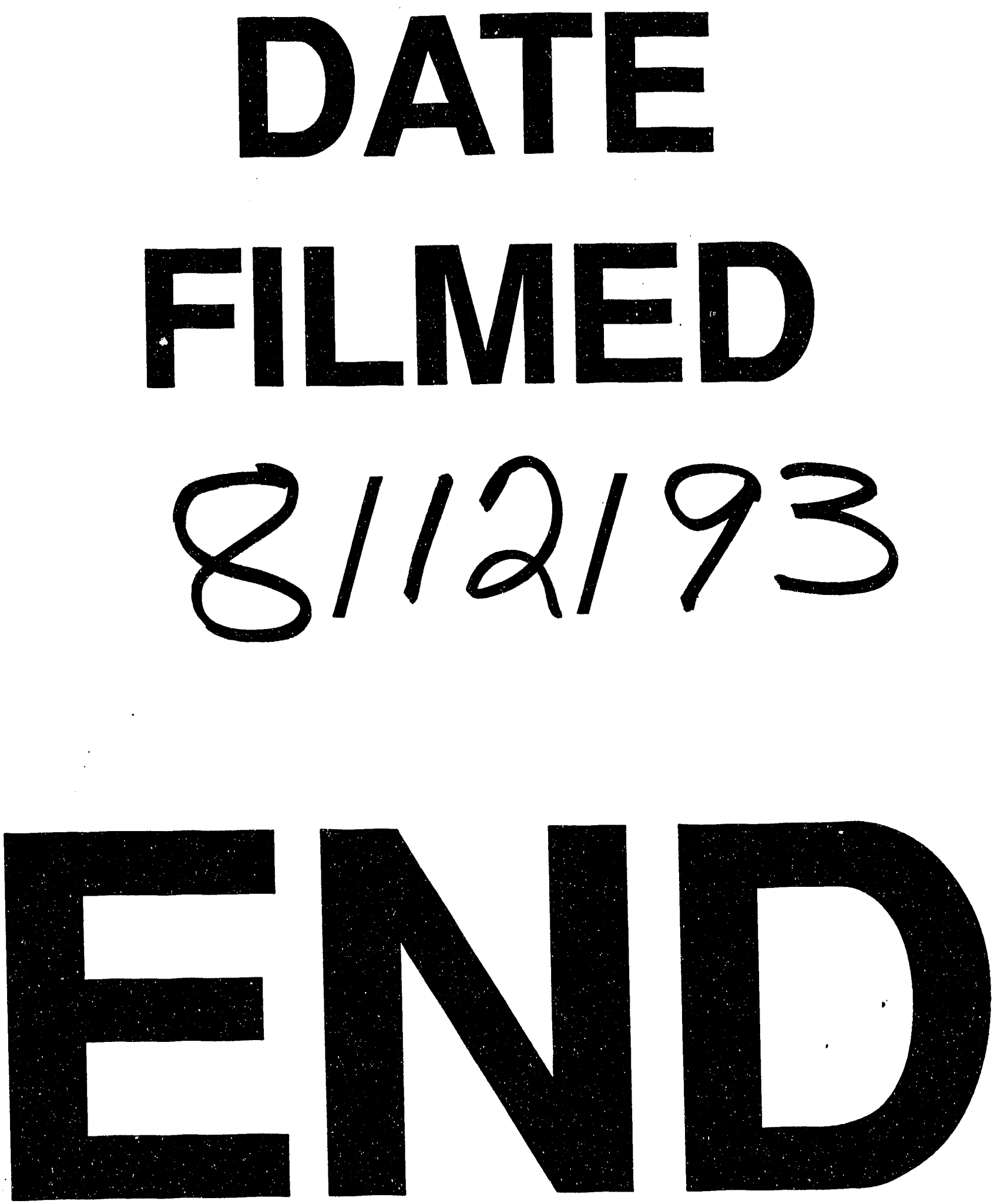
